Historic, Archive Document

Do not assume content reflects current scientific knowledge, policies, or practices. 



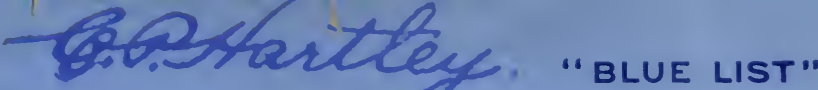

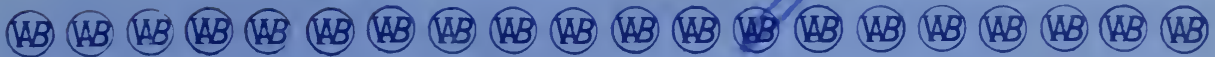

(AB)

$(A B)$

$(B B)$

$(A B)$

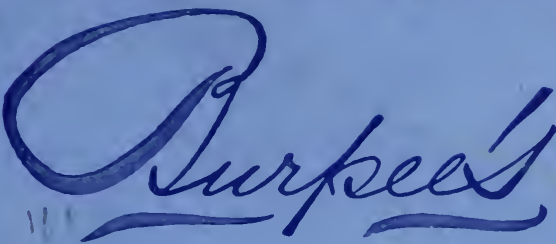

(AB)

that Grow

$(A B)$

(ABB

(AB)

(ABB)

$(4 B)$

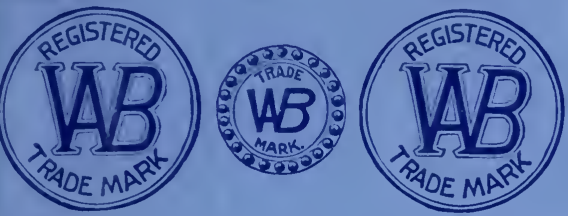

(AB) BURPEE'S $(A B)$

$\triangle B B$ SEEDS

are sold in any quantity, but

(AB) ONLY UNDER SEAL $A B$

(AB) They are Genuine $\triangle A B$

(AB) Seal is Unbroken $A B$

Packages of an

AB ounce or more are DATED 1914
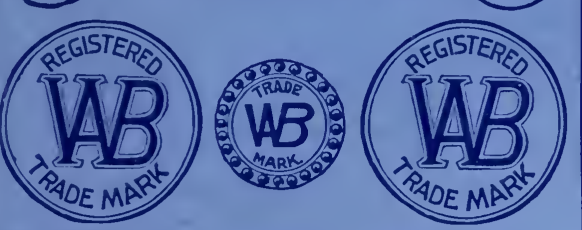

(सB)

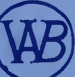

Wholesale

Prices for

Market

Gardeners

Florists and

Farmers'

Clubs

(AB)

$(A B)$

$(B B$

(ABB

(BB)

(ABB

(AB)

(ABB)

(BB)

(AB)

$(B B)$

$(B B)$

(AB)

(AB)

(ABB

$(B B$

(BB)

$(B B)$

(4BB)

(ABB

(AB W. ATLEE BURPEE \& CO., Seed Growers

(AB) Burpee Buildings: North Fifth St. Philadelphia, Pa.
York Ave., and Buttonwood St. Pall

(BB)

(ABB

$(B B)$

(AB) Seed Gardens and Trial Grounds at our famous FORDHOOK FARMS, Bucks Co.., Pa.,

(BB)

SUNNYBRooK FARM, New Jersey, and Burpee's FLORADALE FARM in California

(ABB)

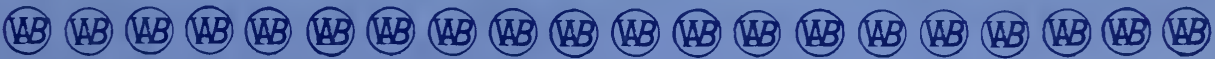
Copyright, 1914, BY W. AtLee Burpee \& Co.. PHILAdelphia 


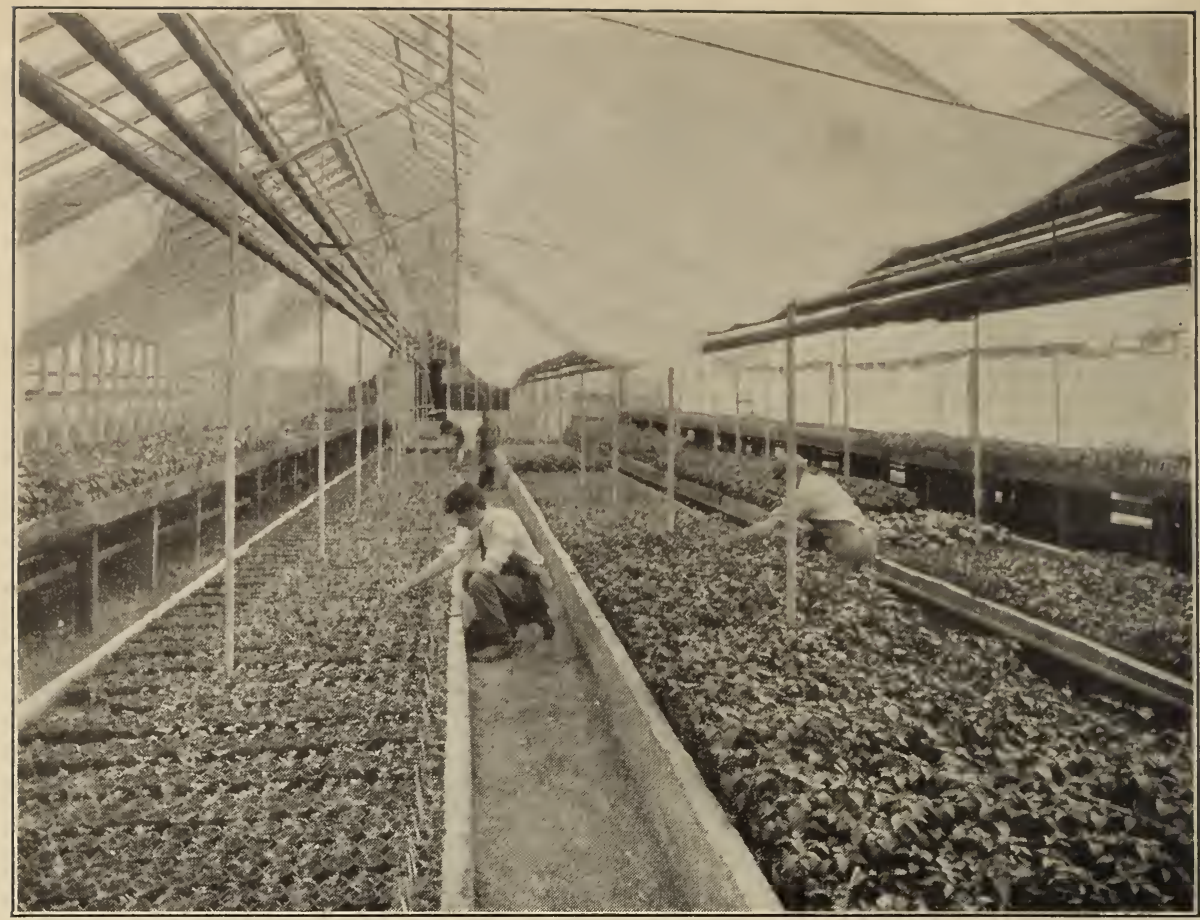

The Lower Range of Greenhouses at Fordhook,-a May photograph. Many trials of Peppers, Egg Plants, etc., have been "potted up" and will soon be ready for setting out.

\section{Burpee's Fordhook Farms are the Largest and Most Complete Trial Grounds in America}

At FORDHOOK FARMS (supplemented by our farms in California and New Jersey) all seeds are tested, but we "hold fast only to that which is good !" The field trials number fully seven thousand, while more than fifteen thousand soil tests for vitality are made also every year. The vitality can be proved easily before planting, but not even an "expert " examination would reveal whether seeds are of a high-grade pedigree strain or the veriest rubbish.

The fact that more planters order direct from us, - year after year,- than from any other firm in America shows that BURPEE'S "SEEDS THAT GROW" have been proved trustworthy. A mistake may occasionally occur, however, while success depends largely upon conditions of soil and climate, hence no honest seedsman could assume responsibility for more than the price actually paid by the purchaser. For thirty-seven years we have stated plainly that,

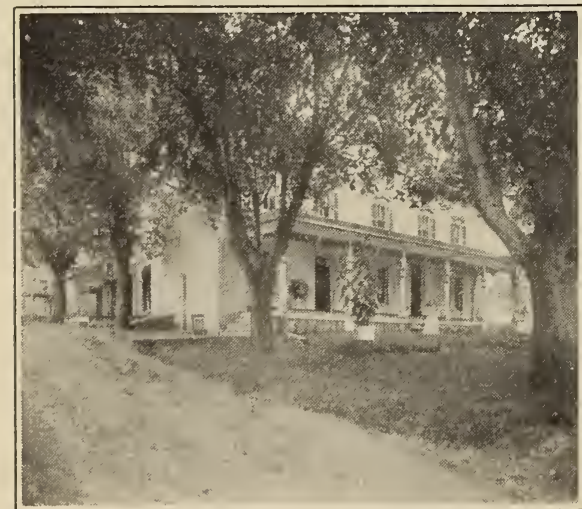

One of the Seven Entrances to FORDHOOK FARMS. should failure result from any fault of the seed, we would promptly refund the price paid. This ought to convince even new customers that we have confidence both in the quality of BURPEE'S SEEDS and in the safeguards with which we surround their growing, cleaning, and packing.

At no other farms in America is there expended so much time and money each season in "proving stocks," while at no other warehouse is greater care exercised in handling seeds. Planters who may visit Philadelphia are invited to inspect the BURPEE BUILDINGS, where we shall be pleased to explain the workings of the various departments. We have nothing to conceal, and are glad, also, to have customers examine the crops and trials during the season at our FORDHOOK, SUNNYBROOK and FLORADALE FARMS.

W. ATLEE BURPEE \& CO., Seed Growers, Philadelphia, Pa. 


\section{"The Best Seeds that Grow!"}

This has been our motto for many years. It is not a mere advertising "catch phrase," but represents the BuRPEe QUALITY-STANDARD IN SEeds,-uniformly as good as it is possible to produce. Growing seeds of the highest grade is not only our business but our pleasure as well. So careful are we of the reputation established by conscientious work for thirty-seven years that we prefer to report "Sold out" rather than to purchase any seeds of doubtful pedigree, with which to fill orders when our own stocks are exhausted.

\section{Quality is Our Aim Always. We do not attempt to compete} merely in price. It is quite true (his is a great big BUT!) they are worth much more. Were not this a fact it would not have been possible for us to secure the largest mail-order seed trade in the world!

We are exclusively a catalog house and never send out travelers to solicit orders, even at wholesale. Consequently there are several houses who supply a greater bulk of seeds at wholesale than do we, but we flatter ourselves that we retain the exclusive trade of many intelligent Market Gardeners throughout America who realize that, in seeds, "the best is the cheapest."

\section{Burpee's Seed Annual for 1914. Our complete Retail Catalog}

You have failed to receive it, kindly write at once and a duplicate copy will be forwarded.

\section{Burpee Buildings:}

North Fifth Street,

York Avenue and

Buttonwood Street,

Philadelphia.

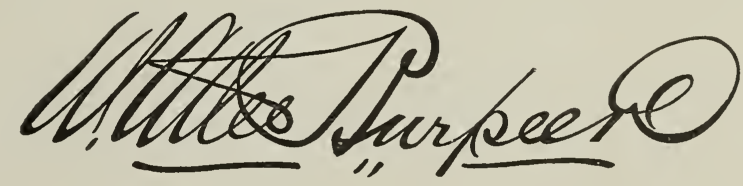

Seed Gardens and Trial Grounds at our famous FORDHOOK FARMS, Bucks County, Pa., SunNybrook Farm, New Jersey, and Floradale Farm, Lompoc, California.

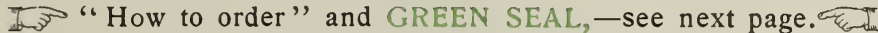

\section{An die amerikanischen Handelsgärtner.}

EIT einer Reihe von Jahren haben wir einen speziellen Katalog für Handelsgärtner veröffentlicht, und das stetige Wachstum unserer Kunden in diesem Beruf beweist am besten, dass die
verstehen.

Und warum? Der Handelsgärtner ist es, der von dem Gelingen oder Misslingen einer Aussaat mehr als jeder andere Pflanzer abhängt. Wenn einem Landwirte ein paar Reihen Gemüse nicht recht gut stehen, dann sät er eben mehr und - wartet. Wenn einem Handelsgärtner eine Aussaat misslingt, dann heisst es einen Gewinn von vielen Dollars einbüssen. Der Markt wartet nicht; wer das Erste und das Beste bringt, der macht das Geschäft, und Gärtner, die Burpee's Samen säen, sind vor den meisten Misserfolgen durch unsere ausgedehnten Versuche geschützt.

Wir wissen, was wir verkaufen. Dies sollte kein Handelsgärtner unterschätzen. Jahr für Jahr unterhalten wir ausgedehnte Versuchsfelder, wo wir Qualität ausprobieren. Es kostet uns viele Tausend Dollars jedes Jahr, den Wert der von uns verkauften Sämereien auszufinden, doch belohnt es sich schliesslich. Unsere Kunden haben durch all die langen Jahre des Bestehens unseres Geschäftes gelernt, uns Vertrauen zu schenken, und wir werden uns auch in Zukunft bemühen, uns dieses Vertrauens würdig zu erweisen.

In der Hoffnung, auch in diesem Jahre mit zahlreichen Aufträgen beehrt zu werden, deren sorgfältige Ausführung wir uns stets angelegen sein lassen werden, zeichnen wir

\section{mit Hochachtung}

W. Atlee Burpee \& Co. 


\section{Best Seeds that Grow for 1914}

TESTED AND PROVED AT OUR FORDHOOK FARMS

Sold Only Under Seal. Every ounce-package is dated as above. der Seal. Packets, although not dated (because the electrotypes generally require the entire front of the bag), contain fresh seeds of the same choice quality. Packets and ounces, in heavy manilla paper bags, bear, plainly printed, either our full firm Name or Registered TRADE MARK, which is protected by United States Letters Patent. Quarter-pounds, half-pounds, pounds, pints, quarts, and two quarts, neatly done up in strong manilla paper bags, are securely sealed with a long green label worded as follows:

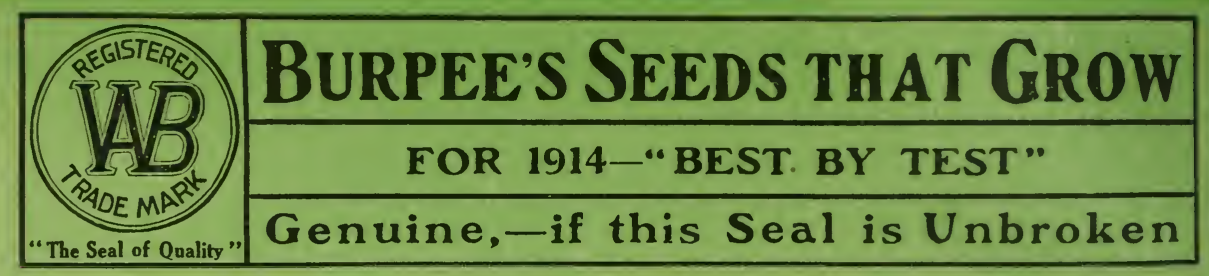

Facsimile of our well=known "Green Seal."

Seeds in Bulk that is, Peas, Beans, etc., by peck or bushel, and quantities of Seeds in BulK, small seeds, have each sack sealed with our Trade Mark on a leaden seal.

331/3 PER CENT. DISCOUNT ON PACKETS

I $\sigma^{\circ}$ After making out your order you will please figure up the total value of Seeds in Retail Packets, at the prices quoted "per packet," and then deduct one-third. Dos Prices by weight or measure, by the trade packet, fraction of ounce and ounce are net.

How to Order. Please be careful to sign your name, post office, county, and . State on each and every letter sent us. Cash should accompany the order. Send money at our risk either by post-office order, express order, bank draft, personal check, or the cash by registered letter. We are responsible for the safe arrival of the seeds in first-class condition,- - therefore you run no risk whatever. We accept postage stamps the same as cash, but prefer either post-office or express money orders.

Our Terms are Cash with the Order, unless you are personally known to us, Our Terms or in a business where we can learn your financial standing from the ratings in the commercial agencies. IN Our prices are fixed too close to cost to allow for losses from bad debts, and hence we must maintain our rule of "cash with the order" or C. O. D. by express, as explained below, excepting only in the cases named, when we shall expect remittance to be made within thirty days.

C. O. D. Shipments when $\$ 2.00$ is only by express (not by freight) dence of for upon arrival. For quantities of more than one hundred pounds the charges by freight are much less than by express, and therefore it is better on large orders to have shipments made by freight, - - remitting the full amount with the order.

There is no reason why you should not remit with the order, as you can easily figure the exact cost, - the prices being given plainly in this catalog, and there are no extra charges except for postage, when seeds are ordered at these prices to be sent by mail.

Seeds by Mail. The prices in this MARKET GARDENERS PRICE LIST do when ordered alone. The purchaser pays freight or express charges upon receipt. If Seeds are ordered by mail, the cost of postage ( $20 z$. for I ct., $8 \mathrm{cts}$. per lb.) must be sent with the order. Peas and beans cost 15 cts. per qt., and Sweet Corn 12 cts. per qt., postage.

I $v^{3}$ Seeds and Bulbs are admitted to The Parcels Post, but at the same old third class flat rate of $\mathbf{2}$ ozs. for $\mathbf{1}$ ct., irrespective of distance carried. To points within one hundred and fifty miles from Philadelphia the weight limit is fifty pounds, while to places further distant a single parcel must not weigh more than twenty pounds. Seeds and bulbs can now be sent $C . O . D$. by mail. You run no risk in sending cash with order. Our reputation as trustworthy responsibility can be ascertained by making inquiry of any Bank, Trust Company, or Wholesale Merchant who subscribes to either of the Commercial Agency Reports. Low We do not charge for bags or boxes.

W. ATLEE BURPEE \& CO., PHiladelphia, PA. 


\section{Helps for Market Gardeners and Florists. BORDEAUX MIXTURE FORMULA.}

Into a 50-gallon barrel pour 30 gallons of water, and suspend in it 6 pounds of bluestone in coarse sacking. Slake 4 pounds of fresh lime in another vessel, adding water slowly to obtain a creamy liquid, free from grit. When the bluestone is dissolved add the lime-milk slowly with water enough to fill the barrel, stirring constantly.

IVith insufficient lime the mixture sometimes injures the foliage, and it should be tested with a solution obtained by dissolving an ounce of yellow prussiate of potash (potassium ferrocyanide) in one-half pint of water. If there be insufficient lime in the Bordeaux mixture the addition of a drop or two of this solution will cause a brownish-red color, and more lime should be added, until no change takes place when the solution is dropped in.

Use the Bordeaux mixture promptly, as it deteriorates on standing.

Stock solutions of both the bluestone and lime may be kept for any length of time. Make the stock bluestone by dissolving in water at the rate of 2 pounds to the gallon. The stock lime is slaked and kept as a thick paste. Cover both mixtures, to prevent evaporation and keep the lime moist. For the 50-gallon formula add 3 gallons of the bluestone solution to 50 gallons of water, and introduce the stock lime slowly until there is no reaction with the testing solution.

\section{KEROSENE EMULSION.}

The best form for ordinary use is the kerosene-soap emulsion, made by combining 2 gallons of kerosene, $1 / 2$ pound of whale-oil soap, or I quart of soft soap with I gallon of water.

The soap should be dissolved in boiling water and then poured while still boiling hot (away from the fire) into the kerosene. The mixture is then churned violently for about five minutes by means of a force-pump and direct-discharge nozzle, throwing a strong stream by pumping the liquid back upon itself. At the end of this time the mixture will have become of the consistency of thick cream. Properly prepared an emulsion will keep indefinitely, and should be diluted only as needed for use. For most insects, except scales or bark-lice, the staple emulsion should be diluted with from 15 to 20 parts of water.

\section{TOBACCO AS AN INSECTICIDE.}

Tobacco is one of the simplest and cheapest methods of controlling plant pests in greenhouses. It should be used upon the first appearance of the insects, since to kill them after they have accumulated in great numbers it is necessary to make the smoke so strong that injury to plants in one form or another is very apt to follow. Light fumigations at regular intervals will keep most kinds of plant-lice in subjection. In the case of fumigation of plants like roses and violets at least a week should elapse after the use of this method before the flowers are picked. A good way of fumigating is to place a few live coals upon a shovel or other metal receptacle, and upon this lay the tobacco. The house to be fumigated is then closed as tightly as possible, and the smoke allowed to remain several hours. From our Leaflet-Insect Pests in the Garden.

\section{Burpee's Instructive Leaflets on Culture are Free to Planters!}

We have published Two "Vest=Pocket", Guides, one on Vegetables, the other on Flowers, either or both of which will be mailed FREE if asked for with orders, as will be also the Special Leaflets on Culture enumerated below.

How to Make an Asparagus Bed.

How to Grow Garden Beans.

Cabbage and Cauliflower.

How to Grow Celery.

Cucumbers, Squashes, and Pumpkins.

Forage Plants.

Herbs: Their Uses and Cultivation.

Horse-Radish, Rhubarb, and Spinach.

Insect Pests in the Garden.

Melons for All.

Mushroom Culture.

Onions from Seed.

How to Grow Peas.

How to Grow Potatoes.

Root Crops for Stock and Market.

Salads and Garnishes.

Tomato Culture.

The Success of Two Missouri Boys.

How to Grow Vegetable Plants.
The "Home-Hamper" of Vegetables.

Manures: Substitutes, Supplements, Fertilizers and Fertilization.

Storing of Vegetables for Winter Use.

How to Establish a Lawn.

How to Grow Sweet Peas.

The "Spencer" Type of Sweet Peas.

How to Grow Nasturtiums.

How to Grow Asters.

How to Grow Begonias from Seed.

How to Grow the Largest Pansies.

Rare Flowers from Seed.

How to Grow Flowers in the House.

Hardy Biennials and Perennials.

Summer-Flowering Bulbs.

Special Culture of Dahlias.

Growing Vegetables and Flowers from Seed on the Pacific Coast.

Thirty-fifth Anniversary Supplement. 


\section{Quantities of Seed Required in Garden and Field Culture}

Artichoke, French, I oz. to Ioo ft. of drill; 6 Gourd, 2 ozs. to Ioo hills. ozs. to an acre.

Horse Radish Roots, I0, 0oo to I 5, 00o to an acre.

Asparagus, $2 \frac{1}{2}$ ozs. to Ioo ft. of drill; $2 \mathrm{lbs}$. Kale, I oz. to $300 \mathrm{ft}$. of drill; 2 ozs. to an acre; will produce enough roots to plant an acre.

Asparagus roots, $5 \times 2 \mathrm{ft}$., about 4400 plants to an acre.

Beans, dwarf, I qt. to Ioo $\mathrm{ft}$. of drill; $\mathrm{I} \frac{1}{4}$ bush. to an acre.

Beans, dwarf, Lima, I qt. to IOo ft. of drill; $3 / 4$ bush. to an acre.

Beans, pole, I pint for Ioo hills.

Beans, pole, in hills, $4 \times 3 \mathrm{ft}$., Io qts. to an acre.

Beans, pole Limas, 20 qts. to an acre.

Beet, Garden, I oz. to $50 \mathrm{ft}$. of drill; $4 \mathrm{lbs}$. to an acre.

Beet, Mangel, I oz. to $100 \mathrm{ft}$. of drill; $5 \mathrm{lbs}$. to an acre.

Beet, Sugar, I oz. to Ioo ft. of drill; $5 \mathrm{lbs}$. to an acre.

Borecole or Kale, I oz. to $300 \mathrm{ft}$. of drill; 2 ozs. to an acre; I oz. will provide about 5000 plants.

Broom Corn, in drills Io lbs., or in hills 4 to 6 qts. to an acre.

Brussels Sprouts, I oz. to $300 \mathrm{ft}$. of drill; 2 oz. to an acre; I oz. will provide about 5000 plants.

Buckwheat, in drills $1 / 2$ bush., broadcast I bush. to an acre.

Cabbage, I oz. to $300 \mathrm{ft}$. of drill; 2 ozs. to an acre; in frames about 6 ozs. to plant an acre; outdoors for transplanting about io ozs. to an acre.

Carrot, I Oz. to $200 \mathrm{ft}$. of drill; $21 / 2 \mathrm{lbs}$. to an acre.

Cauliflower, $\mathrm{I} / 3$ of an $\mathrm{oz}$. to $\mathrm{IOO} \mathrm{ft}$. of drill; $3 \frac{1}{2}$ ozs. to an acre; I oz. will provide about 2500 plants.

Celery, $1 / 3$ of an oz. to Ioo ft. of drill; 2 ozs. to an acre; I oz. will produce from 8000 to I 5,000 plants.

Celeriac, I oz. to $100 \mathrm{ft}$. of drill.

Chervil, I oz. to I oo ft. of drill.

Chicory, I oz. to Ioo $\mathrm{ft}$. of drill, or $4 \mathrm{lbs}$. to an acre.

Chufas, or Earth Almonds, in drills, one peck will plant an acre.

Collards, I oz. to $300 \mathrm{ft}$. of drill; 2 ozs. to an acre; I oz. will provide about 5000 plants.

Corn, Field, in hills, I qt. to 200 hills; 7 to 9 qts. to an acre.

Corn, for fodder, in drills $3 \frac{1}{2} \mathrm{ft}$. apart, 12 to I 6 qts. to an acre.

Corn, in drills, for soiling, 3 bush. to an acre.

Corn, Kaffir, 3 to $5 \mathrm{lbs}$. to an acre.

Corn, Rice, shelled, in hills, 2 qts. to an acre.

Corn, for soiling, 3 bush. to an acre, broad-cast.

Corn, Sweet, from $1 / 4$ to $1 / 2$ pint to 100 hills; in hills, I peck to an acre.

Corn Salad, 3 ozs. to Ioo ft. of drill.

Cress, Curled, $1 / 2$ oz. to Ioo $\mathrm{ft}$. of drill; about 3 lbs. to the acre.

Cress, Water, I oz. will sow I6 ft. square in drills.

Cucumbers, from I to 2 ozs. to IOo hills; I to 2 lbs. to an acre.

Dandelion, I oz. to Ioo ft. of drill.

Egg Plant, I oz. will sow $300 \mathrm{ft}$. of drill or produce from 1000 to 2000 plants; 4 ozs. to an acre.

Endive, $1 / 4 \mathrm{oz}$. will sow roo ft. of drill; $4 \frac{1}{2}$ lbs. to an acre.

I oz. will provide about 5000 plants.

Kohl Rabi, I oz. to $300 \mathrm{ft}$. of drill; $4 \mathrm{lbs}$. to an acre.

Leek, I oz. to Ioo ft. of drill; 4 lbs. to an acre. Lettuce, $1 / 4 \mathrm{oz}$. to $\mathrm{I}$ oo $\mathrm{ft}$. of drill; 3 lbs.to an acre.

Martynia, $1 / 2 \mathrm{Oz}$. of seed to Ioo hills; $5 \mathrm{lbs}$. to an acre.

Melons, Musk, 2 ozs. to IOo hills; $4 \times 4 \mathrm{ft}$. apart, 2 lbs. to an acre.

Melons, Water, 4 ozs. to Ioo hills; $8 \times 8 \mathrm{ft}$. a part, 3 lbs. to an acre.

Mustard, broadcast, 3 to 5 lbs. to an acre.

Nasturtium, 2 ozs. to I Oo ft. of drill; I5 lbs. to an acre.

Oats, broadcast, 2 to 3 bush. to an acre.

Okra, I oz. to IOo ft. of drill; Io lbs.to an acre.

Onion seed, $1 / 2 \mathrm{oz}$. to $100 \mathrm{ft}$. of drill; 4 to 5 lbs. per acre.

Onion seed, for sets, 50 to 80 lbs. to an acre.

Onion sets, small, I qt. to $40 \mathrm{ft}$. of drill; 8 bush. to an acre.

Parsley, $1 / 2$ oz. to I oo ft. of drill; 3 lbs.to an acre.

Parsnips, $1 / 2 \mathrm{oz}$. to $\mathrm{I}$ oO $\mathrm{ft}$. of drill; $3 \mathrm{lbs}$. to an acre.

Peas, Cow, and Field, broadcast, 2 to 3 bush. to an acre.

Peas, Garden, I to 2 pints to $100 \mathrm{ft}$. of drill; $\mathrm{I} / 2$ to 2 bush. to an acre.

Peanuts, Spanish, 2 bush. in pods to an acre.

Pepper, I oz. will produce about I500 plants; 3 ozs. to an acre.

Potatoes, Sweet, 500 plants to 250 to 325 $\mathrm{ft}$. of row.

Potatoes, White, $1 / 4$ bush. of sets (cut pieces) will plant $300 \mathrm{ft}$. of row; 8 to Io bush. of sets in drills will plant an acre.

Pumpkins, I lb. to from 200 to 300 hills; 3 to 4 pounds to an acre.

Radish, I oz. to IOO $\mathrm{ft}$. of drill; IO to I $2 \mathrm{lbs}$. in drills to an acre.

Rape, Dwarf Essex, broadcast, 3 lbs. to an acre.

Rhubarb, I oz. of seed to I $25 \mathrm{ft}$. of drill; $3 \frac{1 / 2}{2}$ lbs. to an acre.

Salsify, I oz. of seed to Ioo ft. of drill; $8 \mathrm{lbs}$. to an acre.

Soja or Soy bean, $1 / 2$ to I bush. to an acre.

Sorghum, broadcast, Io to I 2 lbs. to an acre.

Spinach, I oz. to I oo ft. of drill; $8 \mathrm{lbs}$. to an acre.

Spinach, broadcast, 30 lbs. to an acre.

Squash, Fall and Winter, 8 ozs. to Ioo hills; 3 to $4 \mathrm{lbs}$. to an acre.

Squash, Summer, 4 ozs. to roo hills; 3 lbs. to an acre.

Sugar Cane, 3 to 5 lbs. to an acre.

Sunflower, Mammoth Russian, 8 lbs. to an acre.

Tares, Spring, or Vetch, in drills; I bush. to an acre.

Teosinte, 3 lbs. to an acre, in drills $3 \frac{1}{2}$ to $4 \mathrm{ft}$. apart.

Tobacco, I oz. to 5000 plants; 2 ozs. to an acre.

Tomato, I oz. of seed will produce from 3000 to 4500 plants; 2 ozs. to an acre.

Turnip, I oz. to $200 \mathrm{ft}$. of drill; 2 lbs. to an acre; broadcast, I lb. to an acre.

Vetch, Common Kidney, I bush. to an acre.

Vetch, Hairy, I bush. to an acre.

Wheat, broadcast, I $1 / 2$ to 2 bush.; in drills, $\mathrm{I} 1 / 4$ bush. to an acre. 


\title{
Wholesale Prices of
}

\section{Burpee's Vegetable Seeds}

For Market Gardeners and Farmers' Clubs

\author{
DW THIS LIST CANCELS ALL PREVIOUS QUOTATIONS द्व,
}

By the most thorough garden and field trials of all varieties of Vegetables, we are enabled to keep posted constantly as to the merits and demerits of each variety and of different strains of the same variety. It is our aim always to offer the very best stocks that constant care

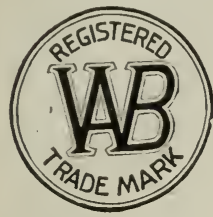
and selection can produce.

We grow seeds, and we grow seeds just as good as we can. BurpeE's Seeds are not "cheap seeds," but are sold at prices as low as seeds of equal quality can be had anywhere. No matter what price you might pay you could not get better seeds.

We have marked with a bull's-eye [○] those that we consider the very best of their respective types, for general

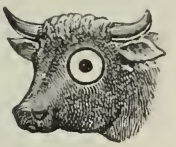
cultivation.

The Prices of Seeds by WEIGHT or MEASURE are NET. $1 / 2$ lb. or $1 / 2$ bushel supplied at pound and bushel rates. The seeds are shipped as directed, either by express or ireight, at expense of the purchaser. rate of 2 ozs. for 1 ct. or 8 cts. per lb., 12 cts. per quart on sweet corn, or 15 cts. per quart on beans and peas) must be sent to cover cost of postage.

I -5 Seeds in retail PACKETS are subject to a DISCOUNT of 331/3 PER CENT. This discount applies only to seeds in retail PACKETS. TुS See page 2.

In s' $^{5}$ Prices by weight or measure, and by the ounce or fraction of ounce, are net.

\section{ARTICHOKE.}

The French or Globe Artichoke is cultivated for the flower-heads which are produced the second season and annually thereafter. The plant is a strong grower and resembles a large thistle in character; it is quite hardy in well-drained soil south of Virginia. Further north it should be wintered in a cold-frame or planted in welldrained ground and covered thickly with long straw during the winter months. Heavy feeding and thorough cultivation are necessary to secure good results. The plants produce the finest "heads" after the second season.

1 Large Green Globe. The standard variety,

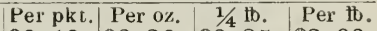

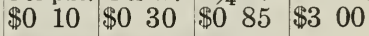

\section{ASPARAGUS.}

Full directions for starting and managing a bed are given in our leaflet, "How TO MAKE AN ASPARAGUS BED," which we send free to customers who ask for it with their orders.

The markets in different cities call for asparagus of different types. Thus the New York market wants a large white or blanched stalk, while the Philadelphia market prefers the green stalk which is grown above the ground. For producing the green-colored stalks Conover's Colossal, Barr's Mammoth, and Palmetto are all desirable, the latter being especially strong and vigorous in growth. GIANT ARGENTEUIL is very popular in the French markets and is quite largely planted by market gardeners in our Southern States. BARR'S MAMMOTH and Columbian Mammoth White, with good feeding, produce very large thick stalks which are naturally light in color and blanch very readily; for most markets they do not require to be blanched artificially.

\begin{tabular}{|c|c|c|c|c|}
\hline $\begin{array}{l}3 \text { Barr's Mammoth. ○ The finest large-sta } \\
5 \text { Columbian Mammoth White. Produces } \\
6 \text { Giant Argenteuil. Stalks large and thick, } \\
\text { y Conover's Colossal. The standard variety } \\
8 \text { Palmetto. Large, thick, dark-green shoots }\end{array}$ & $\begin{array}{r}\text { Per pkt } \\
\$ 0 \text { 0 } \\
5 \\
5 \\
5 \\
5 \\
5\end{array}$ & $\begin{array}{r}\text { Per } 0 z \text {. } \\
\$ 007 \\
8 \\
8 \\
7 \\
7\end{array}$ & 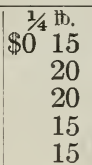 & 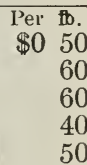 \\
\hline
\end{tabular}

\section{ASPARAGUS ROOTS.}

Conover's Colossal, one year old,.

Conover's Colossal, two years old,

Palmetto, one year old,.

Palmetto, two years old,.

Giant Argenteuil, one year old,

Giant Argenteuil, two years old,

Barr's Mammoth, one year old,

Barr's Mammoth, two years old,... .

Columbian Mammoth White, one year old,

Columbian Mammoth White, two years old
Per 100. Per 500. Per 1000.

$\begin{array}{llllll}\$ 0 & 40 & \$ 1 & 90 & \$ 3 & 75\end{array}$

\begin{tabular}{l|ll|ll}
45 & 2 & 15 & 4 & 25
\end{tabular}

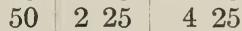

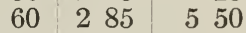

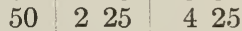

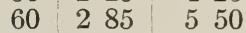

$50 \quad 225 \quad 425$

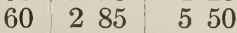

$\begin{array}{llllll}50 & 2 & 25 & 4 & 25\end{array}$

$60 \quad 285 \quad 550$

Ib- Write for special prices on large quantities. 


\section{BUSH BEANS (Green-Podded Varieties).}

These are planted largely in all sections for the early spring market and to a lesser extent for a supply of green string beans during the summer and fall months. While commonly called "string beans " or "snapshorts,"

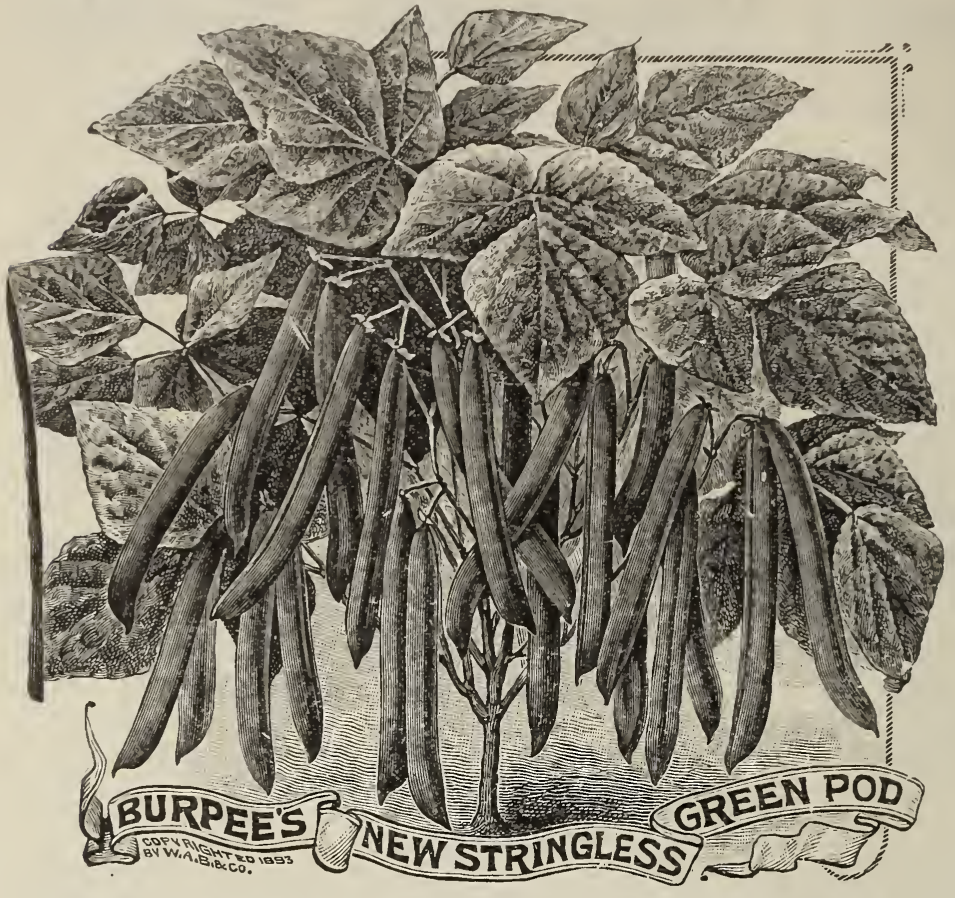
the improved varieties are entirely free from any string or fiber in the pods. In some sections, however, where the season is short, cool, and wet, the older varieties are hardier and less liable to rust than the more fleshy finer pods of the improved types. Next to BurpeE's FORDHOOK FAVORITE (see page 8 ) the very finest and earliest of all green-podded beans is BURPEE'S STRINGLESS GREEN-POD;-under ordinary conditions this can be planted quite early and will withstand as much frost as the older and less desirable sorts. Next in earliness and quality is the Improved Round Pod strain of the Extra Early Red Valentine. The Black Valentine matures early, producing long round straight pods which are tender if gathered quite young. Following these we have the GiantStringless Green-Pod, which produces a larger and equally fleshy pod, but later than either of the above. To fill out the season in this finest type of fleshy green-pod snapshorts we would recommend planting the Extra Early Refugee, to be followed by the well-known Refugee, or Iooo to I. KEENEy's STRINGLESS REFugeE will eventually displace the two preceding strains.

Longfellow is an extra early variety, producing long round, brittle, and stringless green pods. The Early Yellow Six Weeks and the improved or more fleshy-podded Round Yellow Six Weeks are similar in growth to the old and discontinued Early Mohawk, but the pods are not so large nor quite so early; they are, however, more fleshy and finer in quality.

EARLy Bountiful is a stringless Early Six Weeks, with flat, green pods which are tender and stringless; it is prolific and continues in bearing a long time.

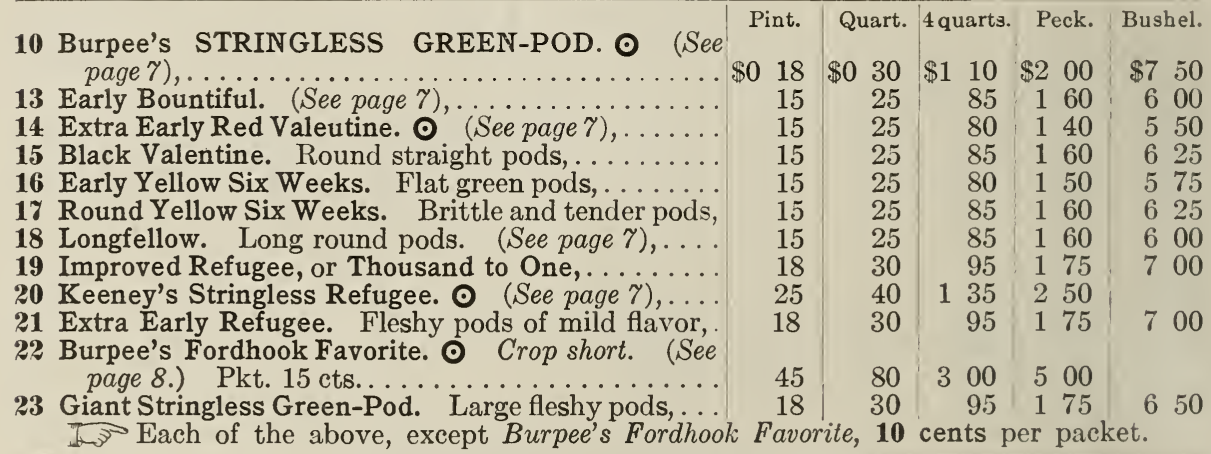

\section{BUSH BEANS (Varieties for Shell Beans).}

These are of two types, - the first of which includes the Dwarf Horticultural and Goddard or Boston Favorite. They are planted in cool New England and other Northern States for use as green shell beans during the summer months, and are grown in sections where the season is too cool for success with the Lima bean. The White Marrowfat is what is known as a soup bean; they are grown on a large scale for sale in a dry state during the winter months. All these varieties should be planted in rows three and a half to four feet apart for horse cultivation, dropping three or four seeds in hills one foot apart in the row. The land should be rich and the plants given frequent cultivation during growth. When pods ripen the plants may be pulled up on a clear day, well dried and stored in a barn for threshing when convenient.

Pint. Quart. 4quarts. Peck. Bushel.

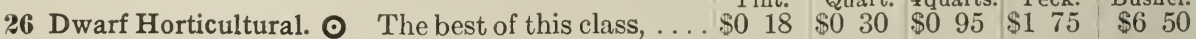

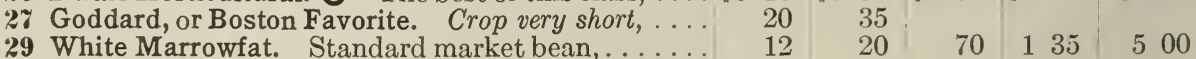

29 White Marrowfat. Standard market bean, . . . . . 12 . 120 
10 Burpee’s Stringless Green-Pod.๑

This famous Bean, first named and introduced by us twenty years ago, is unequaled! It combines unusual hardiness, extreme eurliness, and wonderful productiveness with pords of handsome appearance and finest quality. Extra early plantings may be made to produce the earliest crop, and even with

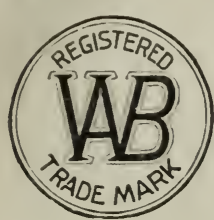
later plantings BURPEE'S “STRINGLESS” is the quickest to produce pods.

By repeated plantings pods may be had in constant succession from spring until cut off by heavy frosts in the fall. Combined with the extra hardiness and early maturity, the pods are the finest in quality, of a rich green, very round and straight, five inches long, solidly meaty and broad,-deeply suddle-backed, caused by the rounded swell of the fleshy sides. The pods are tender, brittle, and of finest flavor, always entirely stringless even when fully matured. In a word, all planters now agree that BURPEE's STRINGLESS is absolutely unequaled! We could fill many pages with testimonials and enthusiastic reports. Per pkt. 10 cts.; pint 18 cts.; quart 30 cts.; 4 quarts $\$ 1.10$; per peck $\$ 2.00$; per bushel $\$ 7.50$.

${ }_{20}$ Bean, - Keeney's Stringless Refugee. $\odot \quad \begin{aligned} & \text { For many years the Refugee has } \\ & \text { been recognized as one of the most }\end{aligned}$ desirable sorts, but unfortunately the pods have had always a slight string. In this "STRINGLess" REFTGEE the string has been entirely eliminated, while the variety has lost none of its good qualities. Of true bush habit, the plants attain a height of eighteen inches and are very prolific. The broad, handsome pods, nearly round in form, average about five and a quarter inches long; of a light-green color, they are brittle, tender, fleshy and absolutely stringless at all stages of growth. Our regular strain of Refugee (No. I9 on page 6) is extra fine and has been purchased eagerly by planters and canners everywhere, but if we "know beans" (and we think we do!), this NEw STRINGLESS REFUGEe will eventually displace all other strains. It is unequaled for commercial canning, as the tender pods retain their color, and being entirely stringless the quality of the canned goods will be far superior. See illustration of pod to the left. Crop very short. Per pkt. 10 cts.; pint 25 cts.; quart 40 cts.; 4 quarts $\$ 1.35$; peck $\$ 2.50$.

\section{${ }_{14}$ Extra Early Red Valentine $\odot$}

(Improved Round=Pod Strain). Plants are of dwarf, compact bush growth, fifteen to eighteen inches high, very prolific; they are hardy and early in maturing. Pods are four inches long, sharply pointed, round and very fleshy, being deeply saddle-backed, brittle even when fully grown, with strong strings, which are easily removed when preparing pods for cooking. The pods are of fine flavor and next best in quality to Burpee's Fordhook Favorite and Burpee's Stringless Green-Pod. Per pkt. 10 cts.; pint

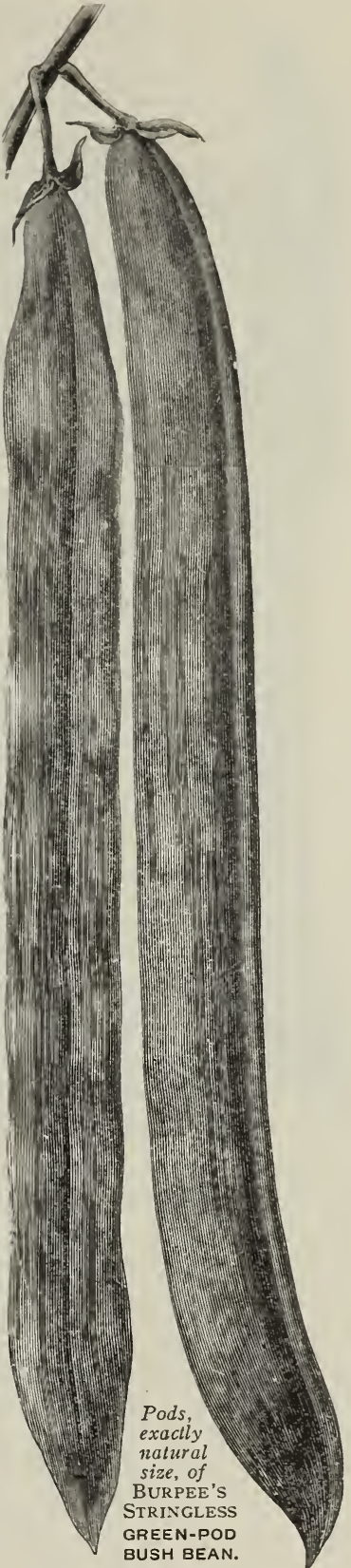

15 cts.; quart 25 cts.; 4 quarts 80 cts.; peck $\$ 1.40$; bushel $\$ 5.50$.

Early Bountiful. Of thrifty growth and very hardy. The 13 Early Bountiful. stringless and tender flat green pods are produced very early in the season and the bush continues in bearing for a long time. It is practically a stringless Early I ellow Six Wceks. Per pkt. 10 cts.; pint 15 cts.; quart 25 cts.; 4 quarts 85 cts. ; peck $\$ 1.60$; per bushel $\$ 6.00$.

Undoubledly the very best strain of REFUGEE in cultivation. Especially desirable for canners.
18 Longfellow. An extra early variety producing long round less when 4 quarts 85 cts.; peck $\$ 1.60$; per bushel $\$ 6.00$. 


\section{: Burpee's Fordhook Favorite Bush Bean, $\odot$
A White-Seeded Stringless Green-Pod.}

This is undoubtedly the best green=podded bush bean yet produced! The original Burpee's Stringless Green-Pod, so long famous as unequaled, matures from three to five days earlier, however, and for first-eurly will probably still remain as popular as ever. Market gardeners to whom a few days do not matter will probably prefer this New White=Seeded Stringless Green=Pod when the seed cun be hud in sufficient quantity.

The bushes attain a height of eighteen to twenty inches, are very vigorous, and their prolific character is immediately noticed when one separates the foliage at the top. The leaves are of a bright dark green, quite heavy, but not overabundant, so that the strength of the plant is concentrated upon the production of an enormous crol of handsome pods. The pods measure from five and one-half to six and one-half inches long; they are one-half inch wide and one-half inch thick,- - so full and fleshy that they are almost perfectly round. They are brittle, juicy, entirely free from fiber and $a b$ solutely stringless at all stages of growth. The seed being white can be used for dried beans in the winter. Crop very short. Per pkt. 15 cts.; $1 / 2$ pint 25 cts.; pint 45 cts.; quart 80 cts.; 4 quarts $\$ 3.00$; per peck $\$ 5.00$.

\section{Large-Seeded Stringless Bush Bean,- ${ }_{55}$ Burpee's White Wax.๑} Of sturdy, upright growth, the bushes are heavily laden with a magnificent crop of large handsome wax pods. The pods are straight, of a bright lemon-yellow, brittle, meaty, and entirely stringless at all stages of growth. It is what canners and truckers have been seeking for years, - as it combines quantity, quality, and beauty in the pods, which can be used as a string-bean until large enough to shell, while the seed, being large and pure white, is most desirable as shell-beans both for summer and winter use.

\section{"Stringless" White Wax is the first} seeded Wax Bean of really fine quality! The beans, being pure white, present the most attractive appearance when cooked; - the fresh pods remain tender longer than those of any other variety. The plants continue in bearing for a long period. It outyields the prolific Davis' White Wax, while it is incomparably superior in quality! Planters report that for snapshorts, for green shell-beans, and as a dry bean BurpeE's White WAX is the

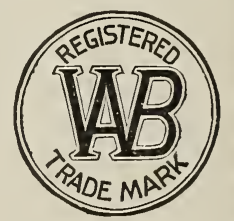
finest they have ever grown. Unfortunately, the stock still throws a few green pods. Per pkt. 10 cts.; pint 20 cts.; quart 35 cts.; 4 quarts $\$ 1.30$; per peck $\$ 2.50$; per bushel $\$ 9.00$.

\section{${ }_{41}$ Rust-Proof Golden Wax. $\odot$}

Pods rather flat, but of good quality; four inches in length, half an inch broad, of light golden yellow; quite brittle, with only slight strings when young. Plants stiffly erect, bearing a large crop of fine pods held well above the soil. Pkt. 10 cts.; pint 20 cts.; quart 35 cts.; peck $\$ 2.25$; per bushel $\$ 8.50$.

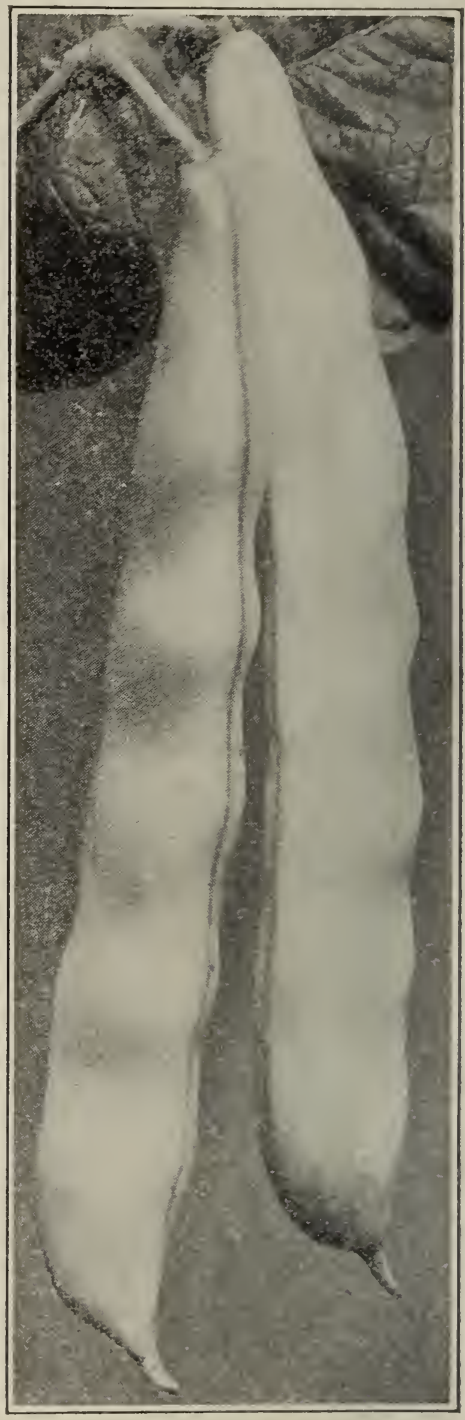

BURPEE'S STRINGLESS WHITE VIAX BEAN. 


\section{BUSH BEANS (Wax-podded Varieties).}

In these yellow- or golden-podded sorts, which are frequently called "Bulter Beans," we have similar distinct types in pods as in the green-podded sorts. That is, the older varieties with flat pods have more tendency to strings and fiber than the improved round pod strains, which are solidly fleshy and entirely stringless. Of these fine round-pod sorts BURPEE'S BRITIV IV is the est development closely followed by BURPEE'S SADDLE BACK WAX. Both are of strong growth, producing round pods of good length which are so fleshy that they are sliglitly saddle-backed or creased down the center of the pod. Prolific Dou pod. IVax is the earliest maturing wax-poddec variety and is largely planted for market. PENCIL-PoD B L IVAX has magnific straight rounded pods, light golden yellow in color, and of the finest quality; a fine variety to succeed Burpee's Saddleback Wax. The REFUGEE WAX resembles the green-podded Refugee both in season and character of pod.

The older types with flat pods are still more readily salable in some localities. We

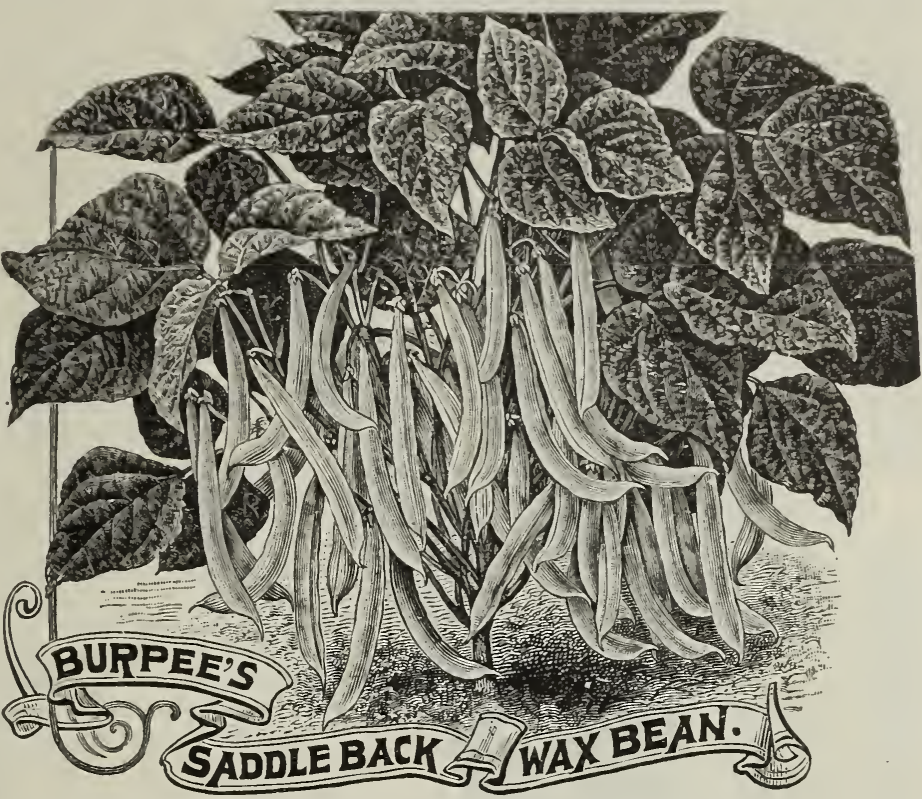
do not consider them.

as a rule, so productive nor as desirable as the improved round-pod strains. The standard variety of this type is the popular Rust-PRoOF Golden WAx. Wardwell's Kidney Wax, Currie's Rust-Proof IVax, and Davis' While Wax are all good varieties of this type and excellent market sorts.

BURPEE'S NEW KIDNEY IVAX is a decided improvement on the Wardwell's Kidney Wax, with longer and more fleshy pods, absolutely free from strings, with a stronger growth and nearly twice as productive. BuRPEE'S IVHITE WAX, our new flat pod white-seeded wax bean, bearing straight handsome golden pods, is free from rust, strings, or fiber; the best of its type for market or canners, while the white beans are readily salable for winter use. Hodson Wax is most desirable to grow for market on account of its great productiveness; the long, handsome pods are almost blight or rust proof, but must be picked while young, as they quickly become quite tough.

33 Burpee's Brittle Wax. $\odot$ (See page 10),

36 Prolific Black Wax. Extra early. Crop short,

41 Rust-Proof Golden Wax. $\odot$ (See page 8),

44 Burpee's New Kidney Wax. $\odot$ (See page 10),

45 Wardwell's Kidney Wax. Straight flat pods,

48 Pencil-Pod Black Wax. $\odot$ Straight rounded pods,

50 Burpee's Saddleback. $\odot$ (See page 10),

51 Hodson Wax. Long flat pods. .

52 Currie's Rust-Proof Golden Wax. Productive,

54 Refugee Wax. Pods stringless,

55 Burpee's Stringless White Wax. $\odot$ (See page 8),

56 Davis' White Wax. Popular with canners,...
Pint. Quart. 4 quarts Peck. Bushel.

$\begin{array}{llllllllll}\$ 0 & 20 & \$ 0 & 35 & \$ 1 & 30 & \$ 2 & 50 & \$ 9 & 00\end{array}$

$\begin{array}{lllllll}20 & 35 & 1 & 00 & 1 & 75\end{array}$

\begin{tabular}{llll|lllll}
20 & 35 & 1 & 25 & 2 & 25 & 8 & 50
\end{tabular}

$\begin{array}{llllllll}20 & 35 & 1 & 30 & 2 & 50 & 9 & 00\end{array}$

$\begin{array}{llll:llllll}15 & 25 & 1 & 00 & 1 & 90 & 7 & 50\end{array}$

$25 \quad 40 \quad 150 \quad 2500050$

\begin{tabular}{l|lll|llll}
20 & 35 & 1 & 25 & 2 & 35 & 8 & 75
\end{tabular}

\begin{tabular}{l|lll|lllll}
18 & 30 & 1 & 00 & 1 & 85 & 7 & 25
\end{tabular}

$\begin{array}{lllllllllll}20 & 35 & 1 & 25 & 2 & 00 & 7 & 75\end{array}$

$\begin{array}{llllllll}20 & 35 & 1 & 25 & 2 & 00 & 7 & 75\end{array}$

\begin{tabular}{l|lllll|lll}
20 & 35 & 1 & 30 & 2 & $50 \cdot$ & 9 & 00
\end{tabular}

$\begin{array}{llllllllll}18 & 30 & 1 & 00 & 1 & 75 & 7 & 00\end{array}$

In Each of the above, $\mathbf{1 0}$ cents per packet.

Our Seed Beans are Extra Fine! They are grown from pedigree strains rogued are really worth one or two dollars more per bushel than are the less carefully selected stocks, such as are usually sold, and yet the difference in price is not so great! It pays to plant the Best.

For thirty-seven years we have stated plainly that, where failure is caused by any fault of the seed, we would refund the full price paid. This should convince even new customers that we have confidence both in the quality of Burpee's Seeds and in the great care exercised in their growing, cleaning and packing. No honest seedsman could assume responsibility for more than the price actually paid by the purchaser.

"The Value of a Guarantee is not in what is said, but who says it." 


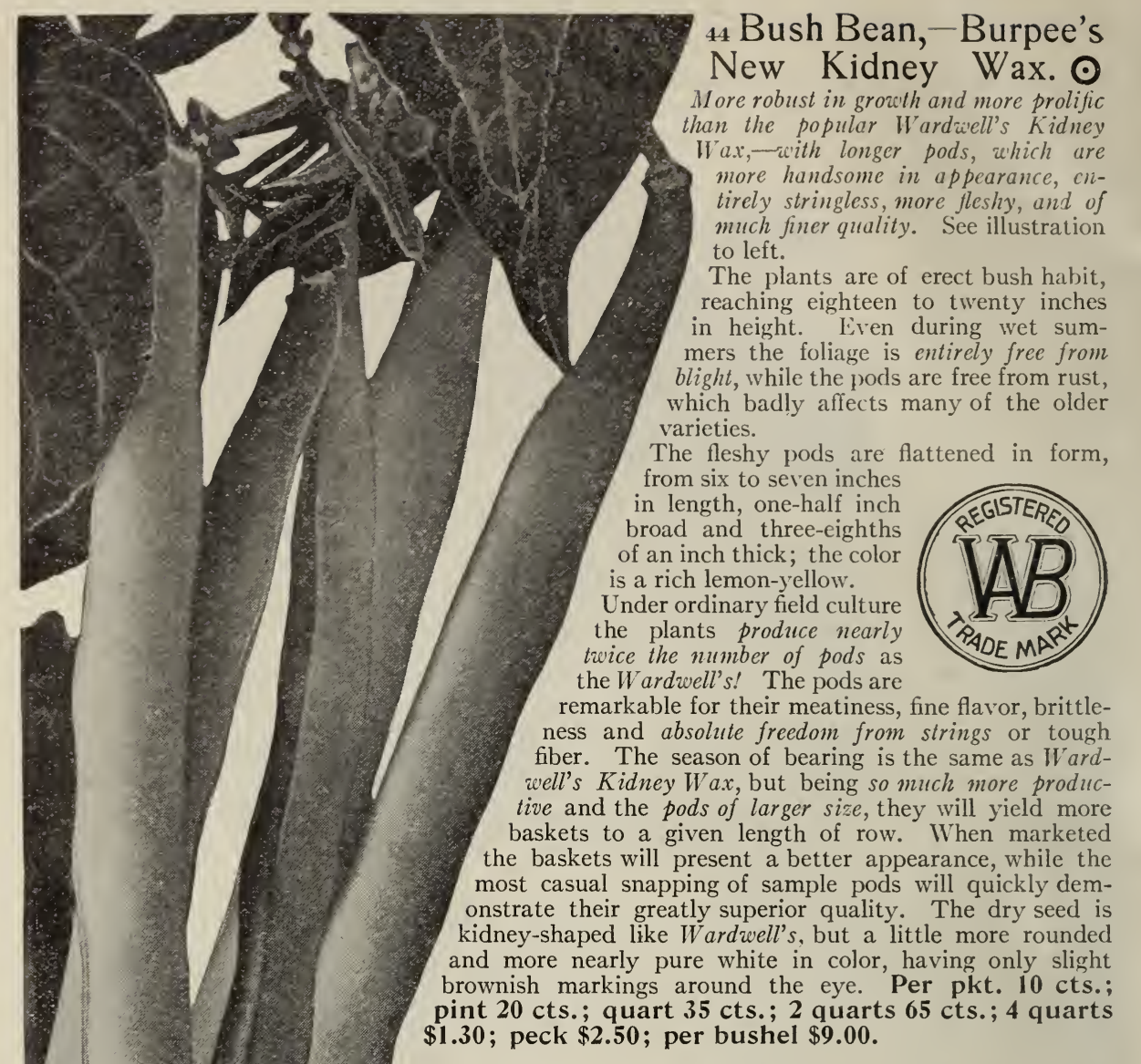

50 Burpee's Saddleback Wax.๑ $\begin{gathered}\text { The } \\ \text { plants }\end{gathered}$

are of strong bush growth, fifteen inches in height, extra productive. The pods are long, nearly straight, well rounded, and so meaty as to be saddle-backed or creased in the center. The pods are so fleshy that the space between the beans is solid meat without any open spaces,- extremely

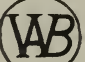
brittle, always stringless, of a rich golden yellow and finest flavor. Per pkt. 10 cts.; pint 20 cts.; quart 35 cts.; 4 quarts $\$ 1.25$; peck $\$ 2.35$; per bushel $\$ 8.75$.

\section{Bush Bean, - 3 Burpee's "Brittle} Wax."॰ The earliest of all Wax Beans! of called the "Best of All!" The bushes are remarkably hardy and extremely prolific, while the handsome fleshy pods are entirely stringless and of the finest quality.

Brittle Wax has already "made a record,"-altogether unearliness, and great productiveness. It combines the most desirable features of both parents,- the Black-Eye W'ax and the Round-Pod Refugee. The plants are of vigorous growth, with large foliage, and appear completely loaded with handsome pods, which are nearly straight and measure $4 \frac{1}{2}$ to 6 inches long. They are

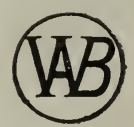
very broad and solidly fleshy,-deeply saddle-backed,-"brittle," and entirely stringless. The pods are unexcelled as snapshorts, while having white seeds showing only a small black dot at the eye. any surplus allowed to ripen will be readily salable as winter shell beans. Per pkt. 10 cts.; pint 20 cts.; quart 35 cts.; 2 quarts 65 cts.; 4 quarts $\$ 1.30$; peck $\$ 2.50$; per bushel $\$ 9.00$. 


\section{${ }_{63}$ The "Burpee-Improved” Bush Lima.॰}

The pods are truly enormous in size,-borne abundantly and well filled with handsome beans which are both larger and thicker than those of the popular Burpee's Bush Lima,- and fully eight days earlier! It differs from the best strains of Burpec's Bush Lima in having uniformly much larger pods, producing more beans, while both pods and beans are not only larger in size but also considerably thicker." The

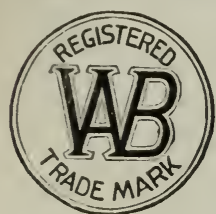
growth is even more vigorous, with heavier foliage. The plants are uniformly upright. Full-grown bushes measure thirty inches in height and twenty-four inches across the top. The blossom-bearing stalks are thrown well out from the foliage and the pods are borne frequently in what might be called "clusters" of from five to eight. The pods measure five to six inches long by one and one-quarter inches wide. Even when of full size the enormous beans are of the most luscious flavor; they are thin skinned and truly delicious; they are ready to market eight to ten days earlier. Per pkt. 15 cts.; $1 / 2$ pint 18 cts.; pint 30 cts.; quart 50 cts.; 2 quarts 90 cts.; 4 quarts $\$ 1.75$; peck $\$ 3.25$; per bushel $\$ 12.50$.

${ }_{65}$ Fordhook Bush Lima Bean.๑

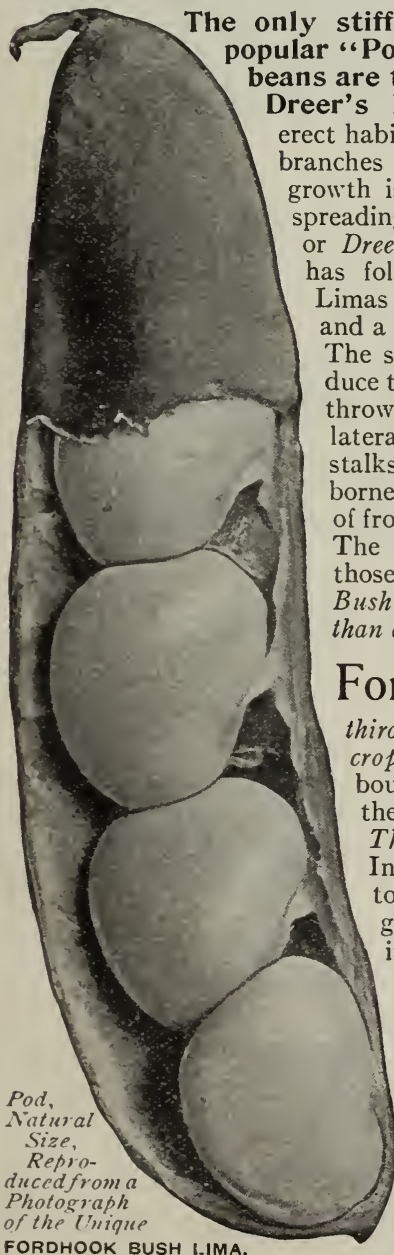

$y$ erect Bush form of the popular "Potato" Lima! Both pods and eans are twice the size of Kumerle or Bush Lima. Bushes of stiffly ect habit, branching freely but with all the held upright. This ideal bush ding growth of the Kumerle (Thorburn Dreer's) Bush Lima. THE FordHoOK foliage like that of the large pole imas; the leaves are large, smooth, and a dark rich green. The stalks that prouce the blossoms are thrown out from the ateral and main ks; the pods are from four to eight. pods resemble ose of the Kumerle (Dreer's) han double the size.

Fordhook

is fully thirtyper cent. a heevio cropper and, therefore, is bound to entirely displace the Kumerle (Dreer's or Thorburn's) Bush Lima. In season it is from four to six days earlier. The

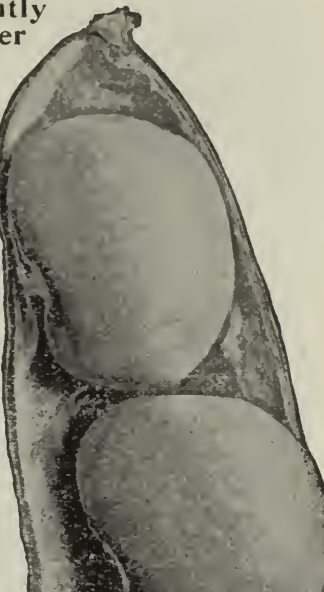



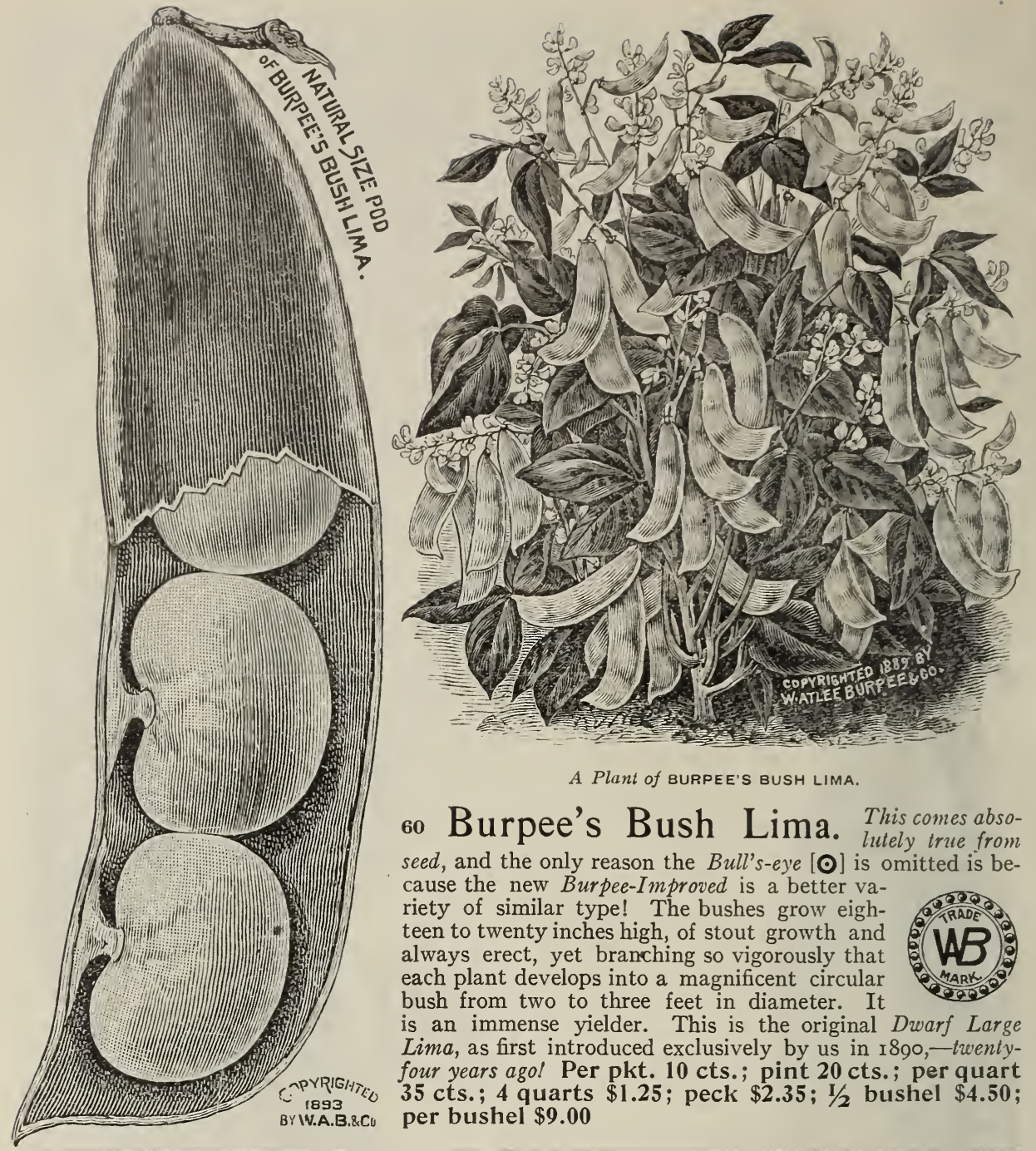

A Plant of BURPEe'S BUSH LIMA.

60 Burpee's Bush Lima. This comes absoseed, and the only reason the Bull's-eye [०] is omitted is because the new Burpee-Improved is a better variety of similar type! The bushes grow eighteen to twenty inches high, of stout growth and always erect, yet branching so vigorously that each plant develops into a magnificent circular bush from two to three feet in diameter. It

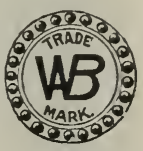
is an immense yielder. This is the original Dwarf Large Lima, as first introduced exclusively by us in 1890 , - twentyfour years ago! Per pkt. 10 cts. ; pint 20 cts. ; per quart 35 cts.; 4 quarts $\$ 1.25$; peck $\$ 2.35$; $1 / 2$ bushel $\$ 4.50$; per bushel $\$ 9.00$

\section{DWARF OR BUSH LIMA BEANS.}

In Bush Limas, as in the pole sorts, there are three distinct types, the earliest of which is the Sinall Sieva or "Butter Bean" of the South. This has small dark-green leaves and small glossy pods. It is extremely early and very productive in light warm soils. Of this type we offer the Henderson Bush Lima and the Wood's Prolific or Improved Henderson, which produces pods and beans about one-third larger than those of the Henderson. BuRPEE'S BUSH LIMA is the dwarf prototype of the Large White Lima, and is of the best market type of Bush Lima Bean, requiring no support and having the advantage of being at least two weeks earlier than the pole type; Burpee's Bush Lima will now have to give way to THE BURPEE-IMPROvEd BuSH LIMA offered on page II.

The third type is the Kumerle or Dreer's Bush Lima, generally known as the Potato Lima. The plants of this variety do not grow upright but spread rather flatly on the ground. The pods come in clusters and are shorter in length than those of the Large Lima, but the beans are quite thick and closely crowded together. BURPEE'S FORDHOOK BUSH LIMA, offered on page II, is bound to displace the Kumerle Bush Lima.

60 Burpee's Bush Lima. Handsome large pods,

Pint. Quart. 4quarts. Peck. Bushel. 63 The "BURPEE-IMPROVED" BUSH LIMA. ๑ Produces large thick beans. (See page 11.) Per pkt. 15 cts.,

$\begin{array}{llllllllll}\$ 0 & 20 & \$ 0 & 35 & \$ 1 & 25 & \$ 2 & 35 & \$ 9 & 00\end{array}$

ORDHOOK BUSH LIMA. ○ The best "potato Lima." (See page 11.) Per pkt. 15 cts., . . . ... .

66 Kumerle, or Dreer's Bush Lima. Crop very short, .
$6 y$ Henderson's Bush Lima. Early and prolific,......

67 Henderson's Bush Lima. Early and prolific,

I ${ }^{\circ}$ Each of the above, except where priced, 10 cents per packet. 


\section{BEANS,-POLE OR RUNNING (Snapshorts, Green- and Wax-Podded Varieties).}

The pole varieties of snapshorts are planted in many sections for a succession to the dwarf busl sorts, because they bear more continually and are more productive. They can be grown either on stout poles, trellis of wire or string, while some varieties are planted with corn,-the corn-stalks forming a suitable support on which the beans climb.

In green-podded snapshorts WHITE CREASEBACK is the earliest and one of the best, having slender round pods which are quite fleshy, brittle, and entirely stringless. "KENTUCKY IVONDER," or Old Homestead, is almost equally as early and yields a much larger pod, frequently eight to nine inches long, very meaty and deeply saddlebacked. Both of these continue in bearing only for a rather limited period. In the BURGER'S STRINGLESS we offer a flesliy round, green-podded snap bean which is as early as the Creaseback, as large as the Kentucky Wonder. and continues much longer in bearing. We consider this the best all-round snap bean of pole growth,-in some localities it is called White-Seeded Kentucky Wonder.

The LAZY IVIFE is a favorite variety on account of its strong growth and great productiveness, as well as the fine flavor of the pods. These are produced in large clusters and are from four to five inches in length, flattened in form, but fleshy when ready for use as a snapshort during September; the dry seed, being of good size, round and pure white, makes it an excellent shell bean for winter use.

The GOLDEN CLUSTER IVAX is an excellent variety with handsome large pods, while the pure white beans can readily be marketed as dry beans during the winter. BURPEE's SUNSHINE WAX produces large waxen-yellow pods of fine flavor. The Horticultural or Wren's Egg is used as a green shell bean in the New England States where the summer is too cool for success with Lima Beans.

The Scarlet Runner is grown both as an ornamental bloomer and for pods, the latter being gathered while young and tender and cut into thin slices and cooked in the same manner as the green-podded snapbeans. Vines are extra hardy and well adapted for a short season or cool location. White Dutch Case Knife is early, has large flat pods and is popular in some sections as a winter shell bean. The Yard Long is a distinct type and has slender fleshy pods two to three feet in length which make good snapshorts; this variety is, of course, grown mostly as an interesting curiosity.

\begin{tabular}{|c|c|c|c|c|c|}
\hline & $\begin{array}{l}\text { Pint. } \\
\$ 018\end{array}$ & $\begin{array}{l}\text { Quart. } \\
\$ 030\end{array}$ & $\begin{array}{l}4 \text { quarts. } \\
\$ 100\end{array}$ & $\begin{array}{l}\text { Peck. } \\
\$ 185\end{array}$ & $\begin{array}{l}\text { Bushel. } \\
\$ 700\end{array}$ \\
\hline $\begin{array}{l}\text { (White-seeded Ken- } \\
\text { ound pods, . . . }\end{array}$ & & & & & \\
\hline aseback. Ear & 18 & & & & \\
\hline Wife's." Very prolific; flat & 18 & 3 & & & \\
\hline e's Sunshine Wax. $\odot$ Yellor & 20 & 35 & & & \\
\hline ter Wax. Long yell & & & & & \\
\hline Case Knife. Fine & 1 & & & & \\
\hline en's Egg: & & 25 & 85 & & \\
\hline & & & & & \\
\hline
\end{tabular}

Each of the above, $\mathbf{1 0}$ cents per packet.

91 Yard Long (Cuban Asparagus Bean). A curiosity; small packets only. Per pkt. 10 cts.

\section{POLE LIMA BEANS.}

Although the dwarf or bush type of Lima have to some extent displaced the pole Lima for market plantings, the latter is desirable for its greater productiveness and long-continued bearing. For a profitable crop the pole Limas need rich soil, stout poles or wire and string supports on which to grow, and thorough cultivation. There are three distinct types, with quite a number of different varieties or strains, the earliest being the Small Carolina, or Sieva, which is very productive but has only small-sized pods and beans. These are popular in the South, where they are known as "Butter Beans."

Of the true Large Limas, the earliest is the EARLY LEviathan, which repeated trials have proved to be the most productive early strain. BURPEE'S NEW "GIANT-PODDED" is the largest podded and heaviest cropper of all Limas. It ripens earlier than King of the Garden and outyields this popular variety - the shelled beans are invariably of superb flavor. KING OF THE GARDEN is an improved strain of the Large White Lima, and in good ground produces an enormous crop of fine large beans, which frequently come five to a pod. THE IDEAL is a new main-crop variety maturing a large crop of large pods before frost.

Challenger, also called "Dreer's Pole" Lima, or Potato Lima, has a short thick pod, containing three to four beans each. The beans are very plump, closely crowded together in the pod. It is immensely productive and the beans easily shelled, but rather dry and mealy when cooked. This type is especially desirable for a late market.

96 Early Leviathan. $\odot$ (See page 14),

94 New Ideal. Large pods,

97 Large White Lima. The well-known standard,

98 Burpee's New Giant-Podded. ○ Produces very large pods. (See page 14.) Pkt. 15 cts.,......

99 King of the Garden. (See page 14),

101 Challenger, or Dreer's Improved. The "Potato Lima." (See page 14),

103 Carolina or Sieva (Small Lima). Early and prolific. (See page 14), . . . . . . . . . . . . ....

Ir Each of the above, except Burpee's New Giant-Podded, 10 cents per packet.
Pint. Quart. 4 quarts. Peck. Bushel.

$\$ 020 \quad \$ 035 \quad \$ 135 \$ 250 \quad 950$

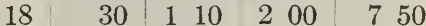

\begin{tabular}{l|l|l|l|l|l|l|l}
15 & 28 & 1 & 00 & 1 & 85 & 7 & 00
\end{tabular}

$\begin{array}{lllllllll}30 & 50 & 1 & 75 & 3 & 25 & 12 & 00\end{array}$

\begin{tabular}{llllll|ll}
18 & 30 & 1 & 10 & 2 & 00 & 7 & 50
\end{tabular}

$\begin{array}{llllllll}18 & 30 & 1 & 10 & 2 & 00 & 7 & 50\end{array}$

$\begin{array}{llllllll}15 & 28 & 1 & 00 & 1 & 85 & 7 & 00\end{array}$

"Butter Beans." In the South the Sieva or small Lima, whether of dwarf or tall growth, is the variety. Is Please state which You want!

- A Bull's Eye is used to mark those varieties which we consider the best of their respective order, you can rely upon obtaining the may prefer others for your section. Of whichever varieties you strains that have been produced for planting in sor - The Best 66 Seeds that Grow. 


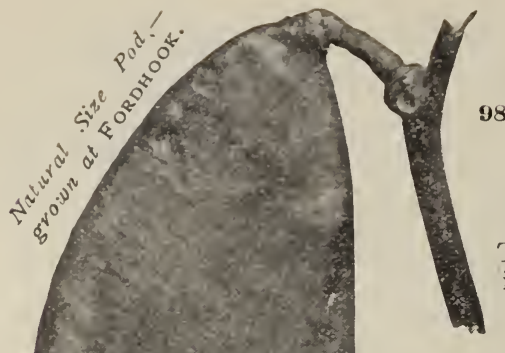

Five Fine Pole Lima Beans,-

98

\section{Burpee's Giant-Podded. $\odot$}

The Largest Podded and Heaviest Cropper of all Lima Beans.

The pods are truly gigantic in size,-frequently measuring from seven to eight and one-half inches in length by

from one and a half to nearly two inches in width. The beans are extra large and of superb flavor. The skin, while thin and tender, is of sufficient strength, so that after shelling the beans are not liable to crack when shipped to market.

Burpee's Giant-Podded is earlier than King of vine yields many more as well as much larger pods! Exceptionally vigorous in growth, the vines attain a height of from ten to twelve feet. A notable characteristic is that when well grown, each vine produces from ten to fifteen laterals or branches,-from the main stalk close to the ground. These lateral branches produce great numbers of the large handsome pods very early for so large podded a variety.

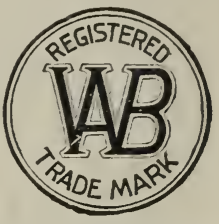
These first pods are succeeded by those on the upper part of the vine, so that the vines carry a tremendous crop,-and continue to bear abundantly until killed by frost.

Burpee's Giant-Podded $\begin{aligned} & \text { excels all other Limas } \\ & \text { in its tremendous vigor }\end{aligned}$ of growth. In rich ground we would recommend planting only two or three seeds to a hill and thinning out to one plant. 'The gigantic pods, borne in clusters of from four to eight, stand out well from the foliage.

\section{Burpee's Giant-Podded Lima will be to} the Pole Lima class what the Burpce-Improved Bush Lima is to other Bush Limas,- the largest podded, largest seeded, and most productive! Private planters often object to size in vegetables, for fear size may be at the expense of quality, but with BurpeE's Giant-PodDed Lima such is not the case, as the beans are always of the most delicious flavor. Per pkt. 15 cts.; pint 30 cts.; per quart 50 cts.; 2 quarts 90 cts.; 4 quarts $\$ 1.75$; per peck $\$ 3.25$; per bushel $\$ 12.00$.

96 Early Leviathan. $\odot$ This is the very earliest. It will not only give large lime ductive, both early and throughout the season. It is a strong grower, clinging well to the poles, and is a sure cropper. The pods differ from those of other early pole limas in being straighter and longer. The pods hang out from the foliage in large clusters and contain three or four and sometimes five large beans to the pod. Per pkt. 10 cts.; pint 20 cts.; quart 35 cts.; 4 quarts $\$ 1.35$; peck $\$ 2.50$; per bushel $\$ 9.50$.

${ }_{99}$ King of the Garden. A strong grower and uniformly quently contain five to six very large large podded. The pods frelent quality, easily shelled; of large size and handsome appearance. Per pkt. 10 cts.; pint 18 cts.; quart 30 cts.; 4 quarts $\$ 1.10$; per peck $\$ 2.00$; per bushel $\$ 7.50$.

101 Challenger, DREER'S or "POTATO" LIMA. Plants are large flat sorts. The pods are produced in clusters, and average three to four inches in length; they are quite thick through, containing three to five thick beans, the ends of which are flattened by being crowded closely together. Per pkt. 10 cts.; pint 18 cts.; quart 30 cts.; 4 quarts $\$ 1.10$; per peck $\$ 2.00$; per bushel $\$ 7.50$.

103 Carolina, Sieva or "Sewee" (The "butter bean" of the ture ture early, are immensely. productive, and continue in bearing throllgholit the season. The vines
are slender, with rather small, shiny dark-green leaves. Per pkt. 10 cts.; pint 15 cts.; quart 28 cts.; 4 quarts $\$ 1.00$; per peck $\$ 1.85$; per bushel $\$ 7.00$. 


\section{GARDEN BEETS (for Table Use).}

Beets are an important feature in most market garden operations. The aim is to secure the very earliest crop in the spring; for this purpose we consider that some of the newer improved varicties are most desirable. producing large and finer roots earlier in the season than the standard extra early sorts. To have beets always in best possible condition for the table it is best to plant seed every two weeks during the season, as there are few vegetables that are as palatable as very young beets. Of these new extra early varieties we would name the New EARLy MODEL, BURPEE'S BLACK-RED BALL, CRIMSON GLOBE, and DETROIT DARK RED. These are all excellent varieties of quick growth, round form, dark, richly colored flesh of finest quality, and are ready for market in the order named. EPICURE is a new main-crop half-long variety producing deeply colored roots of finest flavor.

Of the older varieties, the nearly flat Extra Early Egyptian is the earliest and of the quickest maturity. Next to this come Burpee's Extra Early and Crosby' Egyptian, which are deeper in form, being more nearly round. Edmand's Early, Eclipse, and Dewing's Improved Blood are special strains of decided merit.

BURPEE'S IMPROVED BLOOD and BURPEE'S COLUMBIA grow to quite a large size and have richly colored flesh of the finest quality; they are both excel lent as main-crop varieties. DARK STINSON is exceptionally dark and rich in the coloring of the flesh, but does not grow so large as Columbia.

Long Smooth Blood is planted mainly for winter use and has flesh of the darkest, richest coloring. Baslian's Half-Long Blood is an excellent main-crop variety; the roots are olive-shaped, and have dark red flesh. Early Yellow Turnip is but little grown for market; it is sweet in flavor.

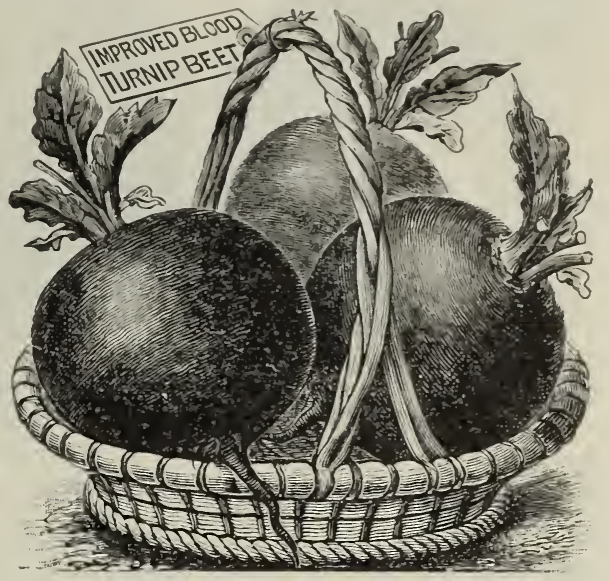

SiviSS CHARD is grown exclusively for tops, the leaves being used as a boiling-green, or the large white stalks are cooked and used in the same manner as asparagus. Lucullus is a distinct strain of Swiss Chard; the leaf is larger than in the regular type and is decidedly crumpled or "savoyed."

IN In lots of 5 pounds each at 5 cents per pound less.

107 Burpee's Extra Early. Extra choice first-early,

109 Extra Early Egyptian. Quick growing; flattened blood turnip,

111 Crosby's Egyptian. Smooth and round roots,

113 Edmand's Early. ๑ Extra early; of finest quality,.......

115 Detroit Dark Red. ๑ Dark-red turnip variety,.

117 Burpee's Columbia. ○ An early main-crop beet. Pkt. 10 cts.,

120 Dark Stinson. $\odot$ Recommended for summer market,

121 Burpee's Black-Red Ball. $\odot$ Deepest blood-red. Pkt. 10 cts.,

122 Crimson Globe. Fine second-early or main-crop,

123 Early Model. $\odot$ Of perfect globe shape. Per pkt. 10 cts.,

124 Eclipse. Extremely early, round, blood-red,

125 Epicure. $\odot$ Fine half-long roots. (See page 1\%.) Pkt. $10 \mathrm{cts.}$

128 Burpee's Improved Blood. $\odot$ A finely improved strain,

129 Bastian's Half-Long Blood. Crop failed.

130 Dewing's Improved Blood Turnip. A popular strain,

131 Long Smooth Blood-Red. A large and excellent late variety,

133 Early Yellow Turnip. Yellow roots of sweet flavor. Pkt. $10 \mathrm{cts}$.,

136 Swiss Chard, Large-Ribbed White. The "Spinach Beet," .

137 Swiss Chard, Lucullus. $\odot$ (See page 1\%.) Per pkt. $10 \mathrm{cts}$.,

\begin{tabular}{|c|c|c|}
\hline $\begin{array}{l}\text { Per oz. } \\
\$ 0 \quad 10\end{array}$ & $s^{1 / 4} \mathrm{lb}$. & $\begin{array}{l}\text { Per lb. } \\
\$ 090\end{array}$ \\
\hline 8 & 25 & 75 \\
\hline 10 & 30 & 100 \\
\hline S & 25 & 85 \\
\hline 10 & 30 & 100 \\
\hline 15 & 40 & 150 \\
\hline 12 & 35 & 125 \\
\hline 20 & 60 & 200 \\
\hline 10 & 30 & 100 \\
\hline 15 & 40 & 150 \\
\hline 8 & 25 & 75 \\
\hline 25 & & \\
\hline 8 & 25 & 8 \\
\hline 8 & 25 & 7 \\
\hline 8 & 25 & 7 \\
\hline 10 & 30 & 100 \\
\hline 8 & 22 & \\
\hline 10 & 30 & 10 \\
\hline
\end{tabular}

00

85

50

25

50

$\longrightarrow$ All garden beets, except where otherwise priced, 5 cents per packet.

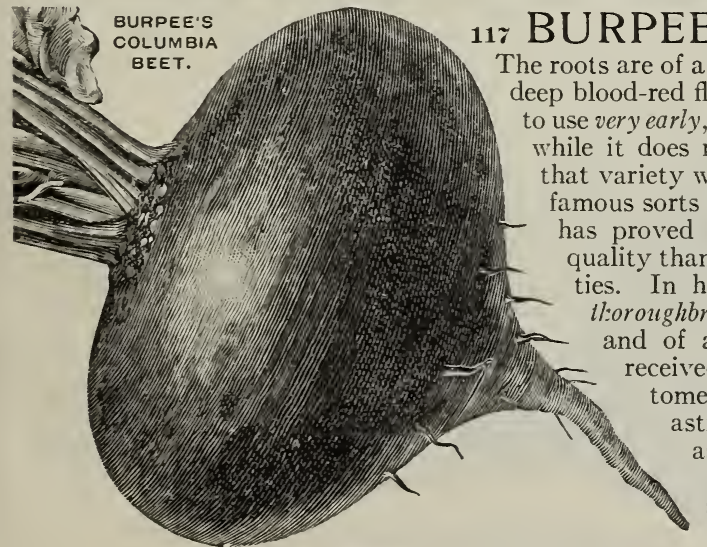

For other choice beets see page 16.

\section{E'S COLUMBIA BEET.๑}

The roots are of a neat turnip shape, with smooth skin and deep blood-red flesh, of rich, tender quality. It is ready use very early, growing as quickly as does the Egyptian, not become coarse and stringy, as does viety when large size. Compared with such sorts as Edmand's and Eclipse, the ColumbiA these two really first-class varie. In habit of growth it is remarkabl and a rich bronze color. We have many voluntary letters from our cusmers, all of whom have been most enthusitic in praise of The Columia BeET, both as an early and main-crop variety. IVe are sure that market gardeners will find it a splendid variety, while its fine flavor as a table beet will delight all private planters.

Per pkt. 10 cts.; oz. 15 cts.; $1 / 4$ lb. 


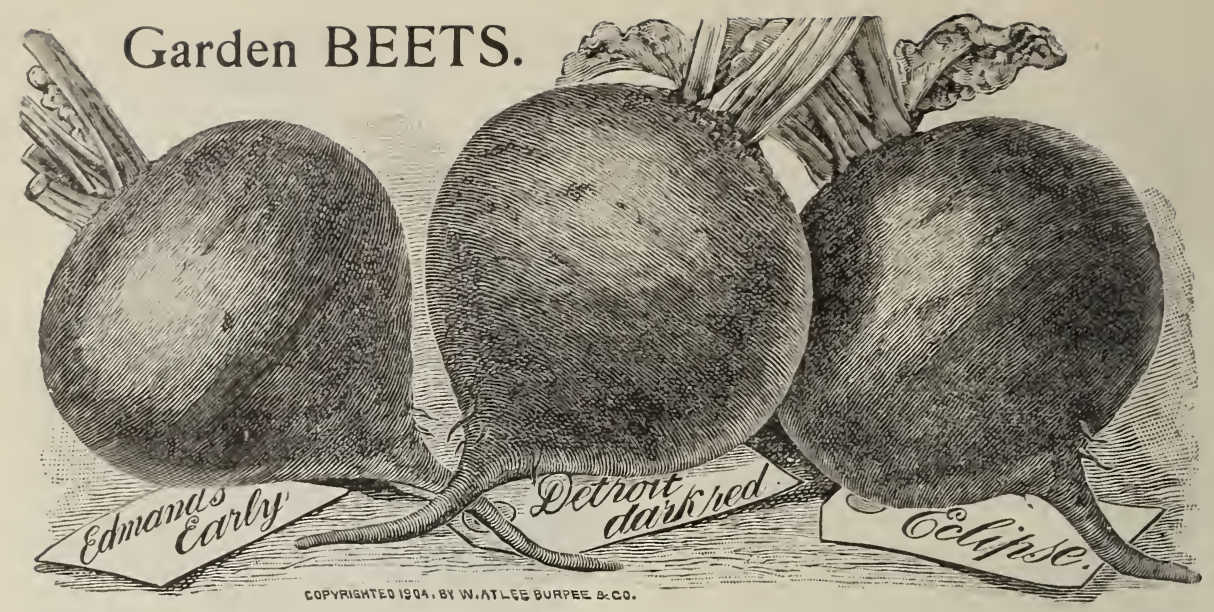

10y Burpee's Extra Early. Extremely fine globular form; the sweet, tender flesh is TIP of alternate rings of light and dark pink. (1D) Per pkt. 5 cts.; oz. $10 \mathrm{cts} . ; 1 / 4 \mathrm{lb} .25 \mathrm{cts}$.; per Ib. 90 cts.

109 Extra Early Egyptian. Grows quickly, producing flat smooth turnip roots averaging two inches in diameter. Per pkt. 5 cts.; oz. 8 cts.; I $/ 4$ lb. 25 cts.; per 1 b. 75 cts.

111 Crosby's Egyptian. $\begin{gathered}\text { Roots are } \\ \text { smooth }\end{gathered}$ and round in form. They are of finer quality than the regular Egyptian combined with the same extra early maturity. Per pkt. 5 cts.; oz. 10 cts.; 1/4 lb. $30 \mathrm{cts}$.; per $1 \mathrm{~b}$. $\$ 1.00$.

113 Edmand's Early. $\odot$ The beets are very smooth, extra early, and of good marketable size. Skin and flesh deep blood-red; extremely sweet and tender. Per pkt. 5 cts.; oz. 8 cts.; $1 / 41$ lb. 25 cts.; per $1 \mathrm{~b} .85 \mathrm{cts}$.

115 Detroit Dark Red. $\odot \underset{\substack{\text { Form grobu- } \\ \text { lar ovoid: }}}{ }$ smooth roots, with small tops; skin blood-red; flesh dark red, zoned with a lighter shade, tender and sweet. Deservedly a popular favorite for canning, because of its extra deep dark-red color. Per pkt. 5 cts.; oz. $10 \mathrm{cts}$.; $1 / 4$ Ib. 30 cts.; per lb. $\$ 1.00$.
120 Dark Stinson. $\odot \begin{aligned} & \text { This is a finely bred } \\ & \text { variety for summer }\end{aligned}$ market. The roots average two and a half inches in diameter, with richly colored leaves only T7 five inches in length. Beets are smooth and AB regular in form, with small tap-root. Flesh is fine grained, free from any woodiness, even when fully grown, and is of dark-red coloring. Per pkt. 5 cts.; oz. 12 cts.; 1/4 lb. 35 cts.; per Ib. $\$ 1.25$.

122 Crimson Globe. Skin smooth and flesh is a deep purplish crimson form regular. The sweet and tender. The foliage is small, of a rich bronze-purple. Per pkt. 5 cts.; oz. $10 \mathrm{cts}$; 1/4 Ib. 30 cts.; per ib. $\$ 1.00$.

123 Early Model. Extremely early, of perfect globe shape liage is very small. The beets are of the deepest blood-red color. Per pkt.10 cts.; oz. $15 \mathrm{cts}$.; $1 / 4$ Ib. $40 \mathrm{cts}$.; per Ib. $\$ 1.50$. 124 Eclipse. Extra early round, smooth, bloodand the home garden. Per pkt. 5 cts.; oz. 8 cts.; $1 / 4$ lb. 25 cts.; per lb. 75 cts. 128 Burpee's Improved Blood.๑ Prodices smooth round roots of medium size with dark-ed flesh, fine grain, very sweet, and retaining its deep coloring when cooked. Tops are small and of uniform growth, the leaf, stems, and veinings being a dark red. It grows quickly and is of superior quality. Per pkt. 5 cts.; oz. $8 \mathrm{cts}$.; $1 / 4 \mathrm{lb} .25 \mathrm{cts}$.; $1 \mathrm{~b} .85 \mathrm{cts}$

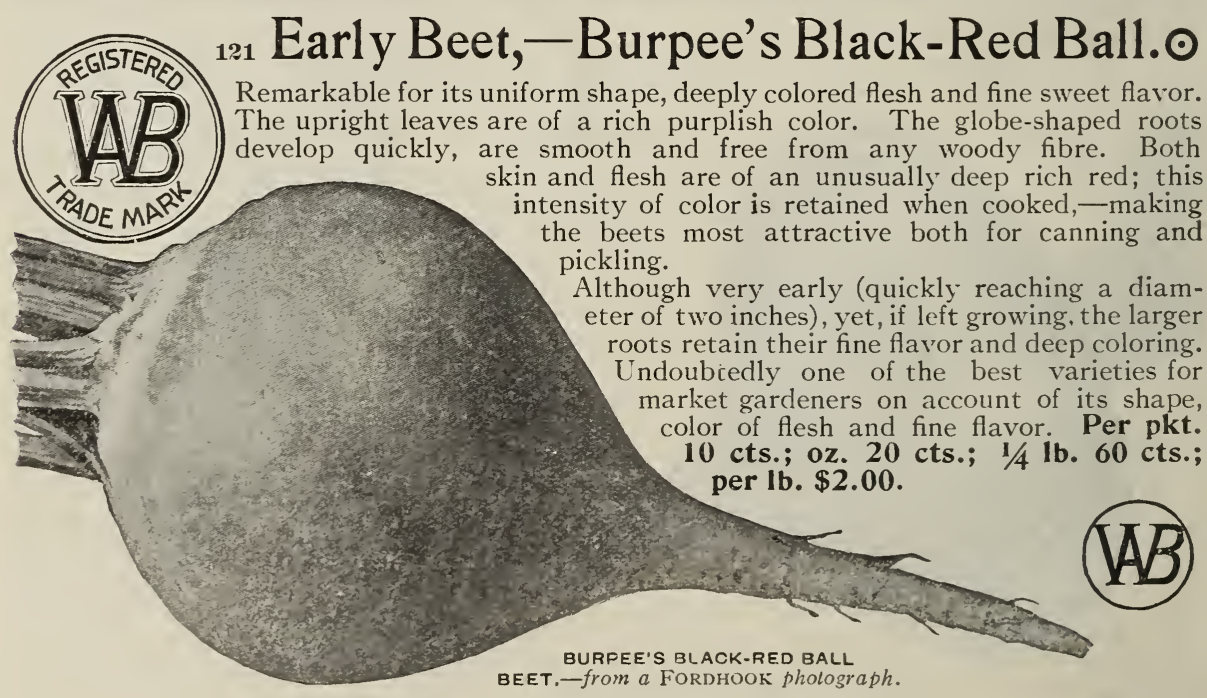




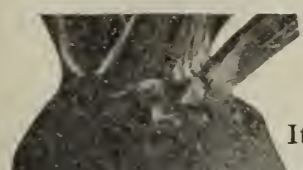

New Half-Long Beet,-“"Epicure.”॰

A Superb New "Quality-Beet" for the Table.

It is with real pleasure that at last we are able to offer American planters seed of this superb new Irish Beet, which we have known and grown at Fordhook for several seasons. EPICURE originated with our friends, Messrs. Alex. I)ickson \& Sons, Belfast, Ireland, who kindly undertook to grow sufficient extra seed to supply the American demand, although previously they had kept the varicty exclusively for their own retail trade. The reputation of EPICURE BEET for unusually fine quality has already reached across the English Channel. Headgardeners of large estates in England have written Messrs. Dickson that when EPICURE was first served word would come from "The Lords and Ladies" that they had never before eaten such delicious beet-root,- and wanted the table thereafter always to be supplied with this one variety.

The New "Epicure" is decidedly betother half-long beet. The beautiful tapering roots are

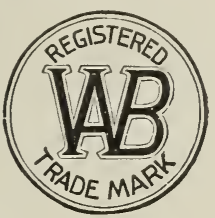
smooth and clean, the flesh is dark blood-red, with practically no trace of white zonings, while the flavor is so exceptionally fine that the name EPICURE secms appropriate.

${ }_{125}$ Epicure when cooked is always tender and delicious; the beets The form is shown in the illustration herewith, which has been reduced from a Fordhook photograph. This beet measured eight and a half inches long by one and three-quarter inches in diameter and weighed four and onequarter ounces. The foliage is rich blackish-crimson. We anticipate a great demand for EPICURE BEET as soon as its sterling merits become known. This season the seed is sold only in sealed packages of an ounce or less, each bearing our Registered Trade Mark. Per pkt. 10 cts.; oz. 25 cts.; 2 ozs. for 50 cts.; 4 one=ounce packages for $\$ 1.00$.

Swiss Chard or "Spinach Beet." Of late much has been this "all-round" vegetable. One grower recommends hilling up and bleaching the stalks so that they may become sufficiently tender to serve as a salad or stewed like celery,- -however, the principal use for this vegetable is to cook the leaves in the same manner as Spinach and the stalks are palatable if prepared and cooked like Asparagus.

\section{New Swiss Chard, or "Spinach Beet."}

137 Lucullus. $-\begin{gathered}\text { See illus- } \\ \text { tration. }\end{gathered}$

The plants grow to a height of two to two and one-half feet. The stalks are as thick and broad as those of Rhubarb, being one and one-half inches broad, heavily ribbed and from ten to twelve inches long below the leaf. These stalks are delicious when cooked and served in the same manner as asparagus.

In the old type of Swiss Chard the leaf portion is smooth; broad and rounded at the upper end; in the new LUCULlus the leaves are larger and sharply pointed at the top, while the $\mathrm{t}$ e $\mathrm{xt} u \mathrm{r}$ e is heavily crumpled or "savoyed," more crisply tender and of finer flavor. The leafy portion of the foliage is cooked and served in the same manner as Spinach. The leaves and stalks served as separate vegetables afford two distinct dishes from the same plant at one time. Per pkt. 10 cts.; oz. 10 cts.; $1 / 4$ lb. 30 cts.; per lb. \$1.00.

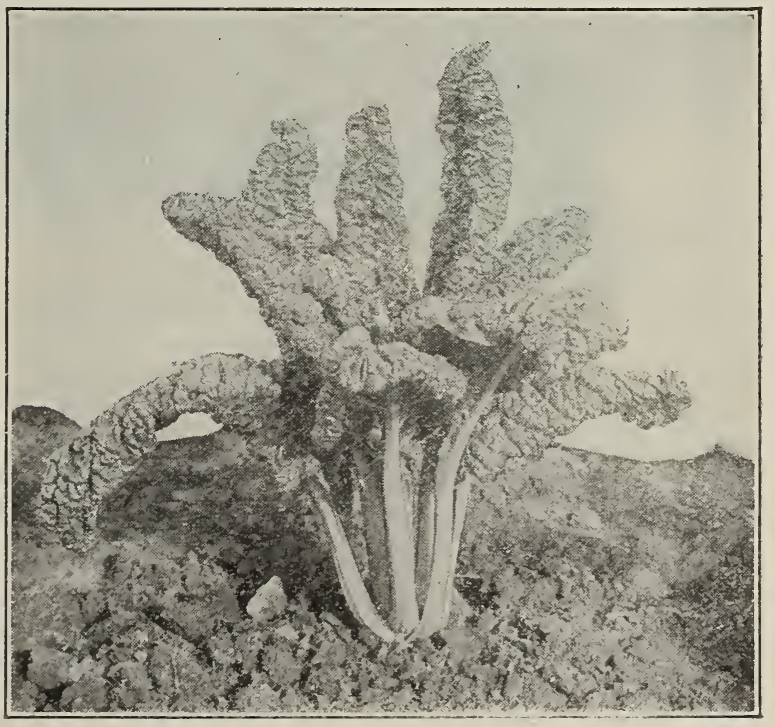

There are tons on tons of seeds that are true to name, but of common quality; honest but poor; they are not Burpee's 


\section{MANGEL WURZEL AND SUGAR BEETS, for Stock Feeding.}

These grow to the largest size of all beets and produce the heaviest bulk of crop for a given area. Where it is desired to add fresh green food for stock rations during the winter months, they will give larger bulk from a given area than any other root crop which can be grown. GOLDEN TANKARD is the most desirable variety for dairy stock, as it is not only very productive, but is the only Mangel having yellow flesh, the coloring tending to add to the color and richness of the milk of cows to which they are fed during the winter. GoldEN GIANT or YeLLOW LEVIATHAN grows to a larger size and is probably the most productive variety, unless this point be conceded to the MAMMOTH PRIZE LONG RED, which grows very long roots with a large rortion of the root above the surface of the soil so that they are easily harvested. Orange or Yellow Globe is shorter, thicker and distinctly oval or round in form; it is more easily handled.

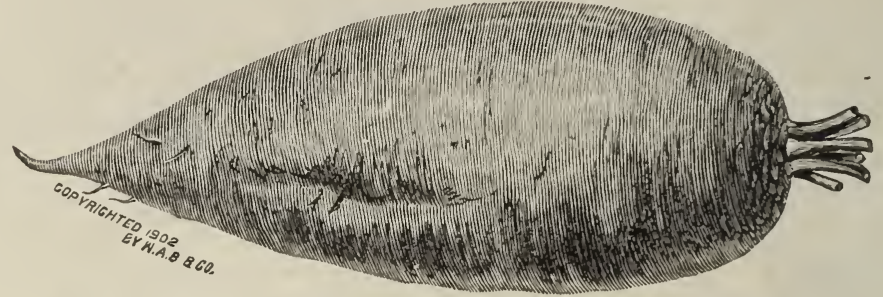

GIANT HALF-SUGAR MANGEL WURZEL.-Most valuable for stock feeding.

Sugar Beets. These are planted quite largely for stock-feeding purposes, and while they do not them higher feedin produce so heavy a crop as Mangel Wurzels, the greater percentage of sugar makes f the largest size of the mangel with the richer quality and higher feeding value of the sugar beet; we think it is destined to take first place as the beet for stock-feeding purposes.

DANISH IMPROVED, first introduced by us from Denmark, has proved especially satisfactory in light soil. where it grows to good size and yields heavy crops; the quality is so fine that our customers frequently report using it as a table beet during the winter. Wanzleben is the standard variety for the production of beet-rootsugar and is also desirable for feeding to cattle. Lane's Imperial is an old standard variety, but is not so productive in proportion of sugar as the newer improved sorts.

Is Write for Special Prices on Large Quantities. q

139 Danish Improved. ๑ Nutritious for cattle feeding, more

$\begin{array}{llllllll}\$ 0 & 07 & \$ 0 & 15 & \$ 0 & 45 & \$ 0 & 42\end{array}$

141 Lane's Imperial Sugar. Roots large and smooth, . . . . . . . $\quad 7 \quad 75 \quad 32 \quad 30$

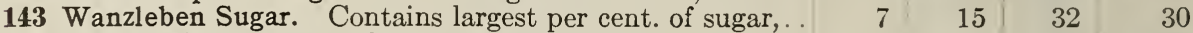

145 Giant Half-Sugar. $\odot$ Of great feeding value, . . . . . . . . . $\quad 7 \quad 7 \quad 15 \quad 35 \quad 32$

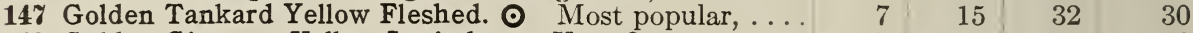

149 Golden Giant, or Yellow Leviathan. Very fine, . . . . . . . $\quad 7 \quad 7 \quad 15 \quad 32 \quad 30$

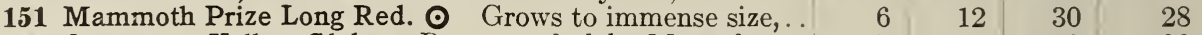

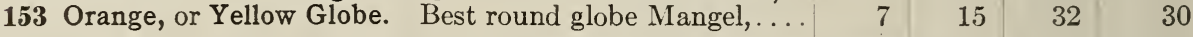

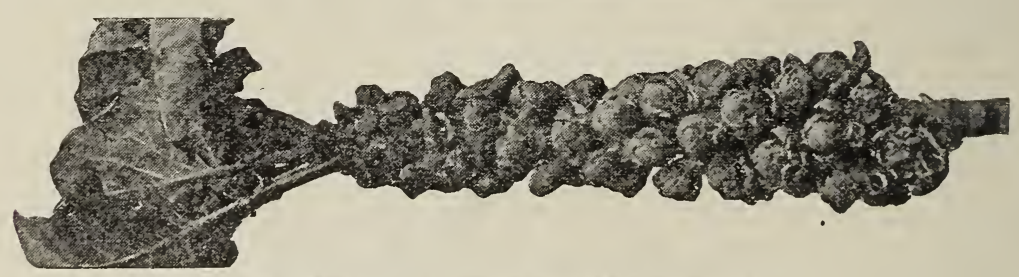

BURPEE'S DANISH PRIZE BRUSSELS SPROUTS.

\section{BRUSSELS SPROUTS.}

These are becoming more and more of a feature as a market crop each year, and some growers in favorable locations now make successive plantings which give them a supply of Sprouts for market throughout the year: the greatest demand, however, comes during late fall and winter months. The plants somewhat resemble cabbage in growth, but make small compact round heads at each leaf-joint on the stalk. These are cut off when well formed, trimmed and marketed in strawberry boxes holding one quart each. The plant is entirely hardy in this section and the heads are usually gathered for market from the open ground during the winter months, but some growers take up the stalks in the fall and store them in cold-frames or root-cellars for winter market. The LONG ISLAND IMPROVED is of dwarfer growth, and in this climate makes harder heads than the taller-growing European varieties. The PERFECTION grows two feet or more in height and makes a large crop of sprouts for winter market; while the PARIS MARKET is rather more dwarf in growth, with smaller sprouts. BURPEE'S DANISH PRIZE is of tall growth and produces a large crop of choicest sprouts.

158 Long Island Improved. ๑ A superior strain,........... \$0 10 \$0 $25 \quad \$ 075 \quad \$ 275$

159 Perfection. Grows about two feet high, . . . . . . . . . . . $\quad \begin{array}{r}5 \\ 15\end{array}$

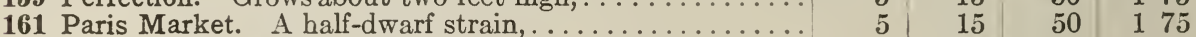

162 Burpee's Danish Prize. ( G Grows three feet high, . . . . . $10 \quad 25,85 \quad 300$ 


\section{Burree’s High-Bred Tested Seed of the Best American-Grown Cabbage.}

Cabbage is more extensively grown in large areas for market than any other vegetable excepting the Potato. All growers recognize the importance of planting only the finest seed. We exercise the greatest care in growing and selecting our Cabbage seed. Not only are the plants grown from the best stock, but they are also inspected carefully before being put away for the winter.

For the earliest supply, seed may be sown in September, and the plants wintered in cold-frames, or young plants started from seed in hot-beds or cold-frames early in the spring. These are set out in rich soil early in the spring. For the fall, or main crop, the seed should be sown about the first of June thinly in drills in the seed-bed, and the young plants transplanted to the rows during the latter part of July, setting them eighteen to twenty-four inches apart in the row, in rows three to four feet apart. The Cabbage is a gross feeder, and to insure best results the soil should be rich and the plants cultivated during growth.

" $\mathrm{How}$ to GrOW" CABBAGE AND CAULIFLOWER. This is the title of our leaflet, giving It is mailed FREE with orders, - if asked for.

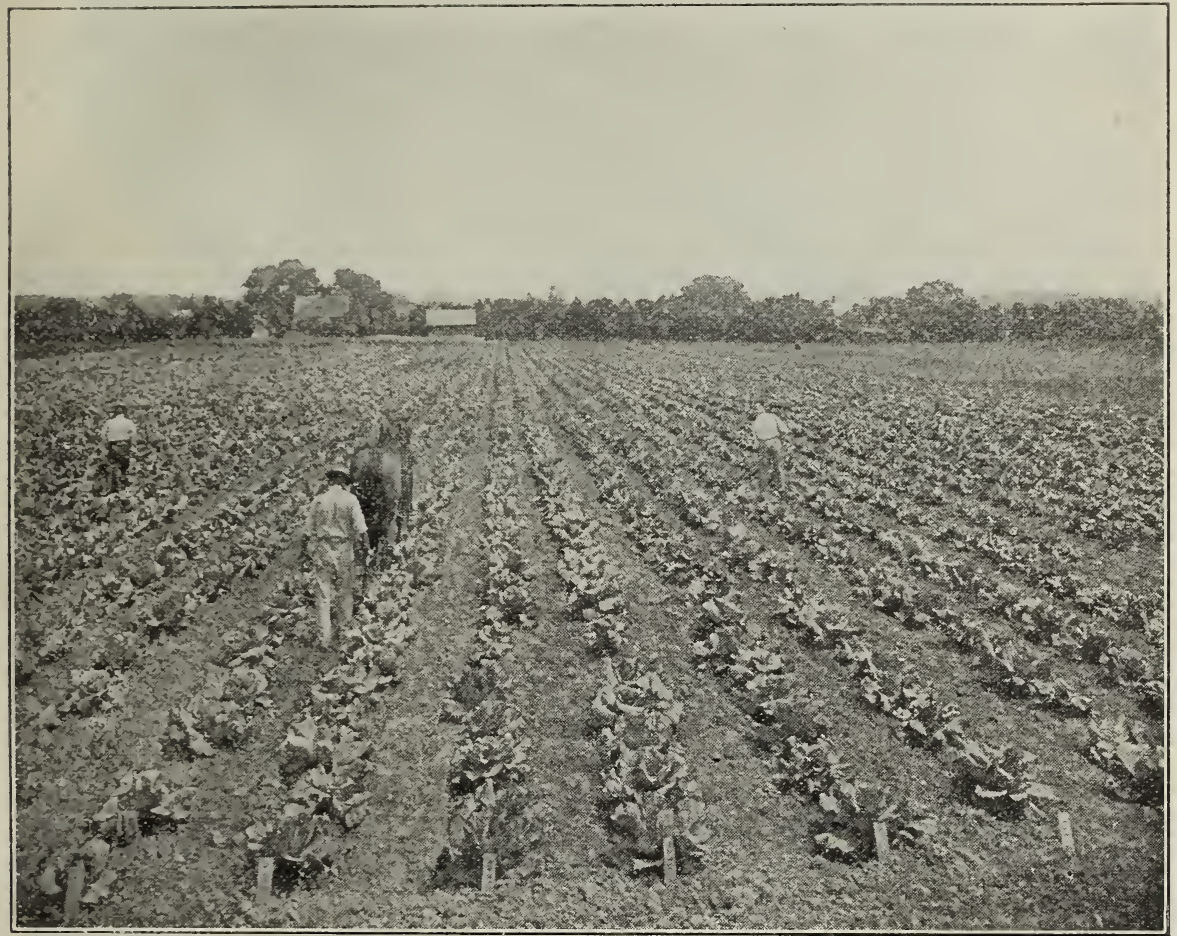

THE EARLY TRIALS OF CABBAGES at Fordhook, from a June pholograph.

\section{CABBAGES, - Earliest Pointed or Oblong-Headed Varieties.}

Of these, the earliest variety is the EXTRA EARLY EXPRESS, producing small, hard, pointed heads.

The best and hardest-heading extra early cabbage, however, is EARLY JERSEY WAKEFIELD, a variety of American development and which is of the finest type for our market.

BURPEE'S SPECIAL STOCK OF JERSEY WAKEFIELD produces very early hard compact heads which are a little smaller in size.

The Charleston, or Large Wakefield, is about ten days later than the Early Jersey Wakefield and grows fully a third larger; it will stand about ten days longer before bursting after it is ready for market; it is an excellent shipping variety. The EARLY WINNIGSTADT is considerably later than the Wakefield, but is even more solid and distinctly green in color.

Seed sbould be sown thinly in drills so that the young plants will grow strong, as slender, long-stemmed plants are of little value.

Is In lots of 5 pounds or more, deduct 10 cents per pound.

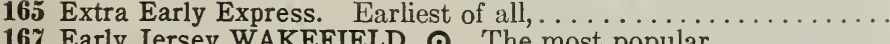

168 Burpee's Special Stock of Jersey Wakefield. $\odot$ Pkt. 10 cts......

\begin{tabular}{|c|c|c|}
\hline Per oz. & $\$ 0^{1 / 4} 60$ & Per lb. \\
\hline 20 & 65 & 2 \\
\hline 25 & 75 & \\
\hline$\overline{2}$ & 65 & \\
\hline 20 & 65 & 2 \\
\hline
\end{tabular}

169 Large Wakefield, or Charleston. Large heads, ..............

20

$65 \quad 225$

I $\omega^{3}$ Each of the above, except where priced, 5 cents per packet. 


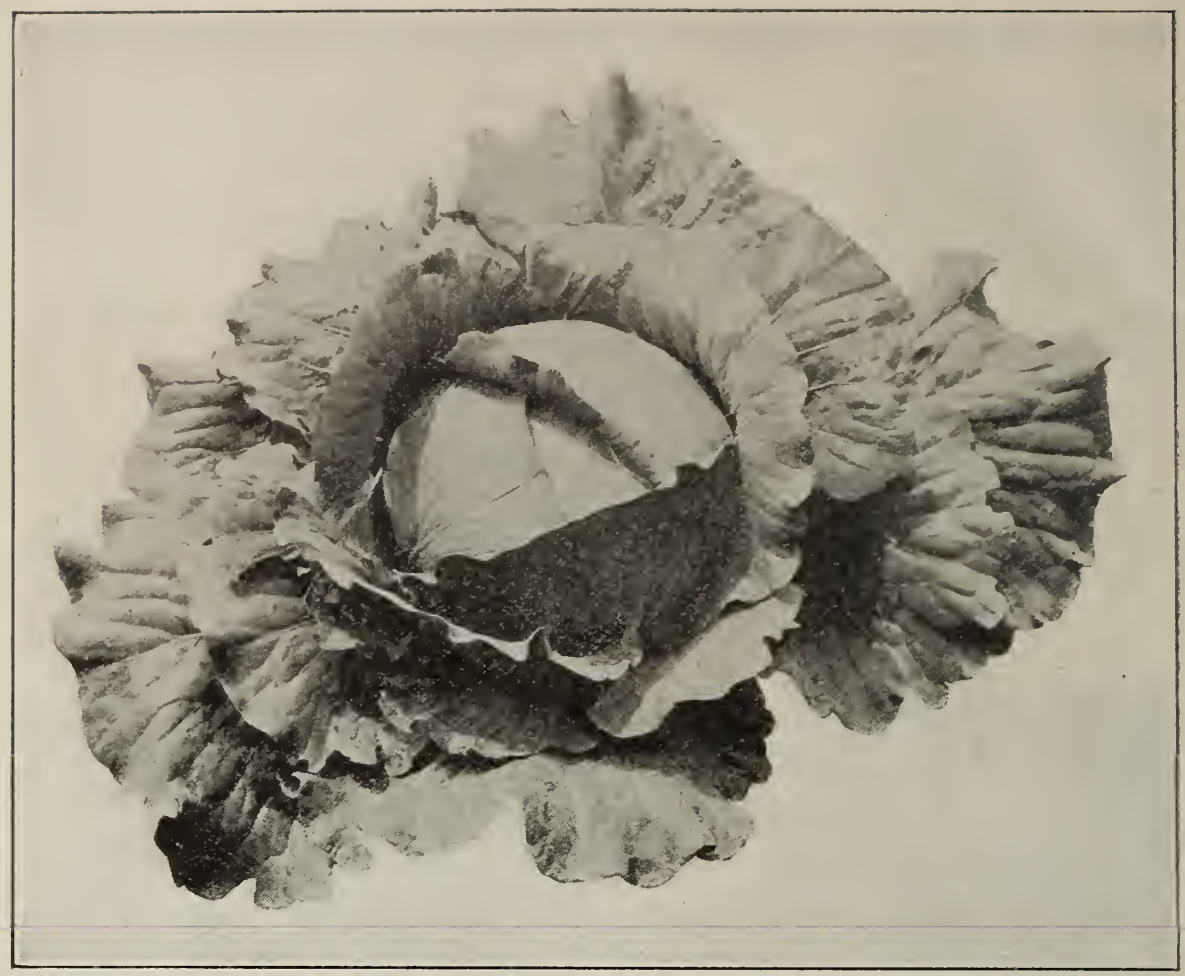

BURPEE'S ALLHEAD EARLY, - from a Photograph taken at Fordhook.

\section{Burpee's Allhead Early Cabbage.๑}

The BEST Early Summer Cabbage, and Equally Good for Winter.

177 Burpee's Allhead was first named and introduced by us twenty-three years ago, summer cabbage that is equally as earl the most uniform in color, form, and size of any variety. The heads are of finest quality, whether cooked or served as cole-slaw. The hard heads grow so free from spreading leaves that a great many more heads than usual with large cabbage can be obtained to the acre. It is really an all=the=year=round Cabbage, being equally good for winter. Per pkt. 10 cts.; per oz. 30 cts.; 2 ozs. for 45 cts.; $1 / 4$ lb. 85 cts.; per lib. $\$ 3.00$.

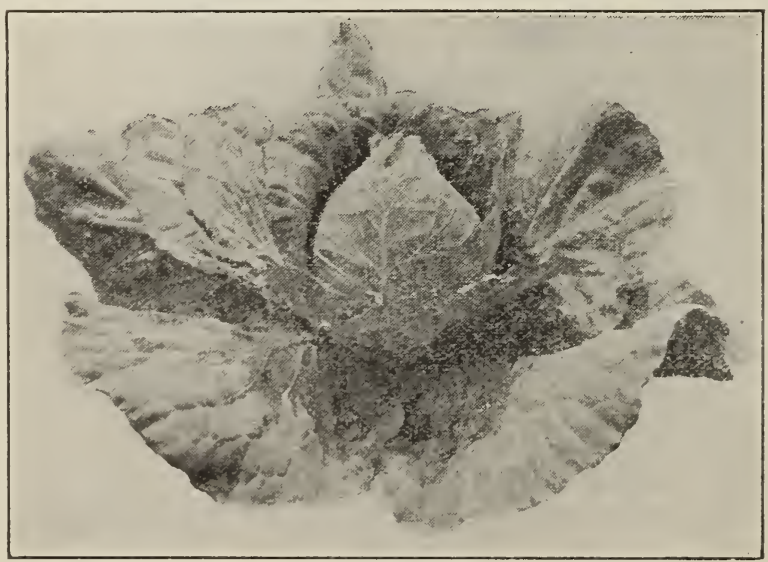

168 Burpee's "Special Stock" of Jersey Wakefield. $\odot$

This is pre-eminently a market gardeners' strain, being thoroughly established by careful selection. The plants are dwarf and compact and produce heads at a very early period. The heads are rather more slender than those of our regular strain (offered on page I 9 ); erect and conical in form, very uniform and even in size as well as in time of heading. Our long experience as seedsmen enables us to assure our market garden customers that this "special stock" of EXTRA EARLY JERSEY IVAKEFIELD fully meets their requireinents in point of earliness and even-heading, so that the entire crop can be cut off and marketed very early in the season. The plants are so compact in growth that nearly one-third more heads can be grown on a given area than from the larger, later strains. Per pkt. 10 cts.; $0 z$. $25 \mathrm{cts}$.; $1 / 4$ lb. 75 cts.; per lb. $\$ 2.50$. 


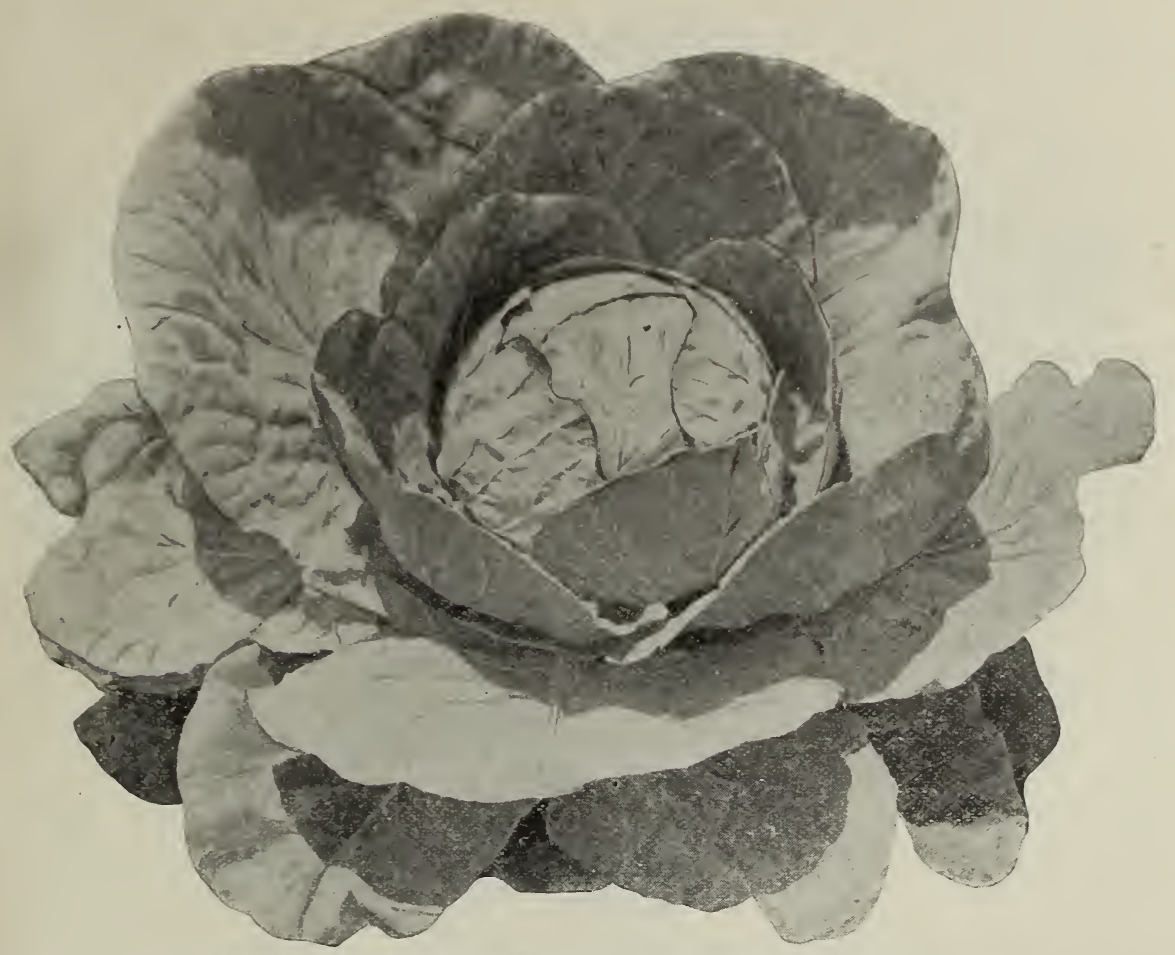

BURPEE'S EARLY STONEHEAD CABBAGE,-from a photograph taken at FORDHOOK.

\section{Early Flat and "Round-Head" CABBAGES.}

These generally grow to a larger size and heavier weight, but are not quite so early as those of the pinted form. The earliest and hardiest of this type is BURPEE's EARLY BASEBALL, which is ready for market as soon as the Early Jersey Wakefield and makes a hard, perfectly round head, five to seven inches in diameter. The First-Early or Eureka is a flat-heading selection of the Jersey Wakefield and is very hardy.

BURPEE'S ALLHEAD EARLY is one of the most valuable of all the early flat-head sorts; the heads are extremely solid and grow to a good size, running from eight to ten inches in diameter in the spring crop, and where grown as a late fall crop will frequently measure twelve to fourteen inches in diameter. ENKHUIZEN GLORY produces fine marketable heads as early as our famous Allhead Early. CoPENHAGEN MARKET is a distinct new valuable early variety from Denmark, - see page 22. FORDHOOK "MAINSTAY-EARLY," introduced in I9I2, produces very early round solid heads, weighing two to three pounds,-just the right size for supplying small families.

BURPEE'S EARLY STONEHEAD (also called VOLGA) is an exceptionally hardy variety, making plants of strong vigorous growth. STEIN'S EARLY DUTCH is of the same season as Succession, and is a very uniform type. Early Dwarf Flat Dutch, Early Summer. Succession, Fottler's Brunswick and All Seasons are all excellent flat-head cabbages of good size and flavor. All of these varieties produce fine, solid heads with only a moderate amount of foliage so that they can be grown quite closely together on good rich soil.

$I \rightarrow$ In lots of 5 pounds, deduct 10 cents per pound.

173 Burpee's Early Baseball. As early as Jersey Wakefield, .

176 Enkhuizen Glory. $\odot$ A fine second early. (See page 24)

177 Burpee's ALLHEAD EARLY. $\odot$ Of finest quality. (See page 20)

178 Copenhagen Market. ○ A large round-headed early. (See page 22),

179 Burpee's Early Stonehead ("Volga"). ○ (See page 22), .

180 Fordhook "Mainstay-Early." $\odot$ Very early. 10 cts. per pkt.,

181 First-Early, or "Eureka." Flat heads of good size. Pkt. 5 cts., .

183 Early Dwarf Flat Dutch. A first-class second-early. Pkt. 5 cts.,

185 Early Summer. A hard-heading variety. Per pkt. 5 cts., .....

187 Succession. $\odot$ An excellent keeper,

188 Stein's Early Flat Dutch ("Acme"). ๑ Extra fine for market, . .

189 All Seasons. Large heads; medium early. Per pkt. 5 cts.,....

191 Fottler's Brunswick. Solid flat heads, . . . . . . . . . . . . . . . \begin{tabular}{l|l|l} 
Per oz. & $1 / 4 \mathrm{lb}$ & Per lb.
\end{tabular}

$\$ 025 \$ 075$

$20 \quad 60 \quad 200$

\begin{tabular}{l|l|ll}
30 & 85 & 3 & 00
\end{tabular}

\begin{tabular}{lll|ll}
35 & 1 & 00 & 3 & 75
\end{tabular}

\begin{tabular}{l|l|l}
25 & 75 & 275
\end{tabular}

85

\begin{tabular}{l|l|l|l}
20 & 60 & 200
\end{tabular}

\begin{tabular}{l|l|ll}
20 & 60 & 2 & 00
\end{tabular}

$20 \quad 65 \quad 225$

\begin{tabular}{l|l|ll}
30 & 85 & 3 & 00
\end{tabular}

\begin{tabular}{l|l|ll}
25 & 75 & 2 & 50
\end{tabular}

\begin{tabular}{l|l|ll}
25 & 75 & 2 & 75
\end{tabular}

\begin{tabular}{l|l|l}
25 & 75 & 250
\end{tabular}

Each of the above, except where priced, 10 cents per packet.

The cost of the very Best Seeds is so small, compared with value of the resulting crops, that sensible planters know they cannot afford to risk seeds of doubtful pedigree,-and we know just as well that we cannot afford to risk our hard-earned reputation by selling stock of uncertain character. 


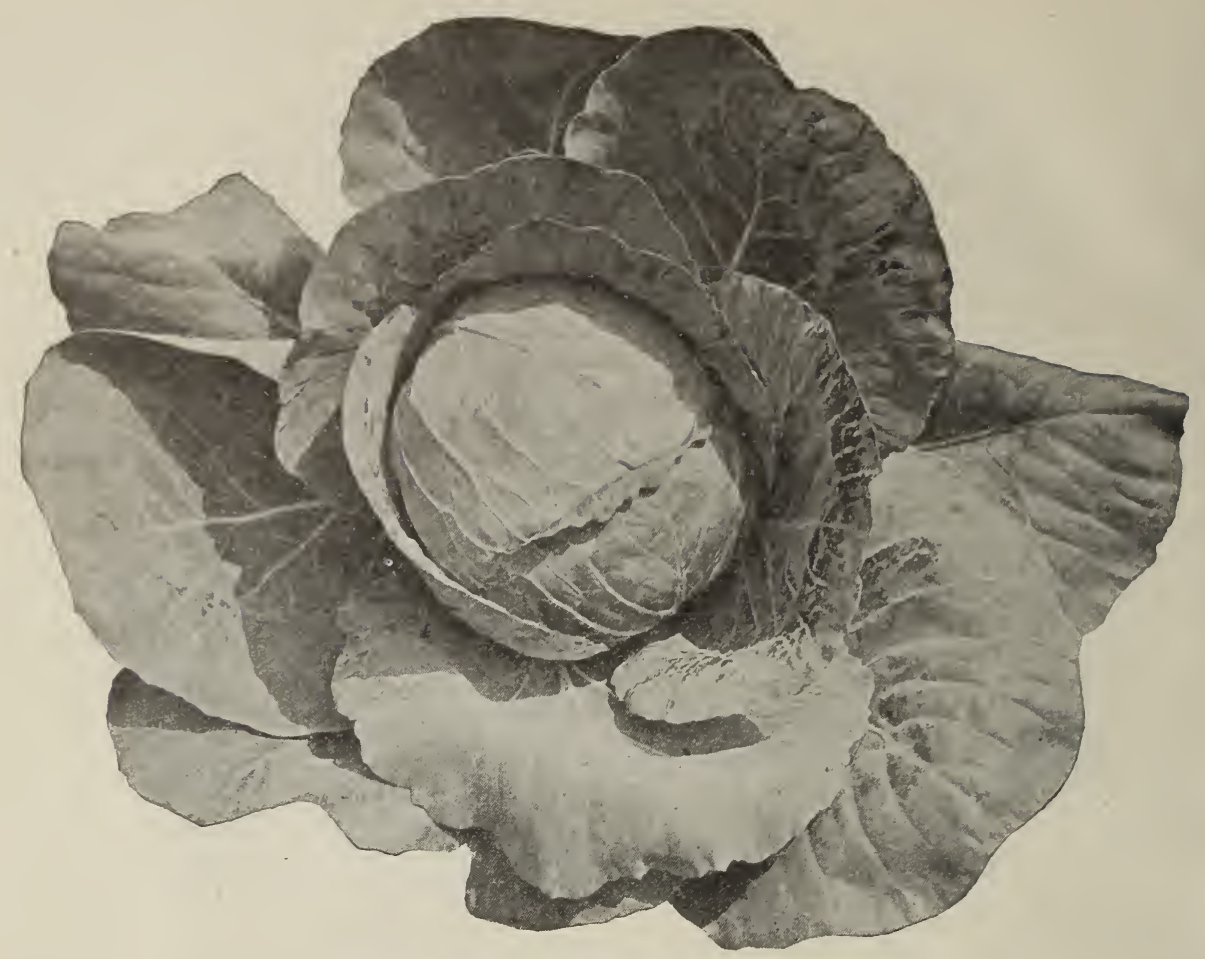

THE NEW EARLY " COPENHAGEN MARKET" CABBAGE.

From a photograph taken at FORDHOOK FARMS.

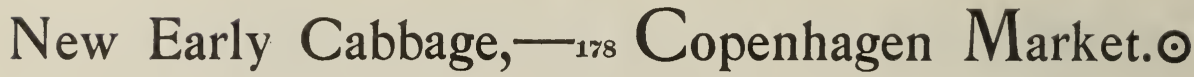

In four seasons' thorough trials at Fordhook and for the past three years with thousands of growers throughout America, COPENHAGEN MARKET has proved its unique value in being the only round-head Cabbage of good size to mature as early as Jersey Wakefield,-and, of course, yielding heavier crops!

It is undoubtedly without a rival as the finest large round-headed early Cabbage in cultivation. The type is thoroughly fixed, the heads maturing all at the same time-(this being a great consideration to Market Gardeners, entailing less labor in harvesting the crop and allows the ground to be cleared at the first cutting). The heads average about ten pounds each in weight, are very solid, with small core and of fine quality. It matures as early as Charleston Wakefield, and will give a much heavier yield per acre than that popular variety. The plant is short-stemmed, the heads being produced almost on the ground level. The leaves are light green, rather small, saucer-shaped, and always tightly folded. The plants, therefore, can be set closer than is usual with varieties of similar size. Per pkt. $10 \mathrm{cts.}$; 0z. $35 \mathrm{cts.;}$ per $1 / 4 \mathrm{lb}$. $\$ 1.00$; per lb. $\$ 3.75$.

\section{${ }_{179}$ Cabbage,-Burpee’s Early "Stonehead" (Volga). $\odot$}

A most distinct type which is especially adapted for cool locations. It generally matures after our famous Allhead Early (described on page 20), but in some seasons and localities is almost as early as the Jersey Wakefield. The plants are of low growth, with spreading, saucerlike outer leaves, making a total diameter of two feet. The heads are deep through and smoothly rounded on the top as distinct from the flat type. The heads are exceptionally hard and solid, of great weight and stand a very long time before bursting. Of a distinct light gray color, the spreading outer leaves shade the soil about the roots very effectually. EARLY STONEHEAD is excellent also for a fall and winter crop; coming on quickly, attaining large size and heavy weight; it is an excellent variety to plant for making "krout," etc. Per pkt. 10 cts.; oz. 25 cts.; 1/4 lb. 75 cts.; per 1 b. $\$ 2.75$.

A Bull's Eyye is used to mark those varieties which we consider the best of their respective Order order, you can rely upon obtaining the choicest The Best "Seeds that Crow." 


\section{MAIN-CROP CABBAGES,-For Fall and Winter.}

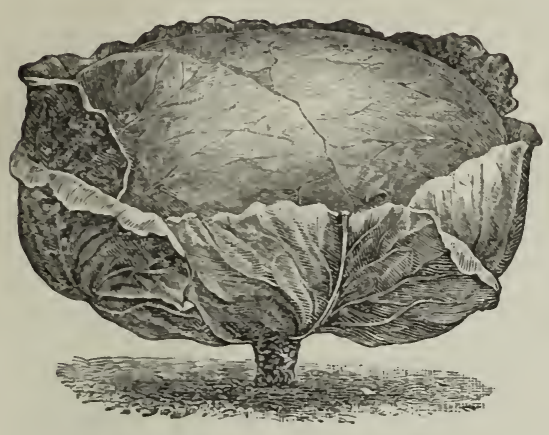

BURPEE'S SHORT-STEM DRUMHEAD.

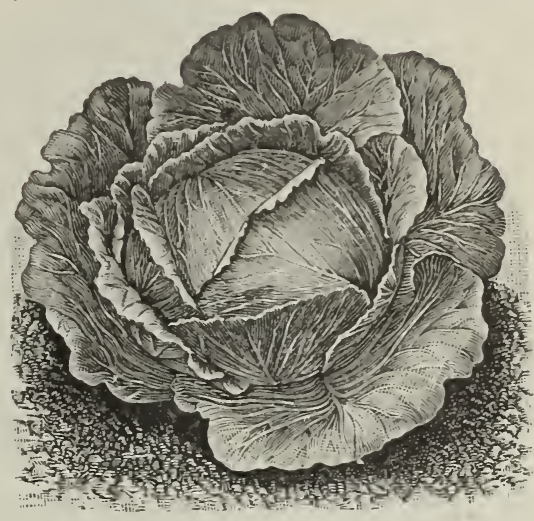

AUTUMN KING, OR WORLD-BEATER.

Among these the best known type is the Flat Dutch, of which there are a number of special strains which are favored in certain localities. For general cultivation and great productiveness we would especially recommend BURPEE'S SUREHEAD, as this is of remarkably strong, vigorous growth and produces uniformly large solid heads of the finest quality. BURPEE'S SHORT-STEM DRUMHEAD is a large, sure-heading variety of very compact shortstem growth, so that a very large crop of fine heads can be grown by close setting. This sort is slightly earlier than Surehead and is a very dependable market variety.

The DANISH BALLHEAD makes a very profitable late crop for cool locations. These cabbages are imported in large quantities in the spring from Denmark and bring high prices on account of their great solidity. They do not succeed when planted in a warm climate, but in the cooler Northern States reach their finest development, making heads of extreme solidity and hardiness and keep better when stored away for spring market than those of any other type. The seed we offer of this variety is grown and selected especially for us in Denmark.

In BURPEE'S DANISH ROUNDHE.4D we offer a variety which is even better adapted to our climate than Danish Ballhead. While the heads are equally solid, the plants do not blight as readily under our hot summer suns and the interior is more tender.

BURPEE'S LARGE LATE STONEHEAD is a very distinct and extremely hardy vigorous grower, being similar in all respects to Burpee's Early Stonehead, excepting that both the outer leaves and heads grow to a larger size. Burpee's "Lalc Stonehead" has given splendid results, especially where planted on dry land or in hot dry seasons, and we think it is destined to become a leading market sort in many sections where Danish Ballhead would not succeed; the heads are equally hard and of excellent keeping quality.

AUtumn KING, or "World-Beater," is the largest sort of the Drumhead type. It needs rich ground and a long cool season to fully develop the extra-large heads. Perfection Drumhead Savoy is the best adapted of all Savoy Cabbages for our American market, and many markets prefer this "green" or curly cabbage, as it is considered more tender and finer in flavor.

The Red Cabbages are planted extensively for fall and winter use in the markets of northern cities populated by Germans. They are extremely hardy, and the trimmed heads are a deep purplish-red color; used for pickling and slaw. The Red Drumhead is a very solid, perfectly round head, growing six to seven inches in diameter, of dark rich coloring. MAMMOTH Rock RED grows to a larger size, having heads of flattened form, but the coloring is not quite so rich as in the smaller round-head types. The DANISH ROUND RED produces round or ball-shaped heads of great solidity and intensely deep rich coloring.

194 Premium Flat Dutch. An improved strain of the Large Late Flat

199 Burpee's SHORT-STEM DRUMHEAD. $\odot \ddot{A n}$ exceedingly fine

207 Autumn King, or World-Beater. Very large solid heads,.......

213 Mammoth Rock Red. Solid heads, averaging ten pounds each,

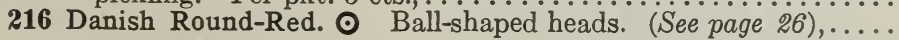

\section{Is In lots of 5 pounds, deduct 10 cents per pound.} Dutch. Per pkt. 5 cts.,......................... \$0 $20 \$ 060 \$ 200$

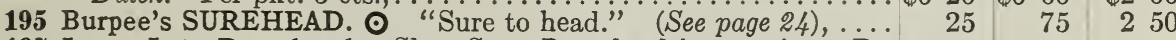

197 Large Late Drumhead. Short-Stem Drumhead is superior. Per pkt. 5 cts. main-crop variety and very popular with market gardeners....

201 Burpee's Late STONEHEAD. ○ Fine for winter,...........

203 DANISH BALLHEAD. ○ Danish grown. (See page 25 ).......

205 Burpee's DANISH ROUNDHEAD. ○ (See page 26),..........

206 Filderkraut, or Pomeranian Pointed Heading. Per pkt. 5 cts.,..

SAVOY CABBAGE.

209 Perfection Drumhead Savoy. ๑ Hard heads; of finest quality.

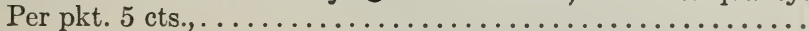

\section{RED CABBAGES.}

215 Large Red Drumhead, or Red Dutch. The standard variety for

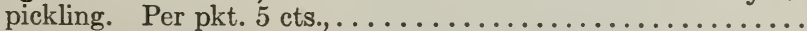

Per oz. 1/4 lb. Per lb.

\begin{tabular}{l|l|l|l}
15 & 50 & 175
\end{tabular}

$18 \quad 60 \quad 200$

$25-75 \quad 250$

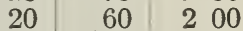

$20 \quad 65 \quad 225$

\begin{tabular}{l|l|l}
15 & 50 & 175
\end{tabular}

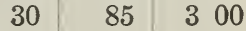

25 Dw Except where priced, each variety is $\mathbf{1 0}$ cents per packet.

There are tons on tons of seeds that are true to name, but of common quality; honest but poor; they are not Burpee's 


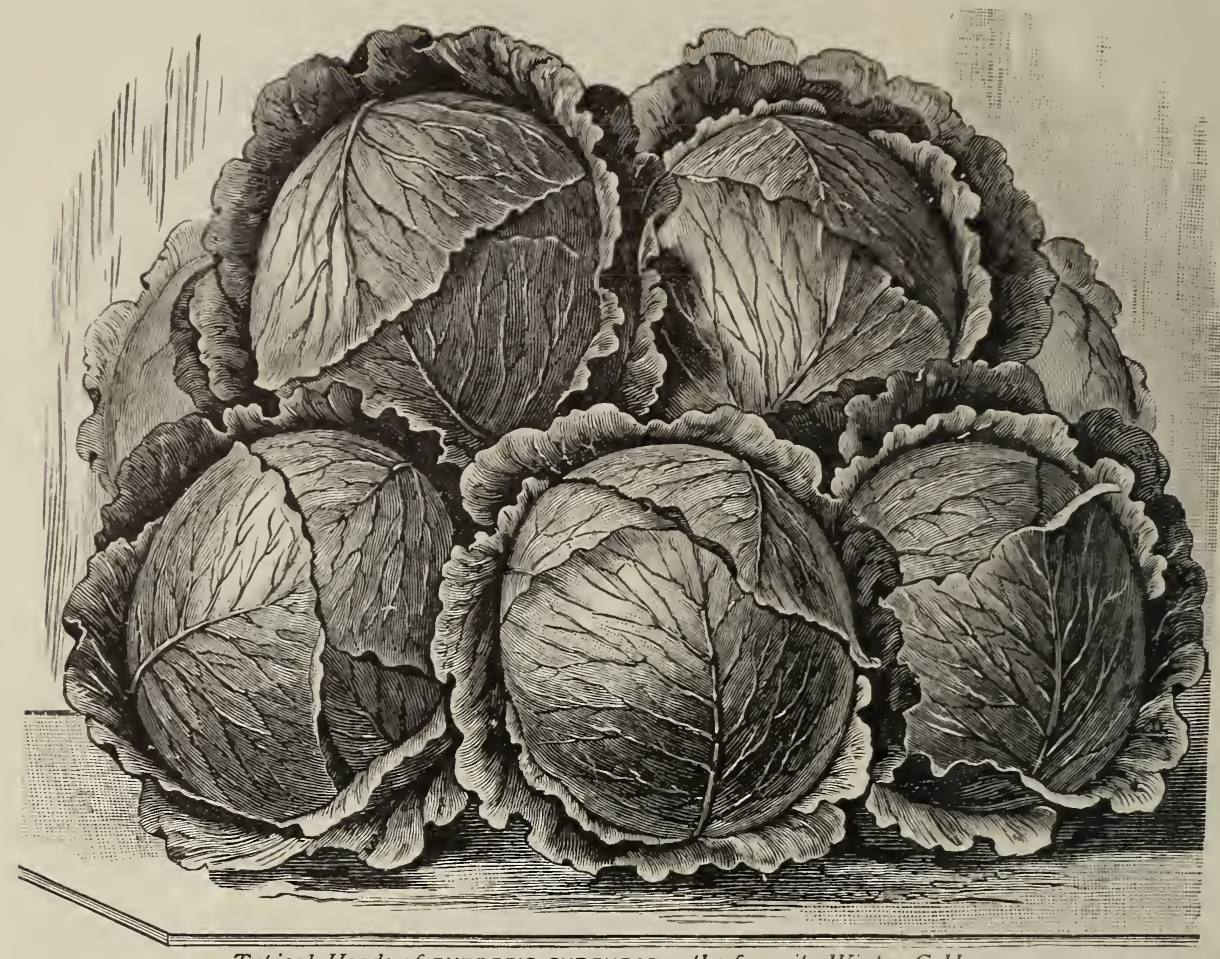

Typical Heads of BURPEE'S SUREHEAD,-the favorite Winter Cabbage.

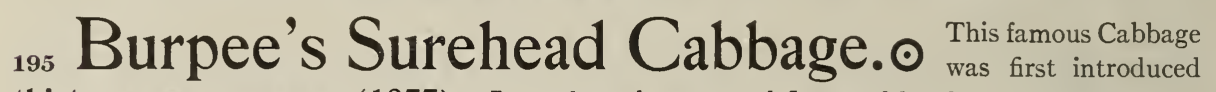
thirty=seven years ago (1877). It produces large round flattened heads, of the Flat Dutch type, and is remarkable for its certainty to head. It is ALL HEAD and always SURE TO HEAD. The heads are remarkably uniform, extremely hard, fine in texture, and ordinarily weigh from ten to fifteen pounds each. It is very sweet flavored, has but few loose leaves, keeps well, is good for shipping, and is just the variety and quality to suit all lovers of good cabbage.

Per pkt. 10 cts.; oz. 25 cts.; $1 / 4$ lb. 75 cts.; per lb. $\$ 2.50$.
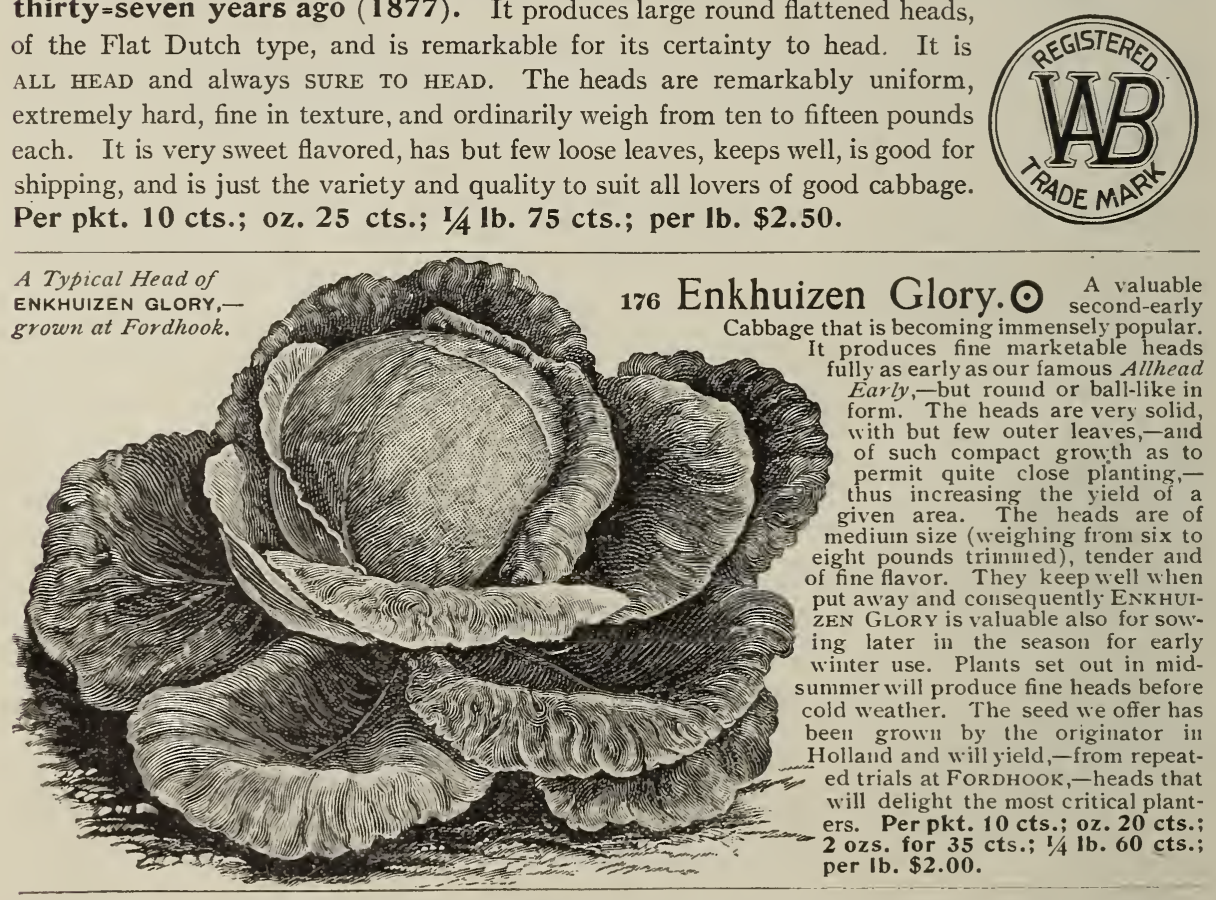

$\odot$ Please bear in mind $\odot$ that a bull's=eye $[\odot]$ means that we consider varieties so marked the 


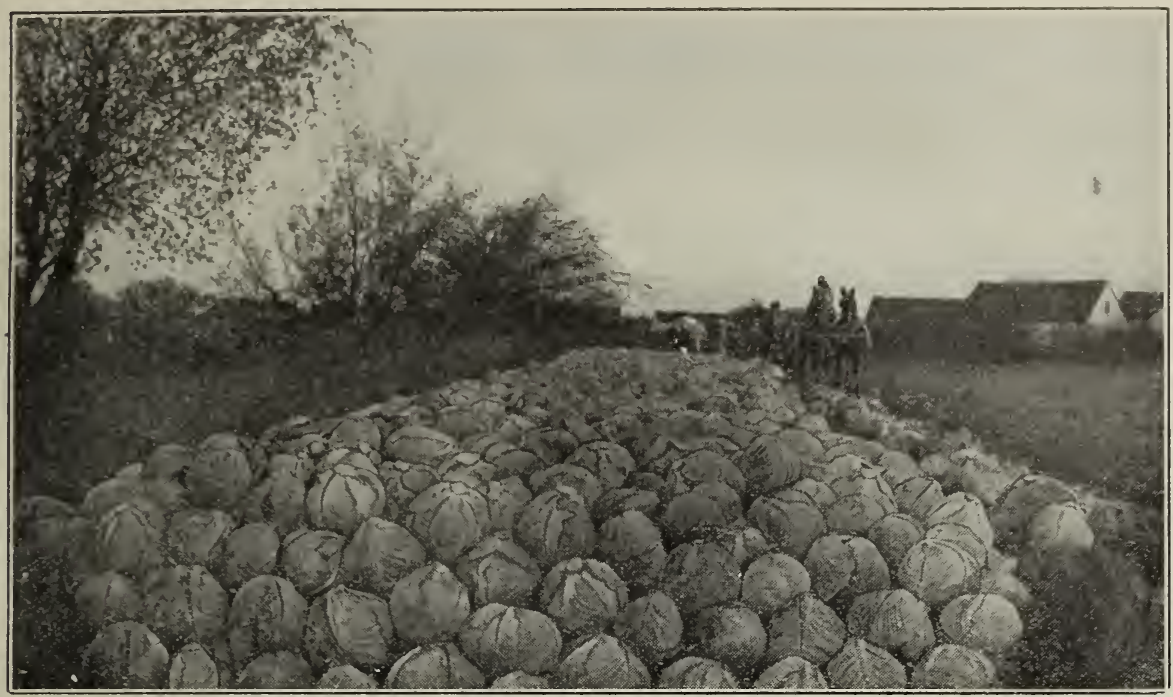

Burying "BALLHEADS" for winter,-from a November Photograph taken in Denmark.

ras True Danish Ballhead Cabbage. $\odot$

This famous Cabbage was first introduced by us from Denmark twenty=seven years ago and our Danish=grown seed is absolutely unequaled! It is highly esteemed for winter use by reason of esteemed for winter use by reason
the great solidity and excellent keeping qualities of the heads. Large quantities of these cabbages have been imported for spring sales from Denmark, and have proved most popular in our markets. It is an easy matter to grow this same cabbage in cool locations in our own country, and we offer seed of the finest selected strain, which has been grown especially for us in Denmark. From repeated trials, as well as from the experience of many customers purchas-

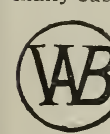
ing this seed, we are conmost carefully grown strain surpasses in even growth and head-

ing, as well as in uniform size and solidity of heads, any other strain of the so-called "IIollander Cabbage." The magnificent heads are nearly round in form, very hard and solid; they keep in finest condi-

tion when buried through the winter, coming out solid in spring. Per pkt. 10 cts.: oz. 20 cts.; $1 / 4$ lb. 60 cts.; per lb. $\$ 2.00$. Is This price is for our Imported Danish=grown Seed, which is the Best that Denmark produces,-see illustration from a photograph.

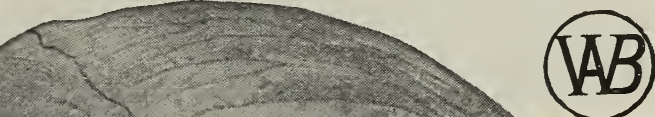

Thousands of Testimonials could be printed, did space permil! These apply not only to our Thousands of Testimonials famous SPECIALTIES, such as the Danish Ballhead described above, but also to our Superb Re-selected Stocks of Standard Vegetables and Flowers. Many of these letters are from customers who have planted BURPEE'S SEEDS for ten, twenty, and even for more than thirty years, - and always with satisfaction! We hope our friends (for our customers are our friends) will not hesitate to write us their experiences, even though we cannot afford to pay "Uncle Sam" an extra cent postage in addition to cost of paper and ink to publish any considerable number of such letters received. They are none the less appreciated and do us good in giving encouragement to persevere in our work of trying constantly to improve existing strains of seeds as we 1 as to introdince Distinctive Novel.ties of real merit. 


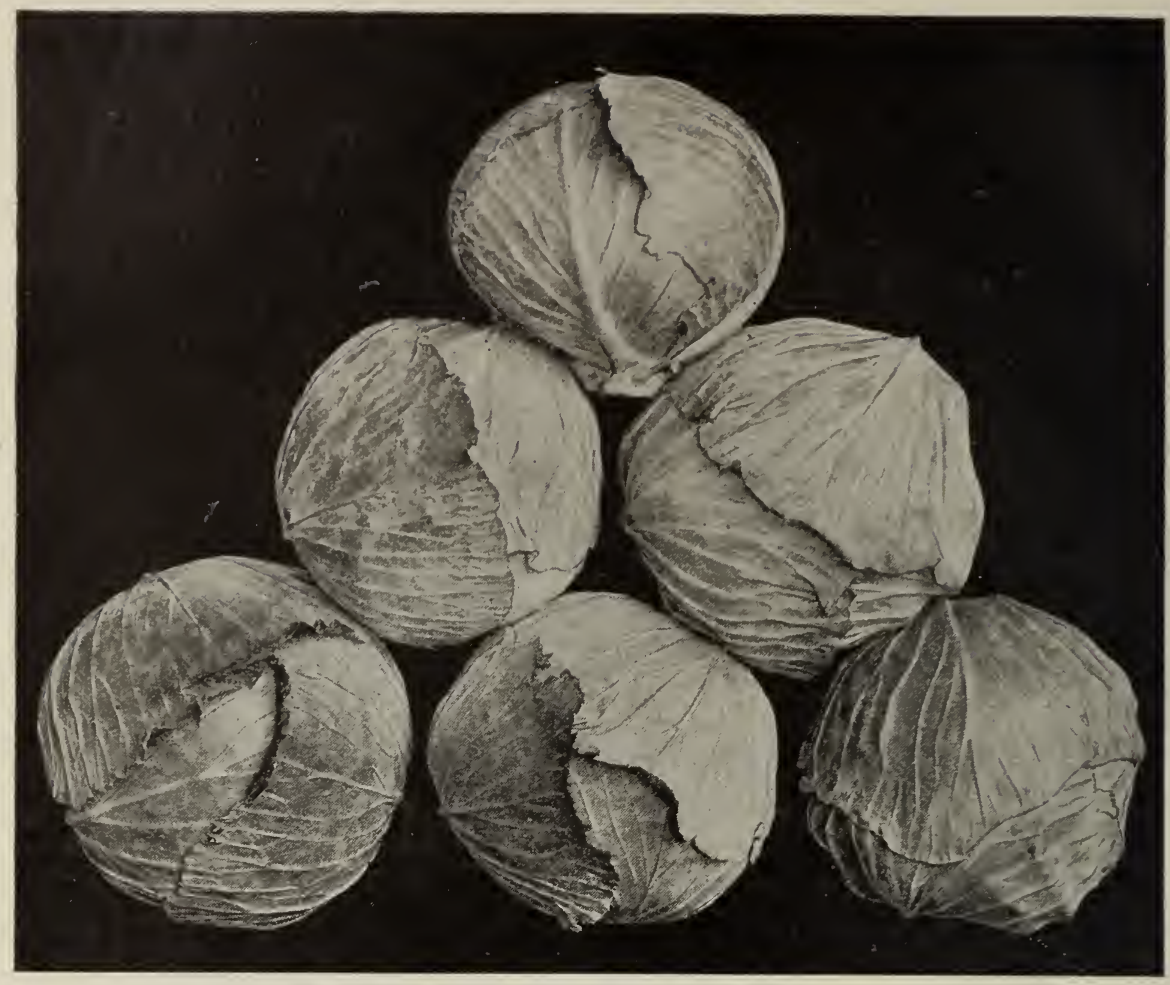

\section{${ }_{205}$ Burpee's “Danish Roundhead” Cabbage.॰}

An Earlier Shorter Stemmed Type of the Famous "Danish Ballhead."

Of more robust growth, the heads are heavier and of equally fine quality. The original Danish Ballhead Cabbage (first introduced by us twenty-seven years ago) is esteemed for the extreme

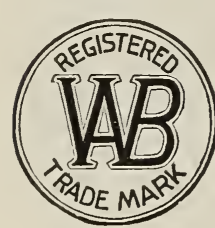
solidity and great weight of the heads as well as for its superior keeping qualities, but it can be grown successfully only in a comparatively cool location. "Danish Roundhead" has less outer foliage and is better able to resist blight, being, in most sections, as vigorous in growth as the best American types. The heads average larger and mature nearly two weeks earlier. The heads are unusually solid, and beautifully white when trimmed. They are splendid keepers when stored away for the late winter and spring, at which time the fine heads bring the highest market price. Per pkt. 10 cts.; $0 z .20$ cts.; I/4 lb. 65 cts.; per Ib. \$2.25.

\section{Burpee's Danish "Round-Red" Cabbage. $\odot$}

This grand novelty is the third distinct variety of Cabbage that we have introduced from

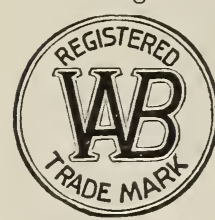
Denmark. It produces round or ball-shaped heads of great solidity and intensely deep rich coloring. The plant is of strong, compact growth. The heads are perfectly round, from six to eight inches in diameter. The leaves composing the heads are of an unusually deep purplish red; this rich coloring extends to the center of the head, showing only a small portion of white when cutting across the veins and tissue. The extra dark coloring, remarkable hardness and large size of heads make it an excellent market type, as well as most desirable for the housewife in slicing for slaw, salads, etc. Per pkt. 10 cts.; I/2 oz. 30 cts.; oz. 50 cts.; 2 ozs. 85 cts.; $1 / 4$ Ib. $\$ 1.50 ;$ per Ib. ; $\$ 5.50$.

In 1887 Twenty-seven years ago, when we introduced the Danish Ballhead CABBAGE, after our first visit to the Island of Amager, little did we think that in a quarter of a century it would become so popular with large growers for market in America. It is now grown on vast areas, and thousands of pounds of seed are required each year to supply our trade. We continue to have grown for us seed from the same stock that first made its reputation, and never handle any seed except that produced for us under contract in Denmark. 


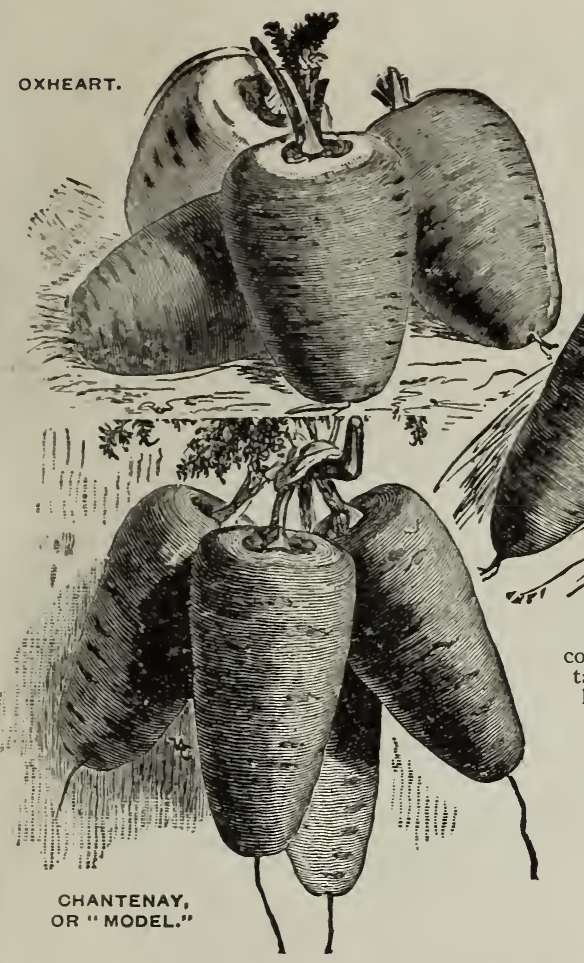

\section{Best Garden CARROTS.}

Gardeners wishing early strains which will mature uniformly, or longer later sorts with roots of even form and color for bunching, will find our seed absolutely unsurpessed.

absolutely unsurpassed. The French Forcing is the smallest and earliest of all, closely followed by the Early Scarlet Horn, which is about three inches long and decidedly stumprooted.

CXHEART and CHANTENAY, or MODEL," are five to six inches long: longer, but both are $\mathrm{th} \mathrm{ick}$ decidedly $\mathrm{s} \mathrm{t} u \mathrm{~m} \mathrm{p}$ rooted, and of $f$ inest quality. DANVERS is DANVER is a popular
rich orangecolored carrot, six inches long, of medium size, and with tapering roots, blunt at the end. NANTES is a splendid half-long variety. The St. Valery. and Improved Long Orange are both long and rather slender; they need a light soil for successful growth and harvesting. I. 5 While those in the lower list are the varieties chiefly grown for stock feeding on account of their great productiveness, we would call attention also to the fine feeding value, as well as the greater ease in harvesting, of a choice table variety like the Chantenay, Oxheart, or Danvers. The seed costs but little more, and the crop is available for market if opportunity offers.

One ounce of seed will sow 200 feet of drill. two and a half pounds will plant one acre of land in rows three feet apart.

ISAsk for our LEAFLET ON ROOT CROPS, giving directions for seeding and handling the crops.

\begin{tabular}{|c|c|c|c|}
\hline & $\begin{array}{l}\text { Per oz. } \\
\$ 012\end{array}$ & $\$ 0^{1 / 4 \mathrm{tb}} 35$ & $\begin{array}{l}\text { Per tb. } \\
\$ 125\end{array}$ \\
\hline dard e & 10 & & \\
\hline of the finest & 10 & & \\
\hline I Guerande. $\odot$ Of sple & 8 & 5 & 75 \\
\hline dark orange, & & & \\
\hline & 8 & & \\
\hline vrang & & & \\
\hline aint Valery. & & 25 & \\
\hline
\end{tabular}
I $\rightarrow$ Each of the above, 5 cents per packet.

\section{CARROTS,--for Stock Feeding.}

These are grown for feeding to stock during the winter months and are desirable when used in connection with grain and dry forage as an appetizing relish to keep stock in fine condition. Carrots are especially useful to have on hand for the benefit of the stock in cases of sickness. Full directions for growing these and other root crops for stock feeding are given in our LEAFLET ON ROOT CROPS, which is sent free to customers if requested.

Improved Short White has a very large root, three to four inches in diameter at the top, and gradually tapering throughout the length of six to eight inches. The plant is a strong, vigorous grower and will produce a very large crop from a given area under favorable conditions.

The Large White and Large Yellow Belgian Carrots produce large roots three to four inches in diameter at the top and eight to ten inches in length. The Large

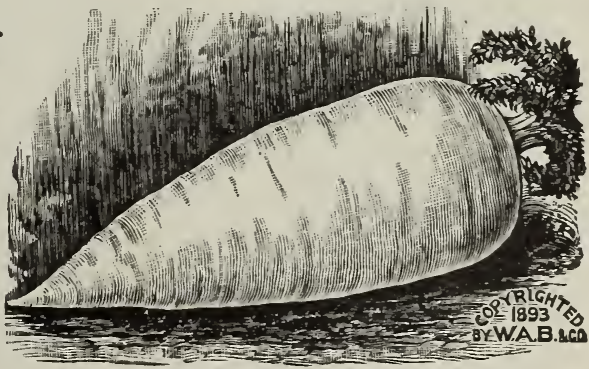

IMPROVED SHORT WHITE CARROT.

White has white skin and flesh, while the Yellow has skin and flesh of a deep lemon-yellow. Two to three pounds are required to plant one acre.

235 Improved Short White. $\odot$ The best and most productive, . . . $\$ 0 \begin{array}{lllllll}08 & \$ 0 & 25 & \$ 075\end{array}$

238 Large White Belgian. Large white; very productive,......... $6 \begin{aligned} & 6 \\ & 15\end{aligned}$

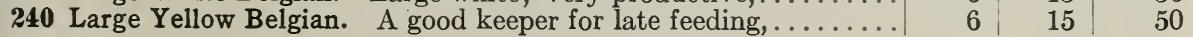

do 5 Each of the above, 5 cents per packet. 


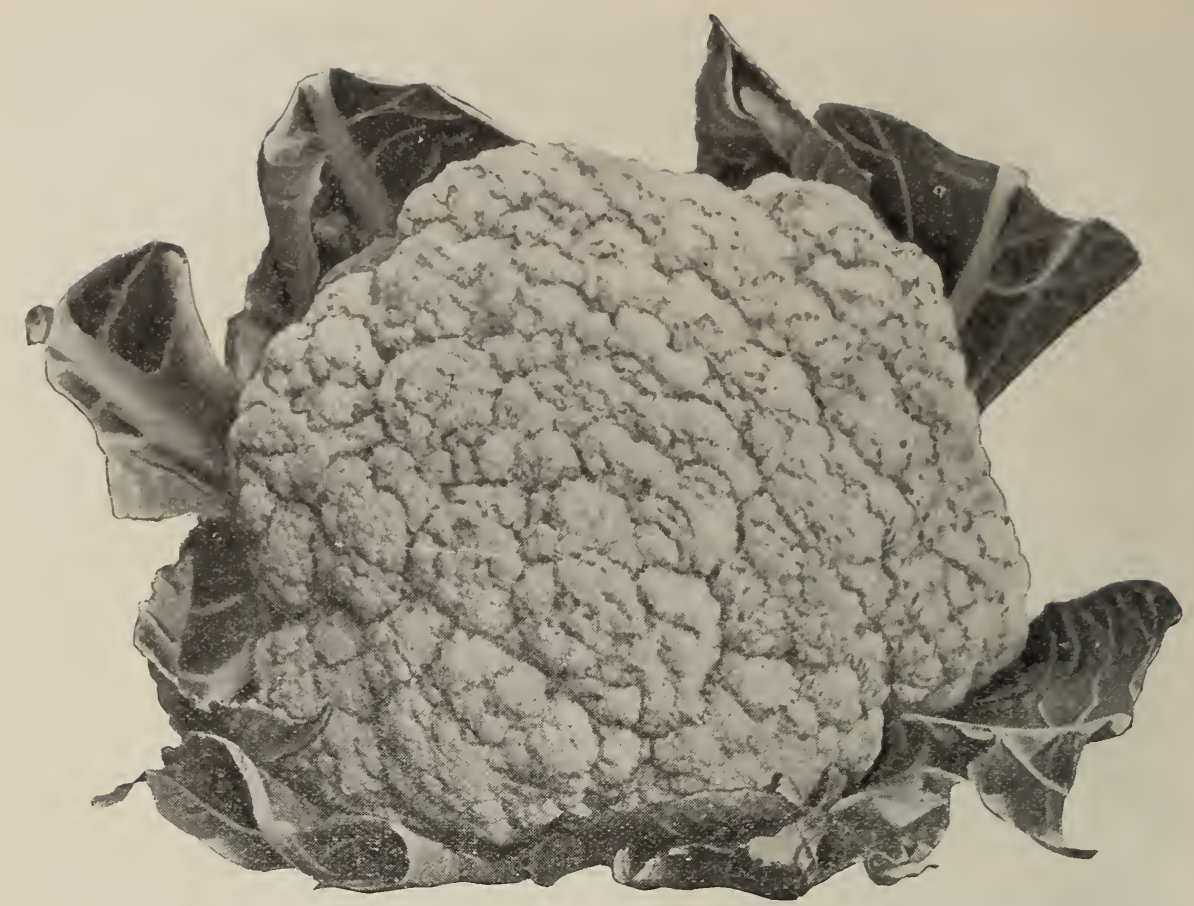

BURPEE'S NEW "DRY WEATHER" CAULIFLOWER,-accurately reproduced from a Photograph.

\section{${ }_{245}$ Burpee's “DRY-WEATHER” Cauliflower.๑}

Similar to Burpee's Best-Early, it produces equally large, solid, pure white heads and is only about a week later. It is especially adapted for growing in dry locations where other varieties fail. To secure the best heads, it is essential, however, to make soil quite rich and give thorough cultivation. While especially adapted forg rowing in dry locations it will produce heads equally as fine as the best varieties in more favorable situations and is superior to any other excepting only Burpee's Best-Early. By the use of this strain fine cauliflower can be grown in many dry districts where it has been impossible heretofore to raise this luscious vegetable. Half size pkt. 15 cts.; per pkt. 25 cts.; $1 / 4$ oz. 70 cts.; $1 / 20 z . \$ 1.25 ;$ per oz. $\$ 2.50 ; 1 / 41$ b. $\$ 9.00 ;$ per $1 \mathrm{~b} . \$ 34.00$.

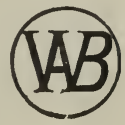

\section{CAULIFLOWER.}

The type of cauliflower most generally planted for market is the Early Dwarf Erfurt, of which there have been developed a number of selections showing increased earliness, dwarfer short-stemmed growth, with larger, finer heads, and more sure heading tendency. The very finest and highest development of this type is BURPEE'S BESTEARLY, which is carefully grown for our trade in Denmark, where the finest cauliflower is produced.

BURPEE'S DRY-WEATHER is a special selection of similar type for planting in dry sections or hot summers where the ordinary strains of cauliflower do not succeed. It produces larger heads than Burpee's Best-Early, and has given splendid results under such conditions, as is evidenced by the numerous testimonials received from our customers and the increasing demand for seed of this variety.

Early Snowball and Extra Early Dwarf Erfurt are fine strains of the Erfurt type, and are valuable for earliness in the order named.

The later and less expensive varieties are more hardy and less liable to blight. The Extra Early Paris is very dwarf and is useful for planting in the early spring, but the heads are not so large nor as solid. Algiers and A utumn Giant are strong-growing large late varieties, which produce good heads'when planted where the summers are comparatively cool.

244 Burpee's Best-Early. ○ (See page 29.) Half-size pkt. 15 cts.; per $1 / 4$ oz. 70 cts., ......................... $\$ 0 \quad 25 \quad \$ 2 \quad 50 \quad \$ 900 \quad \$ 3400$

245 Burpee's Dry-Weather. $\odot$ (See above.) Half-size pkt.

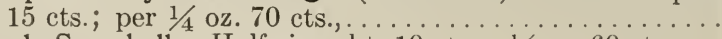

247 Early Snowball. Half-size pkt. $10 \mathrm{cts}$; 1/4 oz. $60 \mathrm{cts.}$,

249 Extra Early Dwarf Erfurt (Extra Selected), 1/4 oz. 50 cts.,.

250 Early Dwarf Erfurt. The well-known standard, ........

252 Extra Early Paris. Used for forcing. $1 / 2$ oz. 35 cts.,.....

256 Algiers. Of vigorous growth, large heads. $1 / 2 \mathrm{oz} .35 \mathrm{cts}$., .

258 Veitch's Autumn Giant. Very late. $1 / 2 \mathrm{oz} .25 \mathrm{cts} ., . .$. .

\begin{tabular}{r|rr|r|r|r|r}
25 & 2 & 50 & 9 & 00 & 34 & 00 \\
20 & 2 & 00 & 7 & 50 & 28 & 00 \\
15 & 1 & 75 & 6 & 75 & 26 & 00 \\
10 & & 90 & 3 & 00 & 10 & 00 \\
10 & & 65 & 2 & 00 & 7 & 50 \\
10 & & 65 & 1 & 85 & 7 & 00 \\
10 & & 45 & 1 & 35 & 5 & 00
\end{tabular}




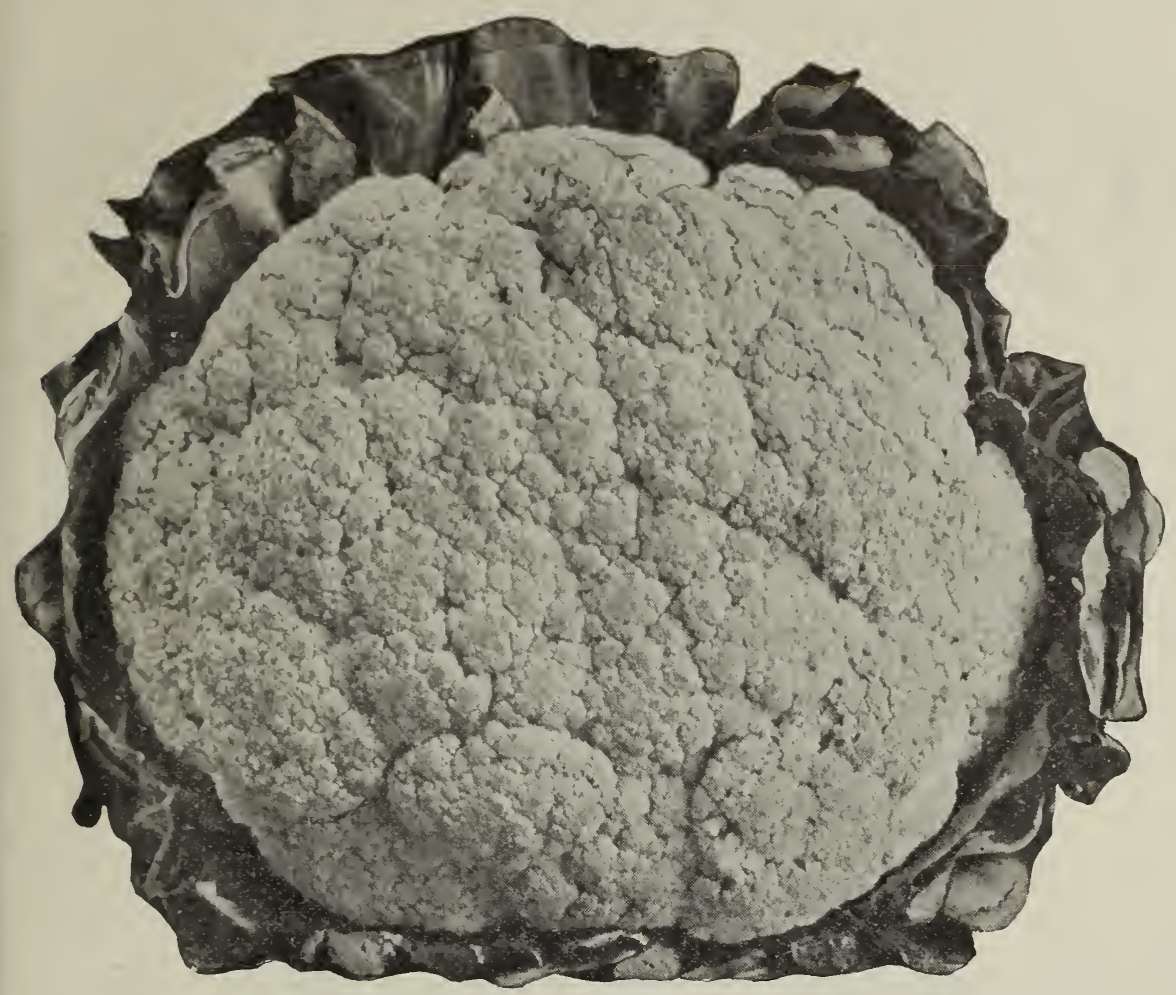

A trimmed head of BURPEE'S BEST-EARLY CAULIFLOWER,-accurately reproduced from a Photograph.

\section{${ }_{2+4}$ Burpee’s Best-Early Cauliflower.๑}

The earliest and best quick=growing Cauliflower. This grand strain was first introduced by us t wen $y=$ seven years ago (in 1887), and has fully maintained all the merits then claimed for it. The plants are of strong growth, with erect pointed dark-green leaves growing closely about the head. It is remarkable both for the extreme earliness and certainty with which the plants produce fine heads. In good soil the heads measure eight to ten inches across; they are a pure snowy white, with very close compact curd of extra fine quality. So extremely solid and deep are the nearly globeshaped heads that they weigh heavier than other heads of equal size. Had we space to spare we could publish many testimonials from experienced growers, who are most enthusiastic in stating that this is, beyond doubt, all its name implies,-“" The BEST=EARLY Cauliflower."

Half = size pkt. 15 cts.; pkt. 25 cts.; $1 / 4$ oz. 70 cts.; $1 / 4$ lb. $\$ 9.00 ; 1 / 2$ lb. $\$ 17.00$; per Ib. $\$ 34.00$
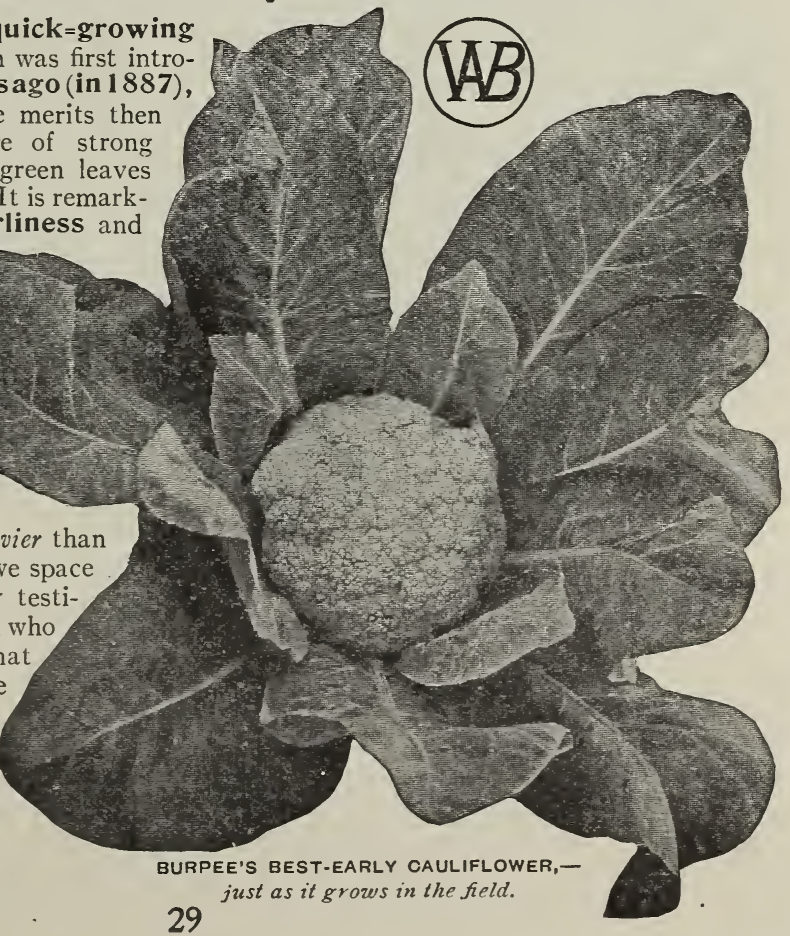


\section{CELERY.}

In growing celery for market it is most important that the seed planted shall be the finest selected strains, so that the plants will be uniform in growth and color, and free from sports which would interfere with the proper blanching. Where the plants are of an even height, the rows can be more quickly blanched, and if the product is uniform there is little or no waste when preparing the bunches for market. The introduction of the so-called "self-blanching" type has greatly extended the cultivation of celery and also the period during which it can be marketed. The markets of our large cities are now practically supplied with fine blanched celery throughout the year. Early celery shipped from the extreme South now joins seasons with that which is stored throughout the winter in the Northern States.

\section{CELERY,-Self-Blanching Early Varieties.}

Of these, the Golden SELF-Blanching is the finest and most generally grown. The plants are of strong stocky growth, with broad thick stalks which blanch readily to a clear waxen yellow. Owing to the great demand for this variety, which we first introduced, there has been considerable trouble with plants which produce hollow stalks from cheap strains of seed. Our special French-grown seed, which is produced by the originator, can be depended upon to yield crisp solid stalks of the finest type, and is almost entirely free from any green-stalked rogues or sports. The American-grown seed we offer has been produced from the French stock and has given satisfaction to critical planters everywhere.

WhITE Plume is the earliest celery in cultivation. It is distinct from the Golden Self-Blanching in being taller in growth, more slender in stalk, and blanches to a pure snowy whiteness. In the growing state the stalks and leaves are a dark rich green, but when earthed up for blanching when the weather gets cool in the fall, the stalks and leaves blanch most readily pure white. It is a valuable market sort on account of its extreme earliness, but is not a good keeper nor so fine in flavor as the Golden Self-Blanching.

\begin{tabular}{|l|l|l|l|l|l|l|l|l|l|l|l}
\hline & $1 / 2$ oz. & Per oz. & 2 ozs. & $1 / 4$ lb. & Perlb.
\end{tabular}

260 Golden Self-Blanching. ○ American-grown seed, $\$ 0 \quad 35 \quad \begin{array}{llllllllll}\$ 0 & 70 & \$ 1 & 10 & \$ 1 & 85 & \$ 7 & 00\end{array}$

262 Golden Self-Blanching. $\odot$ Originator's seed grown

in France; - the most popular strain. (See page

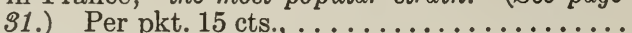

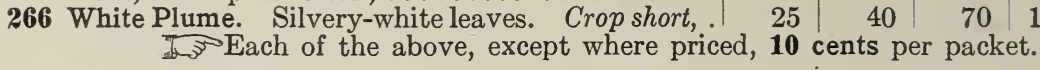

\section{Winter Varieties of CELERY.}

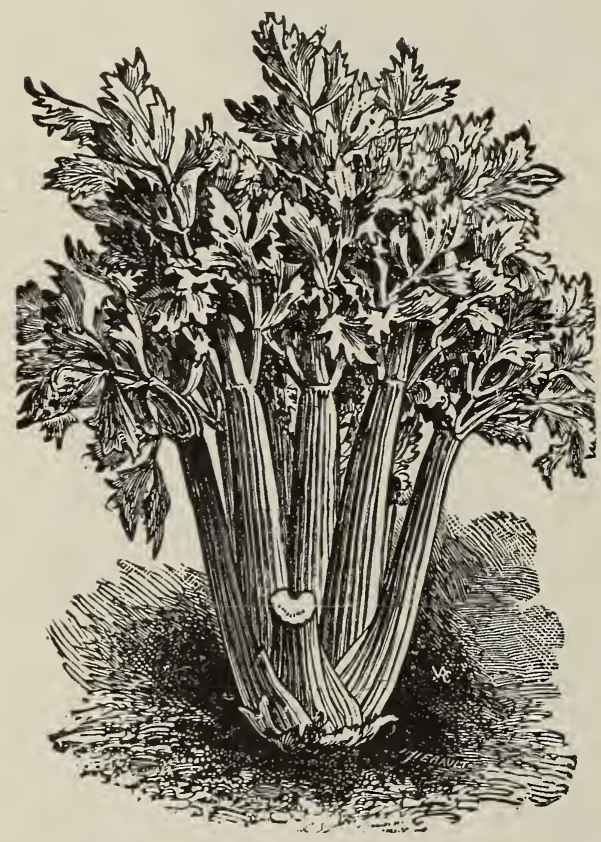

GIANT PASCAL CELERY.

The original type of celery. The stalks during growth have a rich deep green coloring which must be eliminated in the fall by a careful earthing up or exclusion of light from the growing stalks. These varieties being more solid, have better keeping qualities when stored for winter than the quick-growing self-blanching type.

In the newer sorts, such as WINTER QUEen and EVANS' TRIUMPH, the green coloring is not so deep nor so firmly fixed, so that they are more readily blanched. These two varieties are of shorter, stockier growth, with broader, heavier stalks than the older varieties, making them more readily handled in growth, blanching and in storing away for the winter as well as when putting them in bunches for market. GIANT PASCAL is an extra fine variety of dwarf, stocky growth, forming large bunches of broad, thick, heavy stalks, which blanch to a paper whiteness, are entirely free from strings, and more crisp and brittle than those of any other variety. It is the finest of all winter celeries for winter in a home market, but is too brittle to stand shipment any distance. DWARF GOLDEN HEART is a market standby, being broad stalked, short and stocky in growth, with the inner stalks or heart of a rich golden yellow. Giant White Solid is of tall growth but with large solid stalks, of fine appearance and flavor when properly blanched. Dwarf LargeRibbed, also called Kalamazoo, is a standard market variety, but the stalks are not so broad nor do the plants make as large bunches of stalks as the newer sorts.

In growing winter celery it is important that the plants should be well earthed up in the row and the blanching of the stalks should be well advanced before they are stored away for the winter, as it requires a long time to blanch them if put away in the green state.

CELERIAC is grown for the large round roots which are cooked like beets or turnips.

I $\rightarrow$ You should read the plain directions given in our Leaflet on CELERY CULTURE which will be sent Free, - if asked for in your order.

In lots of 5 pounds, 10 cents a pound less.

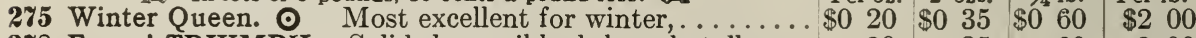

Per oz. 2 ozs. 1/4 lb. Per lb.

278 Evans' TRIUMPH. Solid, large-ribbed, broad stalks, . . . $20 \quad 35 \quad 60 \quad 200$

280 Giant White Solid. Tall growing. Per pkt. 5 cts., . . . . . $20 \quad 35 \quad 60 \quad 200$

282 Giant PASCAL. ๑ A splendid keeper................. $25 \quad 45 \quad 7575$

284 Dwarf Golden Heart. Golden-yellow heart. Pkt. 5 cts., $\quad 20 \quad 35 \quad 60 \quad 200$

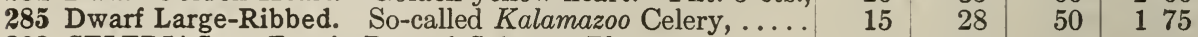

293 CELERIAC, or Turnip-Rooted Celery. Pkt. 5 cts., . . . . . $20 \quad 35 \quad 65$ 20

D? Each of the above, except where priced, 10 cents per packet. 


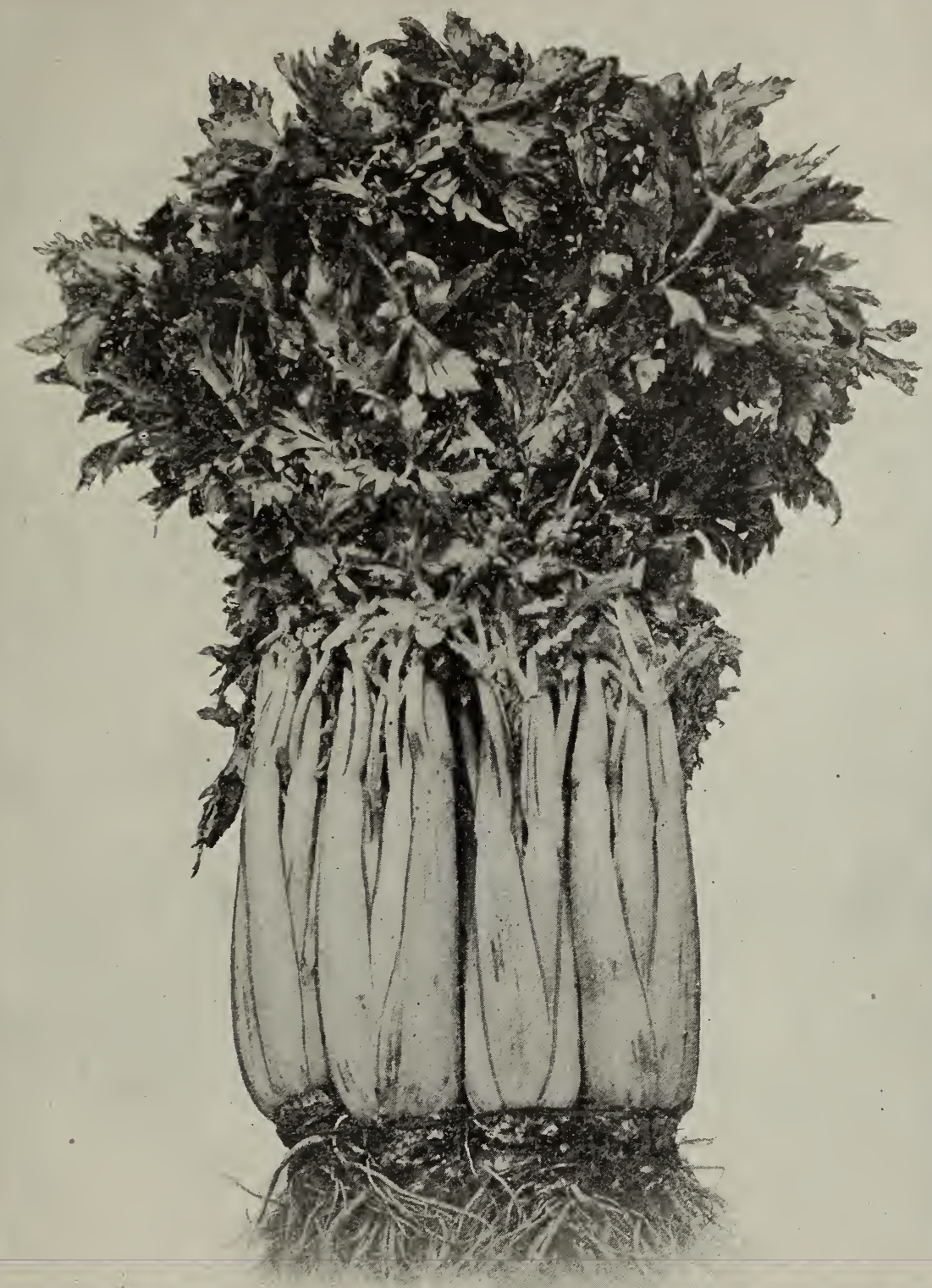

GOLDEN SELF-BLANCHING CELERY,-From a Photograph.

The above illustration is from a photograph of twelve stalks sent us by the NILES CELERY COMPANY, Wellsboro, Penna., and were produced from seed purchased of us. The twelve stalks weighed twelve pounds, measured twenty-seven inches in circumference and twenty inches high. The NILES CELERY COMPANY have for several years purchased large quantities of our French-Grown Seed, - than which there is none bettert

\section{${ }_{262}$ Celery,-Golden Self-Blanching.๑}

It is of dwarf compact habit, with thick, solid, heavily ribbed stalks which blanch easily to a clear waxen yellow. When grown in rich moist soil, the stalks are numerous, each plant being fully as thick through as the largest of the tall late sorts, and with a very large solid heart of beautiful golden-yellow stalks and leaves. The stalks are crisp and solid, free from stringiness, and of most delicious flavor. Finest French-grown seed, which is unsurpassed. Per pkt. 15

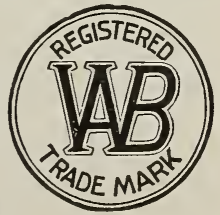
cts.; 0z. $\$ 1.25 ; 2$ ozs. $\$ 2.35 ; 1 / 4$ lb. $\$ 4.35 ;$ per lb. $\$ 17.00$. 


\section{CHICORY.}

Chicory is grown largely in some localities as a substitute for coffee, the roots being sold usually on contract to the factories. To secure fine, large roots the soil should be rich and deeply worked, plants thinned out to four inches apart. Witloof is now largely grown for use as a winter salad,-full cultural directions are given on page 47 of BURPEE'S ANNUAL FOR I014.

295 Large-rooted, or Coffee. A choice strain, 297 Witloof-Chicory. Excellent as a salad, .

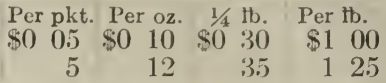

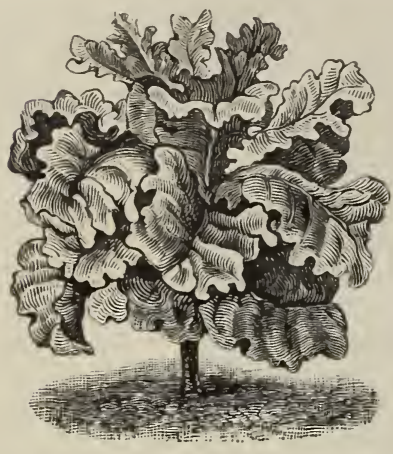

\section{COLLARDS.}

This is a type of Cabbage grown for winter use in the Southern States, both to furnish a large amount of green forage for stock, and also a fine boiling "greens" for table use. The plant grows quickly and produces a large quantity of tender foliage on a tall stein. The young leaves at the top of the stalk form a loose head and furnish the portion for table use, being very tender and delicate in flavor when boiled. For garden culture, seed may be started in a regular seed-bed during June or July and transplanted to the garden like Cabbage. For field culture the seed is sown thinly in drills three feet apart, requiring two to three pounds per acre. When well started, plants should be thinned out to stand five or six inches apart in the row. Thorough cultivation will greatly increase growth of the plants and produce leaves of larger size, more tender and of finer flavor than if plants are allowed to become stunted in hardpacked soil.

"How to Grow" CABBAGE AND CAUliflower. This is tical information for FREE with orders, - if asked for.
299 Georgia. Used in the South for "greens," . 300 North Carolina Blue Stem. ○ A very fine strain,

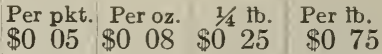

\begin{tabular}{l|llr}
5 & 10 & 30 & 100
\end{tabular}

CHIVES Chives are perfectly hardy perennial plants of the onion type. They are grown for their $\mathrm{CHIVES.} \mathrm{small} \mathrm{leaves,} \mathrm{which} \mathrm{are} \mathrm{produced} \mathrm{freely} \mathrm{very} \mathrm{early} \mathrm{in} \mathrm{the} \mathrm{spring,} \mathrm{for} \mathrm{giving} \mathrm{a} \mathrm{mild} \mathrm{onion}$ flavor to various dishes. Roots, grown at FORDHOOK FARMS, per bunch, 15 cts.; 2 bunches for 25 cts.

\section{CORN SALAD. (Fetticus.)}

This is an extremely hardy, quick-growing plant the leaves of which furnish an excellent substitute for Lettuce during winter. As the plants grow freely only in cool weather, the seed should not be sown until late in August or early in September, and further plantings for succession may be made in October. Sow thinly in drills ten to twelve inches apart to admit of hoeing before the ground freezes. It is quite hardy, but when wanted for use during winter it is best to protect the plants with a light mulch after the ground freezes.

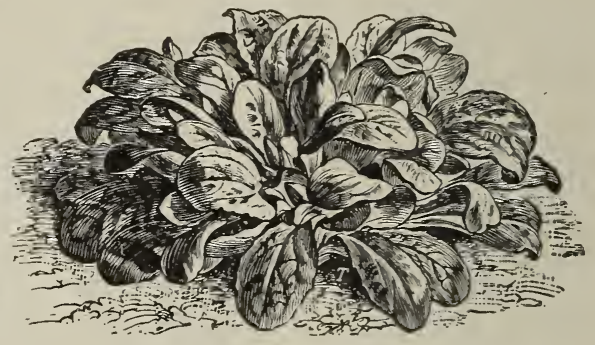

LARGE ROUND-LEAVED CORN SALAD.

351 Large Round-Leaved, Large-Seeded, makes a delicious salad, .

Per pkt. Per oz. $\quad 1 / 4$ tb. Per tb.

$\begin{array}{lllllllll}\$ 0 & 05 & \$ 0 & 07 & \$ 0 & 15 & \$ 0 & 50\end{array}$

\section{"Proved by Test," Unless you should order some variety that we do not catalog and instruct that we get it for you (when we shall send it at your risk,--in its original package), you may be abso-} lutely sure that you will receive from us only such stocks of strictly high-grade seeds as have been proved absolutely "Best by Test."

Many seedsmen have much to say about tested seeds, but unfortunately with most dealers this applies only to blotter tests for vitality. Our tests for vitality are soil tests. While necessary that seeds grow, it is of prime importance that they shall be of choicest selected strains, such as can be relied upon to produce products "true to type." This can be learned only by thorough field trials. No other seedsmen in America make so many or such complete trials as are conducted annually at our famous FORDHOOK and SUNNYBROOK FARMS.

WE KNOW SEEDS by means of the FORDHOOK TRIAL GROUNDS. We sell only seeds known to be good-THE BEST SEEDS THAT GROW! 


\section{Burpee's Selected Strains of SWEET CORN.}

This is a standard table delicacy throughout our country, where it has reached the highest development in the greatly improved varieties of to-day. By a proper selection of varieties it may be had in constant supply, from earliest summer until cut off by hard frosts. For the earliest supply and extreme Northern States, only the hardier Extra Early varieties can be planted. These mature also very early from our choice Northern-grown seed in the Southern States, but the quality of the later sorts is so much superior that we would recommend only a single planting of Extra Earlies in warm locations, where the finer sorts can be grown. The seed of the Extra Early varieties is rather hard and flinty in character and can be planted quite early when the trees are starting out in leaf. The seed of the true Sugar varieties, however, is very much shriveled. This seed is liable to rot instead of germinating if planted before the soil becomes warm. The weather should be warm and settled, with the trees well out in leaf, before planting. In our own grounds at FORDHOOK FARMS we plant the large late varieties, such as Burpee's While Evergreen, until the middle or last of July. Then we make two or three plantings, a week apart, of the Extra Early sorts, which furnish an abundance of ears during the cool fall months until growth is stopped by severe frost. Do not neglect these late plantings, but keep putting in fresh plots as soon as the ground is available in the garden, and encourage quick growth by thorough cultivation. We seldom fail to get fine ears from these late plantings, while the stalks make most excellent forage

\section{Varieties of Table or "Sugar" Corn.}

In true sweet corn the Early Fordhook is still the very earliest of all. The true stock of EARLY FORDHOOK is distinctly earlier than Cory and other extra early sweet corns.

BURPEE'S EARLY COSMOPOLITAN is the earliest large-eared sort and is of excellent flavor, coming in right after Early Fordhook, and in our trials is frequently as early as the Cory, with a larger, finer, better filled ear. RED-COB CORY, WHITE-COB CORY, EARLy MINNESOTA and Kendel's Early Giant are standard extra early sorts. BURPEE's EARLY SHEFFIELD is a cross-bred variety of strong, hardy growth, with stalks six feet in height and producing large, well-filled ears at the same season as the Crosby's Early TwelveRowed. It is a little larger and later than Early Cosmopolitan.

"Howling Mов" is a large-eared early variety, only three to five days later than CORY, with a much larger ear, and of exceptionally fine flavor.

BURPEE'S GOLDEN BANTAM is a unique and very distinct early sweet corn of rich flavor, the grains being of a deep golden yellow. Owing to its extreme hardiness it can be planted earlier in the spring than other sweet corns. and will yield the earliest ears. If planted at the same time, the season is about the same as for Crosby's Twelve-Rowed. On account of its very distinct appearance it would not take well on the market until its splendid flavor becomes known, when there will be a great demand for this variety, which many consider the finest flavored of all sweet corns. It is especially adapted for the cool climate of the New England and other Northern States. SEY. MOUR'S SWEET ORANGE produces a larger ear and is ready for the table one week later.

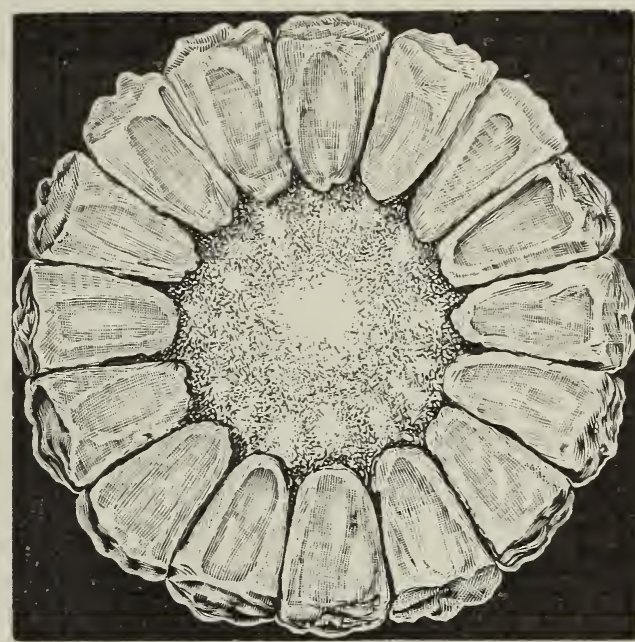

BURPEE'S NEW "WHITE EVERGREEN" SWEET CORN.

Section of an Ear,-from a Photograph.

BURPEE'S EARLIEST CATAwBA follows our Golden Bantam in season; it is of very sweet flavor,-see page 36

CROSBY'S EARLY TWELVE-ROWED and EarlyMammoth are both excellent second-early or midseason varieties of good growth and producing ears of medium size with grains of fine flavor, Black Mexican, so called on account of the color of the seed, is a medium-early variety producing broad grains of very sweet flavor.

STOWELL'S EVERGREEN is the standard large-eared main-crop or late sort. BURPEE'S WhITE EVERGREEN is the finest development of the Stowell's type, having been established by long-continued selection in pure white color, large size of ear, depth and sweetness of grain and extremely strong vigorous growth. On good land the stalks frequently set and develop three good ears to a stalk. Mammoth Late is a little later in season than Stowell's Evergreen and produces mammoth ears of excellent quality.

COUNTRY GENTLEMAN is a late variety, producing three or four slender ears to a stalk. These ears are closely filled with small, deep grains, placed in irregular rows, sometimes known as "Improved Shoe-Peg."

302 Burpee's Earliest Catawba. $\odot$ A rival to Golden Bantam. (See page 36.) Pkt. 15 cts.,....................

303 Burpee's Early Sheffield. Very hardy and early,

305 Early Fordhook. $\odot$ Large ears, early and sweet,

$\$ 030 \$ 100 \$ 175$

Bushel.

308 Red-Cob Cory. A popular extra early,

309 White-Cob Cory. Produces uniformly large ears, .

310 "HOWLING-MOB." $\odot$ (See page 36),

311 Burpee's Early Cosmopolitan. Large handsome ears,

313 Early Minnesota. An old favorite,

314 Seymour's Sweet Orange. - (See page 35.) Pkt. 15 cts.,

315 Crosby's Early Twelve-Rowed. $\odot$ Very popular,

328 Kendel's Early Giant. Earlier than Crosby's, . .

331 Early Mammoth. Very thick large ears,

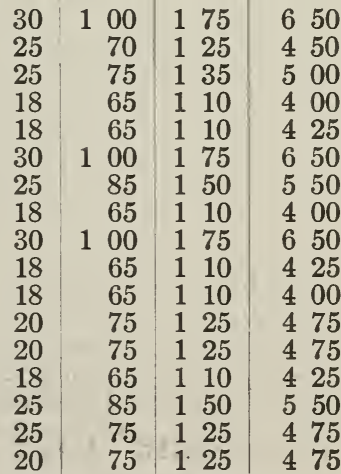

333 Burpee's White Evergreen. $\odot$ (See page S7),

335 Stowell's Evergreen. (4 bush. at $\$ 4.00$ per bush.)

337 Country Gentleman. $\odot$ (See page 37 ),

340 Black Mexican. The kernels are very sweet, 


\section{There are two kinds of Sweet Corn,-one is Golden Bantam.}

The lucky man has Golden Bantam in tassel. There are two kinds of sweet corn. One is Golden Bantam. You do not know about it, and, tnerefore, you cannot get it. If the husks the Prodigal Son lived on had been Golden Bantam husks, the fatted calf would have lived to give milk. Starters of movements might start one to put Golden Bantam in the grocery store. It looks like field corn that was taken too young. The ears are small and the color forbids until experience teaches that the kernels are sugar and the color really golden. The market for it must be made by increasing numbers of people who have had at least one sitting in front of a platter of the little golden ears, ten minutes out of the garden if possible.-The Chicago Tribune's WeekLy AlmaNAC, July 2oth, IOI3.

\section{As We Approach Autumn.}

A goldfinch swings from the wild sun flower, inspecting the full granary of that provident plant. A cat bird is in the witch-hazel and a crow at the top of a tall white oak. Beyond a grape arbor is a field of corn, and beyond the field the dark green of thick woods through which runs a wagon trail

In the heat of the sun the field of corn ripens as any field of corn, but when the goldfinch has hidden in the thicket and the cat bird flitted, when the crimson of the sunset has flooded the dark green of the woods and died away and when the full August moon has risen to light the winding wagon road the Little People come out to cultivate their favorite maize.

They bring the syrups of clover, the elixir of sweet alyssum, and the essence of mignonette; they draw from their stores of the best running of sap from the sugar maples and honey from the combs filled by selected bees which worked in Elysian fields in a south wind after a night of rain; they come with the spices of the Spice Islands and the juices of many sweet berries, with the juice of muskmelon and the milk of cocoanuts, with the juice of sugar-cane and of many fruits.

In the light of the full August moon they work in the field of favorite maize where, in each hill the husbandman planted, they had dropped pieces of gold from the treasure of the Leprechaun. They work all night in the light of the moon and in the morning the goldfinch comes back to the wild sun flower and the cat bird to the witch-hazel and the field of corn standing beyond the grape arbor and against the dark green of the thick woods looks like any other field of corn and in the heat of the day ripens as any other field of corn.

But when the husbandman has gone forth and picked an armful of ears, when the good wife has brought a large pot of water to boil, when the yellow ears have come out of their green sheaves, gone into the pot and have come out of it again, when they are on the table, flanked by butter and salt and when the first juices have been released in the genial processes of mastication, then it is known that this corn did not ripen as other corn, but came marvelously from the alchemy of nature.

The field that stood beyond the grape arbor and against the dark green of the thick woods was GoLDEN BANTAM SWEET CORN.

The Tribune's Weekly Almanac in THE CHICAGo Sunday TRIBUNE, August 17,1913

Golden Bantam is the best and most deliever eaten, and seems to be quite adaptable to our climate, which is a short season, the spring being late. In sending our order for the seeds we would just like to s2y that we were delighted with results from the seeds we received from you the past two years. - MRS. R. D. AdAMS, Truro, N. S., Canada, March II, I913.

Golden Bantam which I have grown for the corn four years, is the finest recommending it and all your seeds to niy friends; there is real joy in growing such seeds. My garden is much admired and I give the Burpee seeds the greater part of the credit.-MRS. CARRIE W. HUGHES, 429 E. Broad St., Columbus, Ohio, February 8 , 1913.
Golden Bantam cannot be surpassed. I your Brittle $W a x$ is more than you claim for it; they were sweet, tender and were over seven inches long. Stringless Green-Pod and Dwarf Horticultural were excellent. Blue Bantam, New Prolific and British Wouder Peas were delicious. Early May King and Wayahead Lettuce are of the finest quality: Golden Neckless and White Neckless Turnips are solid and choice quality. The Beets and Carrots are of rich flavor. This is only my second year oll a small farm. but I believe your seeds to be "Best Seeds that Grow." They yield abundantly and the vegetables are delicious. I was in the retail grocery business for over forty years, so I think I am quite a good judge of quality.-J. D. BENKEN, Broadalbin, N. Y., November 6, I912.

Golden Bantam was excellent and your seeds are without a doub ence.-AlBert C. PERK1NS, Gardener to R. A. Duiton, Esq., I6o St. James St., Montreal, Canada, March 9, 1913.

Golden Bantam is doing finely; Mine is the first roasting ear in this neighborhood and my mother will have second. We both have GoLDEN BANTAM for first early, but mine was planted first, about April 15th. The Sunnybrook Earliana Tomato is doing fine. I planted seed in the hotbed April 1oth, and have tomatoes now that are $7 \frac{1}{2}$ inches in circulnference. The Dwarf-Giant Tomato does well here and is especially easy to transplant. From roo transplanted I lost only three and they were taken by cutworms. My mother has bought seeds from you for about thirty. five years, with the exception of one year when you did not send her any catalog and she wouldn't ask for it. But one year was as long as she could stand it and she asked for your catalog the next year. Last year my mother purchased some seed of your Rainbow Corn and it was beautiful.-MRS. EDITH M. SCHNEIDER, Heartwell, Nebraska, June 27, I9I3.

Golden Bantam for Corn, Dwarf-Giant and Burpee's Matchles for Tomatoes, Gibraltar for Onions, with Wayahead for Lettuce, give us best results.-MRS. D. F. SHOVER, 2716 Fifth Ave., McKeesport, Pa., November 25, IgI2.

Golden Bantam was the best ever, as was also your Wayahead Lettuce. The Little Marvel Peas were wonderful croppers, in which respect I do not believe they were surpassed, if equaled, by your Blue Bantam.-RALPH G. WARING, Auburn, N. Y., February 24, IgI3.

Golden Bantam is all you say it is. Have rolden Bantam planted it for a number of years, and this year by planting for a succession will have nothing else. The Six Superb Spencers and IgI2 mixtures of Sweet Peas were simply glorious. The vines were strong and grew so high that some of the tops I could only reach with my upward stretched hand, and I ain five feet six. They bloomed profusely. There were nearly always four flowers on a stem and double ones of every kind, I think.-Thus wrote MRS. L. L. STINSON, I5I4 8th Ave., Greeley, Colorado, when placing all order on March 2, I913.

\section{Burpee's Golden Bantam}

has become so popular that many first-class hotels and restaurants now print on their daily menus "Golden Bantam Sweet Corn." BuRPEE's GoldEN BANTAM's wonderful popularity has led to the introduction of several other yellow varieties, but we know by repeated trials at FORDHOOK and by letters received from private planters and market gardeners that HaL. B. FullerToN, Director of the Long Island Railroad Experiment Stations, is right when he describes it as unique,The Same "Old Chunk of Sweetness,"-Golden Bantam! 


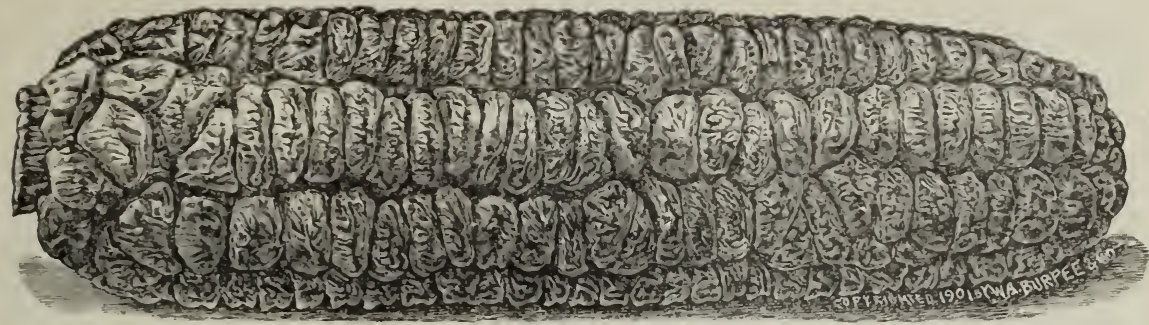

BURPEE'S "GOLDEN BANTAM" SWEET CORN.

Early Sweet Corn,-Burpee's “Golden Bantam.”॰

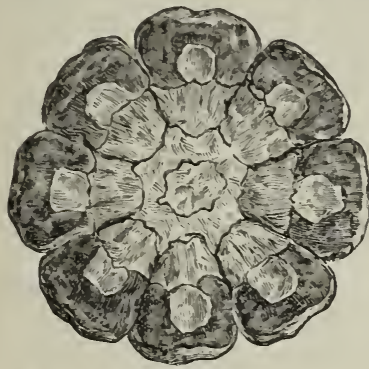

BURPEE'S GOLDEN BANTAM,Section of an Ear. 301 Golden Bantam is becoming each year more because of its extreme-early character, vigorous growth and surpassingly delicious flavor. We have had hundreds of most enthusiastic letters from customers, giving it the highest praise as the finest extra=early sweet corn they have ever grown.

Although the dry grain is entirely free from any flinty glaze, it is exceptionally hard and firm, hence can be planted earlier than any other true Sweet Corn. The stalks are dwarf and sturdy in habit, growing to a
height of four feet ; they bear two and three good ears, which are set well above the ground. The MARK. ears, five to seven inches in length, have eight rows of broad yellow grains, extending to the extreme rounded tip.

Many Market Gardeners report that they find GoLDEN BANTAM their most profitable variety throughout the season (from successive plantings) as soon as customers get acquainted with $i t s$ splendid flavor and distinct color. Golden Bantam is as distinct in flavor from that of white varieties as in color,--being that it does not need scoring or cutting across the grain. Per pkt. (two ounces) 15 cts.; per pint 18 cts.; quart 30 cts.; 2 quarts 55 cts.; 4 quarts $\$ 1.00$; peck $\$ 1.75$; per bushel $\$ 6.50$.
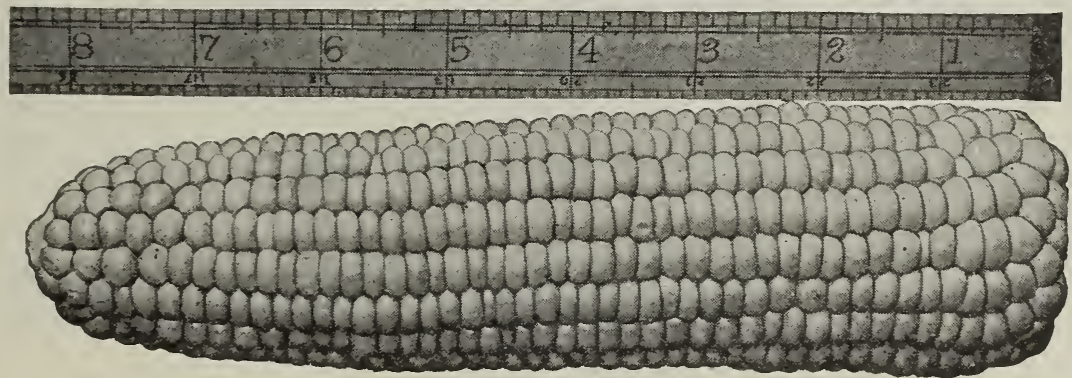

SWEET-ORANGE SWEET CORN,- much reduced in size. Engraved from a Photograph.

\section{Corn,--Sweet-Orange. $\odot$}

"Sweet-Orange" is a most desirable second-early or mid-season variety, growing good ears to a stalk. The ears, ready for use five days to a week after the Golden Bantam, are from six to seven inches in length, with twelve to fourteen rows of deep, rather slender grains of a light canary-yellow. It is fully equal in surpassingly delicious flavor to our famous Golden Bantam! Some planters even prefer it, because of its larger ears and the longer time that they remain in fine edible condition.

314 Sweet-Orange is certainly a fitting companion to follow Golden Bantam. Of exceptionally sweet, tender and full of milk. A great point of merit is that after the grains develop they remain tender and retain their sweetness for a longer period than those of any other second-early corn. Reports from northern localities praise the hardiness of growth and early maturity, while those from the South speak of the protection afforded from worms and smut by the strong heavy husk. Per pkt. (two ounces) 15 cts.; per pint 18 cts.; quart 30 cts.; 4 quarts for $\$ 1.00$; peck $\$ 1.75$; per bushel $\$ 6.50$.

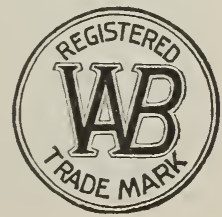




\section{Extra Early Sweet Corn, 302 Burpee’s Earliest Catawba. $\odot$}

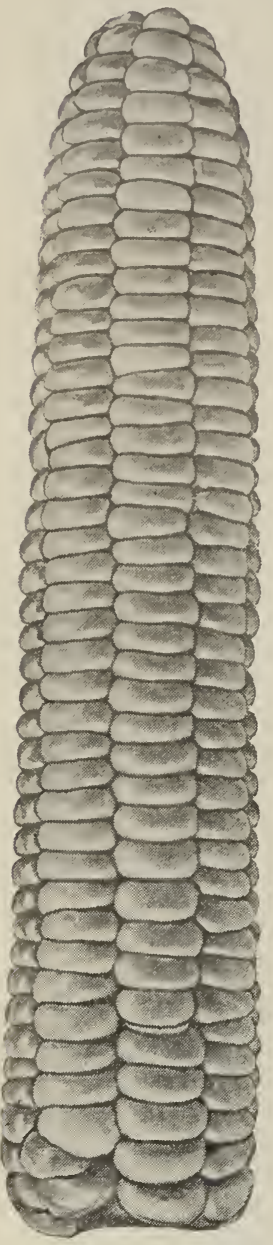

BURPEE'S EARLIEST CATAWBA SWEET CORN

\section{The First Real Rival Yet Discovered to Burpee's Golden Bantam.}

\section{Earliest Catawba resembles our famous Golden Bantam}

in dwarf growth and extreme earliness, to four and one-half feet in height, setting one to three fine ears to a stalk where grown in hills. Grown singly in long rows the plants sucker freely and then frequently bear as many as four and five good ears from a

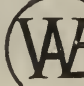
single seed!

Earliest $\mathrm{C}$ a t a w b a produces uniformly handsome ears from six the right size to eat from the cob, which is well filled to the tip with eight rows of broad grains. When ready for use the grains are pearly-white, slightly flushed with rosepink, but in the dry seed the color is the exact counterpart of a fine Catawba grape,a dark rich purple shaded with rose. The small cob is white. Earliest Catawba is most distinct in appearance. The entire outer husks on the ear are shaded heavily with dark red. This reddish coloring in the stalks and blades of the sweet corn plant has been valued by old gardeners as a sure indication of the finest flavor, and this tradition is fully justified when an ear of the CATAWBA is sampled in the field or on the table. Some growers pronounce it even more lender, more juicy, and more deliciously sweet than the popular favorite Golden Bantam!

302 Catawba as grown at Fordhook closely follows our Golden Bantam seventy to seventy-five days from time the seed is planted. We have received letters stating that in New York, its home country, it is not only the sweetest but also the very earliest of all! Pkt. 15 cts; pint 18 cts.; quart 30 cts.; 2 quarts 55 cts.; 4 quarts $\$ 1.00$; peck $\$ 1.75$; per bushel $\$ 6.50$.

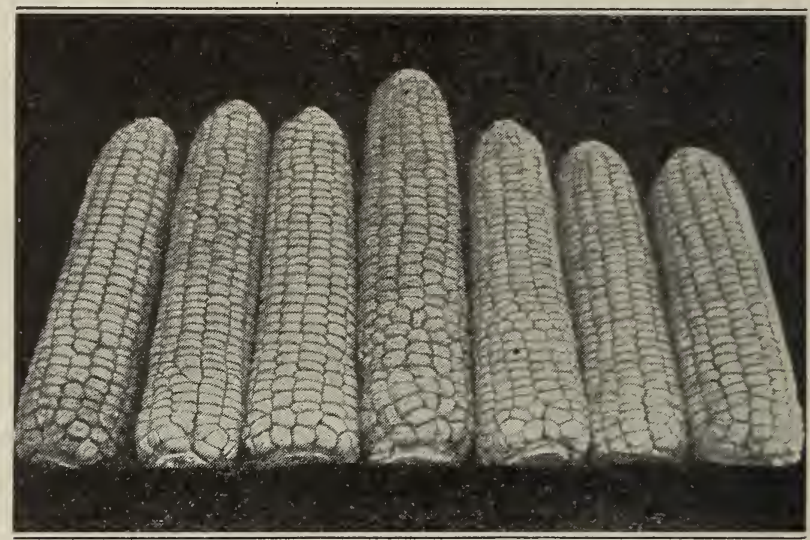

HOWLING MOB SWEET CORN,--from a Pholograph.

\section{${ }_{310}$ Large-Eared Early Sweet Corn,-“"Howling-Mob.”}

How ling-Mob has quickly become popular with planters desirous of being "first in market" with superb large ears of sweetest quality. During season of I9I I the demand for seed Der trade, reserving every bushel for planter who were quick to recognize the sterling merits of this variety, whether for use in the home garden or offering for sale in markets demanding large ears of the finest quality.

H ow ling-Mob originated with C. D. Keller, of Toledo, Ohio and its peculiar but apt name refers to the vociferous demand for the ears when Mr. Keller takes them to market. In developing this corn he aimed to secure a large ear,- - see illustration of ears from a pholograph, -early in the season, possessing the sweet flavor of the later varieties. The stalks are of strong, vigorous growth, four and one-half to five feet in height, have abundant foliage and generally produce two fine ears to a stalk. The ears measure seven to nine inches in length with twelve or fourteen rows of good-sized pearly-white grains. They are covered with a heavy husk which extends well out from the tip of the ears and affords good protection from the green worms which are so often destructive of early varieties.

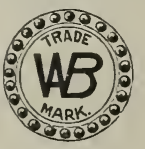

310 Burpee's Early "Howling-Mob" is ready for use only three to five days both are planted at the same time, but the ears are later than the extra early Cory when sweeter that it should really be compared with the second-early Crosby's Twelve-Rowed and other varieties of a later season. The seed we offer has all been grown by the originator, and the originator's stock can be oblained only from us. Per pkt. 10 cts.; pint 18 cts.; quart 30 cts.; 2 quarts 55 cts.; 4 quarts $\$ 1.00$; peck $\$ 1.75$; per bushel $\$ 6.50$. 


\section{Sweet Corn, Burpee's New White Evergreen.๑ \\ (See illustraticn.)}

White Evergreen has ears fully those of the regular Stowell's, and is about five day's earlier, while the grains remain tender considerably longer. Its most

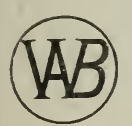
valuable feature is the $\mathrm{ex}$ treme paper-whiteness of the grains, which makes not only a more attractive ear when served on the table, but is most important for the canner. It retains ils whiteness when put up in cans as distinct from the yellowish tinge of the still popular original Stowell's Evergrecn.

White Evergreen makes strong vigorous stalks, height. The ears have white tassels and light-colored silk. The ears contain sixteen or more rows of deep grains, which are protected by a thick, heavy husk. Two and even three fine ears are frequently produced on each stalk. Per pkt. 10 cts.; pint 12 cts.; quart 20 cts.; 4 quarts 75 cts.; peck $\$ 1.25$; per bushel $\$ 4.75$.

\section{Country Gentleman. $\odot$}

This late or main-crop variety is the result of a cross of the Ne Plus Ultra with the Stowell's Evergreen, producing a larger ear than the former, but retaining its productiveness, similar fine quality, and irregular "shoe-peg" arrangement of the crowded, slender, deep grains. The ears, being so much larger than those of the original type, are more desirable in most localities as a market variety. Per pkt. 10 cts.; pint 15 cts.; quart 25 cts.; 4 quarts 85 cts.; peck $\$ 1.50$; per bushei $\$ 5.50$.

305 Early Fordhook. (- This is the largest-eared extra earlies, - the ears averaging six to seven inches in length. It WB is two to three days earlier than Cory and cob of pure white coloring. The ears are eight-rowed, with quite small $\mathrm{cob}$ and deep grains. Per pkt. 10 cts.; pint 15 cts.; quart 25 cts.; 4 quarts 75 cts. per peck $\$ 1.35$; per bushel $\$ 5.00$.

311 Burpee's Early "Cosmopolitan." 'This grand new variety profew days later than First of All or Early Fordhook. In size of ear and fine quality it equals the best second-earlies, such as Crosby's. The stalks grow five to six feet in height. The ears are of most handsome appearance, Tight to nine inches long, with ten or AB more rows of large grains. The cob is pure white and the ear is well filled. the grains at the top making a round point to the ear. The ears are just the right market size. It is most desirable to plant at intervals throughout the season for a succession of crops. Per pkt. 10 cts.; pint 15 cts.; quart 25 cts.; 4 quarts 85 cts. peck $\$ 1.50$; per bushel $\$ 5.50$.

Is To have the finest sweet corn, it must be picked in just the right condition, that is, when the skin of the grain breaks at the slightest puncthe skin.

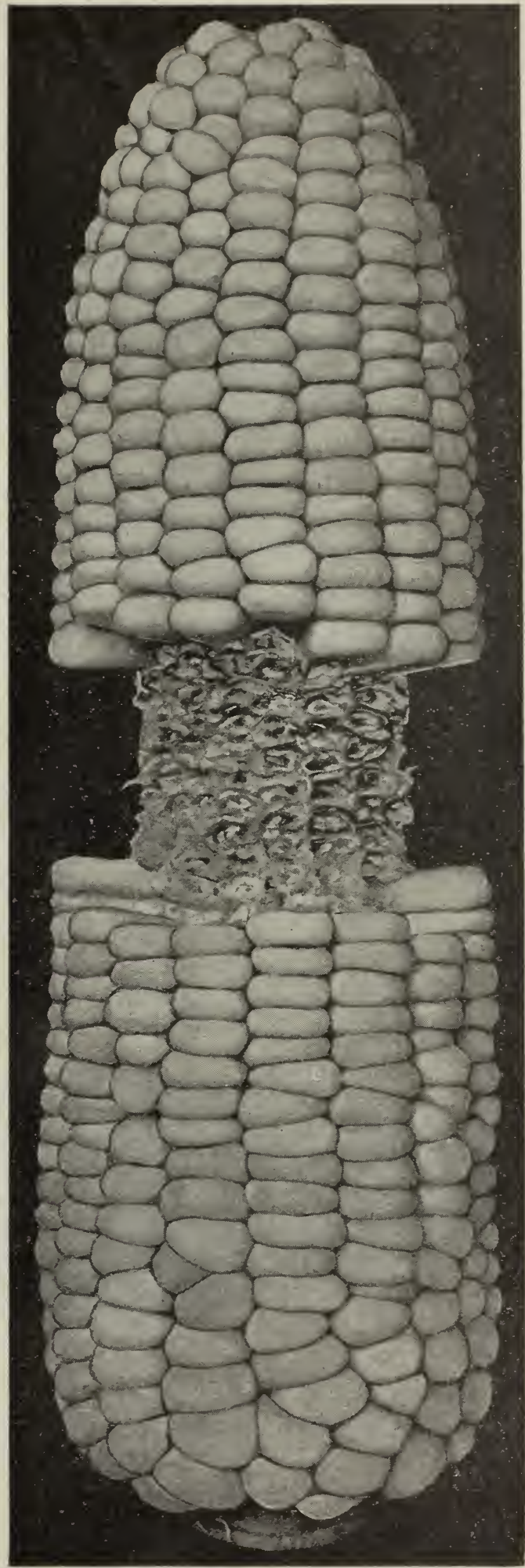




\section{Three types of the hardy EARLY ADAMS CORN.}

EXTRA EARLy ADAMS is a dwarf-growing type as planted in the South, and is adapted for the first or earliest planting in the Northern States. The stalks grow to a height of five feet and set one or two rather short, wellfilled ears near the base. On account of the hardiness of the grains it can be planted earlier in the spring than seed of the true sweet corns; in this way it is frequently of value in obtaining the earliest market crop.

ADAMS EARLY is entirely distinct from the preceding, having a strong, tall-growing stalk from seven to eight feet in height, producing one or two large long ears which are set well up upon the stalk. The ears are as large as those of Stowell's Evergreen, or even longer, and have a thick heavy husk which affords protection from the worms that frequently destroy so large a portion of the early crop of sweet corn.

BURPEE'S DREADNAUGHT AdAMS EARLY is an improved development of the Large Adams Early, the stalks growing to an equal height and producing larger and thicker ears which are fuller at the outer end and more closely resemble those of the large sweet corns. In our grounds this "Dreadnaught Adams" from northern-grown seed is distinctly earlier, finer in flavor and more tender when gathered at the proper stage than the regular southern type of Adams Early.

345 Extra Early Adams. Extremely hardy,

347 Adams Early. Desirable for planting in the South......................

349 Burpee's "Dreadnaught" Adams Early. An improved

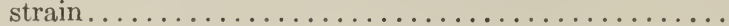

\begin{tabular}{|c|c|c|c|}
\hline $\begin{array}{l}\text { Quart. } \\
\text { \$0 } 15 \\
15\end{array}$ & $\begin{array}{c}4 \text { quarts. } \\
\$ 045 \\
45\end{array}$ & $\begin{array}{r}\text { Peck. } \\
\$ 085 \\
85\end{array}$ & $\begin{array}{l}\text { Bushel. } \\
\$ 325 \\
325\end{array}$ \\
\hline 15 & 45 & 85 & 32 \\
\hline
\end{tabular}

Io $v^{5}$ Each of the above, $\mathbf{1 0}$ cents per packet.

\section{POP CORN.}

Pop corn is quite largely planted as a market crop in some sections. It should be grown rather thickly on poor ground, as the grains nust be small and hard. It should not be planted near field or table corns, as it mixes readily with other types.

\begin{tabular}{l|l|l|l|} 
& Pint. & Quart. 2 quarts. 4 quarts. & Peck.
\end{tabular}

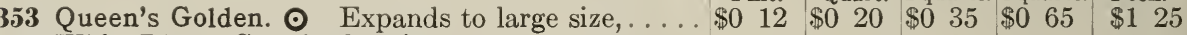

355 White Rice. Standard variety,............. $12 \quad 18 \quad 30 \quad 55 \quad 100$

359 New California Yellow. $\odot$ Pkts. only.

360 Golden Tom Thumb. Pkts. only.

ID $\sigma^{\rightarrow}$ Each of the above, $\mathbf{1 0}$ cents per packet.

\section{CRESS.}

The Fine Curled or Pepper Grass is grown from seed sown thickly in drills in the early spring or fall. The plants are cut and tied in bunches, for sale in the same manner as water cress. One ounce will sow 200 feet of drill.

Water Cress may be grown easily in shallow ponds or along the edges of shallow streams of fresh, running water and meets with a ready sale in city markets during winter and early spring. Seed should be sown in a damp location and the young plants transplanted to the stream or pond. One ounce will sow a plot of seed-bed sixteen feet square.

\begin{tabular}{r|l|l|l|l|} 
Per pkt. & Per oz. & $1 / 4 \mathrm{lb}$. & Per lb.
\end{tabular}

364 Fine Curled, or Pepper Grass. An excellent salad, . . . . \$0 05 \$ $\$ 0 \begin{array}{lllllll}\$ 0 & 07 & \$ 0 & \$ 0 & 40\end{array}$

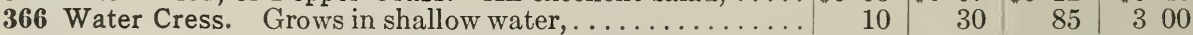

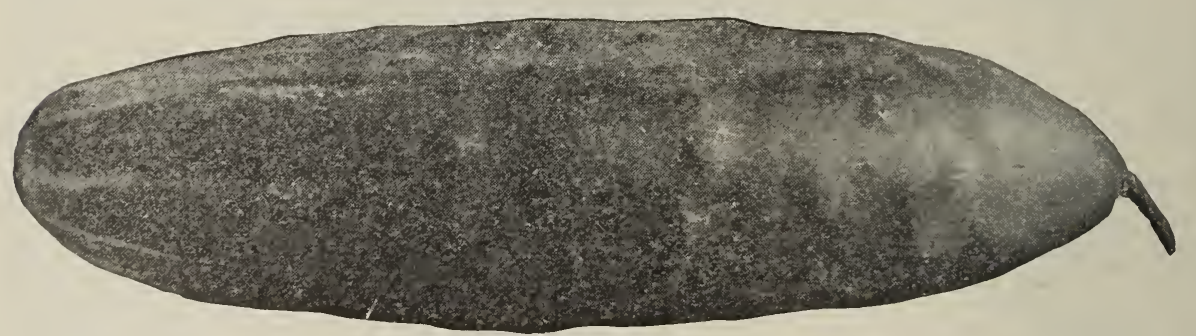

DAVIS' PERFECT CUCUMBER, -reproduced from Photograph.

400 Davis' Perfect Cucumber. $\odot$ As now selected is well worthy of praise. The long, even fruits are of fine form, with an intensely dark rich green skin. With very few seeds the solid white flesh is of superb quality for slicing. So handsome and regular are the fruits that they bring an extra price on market, - - often being taken for "hot-house grown." The vines are of strong growth and quite prolific. Per pkt. 5 cts.; oz. 10 cts.; $1 / 4$ lb. 30 cts.; per lb. $\$ 1.00$. 


\section{CUCUMBERS.}

Cucumbers are planted in large areas both for market fruits and for pickling purposes. For a profitable return it is important to select a variety adapted for your purpose, soil, and season. In the cool Northern States the Early Russian, which is the earliest of all cucumbers, will make a good growth and a very early crop of small fruits for market, but this variety is chiefly adapted for planting where small-sized fruits are needed for pickling, as for table purposes it has no value outside of its extreme earliness. This is true also to a greater or less extent of the other extra early varieties, such as the Early Green Clusler, Early Frame, Green Prolific, and Everbearingnone of which under ordinary garden conditions reach a length greater than four to five inches.

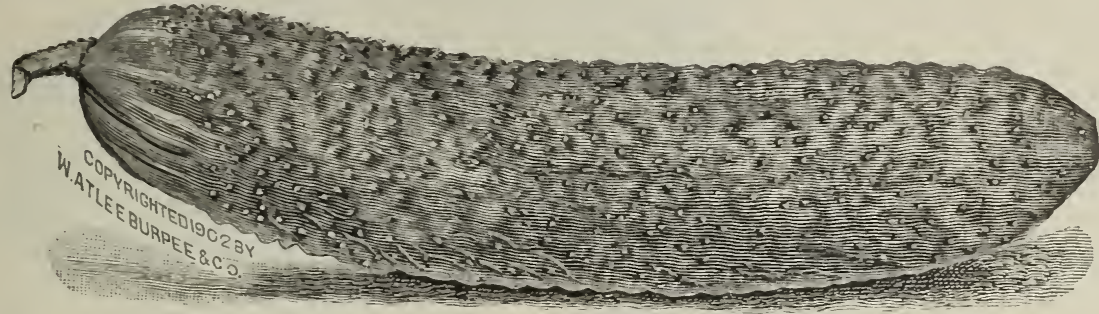

CUMBERLAND PICKLING CUCUMBER.

The earliest market variety, producing fruits of good size, and even, regular form is BURPEE'S EXTRA EARLY White SPINE, and we consider this the best to plant under general conditions for the early market crop; the fruits average about six inches in length, of smooth outline and attractive appearance. The White Spine type is the most popular and best known in the market, and for a general market crop of good size and smooth regular fruits we recommend FORDHOOK WWHITE SPINE because of its strong vigorous growth, great productiveness, and fine appearance of the deep green fruits. IMPROVED ARLINGTON WHITE SPINE is also a very uniform variety and of a desirable size and shape. Cool and Crisp is an extra early White Spine, rather more slender than Burpee's Exlra Early, while the Klondike is of good size, regular form and a rich dark green, and is now largely grown in Florida for shipping to Northern markets. The DAVIS PERFECT as now selected is well worthy of the attention of those growers who are desirous of supplying their trade with cucumbers resembling hot-house varieties.

BURPEE'S FORDHOOK FAMOUS is of the White Spine type, growing to an extra large size, and has fruits which are very thick-meated and especially fine in flavor. It is best adapted, however, to a cool location, as the vines are apt to blight to some extent in hot dry seasons.

EVERGREEN, or Extra Long White Spine, produces smooth regular fruits which are frequently twelve inches long.

FORDHOOK PICKLING is of strong growth, very attractive and a desirable size and shape for large pickles. CUMBERLAND PICKLING is large, light in color, and thickly set with spines; especially fine for fancy pickles. LONDON LONG GREEN is an old favorite, producing large fruits of extra length. BURPEE'S GIANT PERA produces large, smooth, light green fruits of mild flavor. Japanese Climbing is of extra strong vigorous growth, producing large deep green fruits of good flavor, and in our trials we have found that this variety withstands the dry summer weather more successfully than ordinary types. West India Gherkin is a small pickling fruit, two inches in length and quite seedy; it is grown exclusively for pickling.

I ${ }^{5}$ iVhen ordering ask for our Leaflet on How to Grow Cucumbers, SQuashes ANd Pumpkins.

\begin{tabular}{|c|c|c|c|}
\hline 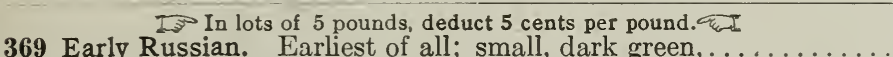 & $\begin{array}{l}\text { Per oz. } \\
\$ 008\end{array}$ & $\begin{array}{l}1 / 4 \mathrm{tb} \\
\$ 0 \\
25\end{array}$ & $\begin{array}{l}\text { Per tb. } \\
\$ 0\end{array} 85$ \\
\hline 371 Early Green Cluster. A short, prickly, seedy variety, & $\begin{array}{r}\$ 0 \\
80\end{array}$ & $\$ 025$ & \\
\hline 373 Early Frame, or Early Short Green. For slicing and pickling, & 8 & 25 & 75 \\
\hline 375 Thorburn's Everbearing. $\odot$ Vines bear continuously, . . . . . & 10 & $2 \tilde{5}$ & \\
\hline 377 Extra Early Green Prolific, or Boston Pickling, ○... & 8 & 25 & 75 \\
\hline 379 Burpee's Extra Early White Spine. $\odot$ (See page 40$), \ldots \ldots \ldots$ & 10 & & \\
\hline 381 Improved Arlington White Spine. A fine strain. (See page 40), & 10 & 30 & 100 \\
\hline $\begin{array}{l}\text { Burpee's Fordhook White Spine. } \odot \text { A very fine strain. Per pkt. } \\
10 \text { cts. }(\text { See page } 40), \ldots \ldots \ldots \ldots \ldots \ldots \ldots \ldots \ldots \ldots \ldots \ldots \ldots \ldots \ldots\end{array}$ & 10 & 30 & \\
\hline 385 Extra Long, or Evergreen White Spine. Grows 12 inches long, . & 10 & 25 & \\
\hline 386 Klondike. A dark-green White Spine, $\ldots \ldots \ldots \ldots \ldots \ldots$ & 10 & 25 & \\
\hline 387 Cool and Crisp. Extremely early White Spine, .... & 8 & 25 & \\
\hline 393 Burpee's Fordhook Famous. $\odot$ (See page 40.) Per pkt. 10 cts., & 15 & 40 & \\
\hline 395 Burpee's Fordhook Pickling. $\odot$ Best for pickling, $\ldots \ldots \ldots \ldots$ & 10 & 30 & 10 \\
\hline 397 Cumberland Pickling. A fine pickling variety,.. & 8 & & \\
\hline Long Green. $\odot$ Dark & 8 & & \\
\hline Perfect. $\odot$ Quality sur & 10 & & \\
\hline Burpee's Giant Pera. 15 to 18 inches long. Per pkt. 10 & 15 & & \\
\hline Japanese Climbing. Long tendrils permitting it to climb & 12 & & \\
\hline dia Gherkin. Exclusively for pickling, ... & 12 & 35 & \\
\hline
\end{tabular}

413 English Frame, or Forcing. Small packet 25 cts.

If $\rightarrow$ Each of the above, except where priced, 5 cents per packet.

For thirty-seven years we have stated plainly that, where failure is caused by any fault of the seed, we would refund the full price paid. This should convince even new customers that we have confidence both in the quality of BURPEE'S SEEDS and in the great care exercised in their growing, cleaning, and packing. No honest seedsman could assume responsibility for more than the price actually paid by the purchaser.

\section{"The Value of a Guarantee is not in what is said, but who says it."}




\section{"Four of the Finest" White Spine Cucumbers.}

${ }_{379}$ Burpee's Extra Early White Spine. $\odot$ See illustration herewith, engraved

strain of the popular White Spine Cucumber, which is most desirable for its extreme earliness. It is earlier than the Fordhook or special forcing strains. The fruits are slightly

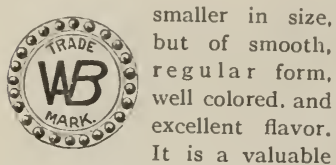
variety to plantfor early market. Per pkt. 5 cts.; oz. 10 cts.; $1 / 4$ lb. $30 \mathrm{cts}$.; per $1 \mathrm{~b} . \$ 1.00$.
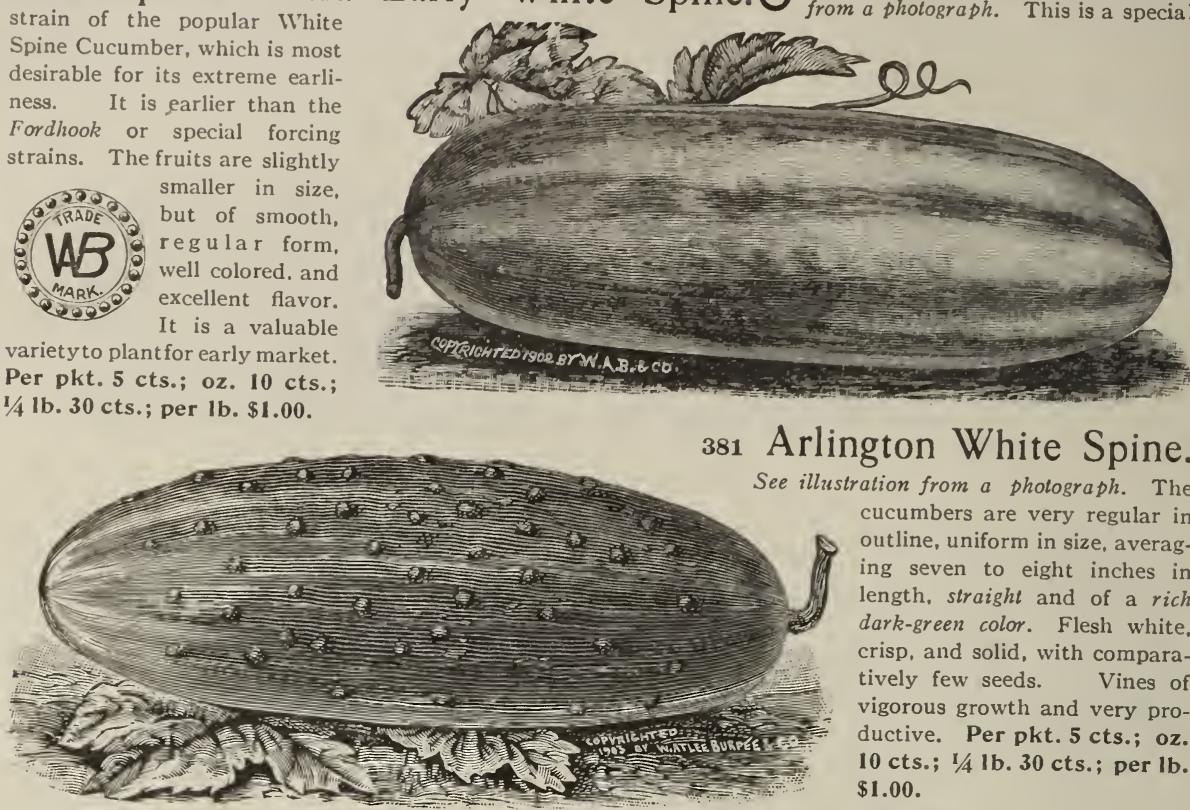

Arlington White Spine. cucumbers are very regular in outline, uniform in size, averaging seven to eight inches in length, straight and of a rich dark-green color. Flesh white, crisp, and solid, with comparatively few seeds. Vines of vigorous growth and very productive. Per pkt. 5 cts.; oz. 10 cts.; 1/4 lb. 30 cts.; per lb. $\$ 1.00$.
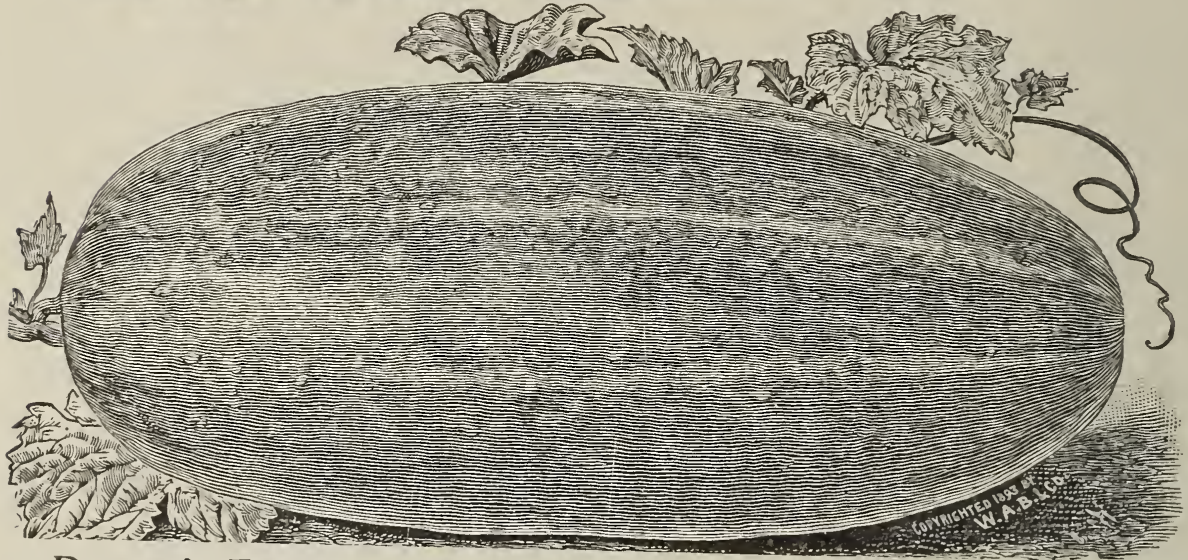

383 Burpee's Fordhook White Spine. - See illustration above, accurately reproduced cylindrical in form, slightly pointed at the ends, perfectly smooth, of a photograph. The fruits are nearly with distinct white lines at the blossom end. They are of extremely handsome and attractive appearance. Vines are vigorous in growth and enormously productive. Fruits retain their only the new "Fordhook Famous." They retain also their than any other variety, - excepting well formed. Splendid as table cucumbers ain also their fine quality even after the seeds are commercial pickles. Per pkt. $10 \mathrm{cts}$; oz. $10 \mathrm{cts}$. $1 / 41 \mathrm{~b}, 30 \mathrm{cts}$ it is equally as desirable for

393 Burpee's Fordhook Famous. $\odot$ The longest White Spine, the finest flavored of all. cucumbers; always straight and well formed, they never turn yel-

low, and critical
buyers are willing
to pay an extra
price on market doubtedly the finest long-fruited strain in cultivation. Per pkt. 10 cts.; oz. 15 cts.; $1 / 4$ lb. 40 cts.; per lb. $\$ 1.40$.

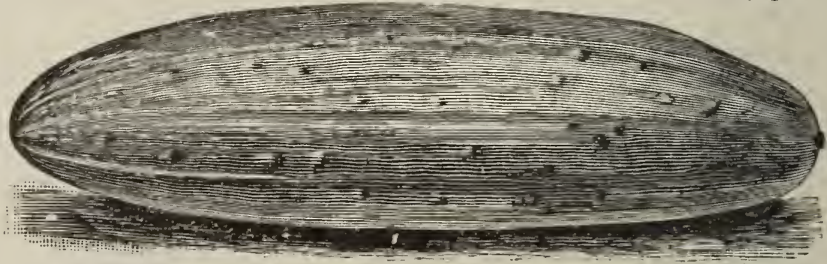

FORDHOOK FAMOUS CUCUMBER,-from a Pholograph reduced in size. 40 


\section{DANDELION.}

The dandelion is quite extensively grown to furnish leaves for an early spring salad. It finds quite a ready sale in the winter and early spring. The Improved Large-Leaved grows to a much larger size and yields many times the quantity of foliage of the common wild type. One ounce of seed will sow roo feet of drill.

114 Cultivated, or French Common,

\begin{tabular}{c|rrrr|rr} 
Per pkt. & Per oz. & $1 / 4$ & lb. & Per lb. \\
$\$ 0 ~ 05$ & $\$ 0$ & 12 & $\$ 0$ & 35 & $\$ 1$ & 25 \\
10 & & 30 & & $\$ 5$ & 3 & 00
\end{tabular}

115 Improved Large-Leaved,

\section{EGG PLANTS.}

The Egg Plant is becoming more and more popular in our markets and the market season is greatly prolonged by early shipments from the South. The large smooth fruits, free from spines and of a dark rich coloring, are most popular and make the most satisfactory shippers, as they arrive in the best order, and the deep coloring adds to their fresh appearance.

BURPEE'S BLACK BEAUTY is not only the earliest of this popular large-fruited type, but is also the smoothest and richest in coloring. In comparative plantings in the truck growing sections of Southern New Jersey it has proved to be at least a week or ten days earlier than the New York Improved Spineless. The "eggs" are darker and the color extends clear to the extreme end of the blossom end, which in the older varieties is apt to have a white or light purplish blotch.

The New York Improved Spineless is the well-known standard market variety and of which we offer an exceedingly fine strain. Early Long Purple has pear-shaped fruits six inches long, but seldom more than two inches in diameter: it matures very early and is prolific, but is too small for the general market.

\section{How to Grow Egg Plants.}

In our vicinity seed should be sown in March in a warm hot-bed in light, rich soil, or they may be started in a box in the sunny window of a warm room. The hot-bed should be kept warm and carefully covered at night. Sow thinly, and when young plants show two or three leaves, transplant them to stand three inches apart each way; or, if growing indoors, set them in smali flower-pots. Kept constantly warm and moist they will make fine, large plants by the time the weather is warm enough to set them outdoors, which should not be done until the trees are out in full leaf.

Set plants in rich soil two feet apart each way. Hoe frequently to keep soil loose and fine. As season advances the soil about the plants should be covered with a mulch of hay or straw two inches deep to preserve moisture.

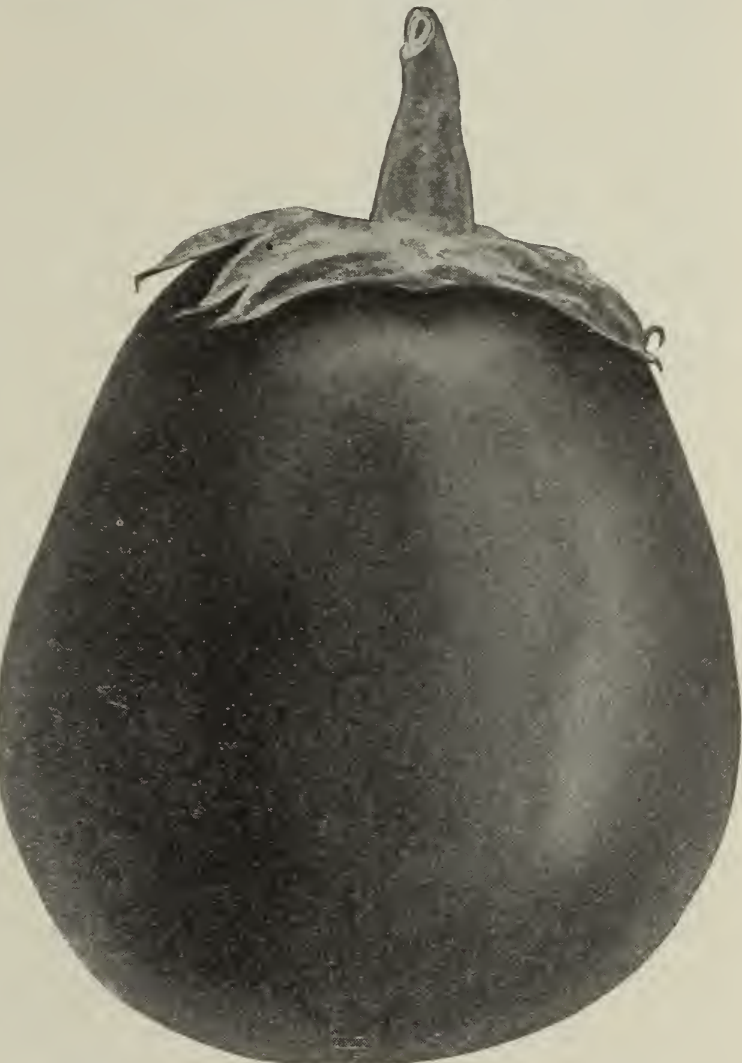

BURPEE'S BLACK BEAUTY EGG PLANT, - from a photograph. 422 New York Improved Spineless. A fine strain of this standard variety, .............................. 428 Early Long Purple. Oblong; very early. Crop failed.

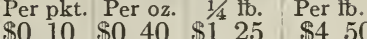

\begin{tabular}{l|l|l|l|l|l}
10 & 35 & 1 & 00 & 3 & 50
\end{tabular}

\section{ENDIVE.}

The finely cut ornamental leaves furnish an attractive bitter salad for the fall and winter and also for the spring months. The plants are used also for decorative purposes when blanched during fall and winter. To accomplish this blanching the outer leaves are gathered closely together and loosely tied at the top with a wisp of straw or soft twine for about a week or ten days.

These blanched plants are especially used for ornamentation of baskets of oysters, etc., which has given it the name of "Oyster Endive" in this and other Northern States. The Green Curled and White Curled have narrow leaves with the edges deeply laciniated, the only difference is that the White Curled has naturally leaves of a light golden-yellow tint which do not need any tying up. The GIANT FRINGED, or "Oyster Endive," is similar to the Green Curled, but has larger and longer leaves. The BATAvian has broader and larger leaves with rounded ends and is not so deeply cut as the fringed varieties; this is the variety known on the market as Escarolle.

430 Green Curled. The most popular variety,...

432 White Curled. The most attractive in appearance. Crop failed.

434 Giant Fringed, or "Oyster" Endive. ○ Has a large white heart, 436 Broad-Leaved Batavian (Escarolle). Broad, thick leaves, ......... Do Each of the above, 5 cents per packet.
Per oz. $1 / 4 \mathrm{tb}$. Per lb. $\$ 010 \$ 030 \quad \$ 100$

\begin{tabular}{ll|l|l}
10 & 35 & 1 & 25
\end{tabular}

\begin{tabular}{ll|l}
10 & 30 & 1
\end{tabular}




\section{GOURDS.}

The dried shells of the Sugar Trough and Dipper Gourds are especially useful for many purposes. In the South the sponge-like lining of the Dishcloth Gourd is used for washcloths, etc., when cleaned and dried. The Nest-Egg is a small, white. egg-formed Gourd, ranging from the size of a small pullet's egg to a large duck's egg. When well dried they are not liable to breakage and damage by frost, and hence are desirable as nest-eggs.

\begin{tabular}{l|l|l} 
Per pkt. Per oz. $1 / 4$ tb. Per tb. &
\end{tabular}

438 Nest-Egg. Size of hen's eggs, ................. \$0 10 \$0 20 \$0 50 \$ $\$ 175$

440 Sugar Trough. Useful for household purposes, . . . . . . . $\quad 10 \quad 10 \quad 20 \quad 60 \quad 200$

442 Dipper. Makes excellent dippers, . . . . . . . . . . . . $10 \quad 20 \quad 65 \quad 225$

444 Dishcloth, or Luffa. Sponge-like; porous lining, . . . . . . $10 \quad 25 \quad 75 \quad 275$

\section{New HORSE-RADISH from Bohemia. \\ Maliner-Kren. $\odot$ MALISER KREX moracea) was brought from Bohemia in 1899 by $\mathrm{Mr}$. David Fairchild, Agricultural Explorer for the office of Plant Introduction of the United States Depart- ment of Agriculture. \\ Roots of uniform length, in bunches of $50,-\mathbf{5 0}$ cts. for $50 ; 80 \mathrm{cts}$. per $100 ; 200$ for $\$ 1.50 ; 500$ for $\$ 3.25$; or $\$ 6.50$ per 1000 roots.}

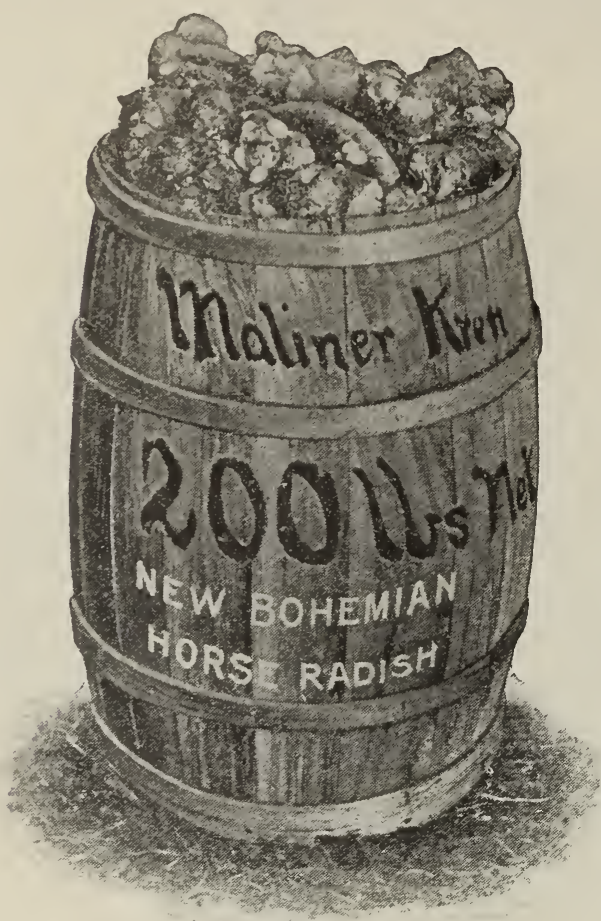

An Expert's Opinion. $\begin{gathered}\text { It is } \\ \text { much }\end{gathered}$ earlier; planted same day, April I 2th, side by side of common sort; plenty of it had very large roots September I5th, while the common variety had scarcely begun to make any root at all.

We commenced digging it for market October Ist. and had plenty of roots that weighed two and onehalf pounds, which readily brought in New York markets seven cents per pound wholesale; at same time the common sort was not large enough to be profitable to dig, -in fact, the whole crop of

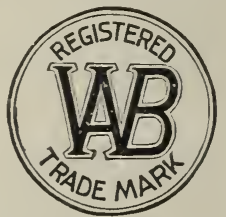
the Maliner Kren could have

been marketed in September and October, while the common variety is not really matured till spring.

It has larger roots, producing nearly one-third more to the acre than the common sort after lying in the ground all winter. Horse-radish is like other vegetables, - has to ripen before it gets its good qualities. Green horse-radish, that is to say, that which is dug before fully grown, is apt to have a bitter taste and turns black after it is grated and soon loses its strength. The Maliner Kren, ripening earlier as it does, will be sought after by the picklers as soon as this fact becomes known. It does not have to be peeled or scraped before grating; has a very thin skin, similar to new potatoes, which can be taken off in same way; is white as chalk.-Extract from letter received from HON. B. D. SHEDAKER, Edgewater Park, N. J.

Horse-Radish. The common variety we offer is of the same high quality which has given SMall Roots put up in bunches of 50: Per $100,50 \mathrm{cts} . ; 500$ for $\$ 2.25 ;$ per $1000, \$ 4.25$.

\section{KALE or Borecole.}

This popular boiling green for winter and early spring use is being planted more largely each year as a market crop. Shipments from Southern States reach northern markets during the winter months in large quantities, and in some sections it is almost as popular as spinach.

In the Northern States the plants are started and set out singly like cabbage, and then form large rosettes of finely cut leaves which frequently reach a diameter of two feet or more, the leaves being pulled from the stem for use as needed, but for market the smaller or young heads are preferred. The Dwarf German and Tall Green Curled Scotch have long, plume-like leaves with edges finely cut. The Dwarf Siberian is extremely hardy, but the leaves are broader, smoother, and not so heavily curled.

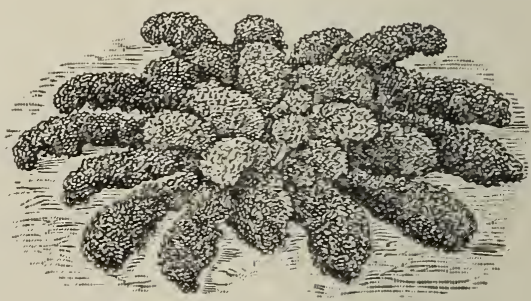

DWARF GERMAN CURLED KALE.

Per oz. 1/4 tb. Per tb.

446 Dwarf German, or Dwarf Curled Scotch. ๑ Dwarf growing,... \$0 08 \$0 $20 \quad \$ 065$

448 Dwarf Siberian. Extremely hardy; large broad leaves, ........ $\quad 8 \quad 20 \quad 60$

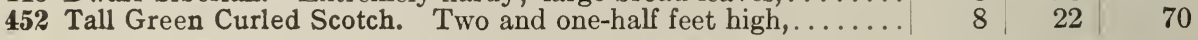

In $\rightarrow$ In regular-size packets, each, 5 cents per packet. 


\section{KOHL-RABI, \\ or Turnip-Rooted Cabbage.}

In growth this is halfway between cabbage and turnip; the edible portion is the large bulb which forms on the stem above the soil. By making successive sowings, tender bulbs may be had throughout summer and fall, and are highly esteemed for their mild, delicate, cabbage-like flavor.

Grown in the same manner as cabbage, though the seed may be sown thinly in drills where the plants are to stand, and when well started, thinned out to eight inches apart, but the best results will be had from transplanted plants in rich, well-cultivated soil. The bulbs must grow thickly and be gathered for market while young and tender, so that several plantings should be made rather than a large area at one time. Early White and Early Purple Vienna are the best for table use. The Large Green or White, being large and coarse-fleshed, is suitable for stock only. One ounce of seed sown thinly will furnish about 2000 plants.

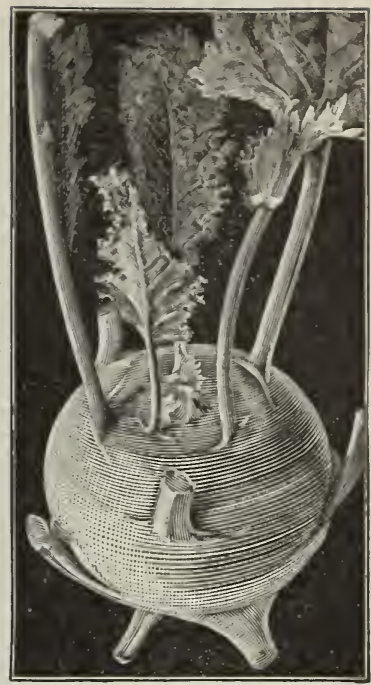

Per oz. $1 / 4$ lb. Per lb.

456 Early White Vienna. ๑ The best for table use,.............. \$0 $20 \$ 0 \quad 60 \$ 200$

457 Early Purple Vienna. Differs only in color, ................ $20 \quad 60 \quad 200$

459 Large Green or White. Excellent for stock feeding, . . . . . . . . $\quad 8 \quad 825$

Di In regular-size packets, each 5 cents per packet.

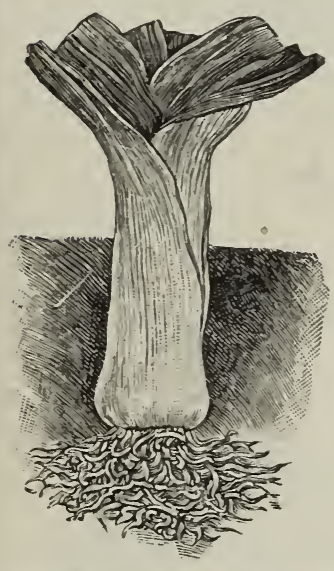

\section{LEEKS.}

Leeks are hardy and the flavor is improved by freezing. Sow thinly in drills in the spring in same manner as for onions. Thin out or transplant as soon as large enough to stand six inches apart in the row, having the rows two feet apart. Keep well hoed and free from weeds, and early in the fall draw earth up about the stems in the same manner as you do in blanching celery. They produce a thick stem, the blanched portion of which is used the same as early bunch-onions in the spring. Earthed up in this manner they can be let stand in the rows where growing until spring. Later sowings are frequently made to furnish small plants which are used in making up bouquets of pot-herbs for market. The spring-sown plants can be used if not thinned out, as they are where the large stems are desired,- - much smaller stem being preferred for this purpose. The Broad London or American Flag and Monstrous Carentan have very thick fleshy stems. One ounce will plant 100 feet of row.

Per pkt. Per oz. $1 / 4$ tb. Per tb.

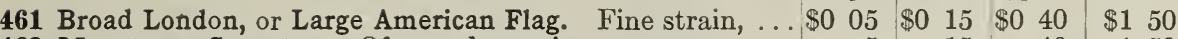
463 Monstrous Carentan. Of very large size,........... 5 5 $15 \quad 40 \quad 150$

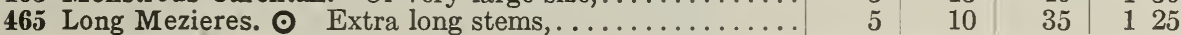

Lettuce makes one of the most appetizing and desirable additions to the table at all seasons. Fine heads, or Lettuce close, compact bunches of tender leaves can be grown from seed in a short time in rich soil and with thorough cultivation. By a proper selection of varieties, repeated small plantings, and the use of glass-covered " "Cumes during the winter a constant supply may be had throughout the year. For early spring the large curled or "Cutting" and the "Butterhead" Lettuces are most satisfactory. For midsummer or warm weather the "Crisphead," the large-growing "Cutting, " and the Cos are all desirable. For fall all varieties do well from seed planted in August, while for winter culture under glass we recommend the earliest and forcing head varieties, and for large heads, the Deacon and California Cream Butter.

Seed should be sown thinly in drills where the plants are to stand in the garden. When well started thin out to eight to twelve inches apart, according to size of the variety planted. Keep the ground constantly loose by frequent hoeings. Any check in growth such as would result from a hard-baked soil will interfere with the forming of proper heads and also sacrifice much of the crispness and mild flavor. For home use, only a small planting of seed should be made at one time, repeating the plantings at least once in two weeks, or planting at one time a number of varieties which will be ready for use in succession. These plantings in the open ground should be continued until the middle of August. To raise plants for setting in the hot-beds and cold-frames for winter use, the seed should be sown in September. 


\section{Earliest and Forcing Varieties of LETTUCE.}

These are grown mainly for a quick crop of head-lettuce in a cool greenhouse during the winter months, or small plants are set in cold-frames in the fall to make market heads the following spring. The earliest sorts when

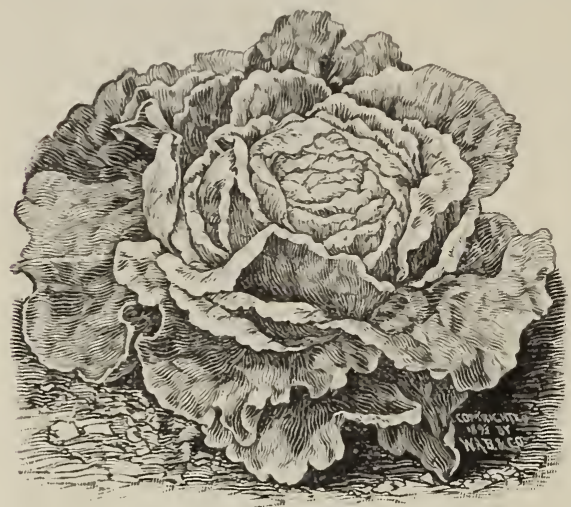

EARLY DUTCH SPECKLED BUTTERHEAD. planted in the open ground do not make a satisfactory growth and will run to seed without heading should the weather become hot and dry, but if started late in the summer or early in the fall, will nearly all produce fine solid heads, as they require a cool temperature for their growth and development.

A favorite forcing variety is the While-Seeded Tennis Ball, or "Boston Market," and under good conditions this will make a head six inches in diameter. Wheeler's Tom Thumb is smaller, earlier and very fine for greenhouse planting. The GRAND RAPIDS is largely grown as a winter crop in the middle Western States, forming a large close bunch of loose tender leaves, being a nonheading sort, but the heading type is preferred in the Eastern States. The BLACK-SEEDED TENNIS BALL and Yellow-Seeded Butter are good sorts both for forcing and for the earliest heads from plantings in the open ground. MAY KING is an excellent variety both for forcing and an early crop in the open ground. It makes solid, well-folded heads of a light green, the inner leaves blanching to a golden yellow. When grown in frames the outer leaves are slightly edged with brown.

BURPEE'S EARLIEST "WAYAHEAD" is extremely early and very solid heading,- - see page 45 .

BIG BOSTON is a strong, vigorous, large-heading sort, especially adapted for growing in cold-frames or in a very cool greenhouse, as it needs a temperature of five to ten degrees cooler than the earlier smaller sorts. The new Black-Seeded Big Boston is really a beautiful stock of the parent variety.

Early. Dutch Speckled Butter is a very hardy sort and especially recommended for winter or in cold-frames for early spring market. Unrivaled is excellent for growing under glass during the winter months or in the open ground in the Southern States; it is brighter in color and with heads more tightly folded than the Big Boston. NAUMBURger is an excellent cold-frame and open ground variety; it is about the same in season as $M a y K i n g$.

I. In lots of 5 pounds, deduct 5 cents per pound.

467 White-Seeded Tennis Ball, or Boston Market. Very popular,

469 Black-Seeded Tennis Ball. ๑ Splendid for forcing,

471 Yellow-Seeded Butter. Dense yellow heads; crisp and tender,

473 Wheeler's Tom Thumb, b. s. Splendid hard little heads,

$4 \% 4$ May King, $\odot w . s$. Highly recommended,

475 Big Boston, $\odot$ w.s. Most popular for forcing. (See page 45),

476 Burpee's Earliest Wayahead, ๑ w. s. (See page 45.) Pkt. 10 cts.

47 Unrivaled, $w$.s. Similar to Big Boston, but lighter colored,

478 Naumburger, or Tenderheart, $b . s$. An excellent early variety; fine for forcing and planting in the open. (See page 45),

479 Black-Seeded Big Boston. $\odot$ (See page 46)

483 Early Dutch Speckled-Butter, $\odot$ w. s. Very solid little heads,

485 Grand Rapids, $\odot$ b.s. Large compact bunches of leaves...

\begin{tabular}{rr|r|r|rr} 
Per oz. & $1 / 4$ & lb. & Per lb. \\
$\$ 0$ 10 & $\$ 0$ & 30 & $\$ 1$ & 00 \\
12 & & 35 & 1 & 25 \\
12 & & 35 & 1 & 25 \\
10 & & 30 & 1 & 00 \\
15 & & 40 & 1 & 50 \\
15 & & 40 & 1 & 50 \\
40 & 1 & 10 & 4 & 00 \\
15 & & 40 & 1 & 50 \\
& & & & \\
15 & & 45 & 1 & 60 \\
20 & & 60 & 1 & 85 \\
15 & & 40 & 1 & 50 \\
15 & & 40 & 1 & 50
\end{tabular}

"W Each of the above, except Burpee's Earliest "Wayahead," 5 cents per packet.
474 May King. $\odot$ The plants growth, practically all head, and extremely handsome. From early spring plantings in the open ground they grow quickly to a diameter of six to seven inches with the broad, light green, outer leaves folding closely about the round solid head; in cool weather the edges of these outer leaves are lightly tinged with brown. The inner leaves (practically the entire head) are blanched to a rich golden yellow and have a specially fine, rich buttery flavor. The round solid heads are so firmly folded that they can be shipped to distant markets and arrive in good condition. We recommend repeated plantings of this new early variety in the spring, and again during August and September for fall use. Per pkt. 5 cts.; $0 z .15$ cts.; $1 / 4 \mathrm{lb}$. 40 cts.; per lb. $\$ 1.50$.

Lettuce Seed offered by us is the very choicest selected strains. The crops are most carefully "rogued,"--true to type.

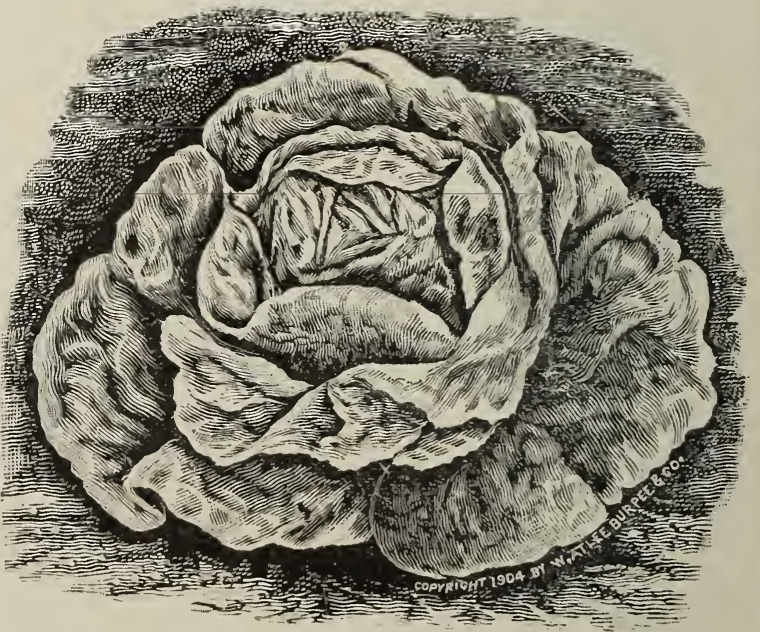

Extra Early Letluce, "MAY KING,"-from a Pholograph. 


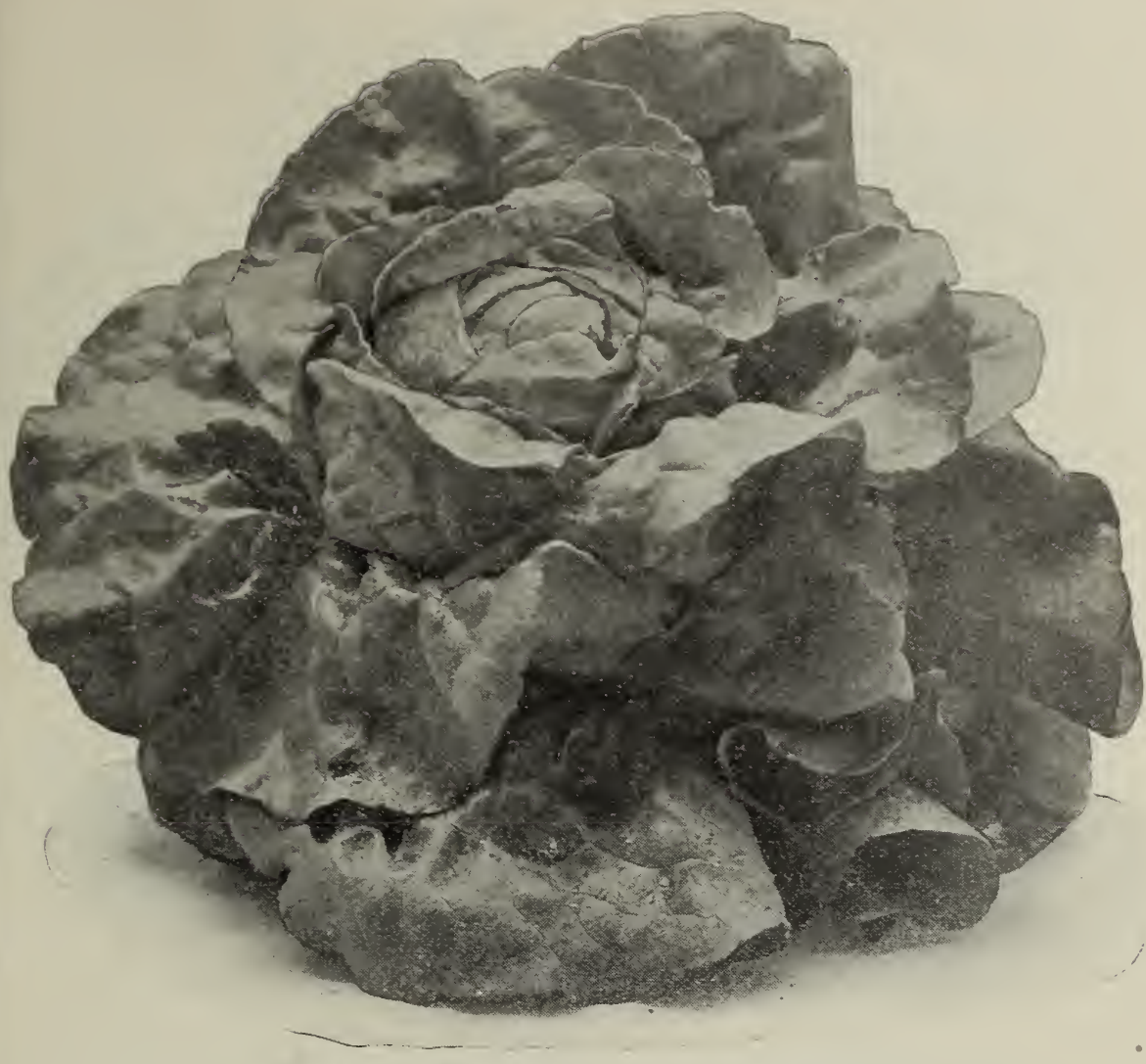

BIG BOSTON LETTUCE,-from a Fordhook photograph.

\begin{abstract}
475 Big Boston Lettuce. @ See illustration from a photograph taken at Fordhook. the winter months, as it produces heads of very large size, often ten to twelve inches across and succeeds better in a cooler temperature than most forcing strains. The large heads are beautifully blanched and of superior quality. It heads well also in the open ground during cool weather of spring and fall, and is very popular in the South to grow for shipping North. Our seed is the choicest it is possible to produce.
\end{abstract}

Per pkt. 5 cts.; per $0 z .15$ cts.; $1 / 4$ lb. 40 cts.; per lb. $\$ 1.50$.

476 Burpee's "Wayahead" Lettuce $\odot$ is not only earlier Nansen, and other choice extra-early varieties, but the heads are also larger in size and more tightly folded. The outer leaves are a light green while all the inner leaves of the head are nicely blanched to a rich, buttery-yellow tint. BURPEE'S EARLIEST "WAYAHEAD" stands a longer time before running to seed than any other early head variety. Crop of seed very short.

Per pkt. 10 cts.; per oz. 40 cts.; $1 / 4$ lb. $\$ 1.10$; per lb. $\$ 4.00$.

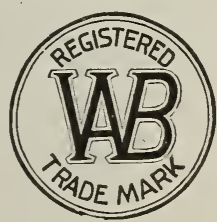
${ }_{488}$ Lettuce,-
"Naumburger."
An excellent variety for growing in cold- frames or for an early crop in the open ground. It is a little later in season, and grows to a larger size than our new Earliest "Wayahead," -being about the same in season as the popular May King, offered on page 44. Heads are of large size and compactly folded, the outer leaves being light green, slightly edged with brown, while the interior portion is blanched to a bright golden yellow, of rich, "buttery" flavor. At FORDHOOK it heads even more uniformly and more solidly than the May King and stands for a longer time after heading without bursting open or running to seed.

Per pkt. 5 cts.; per oz. 15 cts.; $1 / 4$ lb. 45 cts.; per lb. $\$ 1.60$. 


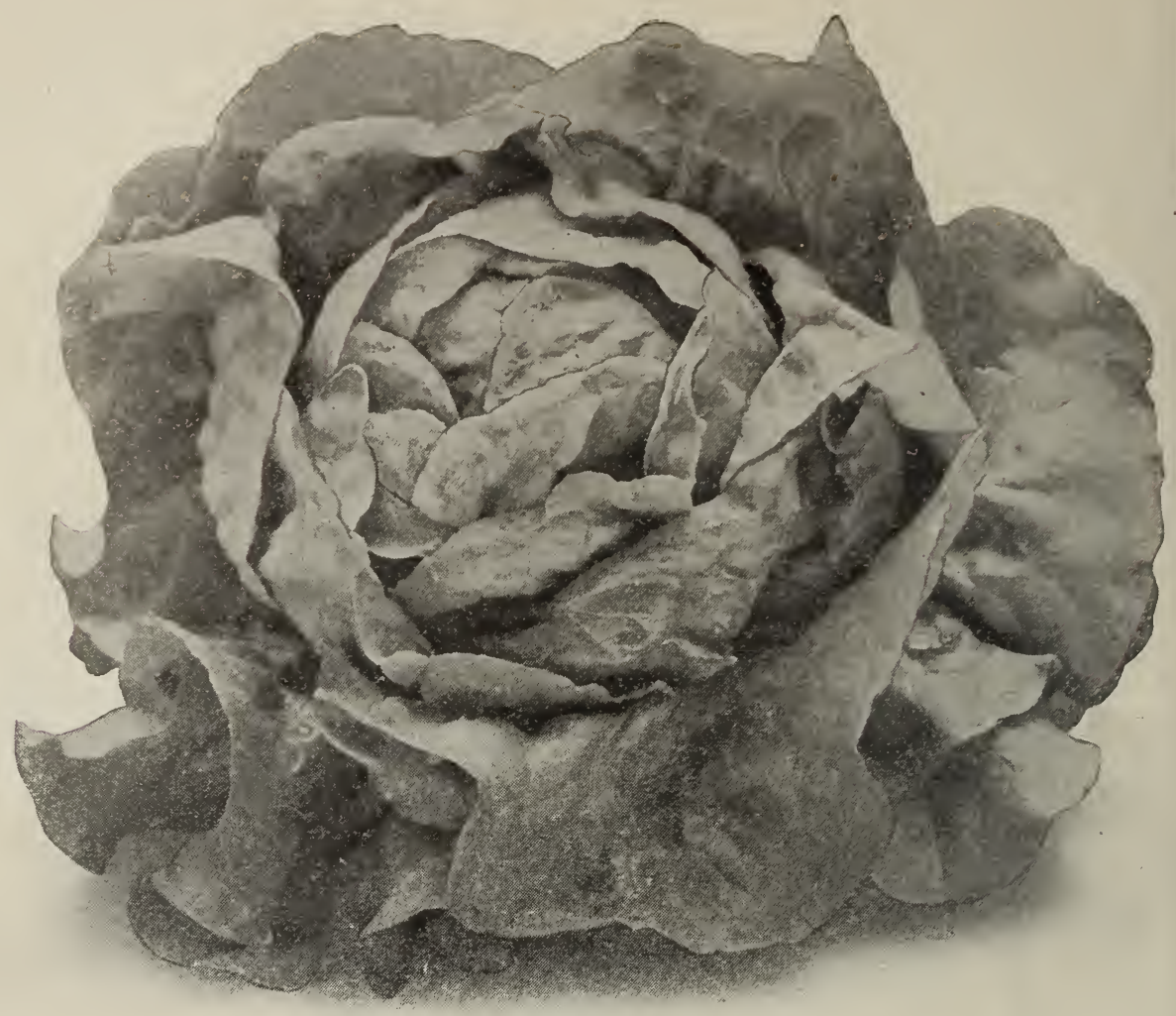

BLACK-SEEDED BIG BOSTON OR “PREFERRED” LETTUCE,-from a Fordhook photograph.

\section{Black-Seeded Big Boston (Preferred) Lettuce. $\odot$}

When looking over the crop in California, we made the following note: "A beautiful lettuce, leaves a trifle smaller and rather lighter shade of green with less color on edges." Comparing the same variety with our selected strain of Big Boston (as offered on page 45) in the trials at FORDHOOK FARMS we had to admit, however, that it was impossible to pick out rows without the finder. Therefore, all that we would say now of the BLACK-SEEDED BIG Boston is that it is a beautiful straight stock of Big Boston Lettuce. The plants form large but hard heads, which even in very wet and cold weather continue remarkably sweet and crisp. The plants measure twelve to fifteen inches across and the solid heads from five to six inches in diameter. Per pkt. 5 cts.; per oz. 20 cts.; $1 / 4 \mathrm{lb}$. $60 \mathrm{cts}$.; per Ib. $\$ 1.85$.

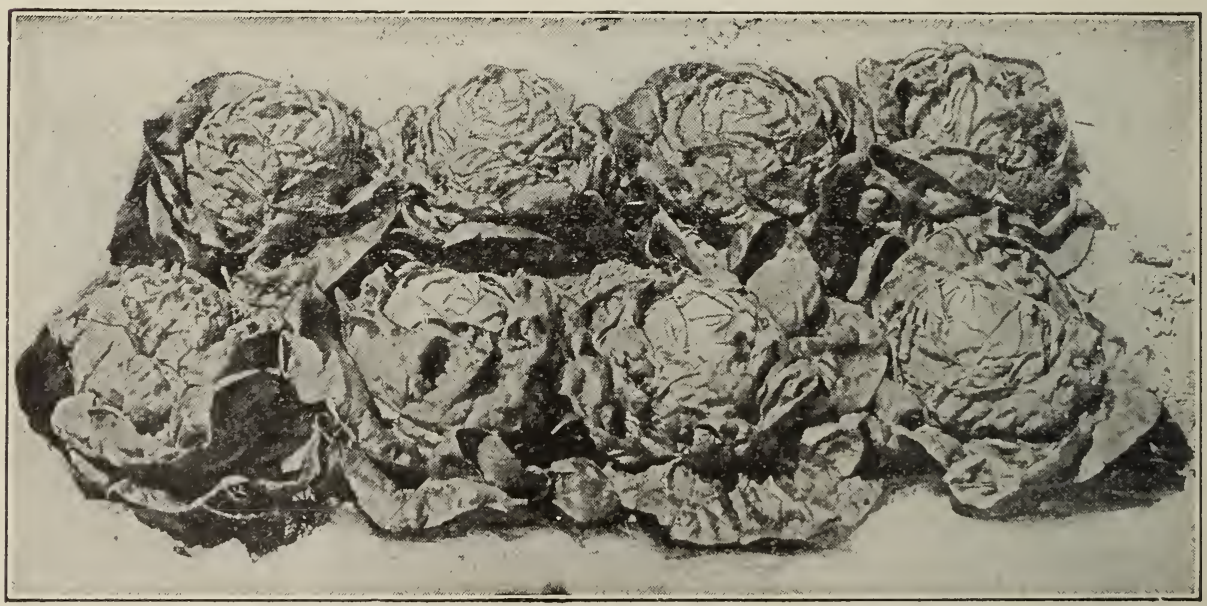

BURPEE'S EARLIEST "WAYAHEAD" LETTUCE,-just as it grows,-from a Pholograph. 


\section{LETTUCE,-“Loosehead” or Cutting Varieties.}

These are planted largely in some sections for an early spring supply. They do not form tightly folded heads, but make a close compact bunch of leaves, and where the plants are properly thinned and cultivated they attain large size. The Early Curled Silesia or Curled Simpson has light golden-yellow foliage with finely cut or fringed edges. This is the "curly" lettuce of the old-time gardens and very popular in some sections. Our strain is very carefully selected and is annually planted by the most particular Market Gardeners.

The BLACK-SEEDED SIMPSON is the standard cutting or curly lettuce for the garden or market where lettuce is sold by the pound, making very large, compact bunches of heavily crumpled leaves of a light golden hue, with the young center leaves of a still lighter coloring. It grows quickly, is highly ornamental, of crisp, refreshing flavor and stands a long time before running to seed.

The MORSE is similar in size to the Black-Seeded Simpson, but is a white-seeded sort, making semi-heads or having the center of the plants tightly folded and blanching naturally to a lighter shade. It is the finest of the cutting type for the open ground. The plants being so close and compact in growth, it can be marketed almost as readily as the closely folded heads of the cabbage type.

Early Prize-Head is of similar growth, but the goldenyellow leaves are shaded and edged with brown. BURPEE's TOMHAN.NOCK is a strong grower, reaching very large size when given sufficient space in which to develop. The large leaves are finely edged and heavily shaded with brown.

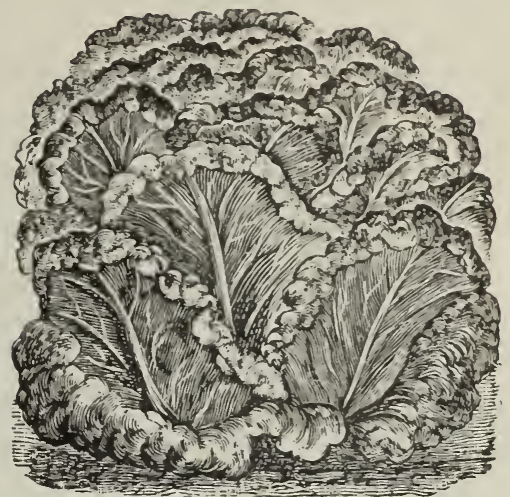

BURPEE'S TOMHANNOCK LETTUCE.

In In lots of 5 pounds, deduct 5 cents per pound.

Per oz. $\quad 1 / 4$ tb. Per tb.

490 Early Curled Simpson, or Silesia. $\odot$ w. s. Most popular for family gardens; fine for cutting.

$\$ 0 \quad 12 \$ 0 \quad 35 \$ 1 \quad \$ 10$

493 Black-Seeded Simpson. The standard cutting variety, ........ $12 \quad 35 \quad 110$

494 The Morse, $\odot$ w.s. Similar to B.-S. Simpson, but white-seeded,.. $\quad 12 \quad 35 \quad 125$

496 Burpee's Tomhannock, $\odot$ w. s. Of fine flavor; tinged brown,... $\quad 10 \quad 30 \quad 100$

497 Early Prize-Head, w. s. Large heads; green, tinged with brown,. $\quad 12 \quad 35 \quad 110$

In $\rightarrow$ Each of the above, 5 cents per packet.

\section{Cabbage LETTUCE,-Crisp-Head Varieties.}

The crisp-head varieties, while forming heads of closely folded leaves in the same manner as the butterhead type, are entirely distinct in texture of the foliage. They are especially valuable for growing during the hot summer months, as the leaves are always crisp, brittle, and mild in flavor-resembling stalks of well-blanched celery in this respect. Really there is nothing more palatable as a salad than these crisp-head lettuces-at FORDHOOK we always have a liberal supply for summer use.

HANSON is probably the best known and forms a large, slightly flattened head of good size. This and Denver Market are planted early in the spring for a market crop. BURPEE'S ICEBERG is the finest of all for producing well-blanched heads during the heat of midsummer; it grows to a good size and is a thoroughly reliable variety. GIANT GLACIER is a newer variety, growing to a larger size, but in other respects does not surpass the Iceberg.

BURPEE'S BRITTLE-ICE is quite distinct in growing to an extra large size and making very large, wellblanched heads similar in size to those of the New York or "Wonderful," but which are of a light green and cooler looking than the deep green of the New York; it is more attractive in every way. The NEw YORK, or "Wonderful," is a strong grower and produces heads of immense size; - is a popular standby for the hot summer months where no especial attention is paid to quality.

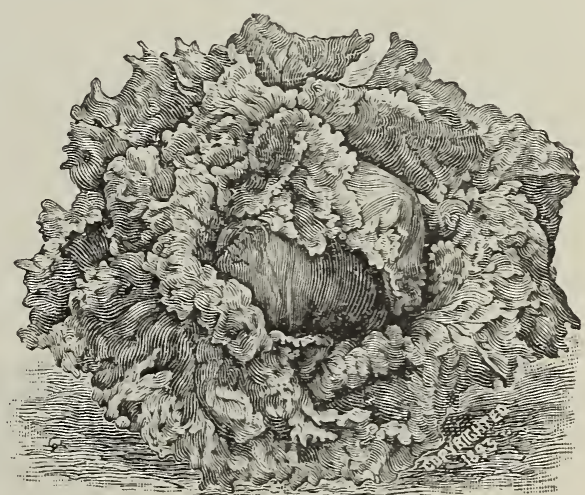

BURPEE'S ICEBERG,一from a Photograph.
Is In lots of 5 pounds, deduct 5 cents per pound. E-

522 Hanson, $\odot$ w. s. Beautifully blanched solid heads, . .

524 New York, or Wonderful, $w$. $s$. Immense heads; deep green,...

526 Denver Market, w. s. Large conical heads of finest quality,... .

528 Burpee's Brittle-Ice, $\odot$ w. s. (See page 48.) Pkt. 10 cts.........

530 Burpee's Iceberg, $\odot$ w. s. Always crisp and tender. (See page

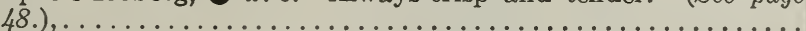

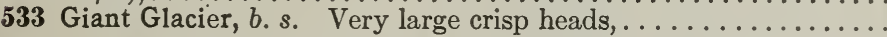

Is Each of the above, except Burpee's Brittle-Ice, 5 cents per packet.
Per oz. 1/4 tb. Per tb.

\$0 12 \$0 35 \$1 25

$20 \quad 60 \quad 200$

\begin{tabular}{l|l|ll}
12 & 35 & 1 & 25
\end{tabular}

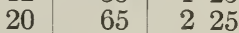

$15 \quad 40 \quad 150$

$12 \quad 35 \quad 125$

WE KNOW SEEDS by means of the FORDHOOK TRIAL GROUNDS. We sell only seeds known to be good-THE BEST SEEDS THAT GROW! 


\section{${ }_{528}$ Burpee’s New “Brittle-Ice” Lettuce.๑}

Very Large, Extremely Crisp, Hard-heading, and Extra Long-standing.

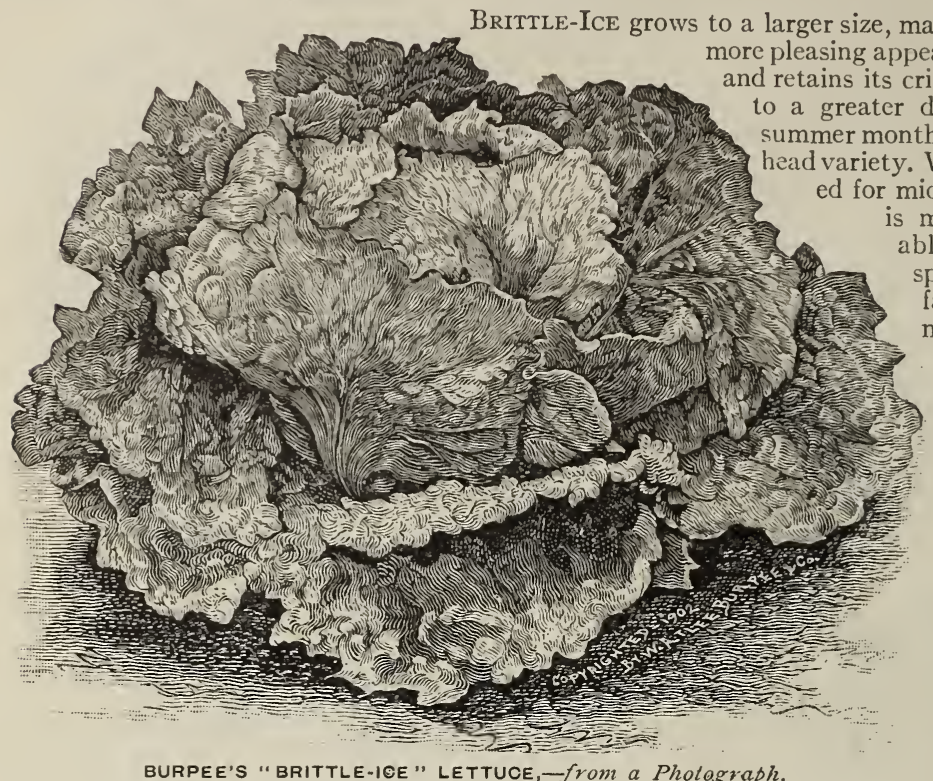

is most

able also for

spring and

fall, but is

not suitable for shipment to distant markets.

The plants are of quick strong growth, attaining a diameter of twelve inches with good cultivation. The leaves are of a s of $t$ bright green, growing closely around the head. The heads are tightly folded, six to eight inches in diameter, blanched to a silvery white and nearly as

crisp and brittle as celery. Per pkt. 10 cts.; oz. 20 cts.; $1 / 4$ lb. 65 cts.; per lb. $\$ 2.25$.

\section{${ }_{530}$ Burpee’s ICEBERG Lettuce.॰}

This famous variety is the surest and hardest heading of all the crisp-headed varieties. It is most highly esteemed for its beautiful appearance and mild flavor during the hot summer months. The plants are of medium size, but produce large, conical heads, which are tightly folded and blanch to a beautiful white. The outer leaves are a light green, finely fringed, and grow up closely about the large conical head.

The unusual solidity of the heads is insured by the large white main ribs of the leaves, each of which, curving strongly into the center, acts like a truss, making it impossible for the leaves to open outward and expose the center, which is constantly thoroughly blanched.

Per pkt. 5 cts.; oz. 15 cts.; $1 / 4$ lb. 40 cts.; per lb. $\$ 1.50$.

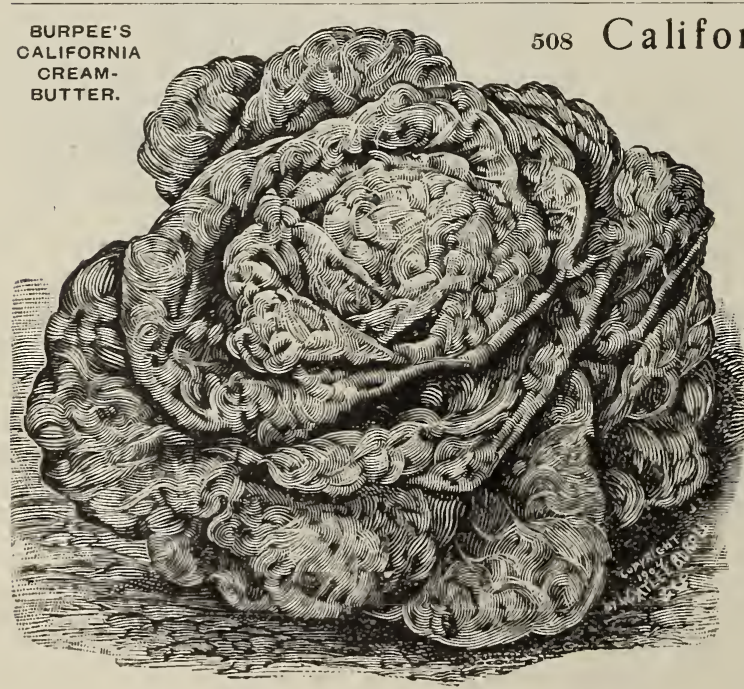

nia Cream-Butter, or "ROYAL." See illustration from $\odot$ the open ground, producing very large solid heads in cool weather. Largely planted in the Southern States for shipping to the northern markets during the winter. Heads of large size, very solid, and the interior portion blanched to a beautiful white. The genuine stock of this popular lettuce can be distinguished by very small spots on the outer leaves. Per pkt. 5 cts.; oz. 15 cts.; $1 / 4 \mathrm{Ib}, 40 \mathrm{cts}$.; per lb. $\$ 1.40$.

514 Burpee's Butterhead A grand mammoth hard head. - heading Cabbage Lettuce. Plants twelve inches across, with extra large, solid, round heads that are particularly rich and buttery in flavor; always well blanched and tender. The inner leaves are beautifully white and curled like a fine Savoy Cabbage. Splendid for summer use, both for the home table and for market. Per pkt. 5 cts.; oz. 15 cts.; $1 / 4$ lb. 40 cts.; per lb. $\$ 1.50$. 


\section{CABBAGE. LETTUCE,-Butterhead Varieties.}

These are the tight-heading varieties which resemble a small cabbage in appearance; the leaves comprisin the head being closely folded together and the interior portion blanched either to a clear paper-white or to a ricl buttery yellow. This type of lettuce is most in demand in the markets of our Eastern cities, the earliest supply coming from crops grown in the open ground in the Southern States, followed by that grown in cold-fraines in the nearby market gardens, and later through the summer and fall by plantings grown in the open ground.

NANSEN, or "Norlh Pole," is an extra-early sort for an outdoor crop. SALAMLANDER and MAMMOTH BLACKSEEDED BUTTER are large good heading varieties for summer use, with curly leaves of a rich golden green. BURPEE'S BUTTERHEAD is of the same season, but grows to the largest size and makes the best folded heads.

DEACON, or "San Francisco Markel," is one of the most reliable of large-heading lettuces to plant for inarket in the open ground, and with good cultivation will produce very large. firmly folded heads, with the thick tender leaves blanched to a rich buttery hue. The plants will stand for a considerable length of time after heading before running to seed. ALL SEASONS is similar to Deacon, but has black seed and stands even for a longer length of time before "shooting" to seed.

CALIFORNia CREAM-Butter and Philadelphia White Cabbage are of distinct character, having glossy foliage of firm texture, and are especially adapted for growing fine heads in cool sections. These, together with the Big Boslon

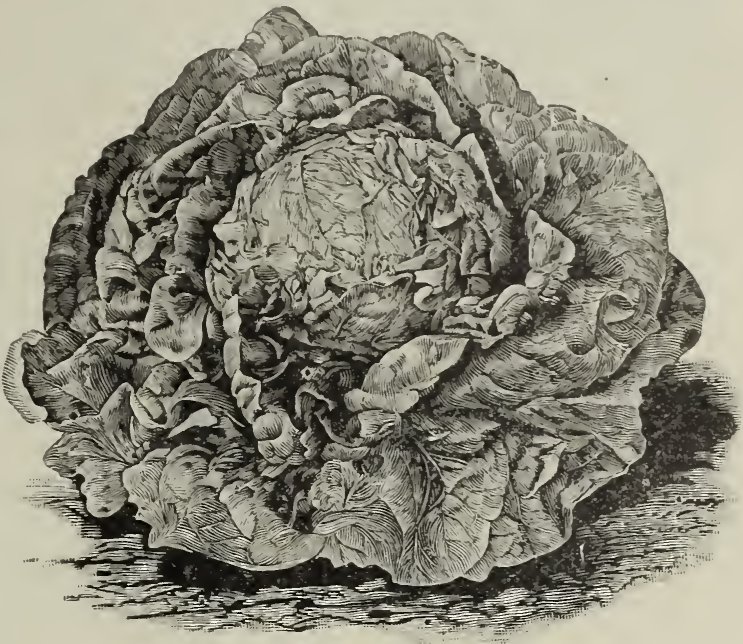

MAMMOTH BLACK-SEEDED BUTTER LETTUCE.

and Black Seeded Big Boston, are the best varieties to plant in the fall in the South in the open ground to produce heads in the early spring. MaximuM (Immensily) is a very strong-growing variety, and under favorable conditions will make plants fifteen inches across, with heads as large as a small cabbage.

BURPEE'S HARDHEAD is a fine-heading sort to grow during the cool fall months or very early in the spring, making large firm heads which blanch to a beautiful golden tint. MAY KING, offered on page 44, is also of the Bullerhead type. For early spring planting in the open ground this variety is unequaled.

498 Philadelphia Early White Cabbage, w. s. For growing in cold frames,

504 The DEACON, $\odot$ w. s. Large firm heads of finest quality,

505 All Seasons, $\odot$ b. s. Large solid heads,

506 NANSEN, or North Pole, w. s. Hard heads; very early,

508 California CREAM-BUTTER, ○ b. s. (See page 48),.

509 Maximum (Immensity), $b$. $s$. Similar to preceding, but larger, .

511 Burpee's Hardhead, w. $s$. Outer leaves tinged bronze, . . . . . . .

514 Burpee's Butterhead, $\odot$ w. s. (See page 48),

\begin{tabular}{|c|c|c|}
\hline Per oz. & $1 / 4 \mathrm{tb}$. & Per lb. \\
\hline 10 & $\$ 030$ & $\$ 100$ \\
\hline 12 & & 110 \\
\hline 15 & 40 & 150 \\
\hline 10 & 30 & 100 \\
\hline 15 & 40 & 140 \\
\hline 15 & 40 & 150 \\
\hline 12 & 35 & 125 \\
\hline 15 & 40 & 150 \\
\hline 12 & 35 & 125 \\
\hline 10 & 30 & 100 \\
\hline
\end{tabular}

518 Mammoth Black-Seeded Butter. $\odot$ Large heads; white leaves,

In $\rightarrow$ Each of the above, $\mathbf{5}$ cents per packet.

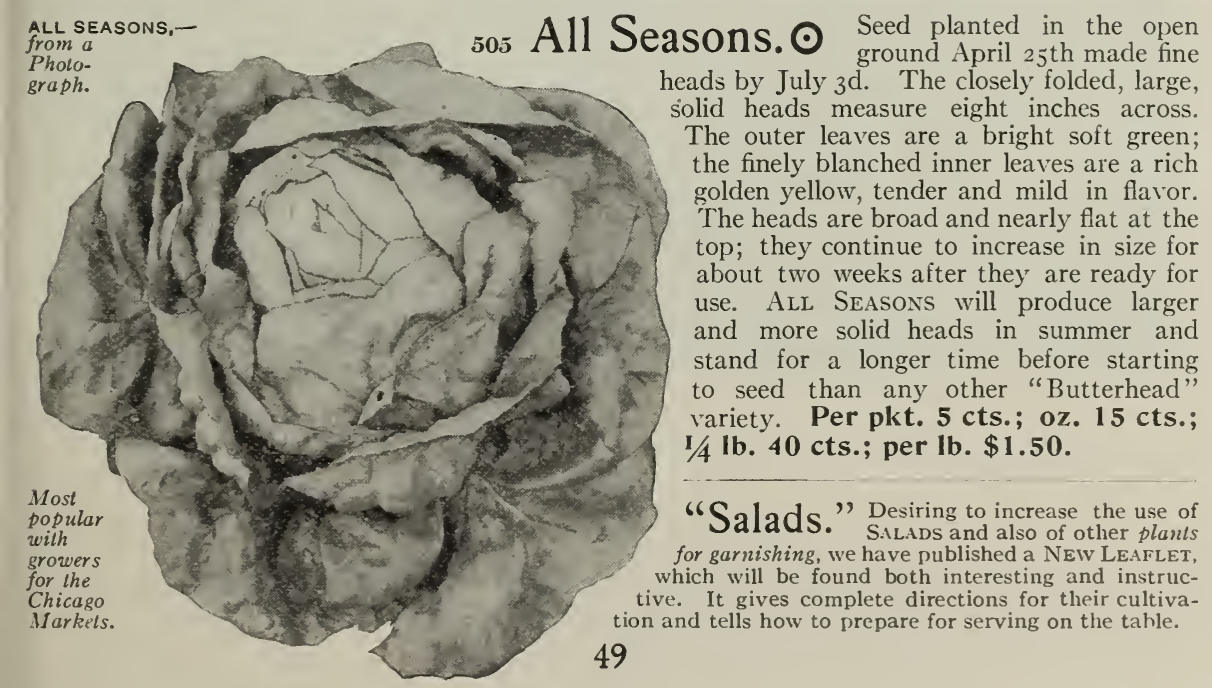




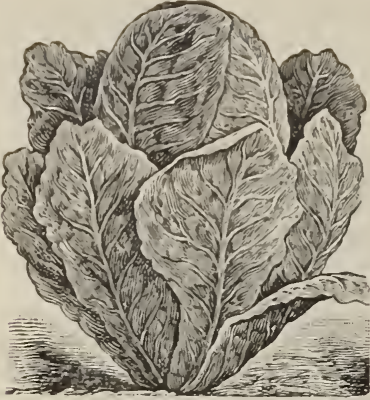

DWARF WHITE HEART LETTUCE.

\section{COS LETTUCE,-“Celery” or Romaine.}

This type is very distinct, the plants being of erect growth; the inner leaves grow close together at the top and in some varieties blanch readily without any extra care. In others, where they do not fold so closely, the tops of the leaves are gathered loosely together and tied with wisp of straw for a few days before marketing. They are always crisp and mild when grown in favorable locations, and readily command the highest price where consumers are familiar with them. They are equally as desirable for providing fresh crisp lettuce of mild flavor during the hot summer months as the crisp-head type.

Cos lettuce is extremely popular in Europe, but is not grown as generally in this country as it should be.

The ECLIPSE, or Express, is a dwarf extra-early sort, being smaller or earlier than anything in this type heretofore grown. The entire plant grows so compactly that it is practically "all head" and is about six inches in height, the outer leaves being a deep green in color. DWARF WHITE HEART is the next in earliness, but grows fully twice the size and is a light green in color. These two have the upper ends of the leaves well folded over the plant, thus making a naturally blanched "head" and do not require tying to prepare them for market. PARIS WHITE Cos is a still taller variety, from ten to twelve inches in height, erect leaves having pointed ends. The outer leaves of this variety should be gathered at the top and tied loosely for a few days to complete the blanching.

In In lots of 5 pounds, deduct 5 cents per pound. Per oz. $1 / 4$ tb. Per tb.

535 Eclipse, or Express Cos, w. s. Earliest of all,............. \$0 $12 \quad \$ 0 \quad 35 \quad \$ 125$

537 Dwarf White Heart Cos, $\odot$ w. s. Crisp and mild. P. Pkt. 10 ct.... $\quad 28 \quad 85 \quad 325$

539 Paris Self-Folding White Cos, w. s. Grows to large size,........ $12 \quad 35 \quad 125$ IJ ${ }^{3}$ Each of the above, except Dwarf White Heart, 5 cents per packet.

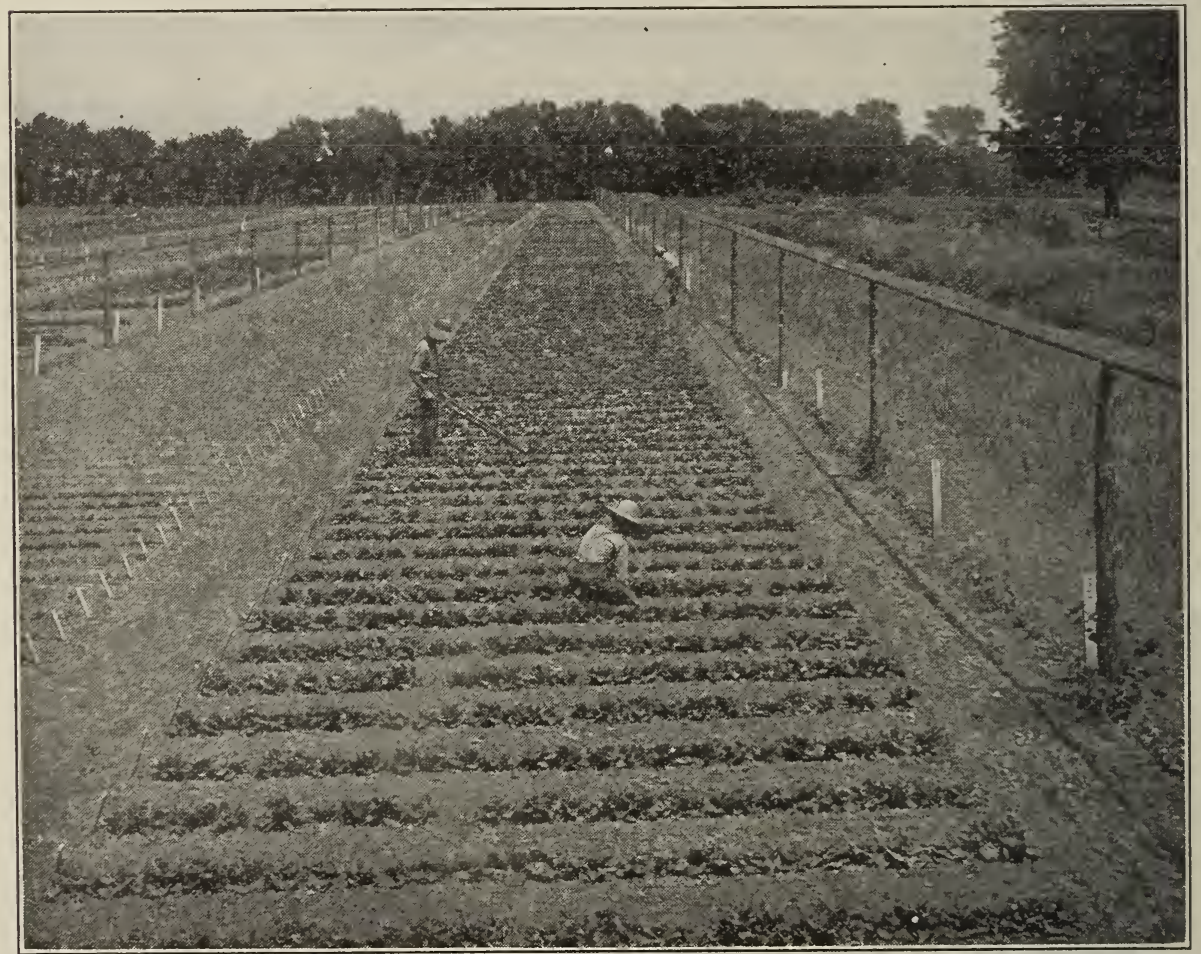

Two hundred and forty-eight trials of lettuce at FORDHOOK FARMS, - this picture also shows $a$ part of the overhead system of irrigation and a portion of two hundred and thirty-three trials of Onions (to right) and (to left) one hundred and nine trials of pansies.

- A Bull's Eye is used to mark those varieties which we consider the best of their respective you order, you can rely upon types. You may prefer others for your section. Of whichever varieties strains that have been produced for planting in ror $4-$ 


\section{MARTYNIA.}

The Martynia, or Unicorn Plant, is quite ornamental in growth, and bears spikes of Gloxinia-like flowers, followed by hairy seed-pods of a peculiar shape. These pods are gathered while young and pickled in vinegar; if let grow too large they become hard and woody. Plants require considerable warmth, and seed should not be sown until the trees are out in full leaf. When well started, thin out to one foot apart in the row and make rows three feet apart.

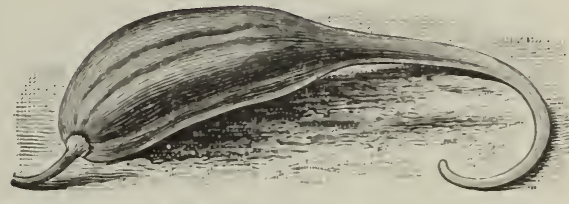

Per oz. 1/4 th. Per th. $\$ 0 \quad 20 \$ 070 \quad \$ 2 \quad 50$

541 Martynia proboscidea. For pickles. Pkt. $10 \mathrm{cts}$,

\section{MUSK MELONS.}

In musk melons a carefully selected strain of seed counts very greatly toward a profitable crop for the market garden. We can confidently recommend the strains we offer in this respect, as we have introduced a large number of standard sorts in cultivation at the present time, notably the BURPEE'S NETTED GEM, or, as it is popularly known, "Rocky Ford." This variety is now grown to a greater extent than any other for market. Many of the most critical planters come to us each season for their seed of this variety to plant for market, in preference to saving their own seed or risking a crop from seed which they might purchase more cheaply elsewhere.

Our crops of melon seed are grown especially for seed, and are saved from first-class fruits which are carefully inspected before the seed is gathered. We can assure our customers that these strains are THE VERY BEST that it is possible to produce, and will give most satisfactory results when planted under favorable weather conditions.

\section{MUSK MELONS,-Green Fleshed Varieties.}

All of the large-fruited sorts succeed best in a rather cool location, while in warm light soils the smallerfruited kinds mature more quickly and give the best returns.

BURPEE'S NETTED GEM, or ROCKY FORD, is the most popular green-fleshed melon for shipping in crates or baskets, and our selected strain will produce fine fruits of even size, correct outline, and close dense netting, combined with the finest quality of flesh and flavor.

BURPEE'S CHAMPION MARKET is a round, heavily netted melon, similar to the Netled Gem, but considerably larger and not so early. BURPEE's MATCHLESS is a large oval or oblong type of the Netted Gem, equaling the Champion Market in size. The "OLD FASHIONED" JENNY LIND is the small flat extra early "Citron" of the eastern markets, and was very popular before growers commenced to produce fruits more round in shape; very early and hardy. The Round Jenny Lind is a selection made by eastern growers in an endeavor to obtain a larger melon of the same delicious flavor.

HACKENSACK, or "Turk's Cap," is a larger, slightly flattened fruit, heavily netted, while the EXTRA EARLY HACKENSACK is a selection from it, of earlier maturity. LONG ISLAND BEAUTY is another large, heavy-ribbed and well-netted fruit of the same season as Early Hackensack, but more flattened in form.

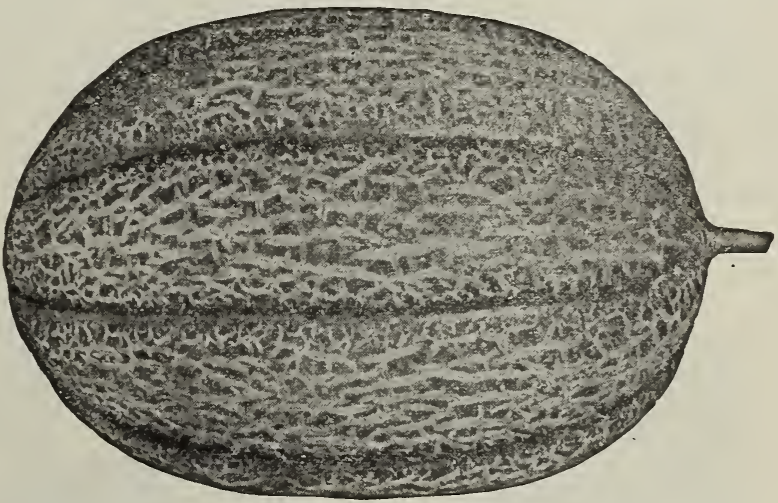

BURPEE'S MATCHLESS MUSK MELON.

BURPEE'S MELROSE is a smoothly round fruit of good size, without ribs, and the surface is covered with dense netting. The flesh is light green tinted with rich salmon next to the seed cavity. ACME, or Baltimore, is an oval fruit with a slight neck at the stem end and grows a third to a half larger than the Netted Gem.

MONTREAL NUTMEG is a very large. strong-ribbed and heavily netted sort, which is of superb quality when grown in cool locations; this is the variety which is grown exclusively on the Island of Montreal and commands such high prices in the eastern markets during the fall months.

\section{In In lots of 5 pounds, deduct 5 cents per pound.}

IRT "ROCKY FORD" (

(

54 Burpee's Matchless. ○ Oval shaped. Per pkt. $10 \mathrm{cts}$., ......

548 Round Jenny Lind. A round selection from original variety,.... .

550 "Old Fashioned" Jenny Lind. Of finest flavor. Per pkt. 10 cts.,

552 Hackensack, or Turk's Cap. Large; flattened at both ends,....

554 Extra Early Hackensack. ๑ Ten days earlier than preceding,...

556 Long Island Beauty. ๑ Of finest quality,

558 Burpee's Melrose. Light-green flesh, shading to salmon. Per

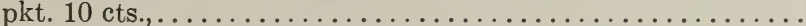

560 Prolific Nutmeg. Well ribbed and heavily netted,...........

562 MONTREAL Green Nutmeg. $\odot$ Of superb quality,...........

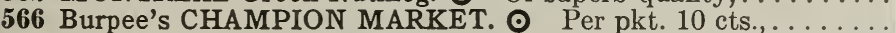

568 Burpee's Bay View. Oblong melons of large size; thick fleshed,

570 Acme, or Baltimore. Flesh firm and of fine quality,...........

S Each of the above, except where priced, 5 cents per packet.
Per $\mathrm{tb}$.

$\$ 060$

125

75

100

75

80

100

\begin{tabular}{l|l|l}
10 & 30 & 90
\end{tabular}

\begin{tabular}{l|l|l}
8 & 25 & 75
\end{tabular}

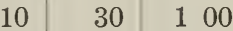

\begin{tabular}{ll|ll}
10 & 30 & 1 & 00
\end{tabular}

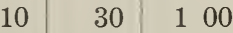

\begin{tabular}{l|l|l}
8 & 25 & 1
\end{tabular} 


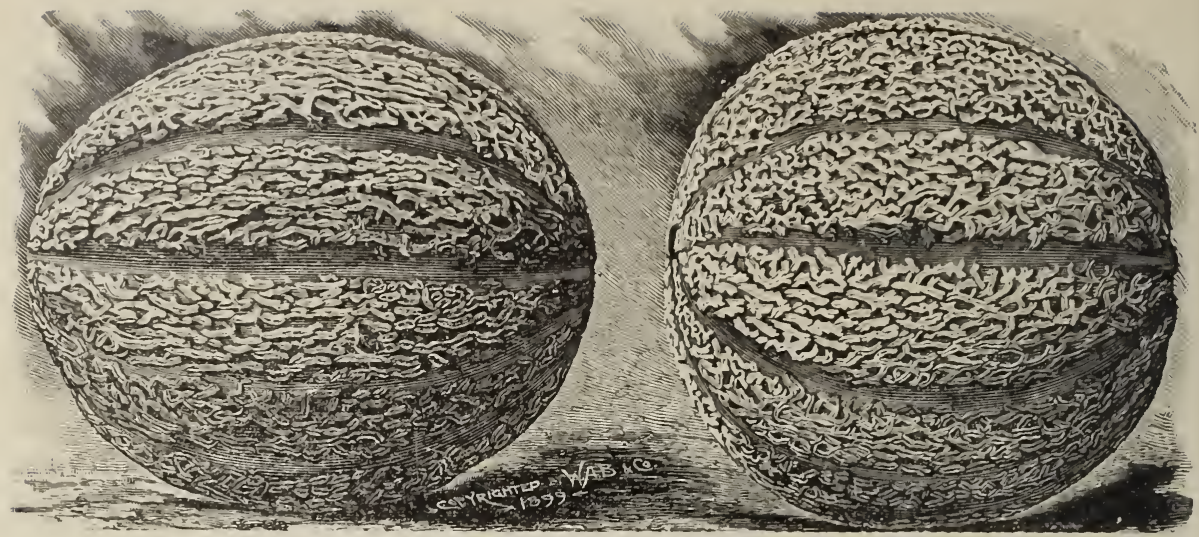

Two Specimens of BURPEE'S NETTED GEMS, - engraved from a Pholograph.

\section{${ }_{544}$ Burpee's NETTED GEM, or “Rocky Ford.”๑}

First named and introduced by us thirty-three years ago (1881), this is the variety that has made Colorado famous for its luscious "ROCKY FORD" Melons.

The variety grown [at Rocky Ford, Colorado] is the NETTED GEM, which Burpee claims to have the distinction of originating. Good seed is a prime requisite for success. Few have made any systematic selection of seed, looking well to the shape, size, solidity, depth

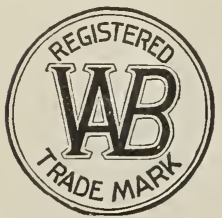
of flesh, seed cavity, color of flesh, and quality. Many have bought from dealers who knew little of the quality of seed sold, and the result is that many melons sold as "ROCKY FORD" are not up to the standard.

A pure "ROCKY FORD" cantaloupe when ripe should have a silver-colored netting which is lace-like in appearance. The skin should be green, turning to a peculiar gray color when the melon is fit for shipping. The flesh should be green in color and so sweet and luscious that it may be eaten close to the rind. The melon should have a small seed cavity and the portion of the flesh immediately surrounding it be slightly tinged with yellow. The melon should weigh about one and a half pounds and be very solid and firm.- Reprinted by special permission from Bulletin No. 62 of The Experimental Station of The Agricultural College of Colorado.

Per pkt. 5 cts.; oz. 8 cts.; $1 / 4$ lb. 20 cts.; per lb. 60 cts.

5\% Burpee's Salmon-Fleshed EMERALD GEM Melon. $\odot$

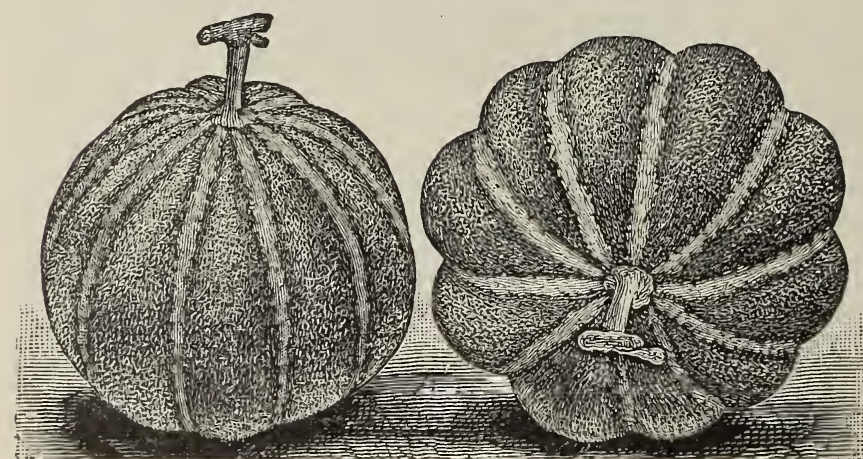

EMERALO GEM MELONS,-engraved from a photograph.

Introduced twenty=eight years ago (in 1886 ), this has long been acknowledged the most delicious in flavorthe standard by which all other melons must be judged! It is also one of the earliest to ripen, and while too soft to stand shipping any great distance to market, it is unequaled for home use or nearby markets. Vines of strong vigorous growth and very prolific. If fruits are gathered as soon as they ripen the vines will continue in bearing throughout the sea- $A B$ son. The melons

as our Netted Gem, but flattened at the stem and blossom ends. The skin is a rich, deep emerald-green, smooth and free from netting. The fruits are heavily ribbed, with narrow bands of lighter green between the ribs. Flesh very thick, with thin rind and small seed cavity, crystalline in appearance, and of a rich salmon color. Per pkt. 5 cts.; oz. 10 cts.; 1/4 Ib. $30 \mathrm{cts}$.; per Ib. $90 \mathrm{cts}$. In lots of $5 \mathrm{lbs}$. or more at $85 \mathrm{cts}$. per Ib.

\section{Proved "Best by Test." Unless you should order some variety that we} you (when we shall send it in its original package), you may be sure that you will receive from us, "to the best of our knowledge and belief," only such stocks of strictly high-grade seeds as have been proved absolutely the "Best by Test." 


\section{MUSK MELONS,-Salmon-Fleshed Varieties.}

The salmon-fleshed Musk Melons, while occasionally soft if allowed to get too ripe, are of the finest flavor nil are especially desirable for home or local markets. BuRPEE's NEIV FURDIOOK is not only the finest flavoreil of all, but being firm fleshed is a splendid shipper.

BURPEE'S EMERALD GEM is a small flat fruit with dark green skin and rich orange flesh of the finest quality. it is the earliest ripening of all melons and of the finest quality for a home market, but the flesh is too soft to stand shipping. BURRELL GEM is a netted oval dark green melon with very firm salmon flesh, - an excellent shipping variety.

Burpee's Spicy Cantaloupe is, as the name signifies, an elongated melon. It is of vigorous growth prolific and very distinct. The melons are large and the rich salmon flesh is invariably of the finest flavor.

PAUL ROSE is an oval fruit of the size and general appearance of Burpee's Netted Gem, but having rich salmon flesh of fine flavor which is sufficiently firm to stand shipping short distances to market. BURPEE's GOLDEN EAGLE has rich orange flesh, and is of strong vigorous growth, very prolific.

OSAGE, or Miller's Cream, is a large round fruit of the same general appearance, coloring, and flavor as our Emerald Gem, and is especially adapted for growing in thin cool sections or elevated locations. Tip Top is round in form, well ribbed and has thick salmon flesh of delicious flavor.

The Banana is a long, slender fruit of peculiar appearance; the fruits are yellow-skinned when ripe, and have deep-orange flesh, with a rich musky flavor.

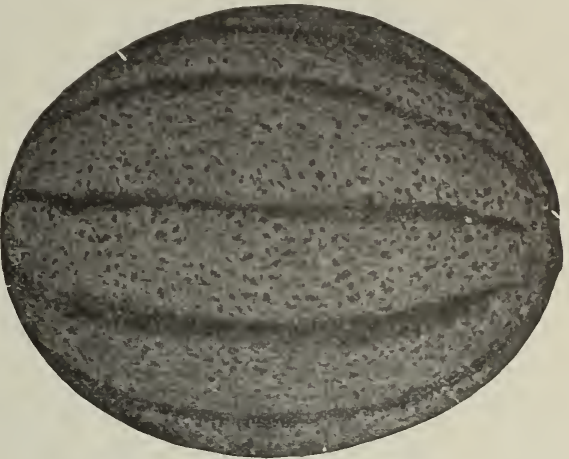

BURRELL GEM,-from a Photograph.

$$
\text { Is In lots of } 5 \text { pounds or more, deduct } 5 \text { cents per pound. }
$$

57t Burpee's New "FORDHOOK." ๑ (See page 54.) Pkt. 10

575 EMERALD GEM. ๑ (Burpee's.) (See page 52.).

576 Burrell Gem. Salmon-fleshed "Rocky Ford,"

57y Osage, or Miller's Cream. Popular in the West; fine flavor,

578 Burpee's "Spicy" Cantaloupe. ○ (See page 55.) Pkt. 10 ets.

579 PAUL ROSE, or "Petoskey." An ideal melon; oval shape,

584 Tip Top. Thick-fleshed, good shipper. Per pkt. 10 cts.,

585 Burpee's Golden Eagle. $\odot$ Extra fine. Per pkt. 10 cts.,

587 Banana. Very long fruits, of delicious flavor. Per pkt. 10 cts., . W Each of the above, except where priced, 5 cents per packet.
Per oz. $1 / 4$ tb. Per tb.

$\$ 012 \$ 030 \quad \$ 090$

$10 \quad 30 \quad 90$

$10 \quad 30 \quad 85$

$10 \quad 30 \quad 90$

$20 \quad 60 \quad 200$

\begin{tabular}{ll|l}
8 & 25 & 80
\end{tabular}

$10 \quad 30 \quad 85$

$15 \quad 40 \quad 140$

\begin{tabular}{l|l|l}
15 & 50 & 175
\end{tabular}

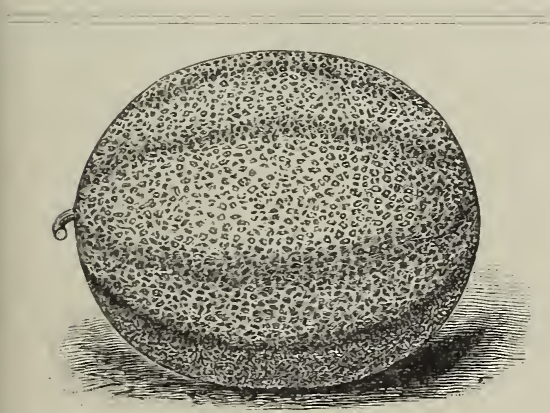

OSAGE, OR MILLER'S CREAM MELON.

\section{5\% Osage, or Miller's Cream.}

This is a popular variety in the West, being hardy and well suited for growing in cool locations. The fruits are much larger than those of the Emerald Gem; nearly round in form, but having the same distinct deep green skin with lighter bands between the ribs, and very thick, firm, orange flesh of exceptionally fine quality. Like the Emerald Gem, it should be gathered as soon as it will part readily from the vine, while the skin is still fresh and green, for if allowed to become too ripe the flesh becomes quite soft. Per pkt. 5 cts.; oz. 10 cts.; $1 / 4$ lb. 30 cts.; per Ib. $90 \mathrm{cts}$.

5r6 Burrell Gem. The melons are six to and a half to five inches in seven inches long by four well ribbed and covered with a fine grayish netting. The skin is a rich dark green, contrasting finely with the deep orange-salmon colored flesh, sweet and tender. Per pkt. 5 cts.; oz. 10 cts.; $1 / 4$ lb. 30 cts.; per lb. 85 cts.

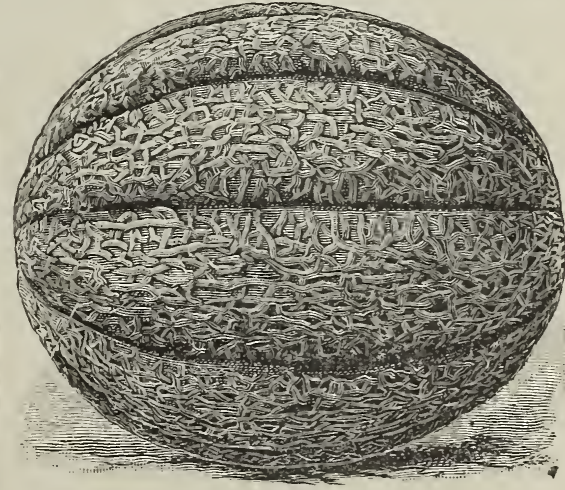

BURPEE'S GOLDEN EAGLE MELON,-accurately engraved from a Photograph.

sss Burpee's "Golden Eagle." $\odot$

The oval fruits average ten inches in length and seven inches in diameter; heavily ribbed and netted, with skin of a light golden hue when ripe. The thick flesh is of a rich salmon, sweet and melting, with a delightful aroma. It is particularly desirable for heavy soils, and continues bearing throughout the season. Per pkt. 10

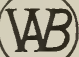
cts.; per oz. $15 \mathrm{cts}$.; $1 / 4$ Ib. 40 cts.; per lb. $\$ 1.40$.

\section{sร9 "Paul Rose," or Petoskey.}

The fruits are nearly round or slightly oval, rather larger than Netted Gem, ribbed and heavily netted; of a light green or faint golden hue when fully ripe. The flesh is thick, of rich deep orange color, and ripens close down to the rind, with small seed cavity. Per pkt. 5 cts.; oz. 8 cts.; $1 / 4$ lb. 25 cts.; per lb. 80 cts. 


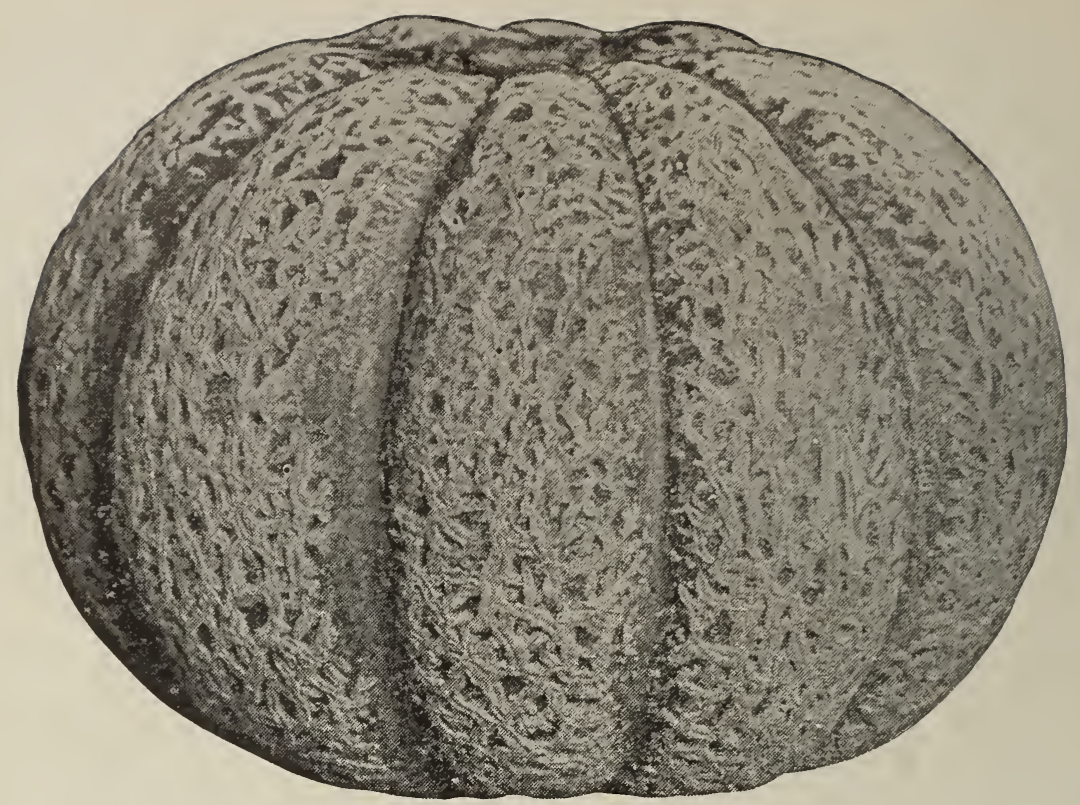

NEW MUSK MELON,-BURPEE'S "FORDHOOK."-Two-thirds Size, from a Photograph.

\section{${ }_{574}$ Burpee's New “Fordhook” Musk Melon.๑}

Pronounced equal to Emerald Gem in delicious flavor. So firm is the rough-netted skin, and so solid the thick salmon flesh, that the melons carry to market even better than do Burpee's Netted Gem,-the famous "Rocky Ford" Melon.

Fordhook Melon has fairly "leaped into popularity!" While first named and introFor duced by us only in 1908, it is already acknowledged by planters generally as decidedly the best salmon-fleshed melon to grow for market. We could fill pages with

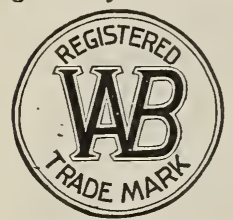
enthusiastic letters of praise,- did space permit! The new FORDHOOK MELON originated in New Jersey as the result of a cross between Burpee's Emerald Gem and the Improved Jenny Lind. As shown by the illustration, it resembles the "Improved Jenny" in form; it is equally as roughly netted, while the skin showing between the netting is emerald-green. The flesh is very thick, of an attractive deep salmon color and surpassingly sweet to the very rind. Some planters say that it is even better in flavor than our famous Emerald Gem, long known as "the most delicious of all melons." The beautiful salmon flesh, while so surpassingly luscious, is not only very thick, but also extremely solid. The thin rind is unusually firm, so that the fruits carry well to distant markets.

Fordhook Melon is most vigorous in growth, very early and extremely prolific. The fruits are ready for market fully as early as the green-fleshed Early Jenny Lind. The vines grow vigorously, and each vine sets from five to nine melons immediately around the stem; frequently the fruits touch one another. The melons are remarkably even in size, weighing from I lb. 8 ozs. to two pounds each. They are always of the handsome form and attractive appearance illustrated above. BURPEE'S "FORDHOOK" MELON is so "thoroughbred" that there are practically no fruits unfit for market.

Per pkt. $10 \mathrm{cts}$; $0 \mathrm{z} .12 \mathrm{cts}$.; $1 / 4$ lb. $30 \mathrm{cts}$; per lb. $90 \mathrm{cts}$. In lots of 5 pounds or more at 85 cts. per $\mathbf{l b}$.

\section{The Burpee-Quality in Melons.}

\section{An Unequaled Record Made in the Past Thirty-Seven Years.}

Ever since we began business in 1876 we have been greatly interested in growing melons for seed and have done much to improve existing varieties of both musk melons and watermelons. Besides extensive field crops for seed, we have fruited in our New Jersey trial grounds as many as one hundred and forty varieties of melons unknown to commerce in a single season. While most of these, particularly those of foreign origin, have proved to be of no real value, yet, with such extensive and repeated trials, it is not surprising that we have introduced eighteen of the Best and Most Popular Musk and Watermelons now in cultivation. This record is unapproached in the history of any other seed house. Ins See page 6 I of Retail Catalog. 


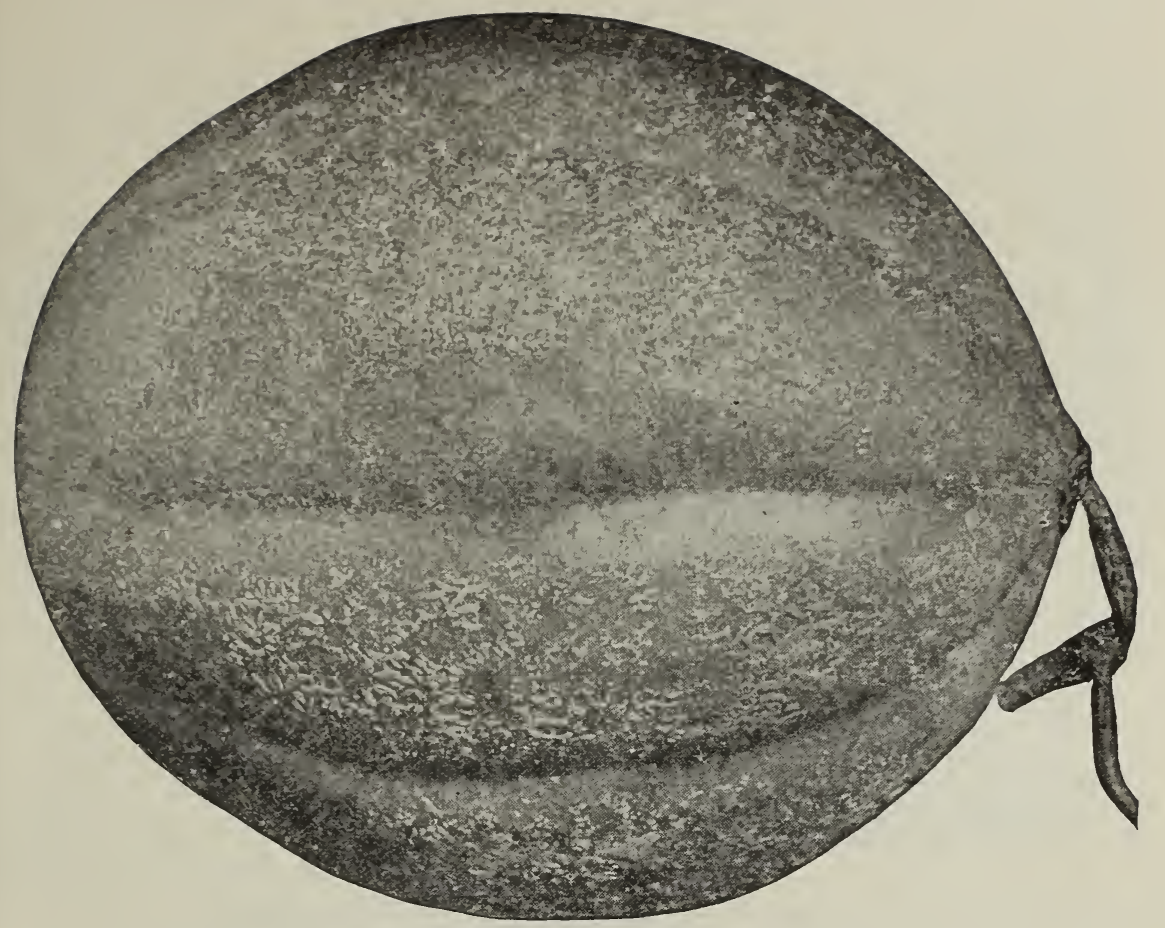

THE "SPICY" CANTALOUPE,-One-half Natural Size as grown at SUNnYBRook FARM, New Jersey.

\section{Melon,-Burpee’s “Spicy” Cantaloupe.๑}

578 The "Spicy", is most distinct both in appearance and peculiarly rich, sugary the melons mature, when the skin becomes also slightly blotched, with a delicate white netting,"like a cobweb." The melons run quite uniform, measuring from eight to ten inches in length by six to seven inches in diameter and are always firm. The seed cavity is so small that there is no tendency towards "cracking open" at the blossom end.

The juicy flesh is of a deep rich salmon color, frequently measuring two inches thick, entirely stringless and exceptionally luscious in flavor,-most tender and practically melting in the mouth. The delicious flavor extends to the very rind. Of vigorous growth, the foliage is of such a firm texture that the vines resist the attack of insects and blight. It is very prolific for so large a variety, frequently producing as many as ten large melons on a vine.

A special demand at high prices for "Spicy" Cantaloupes has arisen

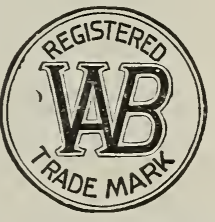
from fancy fruiterers to whom shipments were made by growers who took care to wrap each melon separately in tissue paper and pack in crates. This demand at "top notch" prices is likely to be still further extended as the unusual quality of THE SPICY becomes better known.

Per pkt. 10 cts.; oz. 20 cts.; 2 ozs. 35 cts.; 1/4 lb. 60 cts.; 1/2 lb. $\$ 1.00 ; 1 b . \$ 2.00$.

578 The "Spicy" was first introduced only four years ago (in 1910), but had been known to us since Minden, July 9, 1906, when we first saw a small block at the home of the originator in Minden, Louisiana. In IgO7 we again visited the "SPICY" crop of the originator, who was thenl living in
Indiana, and were pleased to note that the vines were just as productive and the fruits of equally fine flavor as had been those "sampled " by us the previous year in Louisiana.

In 1908 the selection was continued in Illinois (the originator having moved again !) and the melons produced were so remarkably true and of such uniformly superb flavor that we decided our customers should share with us, in 1909, the final testing of what we considered the nearest approach in appearance and favor to the greenhouse-grown foreigit melons concerning which returning European travelers are so apt to enthuse.

Letters received from planters all over the United States contained these expressions : "The finest Melon I ever raised;"-"The very.best Musk Melon;"- "The flavor is unsurpassed;"-"It has a flavor all its own!"-" Find none equal for productiveness and fine eating qualities;"-" Sweet as Honey; "- "The finest flavored:"-"Flesh sweet, melting, and tender:"-"The sweetest melon of its size;"-_"The perfection of melon improvement." After receipt of hundreds of such letters we became convinced that THE SPICY was well worthy of a colored plate and the most prominent page in our roro catalog. Unfortunately we received orders for sixteen thousand packets more of the seed than we could supply. Again in Igr it was possible to offer the seed only in small packets, but since then we have had sufficient to offer by the ounce and pound. However, with our usual conservatism, we would caution planters, who have not yet tested THE SPICY, to plant only a small area to see how it sells upon their own home markets. Markets are peculiar-and so, indeed, are soils and seasons! There is no "one best" of any fruit or vegetable for all conditions. 


\section{WATERMELONS,}

The earliest is Cole's Early, a small oval green- and white-striped fruit. This and Phinney's Early are grown chiefly in northern locations, where the summer is too short and cool for success with those which require a longer season. Hungarian Honey is a very hardy small round-fruited sort, having an extra hard rind or shell with

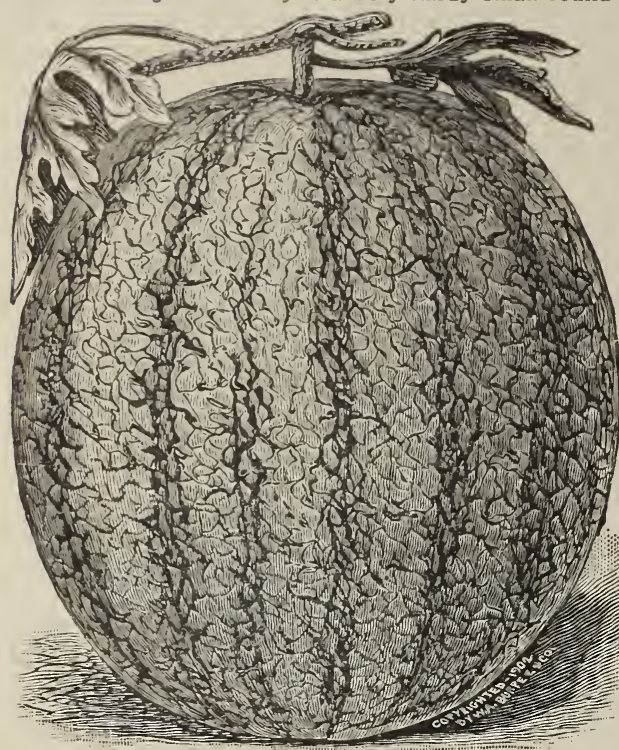

SWEET HEART WATERMELON. bright red flesh of honey sweetness. It is adapted for cool sections and where a small-sized melon is desired.

FORDHOOK EARLY is the earliest variety of good size and fine quality. The melons are of a shortened oval in form and have a sufficiently tough skin to withstand shipping some little distance.

BuRPEe's Halbert HoNey and KLeCKLex SwEETS are both early ripening and of the finest quality, but the former are too tender or brittle to stand shipping by freight and can be used only where the fruit is sold from the wagon in a nearby market. KOLB'S GEM is the popular market type, making medium-sized fruits, oval in form, with green and white stripes.

ICEBERG, or "Blue GeM," resembles Kolb's Gem, but is darker in color and has yellow skin where it rests on the ground. The SiVEET HEART is a large oval or round fruit, of a light grayish-green color.

In large oblong melons, which are so popular in the South, the new SUGAR STICK, which is an oblong type of Sweet Heart, the MCIVER SUGAR, STRIPED GyPSY (or "Rattlesnake"), and ALABAMA SWEET are of fine flavor and most attractive in appearance.

TOM WATSON has quickly become popular with many Southern growers; the melons average from fifty to sixty pounds in weight, are oblong in shape and deep red flesh is crisp, melting and of delicious flavor.

Gray MONARCH resembles the Sweet Heart in color, but is of a large oblong form. DIXIE is a dark-striped melon; the fruits are large, oblong in form, with bright-red flesh; has a tough rind and is an excellent shipper. TRIUMPH is a large, thick, oval melon with dark-green skin and of a good market type. SHAKER BLUE is similar but has white seed; the melons are fully as large as Triumph, but of better flavor.

Florida Favorite produces long deep-green fruits with bright red flesh of excellent quality. BURPEE'S MAMMOTH IRONCLAD and CUBAN QUEEN are both large, well-formed striped melons of fine quality; MAMMOTH SANTIAGO produces melons distinctly barrel-shaped, retaining their thickness throughout the entire length.

Ice Cream, or "Peerless," is an oblong melon with dark-green skin and deep pink sweet flesh. Dark Icing produces round melons of medium size, and of the finest flavor. Round Light Icing differs only in color of skin.

"BABY-DELIGHT" (see page 2I of BURPEE's ANNUAL for I9I4) is a real watermelon of luscious sweetness, but of diminutive size, - the ripe melons weighing from three to six pounds.

\section{$I \rightarrow$ In 5 pound lots, deduct 5 cents per pound.}

588 FORDHOOK EARLY. ○ (See page 5\%.),.

590 Cole's Early. Extra early, but small; green, with white stripes,

592 Phinney's Early. An extra early; of medium size; oblong,.

593 Baby-Delight. ○ An "individual" melon of fine quality. Per pkt. (90 seeds) 10 cts. Per $1 / 4$ oz. 20 cts.; $1 / 2$ oz. 35 cts.,

594 Burpee's Hungarian. Honey. Small; round; rich red flesh,

596 Burpee's Cuban Queen. ○ Large melons; bright red flesh, .

598 Burpee's Mammoth Ironclad. Large oblong; tough rind,

600 Jordan's Gray Monarch, or Long White Icing, .

601 "SUGAR STICK." ○ Sweet red flesh. (See page 58.),

602 Dark Icing, or Ice Rind. $\odot$ Of round form; sugary flavor,

604 Round Light Icing. Light colored skin; red flesh,.

606 Sweet Heart. $\odot$ Oval form; mottled light green skin; red flesh,

608 KLECKLEY'S SWEETS, grown by Kleckley. $\odot$ Pkt. 10 cts.,

609 Burpee's KLECKLEY SWEETS. ○ (See page 59.), . .

611 Burpee's HALBERT HONEY. ○ (See page 59.),

613 Tom Watson. $\odot$ (See page 5\%.) Per pkt. 10 cts.,

614 Kolb's Gem. The great market melon, but of poor flavor,

616 Iceberg, or Blue Gem. The yellow-bellied Kolb Gem, .

618 Dixie. A famous oblong Southern melon; good shipper,.

620 McIver Sugar. Large oblong striped; sugary flavor,

622 Mammoth Santiago. Mammoth fruits,

624 Striped Gypsy, or Georgia Rattlesnake. Of finest quality,

625 Alabama Sweet. Very popular in the South,.

628 Florida Favorite. An oblong melon; of fine flavor,

632 Triumph. Large, oval, solid; dark-green skin,..... .

633 SHAKER BLUE. ○ (See page 5\%.) Per pkt. 10 cts.,

634 Ice Cream, or Peerless. True white-seeded; oblong; luscious,

645 Colorado Preserving. $\odot$ The best for making citron preserves,

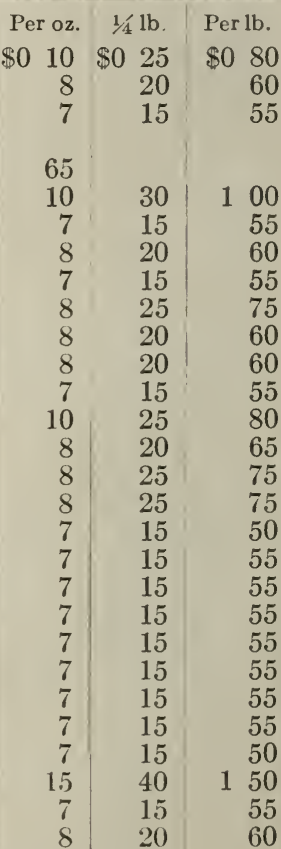

If $5^{5}$ Except where otherwise priced, each of the above, $\mathbf{5}$ cents per packet. 


\section{5ss Burpee’s Fordhook Early. $\odot$}

This is still without a rival as the earliest large $=$ fruited melon in cultivation,when grown from the genuine slock. Planted in hills six feet apart, and without any special cultivation, in our Trial Grounds, we secured a good number of fine large melons before any other varieties had ripened,

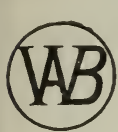
with the exception only of the small Cole's Early and undesirable II arris Earliest. These fruits are of good size, rather short and blocky in form, with large diam. eter. Skin dark green, occasionally with faint stripes of lighter green. Rind quite thin, but skin tough, making an excellent shipping variety: Flesh bright red, crisp, sweet, and of splendid quality,-really one of the finest flavored melons in cultivation to-day. Per pkt. 5 cts.; oz. 10 cts.; $1 / 4$ lb. 25 cts.; per lb. 80 cts.; 5 lbs. or more at 75 cts. per Ib.

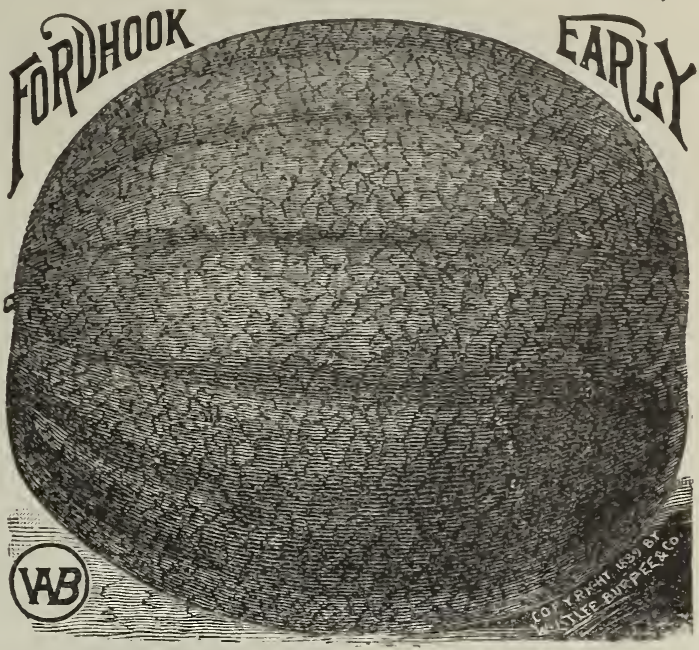

633 Shaker Blue. $\odot$ Melons grow as large as that great shipping variety, the Triumph, but are much "While-seeded large fruits. The melons are a round oval in form, from sixteen to eighteen inches long by twelve to fifteen inches in diameter, and weigh forty to fifty pounds each. The skin is dark green, striped with narrow bands of a lighter in diameter, and weigh forty to fifty pounds each. The skin is dark green, striped with narrow bands of a lighter heart large with no core, and the flavor superb. Per pkt. $10 \mathrm{cts} . ; 0 z .15 \mathrm{cts} . ; 1 / 41 \mathrm{~b} .40 \mathrm{cts} . ; \mathrm{per} 1 \mathrm{lb} . \$ 1.50$.

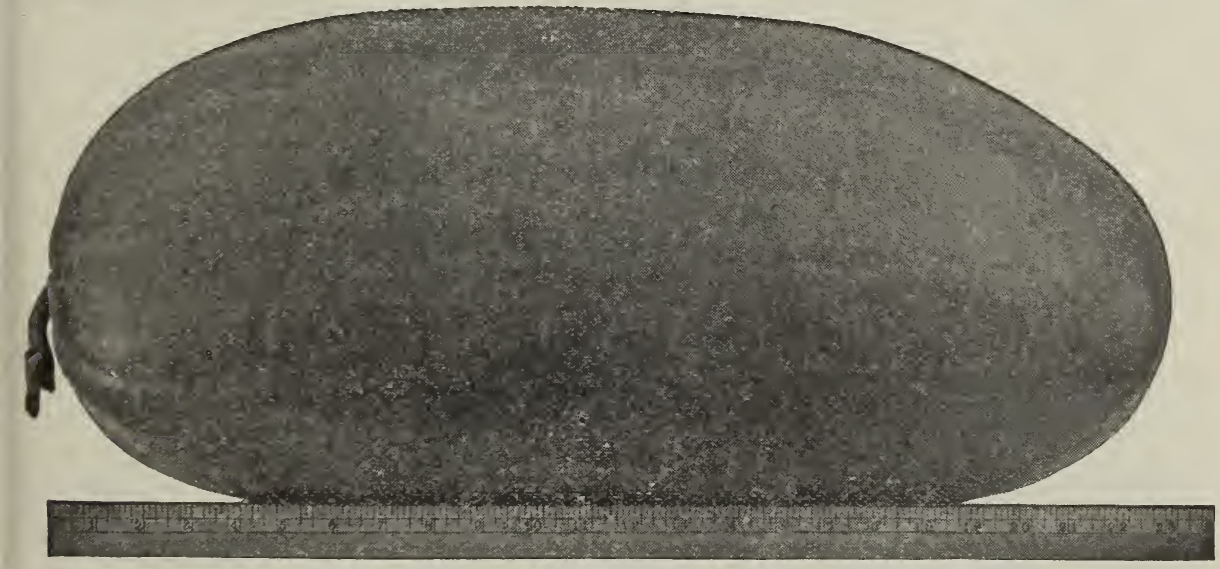

TOM WATSON WATERMELON,-from Pholograph taken July 13, rgog, in Florida.
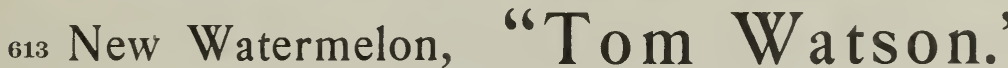

99

In the melon-growing localities the large growers usually consider there are two classes of Watermelons,--first, a thin rind table melon; second, a tough rind shipping melon. The Tom Watson belongs to the latter class; and while it does not compare in quality with Kleckley Sweets, Halbert Honey, Florida Favorite or Fordhook Early, it has proved wherever shipped to be a good eating melon, and one of good flavor,-in fact, superior to any other melon of its class.

On the light lands in Florida they produce Tom Watson Watermelons that are really delicious in flavor, and many growers located there are of the opinion that strong lands, heavy fertilizers and water will ruin the flavor of any Watermelon. It is the opinion of one of the largest growers of Watermelons that "Tom Watson has the best flavor and quality wrapped up in a rind that will carry."

Tom Watson produces melons eighteen to twenty-four inches long by ten to twelve inches in diameter and weighing from fifty to sixty pounds. The dark-green rind is tough but thin, and easily withstands shipments to far-distant markets. The deep-red flesh extends to within threequarters of an inch of the green rind and is of good flavor,-heart large with no sign of core. The seeds are brown tipped with white. The seed we offer has been produced by the most careful growers in America. Per pkt. 10 cts.; oz. 8 cts.; 1/4 Ib. 25 cts.; per lb. 75 cts. 


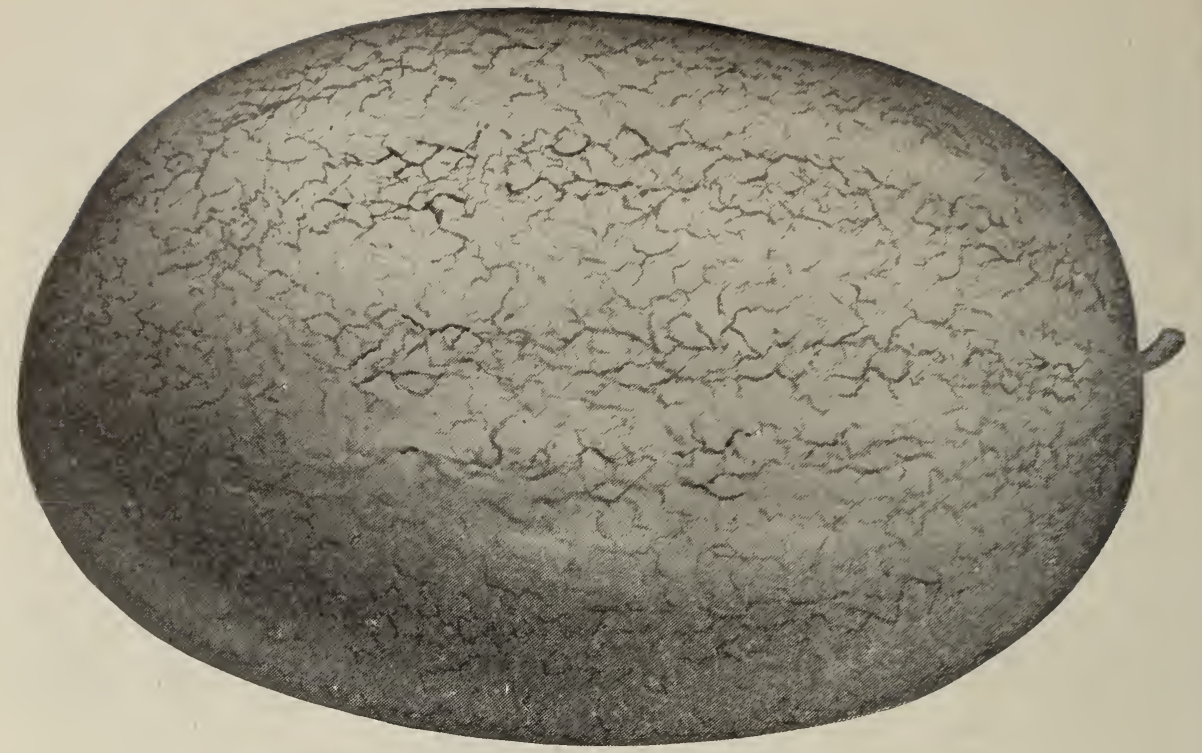

NEW "SUGAR-STICK" WATERMELON,-from a Photograph.

\section{Luscious Oblong Gray "Sugar-Stick.”॰}

601 "Sugar-Stick." ( A large light green or grayish melon of oblong form, comexcellent shipping qualities. "Sug bining handsome appearance with the finest flavor and

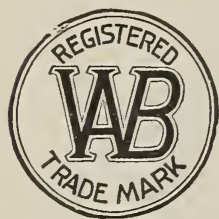
and the Sweet Heart. The result is a fruit of large oblong form, having the bright red, melting, sugary flesh of the Florida Favorite with the tough rind and light green netted skin of the Sweet Heart. The vines are of strong, vigorous growth, setting large melons in good numbers, measuring from twenty inches to" two feet, in length, with an average weight of thirty pounds. The rind is thin and tough, and the skin a light grayish green with narrow darker green lines, giving a mottled effect of small half-inch squares. The flesh is a deep rich red, with broad solid heart, crisp and sugary. The luscious red flesh is entirely free from any coarse stringiness, while the rows of dark black seeds are placed near the rind. Vastly superior to Jordan's Gray Monarch. Per pkt. 5 cts.; oz. $8 \mathrm{cts}$; $1 / 4$ lb. 25 cts.; per lb. 75 cts. In lots of $5 \mathrm{lbs}$. or more at $70 \mathrm{cts}$. per lb.

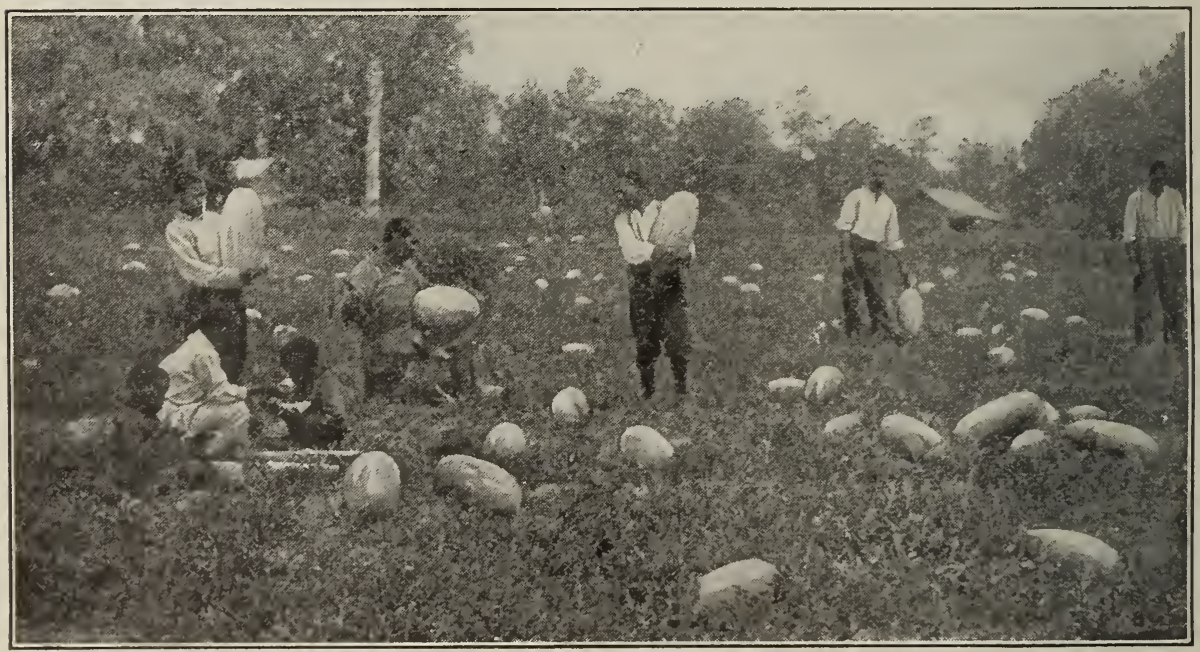

PART OF A FIELD OF SUGAR-STICK WATERMELON.-The colored population in one of our melon-growing districts now pass by the older varieties, always preferring the luscious. Sugar-Stick, even though it may be planted some distance away. 


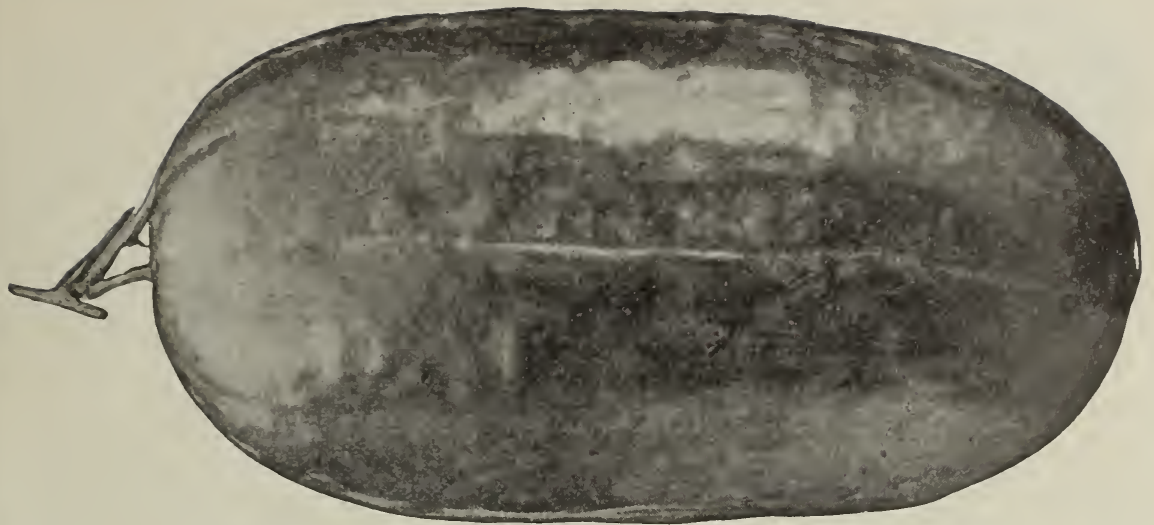

BURPEE'S "HALBERT HONEY" WATERMELON,-from a Photograph.

\section{ø11 Burpee's "Halbert Honey” Watermelon. $\odot$}

The finest of all Watermelons for the home garden and for local markets! HALBERT HONEy fully equals the Kleckley Sweets in superb luscious flavor, and has fruits more regular in outline, with a darker, richer colored skin. The vines are of strong vigorous growth and set fruits very freely,-four or five fine large melons are frequently seen clustered closely together. Will ripen choice fruits even in the Northern States if planted in a good location. The melons average eighteen to twenty inches long and are full or bluntly rounded at both ends. The skin is a dark glossy green. The flesh is a beautiful crimson, the rich coloring and luscious quality extending to the thin rind. A number of planters who sell melons in nearby markets report that the HALBERT HONEY will outsell any other variety, and frequently brings double the price of other sorts, - even when the markets are well supplied with other melons. Per pkt. 5 cts.; 0 z. 8 cts.; $1 / 4$ lb. 25 cts.; per lb. 75 cts.

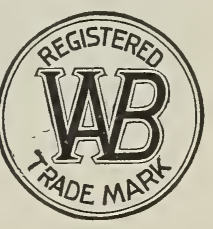

\section{Watermelon,-“Kleckley Sweets.”॰}

This famous "Sweetest of All" Watermelons, first introduced by us seventeen years ago, has become immensely popular. In superb luscious flavor it is equaled only by one other melon, - the new Halbert Honey, described above. While the skin is too tender to admit of fruits being shipped any distance to market, it is most desirable to plant for home use or nearby markets. Fruits are oblong in form, dark-green skin; very thin rind. Flesh bright scarlet, with broad solid heart; the white seeds are placed close to the rind. Flesh most crisp, sugary, and melting in the highest degree; entirely free from stringiness. The

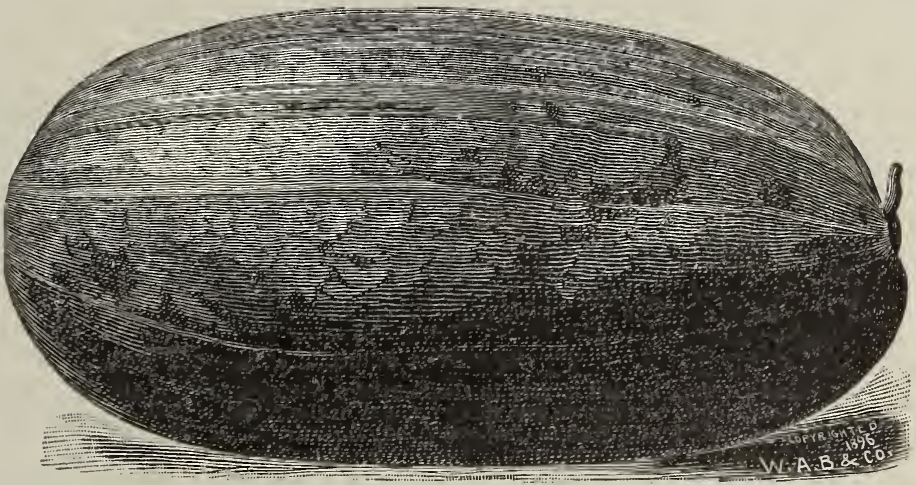

BURPEE'S " KLECKLEY SWEETS" WATERMELON,-from a Photograph. melons average eighteen to twenty inches in length by ten to twelve inches in diameter; of handsome appearance and most uniformly superior quality. With us the melons ripen quite early, and we consider it a most desirable variety for the home garden. For the seed grown by the originator, Mr. Kleckley, upon his home ranch in Texas, we charge : 608 Per pkt. 10 cts.; 0z. 10 cts.; 2 ozs. for 15 cts;; 1/4 lb. 25 cts.; per Ib. 80 cts. For our other choice seed (grown from the original stock) we

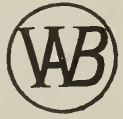
charge: 609 Per pkt. 5 cts.; oz. 8 cts.; 1/4 lb. 20 cts.; per lb. 65 cts.

Above is our description, under which we have sold thousands of pounds of the seed with entire satisfaction. As now improved, however, KLECKLEY SwEETs are quite largely shipped to market and carry well for a distance of say one hundred miles. 


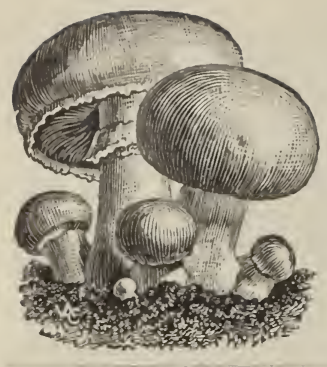

\section{Best English Milltrack MUSHROOM SPAWN.}

We offer our own importation of English Millirack Spawn from one of the most celebrated makers. This Spawn is of exceptionally fine quality and strong vitality. Stored in the cool, dry cellar of our warehouse, under the most favorable conditions, it cannot fail to give satisfactory results in properly prepared beds. For beginners and gardeners wishing to experiment with the growing of Mushrooms we send free with the Spawn, if requested, a Leaflet giving directions for preparing the beds.

Best English Milltrack Mushroom Spawn; 12 cts. per lb.; 10 lbs. for $\$ 1.00$ : $\$ 8.50$ per $100 \mathrm{lbs}$.

In Special prices quoted on large quantities.

\section{MUSTARD.}

This crop is very largely grown in the Southern States as a salad plant for use during the fall, winter, and spring months, and is equally desirable as a fresh salad, ornamental garnish for meat dishes or for a boiling green, like spinach and young beet tops, for the cooler North. By making successive plantings of the seed every few weeks a constant supply of the crisp, pungent leaves may be had in fine condition from early spring until heavy frosts come in the fall. The Black or Brown is the old variety with small leaves and of little value as compared with the newer large-leaved sorts. The White also has small sparse foliage, but produces a good crop of largesized yellow seed, which are used for flavoring and condiments, and which form a standard commercial crop like dried beans. The Chinese and Southern Giant Curled are of strong vigorous growth with quite large leaves, the edges of the light green leaves being finely cut or laciniated. BURPEE'S FORDHOOK FANCY has long, slender. plume-like leaves of a deep green color with the edges deeply cut and heavily curled. It is the most ornamental of all mustards, very productive and stands a long time before running to seed. BURPEE'S ELEPHANT EAR is a new variety with tremendously large, broad leaves of heavy substance and is enormously productive.

647 Burpee's Fordhook Fancy. ๑ Finely curled leaves, .

648 Burpee's Elephant Ear. ๑ Monstrous leaves,....... . .

649 Black or Brown. Grown for salad, . . . . . . . . . . . .

651 White. Better for salad; large seeds used for seasoning,

653 Chinese. Leaves twice the size of preceding, . . . . . . . . . . . . .

655 Southern Giant Curled. The true curled leaf, . . . . . . . . . . .

\begin{tabular}{|c|c|c|}
\hline Per oz & ${ }^{1 / 4} \mathrm{lb}$. & Per lb. \\
\hline 7 & $\begin{array}{r}18 \\
18 \\
\end{array}$ & 50 \\
\hline 6 & 10 & 25 \\
\hline 6 & 10 & 25 \\
\hline 7 & 15 & 45 \\
\hline 7 & 15 & 45 \\
\hline
\end{tabular}

\section{NASTURTIUM.}

The young seed-pods are gathered with a portion of the stem attached before they become hard, and meet with ready sale in the markets for pickling. Two ounces of seed will plant roo feet of drill.

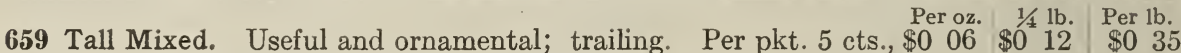
2352 Dwarf (Tom Thumb) Mixed. Pkt. 5 cts.,................ 6.615

For all other varieties of Nasturtiums, please refer to pages 119 and 120.

\section{OKRA.}

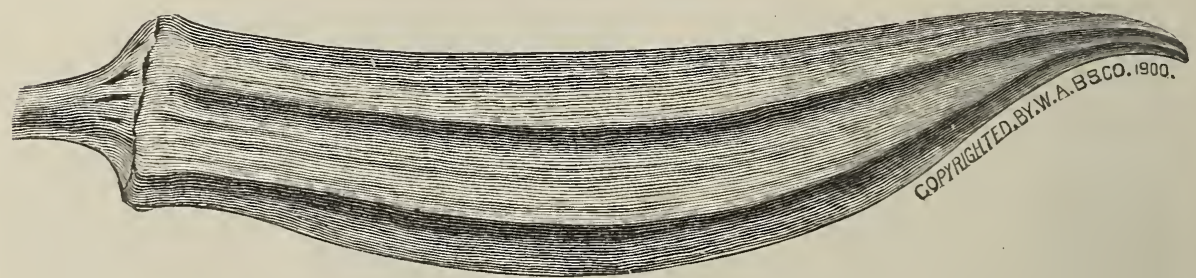

PERFECTED PERKINS' LONG POD OKRA.

OKRA, or Gumbo, is used largely in the Southern States both as a separate dish and for soups, etc.; it is gradually becoming better known and more popular in the North. The pods should be gathered and marketed while still young and tender, before the hard woody fiber develops. DWARF PROLIFIC is excellent for the Northern States, being quite hardy and productive, but has been almost displaced by the PERFECTED PERKINS', which is nearly as dwarf, quite as productive and makes longer, handsomer dark-green pods. LADY FINGER and IVHITE VELVET are southern varieties which have very long slender pods; the former is pale green in color, while the latter, as the name signifies, has pods of a creamy-white tint.

KLECKLEY'S FAVORITE is a new variety, originating with Mr. Kleckley, of melon fame, which has the creamywhite coloring of the White Velvet. It is a good grower, with very attractive pods of good length and thicker than those of either White Velvet or Lady Finger.

661 Dwarf Prolific. Prolific dwarf plants,. Per oz. $1 / 4 \mathrm{lb}$. Per lb.

663 White Velvet. Beautiful, smooth, velvety white pods, . . . . . . . . 0060

\begin{tabular}{|c|c|}
\hline$S_{0}$ & \\
\hline 12 & \\
\hline 15 & \\
\hline 18 & \\
\hline 15 & \\
\hline
\end{tabular}

665 Lady Finger. Long, slender, tender pods, . . . . . . . . . . . . . 66y Perfected Perkins' Long Pod. $\odot$ Long green pods of best quality, Dach variety, $\mathbf{5}$ cents per packet. 


\section{ONIONS.}

To grow onions profitably, the preferences of the markets in which they are to be sold should be consulted as well as the character of your soil. Onions of a certain form or color can be sold more readily and at a better price than can those of another variety with which your market may not be familiar. In selecting a variety you should bear in mind that the flat-shaped onions are the earliest and surest-ripening; - these should be selected either for an extra-early crop or for a soil which is liable to be wet. As a rule, the globe-shaped onions will grow to a larger size and yield a heavier crop to a given area. Those varieties which grow to a very large size require a longer season and should not be planted on light dry soils, or they will ripen prematurely.

II arket gardeners have now come to understand that a crop of large bulbs can be almost as readily and much more cheaply grown direct from the seed in a single season as by the old method of raising sets one year to be carried over and planted again the following spring. The chief purpose in raising sets is to have them to plant out in the fall to grow during fall and winter and make an extra-early crop of bulbs in the spring. This plan is pursued in the South for the earliest market, but we think that where there is sufficient moisture to germinate the seed early in September, equally as satisfactory results can be obtained by sowing the seed directly in the row and thus avoid the extra labor of handling and replanting a crop of sets.

\section{ONIONS,-American Yellow Varieties.}

In this class the Yellow Danvers is the earliest to mature, being followed by the Yellow Dutch, or STRASBURG, which is almost as early and grows to a larger size. The STRASBURG is largely used for growing sets.

YELLOW GLOBE DANVERS is the variety most generally sold in our eastern markets. The bulbs are of a sinooth, round outline, thin-skinned, of a soft light yellow. being most attractive in appearance. SOUTHPORT LARGE YELLOW GLOBE is a still larger variety of the same type and coloring, but growing to a larger size requires a longer season in which to mature and does not ripen so thoroughly in cool moist soils or wet seasons.

BURPEE'S EARLY GOLDEN GLOBE is a very distinct and finely selected strain of early maturity, of even, regular size and handsome appearance; it is destined to become a most popular market sort. The American PRIZE-TAKER is a yellow globe onion of very large size when grown under favorable conditions or by the transplanting method. The large yellow onions, which are sold in the fruit-stores in the fall as Spanish Onions, can be produced in good rich soil from seed of this variety in a single season. Grown in the ordinary way the bulbs will grow fully as large as those of the Southport Yellow Globe, and we consider this one of the most profitable varieties to plant where the crop is to be marketed in the fall or early winter.

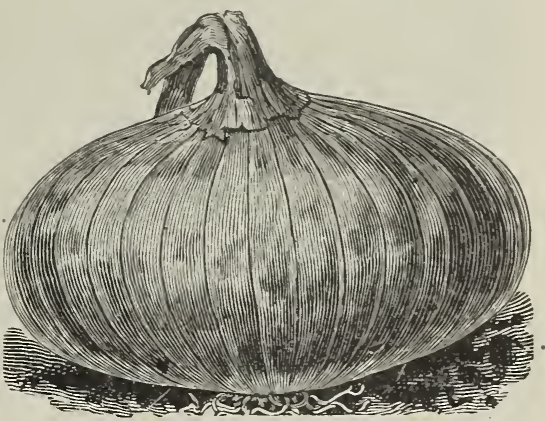

LARGE YELLOW STRASBURG, OR DUTCH ONION.
In lots of 10 pounds or more, deduct 5 cents per pound from lowest price, quoted in last column.

669 Yellow Danvers The

$(S e e$ page 65.) Pers., 5 cts.

671 Yellow Globe Danvers. ( (See page 65.) Per pkt. 5 cts.,

676 Burpee's Early Golden Globe. ๑ Earliest globe-shaped onion. (See page 65),...

67 Yellow Dutch, or Strasburg. Per pkt. 5 cts.,

679 Southport Yellow Globe. $\odot$ Per pkt. 5 cts.,

680 Burpee's "Special Stock" Southport Yellow Globe, $\odot$

681 True American Prize-Taker. $\odot$ (See page 63),
5 tbs. or more,

Per oz. 1/4 tb. Per tb. per tb. $\$ 0 \quad 10 \$ 0 \quad 30 \quad \$ 100 \$ 0 \quad \$ 5$

$12 \quad \begin{array}{llllll}35 & 1 & 20 & 1 & 15\end{array}$

\begin{tabular}{l|lll|l}
18 & 50 & 1 & 75 & 170
\end{tabular}

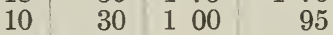

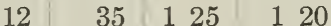

$15 \quad 40 \quad 150 \quad 145$

$15 \quad 40 \cdot 140 \quad 135$

I ${ }^{5}$ Except where otherwise priced, each of the above, $\mathbf{1 0}$ cents per packet.

\section{ONIONS,-American Red Varieties.}

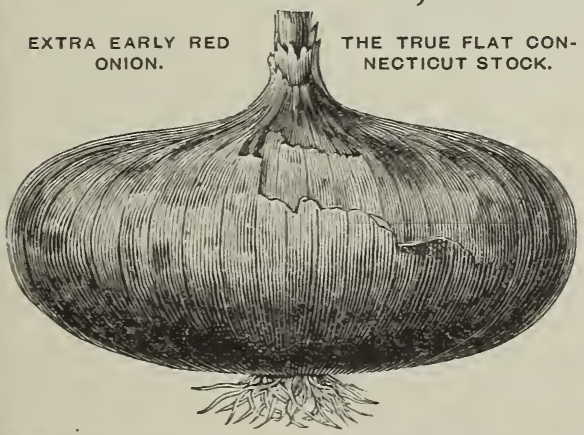

EXTRA EARLY RED produces a medium-sized flat bulb that matures early, ripens evenly, and is a good keeper. RED WETHERSFIELD is the standard maincrop dark-red variety, making thick, flattened bulbs of large size and deep rich coloring. SOUTHPORT LARGE RED GLOBE is uniformly globe- or ball-shaped and is very popular in many of the northern markets. For several seasons well-grown Red Globe Onions have commanded very nearly "top-notch" prices.

BURPEE'S AUSTRALIAN BROWN is in form halfway between the flat and the globe-shaped varieties. It is extremely early, an excellent keeper, and is now largely used in the Southern States for early fall planting to make a spring crop of bulbs. It is a most useful variety where sets are grown in the spring for replanting in the fall, as the sets can be kept in fine plump condition for quite a long period. It is also an especially good variety to plant where the crop is sold by weight, as it weighs more heavily for its bulk than any other red variety.

I. In lots of 10 pounds or more, deduct 5 cents per pound from lowest price, quoted in last column.

685 Extra Early Red. Extra early and long keeping,

687 Large Red Wethersfield. $\odot$ (See page 66),..

689 Southport Large Red Globe. $\odot$ True globe shape,

690 Burpee's "Special Stock" Southport Red Globe. $\odot$ page 64.) Per pkt. $10 \mathrm{cts.}$.

693 Burpee's Australian Brown. $\odot$ (See page 63),

Ex $\rightarrow$ Except where otherwise priced, each of the above, 5 cents per packet.

5 tbs. or more,

Per oz. $1 / 4 \mathrm{tb}$. Per tb. per $\mathrm{lb}$.

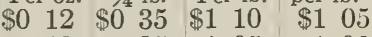
\begin{tabular}{ll|l|l|l|l}
12 & 35 & 1 & 05 & 1 & 00
\end{tabular}

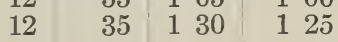

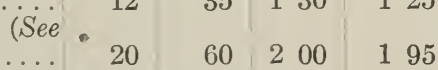

\begin{tabular}{llll|ll}
20 & 60 & 2 & 00 & 1 & 95 \\
12 & 35 & 1 & 10 & 1 & 05
\end{tabular}




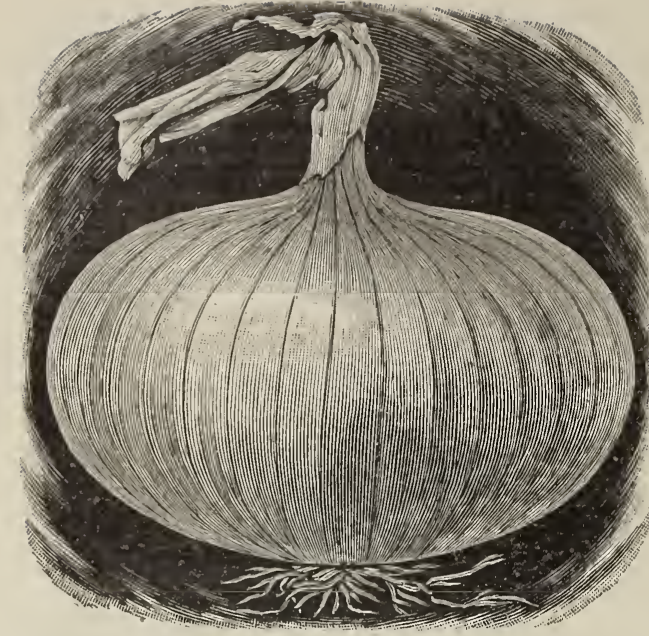

WHITE PORTUGAL ONION.

\section{ONIONS,-American White Varieties.}

White PORTUGAL, or Silverskin (see illustra. tion), is the standard white, and the variety which is largely planted for producing white sets for early spring and late fall planting.

EXTRA EARLy White PEARL (Bloomsdale Pearl) is the earliest white onion and is quite popular in the South for fall planting. This is the variety that is used by most pickling houses, as it matures early when sown in the spring and can be relied upon to produce bulbs of a uniform small size.

The Southport LARGE WhITE GLoBE commands the highest price on the New York market on account of its handsome appearance and exceedingly fine flavor.

697 WHITE PORTUGAL, or SILVERSKIN.๑

This is the standard white variety for general culture. It is equally as desirable for the family garden as for market. The bulbs grow to good size, ripening early and quite evenly. It is a good keeper. The flesh is very mild and sweet. the thin skin a clear silvery white, of very hand. some appearance. Per pkt. 5 cts.; oz. 18 cts.; $1 / 4$ lb. 50 cts.; per Ib. $\$ 1.75 ; 5$ ibs. at $\$ 1.70$ per $1 \mathrm{lb}$.
Is In lots of 10 pounds or more, deduct 5 cents per pound from lowest price, quoted in last column.

695 Southport Large White Globe. $\odot$ A fine strain,...

696 Burpee's "Special Stock" Southport White Globe, $\odot$

697 White Portugal, or Silverskin. $\odot$ Per pkt. 5 cts., ....

699 Extra Early White Pearl. Per pkt. 5 cts., . . . . . . . . . .

In $\rightarrow$ Each of the above, except where otherwise priced, 10 cents per packet.
5 tbs. or more Per oz. $1 / 4 \mathrm{tb}$. Per tb. per tb. $\begin{array}{lllllllll}\$ 0 & 20 & \$ 0 & 60 & \$ 2 & 00 & \$ 1 & 95\end{array}$

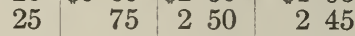

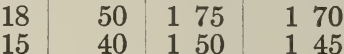

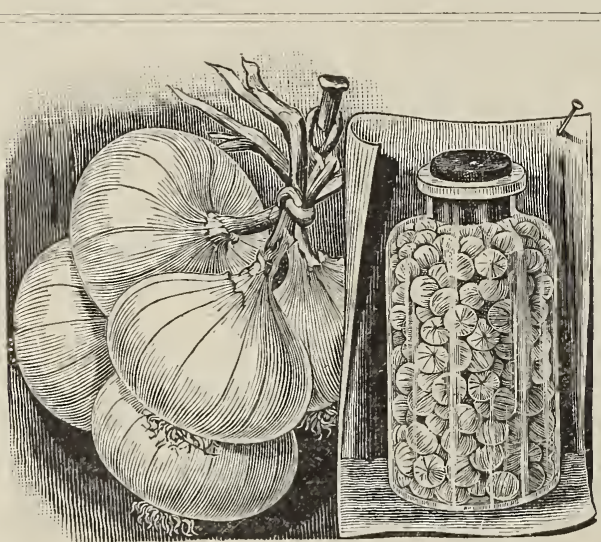

WHITE QUEEN, OR "WHITE PEARL" ONION.

\section{ONIONS, - Italian Varieties.}

These are best adapted for planting early in the fall in the Southern States to produce a spring crop of bulbs, and, as a rule, do not ripen so well from spring planting in the cool Northern States as do the American sorts previously described. Those of the flat form are, of course, the earliest and surest to ripen bulbs.

White OUEEN, or Extra Early Barletta, is a small flat pure white bulb, running from an inch to an inch and a half in diameter and should be left to grow quite thickly in the row. These are mainly planted to produce small onions for pickling. Giant White Italian Tripoli and BuRPEE'S MAMMOTH SILVER KING are large flat white onions and excellent to plant for an early market crop. Mammoth Pompeii produces large bulbs of a reddish-brown color, but the flesh is pure white. BURPEE'S GIGANTIC GIBRALTAR is similar to Prize-Taker in size and coloring, but does not ripen quite so early from seed planted in the open ground; the bulbs are very tender and even more delicate in flavor. Giant Rocca produces large globeshaped, reddish-brown onions with mild, sweet and tender flesh. Silver Ball or White Rocca is a splendid variety, producing very large bulbs of perfect globular form with beautiful silvery-white skin.

In In lots of 10 pounds or more, deduct 5 cents per pound from lowest price, quoted in last column.

701 Earliest White Queen, or Extra Early Barletta, ○.....

705 Giant White Italian Tripoli. Large flat white onions, . .

y06 Silver Ball, or White Rocca. Beautiful globe onions,... .

y07 Burpee's Mammoth Silver King. ○ (See page 68),....

y08 Mammoth Pompeii (Burpee's). Reddish-brown, ........

709 Giant Rocca. Globe-shaped red onions, .............

y11 Burpee's Gigantic Gibraltar. $\odot$ (See page 67.) Pkt. 10 cts.,

\begin{tabular}{|c|c|c|c|}
\hline Per oz. & $1 / 4$ tb. & Per tb. & $\begin{array}{l}5 \text { lbs. } \\
\text { or more } \\
\text { per tb. }\end{array}$ \\
\hline 12 & 35 & 130 & 125 \\
\hline 15 & 40 & 150 & 145 \\
\hline 18 & 50 & 170 & 165 \\
\hline 12 & 35 & 125 & 120 \\
\hline 12 & 35 & 120 & 115 \\
\hline 22 & 65 & 225 & 220 \\
\hline
\end{tabular}

If 5 Each of the above, except where priced, 5 cents per packet.
5 lbs.

45

25

145

120

15

220

- A Bull's Eye is used to mark those varieties which we consider the best of their respective ( strains that have been produced for planting in ror4- The Best "Seeds that Grow." 


\section{Early Australian Brown Onion. $\odot$}

Extra Early, a sure cropper, and extra long= keeping. The bulbs somewhat resemble the Fellow Danvers in size and form, but are thicker through, thus yielding a larger crop both in bulk and weight, and mature (ABB earlier. Where onions AB are sold by weight it a found that and Burpee's Early Golden Globe will weigh about five pounds per sack more than any other varieties. The skin is generally of a bright reddish brown, while the flesh is always white, crisp, extremely solid, and of sweet mild flavor. Per pkt. 5 cts.; oz. 12 cts.; $1 / 4$ lb. 35 cts.; per $1 \mathrm{~b}$. $\$ 1.10 ; 5$ lbs. or more at $\$ 1.05$ per $1 b$.

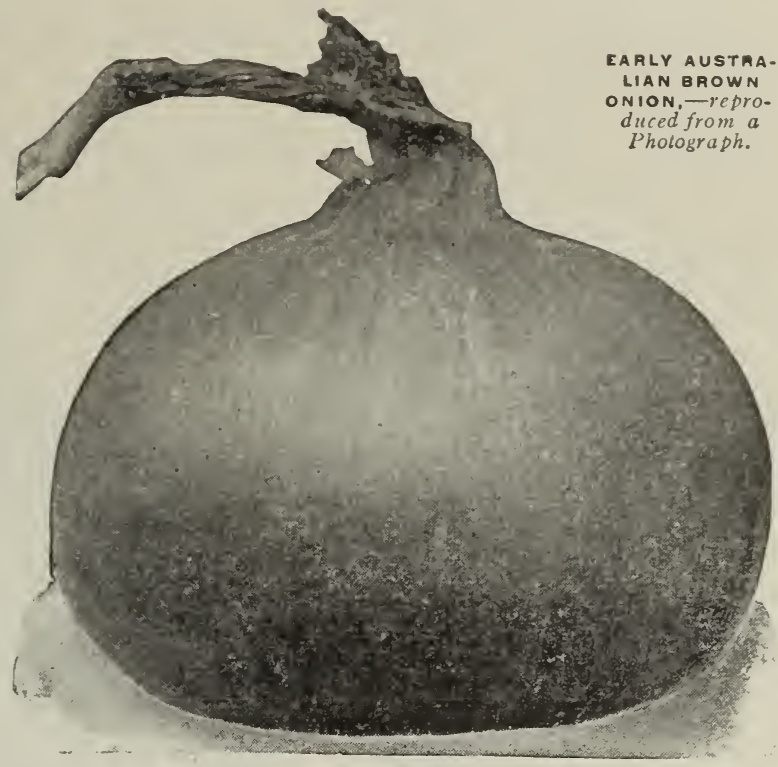

\section{${ }_{6 s s}$ American-Grown Prize-Taker Onion.๑}

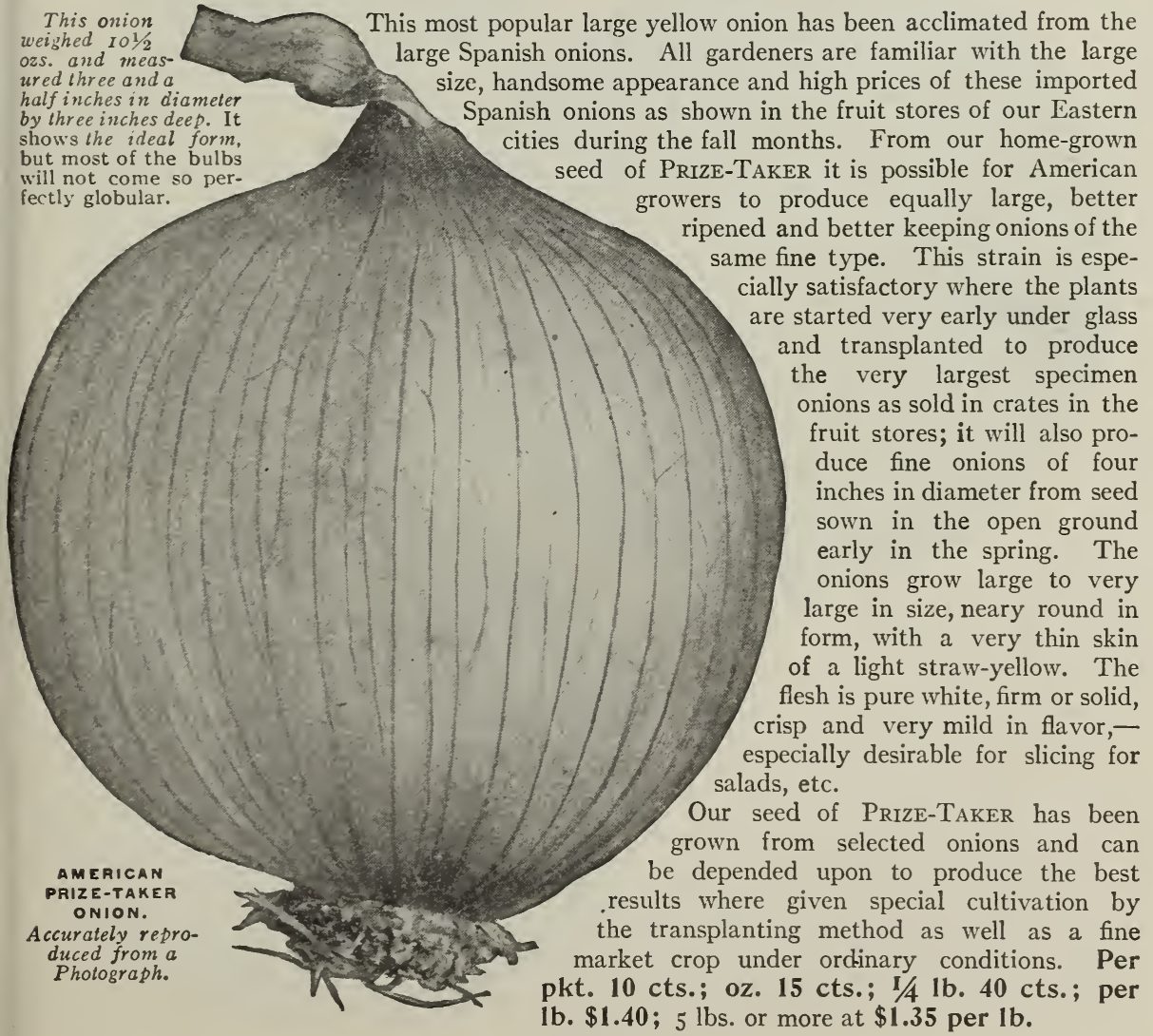




\section{Burpee's "Special Stocks" (Connecticut-Grown) \\ of the}

\section{Three True Southport Globe Onions.}

The true Southport strains of fine large globe-shaped onions have Our "Special Stocks" been established by many years of careful selection by Connecticut growers who produce onions for the New York, Boston and other eastern markets. They are noted for productiveness, uniformity in size and form, sure ripening and good keeping qualities. The superiority of the true SouthPoRT GLOBE ONIONS is shown by the much higher prices quoted in the market reports for these onions than for other varieties.

\section{Burpee's "Special Stock" of Southport Yellow Globe.๑}

This strain produces handsome globe onions with a brownish-yellow skin and crisp fine-grained white flesh. The onions average from two to two and one-half inches in diameter and ripen a little earlier than the Red Globes. Like our other "Special Stocks" of these popular Southport Globe onions, the Yellow GLOBE has been closely selected to the slim or slender-necked plant which insures earlier and surer ripening of the bulbs as well as the best keeping qualities. The tops die down very uniformly before the onions are ready to be pulled. Onions which have to be pulled to ripen while the tops are still green do not keep so well when stored as do those which ripen naturally in the soil where they are grown. Per pkt. 10 cts.; oz. 15 cts.; I $/ 4$ lb. 40 cts.; per Ib. $\$ 1.50$.

have been grown from the finest onions, especially selected to produce the crops of seed now offered. Under proper conditions these stocks will produce large crops of fine wellripented onions of the best

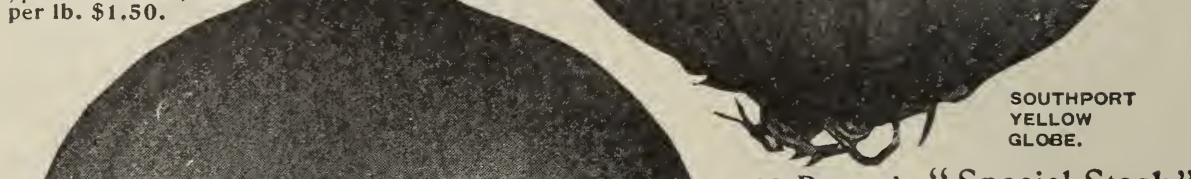
696 Burpee's "Special Stock" Southport White Globe. $\odot$

Of true globe-form, the onions are two to two and a half inches in diameter, with a thin delicate skin of purest paper whiteness. The flesh is crisp, fine grained, snowy white in color and very mild flavor. The bulbs should be stored in a cool dark loft or shed to dry as soon as they are ripe enough to harvest. Per pkt. 10 cts.; oz. 25 cts.; $1 / 4$ Ib. 75 cts.; per 1 b. $\$ 2.50$.

SOUTHPORT RED GLOBE.

690 Burpee's

"Special Stock" of Southport Red Globe.๑

This is the handsomest and most richly colored of all red onions. Perfectly globe-shaped, the onions measure two to three inches in diameter. Remarkably uniform in sizeand form, with the dark rich coloring, they make a most attractive appearance. The plants are thinnecked, ripening down to a hard solid ball,-insuring the largest percentage of market onions and the best keeping qualities.

These "RED GLOBES," as a rule, grow to larger size and will produce a heavier crop than the yellow and white varieties, but do not generally command quite so high a price in the markets. Our "SPECIAL STOCK" was produced from fine market onions of the very best form and richest coloring. We recommend it as the best that can be produced and sure to vield a most satisfactory crop under favorable conditions. Per pkt. $10 \mathrm{cts}$; oz. $20 \mathrm{cts} . ; 1 / 4 \mathrm{lb} .60 \mathrm{cts}$.; per lb. $\$ 2.00$. 


\section{Burpee’s New Early Golden Globe Onion.๑}

This is an improved strain of the Australian Icllow Globe. The onions keep in good condition very nearly if not quite so long as do

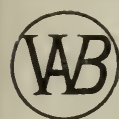
the Austrulian Browns. The onions, of globe form, average from four to six ounces in weight. The light golden-yellow skin, while thin, is sufficiently tough to protect the bulb from bruising when shipped. The onions have an extremely small top, ripen down well, and are just the right size for the family table. They are extremely hard and solid, the pure white flesh being most mild and pleasant in flavor. Per pkt. $10 \mathrm{cts}$.; oz. $18 \mathrm{cts}$.; $1 / 4$ lb. $50 \mathrm{cts}$.; per Ib. $\$ 1.75$.

\section{"How to Grow Onions." Large onions} directly from seed quite as easily and more cheaply than from sets which have been grown a previous season and carried over. In this interesting LEAFLET ON CULTURE we give brief but clear directions for preparing the soil, sowing the seed, cultivating and harvesting the crop, early seedlings in the hot-bed to be transplanted to che garden or field.

or field. $\rightarrow$ This LEAFLET (and others on page 3 ) will be mailed FREE-if requested when ordering. \&
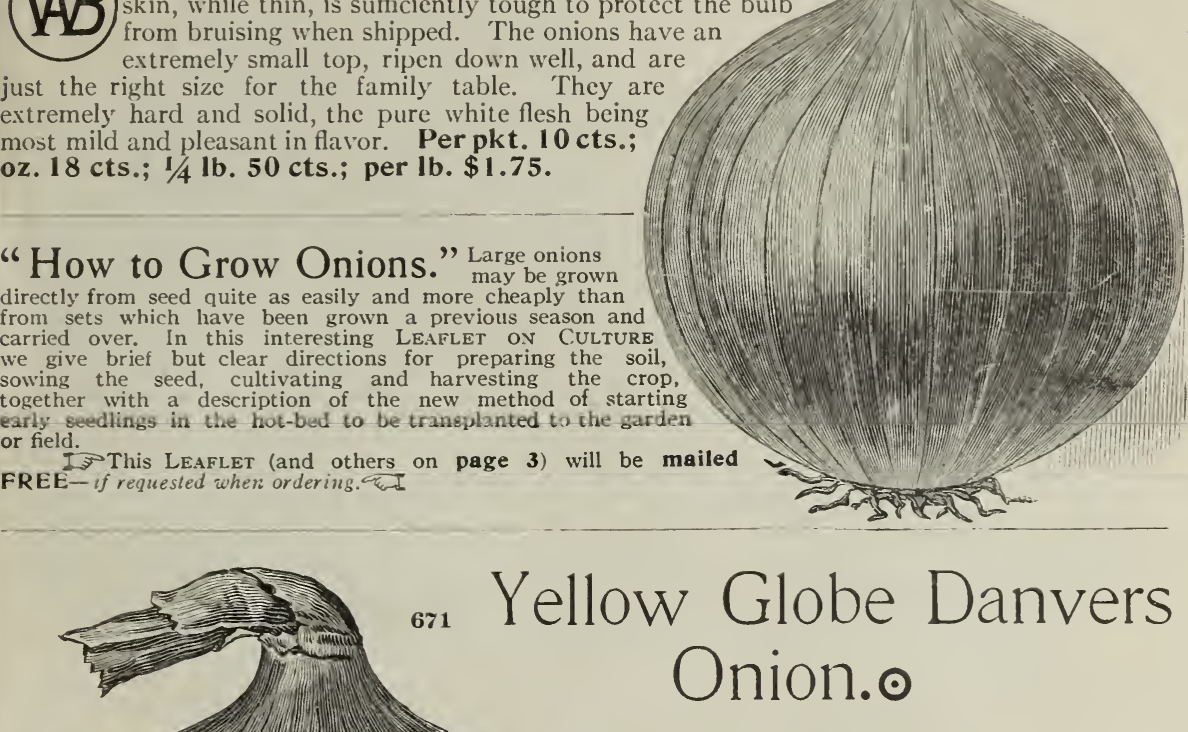

This is the standard variety for winter use in our eastern markets, producing well-ripened bulbs averag-

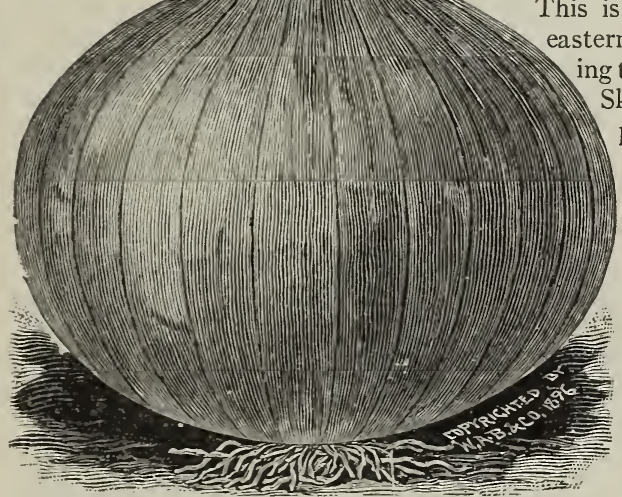

TRUE YELLOW GLOBE DANVERS. Engraved from a Photograph.-R duced in size.
GOLDEN GLOBE "Improved Australian
Yellow Globe.

Skin a light golden brown or pale yellow; flesh pure white, crisp, and mild in flavor. The Yellow Globe Danvers seed we offer is fully equal to the strains grown around Boston. The name "GLOBE" in this connection, however, must be taken comparatively, as the True Danvers Onion is not usually so perfectly globe-shaped as the Southport I'ellow Globe. Other perfectly globe-shaped varieties are generally later maturing than the Yellow Globe Danvers. The illustration was engraved from a photograph. Per pkt. 5 cts.; oz. 12 cts.; 1/4 lb. 35 cts.; per lb. $\$ 1.20 ; 5 \mathrm{lbs}$. or more at $\$ 1.15$ per lb.

677 Y ellow Dutch, or STRASBurg. than the Yellow Danvers,--bulbs are more flattened and of a darker, richer coloring. The onions ripen quite early with pure white flesh of mild flavor. It is one of the best to grow for sets, and is a splendid keeper. Per pkt. 5 cts.; oz. 10 cts.; $1 / 4$ lb. 30 cts.; per Ib. \$1.00. In lots of $5 \mathrm{lbs}$. or more at $\$ 1.05$ per Ib.
669 Yellow Danvers. A good onion, both for the home garden tions than do the globe-shaped varieties, as well as earlier. The thin-necked flattened bulbs are quite thick through; light yellow skin with fine-grained mild white flesh. Per pkt. 5 cts.; oz. 10 cts.; $1 / 4$ Ib. $30 \mathrm{cts}$.; per Ib. $\$ 1.00$.

Good Onion Seed is of the utmost importance. Fully realizing this, we make the purchase of the seed is likely Specialty of the BEST Onion Seed. A dollar saved on first cost of the seed is a small item compared with the expense involved in the proper preparation, fertilizing, and cultivation of the soil. It costs as much to raise a crop of inferior bulbs from poor seed as to produce a crop of fine, evenly ripened bulbs from a selected strain of seed. Our Onion Seed is absolutely" unsurpassed! It is strictly High=Grade "PEDIGREE SEED" of strong vitality. 
I This is the most popular standard variety for winter market in many northern States. It is not an early ripening sort, as it continues in growth throughout the season, and consequently makes very large onions.

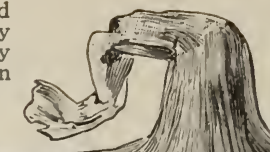

Is The illustration below was engraved, natural size, from a specimen bulb of our LARGE RED WETHERSFIELD, - the most popular of all red onions. The skin is uniformly of a rich, dark-red color.

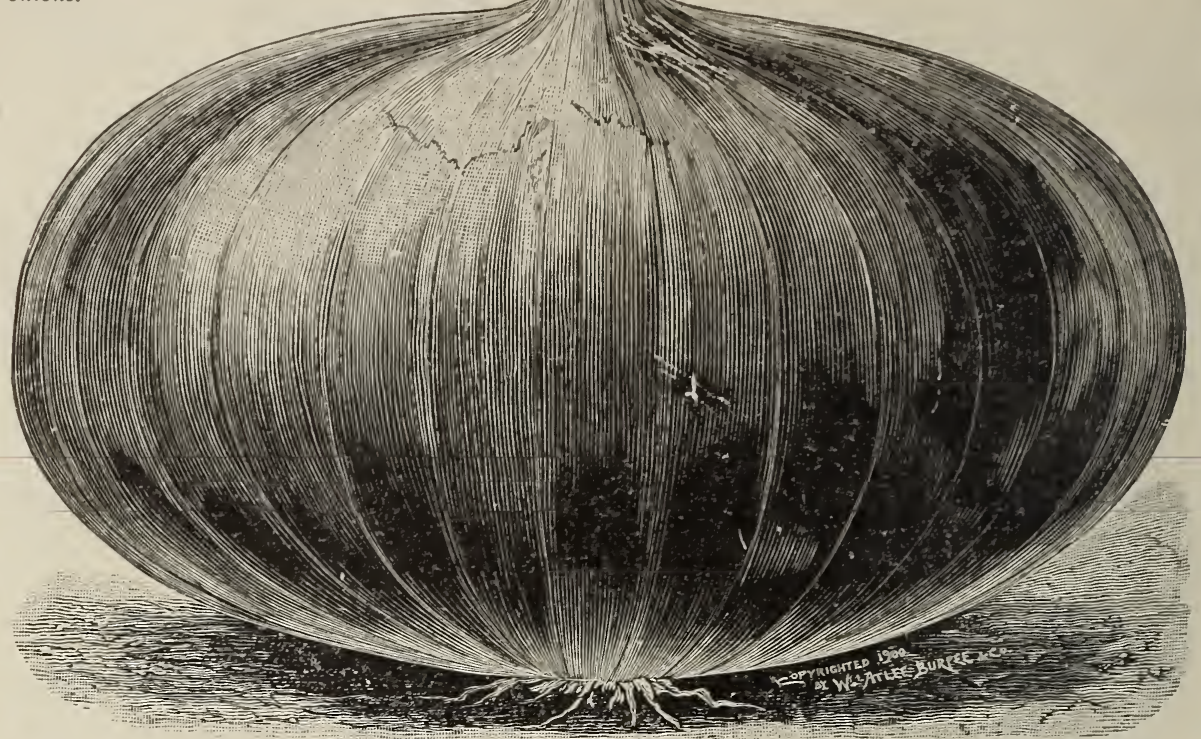

\section{${ }_{687}$ Extra Large Red Wethersfield Onion. $\odot$}

Continued selection of bulbs planted for seed gives us a small-necked, sure-ripening strain, entirely free from scallions or thicknecks. Though well flattened, the solid onions are thick through, as shown in the photograph of a specimen bulb reproduced above. This onion, shown natural size, weighed exactly six ounces. The outer skin is a deep rich purplish red, smooth and glossy; flesh white, lightly tinged with pinkish rose. The large solid onions are nearly as mild in flavor as many varieties with skin of lighter coloring, while they keep well to hold crops for late winter markets. Per pkt. 5 cts.; oz. 12 cts.; 1/4 lb. 35 cts.; $\$ 1.05$ per lb.; 5 lbs. at $\$ 1.00$ per lb.; $10 \mathrm{lbs}$. or more at $95 \mathrm{cts}$. per lb.

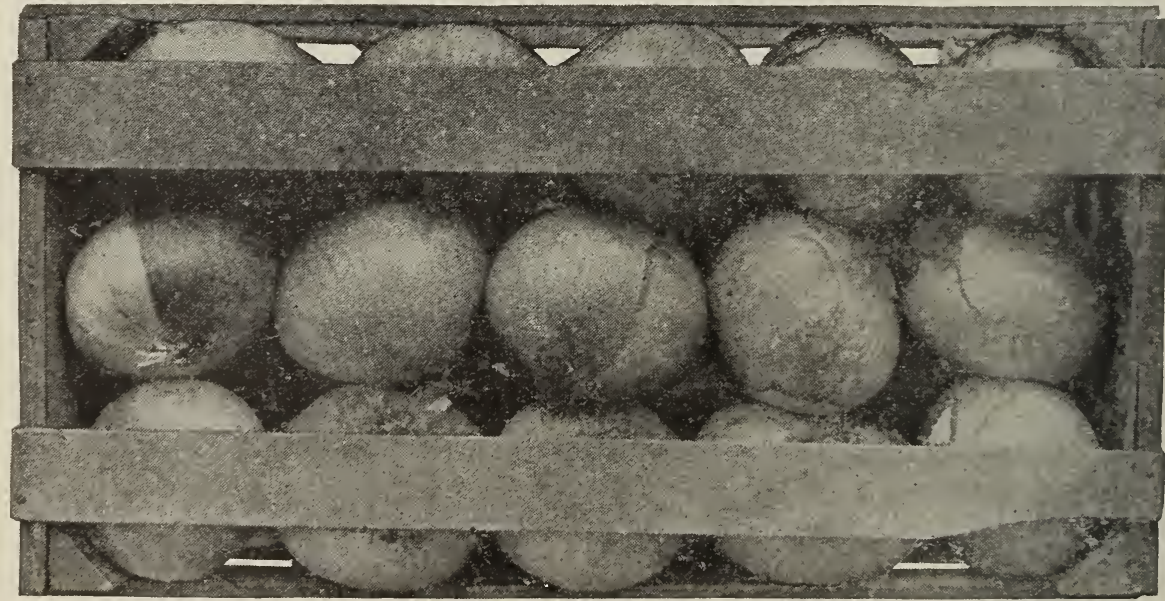

BURPEE'S GIGANTIC GIBRALTAR ONION.

The above crate of Gigantic Gibraltar Onions, grown from our seed, was photographed in March, 1907. It is what is known in Rocky Ford, Colorado (where the onions were grown), as a standard crate, measures $\mathrm{I} 2 \times \mathrm{I} 2 \times 24$ inches, and contained forty-five uniformly handsome onions. An acre, from plants raised in a hot-bed and afterward transplanted, produced thirty-one tons of bulbs which sold for $\$ 30.00$ per ton, or $\$ 930.00$ for the crop. IN $\$$ Prices for seed of BURPEE'S Gigantic Gibraltar OnIoN are given on next page. 


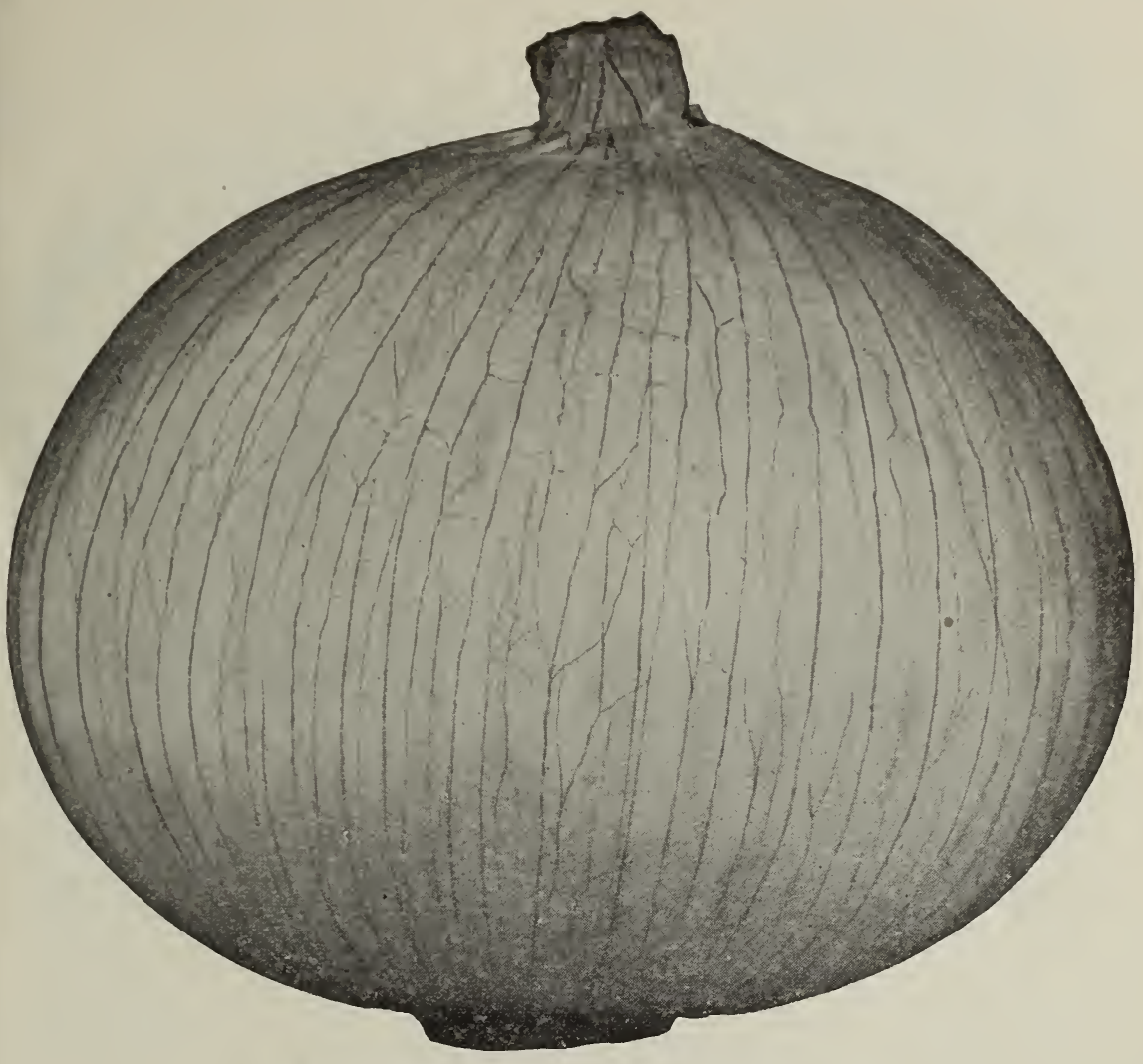

BURPEE'S GIGANTIC GIBRALTAR ONION.

The specimen pholographed was grown by J. M. DiefFENBACHer, Ames, Iowa, and weighed I lb. $73 \% 4$ ozs.; measured 5 inches in diameter.

\section{${ }^{n}$ Burpee’s Gigantic Gibraltar. $\odot$}

\section{(See Colored Plate on Page 5 of Burpee's Annual for 1914.)}

While the ripened bulbs are similar to those of the Prize-Taker in size and form, it is even better adapted to growing in warm locations. The plants continue in growth longer under such conditions, and consequently produce larger bulbs. The leaves or blades are distinct in appearance from those of other varieties, being of a deep green, with a glossy surface, enabling it to withstand dry weather and the attacks of insect enemies. The handsome large bulbs are nearly globular in form. Thin skin of light straw color; flesh white, tender, and mild. These onions are excellent for home use, at any time, while in the growing state during the summer months. Per pkt. $10 \mathrm{cts}$; $02.22 \mathrm{cts}$.; $1 / 4 \mathrm{lb} .65 \mathrm{cts}$.; per Ib. $\$ 2.25$; five pounds or more at $\$ 2.20$ per $1 \mathrm{~b}$.

\section{Early Green Bunch Onions can be Grown from Seed.}

Early green bunch onions can also be grown direct from the seed in the Northern States by selecting and preparing a well-drained plot of ground early in September and sowing the seed thinly in the rows where the young onions are to be grown. The onion plant is very hardy, making a good growth during the cool fall months and starting a new growth very early in the spring, where planted in a well-drained soil or in a bed slightly elevated above the surrounding surface, so that any surplus moisture from heavy rains or melting snows will drain away quickly. By sowing the seed early in September you get from four to six weeks' earlier start in growth than you do from the sets or small onions which are usually planted out in October, and effect a very large saving in the cost of the sets or the labor and expense of growing them the preceding spring. For green bunching, the globe or ball-shaped varieties are the most desirable, as the young plants grow with thicker or heavier stalks than the early flat varieties. 


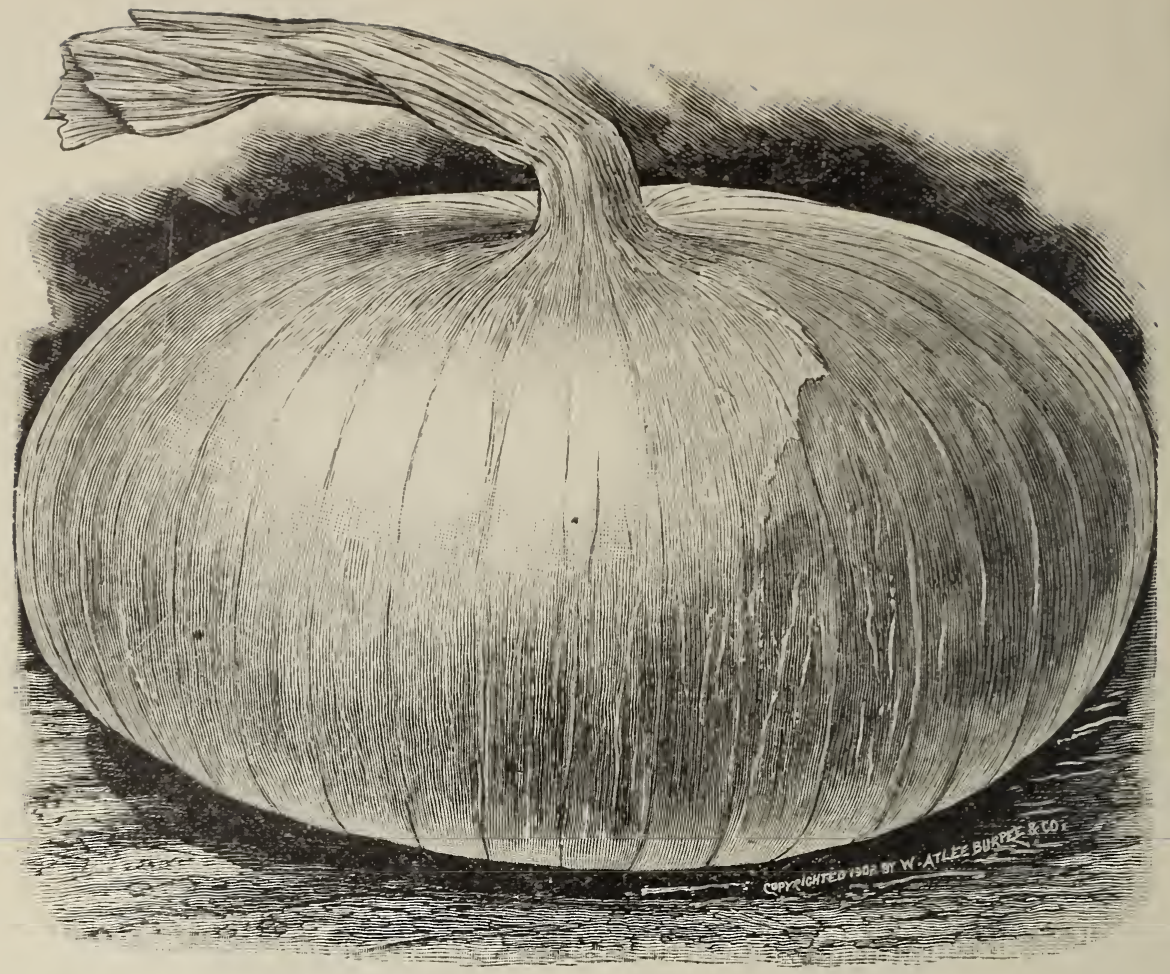

BURPEE'S MAMMOTH SILVER KING ONION,-Natural Size, from a Pholograph.

\section{${ }_{707}$ Burpee's Mammoth Silver King Onion.๑}

This splendid large white Onion was first introduced by us in 1884 , and quickly became a

leading popular sort to grow for market in many localities. The large bulbs are of at-

TI tractive form, flattened but quite thick through. Under good cultivation the average

(1) diameter is from five to seven inches, single bulbs often attaining a weight of from two to three pounds each. The thin skin is a clear, silvery white, flesh snow-white, sweet and tender. They grow quickly, mature quite early and sell well in autumn and early winter. Per pkt. 5 cts.; oz. 18 cts.; 1/4 lb. 50 cts.; per lb. $\$ 1.70$.

\section{ONION SETS AND BULBS.}

We do not make a specialty of these, as we consider it a greater advantage to market gardeners to grow their main crop of onions direct from the seed. For the convenience of our customers, however, who wish to plant

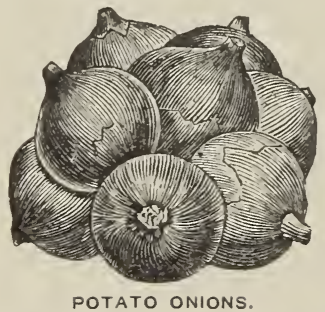

POTATO ONIONS. sets in the fall for an early crop of green bunch onions or "scullions," and for those who wish to put out a limited area of sets to produce the earliest crop of bulbs for market, we offer choice well-ripened sets of the following varieties. White SETS are grown from While Porlugal Onion seed. Our YelLow SETS are grown from the Yellow Strasburg, which makes a large, well-ripened bulb of a light golden-brown color.

The YELLOW POTATO ONIONS are usually planted early in the fall or in northern sections very early in the spring. Small sets will produce large, wellripened bulbs the following season, while the larger ones planted early in the fall will make a cluster of green bunch onions in the spring or later a cluster of small sets for replanting. The WHITE MULTIPLIER also increases at the root and makes a small, round, hard, white bulb, averaging one inch in diameter, which sells very readily on the market as pickling or small stewing onions. It does not at any time make large bulbs.

Egyptian, or "Perennial Tree Onions," is an exceptionally hardy variety which is planted in the fall for the earliest spring bunch onions and can be used only for this purpose. as it does not at any time make ripened bulbs. They should be planted in the fall. This variety cannot be supplied between March Ist and September Ist.

White Onion Sets (Best Philadelphia),

Yellow Onion Sets (Best Philadelphia),

Potato Onion Sets (Yellow),

White Multiplier Onion Sets,

Egyptian, or Perennial Tree,

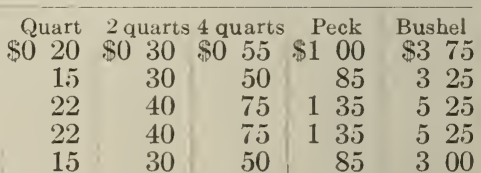

an Prices vary according to the market,-please write for quotations. 


\section{PARSLEY.}

Parsley is the most extensively used plant for flavoring or garnishing, and there is a steady demand in the market throughout the year for small bunches of fine well-curled leaves. The varieties are all similar in growth, differing mainly in the finely curled or mossed characte of the foliage. Our DARK MOSS-CURLED has very finely curled leaves of a rich dark-green color.

The TURNIP-Rooted PARSLEY is grown solely for the root, which resembles a small turnip and is used for flavoring stews, soups, etc. In this variety the plants should be thinned out to stand only one in a place and a little distance apart in the row; they should be given good cultivation throughout the season of growth. The seed should be sown thinly in drills as early in the spring as the soil can be dug in a fine loose condition; it germinates best during cool, moist weather. When well started, thin out or transplant to stand six inches apart in the row.

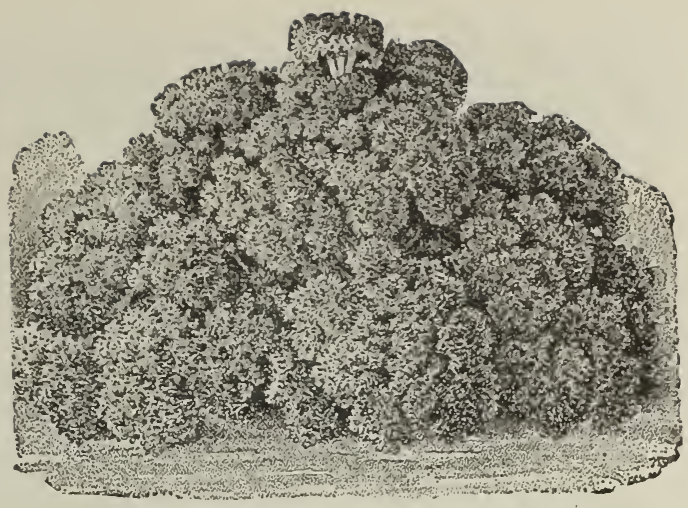

EXTRA DARK MOSS-CURLED PARSLEY.

5 ths.

or more,

I 5 Each variety, 5 cents per packet.

14 Plain, or Single. Plain leaves, excellent flavor,

$\$ 0 \quad 10 \quad \$ 0 \quad 30 \quad \$ 1 \quad 00 \quad \$ 0 \quad 95$

715 Double Curled. Dwarf; crimped leaves, .

\begin{tabular}{ll|l|l|l}
10 & 30 & 1 & 00 & 95
\end{tabular}

717 Extra Curled Dwarf, or Emerald. ○ Leaves bright green, $10 \quad 30 \quad 100 \quad 95$

719 Dark Moss-Curled. Dark-green curled leaves, ......... $10 \quad 30 \quad 100 \quad 95$

721 Fern-Leaved. Delicately cut leaves,.....

723 Turnip-Rooted, or Hamburg. Grown for the edible roots, . $\quad \begin{array}{llll}10 & 30,1 & 00 & 95\end{array}$

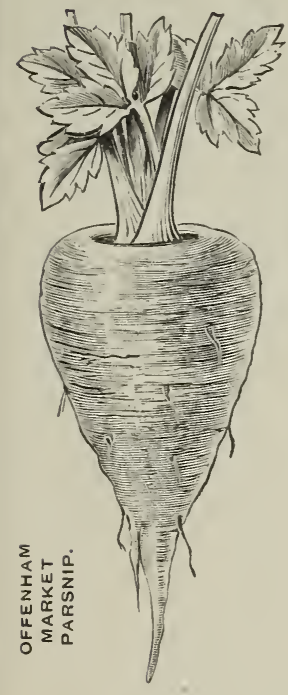

\section{PARSNIPS.}

These are esteemed for the table during winter and early spring months. They are entirely hardy and are usually left in the ground where grown until needed for market, as a hard freezing develops the richness of the sugary flavor. They are very desirable also for stock feeding and any surplus can be used for this purpose.

Seed should be sown as early as the soil can be prepared in a fine, loose condition, as it germinates slowly and starts most freely when the soil is cool and moist. In dry weather the covering should be packed firmly. For hand cultivation in the garden, rows may be planted twelve to fifteen inches apart in rich soil. When well started, thin out to stand six inches apart in the row.

EARLY SHORT ROUND is, as its name implies, of rounded or turnip-shape, of quick growth; it is planted for summer and early fall market, or to use in connection with leeks, carrots, etc., in making bunches of pot-herbs for flavoring. LONG SMOOTH, or HOLLOW CROwN, is the popular smooth carrotshaped parsnip of our winter market; the GUERNSEY is an improved type, broader at the top and rather shorter in length. Both are very fine and will yield heavy returns when cultivated in good ground. OFFENHAM MARKET is a heavy-shouldered "intermediate-shaped" shallow-rooting parsnip. It thrives well even in shallow soils.

\section{Our Leaflet on Forage Crops. This leaflet} lirections for seeding and handling the crops, together plain for feeding purposes. This information will prove of interest to every progressive farmer and to the truck grower who plants green crops to turn under to enrich the soil. This Leaflet will be mailed FREE to any of our customers who ask for it when ordering.

I $\rightarrow$ Each variety, 5 cents per packet.

824 Offenham Market. $\odot$ The English favorite,

725 Guernsey. An Improved Hollow Crown, .

727 Long Smooth, or Hollow Crown. The old standard,

728 Early Short Round. The earliest, but small,

\begin{tabular}{|c|c|c|}
\hline $\begin{array}{l}\text { Per oz. } \\
\$ 008\end{array}$ & $\begin{array}{ll}1 / 4 & \text { tb. } \\
\$ 0 & 20\end{array}$ & $\begin{array}{l}\text { Per 1b. } \\
\$ 050\end{array}$ \\
\hline 7 & 15 & 45 \\
\hline 7 & 15 & 45 \\
\hline 8 & 20 & 50 \\
\hline
\end{tabular}

5 tbs. or more, $\$ 045$ 40 40 45

\section{○ A Bull's-eye according to the "Century Dictionary," means a} can be made. We have marked with a bull's-eye [๑] those varieties of seeds which we consider the very best of their class for general cultivation. Even inexperienced planters, who might be confused by our complete list, can make no mistake by selecting the varieties marked with a bull's-eye.

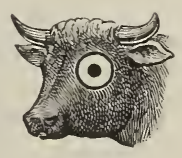




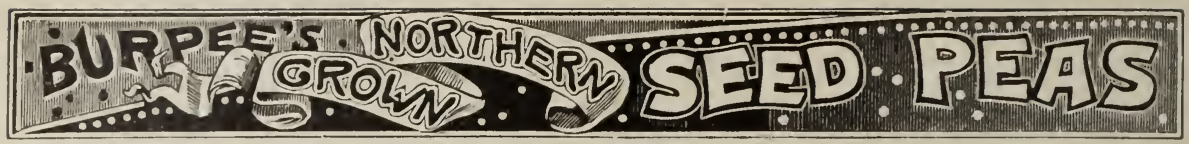

Peas are the most extensively planted of all garden vegetables, but not nearly so much attention is paid to a selection of varieties which will mature in succession as there should be. There has been a wonderful improvement in quality during the past thirty-five years. Our list is complete as to prolonged season of bearing and distinct character of growth, at the same time carefully selected to include only those of superior quality and productiveness. Our Seed Peas are of the best quality obtainable, being all grown far north, thoroughly clean and carefully hand-picked. They are raised from finest selected strains, and the growing crops are rogued to remove all improper types of growth.

The first planting of early peas should be made as early in the spring as the soil can be dug in a fine, loose condition, using a variety like Burpee's Best Extra Early, "Prolific" Extra Early or Alaska, having small, round, hard seed, as these will not be injured even if the soil freezes after they are planted. The larger wrinkled seed is apt to rot instead of germinating, if planted before the soil becomes slightly warmer on the advance of spring. These extra earlies, aside from being hardy, mature quickly, and when gathered young are very tender and of good flavor. The wrinkling of the seed in more tender varieties is due largely to quantity of sugar present. As in Sweet Corn, the varieties having the finest flavor produce the most shriveled seeds.

Some gardeners make a sowing of BURPEE'S BEST EXTRA EARLY late in the fall, seed lying dormant in the soil all winter and germinating very early in spring. As soon as the first planting of Extra Earlies appears above the ground a second sowing should be made, and as by this time the weather and soil will have become warmer, seed of one or more of the wrinkled varieties may be also sown. We would advise making successive plantings one or two weeks apart thereafter. In our locality all but the very large podded varieties mildew badly during hot weather late in July and during August, but from plantings of extra earlies and second earlies made between the first and middle of August we obtain a fine supply of most delicious peas in the cool fall before heavy frosts. For the home garden and for field culture on a large scale, the improved strains of dwarf, bush-like growth are of great advantage, as they are almost equally as productive as tall sorts, while rows may be planted more closely together, do not require support, and are more easily cultivated during growth. Use one quart to one hundred feet of row; two bushels per acre in rows four feet apart.

\section{PEAS, Round-Seeded Extra Early.}

BURPEE'S BEST EXTRA EARLY is the earliest and sweetest of all extra-early peas;-the seed, being smooth, round, and hard, can be planted in well-drained soil as early in the spring as the ground can be properly prepared, or late the preceding fall to lie dormant in the soil all winter and grow early in the spring. This latter plan in welldrained soil gives the very earliest supply of peas which can be grown in the spring. Under favorable conditions

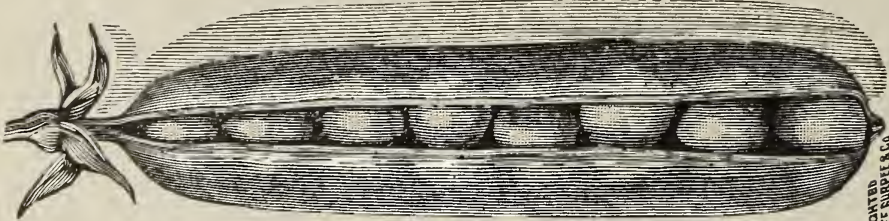

this variety from spring sowing will make pods for market in about sixty days from the time the seed is planted. In many localities plantings in succession of this variety are made to afford a continuous supply, in preference to using the large. seeded later sorts for a summer crop. In addition to this we have found

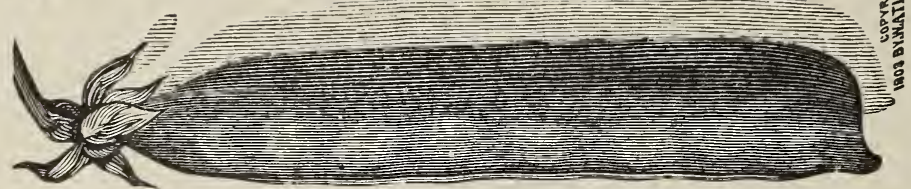
that Burpee's Best Extra Early, planted during the month of August, making two or more plantings, gives us the largest and best supply of sweetflavored peas for fall use and market;- therefore we strongly recommend Burpee's Best Extra Early BURPEE'S BEST EXTRA EARLY PEA.

as the very best market pea. In ordinary soils the vines grow about eighteen inches in height, very regular and even in type, and do not require any brush or support whatever.

PROLIFIC EARLY is of similar extra early type, but the vines and pods grow fully a third larger and thus make a more profitable crop in regards to quantity of product that can be marketed from a given area. It is about five days later than Burpee's Best Extra Early, but the quality is equally as fine. ALASKA, or "Earliest of All," is a blue-seeded variety, entirely hardy and extremely early; the flavor, however, is not equal to the white-seeded extra earlies; the strain we offer is especially fine.

The new ExTRA EARLy PILOT is a round-seeded variety producing large pods three days earlier than Gradus.

\section{Selected strains-all hand-picked.}

731 Burpee's Best Extra Early. ○ (See page 71),

73y New "Prolific" Extra Early. ○ (See page 71),

739 Alaska, or Earliest of All. (See below). .

749 (See page 1 )...

t." - (See page 71),...

tos Each of the above, 10 cents per packet.
Quart. 4 qts. Peck. Bushel.

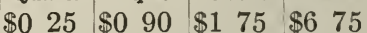

\begin{tabular}{l|l|l|l|l|l}
25 & 90 & 1 & 75 & 6 & 75
\end{tabular}

$\begin{array}{llllll}25 & 85 & 1 & 65 & 6 & 25\end{array}$

\begin{tabular}{ll|ll|ll}
1 & 25 & 2 & 25 & 8 & 50
\end{tabular}

Also called "Earliest of All." We offer an improved Reselected Strain that is 739 Alaska. really purel Of the same type of growth and same size pods, it is as early as Burpee's Best Extra-Early, but the peas are not equal in flavor. The vines grow from twenty to thirty inches in height, bearing well-filled medium-sized pods. The dry seed is of a bluish-green color. It matures practically the entire crop all at one time. It is the most popular first-early pea for canning. Pkt. 10 cts.; pint 15 cts.; quart 25 cts.; 2 quarts 45 cts.; 4 quarts 85 cts.; peck $\$ 1.65$; per bushel $\$ 6.25$.

"Like Peas in a Pod," But-you want the pods also to look alike! You are sure of Like Peas in a Pod, first-class selected stocks and the finest hand-picked samples, if you FREE to customers who ask for it when ordering. 
737 New "Prolific" A long-
Extra-Early Pea. $\odot$ podded
Ext r a Early, containing one or two more peas to a pod and bearing more pods to the plant than any other strain of Extra Eralies. The illustration shown herewith was engraved exactly natural size from a photograph of three pods.

It is a conservative estimate to state that this "NEw Prolific" will produce twenty to thirty per cent. larger crop and is ready for market only four days behind Burpee's Best Extra Early. The vines average twenty-four to thirty inches high and produce pods singly. One picking will take about three-fourths of the crop, and a second picking, which is to be made about three days later, will take the balance. It is remarkably uniform and very free from sports of any kind. The peas are of the finest quality.

Our stock is grown for us by the originator, who has developed this superb new "PROLIFIC" strain from one pod of an extremely vigorous plant. Per pkt., 10 cts.; quart 25 cts.; 2 quarts 45 cts.; 4 quarts 90 cts.; peck $\$ 1.75$; $1 / 2$ bushel $\$ 3.40$; per bushel $\$ 6.75$; 10 bus. or more at $\$ 6.50$ per bushel.

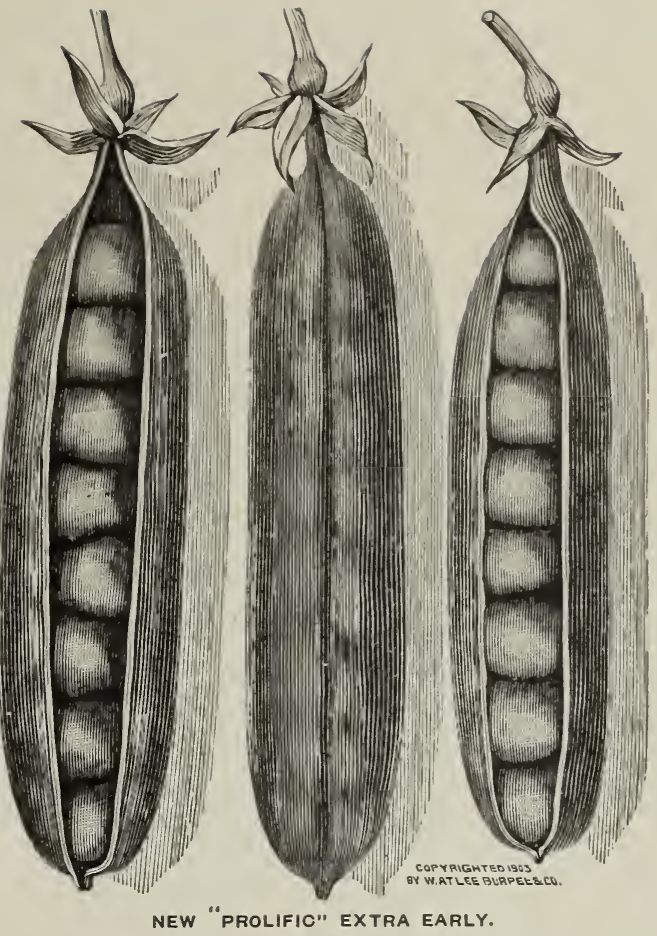

${ }_{731}$ Burpee's Best Extra-Early. $\odot \quad$ The best strain of Extreme form Extra Early Peas yet developed! This superb new "Parly and remarkably unimost careful expert work of selection and reselection continued through a long

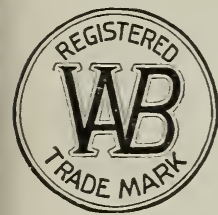
series of years. It excels in purity of stock and freedom from sports all other extra early peas ever offered in this or any other country. See illustration on page 70.

Equally as early as the choicest stock of Alaska, the peas are much better in flavor. The vines are quite slender, of very quick growth, and average eighteen to twenty-four inches in height. The pods are well filled and the entire crop can be gathered generally in one picking. Where planted exclusively, sowings should be made every week to insure a constant supply of fresh young pods. Pkt. 10 cts.; pint 15 cts.; quart 25 cts.; 2 quarts 45 cts.; 4 quarts 90 cts.; peck $\$ 1.75$; $1 / 2$ bushel $\$ 3.40$; bushel $\$ 6.75 ; 10$ bus. or more at $\$ 6.50$ per bushel.

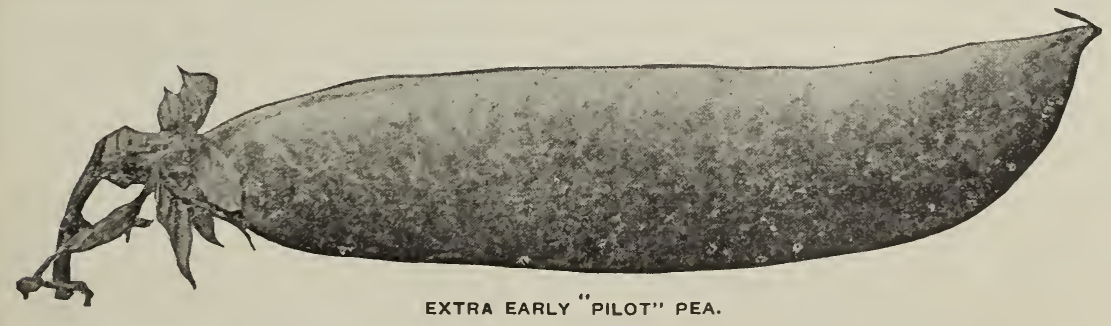

742 Extra Early "Pilot" Pea: ○ The Pilot is "far and away ahead" of peas. The pods and peas are nearly as large as those of Gradus (see illustration), while they are produced three days earlier, - as early as the best selected small smooth-seeded extra earlies. They can be planted, of course, much earlier than Gradus, and while not wrinkled, the peas are almost equal in flavor. The vines, of vigorous growth, attain a height of three feet and bear throughout the length of the haulm quite a large proportion of pods in pairs. Per pkt. 10 cts.; per pint 20 cts.; per quart 35 cts.; 4 quarts $\$ 1.25$; peck $\$ 2.25$; per bushel $\$ 8.50$. 


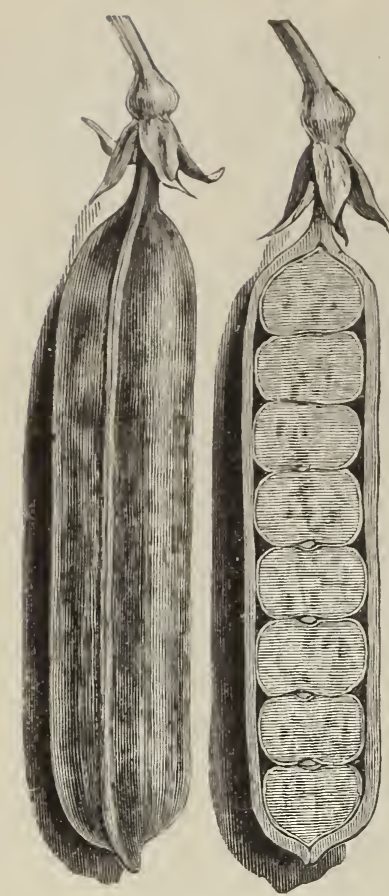

Pods of NOTT'S EXCELSIOR PEA,from a Photograph.
PEAS, - Extra Early Wrinkled Varieties.

While of very early maturity, yet, on account of the tender or wrinkled character of the seed, which is due to the large percentage of sugar they contain, these cannot be planted so early as the round, hard-seeded sorts. If planted before the ground has become slightly warm and dried out in the spring, the seed will rot before germinating.

AMERICAN WONDER is the earliest of the low-growing dwarf or bush type with heavy dark-green foliage, and if planted at the same time comes in immediately after Burpee's Best Extra Early. The pods are of good size and well filled with peas of excellent sweet flavor. NOTT'S EXCELSIOR is an improved type and equally early, but the pods are slightly longer and squared or blunt at the end. It is rather more productive than A merican Wonder. EXTRA EARLy PREMIUM Gem grows a little taller and is a few days later in maturity than the preceding sorts, but is regarded as a very productive and profitable market type of the dwarf early peas. LiTTLE MARVEL is of very uniform dwarf growth, fifteen inches high, same season as Nott's Excelsior, but vines more slender and foliage smaller; immensely productive. Pods round and always well filled. A most desirable dwarf variety for Market Gardeners. BuRPeE's Extra EARLy BluE Bantam, combines extreme earliness, superb quality and unusual productiveness. The dwarf vigorous vines average fifteen inches in height and carry heavy crops of pointed, deep bluish-green pods. None of these varieties requires any brush or support, and in good ground the rows may be planted as closely together as they can be conveniently cultivated; generally the entire crop can be gathered in one or two pickings, thus clearing the ground early in the season for some other crop.

Gradus (also called "Prosperity") is a large-podded variety of extreme earliness, which comes in right after Burpee's Best Extra Early, having a slender vine which grows about two feet in height and produces extra long pods well filled with large, sweet, and very tender peas which are regarded as being fully equal in quality to the finest of the large-podded late sorts. Farther north, in cool locations, this variety will attain a height of four feet and make a more continuous production.

THOMAS LAXTON is similar in growth and size of pod to Gradus, but a few days later, while the large pods are square-ended or blunt. Both vine and peas are of a darker, richer green than Gradus, and by many the Laxion is considered slightly superior in flavor. These two, while they can be grown without support, will give the best results and finest pods if the vines are furnished with either brush or a suitable trellis to support them. READING WONDER is an early wrinkled dwarf-growing variety producing peas about the same time as Gradus. PIONEER is an early dwarf variety of great merit, growing only twelve inches high and produces large pods filled with peas of fine flavor.

\begin{tabular}{|c|c|c|c|c|}
\hline ; of fine quality. (See & Quart. & & Peck. & Bushel. \\
\hline & & & $\$ 2$ & \\
\hline 6 The & & & & \\
\hline rly as Grad & & & & \\
\hline - Very ea & & & & \\
\hline age 74), . & & & & \\
\hline & & 125 & 225 & \\
\hline - $\quad(\mathrm{See}$ & $\begin{array}{l}30 \\
35\end{array}$ & & & $\begin{array}{ll}6 & 75 \\
8 & 00\end{array}$ \\
\hline
\end{tabular}

Each of the above, except where otherwise priced, $\mathbf{1 0}$ cents per packet.

\section{The Best First-Early Dwarf Wrinkled Pea,- Burpee's Extra-Early "Blue Bantam.”。}

${ }^{754}$ Burpee's "Blue Bantam," first introduced by us, is bound to rank wrinkled peas. For combination of extreme earliness, superb quality, and unusual productiveness it is unequaled. The dwarf, vigorous vines average fifteen inches in height and carry really enormous crops of large, deep bluishgreen pods. The handsome pointed pods, generally borne singly, measure four to four and one-half inches long and are tightly packed with eight to ten extra large, deep bluish-green peas. These peas are not only large in size but of most luscious flavor. The pods are ready to pick as early as American Wonder, while double the size, -in fact, they average one and one-half times the size of the popular Little Marvel described on page 74. Unfortunately the supply of seed is very short this season. Per pkt. (2 ounces) 15 cts.; $1 / 2$ pint 25 cts.; per pint 40 cts.; per quart 75 cts.

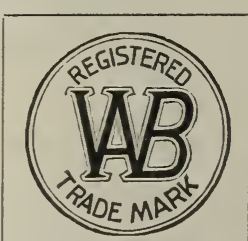

"The Seal of Quality."

WE KNOW SEEDS by means of the FORDHOOK TRIAL GROUNDS. We sell only seeds known to be good-THE BEST SEEDS THAT GROW! 


\section{${ }_{745}$ Extra Early GRADUS, also called "Prosperity" Pea.๑}

This popular new large-podded wrinkled pea of finest quality ma= tures pods only two or three days later than the small-podded round= seeded extra earlies. The vine has heavy stems with large light-green leaves, and grows three feet high. It produces uniformly large pods, measuring from four to four and a half inches in length, nearly round, and well filled with very large handsome peas of the finest flavor. The peas remain tender and sweet for some time after they are large enough to use. The illustration was engraved from a photograph of Gradus, - note the contrast with pods of Burpee's Best Extra Early, shown on page 70; this is a fair comparison, as both are exactly natural size. Per pkt. 15 cts.; pint 20 cts.; quart 35 cts.; 4 quarts $\$ 1.10$; peck $\$ 2.10$; per bushel $\$ 8.00$; 10 bushels or more at $\$ 7.75$ per bush.
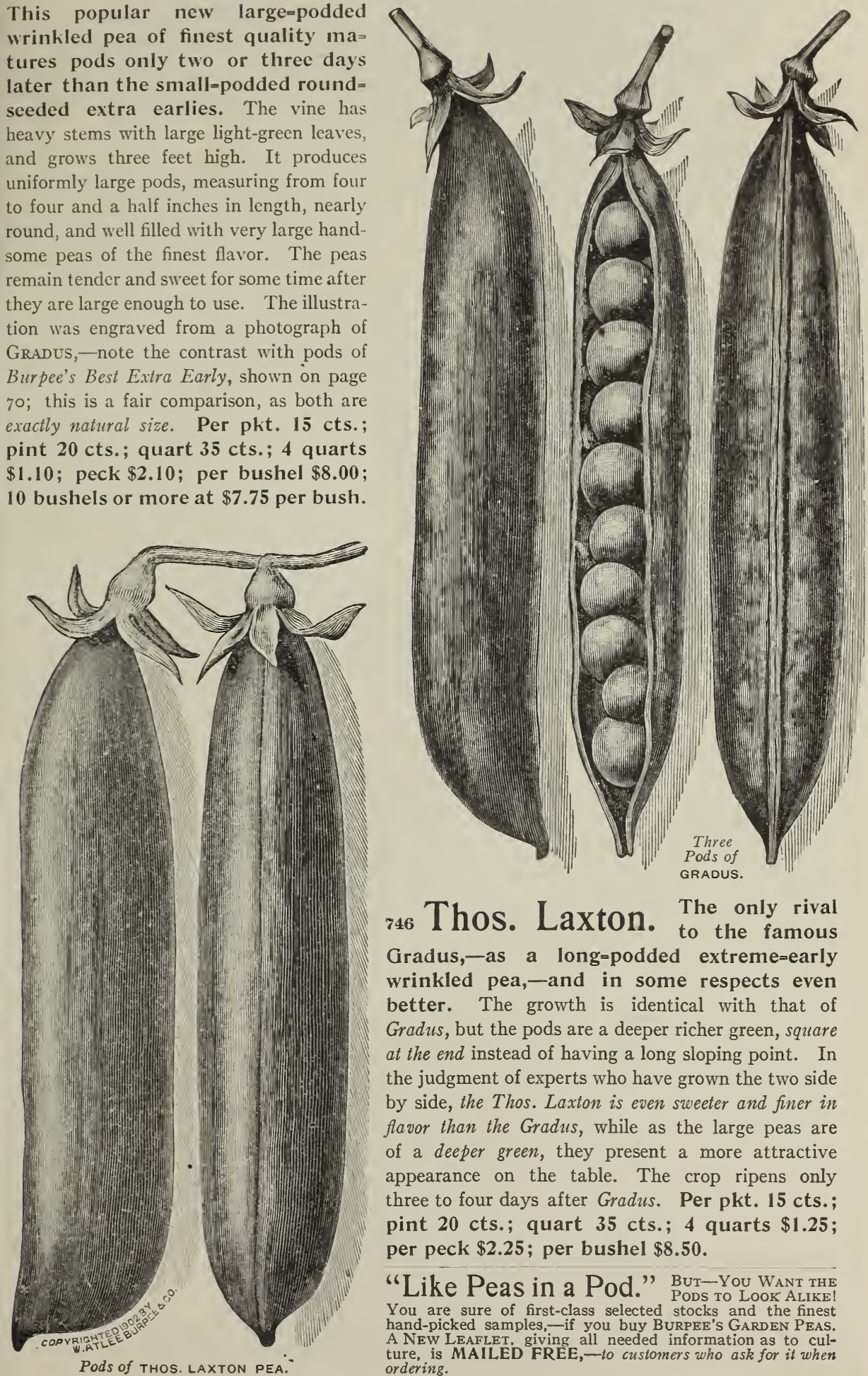

746 Thos. Laxton. The only rival

Gradus, - as a long=podded extreme=early wrinkled pea,-and in some respects even better. The growth is identical with that of Gradus, but the pods are a deeper richer green, square at the end instead of having a long sloping point. In the judgment of experts who have grown the two side by side, the Thos. Laxton is even sweeter and finer in flavor than the Gradus, while as the large peas are of a deeper green, they present a more attractive appearance on the table. The crop ripens only three to four days after Gradus. Per pkt. 15 cts.; pint 20 cts.; quart 35 cts.; 4 quarts $\$ 1.25$; per peck $\$ 2.25$; per bushel $\$ 8.50$.

"Like Peas in a Pod." But-You Want the You are sure of first-class selected stocks ToOK ALIKE! hand-picked samples, -if you buy BURPEE'S GARDEN PEAS. A NEW LEAFLET, giving all needed information as to culture, is MAILED FREE,-to customers who ask for it when ordering. 


\section{Five Popular Dwarf Wrinkled Peas.}

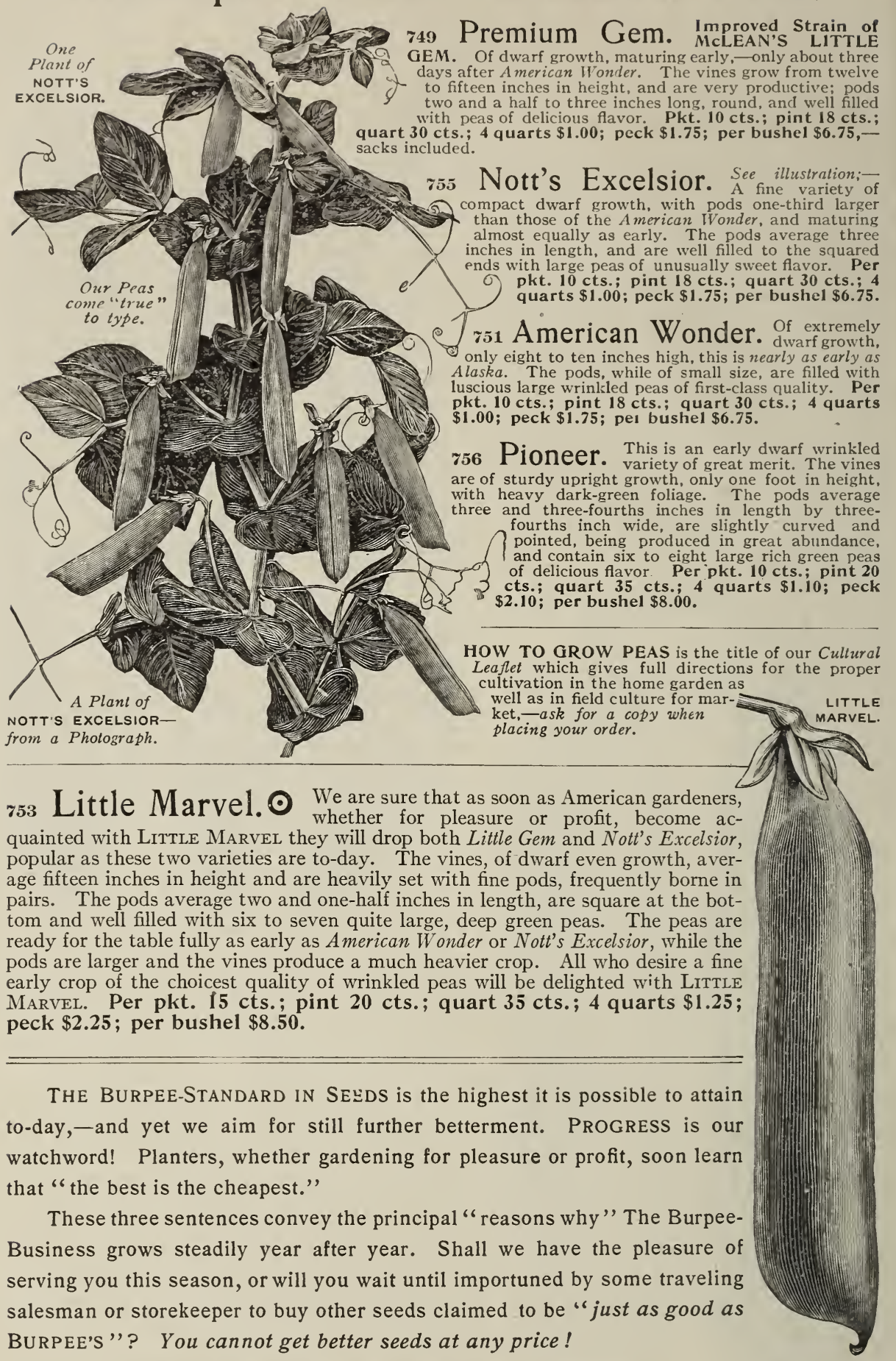

Burpee's Seeds Make Friends for Burpee. Ordering Seeds of Burpee Becomes a Habit. 


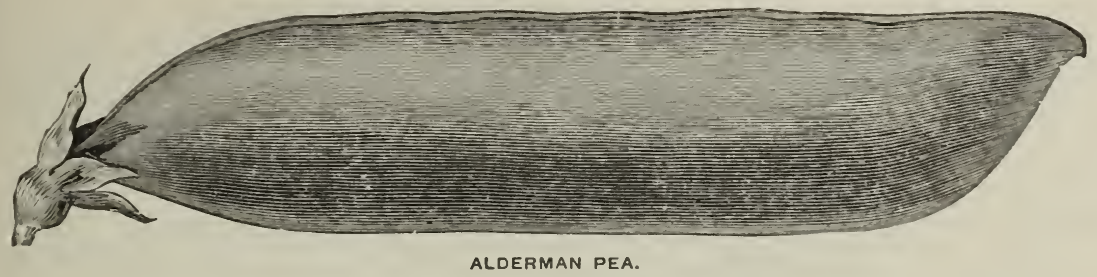

\section{PEAS,-Second-Early and Main-Crop Varieties.}

These are of two distinct types of growth, namely: those of low dwarf growth, fifteen to eighteen inches in height, which do not require any support, and those making vines of running growth, varying in different varieties and soils from two and a half to five feet in height and which will give the best results if provided with a brush support or a suitable trellis of string or wire.

For the home garden and for field culture on a large scale, the improved strains of dwarf, bush-like growth are of great advantage, as they are almost equally as productive as tall sorts, while rows may be planted more closely together, do not require support, and are more easily culivated during growth. Use one quart to one hundred feet of row; two bushels per acre in rows four feet apart.

BRITISH WONDER in season is between Nott's Excelsior and Stratagem. It produces abundantly mediumsized pods which are always well filled with peas of finest flavor. Carter's Daisy or Dwarf Telephone is a very large-podded variety, with peas of the largest size and fine sweet flavor; it is slightly earlier than Stratagem.

STRATAGEM is the standard large-podded late sort; the very large pods and peas are of a light-green color, exceptionally sweet and tender. PRIZE WINNER is of the Stratagem type and ranks high in England as a secondearly. DWARF CHAMPION or Juno makes a close, short-jointed growth, eighteen inches to two feet in height, thickly set with fine large peas of the popular Champion of England type and flavor; it is one of the most productive of the dwarf-producing late sorts.

These dwarf large-podded peas are a distinct advantage to market gardeners, as they can be grown without having to provide brush or trellis for their support, and, as the rows can be planted closer together, the planter will produce almost as large a crop on a given area. They do not continue bearing quite so long as the taller varie. ties, and the ground can be quickly cleared for another crop.

BURPEE'S QUALITY and QUANTITY are very productive second-early or midseason sorts, growing two and a half to three feet in height. BURPEE's PROFUSION is slightly later than the preceding, with larger pods and peas of the finest flavor and longer season of bearing. Everbearing, Horsford's Market Garden, and McLean's Advancer are all good productive second-early varieties, growing from two and one-half to three feet in height, and producing round, well-filled pods about three inches in length in great profusion and are all excellent market garden sorts. CHAMPION OF ENGLAND is one of the most popular market varieties for a late crop, being a strong grower and continuous bearer. The pods of our strain are uniformly large in size and well filled with large sweet peas. YORKSHIRE HERO is similar to Champion, but of dwarfer growth; the pods are slightly larger and of rather earlier maturity.

DUKE OF ALBANY is a fine second-early with large dark-green peas of the Telephone type, size and flavor,makes a good variety to come in after Gradus for markets where the large-podded and very sweet large peas are desired. Alderman is similar to Duke of Albany and is one of the finest of the large-podded summer varieties. TELEPHONE is the standard large-podded late or main-crop variety, having long pods well filled with large peas of a rich, sugary flavor. BOSTON UNRIVALED is of the Telephone type, but with slightly larger pods and peas, making a strong growth and is slightly later in season. RoYAL SALUTE matures a little later than Telephone and produces large, handsome, well-filled pods.

SENATOR is of the same season as McLean's Advancer, but is more productive and the pods are larger. Vines grow two feet high. Laxton's Evolution grows four feet high and bears magnificent long pods containing eight to ten large wrinkled peas of rich sugary flavor.

QUITE CONTENT, under favorable conditions, attains a height of five to six feet and vigorous vines carry large crops of truly gigantic pods. The peas are ready for use the same time as Alderman.

Selected strains-all hand picked.

758 Senator. $\odot$ (See page 76.) Per pkt. $15 \mathrm{cts}$

y61 Burpee's Quan

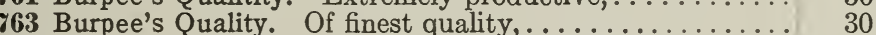

765 Burpee's Profusion. ๑ A very heavy yielder, ........

67 Duke of Albany. Handsome long pods

792 Horsford's Market Garden. A heavy bearer

773 Telephone. Large peas of rich, sugary flavor,.

799 Laxton's Evolution. Magnificent long pods,... .

781 Yorkshire Hero. A fine second-early,..........

783 Boston Unrivaled. $\odot$ An improved Telephone,...

785 Alderman. ( Similar to Duke of Albany. (See page 76),

786 British Wonder. ๑ Very sweet. (See page 76),......

788 Prize Winner. Similar to Stratagem, . . . . . . . . . . . .

789 Stratagem. Of finest quality, . . . . . . . . . . . . . .

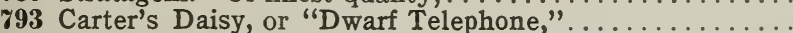

798 Royal Salute. $\odot$ (See page $7 \%$.) Pkt. 15 cts.,

799 Champion of England. The popular standard,

800 Dwarf Champion or Juno. $\odot$ Dwarf growing main crop,
Quart. 4 qts.

Peck.

$90 \quad 175$

$110 \quad 200$

$110 \quad 200$

$110 \quad 200$

100

$90 \quad 175$

$90 \quad 175$

$100 \quad 185$

$135 \quad 250$

$\begin{array}{lll}85 & 1 & 60\end{array}$

$110 \quad 200$

$30 \quad 1 \quad 10$

60200

\begin{tabular}{lll|ll}
30 & 1 & 00 & 1 & 85
\end{tabular}

$30 \quad 110$

$30 \quad 1 \quad 10$

25

30

35

25

30
90

110

125

$90 \quad 175$

$\begin{array}{llll}100 & 185\end{array}$
Bushel.

$\$ 900$

650

750

750

750

700

650

650

700

900

600

750

700

800

800

675

750

850

650

700 ibs All the above, except where priced, 10 cents per packet.

Our Seed Peas are of the best quality obtainable, being all grown far north, thoroughly cleaned, growing crops are thoroughly rogued to remove all improper types of growth. 


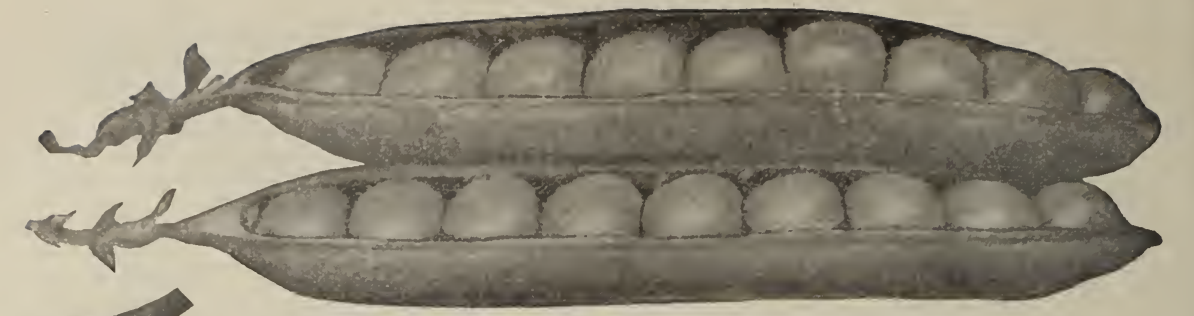

Fine Pods of SENATOR PEA, - engraved from a Pholograph, nalural size.

QUITE CONTENT

PEA.

\section{Seven of the Best Garden Peas.}

758 Senator. $\odot$ A grand new secondeearly; productive of large, luscious, 758 Senator. 0 wrinkled peas. Of the same season as McLean's Advancer, the pods are much larger and the vines much more productive. The handsome large round pods are well filled with from seven to ten peas in a pod; qualiiy excellent, sweet and tender, even when the peas are large. Vines grow two feet high and carry a large crop. We are sure that all who try it will be delighted with both quantity and quality of the crop! Per pkt. 15 cts.; pint 25 cts.; quart 40 cts.; 2 quarts 75 cts.; 4 quarts $\$ 1.35$; peck $\$ 2.50$; per bushel $\$ 9.00$.

z61 Ouantity The vines grow three feet in height, branching freely, and are 761 uantity. covered with round, well-filled pods, borne in pairs. The pods contain from seven to nine large peas, of good quality, closely crowded peck $\$ 2.00$; per bushel $\$ 7.50$.

76.5 Burpee's Profusion. O Of strong, vigorous growth, the haulm branching freely. The pods are borne in reaching three feet in height and ; they measure three and a half inches in length, closely filled with seven to nine large luscious peas. The (AB plants bear continuously for several weeks. Per pkt. 10 cts.; pint 18 cts. quart 30 cts.; 4 quarts $\$ 1.10$; peck $\$ 2.00$; per bushel $\$ 7.50$.

${ }_{783}$ Boston Unrivaled. An improved strain of the popular Telephone. broad pint each containing seven to eight very large peas of finest flavor. Per pkt. $10 \mathrm{cts}$. pint 18 cts.; quart 30 cts.; 4 quarts $\$ 1.10$; peck $\$ 2.00$; per bushel $\$ 7.50$.

785 Alderman. (- Similar in growth and appearance to the Boston Unrivaled 785 Aldernan. -2 the pods being ready for use about five days later. It is one of the finest of the large-podded summer varieties. The haulm grows five feet in height and is of a rich dark-green coloring, as are also the large pods. Pods frequently measure nearly six inches in length and contain from eight to nine very large peas of superior flavor. Per pkt. 10 cts.; pint 18 cts.; quart 30 cts.; 4 quarts $\$ 1.00$ peck $\$ 1.85$; per bushel $\$ 7.00$.

284 Quite Content -2 is ready for picking at the same time as the wellknown Alderman, which it closely resembles, but with considerably larger pods. Grown under favorable conditions, the haulm attains the height of five and one-half to six feet; the foliage is large and heavy, of a luxurious deep green color. The pods are truly gigantic in size! Of a deep green color, they are produced usually in pairs and grow straight with only a slight curve, as shown in the illustration. Measuring from five to five and one-half inches in length, each pod contains an average of from nine to eleven large peas of delicious flavor. It is a good cropper and continues to bear for a long period. Crop short. Per pkt. 15 cts.; 1/2 pint 20 cts.; pint 35 cts.; quart 60 cts.; 2 quarts $\$ 1.10 ; 4$ quarts $\$ 2.00$.

786 British Wonder. Even sweeter in flavor than either Gradus 786 British Wonder. or Thomas Laxton! The growth is similar to Carter's Daisy, except that the foliage is darker green and pods are not so sharply pointed. It is, however, much more reliable, as it is a sure cropper! The vines grow from fifteen to eighteen inches high. The pods are produced most abundantly and uniformly well filled with large dark-green peas. The peas mature a little earlier than Stratagem or Carter's Daisy. Per pkt. $10 \mathrm{cts}$; pint $18 \mathrm{cts}$.; quart $30 \mathrm{cts}$.; 4 quarts $\$ 1.10$; peck $\$ 2.10$; per bushel $\$ 8.00$.

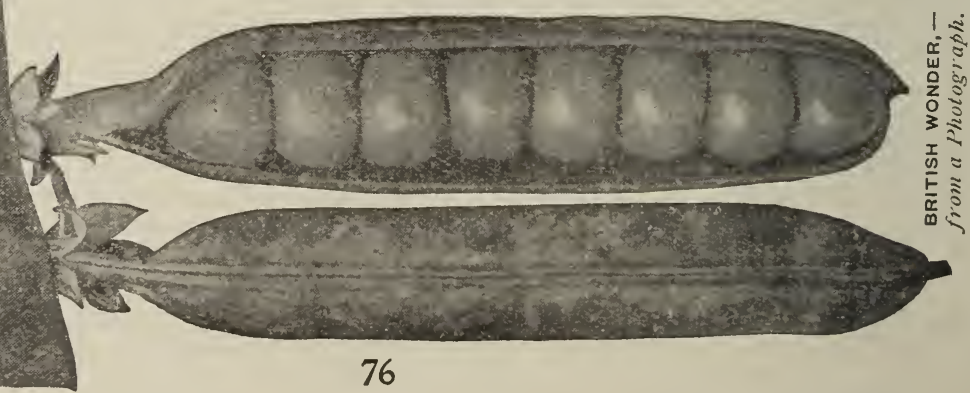




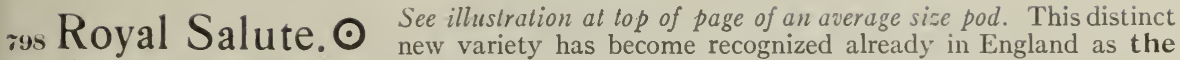
best large=podded main=crop pea. The vines are of strong vigorous growth, heavy, short jointed, branching and of a dark glaucous green color, attaining a height of three and a half feet and heavily set with large full pods. The pods, produced in pairs, measure four to five and a half inches in length by three-fourths of an inch in thickness, straight and pointed, and contain from eight to eleven immense deep-green peas of delicious flavor. Royal SALUTE matures slightly later than Telephone. As a continuous-bearing variety for main crop it is bound to take first place in America as soon as its merits become known. Per pkt. 15 cts.; pint 20 cts.; per quart 35 cts.; 2 quarts 65 cts.; 4 quarts $\$ 1.25$; peck $\$ 2.25$; per bushel $\$ 8.50$.

\section{Edible-Podded Pea,-Giant "Sugar-Sword." $\odot$}

\section{Enormously Productive and Exceptionally Delicious.}

A novelty of unusual importance, "SUGAR-SwORD" has delighted all lovers of the popular edible-podded peas, who were so fortunate as to get some of the seed last year. The vines are most vigorous in growth, attaining a height of six to seven feet, branching freely; when given sufficient support, they present a striking sight covered with the violet flowers and thick, fleshy pods in varying stages of development. The sword-shaped pods are truly gigantic in size, measuring six to seven inches in length by one to one and a half inches in breadth.

The pods are extremely crisp and "full," - as if blown up with wind. They are surpassingly delicious in flavor. Used either as a salad or broken and boiled like string-beans and served with butter sauce, they make "a dish fit for a king!"

Sugar-Sword is a veritable "fill-basket,"-and planted thinly one or two packets 814 Sugar-Sword of the seed should be sufficient to furnish supply for a small family. Per pkt. $10 \mathrm{cts}$.; $1 / 2$ pint $18 \mathrm{cts}$.; pint $30 \mathrm{cts}$.; per quart $50 \mathrm{cts}$.; 2 quarts $90 \mathrm{cts}$; 4 quarts $\$ 1.75$; peck $\$ 3.25$; per bushel $\$ 12.00$.

\section{PEAS,-Marrowfats and Edible-Podded Varieties.}

While Marronfal and Black-Eyed Marrowfal are very old sorts, strong growing and immensely productive but of very poor flavor, having vines four to five feet in height and producing a large crop of pods. Compared with choice garden peas they are not "fit to eat!" Marblehead Marrowfat is a selection of the White Marrowfat, having vines of more uniform growth, with pods and peas of larger size.

In the Edible-Podded or SUGAR PEAS the pods are gathered, broken, and cooked like string-beans when the peas start to develop in the pod or have reached about half their full size. Of these sorts, the Dwarf Sugar grows about eighteen inches in height, producing a heavy crop of small flat pods about three inches in length. Mammolh Melling Sugar has vines four feet in height, producing very large broad flattened pods of a waxenyellow color, which are quite fresh and fully equal to the finest wax beans when gathered and cooked in the same way. Giant "Sugar-Sword" produces large pods of delicious flavor.

Each, 10 cents per packet-all hand-picked.

807 White Marrowfat. Popular in many localities,

809 Black-eyed Marrowfat. Heavy cropper; quality poor,

810 Marblehead Early Marrowfat. Very productive,

811 Dwarf Gray Sugar (Purple Blossom). Edible pods,

814 Giant Sugar-Sword. $\odot$ (See above),.

815 Mammoth Melting Sugar. $\odot$ Large pods of a waxen yellow color,...

\begin{tabular}{|r|rr|rr|r|r|}
\hline Quart. & 4 & qts. & Peck. & \multicolumn{1}{|c|}{ Bushel. } \\
$\$ 0 ~ 22$ & $\$ 0$ & 75 & $\$ 1$ & 25 & $\$ 4$ & 75 \\
22 & & 75 & 1 & 25 & 4 & 75 \\
22 & & 80 & 1 & 40 & 5 & 25 \\
30 & 1 & 00 & 2 & 10 & & \\
50 & 1 & 75 & 3 & 25 & 12 & 00 \\
45 & 1 & 50 & 2 & 75 & 10 & 00
\end{tabular}

"Proved by Test." Unless you should order some variety that we do not

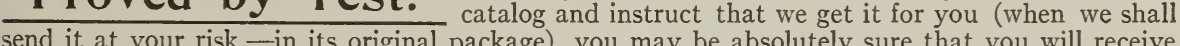
from it at your risk, -in its original package), you may be absolutely sure that you will receive from us only such stocks of strictly high-grade seeds as have been proved absolutely "Best by Test."

Many seedsmen have much to say about tested seeds, but unfortunately with most dealers this applies only to blotter tests for vitality. Our tests for vitality are soil tests. While necessary that seeds grow, it is of prime importance that they shall be of choicest selected strains, such as can be relied upon to produce products "true to type." This can be learned only by thorough field trials. No other seedsmen in America make so many or such complete trials as are conducted annually at our famous FORDHOOK AND SUNNYBROOK FARMS. 
Decidedly the Earliest of all Large Mild Red Peppers, - and the Most Productive of all

\section{Large Peppers!}

From seed started February I5th and plants set out May 20th, the first peppers were picked for market on June 24th. These first fruits measured four inches long and four and a half inches in round circumference; the

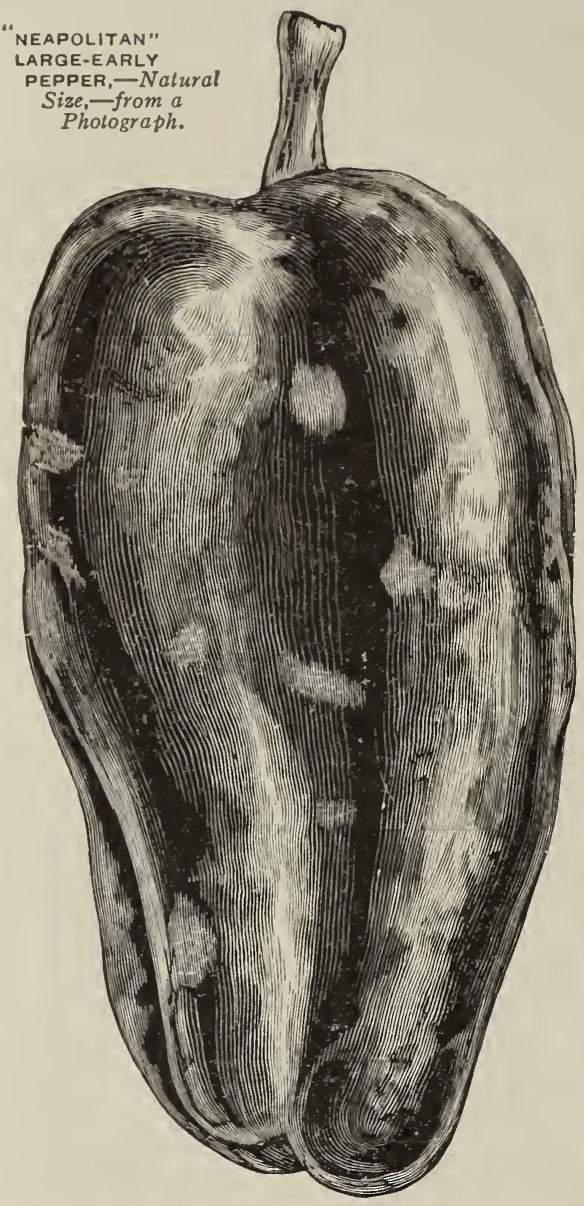
later fruits are slightly larger,-see illustration from a pholograph. No other large pepper develops so quickly, The strong vigorous grow two feet high by large handinches across; they are completely laden with Single plants farry fruits al one timel The peppers grow upright until they become so heavy that their own weight turns them down. The skin and flesh are bright red; they are thick meated, sweet and "mild as an apple;" they carry well and keep in prime condition a long time. So unusually productive is this variety that twelve plants will furnish an ample supply for a family throughout the season. For market gardeners and pickling establishments this NEW LARGE-EARLY "NEAPOLITAN" PEPPER is of incalculable value. Per pkt. 10 cts.; oz. 25 cts.; 1/4 lb. 75 cts.; per Ib. $\$ 2.50$.

\section{Other Peppers.}

In planting peppers for the market it should be kept in mind that as a general rule the smaller the fruit the hotter and more pungent is its flavor, and that those producing the large sweet-flavored fruits which grow to the largest size usually require a longer period for their growth and ripening.

There is a great demand for green peppers of medium size to serve as a cooked vegetable during spring and summer months. The NEAPOLITAN LARGEEARLY is the earliest large mild red pepper.

Next in earliness is the well-known Bull-Nose, which makes a fruit four inches in length and from two and a half to three inches in diameter; this is the standard sweet pepper, but occasionally fruits are somewhat hot in flavor. BURPEE'S RUBY KING is a very large fruit of bright red color and exceptionally mild sweet flavor.

"SWEET UPRIGHT" is one of the thickest "walled" peppers we have ever seen; it is as early as the Sweet Bell or Bull-Nose, of a rich glowing scarlet and of the mildest and sweetest flavor.

BURPEE'S ChINESE GIANT is the largest of all, but is slightly late in ripening; the peppers grow to an immense size and have quite thick tender flesh of very mild sweet flavor. Sweet Mountain is a large sweetfruited sort of the same season as the Ruby King. Dwarf Early Red Squash has fruit somewhat resembling a tomato in shape, and is unusually thick-fleshed and mild. Golden Dawn is a yellow pepper of the same size as the Bull-Nose, while GOLDEN QUEEN is similar in size and season to the scarlet-fruited Ruby King.

Celestial and Fancy Wrinkled Mixed produce small, bright-colored fruits of an inch or an inch and a half in diameter, which are produced in great profusion and have a hot, pungent flavor. Bird's-Eye, Coral Gem, Bouquet, Tabasco, Red Cluster, Red Chili, and Cayenne are small round or slender-fruited sorts of extremely pungent flavor and great productiveness, which are grown and used solely for pickling and flavoring.

818 "Neapolitan" Large Early \& The earliest large mild sweet Per oz. 1/4 tb. Per tb.

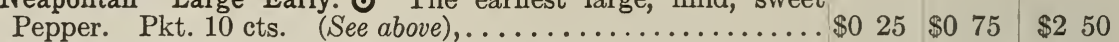

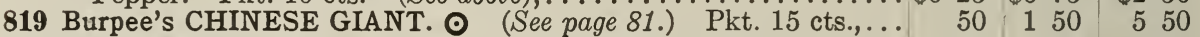

821 Burpee's RUBY KING. ๑ Very mild and sweet. Pkt. 10 cts.,.. . $30 \quad 35 \quad 325$

822 "SWEET UPRIGHT." ๑ (See page 79.) Pkt. $10 \mathrm{cts.,.......} 30 \quad 35 \%$

823 Bull-Nose. Very early; a standard variety,................ $20 \quad 65 \quad 225$

825 Sweet Mountain. Nearly identical with Bull-Nose, . . . . . . . . . . $20 \quad 606$

827 Dwarf Early Red Squash. Thick-fleshed; mild, . . . . . . . . . . . $20 \quad 65225$

830 Burpee's Ruby Pearl. White, turning scarlet. Per pkt. 10 cts., $\quad 40 \quad 110 \quad 400$

837 Long Red Cayenne. True Cayenne; hot and pungent,........ $20 \quad 60 \quad 200$

839 True Red Chili. Small red peppers; very hot,............... $20 \quad 60 \quad 200$

841 Golden Dawn. Golden yellow; mild and sweet, . . . . . . . . . . . . . $20 \quad 606$

843 Golden Queen. ๑ Largest sweet yellow. Per pkt. 10 cts.,..... $25 \quad 75 \quad 250$

847 Red Cluster. Small, thin, hot, coral-red,................. $35 \quad 100 \quad 350$

849 Fancy Wrinkled, Mixed. Of three colors. Per pkt. 10 cts.,..... $25 \quad 75 \quad 250$

851 Celestial. ๑ Creamy white to scarlet,.................... $20 \quad 60 \quad 200$

853 Bird's-Eye, or Creole. Very hot; smallest red. ' Pikt. 10 ct......... 30.85

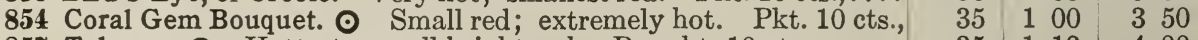

857 Tabasco. ( Hottest; small bright red. Per pkt. 10 cts.,...... $\quad 35|110| 400$ Dos Each of the above, except where priced, 5 cents per packet. 


\section{New Pepper, "Sweet}

Upright." $\odot \begin{aligned} & \text { The best Pepper for } \\ & \text { family gardens and }\end{aligned}$ almost unequaled for market. "S W E E T
UPRIGHT" produces fine large fruits of nearly square or blocky form, with exceptionally thick flesh of the very mildest and sweetest flavor.

The plants are of sturdy erect growth. The fruits are borne stiffly erect, and form at each fork of the branches; they are very broad, divided into four lobes, and when fully ripened are deeply indented at the blossom end. An average pepper measures three inches in length, two and threequarter inches at the stem end and two inches across the blossom end, with a weight of seven ounces.

The color when ripe is rich glowing scarlet both in the thin tender skin and in the unusually thick sweet flesh. The thick flesh is as crisp, mild, and sweet as a fine apple. It is as early as the Sweet Bell or Bull-Nose, with heavier fruit, much thicker flesh and greatly superior in flavor. Per pkt. 10 cts.; oz 30 cts.; $1 / 4$ lb. 85 cts.; per lb. $\$ 3.00$.
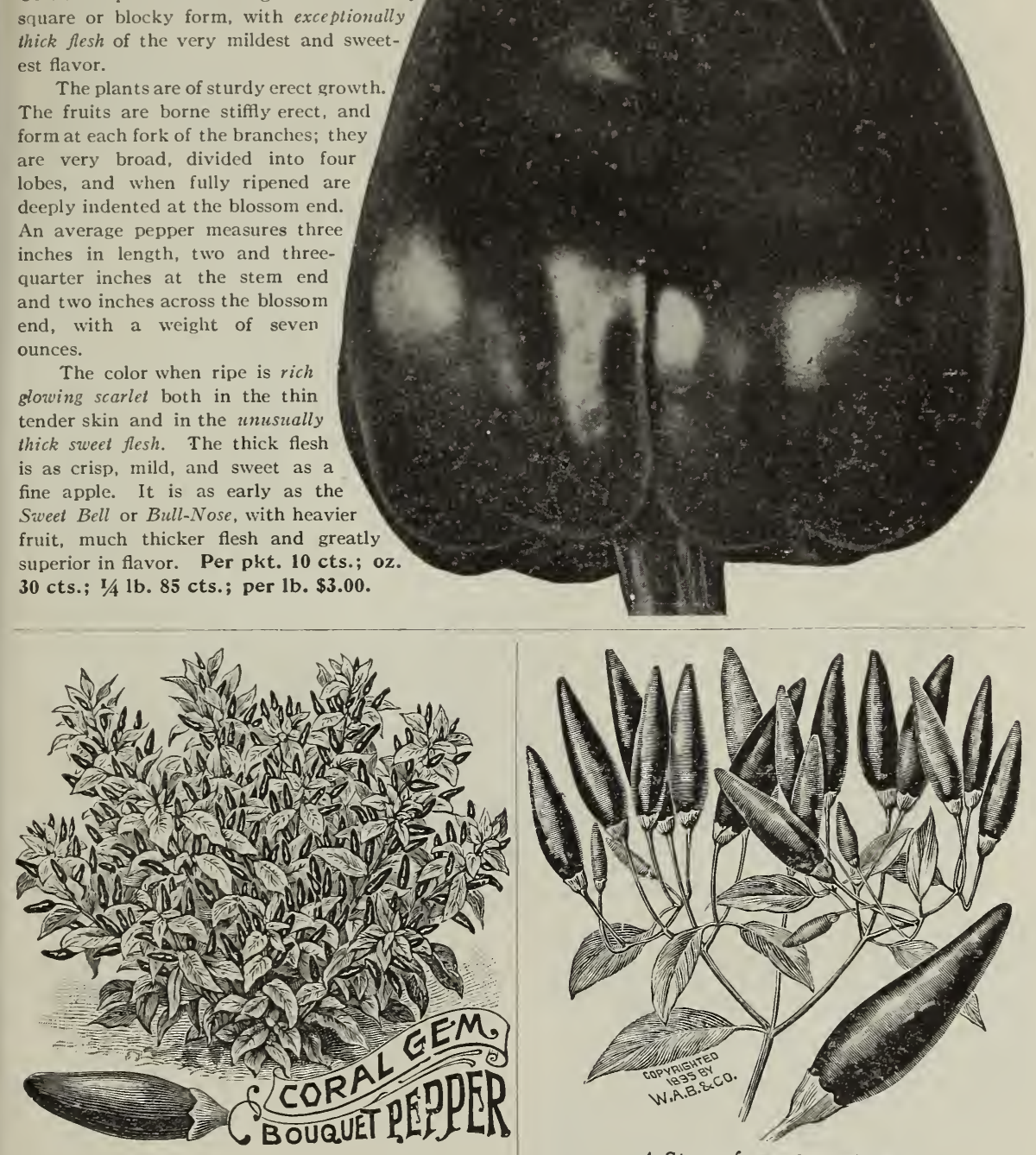

${ }_{854}$ Coral Gem Bouquet. $\odot \underset{\text { and extreme- }}{\text { A beatiful }}$ ly prolific variety of dwarf, compact growth, ten inches in height, literally covered with small scarlet fruits one inch in length, slender and smoothly round. Fruits very hot and pungent. As it ripens a large number of fruits quite early in the season, it is the most desirStates. The plants, being of such dwarf growth, can be grown only from twelve to fifteen inches apart in each direction. Per pkt. 10 cts.; oz. 35 cts.; 1/4 lb. $\$ 1.00$; per lb. \$3.50.

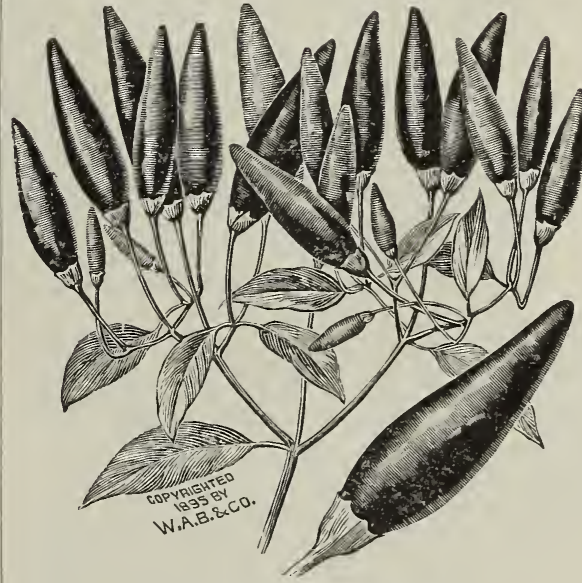

A Spray of tABAsco PEPPER.

857 Tabasco. $\odot$ Of tall, bush-like growth, three ng an immense quantity of small, slender, very hot and fiery fruits one inch in length and vivid scarlet in coloring. This is the true variety, from which the famous Tabasco Sauce is made, but usually fails to ripen fruits as far north as Pennsylvania, by reason of its large growth. Originally from Mexico, the variety has for years been grown in New Iberia Parish, Louisiana, and has made a fortune for the proprietor of The Tabasco Sauce. Per pkt. 10 cts.; oz. 35 cts.; $1 / 4$ lb. \$1.10; per Ib. $\$ 4.00$.

For thirty-seven years we have stated plainly that, where failure is caused by any fault of the seed, we would refund the full price paid. This should convince even new customers that we have confidence both in the quality of BURPEE'S SEEDS and in the great care exercised in their growing, cleaning, and packing. No honest seedsman could assume responsibility for more than the price actually paid by the purchaser.

"The Value of a Guarantee is not in what is said, but who says it." 


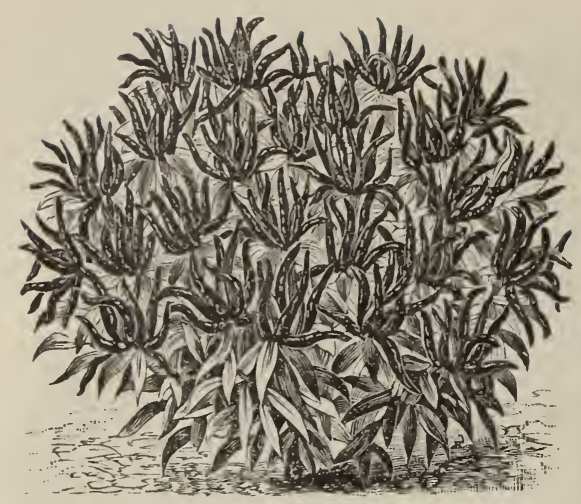

RED CLUSTER PEPPER.

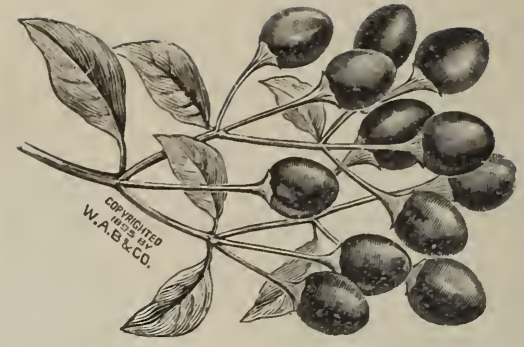

BIRD'S-EYE, OR CREOLE PEPPER.

853 Bird's-Eye, or Creole. The punflavor in a pepper is in inverse ratio to its size. None are hotter or more fiery in flavor than these little "BIRD's-Eyes" or CREOLE PEPPERS, as they are called in the South. They can be used either fresh or dried; the whole plant can be hung up to dry in any outhouse and the peppers removed as wanted. Each plant bears hundreds of peppers.

Compact, bush-like growth, two feet in height, with slender branches and small leaves, bearing a profusion of small, round, scarlet fruits. Requires a long season in which to ripen; very hot and pungent; excellent for sauces. Per pkt. 10 cts.; oz. 30 cts.; $1 / 4$ lb. 85 cts.; per lb. $\$ 3.00$.
847 Red Cluster. Free-branching, bush-like height, having numerous large clusters of slender, scarlet, pointed fruits three inches in length, very productive depend on this variety producing a fine crop. Per pkt. 5 cts.; oz. 35 cts.; 1/4 lb. $\$ 1.00 ; 1 / 2$ lb. $\$ 1.75$; per ib. $\$ 3.50$.

- Pearl Plants of stiffly erect growth, two feet in height and branching freely at the top, being of tree-like habit. The fruits are set in great profusion,
borne stiffly erect, but become occasionally pendent as they ripen. These fruits

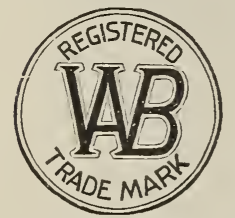
measure two and one-half to three inches in length by about two inches in breadth at the stem end. Until the fruits attain full size they are a rich creamy white, then gradually take on an orange tint and finally turn to brilliant scarlet when fully ripened. The flesh is firm, very thick, crisp and sweet; the peppers can be eaten raw-like an apple-at any stage of growth. The plants, loaded with fruits in the different colorings, are very showy, while the peppers are most useful for cooking or serving where a mild sweet flavor is desired. Per pkt. $10 \mathrm{cts}$.; $1 / 2 \mathrm{oz} .25 \mathrm{cts}$. ; per oz. 40 cts.; $1 / 4$ lb. $\$ 1.10$; per 1 b. $\$ 4.00$.

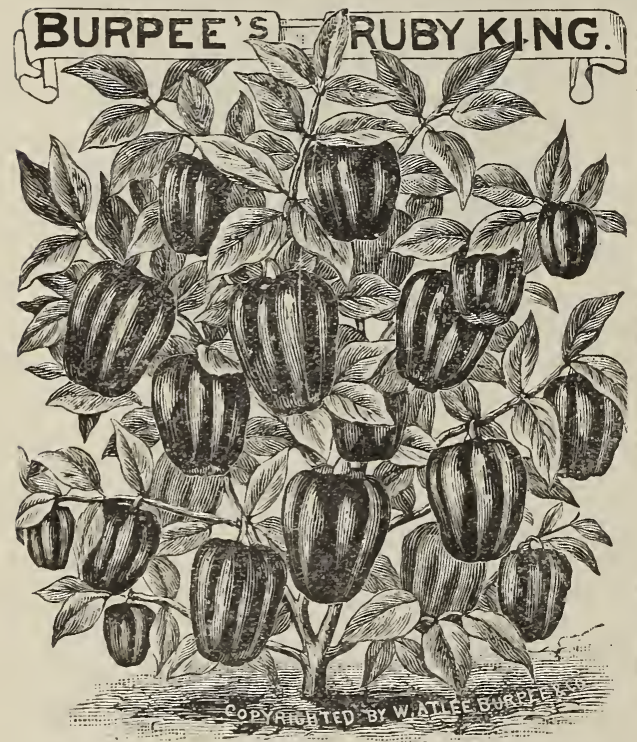

821 Burpee's Ruby King. $\odot$ Introby us thirty years ago, this is the most popular large red pepper. Plants grow two feet high and bear a fine crop of handsome extra large, scarlet fruits. The flesh is quite thick, sweet, and so hand like an apple. Especially fine for mangoes. Per pkt. $10 \mathrm{cts}$. ; oz. $30 \mathrm{cts}$.; $1 / 4$ Ib. $85 \mathrm{cts}$.; per lb. $\$ 3.25$
Stuffed Peppers, Few planters reStuted alize what a delicious vegetable the sweet pepper is when stuffed and baked. In our book, "How TO COOK VEGETABLES," Mrs. Rorer says: "For this use the sweet Spanish peppers, and to each six allow a half pint of chopped cooked chicken, a half pint of stale bread-crumbs, a level teaspoonful of salt and a saltspoonful of pepper, a tablespoonful of chopped parsley, two tablespoonfuls of butter. Cut off the stem end of the peppers and remove the seeds. Throw them in a saucepan of boiling water and cover; stand on the back of the stove fifteen minutes. Mix all the ingredients together except the butter. Melt it and pour over after you have everything thoroughly mixed. Drain the peppers, fill with the stuffing, sprinkle the tops with bread-crumbs. Put here and there bits of butter, stand in a baking-pan, and bake in a quick oven fifteen minutes. Serve with roasted beef."

At FORDHOOK we use for this purpose the "Neapolitan," Large Early, Ruby King, Sweet Uprighit and Chinese Giant, and instead of black pepper for seasoning use a small hot pepper like TABASCO chopped fine. Urge your customers to try a few stuffed peppers and your sales of green peppers will show a decided increase. 


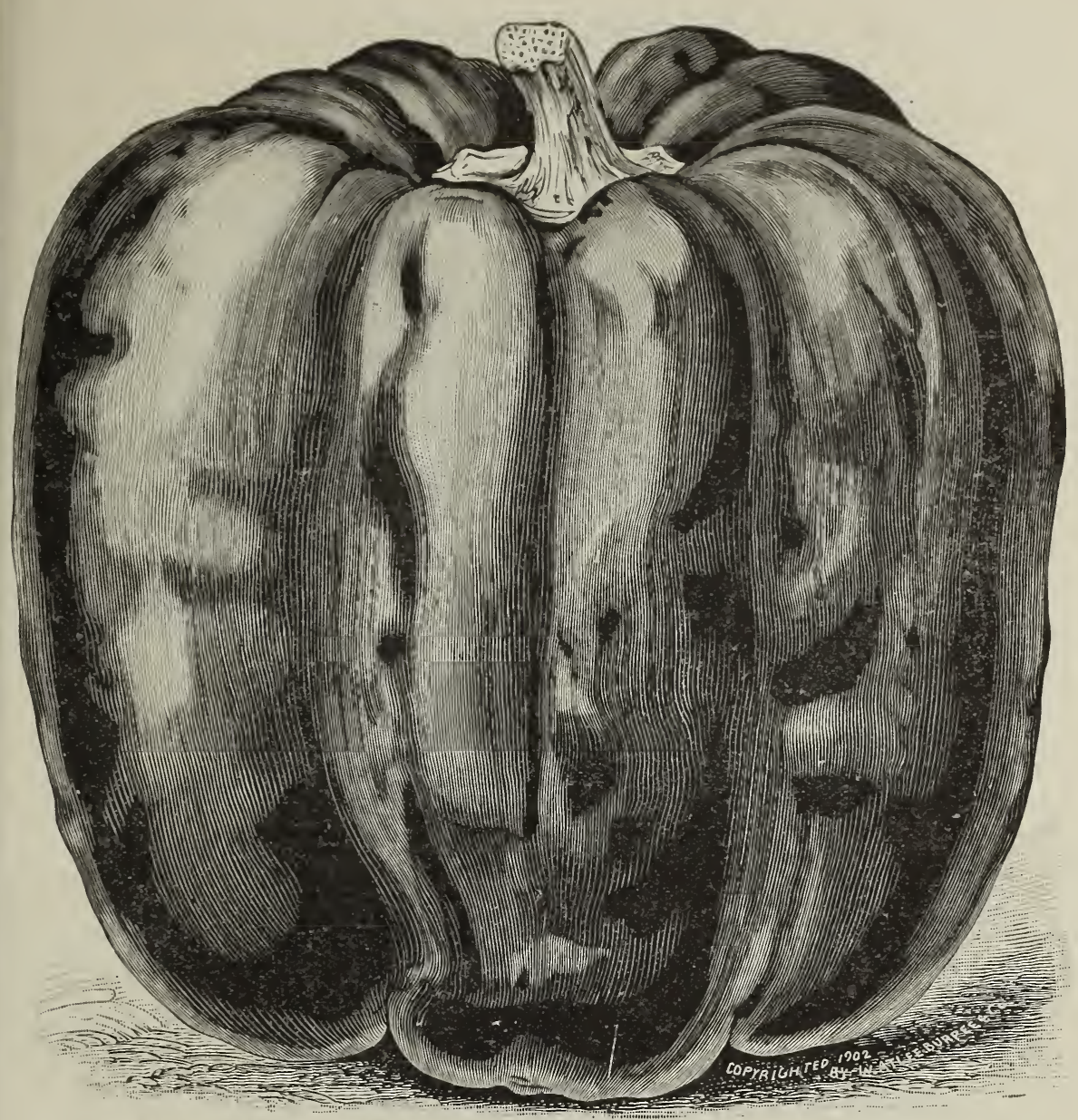

BURPEE'S CHINESE GIANT PEPPER,-from a Photograph,-only the Average Natural Size.

\section{${ }_{819}$ Burpee’s “Chinese Giant” Pepper.॰ \\ Double the Size of Ruby King,--the Largest Mild Red Pepper.}

Chinese Giant is very productive for so large a pepper, while the enormous size and magnificent appearance of the fruits make them sell most readily. The plants are vigorous in growth, but of stocky habit, seldom more than two feet in height. They are well branched and thickly set with enormous fruits. Frequently half a dozen peppers will touch each other, as if on a single bunch. The strong growth of the plants enables them to mature the gigantic fruits only slightly later than our well-known Ruby King.

Chinese Giant produces uniformly monstrous peppers of thick grow four to five inches broad at the top, and are of equal length, divided into four or more large ridges; when ripe they are indented at the blossom end. The first fruits set in a cluster of three to five at base of the plant, and are generally longer than those setting later on the upper branches, although the latter are equally as broad. All are uniformly of most "enormous" size.

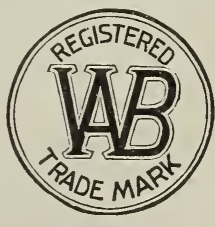
The flesh is extremely mild, - as sweet as an apple,-and unusually thick. It makes an excellent salad sliced and served like tomatoes. True seed of our superb selected strain,- producing uniformly large fruits, -will always be high in price. Beware of "cheap" seed! Crop short. Per pkt. 15 cts.; 1/2 oz. 30 cts.; oz. 50 cts.; $1 / 4$ lb. $\$ 1.50 ; 1 / 2$ lb. $\$ 2.75 ;$ per 1 b. $\$ 5.50$.

There are tons on tons of seeds that are true to name, but of common quality; honest but poor; they are not Burpee's. 


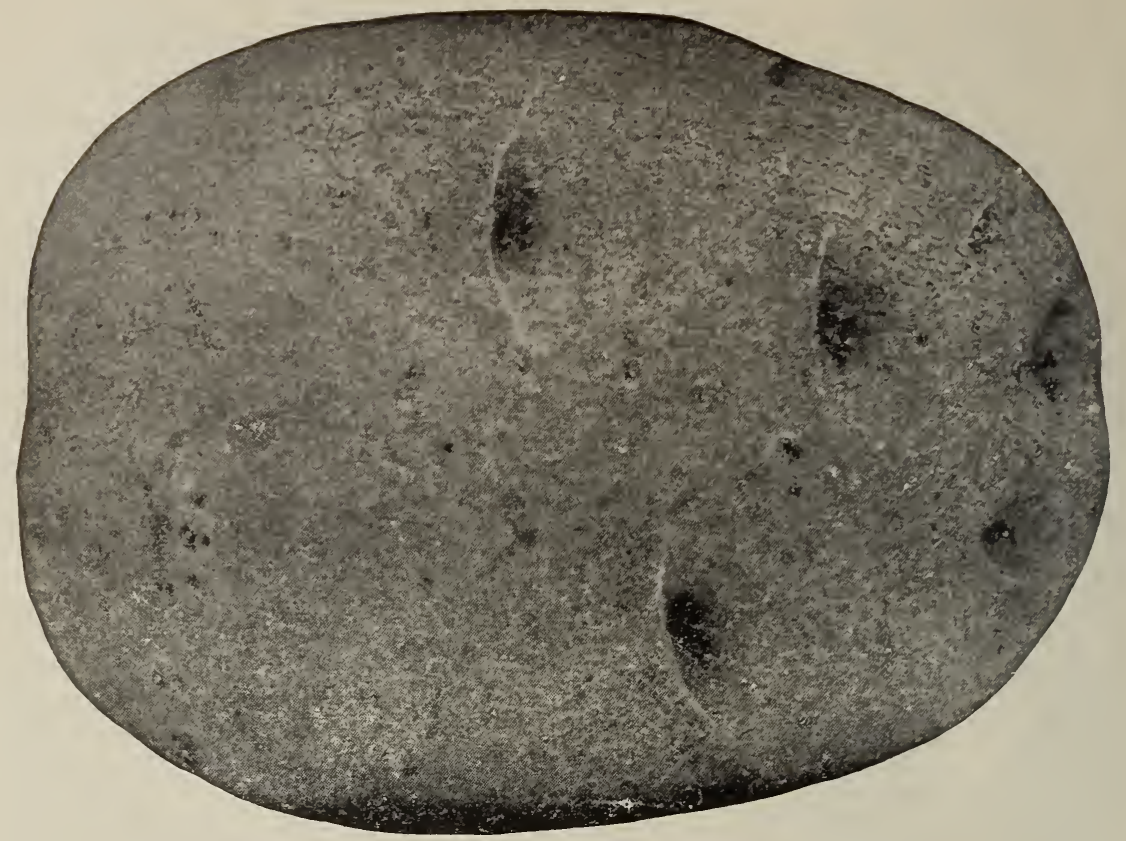

NEW VERMONT GOLD COIN POTATO,-from a pholograph.

\section{POTATOES.}

Farmers and truckers in the Middle and Southern States should renew their seed potatoes at least every two years, as by doing so they will most fully realize the advantage of early maturity and productiveness. Those who grow mainly for seed should plant the choicest Northern-grown stock exclusively, while those who grow for market can obtain satisfactory results combined with moderate expense by planting a sack or two, as may be needed to furnish seed, for the main crop the following season, thus securing the advantage of fresh early-maturing seed at a minimum of expense.

We handle only choice selected Northern stock of the varieties best suited for market and home use, which are put up in sacks containing $165 \mathrm{lbs}$. net, or two bushels and three pecks by measure. Orders for seed potatoes received during the winter are placed on file in rotation as received and shipment is made by freight or express as early in the spring as they can be sent without danger of freezing while in transit. Orders shipped during the cold winter months to Southern customers are entirely at purchaser's risk; but to many points in the South we can make early shipments by boat with comparatively little risk of freezing in transit.

UNCLE GIDEON'S QUICK LUNCH is a seedling of the Peachblow type, very early, round in shape, making a good crop of marketable tubers, which have pink eyes and small splashes of the same color on the white skin It is even earlier than Eureka and makes no second growth, ripening the entire crop very early, and is destined to become the leading market extra early potato.

EUREKA EXTRA EARLY is a round white potato, very early, smooth and snowy white; it makes a larger tuber than the White Triumph, is equally as early and more productive.

BURPEE'S EXTRA EARLY is an oval or oblong smooth white tuber of the finest cooking quality, and the earliest of the oblong type; the vines die early, ripening the crop before the summer blights affect the foliage.

IRISH COBBLER is most popular with growers on Long Island who seek an early market; it is very early and produces very few if any small potatoes; a splendid keeper and of excellent quality.

In a late or main-crop sort, the VERMONT GOLD CoIN combines strong vigorous growth with the largest yield of finest cooking quality, and the tubers are of smooth, handsome appearance and excellent keepers. Burpee's Great Divide is a large oblong variety, with white skin; a strong vigorous grower and very productive on good soils. We also offer choice selected Northern-grown seed of the standard market varieties.

Please note that prices quoted in this catalog are f. o. b. cars or boat in Philadelphia, to be forwarded at purchaser's expense for transportation. If you need several sacks of one or more varieties, kindly write us for special quotations.

In $\rightarrow$ Prices fluctuate, -in case of changes, special prices will be given by letter.

Burpee's Extra Early. (See page 83),....................

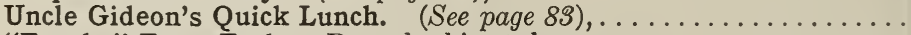

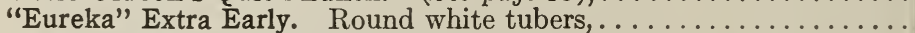
Irish Cobbler. An excellent extra early variety, . . . . . . . . . Early Rose. The old standard early potato,.............. Beauty of Hebron. An old favorite..$\ldots \ldots \ldots \ldots \ldots \ldots \ldots \ldots \ldots$

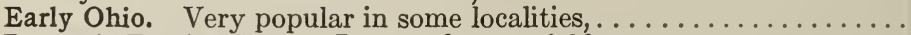
Burpee's Empire State. Late; a heavy yielder,.............. Rural New Yorker No. 2. Of distinct and handsome appearance, ...

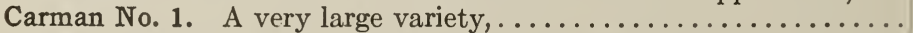

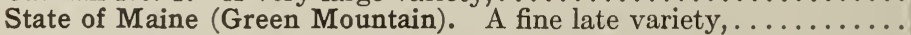
Vermont Gold Coin. The best for main crop,................

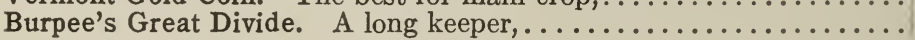

Bushel of 165

Peck. of 60 tbs. tbs. net.

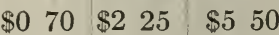

$\begin{array}{lllll}70 & 2 & 25 & 5 & 50\end{array}$

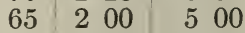

\begin{tabular}{l|ll|l}
65 & 2 & 00 & 4 \\
\hline
\end{tabular}

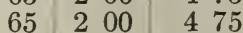

\begin{tabular}{l|ll|l}
65 & 2 & 00 & 4
\end{tabular}

$\begin{array}{lllll}65 & 2 & 00 & 4 & 75\end{array}$

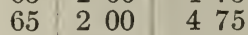

\begin{tabular}{l|l|l}
65 & 200 & 475
\end{tabular}

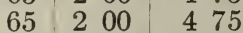

\begin{tabular}{l|lll}
65 & 2 & 00 & 4 \\
75
\end{tabular}

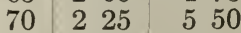

\begin{tabular}{l|l|l}
65 & 200 & 475
\end{tabular} 


\section{Uncle Gideon's Quick Lunch Potato.}

The most valuable first-early potato produced since the famous Early Rose;-ten days to two weeks earlier, it is a surer and heavier cropper and of better quality!

The tubers are nearly globular in form; they run the most uniform in size, color, and quality of

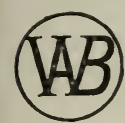
a $\mathrm{n}$ extraearly potato. The eyes are shallow, with a pinkish cast around each eye, while the smooth brownish-white skin is also flaked with rosy crimson,--giving a handsome appearance. They are quickly pared for cooking, as the skin peels easily.

The plant is very distinct in growth. The stalks grow stiffly erect and are closely set with deep green foliage; the leaves are broad and flatly spread. The foliage retains its vigor and rich coloring until the plants are full grown; it has not been affected by

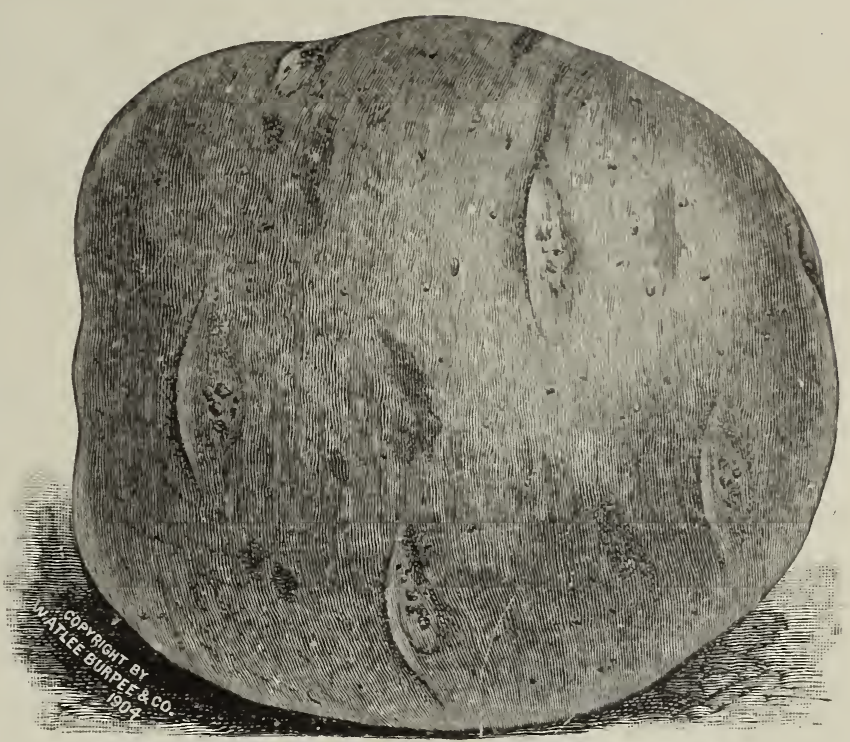

QUICK LUNCH,-from a Photograph, natural size; weight, $73 / 4$ ozs. blight, rot or any disease. As the potatoes mature the vines die down completely to the ground.

\section{Quick I L is more productive than any other first=early potato and} Quick Lunch keeps better! Should the market price of early potatoes not be satisfactory you can safely keep your crop as well as you could the tubers of any late variety! Per peck 70 cts.; $1 / 2$ bushel $\$ 1.15$; per bushel $\$ 2.25$; per barrel sack (I65 lbs. net) $\$ 5.50$. In lots of ten sacks or more at $\$ \mathbf{5 . 2 5}$ per sack.

\section{Potato,-Burpee's Extra Early.}

The finest in quality of all early potatoes, and the earliest variety of good size, excepting only Uncle Gideon's Quick Lunch and Eureka Extra Early. The potatoes are oblong in form,

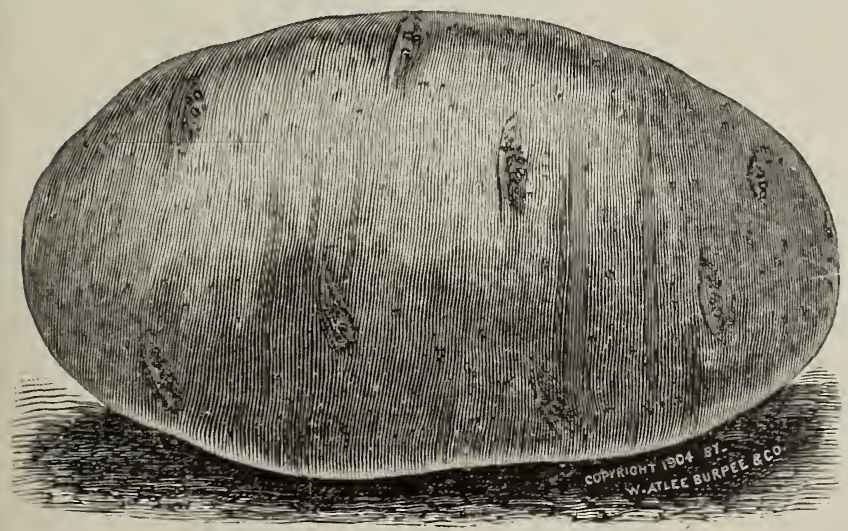

BURPEE'S EXTRA EARLY,-reduced in size. averaging three to four inches in length, with pure white or very pale brownish skin, few eyes, and these quite shallow. The cooking quality of BURPEE's EXTRA EARLY is all that could be desired,-it being the very finest table variety that we have ever grown,excepting only

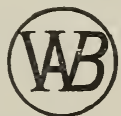
Vermont Gold Coin. It ripens very evenly and the tops die down as soon as the crop is matured, so that the potatoes may be dug and the land planted with second crop for succession. It is the earliest potato that combines size with finest table qualities. Per peck 70 cts.; per $1 / 2$ bushel $\$ 1.15$; per bushel of 60 pounds $\$ 2.25$; per sack of 165 pounds $\$ 5.50$. Crop unfortunately short,-please order EARLY. 


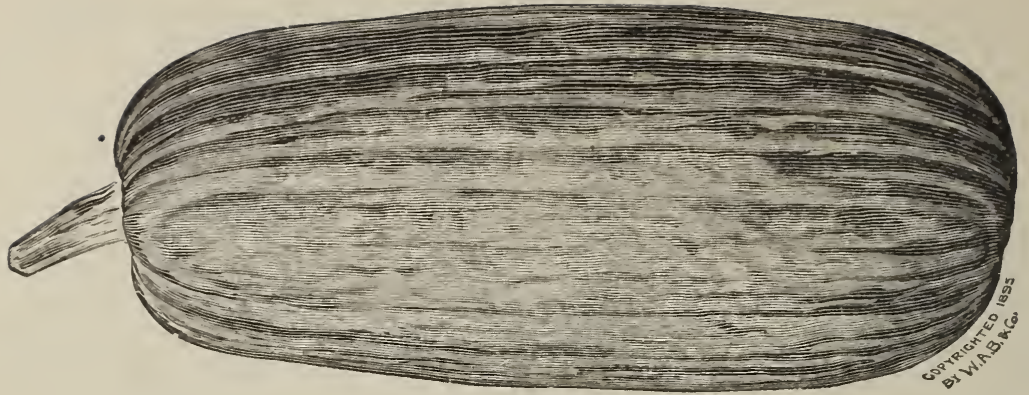

BURPEE'S GOLDEN OBLONG PUMPKIN.

\section{PUMPKINS.}

These are grown usually as a field crop in connection with corn, or are planted as a second crop on ground which has been used for truck during the early spring months. The JAPANESE is a large crookneck sort and is the earliest of all to ripen; it has a dark-green skin mottled with yellow stripes. WHITE CUSH.A w, a large creamcolored crookneck, is one of the finest for making pies; it has a hard, creamy-white skin. Green-Striped Cushaw has rich yellow meat and is the favorite variety in many localities. In these crookneck varieties the large stem or crookneck is clear solid meat or flesh, the seeds being confined to a small cavity in the lower bulb-shaped end.

Small Sugar produces small, round, deep orange-colored fruits, averaging about eight inches in diameter, with rich yellow flesh of fine sweet flavor. LARGE CHEESE is a rather light-brown flat or cheese-shaped fruit. BURPEE'S GOLDEN OBLONG produces oblong, bright orange-colored fruits of good size, with rich-colored flesh.

BrG TOM, or "Improved Large Field," is a large oval fruit with bright orange-colored skin, a strong grower and very productive; it is extensively planted in cornfields. GenUine Mammoth is the largest fruited variety.

In lots of 5 pounds, deduct 5 cents per pound.

861 Small Sugar. $\odot$ Small, orange-colored; sweet,.

863 Big Tom, or Improved Large Field. ๑ Best for feeding stock,

865 Large Cheese. Form flat, like a cheese, . . . . . . . . . . . . .

867 Burpee's Golden Oblong. ๑ Small fruits; rich golden color, .

869 Japanese. Green-striped skin; rich orange flesh,...

870 White Cushaw, or "Jonathan." Thick flesh of fine quality, .

872 Green-Striped Cushaw. Thick flesh of good quality,.

875 Genuine Mammoth, or True Potiron. ๑ Per pkt. $10 \mathrm{cts}$,

\begin{tabular}{|c|c|c|}
\hline Per oz. & $1 / 4 \mathrm{lb}$. & Per lb. \\
\hline $\begin{array}{lll}\$ 0 & 08 \\
\end{array}$ & $\$ 020$ & $\$ 055$ \\
\hline 7 & 15 & 35 \\
\hline 7 & 15 & 50 \\
\hline 8 & 20 & 00 \\
\hline 8 & 25 & 70 \\
\hline 8 & 25 & 70 \\
\hline 8 & 25 & 70 \\
\hline 12 & 35 & 125 \\
\hline
\end{tabular}

$\rightarrow$ Each of the above, except Genuine Mammoth, 5 cents per packet.

\section{Three Choice New Radishes.}

886 Crimson Giant. $\odot$ A fine bright red radish, size, equaling the White Box, White Globe and Burpee's Surprise in size with an earlier season,- - see illustration. It is especially fine for bunching for early market from plantings in the open ground, being ready to market in from twenty-five to thirty days from the time the seed is planted.

This radish is slightly oval or a deep globe in shane; two inches in depth; one and one-half inches in diameter, with thin tender skin of a rich deep crimson color. The flesh is purest white, firm and crisp in texture and of mild flavor. The roots are entirely free from the hollow center or pithy fiber of overgrown small extra-early sorts,- even when twice as large! While the growth of foliage and size of root is rather too large for forcing under glass during winter, the CRIMSON GIANT is easily the finest variety for early plantings in the open ground. Per pkt. 5 cts.; oz. 8 cts.; $1 / 4$ lb. 20 cts.; per 1 b. 65 cts.

878 Burpee's "Rapid-Red."॰ Some planters report that large enough to eat in the almost incredibly srew these radishes

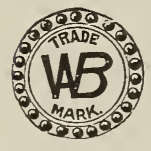
large enough to eat in the almost incredibly short time of twelve days; but the average was from seventeen to twenty days from the
time that the seed was sown until the radishes were ready for market. The radishes are perfectly round; three-quarters of an inch to one inch in diameter, with thin bright red skin, firm white flesh, crisp and mildly pungent. Leaves short and small and only three to four in number when the radishes are ready for use. This new radish is remarkable for its crispness and solidity, while it is of most attractive appearance when bunched for market. Per pkt. 10 cts.; oz. 10 cts.; $1 / 4$ 1b. 30 cts.; per 1b. $\$ 1.00$.

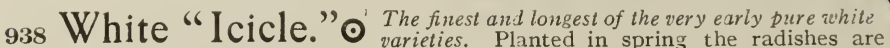
ready for use in twenty to twenty-five days; their long slender form and pure paperwhite skin are most attractive when bunched for market. This radish is not only crisp and tender when young, but retains these qualities until the roots attain large size. Per pkt. 5 cts.; oz. 7 cts.; $1 / 4$ lb. 15 cts.; per lb. 50 cts. 


\section{RADISH.}

This is a leading market garden crop in all sections and seasons. The seed we offer in the different varieties has all been grown from very carefully selected roots with the idea of producing the finest and most even market type. It should be especially borne in mind by the planter that these selected strains have a smaller amount of foliage and produce roots more even in size and maturity,-more richly and brightly colored than common stock which can be purchased at lower prices, but the product of which would not sell so readily nor command as ligh a price on the market. The features of small compact growth of foliage and early maturity are highly essential to a crop of Radishes where these are grown under glass during the winter months for market, which is now a most important feature in the operations of many market gardeners and fiorists in our Northern States. Sucl planters realize the great importance of securing their supply of seed in the finest selected strains and type.

\section{RADISH,-Early Round or Turnip-Shaped.}

These produce small round or turnip-shaped roots, having comparativel small foliage and crisp tender flesh of mild flavor; they are extremely popular during the winter and early spring months. By frequent repeated sowings they unay be liad in finest condition for market throughout the cool months. BuR PEE'S EARLIEST or Improted "Scarlet Button." Early Round Durk Red and Extra Early Scarlet Turnip are extremely early sorts, with smooth round richly colored roots. VICK'S SCARLET GLOBE is of an elongated turnip shape, producing early extremely bright-scarlet medium-sized radishes of fine flavor; one of the most profitable marke varieties. BURPEE'S RUBY PEARL and SCARLE TURNIP IVHITE TIP are similar in size and season. but are distinct and more showy in appearance by having a slender tapered root and a small circle at the base of the radish of a clear white, which contrasts finely with the bright scarlet coloring.

BURPEE'S "RAPID RED" is a small bright red button radish especially adapted for producing a quick crop of the small round radishes grown under glass for the winter market.

BURPEE'S WHITE HAILSTONE is a very flat, extremely early "button" radish, clear white, with very small foliage; it is earlier than other small forcing sorts and is splendidly adapted to plant under glass during the winter months to produce the small "cherry stone" radishes for market. The popular Early IIhite Turnip is slightly larger in size and correspondingly later in developing PhILADElPHIA IVhITE Box is a popular variety for first plantings in the open ground or cold-frames for the earliest spring market.

CRIMSON Giant GLOBE is a new and distinct variety with globeshaped roots. Skin is a bright crimson, flesh white, crisp, and mild. Stands for a long time before getting pithy. It is especially desirable for early outdoor planting.

\section{Radishes. Is there any more appetizing vegetable than the Radish?} Ro In the spring we welcome the early so-called cherrythe delicious long and olive-shaped varieties, especially the IWhile Icicle, whicl has for several years proved to be a first-class "all seasons" variety. Radishes are delicious during the entire growing season if successive sowings are made.
Is In lots of 5 pounds, deduct 5 cents per pound. Ed

877 Burpee's EARLIEST, or "Scarlet Button," $\odot$

878 Burpee's "Rapid Red." ๑ The "earliest of all." "See page 8 i.) Per pkt. 10 cts.,........................

879 Burpee's Hailstone. $\odot$ The earliest White Turnip Radish, . . . .

881 Early Round Dark Red. Very dark in color,...............

883 Vick's SCARLET GLOBE. ๑ Intensely bright color,..........

885 Extra Early Scarlet Turnip. Standard small; round, red, . . . . . .

886 Crimson Giant Globe. $\odot$ (See page 84),.................

893 SCARLET TURNIP, WHITE TIP. $\odot$ Standard in many mar-

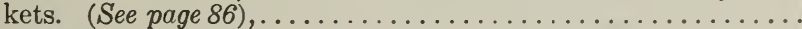

895 Burpee's RUBY PEARL. Brightest red, tipped pure white, ....

897 Early White Turnip. Skin and flesh white; crisp and tender,...

899 Philadelphia White Box. Similar to preceding, but larger,.....
VICK'S SCARLET

GLOBE RADISH, -

engraied from a

Fordhook photograph.
For vears we have paid special allention to Radishes, realizing that they are of the most imarly crops with porlent early crops arth

I 5 Each of the above, except Burpee's Rapid Red, $\mathbf{5}$ cents per packet.

Thirty-nine Leaflets. Instead of giving gificecions for culture in this h1rty-nine Leaflets. "Strictly Business" catalog, we have published Thirty-nine Leaflets and Booklets, any of which will be sent free with orders, - see complete list on enclosed Order Sheet for 1914,- - where you need only check ( $\left.\gamma^{\prime}\right)$ those wanted. No other seedsmen have ever attempted to give gratuitously such valuable information. 


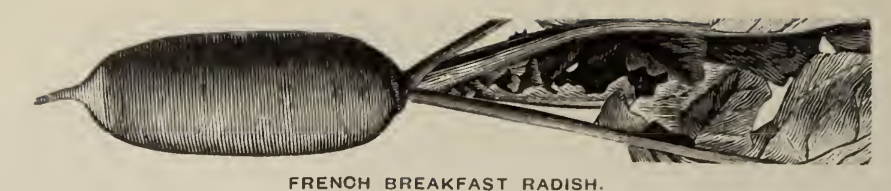

\section{RADISH,-Early Olive-Shaped Varieties.}

BURPEE'S EARLIEST WHITE is a straight slender olive-shaped radish, equally thick at the shoulder and at the blunt lower end. It is of very quick growth, with small foliage and quite as early as Burpee's Scarlet Button; it is very desirable for growing under glass and is ready for pulling in from eighteen to twenty days from the time the seed is planted. Both flesh and skin are of the clearest paper whiteness, very crisp, tender, juicy and mild in flavor. Early White Olive Shape is similar, but not quite so early and with more foliage.

FRENCH BREAKFAST is a straight slender oblong, blunt-shaped at the bottom and a deep rose-pink in color with a large white tip; bright and attractive in color and delicate in flavor. BRIGHT BREAKFAST is identical with French Breakfast, excepting the color, which is a rich dark red. BURPEE'S SURPRISE is a larger oval-shaped variety with deep yellowish-brown skin, and is one of the finest bunching radishes to plant for early market in the open ground.

905 Burpes In lots of 5 pounds, deduct 5 cents per pound. द्या

905 Burpee's EARLIEST WHITE. $\odot$ Per pkt., 10 cts.,.

907 French Breakfast. Red, tipped white; quick growing,

909 Bright Breakfast. ๑ Rich dark red, tipped white, .

Per oz. 1/4t tb. Per tb.

913 Scarlet Olive-Shaped. Quite early; very crisp, .

$\$ 0 \quad 10 \quad \$ 0 \quad 30 \quad \$ 0 \quad 90$

915 Burpee's Surprise. $\odot$ Brown skin; white flesh,

917 Early White Olive-Shaped. White skin; crisp, white flesh,

\begin{tabular}{ll|l}
7 & 15 & 50 \\
8 & 20 & 65 \\
7 & 15 & 45 \\
8 & 20 & 65 \\
8 & 20 & 65
\end{tabular}

Wh Each of the above, except Burpee's Earliest White, 5 cents per packet.

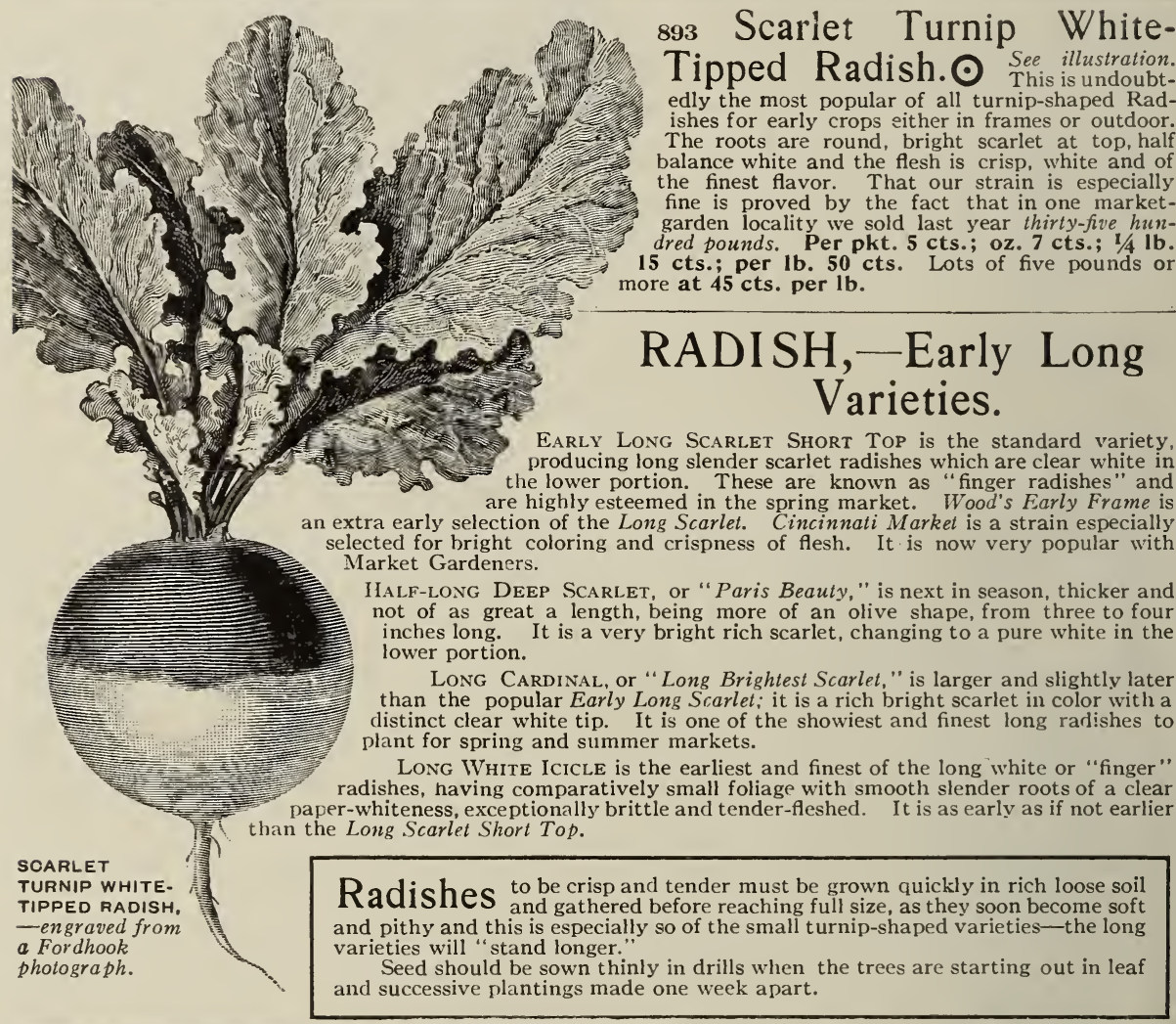

In In lots of 5 pounds, deduct 5 cents per pound.

Per oz. $1 / 4 \mathrm{tb}$. Per th.

928 Early Long Scarlet Short Top. $\odot$ The most popular of all, . . . \$ \$0 $07 \quad \$ 0 \quad 15 \quad \$ 0 \quad 50$

930 Cincinnati Market ("Glass"). Fine strain of Long Scarlet, . . . . . 77 . 75

932 Wood's Early Frame. Similar to Long Scarlet, but shorter, . . . . $\quad 7 \quad 75$

934 Half-Long Deep Scarlet. The New Orleans favorite, . $\quad 7 \quad 7.15$

936 Long Cardinal, or Long Brightest Scarlet. Tipped with white, . $\quad 7 \quad 75$

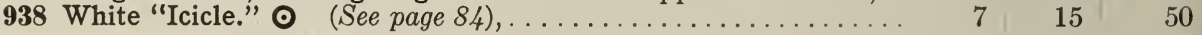

Each of the above, 5 cents per packet. 


\section{RADISH,-Summer Varieties.}

These produce roots of much larger size than the earlier varieties, and although they require a longer time in which to mature, the radishes are crisp, mild in flavor and remain in fine condition for a long period.

Chartiers, or "Shepherd," is the standard long variety for summer, growing to quite a large size, having roots of deep crimson or pinkish purple with long white tip. White VIENNA is a long clear white radish and an extremely popular market type. LARGE WHITE GLOBE is later and larger than the White Box and more nearly round in shape. GOLDEN GLOBE is similar to the Larg White Globe, but has a skin of a rich golden-yellow hue.

White Delicious is a large oval-shaped pure white radish, flesh firm and solid, but crisp and mildly pungent it is not liable to the black rot in heavy soils and wet seasons; excellent for summer market.

WHITE STRASBURG is a strong-growing late variety with crisp hard flesh; plants have ample foliage an produce oval-shaped radishes of large size. Giant While Stultgart is a very late variety with heavy foliage and quite large turnip-shaped roots.

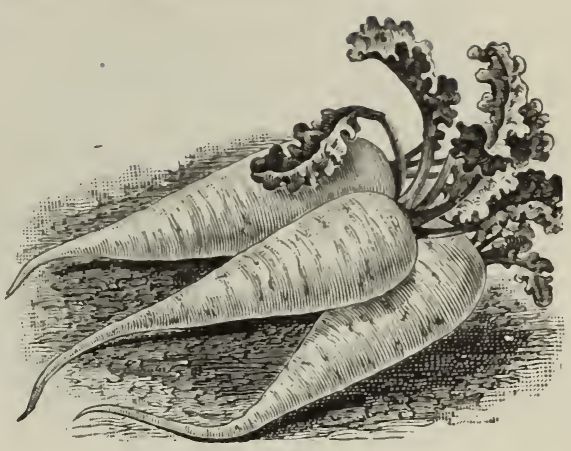

WHITE STRASBURG RADISH.
Is In lots of 5 pounds, deduct 5 cents per pound.

951 Chartiers, or Shepherd. $\odot$ Long; crimson, tipped with white, .

953 Long White Vienna, or Lady Finger Radish. $\odot$ Excellent,

$95 \pm$ White Delicious. $\odot$ Fine for midsummer,

955 Large White Globe. A favorite summer variety,

957 Golden Globe. Yellow skin, white flesh; for summer use,

959 White Strasburg. $\odot$ A fine solid summer radish of large size,

961 Giant White Stuttgart. An immense white summer radish,

\begin{tabular}{|c|c|c|}
\hline Per oz. & $1 / 4 \mathrm{tb}$. & Per tb. \\
\hline$\$ 007$ & $\$ 015$ & $\$ 050$ \\
\hline 8 & 20 & 65 \\
\hline 8 & 25 & 75 \\
\hline 7 & 15 & 50 \\
\hline 7 & 15 & 50 \\
\hline 7 & 15 & 50 \\
\hline 8 & 25 & 80 \\
\hline
\end{tabular}

In Each of the above, $\boldsymbol{5}$ cents per packet.

954 Radish,__White Delicious." - Of good size, handsome appearance, and particfor summer use than the While Vienna. The roots are thicker in diameter, and the flesh is even more solid. It does not grow so quickly, but will stand longer in good condition. The roots are of a pure paper whiteness, half long in form, gradually tapering at the lower end. Pkt. 5 cts.; oz. 8 cts.; 1/4 lb. 25 cts.; 1 b. 75 cts.

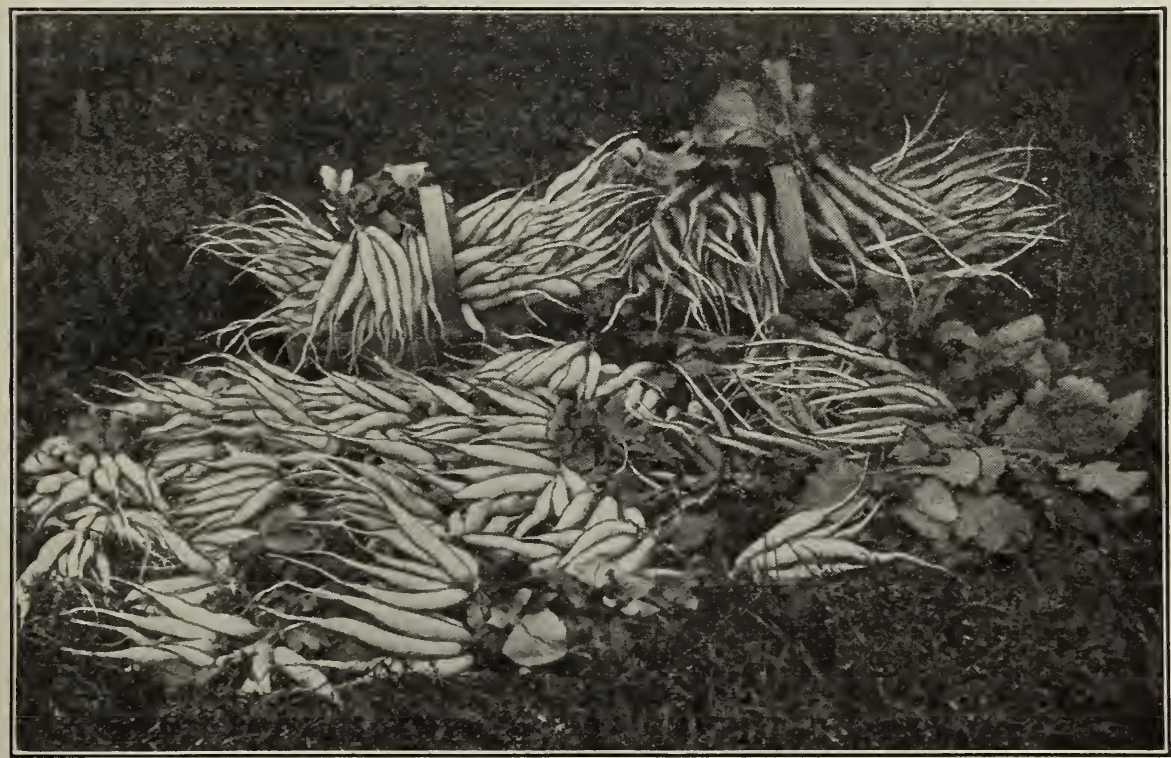

One hundred and twenty-five bunches of White Icicle and Cincinnati Market Radishes grown from Burpee's seeds by L. B. DREv, North Conneaut, Ohio.

- A Bull's-eye, according to the "Century Dictionary," means a shot that hits with a bull's eye [๑] those varieties of seeds which we consider the very best of their class for general cultivation. Even inexperienced planters, who might be confused by our complete list, can make no mistake by selecting the varieties marked with a bull's=eye. $\odot \odot$

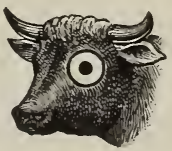




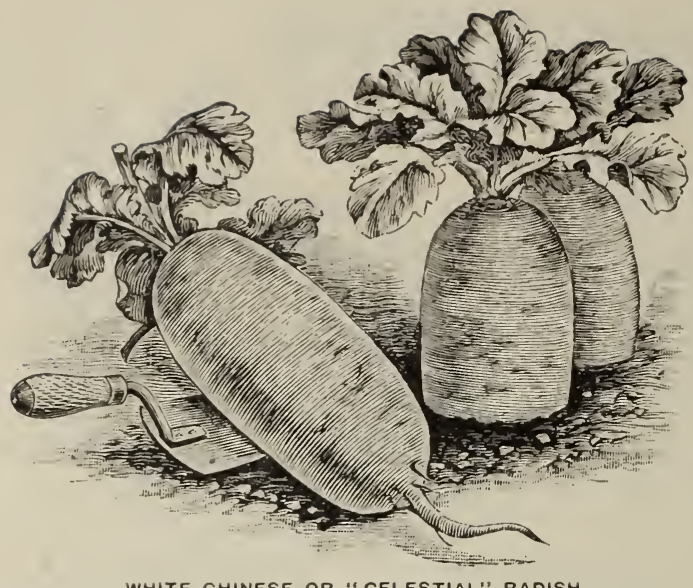

WHITE CHINESE OR "CELESTIAL" RADISH.

\section{RADISH, - Winter Varieties.}

These are of two distinct types: tlose which liave the very hard, firm but finegrained flesh of the European type, which can be kept in good condition throughout the winter, and the Chinese type, which are of extra large size and have white flesh which is tender, crisp, and extremely juicy.

Of the latter the White CHINese (" $\mathrm{Ce}$ lestial") is the largest and best known, producing very large roots which are oval in form and clear white in color. These do not succeed from spring sowing, but make fine large radishes from seed planted the last of July to come on for market during the cool fall months.

California Mammoth White Winter lias flesh of a firmer texture and better keeping qualities than the While Chinese. CH1NESE ROSE makes a radish of large size. The skin is a bright scarlet and the flesh is pure white, crisp, hard, and pungent in flavor.

RoUND BLACK SPANISH and Long Black Spanish are European varieties of very hard but crisp, pungent flesh. The flesh is pure white; the skin is almost black on the outside. Long White Spanish has white skin and flesh; a good keeper.

Is In lots of 5 pounds, deduct 5 cents per pound. Ed

963 White Chinese (Celestial). $\odot$ Best for autumn; extra large,.

965 California Mammoth White Winter. Long; of immense size,.

967 Chinese Rose, or Scarlet China. $\odot$ Excellent; good keeper,.

969 Round Scarlet China. ("All Seasons.") Fine round roots for winter. Highly recommended for fall and winter,.......... 981 Long Black Spanish. Black skin; white flesh, ............... 973 Long White Spanish. White skin and flesh; keeps well, ... . . . . 975 Round Black Spanish. The favorite winter Rettig of Germany,. Each of the above, 5 cents per packet.

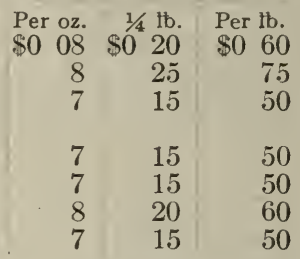

\section{RHUBARB, or Pie Plant.}

Fine roots or clumps of Rhubarb can be grown easily from seed in a sịngle season. The stalks make one of the most profitable and salable market products in the early spring.

979 Myatt's Victoria. The most popular,..... Per pkt. Per oz. 1/4 tb. Per tb.

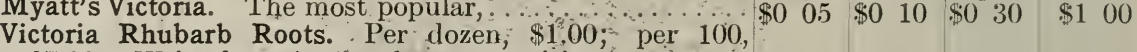
$\$ 7.00$. Write for prices on large quantities.

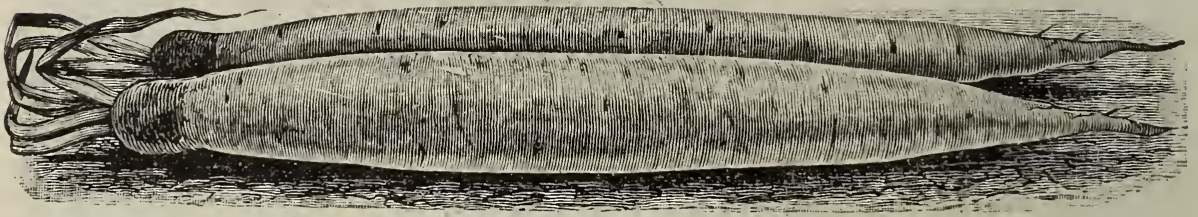

\section{SALSIFY, or Vegetable Oyster.}

This plant is grown for the large straight fleshy roots, which when cooked have a flavor resembling that of Oysters. The roots meet with ready sale during the fall and winter. They are washed, trimmed and marketed like Carrots or Parsnips, or they may be tied in bunches like Asparagus.

The seed should be sown thinly in shallow drills in the spring, in deep, loose soil, and the plants should be kept frequently and deeply cultivated to secure smooth, uniform roots.

981 Iong White The 5 cents per packet. popular standard "White French" variety, . . \$ $\$$ 10 $\$ 030: \$ 100$ 983 Sandwich Island Mammoth. ○ The largest,............... $10 \quad 35 \quad 125$

\section{SORREL.}

The large thick succulent leaves of this plant are sold during the summer and fall for a boiling green, being cooked in the small manner as Spinach or Beet leaves, and also used in making soup. The plants make a strong growth and will yield frequent successive crops. Plant in the spring in the same way as you would Beets.

98 Broad-Leaved French. The best variety,

Perpkt. Per oz. $1 / 4 \mathrm{lb}$. Per tb. $\$ 0 \quad 05 \$ 0 \quad 12 \$ 0 \quad 3.5 \$ 125$ 


\section{SPINACH.}

The lardiest sorts, such as are planted in the fall fur winter and earliest spring, run to seed quickly on the approach of hot weather and do not develop nearly so much foliage as the improved types, which have larger and more abundant foliage, while the leaves are of thicker, heavier substance.

For fall planting the chief variety used is the Norfolk Savoy-Leaved, but for a late planting or very cool locations the Prickly or Winter is an excellent variety. Round Leaved Flanders is very hardy and is recommended for fall planting.

For the earliest spring planting the Norfolk SavoyLeared may be used, but we think it much more satisfactory to use one of the long-standing varieties, such as the Thick-Leaved Round, Long-Slanding or Long-, Standing Prickly. The VICTORIA and "LONG SEASON" are the strongest growing of any of the spring or summer varieties, and will produce the largest amount of leaves and stand equally as long as any of the others before running to seed.

The NEW ZEALAND is a distinct type-(Telragonia expansa) - the plants growing in branching form and are well furnished with thick, succulent leaves. The leaves and stems can be gathered for use at any time af ter they are well grown and the plants will start out into new growth.

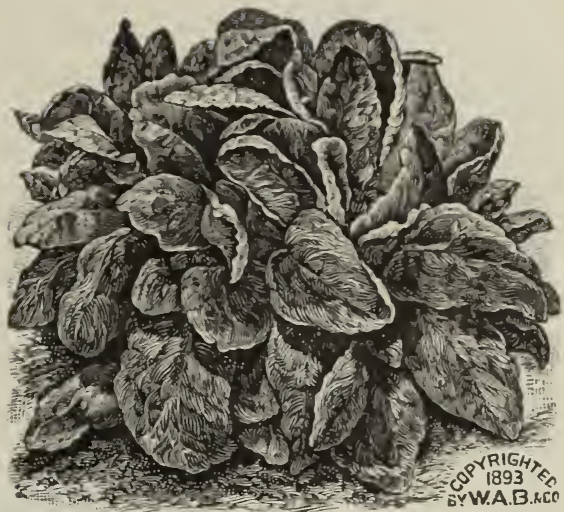

VICTORIA SPINACH, - from a Pholograph.
Write for Special Prices on large quantities.

990 "Long Season." $\odot$ Large dark green leaves,.

991 Victoria. $\odot$ Long-standing; broad, thick leaves,

993 Thick-Leaved Round. Not equal to Victoria. . . . . . . . . .

995 Long-Standing. Fine for early planting,........

997 Long-Standing Prickly. For late spring sowing,

999 Norfolk Savoy-Leaved. The standard in many localities, 1001 Prickly, or Winter. For fall sowing, .

1004 Round Leaved Flanders. Very hardy,

1005 New Zealand (Tetragonia expansa). $\odot$ For summer use

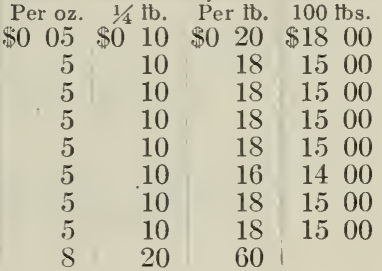

In ${ }^{\circ}$ Each variety named above, 5 cents per packet.

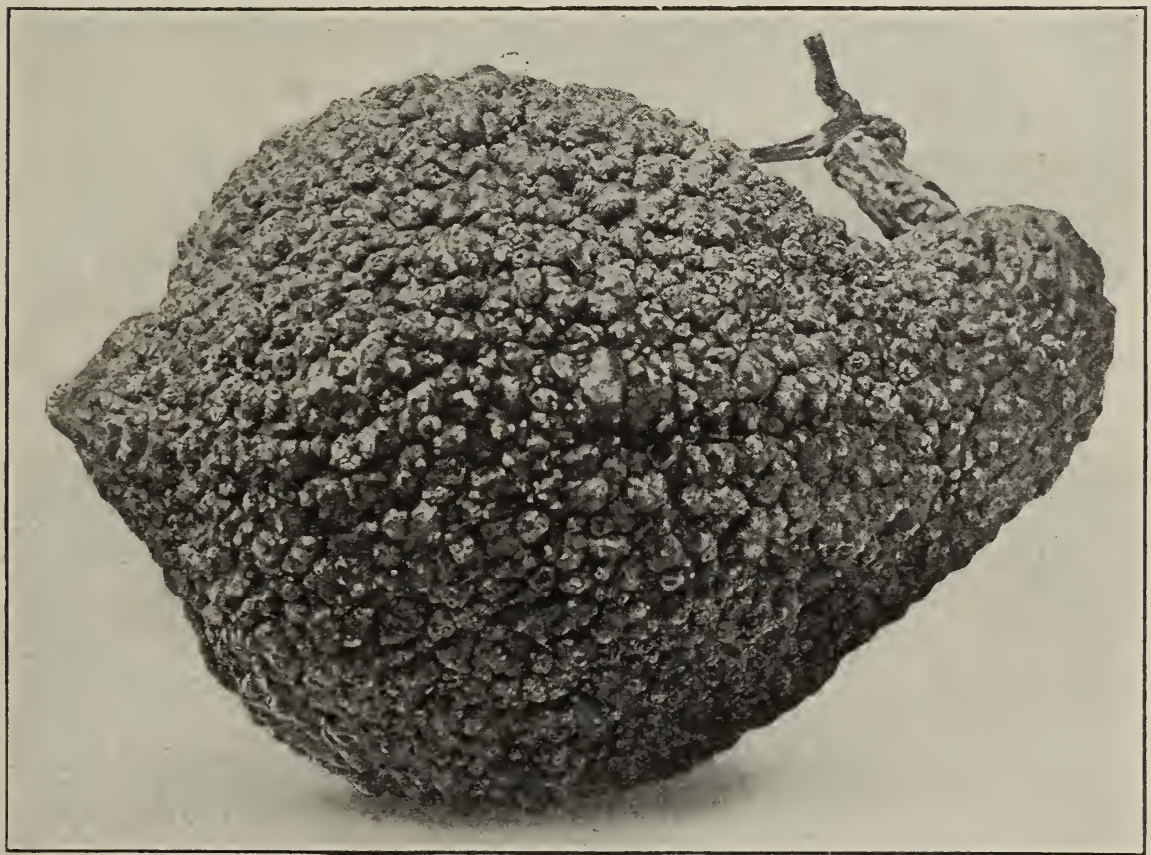

THE TRUE hUBBARD SQUASH.-from a plolograph of a specimen from our TRI.IL GROcinis in Southern Nen Jersey which weighed just TwENTY POunds. 1038-True Hubbard Squash. This is the well-known winter squash, now grown so largely is extra fine. Per pkt. 5 cts. An excellent keeper and of splendid quality. Our strain 


\section{Burpee's Selected Seed of SQUASHES.}

These are of two distinct types,-the SUMMER SOUASH, which is cultivated for the tender young fruits to be used in the green or growving state during the summer months, and the WINTER SOUASH, which furnishes the large hard-shelled fruits that are gathered in the fall before being injured by frost, and stored in a warm dry place for use during winter. A few of the varieties, however, notably our FORDHOOK, may be used in either state.

Seed should be planted in hills about the last of May, when the weather is settled, four feet apart each way for the Bush and Summer varieties, and from six to twelve feet apart for the strong running varieties. To guard against insects in early stages of growth, it is an excellent plan to sow a few radishes or turnip seeds in each hill, as these germinate quickly and the insects attack them in place of the young Squash plants. Vines should be watched closely and sprinkled early in the morning with fine, dry lime or plaster until well started. After they are well established, the vines should be thinned out, leaving only one or two in each hill. Cultivate frequently until the vines start to run, after which they should not be disturbed. Winter Squashes are also frequently planted as a second crop after early peas, onions, and other market crops. This can be done successfully in this State as late as the first of July. Seeds vary greatly in size: A packet contains from 30

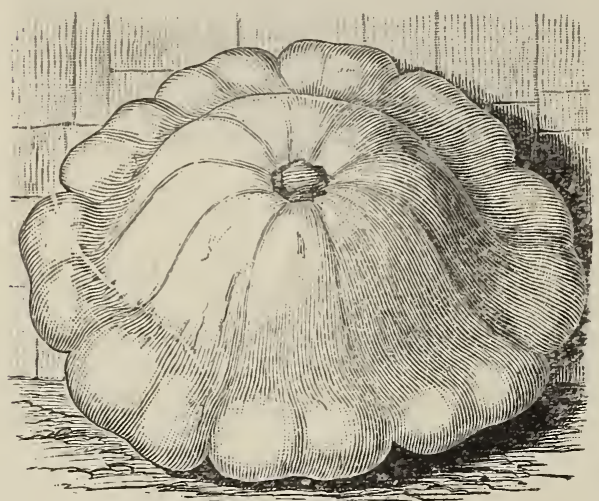

MAMMOTH WHITE BUSH SQUASH. to 100 , an ounce from 120 to 400 seeds. Of Summer varieties use four ounces to roo hills; five pounds per acre in hills four by four feet apart. Of Winter varieties, you will require eight ounces to Ioo hills; three to four pounds per acre in hills eight to twelve feet apart each way.

\section{SQUASH, - Summer Varieties.}

Among the early or summer sorts the EARLY WHITE and YELLOW BUSH and their improved forms, MaMmoth White Bush and MaMmoth Yellow Bush, are the type known as "Palty Pan" or "Cymlings;" " they are very largely grown in the South and also in this section for the summer markets. Further north the WARTED OR SUMMER CROOKNECK is the main type for summer plantings.

In BURPEE'S FORDHOOK SOUASH we have both the bush and running types of growth, and where the squashes are grown for winter use we consider the running variety the most satisfactory, being more productive.

Cocozelle Bush and Long White Vegetable Marrow are excellent varieties for use at mid-summer.

In In lots of 5 pounds, deduct 5 cents per pound.

1010 Early White Bush, Scalloped. (White "Patty Pan.")

1012 Mammoth White Bush, Scalloped. ๑ Similar but larger,

1014 Early Yellow Bush, Scalloped. Deep orange color, . .

1016 Mammoth Yellow Bush. Same as preceding, but larger,

1018 Golden Summer Crookneck. Favorite small crook-necked,

1020 Giant Summer Crookneck. ๑ Eighteen inches long,.. .

1030 Cocozelle Bush. Oblong fruits, excellent for frying,

1031 Long White Vegetable Marrow. The favorite English variety,

\begin{tabular}{|c|c|c|}
\hline Per oz. & $1 / 4 \mathrm{tb}$. & Per tb. \\
\hline 07 & \$0 15 & $\$ 05$ \\
\hline 8 & 20 & \\
\hline 7 & 15 & \\
\hline 8 & 25 & \\
\hline 8 & 20 & \\
\hline 10 & 30 & 100 \\
\hline 8 & 25 & \\
\hline 12 & 35 & 11 \\
\hline 10 & 30 & 1 \\
\hline 10 & 30 & 1 \\
\hline
\end{tabular}

1034 Burpee's Bush Fordhook. Of bushy growth,

Ww Each variety named above, $\mathbf{5}$ cents per packet.

1032 Burpee's Fordhook Squash. $\odot$ This is a most desirable running variety for strong vigorous growtli and wonderfully productive. Fruits oblong in form, eight to ten inches in le $11 \mathrm{gth}$, slightly ridged, smooth thin yellowish skin; flesh very thick and of a light straw-yellow. If gat hered young for cooking, no other Squash-except the new Burpee's Bush Fordhook -approaches it in favor, while if allowed to ripen on the vine they can be stored and will keep in excellent condition unt il late the following June. Either for baking

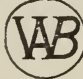
like sweet potatoes or mak ing pies during the winter the quality is unsurpassed. Per pkt. 5 cts.; oz. 10 cts.; 1/4 lb, 30 cts.; per Ib. $\$ 1.00$.

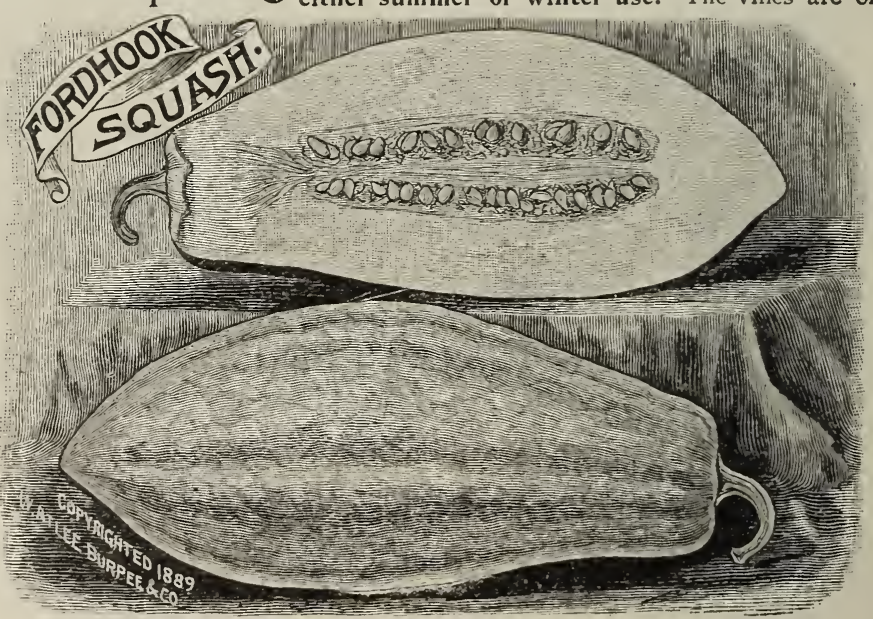




\section{SQUASH,- Winter Varieties.}

DELICATA is similar in size to the runniug Ford hook, but has creamy-white fruits striped with dark green.

In the large-fruited winter squashes the Boston MARROW and HUBBARD are the leading types. The Boston Marrow has an oval fruit, pointed at both ends, with smooth deep orange-colored skin. The HUBBARD is a very large oval dark green-skinned variety. The WARTED HUBBARD is a selection with darker color and thickly warted skin. GOLDEN HUBBARD has the appearance of the original Hubbard, but is of a rich reddish-orange shade. "PIE SoUASH," or Winler Luxury Pumpkin, is of smooth rounded form: flesh is thick and very sweet. Pike's Peak produces large oval fruits of a dark olive-green color; light golden flesh of excellent quality.

ESSEX HYBRID has a broad round orange fruit, slightly flattened at each end, and generally comes with a large nub or Turk's Cap at the blossom end. GoldEN BRONZE is a large oval squash of a darkbronzy-green color

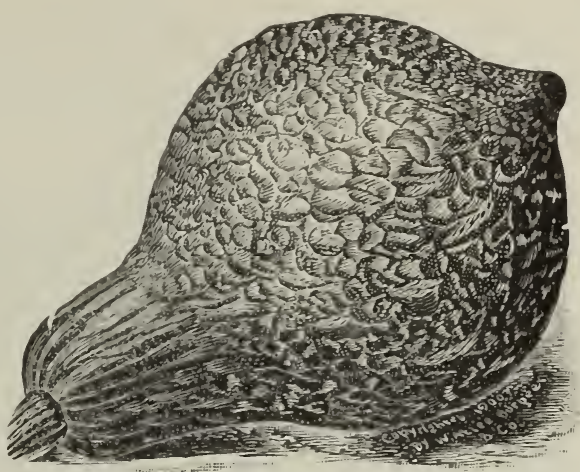

RED OR "GOLDEN" HUBBARD, - from a pholograph.

with rich orange flesh of fine quality. Delicious is similar to the Golden Bronze, but does not grow so large, is lighter in color and somewhat more productive. MAMMOTH CHıL is a large-fruited variety with smooth, reddishorange skin marked with broad bands of faint creamy-white stripes. MAMMOTH WHALE is a very large dark olive green squash of peculiar form.

In lots of 5 pounds, deduct 5 cents per pound.

Boston Marrow. A bright orange squash for autumn,

1038 Hubbard. $\odot$ The well-known and most popular winter squash,

1040 Chicago Warted Hubbard. Heavily warted skin. (See below),

1042 Red, or Golden Hubbard. Orange-red skin. (See below),

1044 Essex Hybrid. A good squash for fall and winter use,

1048 Pie Squash, or Winter Luxury Pumpkin. Excellent for pies,

1050 Golden Bronze. $\odot$ Bronze-green skin,

1052 The Delicious. Exceedingly rich in flavor,

1053 Pike's Peak. Oval fruits; dark olive-green,

1054 Delicata. A small-fruited variety,

1056 Mammoth Chili. Extra large-fruited,

1058 Mammoth Whale. ๑ "Largest of all." Per pkt. 10 cts.

\begin{tabular}{|c|c|c|}
\hline Per $\mathrm{Oz}$ & $1 / 4 \mathrm{tb}$. & Per tb. \\
\hline $\begin{array}{ll}\$ 0 & 08 \\
& 10\end{array}$ & $\begin{array}{l}\$ 0 \quad 20 \\
\quad\end{array}$ & $\begin{array}{ll}\$ 0 & 60 \\
& 90\end{array}$ \\
\hline 10 & 30 & 100 \\
\hline 10 & 30 & 100 \\
\hline 10 & 30 & 100 \\
\hline 8 & 25 & 80 \\
\hline 8 & 25 & 80 \\
\hline 10 & 30 & 100 \\
\hline 8 & 25 & 8 \\
\hline 10 & 30 & 100 \\
\hline 10 & 30 & 110 \\
\hline 12 & 35 & 12 \\
\hline
\end{tabular}

Is 5 Excpt Mammoth Whale, all are $\mathbf{5}$ cents per packet.

1058 Mammoth Whale. $\odot$ See illustration. "Jumbo" of the Squash Family. It is an extra largefruited sort, quite distinct in form and appearance. The squashes grow from two and a half to three feet in length, with a slight neck at the stem end. The large seed end is swelled to a width of twelve to eighteen inches and slightly flattened, giving a most distinct appearance which suggests the name,-" MAMMOTH WHALE." The skin is of a dark olive-green, with slight stripes of a lighter tinge. The fruits frequently attain more than one hundred pounds in weight. Flesh firm and solid, of beautiful orange-yellow and excellent quality. Per pkt. $10 \mathrm{cts}$; per oz. $12 \mathrm{cts}$; ; $1 / 4 \mathrm{lb} .35 \mathrm{cts}$. per $1 \mathrm{~b}$. $\$ 1.25$.

1030 Cocozelle Bush. Of compact bush growth with dark-green foliage four to five inches in diameter. Skin dark green with stripes of a still darker shade. Per pkt. 5 cts.; oz. 8 cts.; 1/4 lb. 25 cts.; per $1 \mathrm{~b} .75$ cts.

1031 Long White Marrow, MA VEGETABLE is similar to the Cocozelle, but rather later in season and the fruits much larger in size. Skin smooth and creamy white. Recommended for slicing and frying. Per pkt. 5 cts.; oz. 12 cts.; 1/4 lb. 35 cts.; per lb. $\$ 1.10$.

1040 Warted Hubbard. This is similar in the well-known Hubbard, while the large dark olive green fruits are supposed to be slightly more heavily warted. Very handsome in appearance; an excellent keeper and of splendid quality. Per pkt. 5 cts.; oz. 10 cts.; 1/4 1b. 30 cts.; per lb. $\$ 1.00$.

\section{Red or Golden Hubbard.}

The heavily warted skin is of a rich orange-yellow, turning to deep salmon-red when ripened. It is equally as productive and fine in quality as the original Hubbard Squash. Per pkt. 5 cts.; oz. $10 \mathrm{cts}$.; 1/4 lb. $30 \mathrm{cts}$.; per lb. $\$ 1.00$.

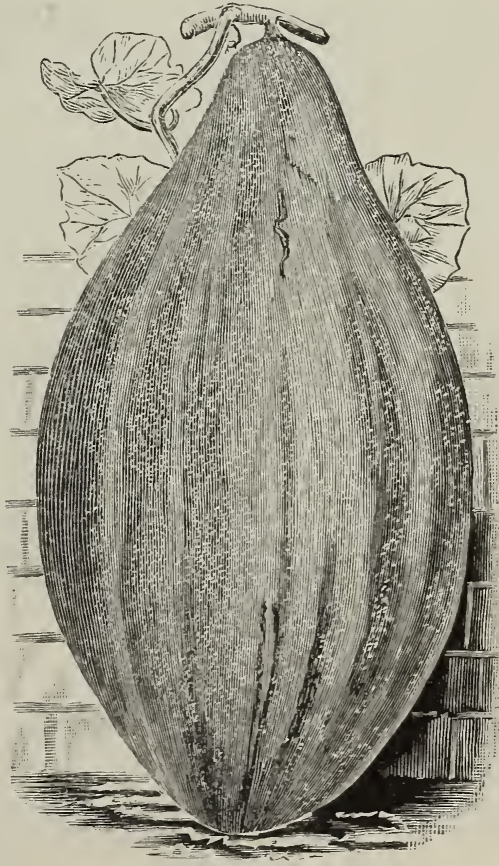

MAMMOTH WHALE SOUASH. 


\section{TOMATOES.}

We recommend EARLiana for warm light sandy sols, and CHALK's EARLY JEwel for cooler locations and heavier soil. For the New England States, FORDHOOK FIRST is a most satisfactory early market sort, while for the extreme North and cooler sections one of the erect bush varieties with heavy potato-like foliage would give the best results, and for such a location we would recommend BURPEE's QUARTER-CENTURY.

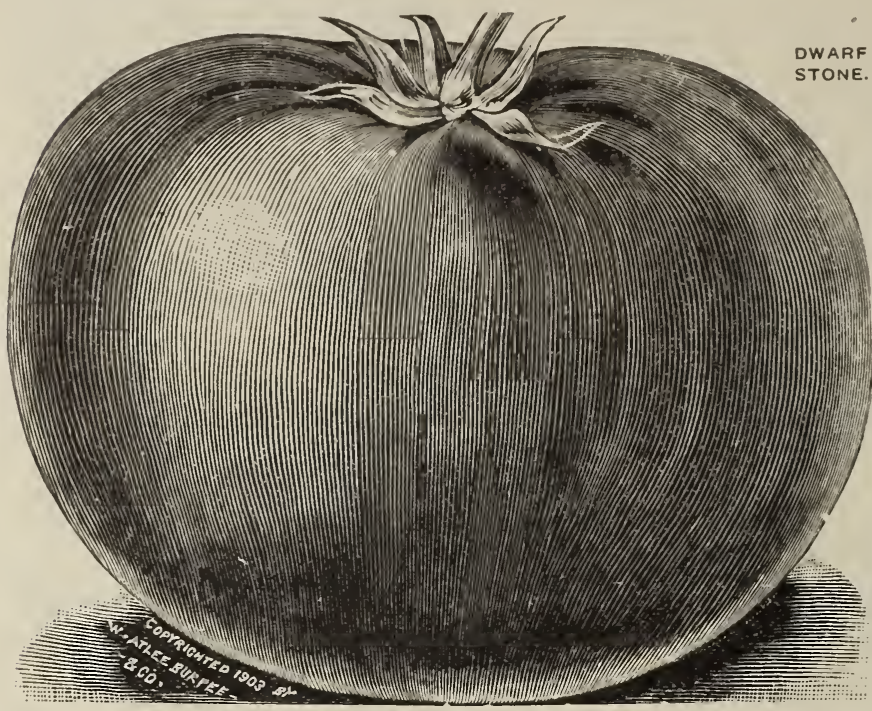

JUNE PINR is an extra early variety of the same type of growth and fruiting as the Spark's Earliana. EARLIEST PINK is the very earliest pink tomato for warm light soils.

ACME and Livingston's BEAUTY are smooth-fruited round, purplish-pink sorts of medium size.

TRUCKER'S FAVORITE is a large smooth purple or deep pink sort.

In the scarlet-fruited sorts, LivingsTON's FAVORITE, PARAGON, PERFECTION and STONE are standard varieties, producing large crops of fine, smooth, bright-red fruits. SUCCESS is a variety of even size and great solidity. TROPHY is an old-time favorite. Victoria WholeSalad, now first introduced produces handsome small solid scarlet tomatoes just right in size for serving whole.

BURPEE'S Matchless is our finest and best scarlet main-crop variety either for market or canning.

In the bush or so-called "tree" varieties, which are of stiffly erect growth and close, heavy, potato-leaved foliage, FORDHOOK FANCY is the most distinct, erect. and the earliest to ripen. DWARF CHAMPION is the original variety and produces a large crop of purplish-red or deep pink fruits. BURPEE'S QUARTER-Century is of the same type as the Champion, but more dwarf and compact, with bright red fruits of good size. DWARF STONE is also of this type, but is later in season and produces the largest fruits of any dwarf variety, excepting Burpee's Dwarf Giant. BURPEE'S NEIV DWARF-GIANT is the largest fruited of all the divarf-growing varieties.

PONDEROSA and TURNER HyBRID ("Mikado") are very large-fruited sorts of finest quality. There is slight call for a yellow tomato in the market, and the best of these are the GOLDEN QUEen, of running growth, and BURPEE'S GOLDEN DWARF Champion, which is of the erect or "bush" growth.

I $\rightarrow$ In lots of 5 pounds or more, deduct 10 cents per pound.

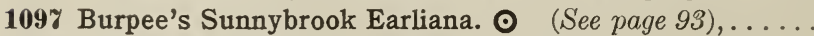

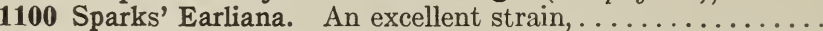

1101 Chalk's EARLY JEWEL. ○ Fordhook Grown. (See page 9 /),

1111 Earliest Pink. As early as Earliana. Per pkt. 5 cts.,........

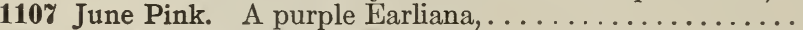

1066 Acme. The well-known standard pink tomato. Per pkt. 5 cts.

1067 Livingston's Globe. Globe-shaped, purple fruits. Per pkt. 5 cts.,

1102 Fordhook First. $\odot$ ForDноок Grown. Best early purple tomato,

$10 \% 0$ Livingston's Beauty. Large; purplish pink. Per pkt. 5 cts.,..

1072 Paragon. The well-known standard red tomato. Pkt. 5 cts.,.

1074 Stone. Large, smooth, solid, scarlet. Per pkt. 5 cts.,........

$10 \% 6$ Livingston's Perfection. Identical with Paragon. Pkt. 5 cts.,

1078 Livingston's Favorite. Bright red, smooth. Per pkt. 5 cts.,. .

1082 Turner Hybrid. Large purple; potato leaf. Pkt. 5 cts.,.

1093 Dwarf Stone. $\odot$ Dwarf growth; scarlet fruits. (See page 96),

1094 Dwarf Champion. Deep purplish red. Per pkt. 5 cts.,........

1095 Burpee's "DWARF-GIANT." ○ (See page 97),.............

1096 Fordhook Fancy. $\odot$ Hardy, dwarf; purplish red. Pkt. 5 cts.,

1098 Trophy. Large, solid, and generally smooth. Per pkt. 5 cts.,

1105 Success. ○ Bright scarlet, second early. (See page 96),.....

1108 Burpee's MATCHLESS. ○ Grown at Fordноoк,..........

1109 Burpee's Matchless. (See page 95). .

1112 TRUCKER'S FAVORITE. $\odot$ Large purple fruits. Grown at

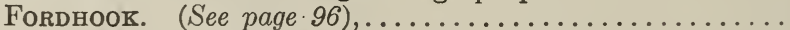

1114 Ponderosa. ๑ Fruits large and solid. (See page 96$), \ldots . . .$.

1116 Burpee's Quarter-Century. Dwarf growth; early; scarlet fruits,

1132 Holmes' Supreme. Fine for forcing; scarlet. Pkt. 15 cts., . . .

1133 Comet. Also excellent for forcing. 'Pkt. $15 \mathrm{cts} ., \ldots \ldots \ldots \ldots \ldots$

1134 Victoria Whole-Salad. $\odot$ Fine for salad. Pkt. 15 cts.

1136 Golden Queen. Large, smooth, pure yellow. Pkt. 5 cts.,

1138 Golden Dwarf Champion. ○ Of upright growth, yellow fruits,.

\begin{tabular}{|c|c|c|}
\hline Per oz. & $1 / 4 \mathrm{lt}$. & Per lb. \\
\hline 8040 & $\$ 110$ & $\$ 400$ \\
\hline 25 & 75 & 275 \\
\hline 30 & 85 & 300 \\
\hline 30 & 85 & 300 \\
\hline 30 & 85 & 325 \\
\hline 20 & 60 & 200 \\
\hline 25 & 75 & 27 \\
\hline 25 & 75 & 250 \\
\hline 20 & 60 & 200 \\
\hline 20 & 60 & 200 \\
\hline 20 & 60 & 200 \\
\hline 20 & 60 & 200 \\
\hline 20 & 60 & 200 \\
\hline 25 & 75 & 250 \\
\hline 25 & 75 & 275 \\
\hline 25 & 75 & 250 \\
\hline 60 & 185 & 700 \\
\hline 30 & 85 & 300 \\
\hline 20 & 60 & 200 \\
\hline 20 & 60 & 225 \\
\hline 30 & 85 & 300 \\
\hline 20 & 60 & 20 \\
\hline 25 & 75 & 275 \\
\hline 45 & 125 & 45 \\
\hline 35 & 85 & 325 \\
\hline 60 & 175 & 600 \\
\hline 60 & 175 & 60 \\
\hline 25 & 7.5 & 250 \\
\hline 30 & 85 & 30 \\
\hline
\end{tabular}
Except where otherwise priced, all the above are $\mathbf{1 0}$ cents per packet. 


\section{${ }_{1007}$ Burpee’s Sunnybrook Earliana,॰}

\section{The "Earliest of All" Red Tomatoes.}

\section{Sunnybrook Special}

produces a closer jointed and more compact vine, set quite as freely with fine smooth tomatoes which are usually ready to market five days earlier! The entire crop can be gathered generally in about three weeks from the time the first fruit ripens.

SUNNYBROOK EARLIANA is undoubtedly the very besl carliesl scarlet-fruited tomato. Gardeners who are seeking to have good smooth tomatoes "first on market" can find nothing equal. It is remarkable for its freedom from the rough fruits which southern growers call "cal-faced" tomatoes. It is a very prolific strain. Not only does the plant bear a large cluster as the crown set, but also produces a number of smaller clusters and single fruits on the side branches.

Dos This Special Slock is grown exclusivcly on our SUNNYBROOR FARM, in Gloucester County, New Jersey, and is sold only under our Registered Trade Mark. Per pkt. $10 \mathrm{cts}$; 1/20z. $25 \mathrm{cts} . ;$ per $0 \mathrm{z} .40 \mathrm{cts} . ; 2$ ozs. $65 \mathrm{cts} . ;$ $1 / 4$ Ib. $\$ 1.10$; per 1 b. $\$ 4.00$.

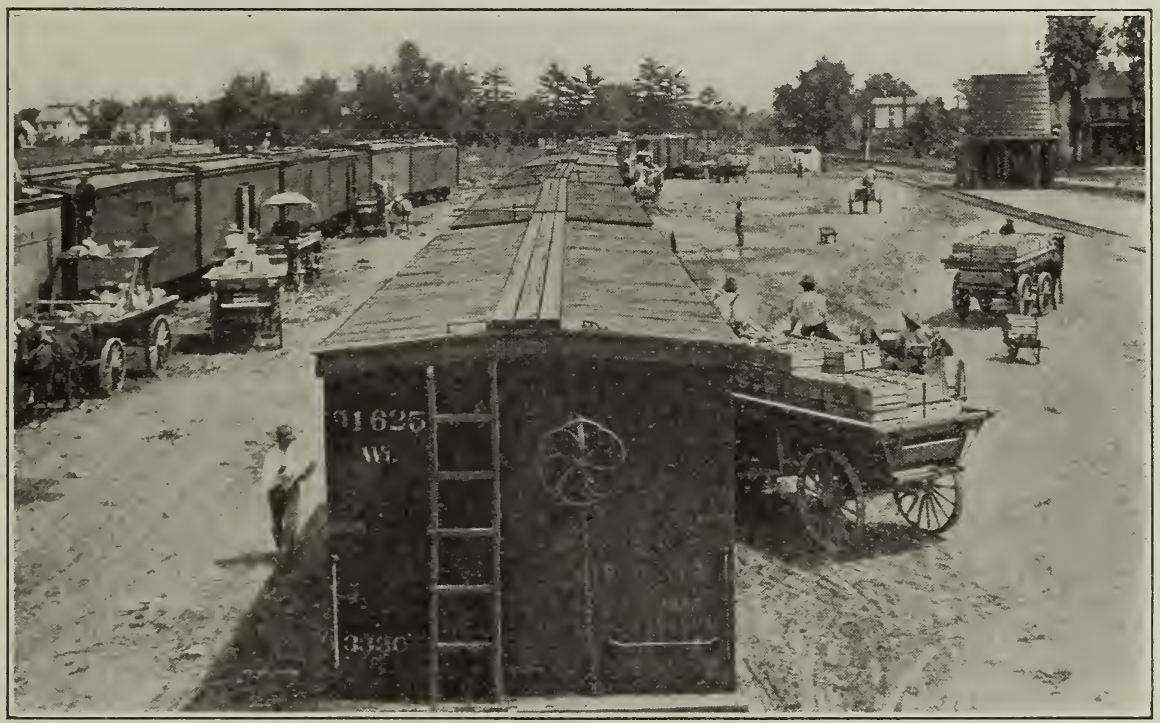

SHIPPING SPARKS' EARLIANA TOMATOES-(thirly carloads in one day!)-from Swedesboro, N. J.

Sparks' Earliana Tomato. In the vicinity of Swedesboro, N. J., the original home great an extent that twenty to thirty carloads, each containing from 600 to $800 \mathrm{crates}$, are despatched daily during July from this single station. It has been stated that generally during the month of July the tomato buyers at the cars pay out $\$ 10,000$ in Swedesboro in five consecutive days, while large quantities are shipped also from the same station by individual growers on consignment.

1100 Sparks’ Earliana. Per pkt. 10 cts.; oz. 25 cts.; 1/4 lb. 75 cts.; per lb. $\$ 2.75$. 


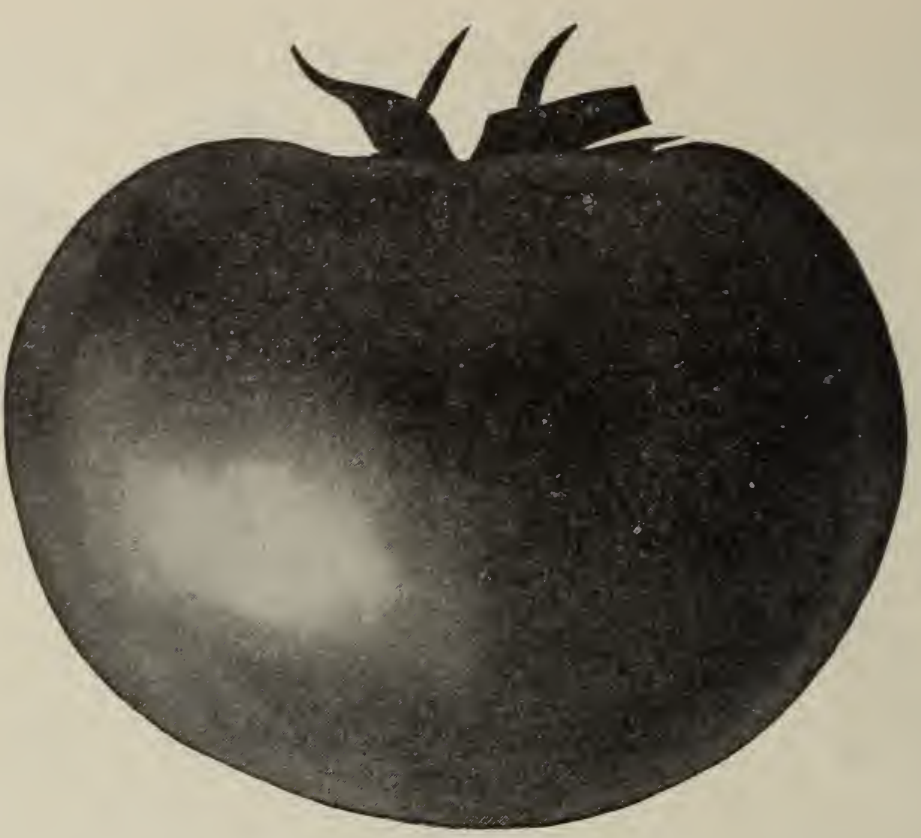

CHALK'S JEWEL, - Natural Size as grown at FORDHOOK,-from a Photograph.

\section{${ }_{1101}$ Tomato, Chalk's Early Jewel.๑}

The largest, smoothest, and finest=flavored extra=early bright red Tomato! Within a week to ten days as early as Sparks' Earliana, it is even a heavier cropper, with meaty tomatoes of larger size and sweeter flavor,--produced continuously throughout the season.

\section{Chalk's " Early Jewel." At Fornноок, from seed planted at the same time and} JEe with plants grown under the same conditions, EARLY JeweL is only about one week later in ripening the first fruits than Sparks' Earliana, while it is a much more desirable variety in many ways. The plants are of strong, robust growth, with ample foliage to protect the fruits from sunscald, and the foliage is not subject to blight.

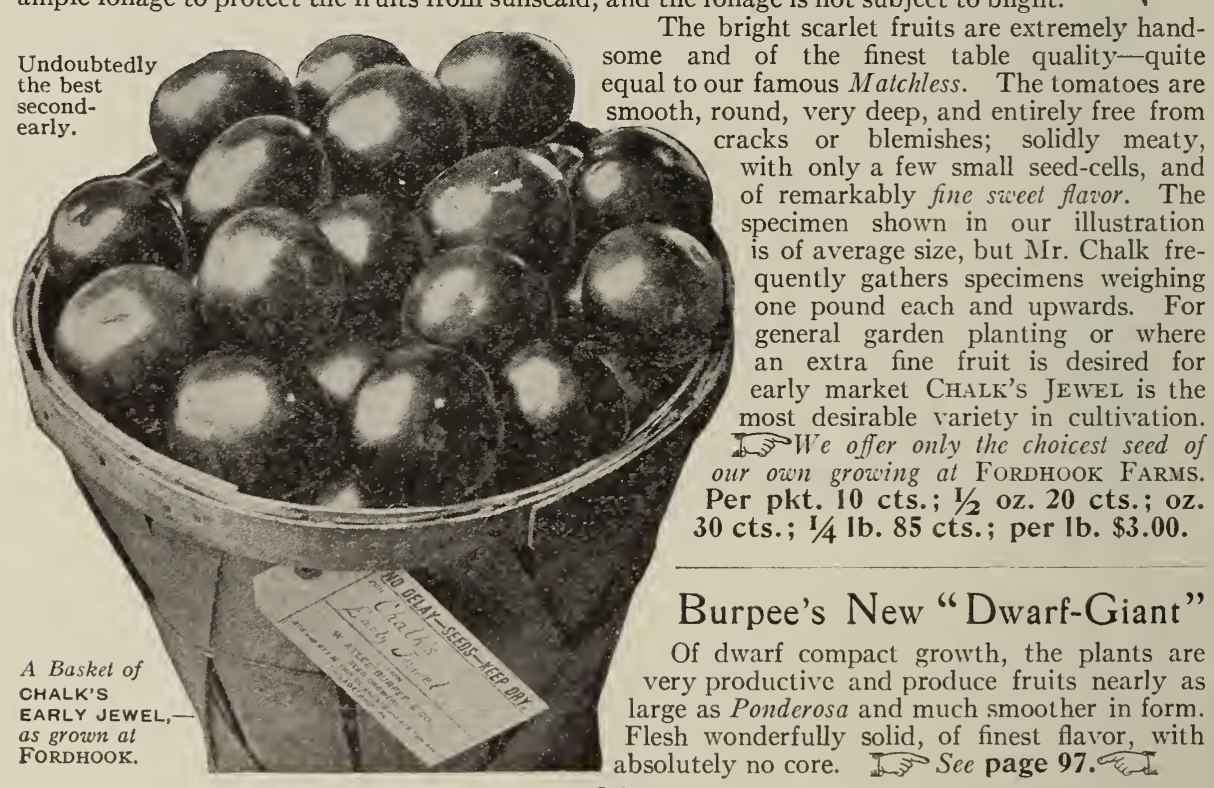




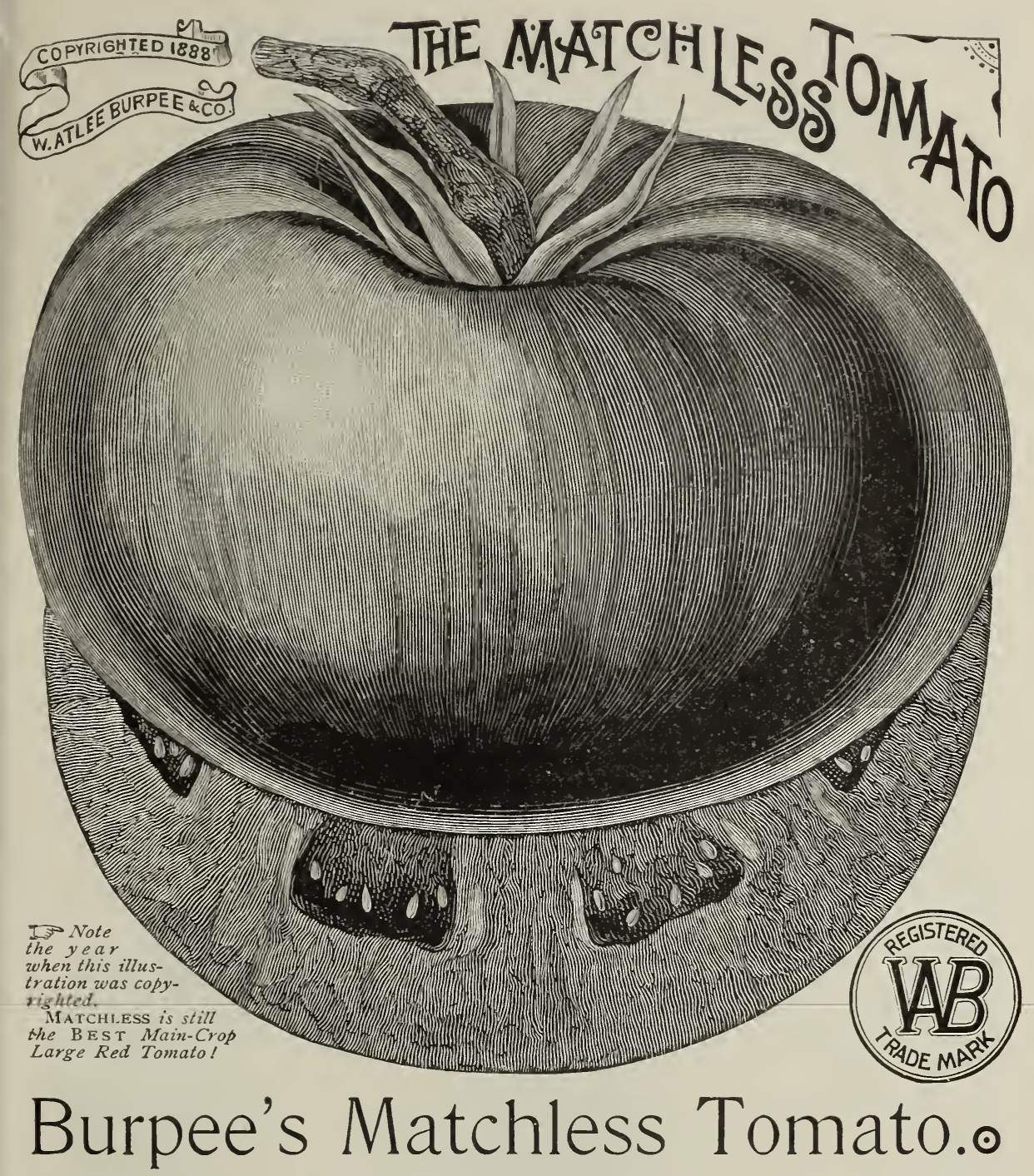

Burpee's Matchless is a strong vigorous grower with thrifty vines which produce Burpee's Matchless large handsome tomatoes most abundantly throughout the season. The fruits, of a rich cardinal-red, are remarkably solid and smooth, free from core and uniformly of the finest flavor. The tomatoes are always of the largest size; they do not become smaller even late in the season, as the healthy growth of vine and foliage carry magnificent crops until killed by frost. After the vines have been killed by frost we have repeatedly noticed that the full-grown green tomatoes remaining were fully as large as the ripe fruits gathered during the season. For tomatoes of the largest size, always perfectly smooth, firm and handsome, long keeping qualities and finest flavor, we say without fear of contradiction that there is no scarlet-fruited tomato the equal of BuRPEE's MATCHLESS.

Burpee's Matchless has been for years the favorite main-crop tomato in many secthat our sales of seed (especially tions, and that it has proved worthy is vouched for by the fact market, for family use and for canning there is no other variety that can equal the MATciless. We know all varieties of Tomatoes, and in our opinion this is absolutely the Best Large Red! 1108 Fordhook-Grown Seed of Matchless. $\odot$ For best selected seed of our own charge: Per pkt. 10 cts.; $1 / 2$ oz. 20 cts.; oz. 30 cts.; $1 / 4$ lb. 85 cts.; $1 / 216$. $\$ 1.50 ;$ per $1 b . \$ 3.00$.

Is Write for Special Prices in large lots.

1109 Matchless grown under contract for us. This seed, which is also first class (or we would 1109 not handle it), we offer at the following prices: Per pkt. 10 cts.; per oz. 20 cts.; 2 ozs. $35 \mathrm{cts}$; $1 / 4 \mathrm{lb}$. $60 \mathrm{cts}$; per $1 \mathrm{~b}$. $\$ 2.00$. W Write for Special Prices in large lots. 


\section{Burpee’s “Trucker's Favorite” Tomato.๑}

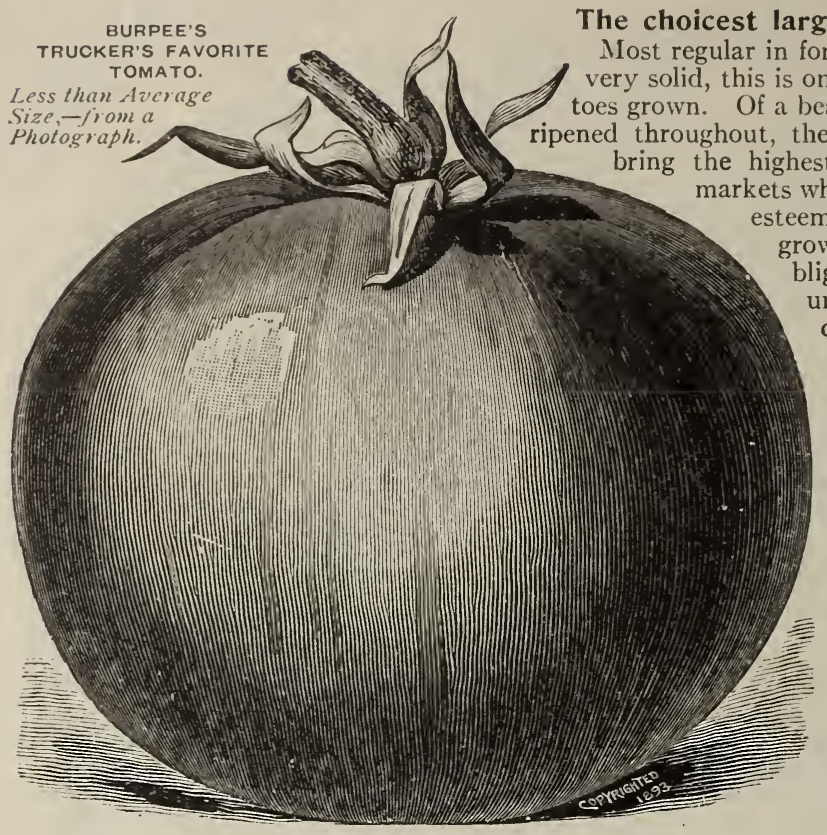

The choicest large=fruited purple Tomato.

Most regular in form and size, thick-meated and solid, this is one of the largest smooth tomaLess than Average 10 toes grown. Of a beautiful purplish-red color, well Photograph ripened throughout, the smooth fleshy fruits always bring the highest prices on our Philadelphia
markets where their fine flavor is specially esteemed. The vines are of strong growth, not subject to rust or blight, and bear enormous crops until killed by frost. The fruits continue of large size to the very last and are unexcelled for slicing or cooking. It is a main-crop variety, maturing the same season as The Matchless and equally as productive.

Is $A$ s a dependable main-crop pink or purple sort no variety in cultivation to-day is the equal of this TRUCKER'S FAVORITE.

1112 Fordhook-Grown. This carefully selected strain cannot be too highly recommended. Per pkt. 10 cts.; 1/2 oz. 15 cts.; per oz. 25 cts.; 2 ozs. 45 cts.; $1 / 4$ lb. 75 cts. ; lb. $\$ 2.75$.

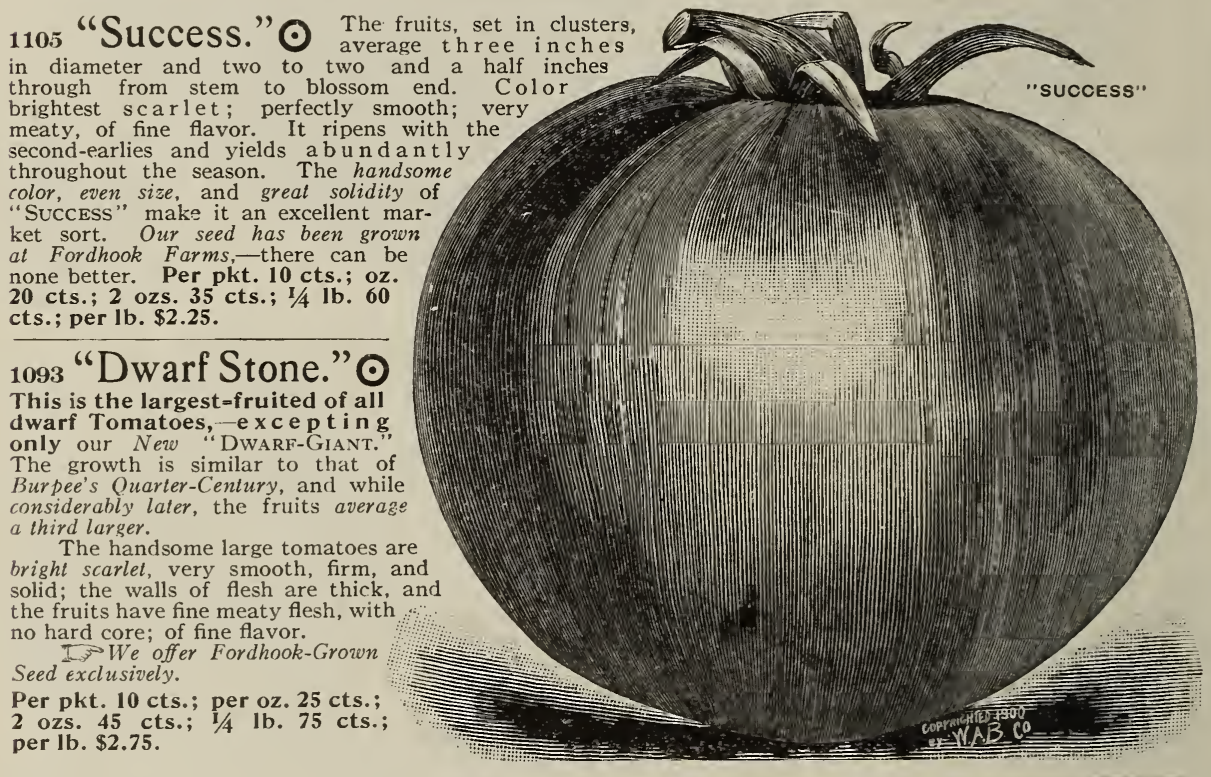

1114 Ponderosa. $\odot$ This variety as now grown by us, - while too much " ribbed" for maring of the Bull's-Eye! Only equaled in size by Burpee's New Drearf-Giant and of fine quality for slicing. The vines are of strong growth. The deep purple fruits are oblong in form, generally ridged or ribbed. They are solidly fleshy with small seed-cells; of extra sweet flavor. Planted in good soil, fruits frequently attain a weight of one pound or more. We offer a selected strain of our nwn growing that produces tomatoes smonther thin usual and very meaty,- "solid as a rock." Per pkt. 10 cts.; 1/2 oz. 25 cts.; oz. 45 cts.; 1/4 lb. $\$ 1.25 ;$ per lb. $\$ 4.50$. 


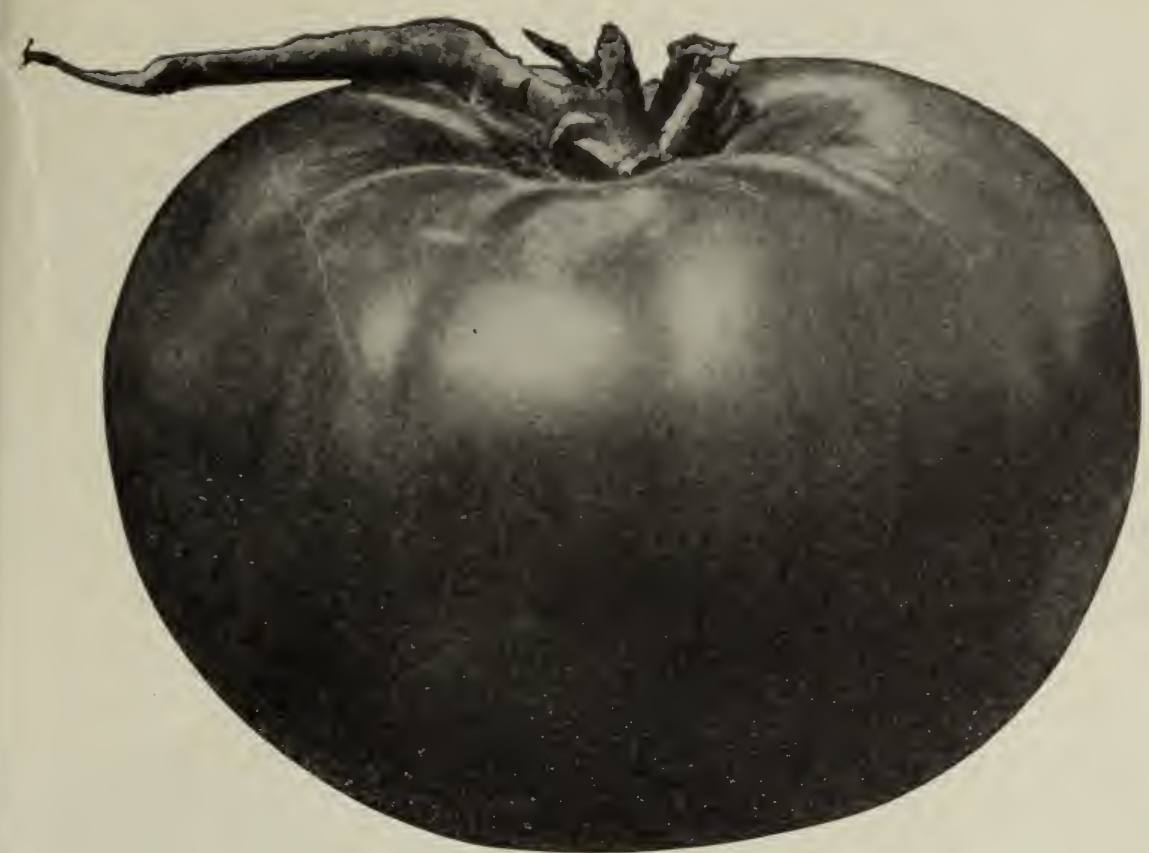

Natural Size BURPEE'S "DWARF-GIANT" TOMATO, zueight 18 ozs.,-from a Photograph.

\section{Burpee's "Dwarf-Giant” Tomato.๑}

\section{A True "Dwarf Ponderosa,"-Introduced in 1909.}

Burpee's "Dwarf-Giant" is much the largest fruited of all dwarf and are uniformly large throughout the season. They are produced in clusters of four to six and weigh from ten to twenty ounces each. The color is a rich purple-crimson and the depth of color is maintained throughout the entire fruit.

"Dwarf-Giant" is the most meaty of all Tomatoes! The flesh is so firm and the tomatoes so heavy that they might be described, with but slight exaggeration, "solid as a rock!" BURPEE's "DWARF-GIANT" is the most nearly seedless of all tomatoes. The firm fine-grained flesh extends to the very center, with no trace whatever of a core. Burpee's "Dwarf-Giant" is unequaled in delicious flavor! This is sayit surpasses even our famous Matchlcss and Trucker's Favorite as well as its parent, Ponderosa. Fruits eaten raw, as an apple, out of the hand, direct from the plants, show an entire freedom from acidity; the luscious quality is most noticeable.

" Dwarf-Giant" is uniformly of compact bush=like growth. While of the true dwarf type, the plants are very like leather in texture. The new "DWARF-GIANT" is most productive and has only one fault t Originated from a cross made between Dwarf Champion and Ponderosa, it naturally inherits the tendency of the latter parent to bear

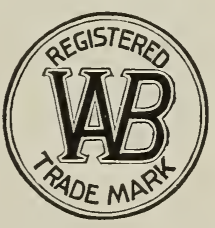
"ribbed" fruits. Even these are so solid, meaty, and of such delicious" flavor, however, that for family gardens this can hardly be zcounted a serious fault.

1095 Burpee's "Dwarf-Giant" is a mid=season or main=crop Tomato. Pout It ripens a week to ten days earlier than Ponderosa and the plants continue to mature the superb "giant-solid" tomatoes, in abundance, until frost. The fruits are so nearly "seedless" that seed of a selected strain will always be costly. Our seed has been produced upon our own farms in Pennsylvania and New Jersey. Per pkt. 10 cts.; one =fourth ounce (about 2700 seeds) $18 \mathrm{cts}$; $1 / 2$ oz. $32 \mathrm{cts}$; per 07. 60 cts.; 2 ozs. for $\$ 1.00 ; 1 / 4 \mathrm{lb}$. $\$ 1.85 ; 1 / 2 \mathrm{lb}$. $\$ 3.50$; per $\mathrm{lb}$. $\$ 7.00$.

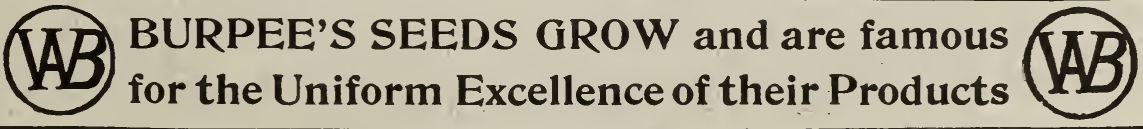




\section{TOMATOES,-Small-Fruited Varieties.}

These are quite largely used in certain sections for making preserves, fancy pickles, etc., and different shapes, colors, and sizes are desired in different markets. The YELLOW PEAR and YELLOw PLUM, which differ only in outline, are those most largely grown for market. RED PEAR-SHAPED is similar to Yellow Pear, excepting in color. The small fruits grow in clusters and have a very distinct neck at the stem end. The Red and $Y$ ellow Cherry Tomaloes have small round fruits about half an inch in diameter and are used for pickling.

BURBANK PRESERVING is of stiff, erect growth, with small heavy leaves, and produces long clusters of very small round bright scarlet fruits of a rich sweet flavor. THE PEACH TOMATO, as its name denotes, has fruits the size and general appearance of a peach, the skin being thin and tender and covered with a soft pubescence resembling the fuzz of a peach in texture. These are used as an ornamental table fruit for eating raw. STRAWBERRY, or "HUSK TOMATO," is a small round yellow fruit about half an inch in diameter, enclosed in a thin husk or outer covering. These are very rich and sweet and largely used in making preserves.

To For many years we have produced at FORDHOOK FARMS all the seed we sell of these small-fruited Tomatoes. Wo It is impossible for us to purchase any seed of equal quality grown elsewhere.

1137 Yellow Plum. Skin and flesh deep yellow,

1139 Pear-Shaped Yellow. $\odot$ True pear-shaped,

1141 The Peach. Resembles the peach in form and color,

1143 Burbank Preserving. $\odot$ Small round fruits. Per pkt. 10 cts.,. .

1145 Yellow Cherry. Small round yellow fruits,

1147 Red Cherry. Little round fruits in clusters,

1149 Pear-Shaped, Red. $\odot$ True pear-shaped,

1151 Strawberry, or Winter Cherry (Husk Tomato). Very sweet; fine for preserves,

Is Each of the above, except Burbank Preserving, $\mathbf{5}$ cents per packet.

\begin{tabular}{|c|r|rr} 
Per oz. & $1 / 4 \mathrm{lb}$ & Per lb. \\
$\$ 025$ & $\$ 075$ & $\$ 2$ & 75 \\
25 & 75 & 275 \\
25 & 75 & 275 \\
25 & 75 & 2 & 75 \\
25 & 75 & 2 & 75 \\
25 & 75 & 2 & 75 \\
25 & 75 & 2 & 75 \\
& & & \\
25 & 75 & 2 & 75 \\
per packet. & &
\end{tabular}

\section{TURNIPS, - Garden Varieties.}

In the warmer States the quick-growing early varieties of turnips are the most popular, while in the cooler Northern States the varieties which have harder, firm-grained flesh and the Ruta Bagas are the ones generally planted for market. The word "turnip" should not confuse the planter, as in the Northern States it is applied

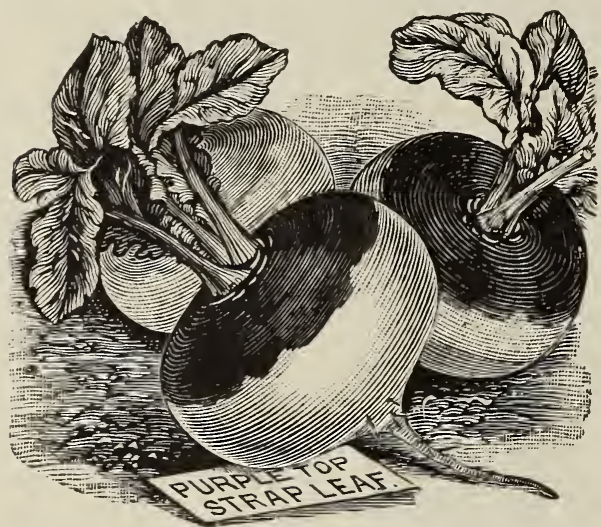
both to the quick-growing early varieties and to the large late winter sorts, as well as to Ruta Bagas; Ruta Bagas, however, require a longer season in which to grow and develop, and should be planted at least six weeks earlier in the summer than it is necessary to plant to secure a crop of quick-growing turnips.

In the early turnips the EARLY WHITE FLAT Dutch StRap-Leaved and EARLy Red or PURPLETOP STRAP-LEAVED are the best known. These, however, are surpassed in earliness in the EXTRA EARLy PURPLE-TOP Milan and Extra Early White MILAN, which are similar except in extreme earliness. They are not good keepers, however, and valuable only for early use. SCARLET KASHMYR, or Cardinal, is a very early flat variety of exceptionally bright deep color. PETROWSKI is very quick growing; deep orange skin, unusually sweet; rich yellow flesh of finest quality. All of the preceding have the distinctly flat root.

RED TOP WHITE GLOBE is a large round variety of very quick growth and most popular either for market or field crop for early feeding. WHITE GLOBE STRAP-LEAVED and WHITE EGG are excellent table sorts of a clear white coloring and producing smooth roots of large size. AMBER GLOBE amd Yellow ABERDEEN are large-growing late varieties, with flesh of crisp hard texture, which are planted both for market purposes and stock feeding in the Northern States. The SWEET GeRMAN, or Long While French, is properly a ruta baga and needs early planting, but is commonly known as a turnip in most sections. GoLDEN BALL, or Orange Jelly, is a medium-sized round turnip; with deep yellow skin and flesh;-firm and hard grained, of fine flavor and excellent keeping qualities.

LONG WhITE, or "Cowhorn," is slender and penetrates the soil quite deeply. It is planted usually either for stock feeding or to grow as a green crop to turn under to entich the soil. The SEVEN-TOP TURNIP is a hardy variety planted in the South to produce leaves for boiling greens or to provide pasture for stock; it does not make any roots.

Is In lots of 5 pounds, deduct 5 cents per pound. E-

1155 Early White Flat Dutch Strap-Leaved. $\odot$ Popular early,

$115 y$ Early Red, or Purple-Top Strap-Leaved. $\odot$ Standard early,

1159 Extra Early White Milan. $\odot$ The earliest flat white,

1161 Extra Early Purple-Top Milan. $\odot$ The earliest in cultivation,

1163 Red-Top White Globe. $\odot$ A fine globe-shaped table turnip,

1165 Scarlet Kashmyr, or Cardinal. Extra early,...

$116 y$ White Globe Strap-Leaved. White globe-shaped; early,...

1169 White Egg. Of handsome oval form, with thin white skin,

1171 Sweet German, or Long White French. Flesh hard; crisp,

1173 Long White, or Cowhorn. Pure white, except at top,

$117 y$ Seven-Top. Favorite in the South for forage,

1179 Large Yellow, or Amber Globe. $\odot$ Fine for table and feeding,

1181 Yellow Aberdeen. For both table and stock feeding, ........

1183 Golden Ball, or Orange Jelly. Very tender and of fine flavor,.

1185 Petrowski. $\odot$ Extra early, flat; sweetest yellow,.. Jos Each variety, 5 cents per packet.
Per oz. $\quad 1 / 4 \mathrm{lb}$. Per lb.

$\$ 008 \quad \$ 025$

$\begin{array}{llll}7 & 15 & 50\end{array}$

$12 \quad 35 \quad 125$

$10 \quad 30 \quad 100$

$7 \quad 15 \quad 55$

$7 \quad 15 \quad 50$

$\begin{array}{lll}7 & 15 & 50\end{array}$

$8 \quad 25 \quad 65$

$7 \quad 15 \quad 50$

$7 \quad 15 \quad 50$

$\begin{array}{lll}7 & 15 & 45\end{array}$

$\begin{array}{lll}7 & 15 & 50\end{array}$

$7 \quad 15 \quad 45$

$\begin{array}{lll}7 & 15 & 50\end{array}$

$8 \quad 25 \quad 70$ 


\section{RUTA BAGAS, - Swedish or Russian Turnips.}

These are very hardy and produce large, smooth bulbs, having crisp, hard, fine-grained flesh. The sinaller size roots are quite extensively used in the markets of the Northern States during the winter months, and this crop is grown also in many sections on an extended scale to furnish green food for stock and cattle during the winter months. The foliage is distinct from that of the earlier turnips, in having long, deeply lobed leaves of a smooth surface and cabbage-like appearance, as distinct from the rough, hairy leaves of deep green coloring of the turnips.

In the table varieties we offer two very distinct ruta bagas, which are of early maturity and of as quick growth as the turnip. These are the GolDEN NECKLESS (yellow fleshed) and WHITE-FLESHED NECKLESS. The roots grow three to four inches in diameter, are smoothly round and have no neck, the strap-leaf foliage starting from a central crown at the top of the bulb in the same manner as in the early strap-leaved turnips.

BURPEE'S BREADSTONE is an improved smooth, white-fleshed ruta baga of the finest table quality. IMPROVED PURPLE-TOP YELLOW or "IMPERIAL HARDY" grows to a large size and has rich yellow flesh of fine quality. These are all excellent table or market varieties. Monarch and Large White are strong-growing productive varieties.

Is In lots of 5 pounds, defuct 5 cents per pound.

Per oz. $\quad 1 / 4 \mathrm{tb}$. Per tb.

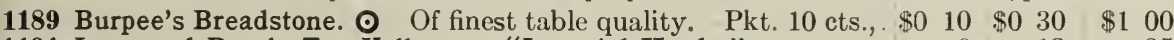

1191 Improved Purple-Top Yellow, or "Imperial Hardy," . . . . . . . $6 \quad 6 \quad 12 \quad 35$

1193 Monarch, or New Elephant. Of oblong form; yellow flesh, . . . . $\quad 6 \quad \begin{array}{lll}6 & 12 & 35\end{array}$

1194 Golden Neckless. ๑ Globe-shaped; yellow flesh, . . . . . . . . . . 7 . 75

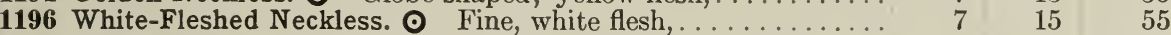

1197 Large White. Large size, white skin; nutritious and sweet, ... $\quad 7 \quad \begin{array}{lll}75 & 50\end{array}$

Is Each variety, except Burpee's Breadstone, 5 cents per packet.

\section{HERBS.}

The planting of herbs as market garden crops varies to a considerable extent as to the varieties grown in different sections. Those which are grown for the seed, such as Dill, Caraway and Coriander, are most extensively planted in the cooler Northern States for markets frequented by Germans, who make the most liberal use of al the seasoning herbs. Sage, Winter Savory and Thyme are planted in large areas in certain sections. The tender leaves and stems are cut and dried during the summer and sold in quantity to the butchers and packing houses, who use them during the winter for flavoring sausage, potted meats, etc.

The most general cultivation of herbs, however, is for small plantings of the most popular varieties to be sold green or dried in small bunches of a single variety or combined with young Leeks, Parsnips, Carrots, small Onions and Parsley in what are known as "Bouquets of Pot Herbs" : these are sold either on the market stall of the grower or at wholesale to the green-grocer. While sold for a small amount, the demand is quite constant and will yield considerable return in the aggregate as well as frequently helping the sale of other green garden products.

OUR SPECIAL LEAFLET, giving full directions for growing the different varieties of herbs, curing them and their uses, will be sent free to customers who ask for it in their orders.

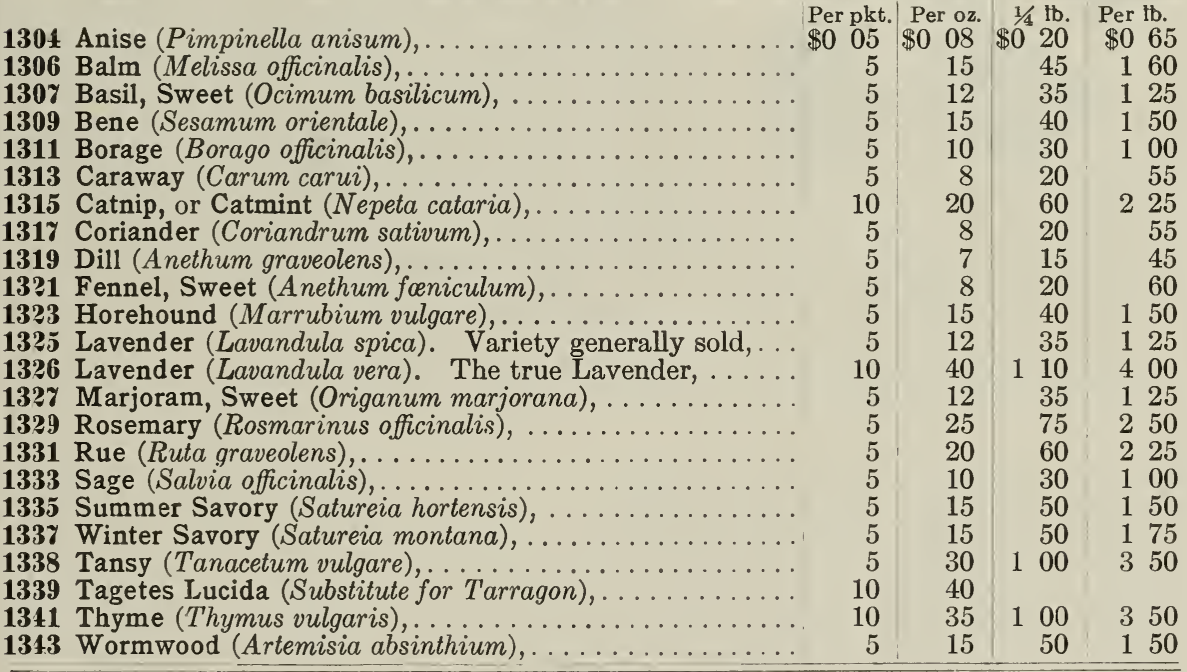

\section{TOBACCO.}

1345 Connecticut Seed Leaf. Old and well known,

1347 Lancaster County Broad Leaf. Popular and profitable,

1349 Havana. Grown from imported seed, . . . . . . . . . . .

Per pkt. Per oz. $1 / 4$ th. Per th.

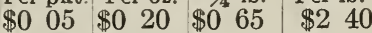

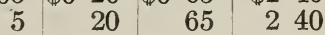

1351 Bonanza Very superior ................

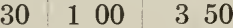

\begin{tabular}{l|l|l|l|l|}
10 & 20 & 75 & 2 & 60
\end{tabular}

1353 General Grant. Matures even in Minnesota,......... $10 \quad 30 \quad 100 \quad 350$

1355 Sterling. One of the earliest to ripen, ............ $10 \quad 30 \quad 85 \quad 300$

135y Improved White Burley. The Western favorite, ......

1359 Improved Long Leaf Gooch. Very long leaves, . . . . . $\quad 10 \quad 20 \quad 65 \quad 250$

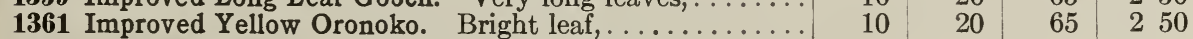

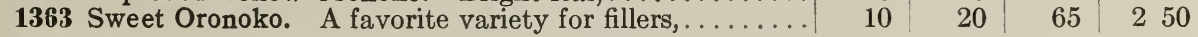




\section{BURPEE'S SELECTED FARM SEEDS.}

Our Farm Seeds are uniformly of the very best grade. They have been grown especially for seed, carefully selected, and thoroughly cleaned. The prices quoted include bags and delivery to any freight depot, express, or vessel in Philadelphia.

'Teosinte (Euchloena luxurians)

Dwarf Essex Rape. (Per 100 lbs. \$9.50),

Kaffir Corn. (Per 100 lbs. \$8.00), ...

Perpkt. Per 0 , $1 / 4$ th. Per th, 10 ll,

Vicia Villosa, or Hairy Vetch ( $\$ 6.75$ per bushel of $60 \mathrm{lbs}$.$) ,$

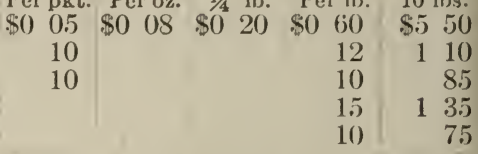

Broom Corn, Improved Evergreen,

Mammoth Russian Sunflower,

Spanish Peanuts (24 lbs. to bushel),

Per qt. 4 qts. l'eck. B ushel. 2 Bush.

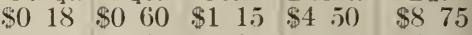

Mammoth Bush Peanuts (14 lbs. to bushel)

\begin{tabular}{lll|ll|ll}
1.5 & 40 & 65 & 2 & 50 & 4 & 85
\end{tabular}

$\begin{array}{lllllll}15 & 40 & 75 & 2 & 75 & 5 & 25\end{array}$

Chufas, or "Earth Almonds," . . . . . . . . . . .

20

20

Soja Bean,

Clay Cow Peas,

IVhip-poor-will Cow Peas,

Silver Hull Buckwheat,

New Japanesc Buckwheat,

Early Orange Sugar Cane,

Canada Field Peas, .

1.5

$\begin{array}{lllllll}60 & 1 & 00 & 350 & 6 & 75\end{array}$

65 $\quad 1 \quad 15 \quad 450,857$

$\begin{array}{llllll}50 & 90 & 3 & 50 & 6 & 75\end{array}$

$15 \quad 50 \quad 9(0) \quad 350 \quad 60$

$15 \quad 50 \quad 90 \quad 35000075$

$\begin{array}{llllll}15 & 25 & 45 & 1 & (60 & 300\end{array}$

$\begin{array}{lllllll}15) & 25 & 45 & 1 & (60 & 3 & 0(0)\end{array}$

$\begin{array}{lllllll}15 & 45 & 85 & 3 & 0(0) & 5 & 85\end{array}$

$\begin{array}{llllll}15 & 40 & 75 & 250 & 4 & 75\end{array}$

\section{FIELD CORN.}

We test annually at FORDHOOK FARMS many new and distinct varieties of field corn, and recommend confi-

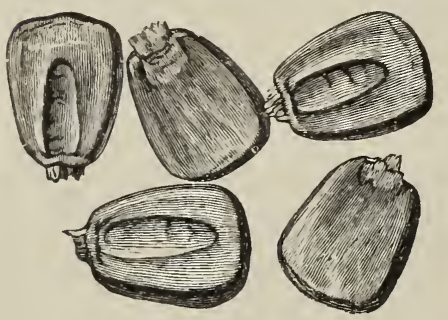

GRAINS OF GOLDEN BEAUTY CORN. dently the following as the most desirable kinds. Early Canada Yellow Flint is long-eared. eight-rowed, and very hardy, ripening in advance of all other large-eared sorts, but, on account of the small fodder and hard flinty grain, is seldom planted where the finer dent sorts will mature, unless quite late as a catch crop on unoccupied ground.

King of THE EARLies and Pride of the North are the finest of the extra early Dent corns, maturing with us in one hundred days from planting; the ears are of good size, grains slender and quite deep, yielding a very large product of shelled corn. Early Mastodon Dent is a heavy cropper and has the largest grain of any early Dent corn. Leaming is medium early, with large ears well filled with deep slender grains.

REID'S YELLOW DENT is now the standard variety in the middle West. It produces well-formed ears nine to ten inches long, well filled, and in a favorable season will average 16 or 18 rows to the ear. WHITE CAP DENT is quite hardy, medium early, with light amber grains, capped with pearly white; the grain is slightly hard and floury. Hickory King is an extra large, white-grained variety, with slender cob. BURPEE'S GOLDEN BEAUTY is a very strong grower and heavy yielder; we consider it one of the best varieties for general planting. Chester County Mammoth grows to a large size, both in stalk and ear, and is second in productiveness only to our GOLDEN BEAUTY, which yields the largest crops of any variety of yellow corn we have ever grown; both require strong, rich soil and a season of four months in which to mature the grain.

EARLY DROUGHTPROOF is a new variety with bright yellow kernels and matures a crop in from ninety to one hundred days from date of planting.

PRIDE OF INDIANA is a pure white corn of large size and is ten days earlier in ripening than any olher large while Dent corn. Our seed was grown by the originator.

King of the Earlies. The best early variety, .

Pride of the North, or Queen of the Prairie,

Mastodon Early Dent. Very handsome ears,

$\sim$ Reid's Yellow Dent. One of the best,.....

$\checkmark$ Burpee's Golden Beauty. Large, handsome yellow grains,

Early Droughtproof. Large ears, bright yellow kernels, ...

Chester County Mammoth. A productive variety, .

$\checkmark$ Improved Leaming. The favorite in many sections, .

Pride of Indiana. Large white dent, quite early,

White Cap Dent. Grains amber-yellow, tipped white,

$\checkmark$ Hickory King. A favorite large-grained white variety,

$\checkmark$ Early Canada Yellow Flint. Earliest of all,

Sugar Corn for Green Fodder,.

\begin{tabular}{|c|c|c|c|}
\hline Pol. & Per & Sack of & 10 \\
\hline $\begin{array}{l}\text { Peck. } \\
\$ 070\end{array}$ & $\begin{array}{l}\text { Bushe! } \\
\$ 240\end{array}$ & $\begin{array}{l}2 \text { Bush } \\
\$ 47,5\end{array}$ & $\begin{array}{l}\text { Bush. } \\
\$ 225()\end{array}$ \\
\hline 70 & 240 & 475 & 22.50 \\
\hline 70 & 240 & 475 & 22.50 \\
\hline 70 & 240 & 475 & 2250 \\
\hline 70 & 26.5 & 525 & 2500 \\
\hline 70 & 240 & 475 & 2250 \\
\hline 70 & 240 & 475 & 2250 \\
\hline 70 & 240 & 475 & 2250 \\
\hline 70 & 240 & 475 & 2250 \\
\hline 70 & 240 & 47 & $22 \quad 50$ \\
\hline 75 & 240 & 47 & 2250 \\
\hline 70 & 240 & 475 & 2250 \\
\hline 75 & 275 & 5) 40 & 2600 \\
\hline
\end{tabular}

For thirty-seven years we have stated plainly that, where failure is caused by any fault of the seed, we would refund the full price paid. This should convince even new customers that we have confidence both in the quality of BURPEE'S SEEDS and in the great care exercised in their growing, cleaning, and packing. No honest seedsman could assume responsibility for more than the price actually paid by the purchaser.

\section{"The Value of a Guarantee is not in what is said, but who says it."}




\section{Burpee’s “Fordhook Finest” Lawn Grass.}

The GRAND PRIZE for Lawn Grass at ST. LOUIS WORLD'S FAIR produced from BuRPEE'S "FORDHOOK FINEST" LAWN GRASS. IVe were awarded also for Lawns the Only Gold Medal at the Lewis and Clark Exposition, Portland, Oregon, I005. These were the highest awards possible, -and obtained by no other American Seedsman. The seed from which these fine lawns were produced was cxiclly the same quality as supplied regularly to our trade.

"Fordhook Finest" is composed exclusively of the best re-cleaned seeds of the choicest fine-bladed much. This mixture weighs 25 grasses, to which is added a suitable quantity of white clover, but not too (o 27 lbs. per measured bushel. Fifty pounds of seed are sufficient for if quickest possible results are desired, seventy-five to ninety pounds per acre can be used. re-cleaned seed-free from chaff-is much stronger in vitality than usual grades; a given measured

Prices for seed to be shipped by express or freight at purchaser's expense for transportation: 28 cts. per 1 b. ; 10 lbs. or more at 26 cts. per Ib.; 100 lbs. at 24 cts. per Ib. $(25 \mathrm{ll}$ )s. or more supplied at this price). This makes the cost about $\$ 6.00$ to $\$ 6.25$ per measured bushel,- - but only at the rate of $\$ 3.36$ per so-called "legal" buslicl of $14 \mathrm{lbs}$. !

We put up this finest mixture in Pound Boxes, with full directions, at $\mathbf{4 0}$

cts. per $1 \mathrm{~b}$. box, postpaid, or $30 \mathrm{cts}$. per $\mathbf{l b}$. box if sent by express.

One pound of seed is sufficient to plant a plot of $20 \times 20$ (or 400 ) square feet.

We recommend seeding at the rate of 50 to $60 \mathrm{lbs}$. per acre, but it would be better to use 75 to 100 lbs. per acre where it is desired to have a good close turf from the start.

I With each order for seed in bulk we enclose our NEw LEAFLET, giving directions for preparing the ground and sowing the seed, together with the subsequent care and proper treatment of the lawn.

"Fordhook Finest" _-by the Bushel. There are still many planters in America who Therefore we have decided to put up the seed in peck and bushel bags, at the rate of 26 Ibs. per bushel.

Price per peck (61/2 lbs.) \$1.56; per busliel (26 lbs.) \$6.24.

\section{Burpee's "SHADY NOOK"}

Lawn Grass. As this mixture is composed of the finest and most costly grasses, it cannot be sold at so moderate a price as our regular lawn mixture. It is all clean heavy seed, free from chaff, and will give the best results with a minimum quantity of seed. By express, at purchaser's expense, 35 cts. per $1 \mathrm{~b}$. Io lbs. or more at $32 \mathrm{cts}$. per lb.
Burpee's "GOLF LIN K S" Mixture. By express or freight, at expense of purchaser, 35 cts. per lb.; Io lbs. or more at $32 \mathrm{cts}$. per $\mathbf{l b}$. While the directions in our leaflet on the care of the lawn will apply to the golf lawn, we shall be glad at any time to answer special inquiries, and our grass seed experts will advise concerning the quantity of seed needed and the best preparation and subsequent management of the lawn preparation and subsequ
and "putting greens."

\section{(AB Burpee's Special Fordhook}

\section{Grass Mixture for Permanent Pastures.}

"One thing is certain, that good pasture land is the foundation of the riches of a farm."-SiNcLAlR.

The most important features of successful farming (especially on the dairy or stock farm) are good hay crops and abundant pasturage. These are more readily and surely obtained by a proper combination of the most suitable

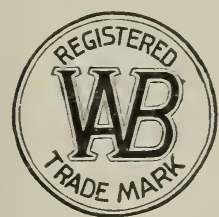
grasses than by the old plan of seeding with Timothy alone or in mixture witl Common grasses than by Red Clover, which generally dies out after the MiXTURE yields a very heavy crop of the finest and most succulent hay early in the season. together with a heavy crop of aftermath or abundant pasturage. We have planted this mixture extensively on our own fields at FORDHOOK FAR.MS for several years, with the most gratifying results, both when sown on dry, sandy hillsides and on moist meadow-lands. The base of this mixture is Orchard Grass, which is of quicker and stronger growth than Timothy and makes better hay when cut while in bloom. The Orchard Grass, however, is combined with a mumber of finer bladed grasses, which give not only greater permanence to the sward, but also entirely overcome the objectionable tendency of the Orchard Grass to grow in clumps or tufts.

We recommend using two busliels, or fifty pounds, of this mixture per acre, and it can be sown with grain or alone on well-prepared land either in the early fall or early spring. It is also an advantage to sow at the saine time, or in the spring, when fall seeded, ten or fifteen pounds per acre of ALSIKE CLOvER, as this variety is much the best for inixed hay and at the same time is hardier and will endure longer in the close thick sod of grass tlian any other. Price of Burpee's Special FordHOOK Mixture For PERManent Pastures 20 cts. per Ib.; Io lbs. or more at $18 \mathrm{cts}$. per lb., - all by express or freight, at purchaser's expense. A measured bushel of this choice recleaned seed weighs about twenty-five pounds.

WE KNOW SEEDS by means of the FORDHOOK TRIAL GROUNDS. We sell only seeds known to be good-THE BEST SEEDS THAT GROW! 


\section{Extra Clean GRASS SEEDS.}

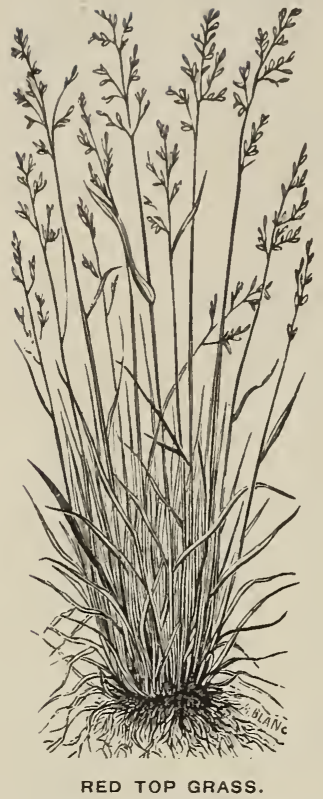

Clean grass seed of strong vitality and free from any admixture of weed seeds is a most essential requisite for successful farming. Pasturage and hay are of chief importance in all kinds of stock raising and feeding, while the rotation with other crops is necessary to keep up the fertility of the soil. We offer choice rlean seed of the leading varieties which are of the best grades obtainable. We shall be glad at any time to assist our customers in the selection of the best varieties for especial locations or purposes, as well as to quote prices on large quantities of special varieties or mixtures. As seed of some of the leading varieties is subject to frequent market changes, prices will be quoted on these by letter at any time.

Trмothy is one of the best-known grasses largely grown for marketing in the large cities, and of excellent value to grow in mixture with other grass to produce hay for stock feeding. It is of the greatest feeding value when well ripened and highly esteemed for feeding horses. HERD, or RED TOP, is a valuable native grass, desirable for meadows, pastures, and lawns in mixture with other grasses.

KENTUCKY BLUE, pre-eminently a pasture grass, resists the tramping of cattle, and thrives best in dry soils, retaining its verdure during the hottest summer weather. It is also fine for lawns. ORCHARD has long been recognized as one of the most desirable grasses both for pasture and hay. ENGLISH RYE is a nutritious permanent grass of quick growth for meadows, pastures, and lawns. ITALIAN RYE thrives in nearly all soils and is superior for irrigated meadows. CRESTED DOGSTAIL, on hard dry soils, is valuable for pastures and lawns.

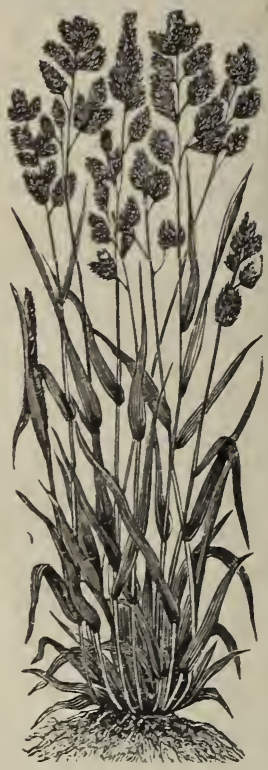

ORCHARD GRASS.

HARD FESCUE is most desirable for dry soils, sheep pastures, and for shady lawns. SheEP FESCUE is of smaller, more compact growth than the preceding. MEADOW FEscue is useful for permanent pastures, very productive and nutritious. CREEPING BENT succeeds in nearly all soils and locations. It is valuable for pastures, lawns, tennis courts and golf links, as it resists tramping and will withstand repeated clipping. MEADOw FoxTAIL is valuable only in the North and should be sown only in mixture with other grasses. TALL MEADOW OAT is desirable for permanent pastures, being of early luxuriant growth, relished by cattle, and makes excellent hay, WOOD MEADOw is a very productive and nutritious grass, adapted for lawns and pastures; thrives well under the shade of trees. ROUGH-STALKED MEADOw is of quick growth, and desirab!e for moist soils. HUNGARIAN BROMR (Bromus Inermis) is a perennial of very luxuriant growth, two to three feet in height; it is an ideal grass for hot dry regions and light or sandy soils.

HUNGARIAN MILLET is one of the most useful annual forage plants, growing quickly in any ordinary soil and withstanding both heat and drought. GOLDEN or GERMAN MILLET is of much larger and stronger growth and is enormously productive on rich soil. EAST INDIA or PEARL MILLET, of very strong growth, eight to ten feet high, should be sown in rows four feet apart and cultivated like corn.

For general planting, either for hay or pasture on widely differing soils, we cannot too strongly récommend our PeRmanent PASTURe Mixture, as it makes a close dense sod, grows strongly and yields large crops of hay. or abundant pasturage. We have found it equally satisfactory for level meadow lands and exposed sandy hillsides, where the close sod is of great value in preventing gullies in heavy storms.

OUR FORDHOOK FINEST LAWN GRASS is compounded of the choicest and best varieties for quickly forming a fine, close, velvety sward, which increases in density each season, if kept properly rolled and frequently mown. We send free with the seed, if requested. full directions for preparing and seeding the lawn.

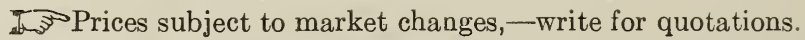

Per to. Bushel.

Grass Mixture for Permanent Pastures. (10 lbs. or more at $18 \mathrm{cts}$.),

SO 20

28

35

Burpee's "Shady Nook" Lawn Grass. (10 lbs. or more at 32 cts.), .

Burpee's "Golf Links" Mixture. (10 lbs. or more at $32 \mathrm{cts}$.),

Fancy Cleaned Kentucky Blue Grass (Poa pratensis). (20 lbs. to the bushel),

Fancy Herd, or Red Top (Agrostis vulgaris). (32 lbs. to the bushel),

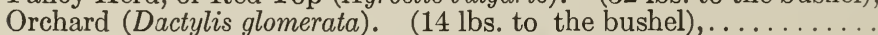

Tall Meadow Oat (Avena elatior). (10 lbs. to the bushel),. .

Wood Meadow (Poa nemoralis). (20 lbs. to the bushel),

Rough-Stalked Meadow (Poa trivialis). (20 lbs. to the bushel),

Meadow Foxtail (Alopecurus pratensis). (7 lbs. to the bushel),

Bromus Inermis (Hungarian Brome). (14 lbs. to the bushel),.

English Rye (Lolium perenne). (24 lbs. to the bushel),. .

Italian Rye (Lolium talicum). (20 lbs. to the bushel),.

Crested Dogstail (Cynosurus cristatus). (25 lbs. to the bushel),

Hard Fescue (Festuca duriuscula). (20 lbs. to the bushel),

Meadow Fescue (Festuca pratensis). (22 lbs. to the bushel),

Sheep's Fescue (Festuca ovina). (18 lbs. to the bushel),

Creeping Bent (Agrostis stolonifera). (25 lbs. to the bushel),

Timothy (Phleum pratense). (45 lbs. to the bushel.) Write for prices,

Hungarian Millet.

Fluctuates .about about

East India or Pearl Millet. (Pencillaria.) (10 lbs. or more at 10 cts. per lb.),
$\$ 360$

900

250

210

625

650

200

280

250

245

675

450

385

425

825

210

265 


\section{CLOVER SEED.}

The Clover seed we offer is exclusively of the finest grades, and is free from trash veed seeds, or dodder. We do not attempt to compete in price with the low-priced grades usually sold in country stores and by jobbers. The additional cost for the best and cleanest seed is money well invested, when the prime importance of securing a good stand with freedom from noxious weeds is considered. While the seed we offer is all of high germinating power, we advise sowing a liberal quantity to insure a satisfactory stand, as the extra cost of five or ten pounds more seed per acre is very slight as compared with cost of plowing and reseeding, aside from the loss of a season's crop of hay or pasturage.

The common or RED MEDIUM ClOver, frequently called Cow Grass, and its larger type, the MaMmoth PE.t-Vine Clover, are the varieties usually sown in the Northern and Middle Western States, either alone or in connection with grasses. Both are strong-growing biennials, yielding two or more crops of valuable forage per season, and endure for several years.

ALSIKE or HYBRID CLOVER is not so generally known, but we consider it of even grealer value. It is especially desirable for sowing with other grasses for mixed hay, as the stalks are more slender, grow to a greater height, and, blossoming later, it is in the best condition for cutting at the same time as Timolhy and other late-flowering grasses. It is also more persistent than the Red Clovers and will endure longer in the sod when grown with other grasses.

The CRIMSON or ITALIAN ClOveR is an annual variety of very rapid growth during cool moist weather, and is largely planted for a green crop to turn under in the spring. If sown late in the summer or early in the fall among cultivated crops, it will grow strongly during the winter, affording a dense heavy mat of green foliage to turn under in the spring in ample season for planting corn and other crops. Gathering large quantities of nitrogen from the atmosphere, it is a wonderful soil enricher when used in this manner. It can also be cured into excellent hay if cut before the hairy seedheads form; if these are allowed to mature, they are quite injurious when fed to stock, forming hair-balls in the animal's stomach.

ALFALFA, or LUCERNE, is largely grown in the West, and is being extensively planted in the Eastern States. It is a perennial clover-like plant growing from two to three feet high, and is especially valuable for dry climate and soils, as the roots penetrate deeply. When once established it increases in strength with succeeding years. It endures for many years, makes a rapid growth, and yields immense crops of valuable forage,-from three to five cuttings in a season. It is of great value as a soil enricher. For the best results, seed should be sown alone early in the spring or during the month of August, according to location.

SAINForn, also called French Grass and Holy $H a y$, is a perennial plant of cloverlike growth, thriving best in chalky and sandy soils, dry gravel, etc. The stand improves with age, the well-established plants being of strong luxuriant growth, excellent for forage and to enrich the soil. It will resist drought much better than other clovers and is extremely valuable to prevent soils from washing during heavy rains, as well as binding and enriching light, loose soil. It is rather tender in our northern winters and is not recommended for sowing north of Virginia.

The White DUTCH CLOVER thrives in almost all soils and climates; valuablein mixture with other grasses for lawns and pastures. It is highly nutritious and very enduring. The blossoms afford the finest bee pasture and make the most delicious honey.

Clover seeds should be sown broadcast quite early in the spring (sow Alfalfa during August) at the rate of fifteen to twenty-five pounds per acre.

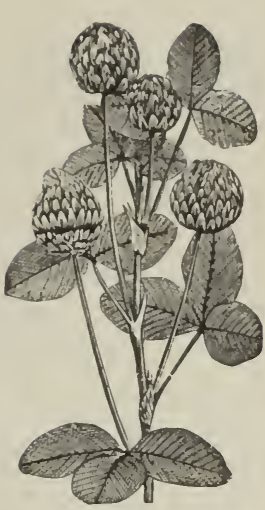

ALSIKE CLOVER.

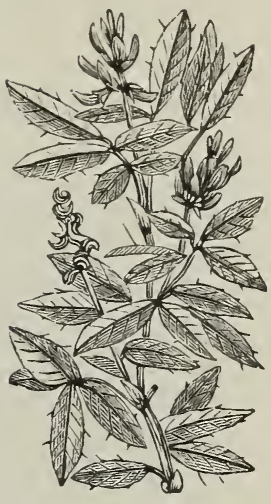

ALFALFA, OR LUCERNE.

Do Prices subject to market changes; write for quotations.

Per tb.

Red Medium (Trifolium pratense). (Write for prices),.............. Fluctuates. Mammoth Red, or Pea-Vine (Trifolium pratense hybridum). (Write for prices),. Fluctuates. Alsike, or Hybrid (Trifolium hybridum). (Bushel of 60 lbs., about \$15.50), ...... \$0 28 Alfalfa, or Lucerne (Medicago sativa). (Bushel of 60 lbs., about $\$ 10.00), \ldots \ldots \ldots \ldots .20$

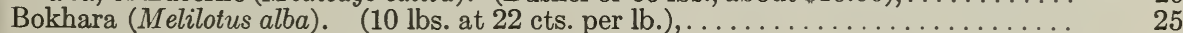
White Dutch (Trifolium repens). (10 lbs. at 40 cts. per lb.),.............. 42

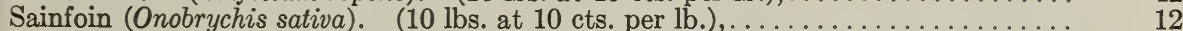

Crimson Trefoil, or Scarlet Italian (Trifolium incarnatum). (Bushel of 60 lbs., about $\$ 6.00)$

\section{OATS.}

The WHItE TARTAR KING is a very hardy and enormously productive variety. In our Northern States it has proved to be much superior to the older varieties, producing large crops of heavy, plump, white grain of the finest character.

The DANISH ISLAND is a very hardy variety, with strong stiff straw: it is a heavy yielder, and in northern New York has replaced most other varieties. The WELCOME OATS grow quite tall, furnishing a large crop of fine straw, while the large branching heads yield an immense crop of heavy grain.

The GOLDEN GIANT SIDE OATS are very hardy and productive; we have found this variety especially adapted to thin land and dry hilly locations. Sow two to three bushels per acre broadcast, as early in the spring as the ground can be properly prepared.

Danish Island,

\section{Welcome,.}

Golden Giant Side,

White Tartar King,
Bush. of Sack of Per 10 32 ibs. 2 Bush. Bush.

$\begin{array}{llllll}\$ 1 & 40 & \$ 2 & 75 & \$ 13 & 50\end{array}$

$\begin{array}{llllll}1 & 40 & 2 & 75 & 13 & 50\end{array}$

\begin{tabular}{ll|llll}
1 & 50 & 2 & 85 & 14 & 00
\end{tabular}

\begin{tabular}{ll|llll}
1 & 40 & 2 & 75 & 13 & 50
\end{tabular}

BURPEE'S SEEDS GROW and are famous for the Uniform Excellence of their Products 


\section{Burpee's Flower Seeds for Florists.}

\section{Choicest Selected Strains of Annuals, Biennials and Perennials.}

At Fordiook Farms (in Pennsylvania), Sunnybrook Farm (in New Jersey), and our Floradale FARM (in California) we are growing acres of flower seeds, especially those varieties that do best in the different localities. Other flower seeds are produced on contract by careful growers both at home and abroad,- - subject to personal inspection.

\section{ON all ORDERS for SEEDS IN RETAIL PACKETS we}

allow a discount of thirty-three and one-third per cent. from the price quoted "per packet," as stated on page 2.

Growing Flowering Plants from Seed for Spring Sales Florists are all familiar with plants for spring sales from cuttings, but this plan necessitates devoting quite an extended space in the greenhouse to wintering over the stock plants to furnish cuttings in the spring. By growing a supply of plants from our choice varieties of flower seeds early in the spring, much space is saved which can be devoted to cut-flowers or forcing vegetables for market at a time when these bring the greatest returns, and the seeds can be started in the same area as would be required for the cuttings. This is the day of specialties, and it is our great specialty to furnish the best seeds in the finest varieties, while it is yours to sell the flowering plants. Seeds started in the warm, bright days of early spring will grow rapidly into fine blooming plants, and are much stronger and continue longer in bloom than those grown from cuttings. In our list of flower seeds will be found choice new varieties of Begonias, Coleus, Heliotrope, etc., and a fine stock of these may be much more quickly raised from seed than they could be from cuttings, unless a large number of stock plants were purchased. For spring sales as pot plants we would especially recommend Alyssum, Begonias, Marguerite, Carnations, Coleus, Forget-me-nol, Heliotrope, Linaria (Kenilworlh Ivy), Mignonelte, Mimulus, Nasturtium, Pansies, Petunias, Drummond Phlox, Ricinus, Salvia, Stocks, Sunflower, Torenias, Vincas, and Verbenas, with some of the Climbers, such as Coboea, Moon Flower, and Thunbergia.

For summer and fall sales of pot plants: Chinese Primrose, Primula Obconica, Gloxinias, Begonias, Fancy Geranium (Perlargonium and Apple-Scented), and Cyclamens are most readily grown from seed.

For cut-flowers our reputation as HEADQUARTERS FOR THE FINEST SWEET PEAS is well established, but we wish to call the attention of florists to our superior strains of other fine flowering plants suitable for this purpose. Our grand strains of Asters, Balsams, Mignonelle, Pansies, Pinks, Stocks, Gladioli, Tuberoses, etc., will be found described in BURPEE'S NEW ANNUAL FOR I9I4, and those who have never purchased of us in the past, or have neglected planting these valuable adjuncts to the florist's stock of cut-flowers, will derive the best possible results with these most carefully selected and thoroughly tested seeds and bulbs.

\section{Abutílon.}

Our seed, although sold only in mixture, is saved from the choicest named varieties and gives great satisfaction grown either as pot-plants or for bedding.

1503 Royal Prize, Mixed (Per $1 / 8$ oz., 60 cts.) $\$$ PKT. io $\$ 4$. 50

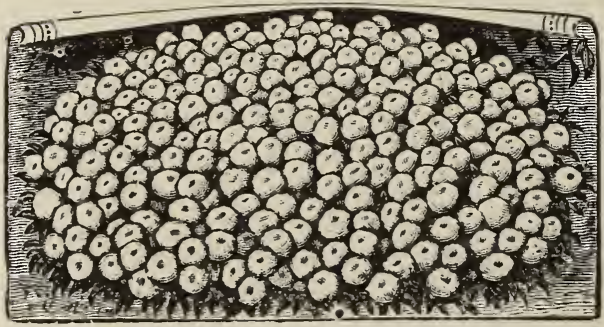

LITTLE GEM.-THE BEST SWEET ALYSSUM.

\section{Alyssum.}

Litlle Gem, a true dwarf of very compact growth, only three inches high when in full bloom, is the finest for potplants or edging, but too short-stemmed for cut-flowers. Benthami is a well-known white variety, while the Bentham compactum is more dwarf and compact in growth and is also known as Tom Thumb. Saxatile is a hardy variety producing a profusion of bright yellow flowers.

1520 Benthami (Sweet Alyssum)

1521 Benthami Compactum. .

1524 Little Gem.

3706 Saxatile Compactum

\section{Ageratum.}

Mexicanum is the old, small, blue-flowered type, growing two feet high, and Albiflorum its white-flowered counterpart. The Tom Thumb varieties, though very dwarf and compact in growth, have heavy foliage and large flowers.

1505 Mexicanum.

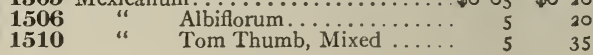

\section{Agrostemma.}

Cali Rosea is an annual, while Coronaria atrosanguinea is a hardy perennial, both being of easy culture. The rose and blood-red flowers are useful for cutting.

1514 Coli rosea ............... PKT. 3704 Coronaria atrosanguinea.

\section{Antirrhinum (Snacdragon).}

Planters in America have for years overlooked the great beauty of the Antirrhinum, but that they are at last awakening to the value of the blooms for use as cul-flowers is proved by the gorgeous displays to be seen in florists windows now in the autumn, winter and spring.

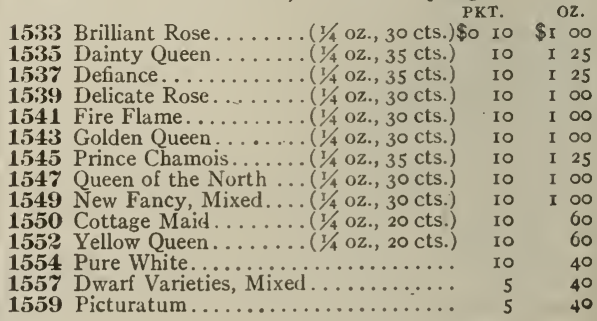




\section{Aquilegia (Hardy Columbine).}

Hardy plants, ornamental both in growth and flowers. Seed should be sown early in the spring and the plants transplanted or thinned out to stand twelve inches or more apart each way. The larger varieties form compact clumps of fine foliage, twelve inches in height and of equal diameter in rounded form. Early in the spring these are surmounted by tall spikes bearing clusters of beautifully colored flowers. The flowers are of distinct and attractive form. They succeed well in moist shaded locations, and are highly ornamental planted among rockwork or in the garden.

These highly ornamental perennials have of recent years become very popular. New Long-Spurred Hybrids have originated through many years of careful hybridizing.

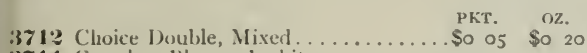
:3714 Curulea, Blue and white 3716 .New Long-Spurred (Per $1 / 40 \%$..., 35 cts.) 371s Skinneri .......... (Per $1 / 40 z ., 30 \mathrm{cts}$. 10.125 x० 125 10 1 o

\section{Arabis.}

Among the first flowers to bloom in spring, the large white heads being useful for cutting.

:3720 Alpina

PKT. SO OZ.

\section{Arctotis.}

Forms a handsome bush for garden decoration, producin freely large silvery white daisy-like flowers. The under part of the petals is of lilac-blue. One of our most attractive annuals.

1.566 Grandis . . . . . . . . .

\section{Asparagus.}

This is most popular with florists, bnth as a decorative pot-plant and for florit decoration; it is quite tasily grown from seed.

3900 Plumosus Ninus... (roo seeds, 50 cts.)\$o I5 $390^{\circ}$ Sprengeri.......... (Per 1/2 0z., 30 cts.) ro \$o 50

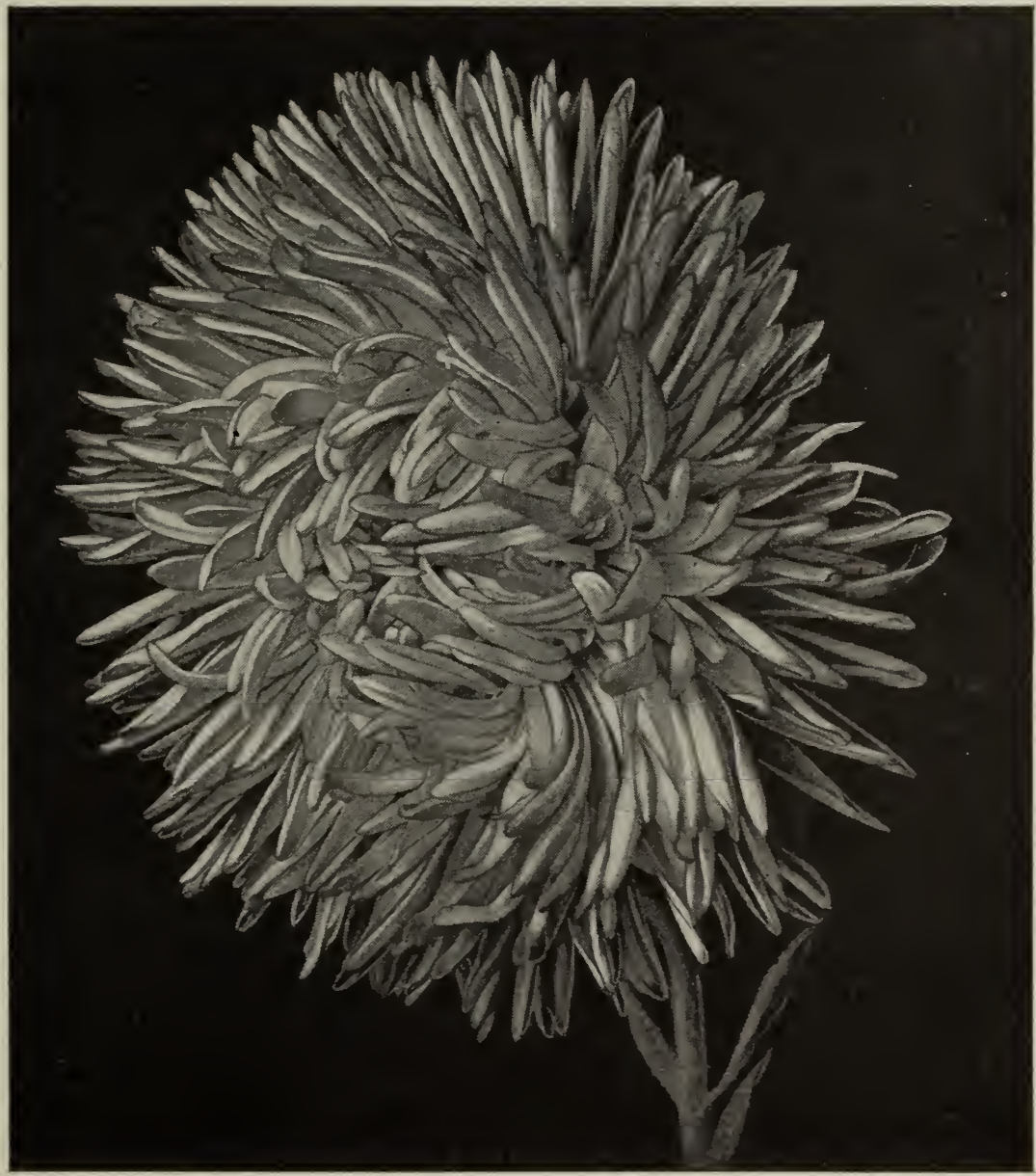

Aster,_-Violet King. Reproduced from a Photograph. The illustration shows how double and 


\section{Best American and European Asters.}

Asters have been for years one of the most popular out-of-door flowers with florists everywhere. It is not so long ago that we depended solely on Europe for our supply of seeds, but during the past ten years, there have been originated American types which have, to a great extent, displaced many of the foreign strains.

Asters succeed best in cool moist climates, doing well both in Pennsylvania and farther North. In the South, fine flowers may be had during the cool fall months by planting seed about the first of June. Plants are quite hardy and will stand light frosts. Seed should be sown thinly in shallow drills in the open ground when trees are starting out in leaf, or may be started indoors in a cool room for earlier flowering. When well started, the dwarf varieties should be thinned out or transplanted six to eight inches apart in the row, while taller varieties should stand ten to twelve inches apart and late tall-branching varieties twelve to fifteen inches apart in the rows, with rows at the same or even greater distance apart to admit of frequent cultivation during growth. The dwarf and moderately tall varieties also make excellent pot-plants, the young plants being transplanted to larger pots as they increase in growth until flower-buds appear.

In localities where flowers are destroyed by the black beetle, these pests may be avoided by planting seed early in the house, so as to have plants for flowers before August when the beetles make their appearance, or by planting seed the last of May in the open ground, so as to have flowers open in September and October after the beetles have disappeared. We

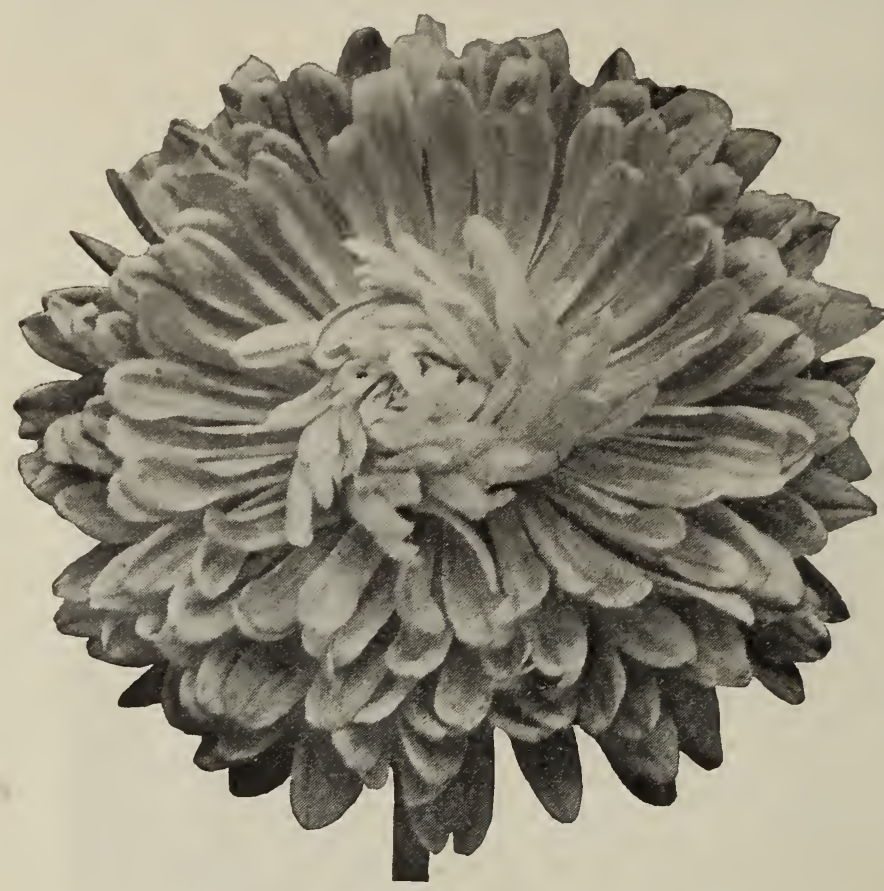
send free, with all orders for seed, if requested, our Leafiet giving full directions for growing the finest Asters.

Asters have always been a favorite at FORDHOOK, and we know by hundreds of trials made annually that the seed we offer will produce flowers of the best quality.

We recommend the planting of a number of varieties to insure a full supply of blooms during the late sum. mer and early fall.

The earliest types to produce fine large flowers are QUEEN OF THE MARKET and COMEr, the former blooming during July while the latter comes into full bloom early in August.

For mid-season flowering, we recommend the VICTORIA, TRUFFAUT'S PEONY-FLOWERED PERFECTION, and the different colors in the DAYBREAK type. These are all stiffly erect or upright in growth, averaging two feet high in good soil, and produce fine large double flowers on stiff stems of good length. The Victoria flowers have flatly spread petals, reflexed or curving downward at the outer edges, while the Paony Perfection have the petals more erect and slightly curved inward.

The Daybreak is of attractive upright growth and produces during August beautiful globe-shaped flowers.

ASTER,-ROYAL LAVENDER,-from a Fordhook photograph.

EARIY BRANCHING or

Royal is a new type or class filling in nicely the season between Oueen of the Market and Semple's or Late Branching.

The CREGO ASTERS commence blooming about the middle of August and continue to produce the large well-formed double flowers throughout September.

For the latest supply, plant the Semple's Branching Asters. These grow two or three feet high and branch very freely, the flowers being of the largest size (21/4 to 4 inches across), and each furnished with a long stiff stem, rivaling the Chrysanthemum.

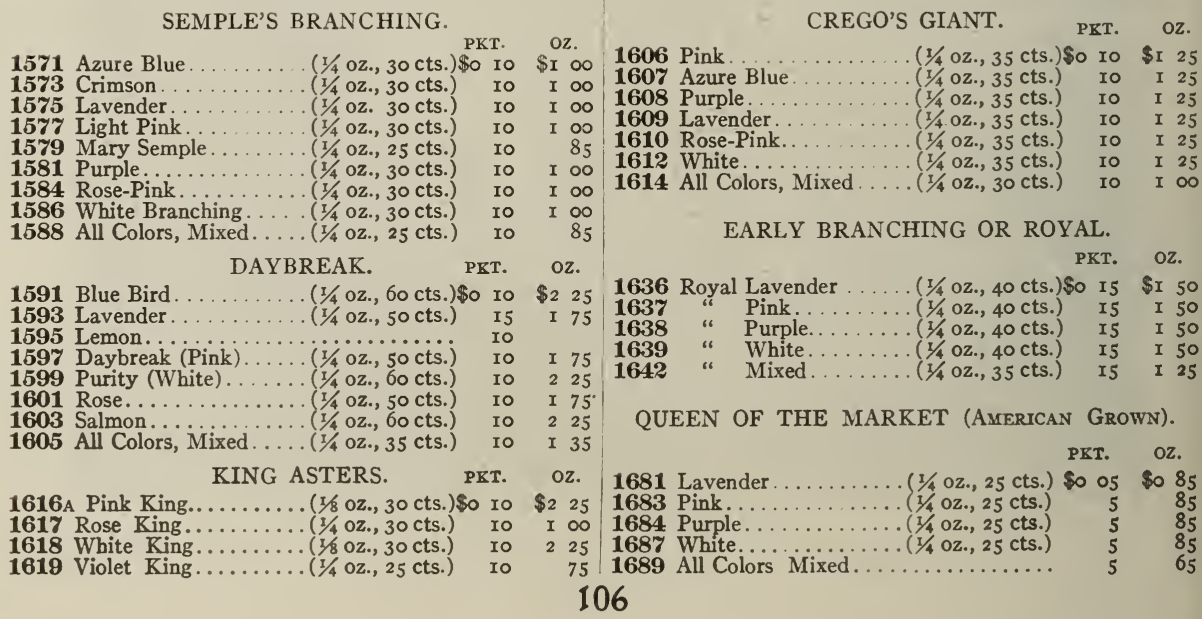




\section{Best American and European Aster Seed.}

OTHER AMERICAN ASTERS.

\begin{tabular}{|c|c|c|c|}
\hline 1615 & Crimson $\underset{(1 / 40 \mathrm{oz}, 35 \mathrm{cts}))_{\mathrm{S}}^{\mathrm{P}}}{\mathrm{P}}$ & & \\
\hline $16 \div 20$ & $\begin{array}{l}\text { Mikado or Rochester } \\
\text { (1/40z., } 35 \mathrm{cts} \text {. }\end{array}$ & & \\
\hline $16 \geq 1$ & $\begin{array}{l}\quad(1 / 4 \text { oz., } 35 \mathrm{cts} \text { ) } \\
\text { Lavender Rochester }\end{array}$ & Is & \\
\hline $16 \div 2$ & $\begin{array}{l}\text { (1/4 oz., } 35 \text { cts. }) \\
\text { White Mikado }\end{array}$ & Is & \\
\hline & America (1/4 oz., $35 \mathrm{cts})$ & 15 & \\
\hline $16 i^{2}$ & $\begin{array}{l}\text { Amenca }(1 / 40 z, 60 \mathrm{cts}) \text {. } \\
\text { Cardinal. (1/8 oz., \$ } 1 . \infty 0)\end{array}$ & $\begin{array}{ll}\text { Ic } \\
\text { I }\end{array}$ & \\
\hline 1626 & Electric. (1/4 oz., $60 \mathrm{cts})$. & Is & \\
\hline 1638 & $\begin{array}{l}\text { Pink Beauty } \\
\text { ( }(1 / 4 \mathrm{oz}, 75 \mathrm{cts}) \text {. }\end{array}$ & IC & \\
\hline $16: 30$ & Pink Peerless & & \\
\hline 1632 & White Fleece $(1 / 40 \mathrm{oz}, 50 \mathrm{cts})$. & IC & \\
\hline 1633.5 & $\begin{array}{l}(1 / 8 \mathrm{Oz},, 40 \mathrm{cts} .) \\
\text { Lavender } \mathrm{Gem}\end{array}$ & IC & \\
\hline 1643 & $\begin{array}{r}(1 / 40 z, 60 \mathrm{cts}) \\
\text { Burpee's New American }\end{array}$ & IC & \\
\hline & Union, Mixed . . . . . & IC & \\
\hline
\end{tabular}

\section{COMET.}

$16+4$ Bright Light Blue bordered with White

1616 Clear (1/4 oz., 35 cts.) ro I 25

( $1 / 4$ OZ., 35 cts.) ro I 25

1650 (1/4 oz.. 35 cts.) Io I 25

(1/4 Oz., 35 cts.) I0 I 25

( $1 / 4$ oz., 35 cts.) I0 I 25 1654 Lilac bordered with White 1656 Pure Lilac

1658 Pu (1/4 Oz., 40 cts.) I0 I 50

1660 All (I/4 oz., $40 \mathrm{cts}$ ) ro I 50 1660 All Colors, Mixed...... Io I

\section{TRUFFAUT'S PAONY-FLOWERED}

1692 Darkest Blue...... (1/40z., $40 \mathrm{cts}$.)\$O PKT. 1692 Darkest Blue......... (1/4 oz., $40 \mathrm{cts}$.)\$ 1696 Snow White.......... (1/4/4 oz., $40 \mathrm{cts}$.) 1698 Finest Mixed............ (1/4 oz., $30 \mathrm{cts}$.

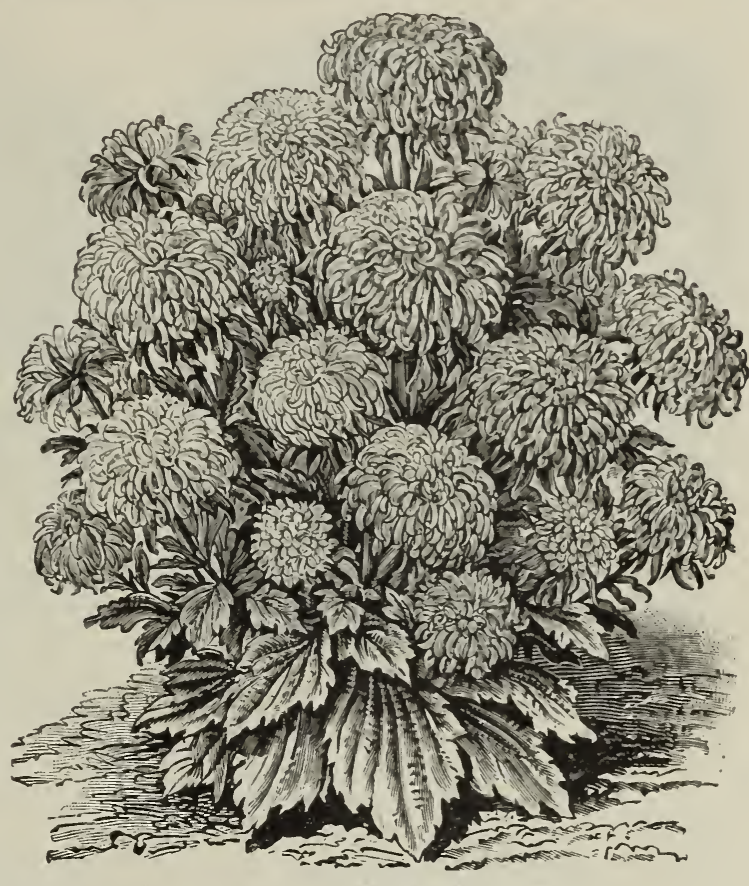

LAVENDER GEM ASTER.

GIANT COMET.

PKT. OZ.

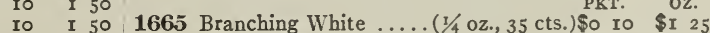
Io I 001667 Giant Comet, Mixed ...(1/4 oz., $30 \mathrm{cts}$.) ro I

\section{European Varieties of Asters.}

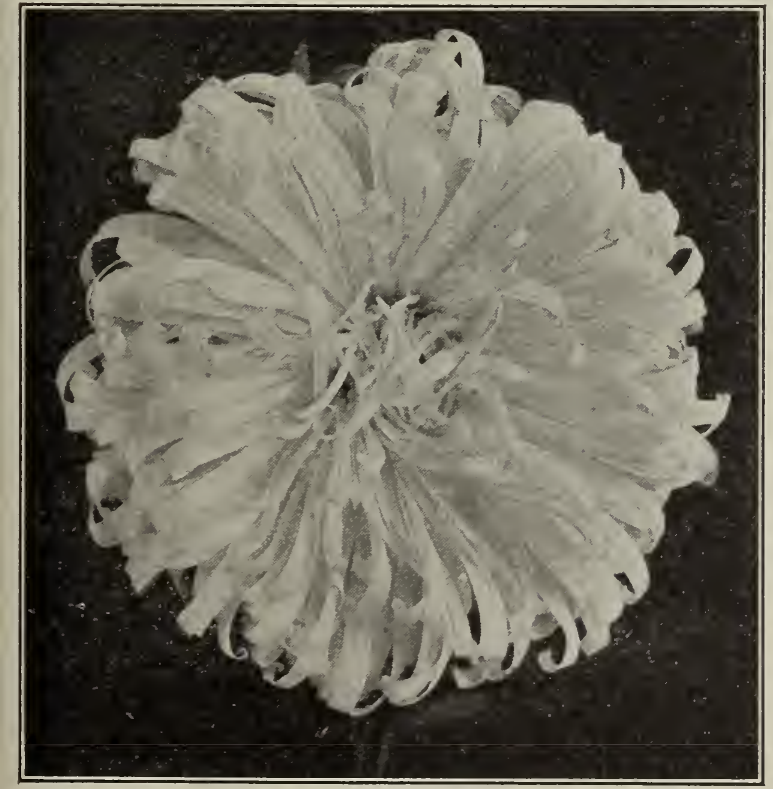

ASTER,-GREGG'S GIANT WHITE,-from a photograph.

VICTORIA

PKT. OZ

1700 Blue(1/4 oz., 50 cts.)\$o Io \$1 75 1702 Scarlet

(1/4 oz., $50 \mathrm{cts}$ ) I0 I 75

(1/40z., 50 cts.) Io I 75 1706 Finest Mixed

$(1 / 4$ oz., 35 cts.) Io I 25

LARGE-FLOWERED DWARF QUEEN.

1670 Crimson

PKT. Oz.

(1/ oz., $50 \mathrm{cts}$ ) \$o Io \$I 75 16 \% Dark Blue

1684 (1/ oz., 50 cts.) Io I 75

( $1 / 4$ oz., 50 cts.) Io I 75 1676 White

1679 Finest (I/4 oz., 50 cts.) Io I 75 $(1 / 4 \mathrm{oz} ., 40 \mathrm{cts}$.) ro I 50

OTHER ASTERS

1723 Japanese Mixed PKT. Oz. (1/40z., 35 cts.)\$O Io \$I 25 1730 Dwarf Chrysanthe-

mum - flowered

Fine Mixed

(1/40z., 25 cts.)
1731 German Quilled,

Mixed......... 545

$\begin{array}{rrr}1735 \text { Mixture......... } & \text { ro } & 85 \\ 1736 \text { Mixed ......... } & 5 & 65\end{array}$ 


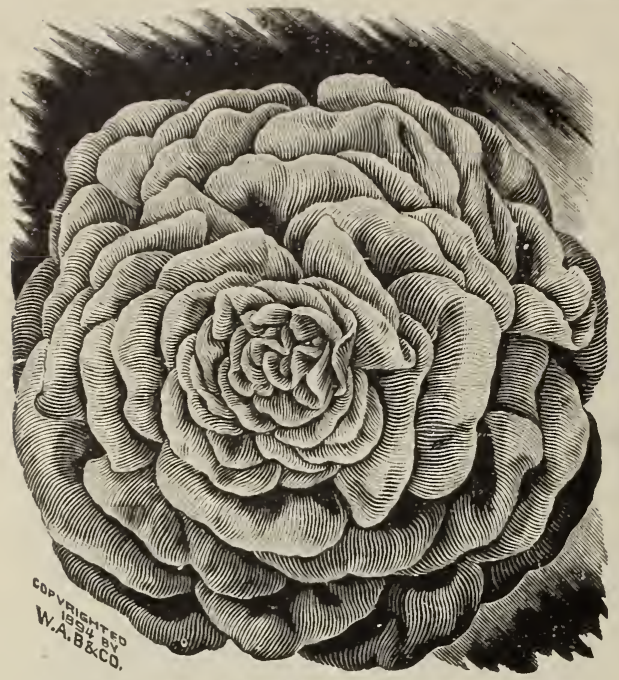

A FLOWER OF BURPEE'S DEFIANCE BALSAM. Engraved from a Pholograph.

\section{Burpee's Defiance Balsams.}

Balsams, or, as they are commonly called, Lady's Slippers, reach their finest perfection of growth and bloom at FORDHOOK, and our strains from many years of the most careful selection can be depended upon to producc the finest double flowers. Our Defiance White is especially selected to produce the best double white flower of largest size and finest camellia form (double centers and reflexed petals) for florists, who grow this variety on a large scale to furnish fine white flowers for design-work through the summer.

1741 Chamois Rose

1742 Burpee's Exquisite.

(I// oz., 50 cts.) PKT. I0 OZ.

1743 Pure Pink

(1/4 oz., 50 cts.) I0 I 75

1743 Pure Pink............ (1/4 oz., 50 cts.) Io I 75

1746 Scarlet White Spotted (1/ oz, 50 cts)

1748 Carlet, White-Spotted. (1/4 oz., $50 \mathrm{cts}$.) Io

1750 Shining Scarlet........ (1/4 oz., $45 \mathrm{cts}$.) Io I 60

1752 Violet, White Spotted . (1//40z, $45 \mathrm{cts})$ IO

1754 Pure White.......... (1/4 oz., 50 cts.) Io I 75

1756 White, Tinted Lilac.... (1/4 oz., 50 cts.) Io I 75

1759 Mixed.

1761 Fordhook Fancy

1762 Fordhook Tricolor

\section{Bellis Perennis (Double Daisy).}

A hardy perennial free-flowering plant of dwarf compact growth. The plants are entirely hardy and

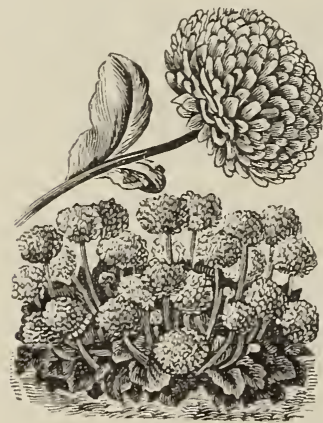
early spring and cool fall months. Seed should be sown quite early in shallow drills, and when well started the plants can be transplanted or thinned out to stand at some little distance apart, as they spread rapidly in rich soil. They also flower freely in a cold-frame during winter months under the same conditions as Pansies and Violets. Plants raised from our choice strains percentage of fine double flowers.

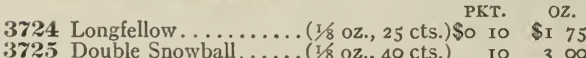

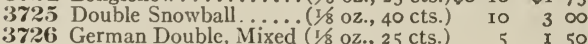
3727 Double Quilled, Mixed (1/80z., $50 \mathrm{cts}$ ) ro 15

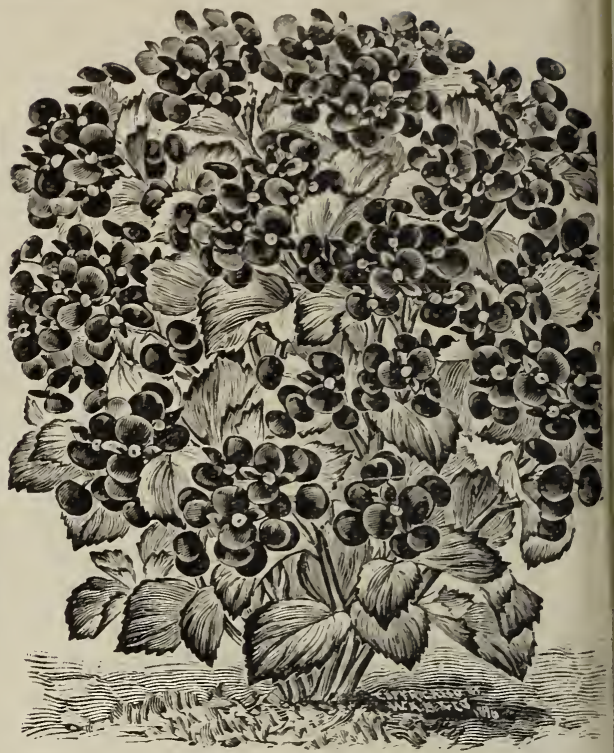

BURPEE'S VULCAN BEGONIA.

\section{Begonias.}

Few florists as yet realize what fine Begonias can be raised quickly and easily from seed for sale as pot-plants or summer bedding or for house blooming throughout the year. Begonia Vernon is a choice strain of the Semperflorens type, which grows finely and flowers profusely in the open ground, having deep pink flowers: Burpce's $V$ ulcan is similar in growth, bearing flowers of the brightest scarlet. Duchess of Edinburgh and Gracilis alba are exceedingly fine and recommended for bedding.

Gracilis Prima Donna produces attractive light pink flowers on handsome plants of compact growth.

\section{Begonia.-Free-Flowering. (Semperflorens.)}

772 Duchess of Edinburgh ..... (1 OKT. 1774 Gracilis Alba................. (3.2 $02 ., 75 \mathrm{cts}$. 1776 Gracilis Prima Donna........ (1) 1778 Vernon................. 1780 Burpee's Vulcan.............. (12 $02 ., 40 \mathrm{cts}$. 1784 Burpee's Special Mixture .....(1, oz., $40 \mathrm{cts}$.) I0 3909 Large-Leaved Rex........ (500 sceds, 40 cts.) 25

Tuberous-Rooted Begonias.

3905 Tuberous-rooted Begonias, Gigantic, SingleFlowered, Mixed. We recommend the single varieties as the best for general purposes. A packet contains aboul 500 seeds. Per pkt. 25 cts.; half-size pkt. 15 cts. Trade Packet of rooo seeds, 35 cts.

3907 Tuberous-rooted Begonias, Double, Fine Mixed, carefully hybridized. Per small pkt. 25 cts. Trade Packet of 500 seeds, $\$ 2.25$

For Prices of Begonia Bulbs see page 145.

\section{Brachycome Iberidifolia.}

\section{(Swan River Daisy.)}

The Swan River Daisy is of a close, compact habit of growth, and is well adapted for small beds or rockeries.

1790 Brachycome Iberidifolia............ \$o 05 \$o 45

\section{Calceolaria (Pocket Flower).}

Fine plants for decorating and pot-plants for early spring ales, while they can, with care, be used also as cut-flowers. 3913 Hybrida, Mixed. ....... (I000 seeds, 35 cts.) So 25 


\section{Calendula (Pot Marigold).}

Very free-flowering plants for summer bedding, blossoming until cut off by frost, and quite desirable for potplants for spring sales. Oriole, large, bright yellow; Royal Marigold, "Trianon," rich sulphur-yellow, shaded with dark brown. Both of these are of the improved largeflowered type, with fine, double centers. Favorile is a new and beautiful variety; the flowers are very double, of a rich sulphur-yellow with a faint creamy-white stripe in center of each petal.

1799 Favorite

1801 Oriole, Bright Yellow

1803 The Royal Marigold, "Trianon
1805 Double, Mixed (Pot Marigold)

So 10 \$o 15

12

\section{Calliopsis.}

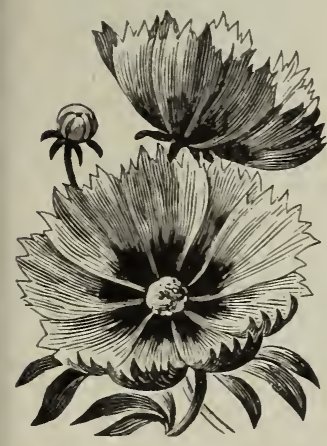

This is excellent for cutting.

Free-flowering annuals of quick growth, fine for bedding, and quite useful for cut-flowers. Coronata has large flowers on good stems, bright yellow deepening to orange at the center, and richly marked with maroon; Drummondii, or Golden Wave, is compact in growth with bright-golden flowers two inches in diameter, with dark-
brown center. Golden Ray is a new variety producing handsome flowers.

Grandiflora is a hardy perennial, blo o m ing throughout the summer, producing large single golden-yellow flowers.

1807 Coronata...................... \$o 05 \$o 20

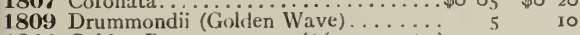
1811 Golden Ray.......... (1/4 0z., 25 cts.) ro 75

1813 Mixed

3768 Grandiflora (Coreopsis).

\section{Campanula, or Canterbury Bells.}

Hardy biennials which produce large bell-shaped flowers in great profusion the second spring from seed. Colors very rich and showy, pure white light and dark blue and pink selfs as well as shaded combinations. Calycanthema is the wellknown "Cup and Saucer" Canterbury Bells. Persicifolia (Pe a c h leaved Bell-Flowers) is a hardy perennial, producing long spikes of blue and white flowers. The spikes frequently measure two to three feet high. Desirable for both garden and pot cul ture.

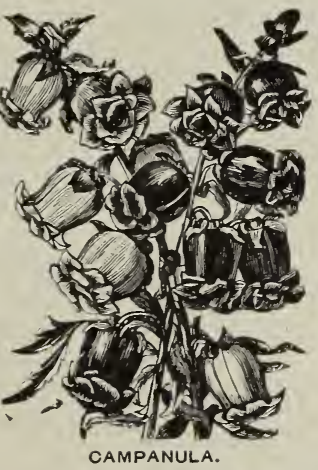

PKר.
Candytuft.

This is one of the most useful flowers for design-work and, by successive sowings, orists can have a fine suply during the summer sea on; it will also produce fine, winter when grown in a cool greenhouse. The Giant HYACINTH-FLOWERED is the inest strain in cultivation producing immense heads of large, snow-white flowers. New Empress also has fine large flowers. Rocket is the strain usually planted by florists, but not so desirable as those mentioned above The Dark Crimson has flow ers of a deep rich crimson while in the New Carmine the flowers are a soft carmine

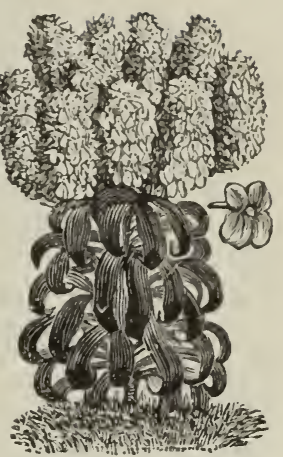
jink.

Sempervirens is a perennial variety with white flowers.

1816 Giant Hyacinth-flowered .......... \$o io \$o 50

1818 Giant Empress......... (Per lb., \$2.50) 5

1820 Tom Thumb (White) ........... 5 . 5 I5

1822 White.............. (Per tb., $6_{5}$ cts.) 5

1824 Rocket.............. (Per lb., 75 cts.) 5 (o

1826 Dark Crimson.................. $5_{5}$ I $_{5}$

1828 New Carmine ................. $5{ }_{5} 25$

1830 Mixed............. (Per th., 75 cts.) 5

1838 Large-flowered Dwarf Hybrids, Mixed 10 6,

3829 Sempervirens...... (Per $1 / 4 \mathrm{oz}$., $60 \mathrm{cts}$.) 10 225

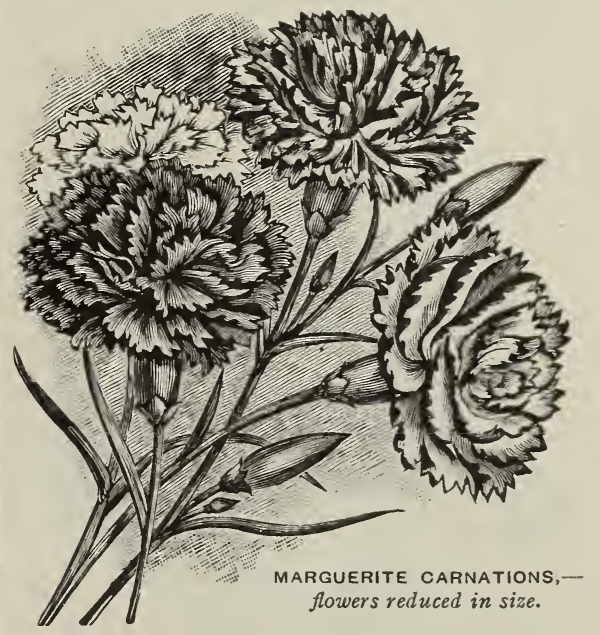

\section{Carnations.}

The Perpetual or Tree Carnation is the type grown by florists for winter blooming in a cool greenhouse, or for summer plants in the open ground.

- The Marguerite Carnations are similar in flower to the preceding, but while the plants do not grow as strongly they come into flower more quickly.

The German and Picotee varieties are very hardy, making compact, bushy plants the first season from seed, with a fine display of flowers late in the spring the second year from planting and each succeeding season.

PKT.

1848 Marguerite, Mixed.... ( $1 / 4 \mathrm{oz} ., 25 \mathrm{cts}$.
3753 German, Extra Fine, Double, Mixed

$\begin{array}{lll}3755 \text { Choice Double, Mixed (1/8 oz., } 50 \mathrm{cts} .) & \text { I } 5 & \\ & \text { (1) } & \text { I } 75\end{array}$

3759 Picotee, Fine Double, Mixed,

(1/8 oz., 25 cts.) I5 I 75

3915 Perpetual, or Tree, Mixed,
(Per Ioo seeds, 75 cts.) 25

( 1 oz., 50 cts.) 25 


\section{Celosia (Cockscomb).}

Th c "Cockscombs" grow only ten or twelve inches in height and are crowned with immense heads or combs of the most velvety form and richest colorings.

Among the Feathered Celosias, the Triumph of the Exposition grows two and one-half feet high and fully as large in diameter, branching freely in pyramidal form, and each branch terminating in a feathery plume of rich crimson. Spicala is of erect growth with round, slender pointed

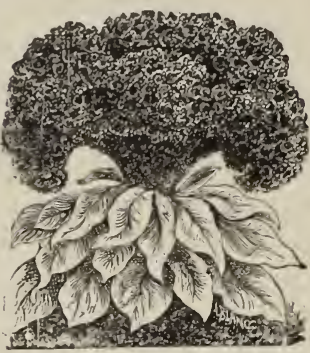

DWARF CELOSIA OR COCKSCOMB. spikes of bloom; very

a new strain of Feathered Celosia of unusual beauty.

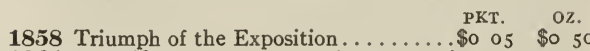
1864 Magnificent......... (1/8 oz., $25 \mathrm{cts}.)^{\text {180 }}$ Io 1866 Spicata.

1912 Cristata Giant Empress ( $1 / 4$ oz., 75 cts.)

1917 6rita Gwarf, Mixed (1/4 oz. 60 cts.) 10 275

\section{Burpee's Flower Seeds} are just as carefully and as thoroughly tested as our Vegetable Seeds, and we know that there is not offered seed of any better quality than the stocks we now have in our warehouses.

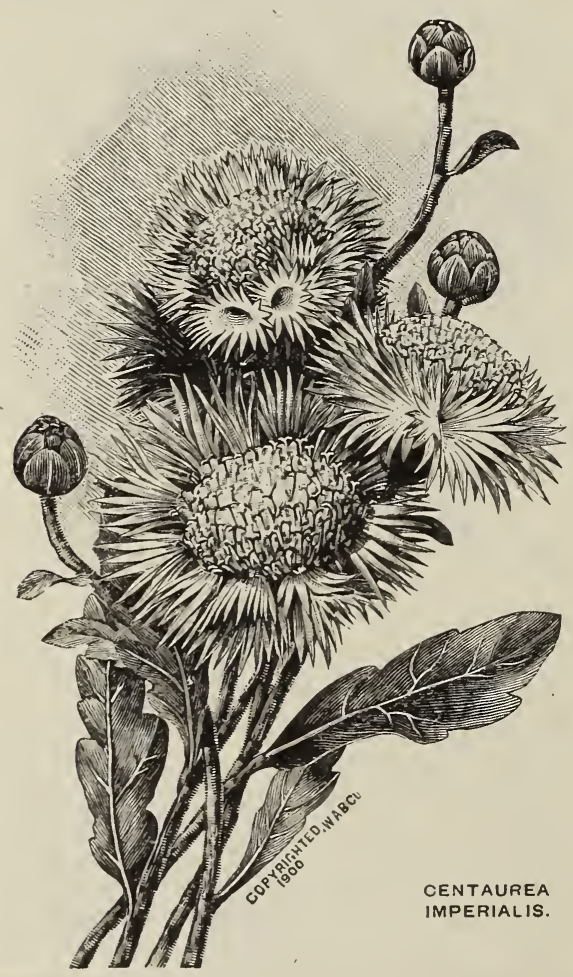

Chrysanthemum.

The annual or summerflowering Chrysanthemums grow best and flower most freely in rather cool locations, not succeeding well during the hot summer of the South. The single varieties produce brightly colored flowers of large size. Inodorum plenissimum is a hardy variety, bearing clusters of double white flowers on long stems; it is useful for cut-flowers. Plants of Coronarium have a ready sale during the spring months.

Of the Perennial Varielies, Mixed, the plants raised from seed sown in the open ground flower freely with us before frost

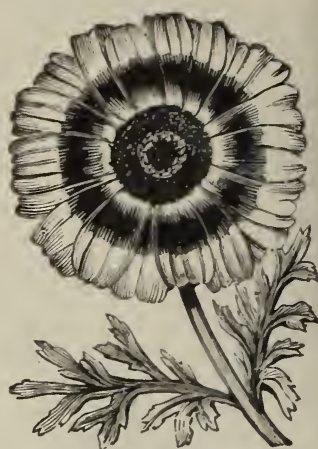

ANNUAL CHRYSANTHEMUM.

in the fall; a large percen-

ers. The Early Single Flowering strain produces symmetrical plants which are literally covered with single flowers during the early fall months.

PKT. OZ.

1896 Annual Varieties, Mixed.......... \$o o5 \$o 15 1903 Coronarium, Double Mixed ........... 5 5 15 1904 Inodorum Plenissimum.............. 5 . 5 3750 Early Single Flowering Perennial Varieties, Mixed ( $\frac{1}{16}$ oz., $\$ 1.25 ; 1 / 8$ oz., $\$ 2.00) \ldots \ldots \ldots \ldots \ldots \ldots \ldots \ldots \ldots$............. 15

\section{Centaurea (Cornflowers).}

The Centaurea Imperialis is a distinct type, originating in a cross of Centaurea Marguerile and Centaurea moschata. This cross has produced a plant of greatly increased vigor of growth, frequently three to four feet in height, with numerous large flowers borne on long stems, in shades of color ranging through white, lilac, rose-pink, and purple. Individual flowers are also beautifully shaded, while the petals are finely fringed, giving a soft feathery effect; they are produced in great profusion. The plants succeed best in rather cool moist soil, and seed should be planted early in spring. Our growing crops of Centaurea Imperialis at FLORADALE always attract the attention of all visitors quite as quickly as do the larger areas of Sweet Peas.

The flowers of the Centaurea Imperialis are always produced on long stiff stems, and are excellent for making summer bouquets or for table decorations.

The Blue Cornflowers are extremely popular and meet with ready sale as cut-flowers; the plants come into bloom early in the season and continue until late in the fall. If seed of these is sown late in the fall it will germinate very early in the spring. Cyanus, Mixed, contains several shades of blue and also pure white-flowered varieties, and we also offer the same in the double-flowered strain. Kaiser Wilhelm produces freely flowers of a rich deep blue.

Marguerite is a distinct type having quite large flowers of a pure snow-white.

A mericana is the tallest and largest growing variety; it attains a height of three feet and produces abundantly large thistle-like lilac-colored flowers.

Candidissima is grown for its large fern-like leaves, covered with a silvery-white pubescence, making a graceful and most attractive plant; it is much the finest of the socalled "Dusty Miller" plants. Gymnocarpa has short, rather stiff silvery foliage.

PKT. $\quad$ oz.

1869 Imperialis, White.....(1/2 oz., $30 \mathrm{cts}$.)\$o Io \$o 50 1876 Imperialis, Mixed...... (1/2 oz., $20 \mathrm{cts}$.) Io 35 1878 Americana............ (1/4 oz., $30 \mathrm{cts}$.) Io I $\infty$

1882 Kaiser Wilhelm................ 5 I 5

1884 Cyanus, Mixed (Blue Bottle)....... 5 I 2

1885 Cyanus, Double, Mixed ........... 5

1888 Marguerite............ (i/2 oz.., 25 cts.) 55

1889 Candidissima........... (1/8 oz., 50 cts.) 10

WE KNOW SEEDS by means of the FORDHOOK TRIAL GROUNDS. We sell only seeds known to be good-THE BEST SEEDS THAT GROW! 


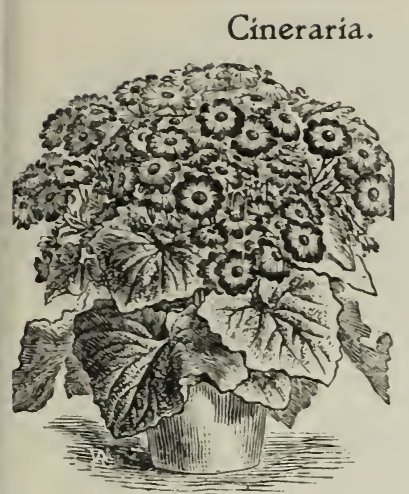

Our strains of the winter-flowering CINERARIA are grown by the leading European specialists, and we especially recommend the largeflowering strain which is produced by growers who make a specialty of this one variety of one variety of
flower seed. To have large plants in flower by December, the seed should be sown in April or May.

PKT. 3918 Fine Mixed 3920 Large-flowering, Finest Mixed,

(rooo seeds, 60 cts.; ${ }_{16}^{1} \mathrm{Oz}$., $\$ 2.50$ )

\section{Coboea Scandens.}

A Mexican climber of rapid growth, quickly attaining great height and producing a profusion of large bell-shaped flowers, of a deep reddish violet-purple coloring. A most graceful, free-flowering climbing vine. Leaves are in pairs on a central leaf-stalk, which terminates in a slender tendri like those of the sweet pea, enabling the vines to cling closely to the poles or trellis.

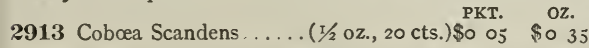

Fow flowers impart such rich "bits of beauty" to $-\rightarrow$ the garden as the different types of NASTURTIUMS. In addition to their use in the garden and on trellises we would recommend planting the seed freely along fences, hedges, etc., or wherever it is desired to have bright colors in profusion. You cannot have too many! See pages IIO and 120 .

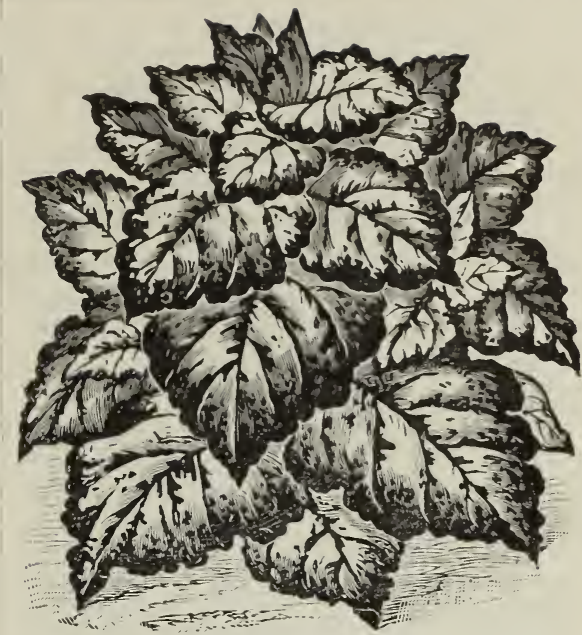

\section{Coleus.}

The Irish Zulu has deep green leaves, tinged with golden yellow, dark purple ribs and veins, bordered with golden bands in center of leaf.

The Fancy Fringed and Laciniated strain has smaller leaves, but the colorings are equally rich, while the edges are finely fringed or notched. The Copper-leaved Coleus has foliage of a rich tawny yellow; the plants are largeleaved. like the Sunset strain, and come true to color from seed, being especially desirable where large beds are to be planted in a solid color.

PKT.

1919 Burpee's Irish Zulu ...... (rooo seeds, 75 cts.)\$o I5

1921 Sunset Strain of Large-leaved Varieties,

1923 Gigantic Copper-leaved. ( (1000 seeds, $65 \mathrm{cts}$.) 1925 Fancy Fringed and Laciniated,

1927 Mixed.

(rooo seeds, 65 cts.) I 5

\section{Cosmos.}

Of quick growth, the plants make large bushes, fully five feet high, which are a mass as grown at Fordhook. beautiful of all Cosinos. 


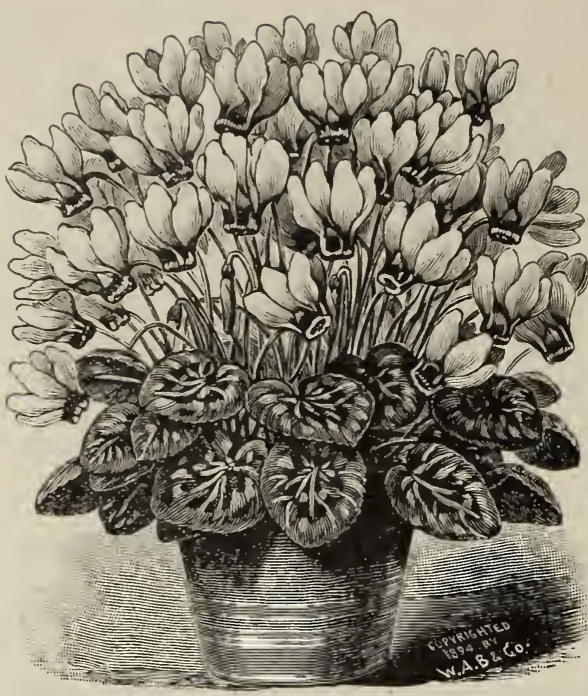

CYCLAMEN PERSICUM GIGANTEUM.

\section{Cyclamen.}

Popular, free-flowering, bulbous plants for house culture, producing graceful, orchid-like flowers most freely during the fall, winter, and spring months. The young plants develop a large, compressed, perennial root-stock or bulb, from which spring the round, glossy, dark-green leaves and tall slender flower-stalks, which bear brillianthued flowers, airily poised above the foliage. The colors range from pearly white to deepest crimson, with many intermediate shades and varied markings.

The Cyclamen is one of the best-selling winter potplants for florists, succeeding admirably in a cool greenhouse or room. To have fine plants in flower for fall and early winter, the seed should be sown in November or December of the preceding season. They succeed best in very rich soil and a cool moist temperature. Grown in this way, large plants in five- and six-inch pots, with twenty or more large blooms, may readily be had for the holiday sales from the giant-flowered strains. The cheaper strain we offer is also very fine.

3922 Persicum, Mixed .. (500 seeds, $75 \mathrm{cts}$.) $\$$ PKT. io $\$_{3}$ o. 3924 " Giganteum, Mixed, (300 seeds, \$1.00) I5

\section{Cypress Vine.}

A rapid-growing summer climber, with finely divided dark-green foliage, thickly starred with the small bright flowers. It is especially adapted for training on strings for ornament where no shade is desired.

2919 Scarlet. $\quad$ PKT. $0 z$.

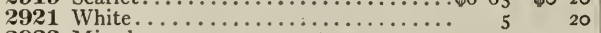

2923 Mixed

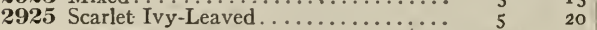

Dahlias.

Seed sown in March will make blooming plants by August, and with our fine strains the grower's stock of Dahlias may be rapidly increased and much diversified in color. The Pompons produce small compact double flowers resembling the Largeflowering Doubles in miniature. The Singleflowered Dahlias are extremely showy and come into flower more quickly than the Doubles and bloom more freely. The new Paony-flowered are, however, rapidly coming to the front. They are semi-double, and bloom very early in the season, free flowering and showy, embracing all colors to be

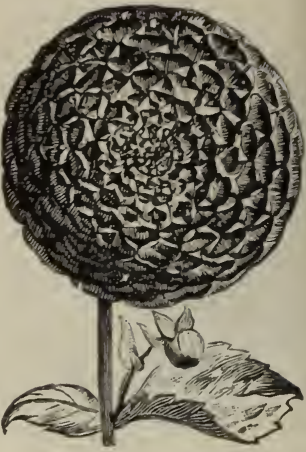

DOUBLE DAHLIA found among Dahlias. Florists who desire separate colors and varieties should depend on roots, for which see pages I 4 I to I 43

1951 Large-flowering, Double Mixed,

PKT. Oz.

( $1 / 4 / 4$ oz., 20 cts.) \$o 05 \$o 65 1953 Extra Choice, Large-flowering Double,

$\begin{array}{lrll}1956 \text { Choice Mixed Pompon (1/4 oz., } 35 \mathrm{cts} \text { ) } & \text { Io } & \text { I } & 25 \\ 19 & & \end{array}$

1958 Extra Choice, Pompon, Mixed,

1965 New Prony-Flowered, (I/4 oz., 50 cts.) Io I 75

1966 "Collarette" Mixed ( $1 / 4 \mathrm{Oz} ., 30 \mathrm{cts}$ ) Io I $\infty$

(Per 1/8 oz., 50 cts.) I5

1968 Superb Single, Mixed, Extra Fine....

1970 Striped Single................ 5

\section{Daisy.}

Shasla Daisy (Chrysanthemum Maximum) produces large single flowers on long stems which are useful for

I $\rightarrow$ For Double Daisies, - see Bellis, page ro8.

3780 Shasta Daisy........ (1/8 oz., 30 cts.) $\$ 0$ I5 $\$ 2$ \$

\section{Delphinium.}

The Formosum flowers from seed the first season, but the spikes are much taller and the plants bloom more freely the second year; the flowers are of the richest dark blue and last well as cut-flowers. The plants live for many years and bloom all summer, a bed of them providing a constant supply of fine flowers throughout the season. 'The mixed strain is identical with the above, but embraces quite a variety of shades, from pale china-blue to the deepest and richest blue found in flowering plants. Belladonna has long been considered one of the best hardy perennials for cutting purposes; it blooms continuously throughout summer and fall, the flowers being more acceptable than the large spiked varieties, being of looser formation. The colors run from very pale blue to deep purple.

PKT. Oz.

3772 Belladonna Seedlings. Our own grow3776 Formosum............... (1/4 oz., 25 cts.) 5 . 75

For many years we have had the largest Mail-Order Seed Trade in the world. This is an acknowledged fact, and there must be a reason for it. There are other firms that issue more expensive catalogs and send out "drummers" to seek trade, while we are exclusively a Mail-Order House. Therefore, the reason must be in the quality of seeds delivered and the character of the service rendered.

We travel many thousands of miles each season to inspect growing crops which are produced for us under special contracts throughout America and Europe,- and also spend much time in making special selections of stock seed upon our own farms,--but never do we travel a single mile to solicit an order! And yet, we want your trade,-if you can appreciate the value of Quality in Seeds. 


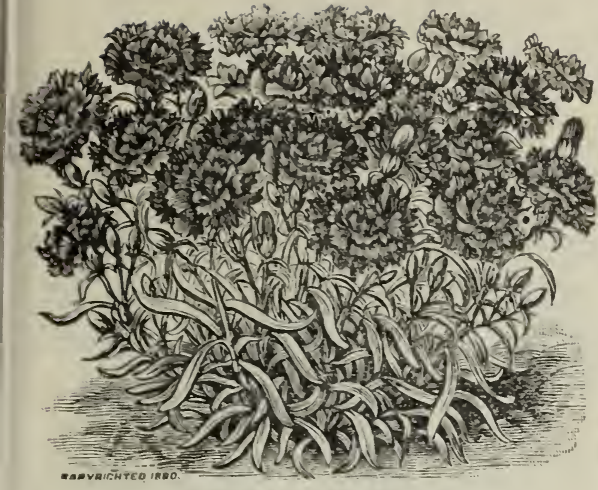

Plant of DWARF FIREBALL DIANTHUS.

\section{Dianthus (Chinese Pinks).}

These are used chiefly for bedding, blooming freely from early summer until cut off by severe frost. Some of the separate colors, like the pure white and the dark scarlet, are fine for cut-flowers, while the bright colorings of both the single and double-flowered strains make fine bouquets. The New Large-flowered Dwarf Double Hybrid is the finest we have ever grown, producing uniformly large, double flowers in the richest colorings. The singleflowered Laciniahus varieties are also especially fine, the flowers measuring two inches or more across, with the edges of the petals finely fringed and brilliantly colored on a silvery-white ground. The Dwarf Varieties are well adapted for borders to flower-beds or the lawn, especially in cool locations. The Fordhook Favorites contain all the finest varieties of the summer-blooming types, and are attractive when in full bloom.

Dianthus plumarius (the Pheasant's-Eye Pink) and Dianthus scoticus, double-flowered, are hardy varieties, blooming freely in May and June the second year from sowing the seed.

1981 Chinensis, Double, Mixed

1984 Diadematus, fl. pl., Mixed

1986 "Sweet-scented Diadem,"

1989 Heddewiggii, Finest Single $(1 / 4 \mathrm{oz} ., 35 \mathrm{cts}$.)

PKT. oz.

1991

(1/2 Oz, 25 cts.

1996

fl. pl., Mixed

,

Mourning Cloak,

$(1 / 4$ oz., 35 cts $)$

Purity...(1/4 oz., $35 \mathrm{cts}$.)

Dwarf Fireball

1997

1999 nowbal

200.5 Large-flowered Dwarf Double Hybrids,

2008 Imperialis, fl. pl

( $1 / 4$ oz., 35 cts.)

2014 Laciniatus Mirabilis.... (1/4 oz., 25 cts.) 2015 Double Salmon Queen (1/8. oz., 25 cts.) 2016 " Vesuvius...(1/4 oz., 25 cts.)

2019 " Nanus, New Hybrids....

2021 “ fl. pl., Mixed.

2027 Nobilis Royal Pinks) (1/4 oz., 30 cts.) 2031 Our Own Mixture of Many Varieties. 2032 Fordhook Favorites, Mixed

3783 Plumarius (Pheasant's-Eye Pink)

3785 Scoticus, fl. pl....... (roo seeds, 60 cts.)

\section{Digitalis (Foxglove).}

Easily grown perennials attaining a height of from three to five feet and producing long spikes of beautiful tubula shaped flowers, many being spotted or blotched.

The While produces freely handsome flowers which are shown off to great advantage by the dark-green foliage Occasionally the flowers come slightly spotted.

3787 Fine Mixed . 3789 White............................

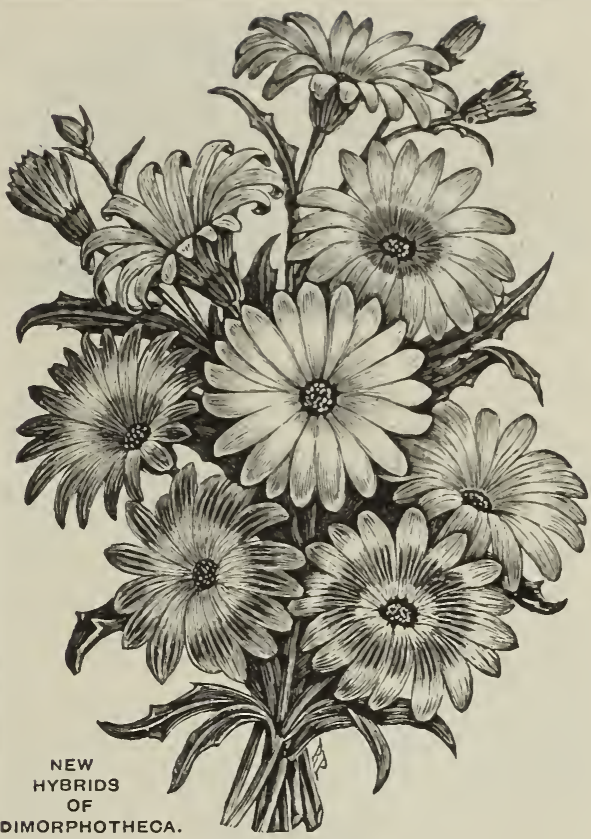

Dimorphotheca.

DIMORPHOTHECA AURANTIACA has certainly well fulfilled the opinion expressed when first offered in Europe in the autumn of I908 that-" "This rare and extremely showy annual would soon become a favorite in all countries on account of its very easy culture and its beautifully colored lowers." It is now grown and admired all over the world.

The hardy plants, of neat branching habit, grow only twelve to fifteen inches high and are exceedingly profuse in flowering. Its Marguerite-like blossoms measure two anc one-half to two and three-quarter inches in diameter. It strikingly brilliant coloring is rendered even more conspicuous by the dark colored disk surrounded by different colores zones. This splendid annual is well adapted for groups or borders; it bears its pretty flowers very early after bein 5 planted out in the open ground in sunny situations and will continue to bloom abundantly during the entire summer.

Aurantiaca produces flowers of a rich glossy orange-gold;

the flowers of Aurantiaca IIybrids vary in color from white the flowers of A urantiaca Hybrids vary in color from white
through sharles of yellow, blue, light red to a dark crimson. 2033 Aurantiaca Hybrids ... (T/4 oz., $40 \mathrm{cts}$.) \$O IO \$I 2038 Aurantiaca...........(I/4 oz., $30 \mathrm{cts}$.) IO I

\section{Burpee's Bush Dolichos.}

This unique and attractive variety comes entirely true to the distinct bush habit of growth. Those who have grown our Daylight Dolichos can readily imagine the extremely attractive appearance of these compact bushes surmounted by equally enormous spikes of pure white flowers which are succeeded by large creamy-white pods. The plants proper average only ten inches in height, with large bean-like leaves, but the magnificent flower-spikes grow from ten to fifteen inches above the foliage. The flowers from ten to fifteen inches above the foliage. The flowers
are snowy white, about one inch across, and resemble those of the flowering pea. Per pkt. Io cts.; oz. $30 \mathrm{cts}$.

\section{Dolichos.}

These climbers are well worthy of culture in every flowergarden. Burpee's "Daylight," a grand free-flowering white variety, and "Darkness," a fine companion with rich dark, purplish-red flowers, are the best of the separate varieties now offered, and the flowers are succeeded by large showy pods of the same distinct colorings. "Iridescent" is so called on account of the peculiar way in which the pods color up; the vine is of quick strong growth.

2927 Darkness............. (Per lb. \$r.oo) \$o o5 \$o $\mathrm{I}_{5}$ 2929 Daylight................ (Per lb. \$1.25) 5 r

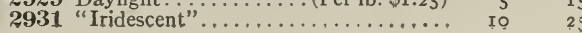




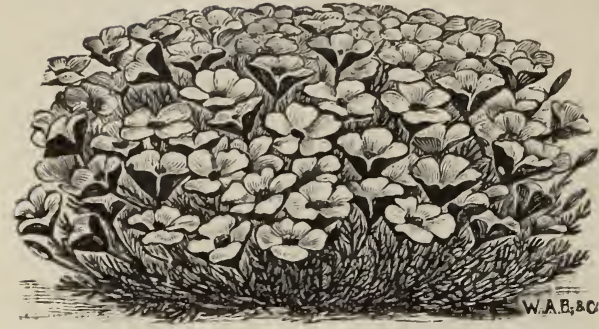

ESCHSCHOLTZIA, OR CALIFORNIA POPPY.

\section{Eschscholtzia (California Poppy).}

Free-flowering plants for summer bedding; the seed should be sown thinly broadcast or in drills where the plants are to bloom. The plants are of low-spreading growth, making a dense carpet of fine feathery foliage thickly starred with the brilliant hued flowers. For richness of coloring Burbank's Fire-Flame will be found unequaled.

2042 Alba (pure white)

2044 Burbank's Crimson-flowering

2046 Douglassii

2047 Burbank's Fire-Flame

2049 Golden West

2051 Mandarin .

2053 Rose Cardinal

2055 Mixed

2112 Bush Eschscholtzia (Hunnemannia)

PKT. Oz. .\$o 05 \$० 20

\section{Euphorbia.}

Heterophylla grows stiffly erect and in the fall produces bracts of brilliant scarlet leaves at the top of each branch, somewhat similar to the well-known Poinsettia. Mar ginata grows in a compact rounded bush two feet in height, and has large green leaves widely margined with white.

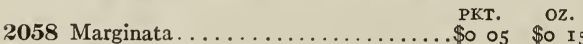
2060 Heterophylla.

05 \$o I

\section{Feverfew (Matricaria).}

A free-flowering, half-hardy, perennial plant growing eighteen inches in height. Seed sown early in spring in the open ground will produce flowers by early fall.

Eximia (f. pl.) has double pure white flowers one-half inch in diameter, and produced in large clusters on a long stem; fine for cutting and quite hardy.

2064 Eximia, fl. pl. (Feverfew)

PKT. OZ. \$o $05 \$ \$ 35$

\section{Forget-Me-Not (Myosotis).}

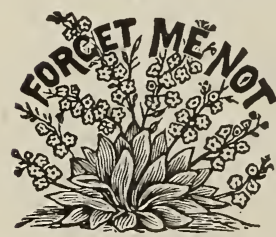

Very pretty flowering plants of dwarf compact growth; nearly all the varieties flower the first season and profusely the second spring; the plants are entirely hardy. Alpestris has deep china-blue flowers; $A$ alba, pure white flowers. Eliza Fonrobert has much longer sprays, and the individual florets are twice the size of the ordinary type; rich china-blue. Plants of these three varieties may be potted in the fall, and will bloom freely in a cool greenhouse during the winter. Palustris is the true swamp variety, and does not flower until the second season.

2068 Palustris $11 / 40 z$ PKT. OZ. \$o 05 \$I 75 2072 "A Alba (White) ............... 5 . 5 . 50 2076 Eliza Fonrobert........ (1/4 oz., 25 cts.) ro 75

\section{Florists and Market Gardeners,}

by planting Gladioli and other summer-flowering bulbs, can easily have an additional source of income at a time when most other crops are past. Is See pages I4I to I47.

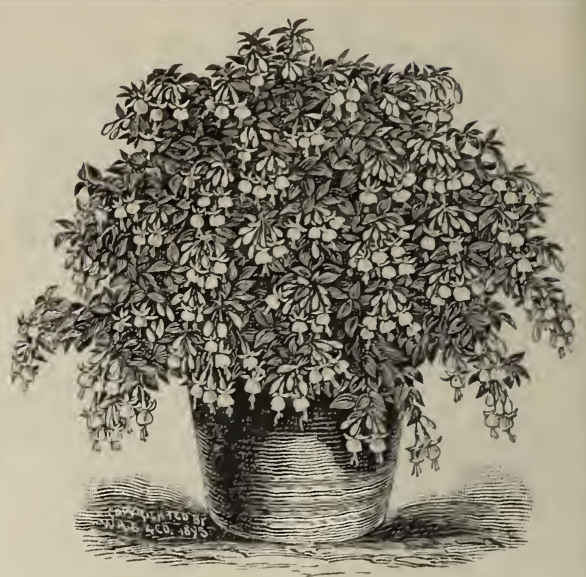

\section{Fuchsia.}

Fine plants of Fuchsia for blooming indoors can be grown easily from seed planted in the spring; these plants may be grown in a cool greenhouse or in partial shade outdoors during the summer and should begin to flower early in the winter. Our mixed strain is saved from a large collection of the finest named varieties. Fuchsia procumbens is of slender trailing growth, very desirable for hangingbaskets and vases; the flowers are insignificant, but are succeeded by quite large seed-pods of rich scarlet coloring.

3928 Double and Single, Mixed .. (500 seeds, \$I.35) \$o I5 3930 Superb Mixed............. (500 seeds, \$I.75) 25 3932 Procumbens............ (500 seeds, $50 \mathrm{cts}$.$) I$

\section{Gaillardia.}

(Mexican Blanket Flower.)

This plant will grow and flower freely in the driest soils and situations. Grandiflora is a hardy perennial, flowering freely all summer. The brilliant yellow and crimson flowers are large, single, and produced on long stems, making it invaluable for cutting purposes. Picta Lorenziana, an annual variety, has double flowers of good size and considerable diversity of coloring.

2084 Fine Mixed

2086 Picta Lorenziana, Double.

3805 Grandiflora (Perennial)

$$
\text { PKT. OO } 5 \text { OZ }
$$$$
\text { I0 } 30
$$

\section{Geranium.}

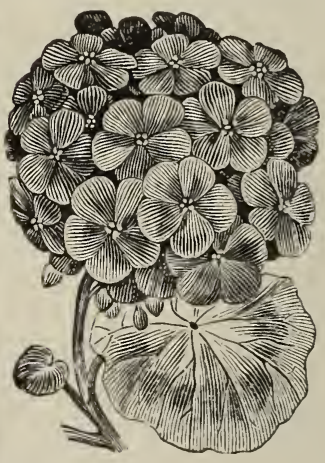

Our Geranium seed is carefully cross-fertilized from choice named varieties. The plants grown from seed produce fine flowers, and sometimes new and attractive shades can be obtained. The Zonale produc e s single-flowered plants of the wellknown bedding type; we also offer a strain producing a large percentage of double-flowered plants of the same type. The Fancy Pelargonium is the Lady Washington Geranium, which flowers so beautifully as pot-plants in the early spring. The $A$ ppleScented is quite distinct, and the best of all the scented-leaved varieties; fine plants of this variety can be grown only from seed, as it does not do well from cuttings.

3934 Zonale, Mixed ....... (1/4 oz., $30 \mathrm{cts}$ ) $\begin{aligned} & \text { PKT. } \\ & \text { \$o }\end{aligned}$ 3936 Extra Choice Zonale..(1/4 oz., $35 \mathrm{cts}$.) I5 5 I 25 3938 Fancy Pelargoniums (ioo seeds, 85 cts.) 25 3940 Finest Double...... (100 seeds, \$1.00) 25 3942 Apple-Scented. . . . . (250 seeds, 50 cts.) 25 


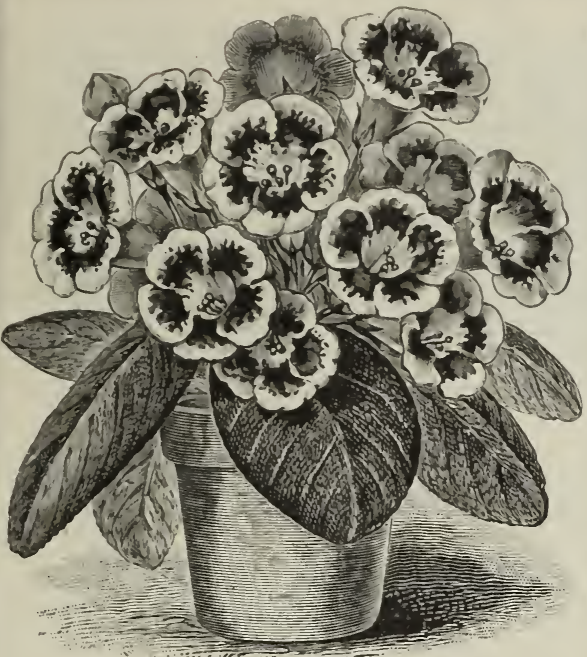

Gloxinias.

The seed we offer is carefully hybridized and can be de pended upon to produce large erect flowers, in the greatest range of colorings. The Giant-flowered strain produces flowers three to four inches across, in the most beautiful colorings and markings.

3955 Giant-flowered, Mixed.... (rooo seeds, \$I.00) \$0 25

\section{Gypsophila.}

A quick-growing plant, bearing a profusion of small, star-like white flowers. Sown early in the spring, it comes into bloom with Sweet Peas, and the graceful sprays are largely used to give a light loose effect to the bouquets of the latter flower.

Paniculata, Baby's Breath, is a hardy perennial variety, and while considerably more graceful than the annual sorts, is later coming into bloom; valuable for cutting.

2092 Elegans Mixed

2094 Covent Garden

3807 Paniculata .

Hollyhock.

This well-known utant produces tall spikes of fine bloums the secoud spring from seed and we should suggest that thorists would find ready sale for the large one-year-old clumps ready for blooming, as they are highly esteemed for mixed flower borders or planting among tlowering shrubs. The Chater's Superb Double Mixed is of our own growth. producing the largest and most double flowers in the great est assortment of colors. The separate colors offered below are all of this same large-flowered type. The line Double Mixed is a splendid double-flowered strain, inferior in size only to the Chater's Superb. The Allegheny strain is large-flowered, frequently only semi-double, but with finely fringed petals

PKT. OZ.

3814 Double Light Pink (Per $1 / 30 z, 60$ cts.)\$o ro \$2 oo

3815 "Maroon...(Per $1 / 4 / 4$ oz., 50 cts.) I0 r 75

3816 "Rose...... (Per 1/4 oz., 6o cts.) ro 200

3817 " $\quad$ Scarlet.... (Per 1/4 oz., 60 cts.) - 10200

(Per 1/4 02., $60 \mathrm{cts}$.)

3822 Chater's Superb Double Mixed,

3824 Fine Double, Mixed. (1/4 oz., $50 \mathrm{cts}$.) Io $\quad$ I 75

3826 Allegheny, Double, Mixed ............. Io 75

Is We make liberal FLORISTS' PACKeTS of any of the above at the rate of $25 \mathrm{cts}$. per packet, net.

\section{Heliotrope.}

The plant is a tender perennial of quick, strong growth Fine flowering plants can be grown readily from seed started in boxes of light rich soil in a sunny window of a warm room during March. These should be transplanted to small flower-pots as soon as large enough and planted out in flower-beds when trees are out in full leaf and the nights quite warm.

The finest plants for summer flowering are grown from our strain of LEMOINE'S GIANT HYBRIDS; the flowers come mainly in the rich purple shades, but white and reddish mauve are also frequent. Seeds sown in February make good large plants for spring sales. Dark Bouquet has close compact heads of deep purple flowers; Lady in White, large clusters of pure white flowers. Our choice Mixed is saved from the regular florist's varieties.

PKT.

2098 Dark Bouquet........ (1/4 oz., 50 cts.)\$o 10

2100 The Black King ...... (1/4 oz., $50 \mathrm{cts}$.) I0

2104 Lady in White.......... (1/4 oz., 50 cts.) 10 $\begin{array}{ll}\mathbf{2 1 0 6} \text { Choice Mixed............ (1/4 oz., } 35 \mathrm{cts} \text {.) } & \text { Io } \$ 125 \\ \mathbf{2 1 0 9} \text { Lemoine's Giant Hybrids, } & \end{array}$

$(1 / 4$ oz., 40 cts. $) \quad$ I5 $\quad$ I 50

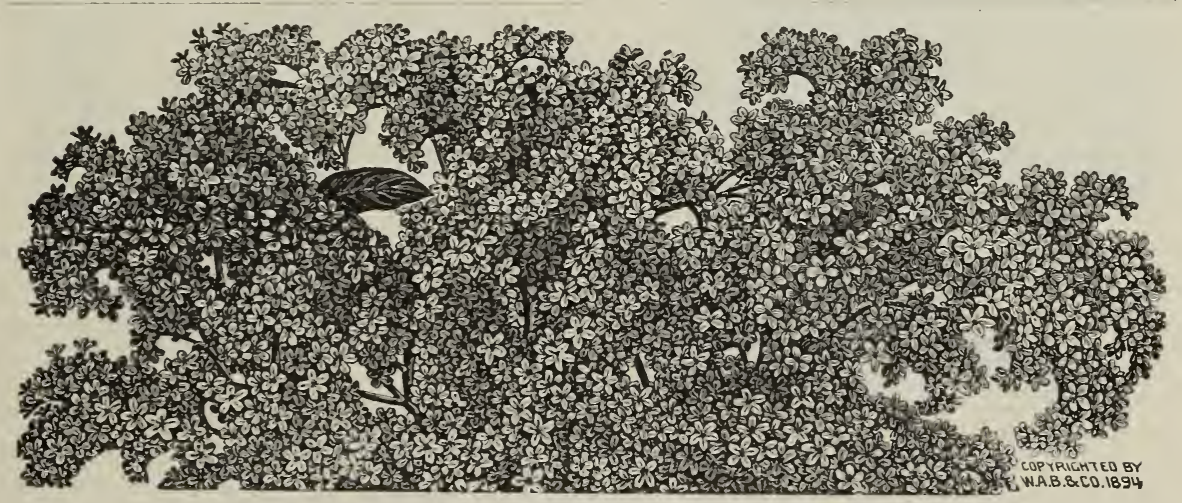

The top portion of a Single Flower cluster, from a Pholograph, of LEMOINE'S NEW GIANT HYBRID HELIOTROPE.

Heliotrope, - Lemoine's Giant Hybrids. This strain has been greatly improved by continued selection at our FORDHOOK FARMS. It is one of the flowers to which we devote especial attention each season. Plants are of strong, vigorous growth, producing immense trusses of the small fragrant flowers. These trusses frequently measure from ten to fifteen inches across, while the fragrance is equally as charming as in the original smaller-flowered type. Easily grown and invariably comes true from seed produced at ForDHOOK. The colorings range from white to dark purple and reddish violet. 2109 Per pkt. 15 cts.; per $1 / 4$ oz. 40 cts.; per oz. $\$ 1.50$ 


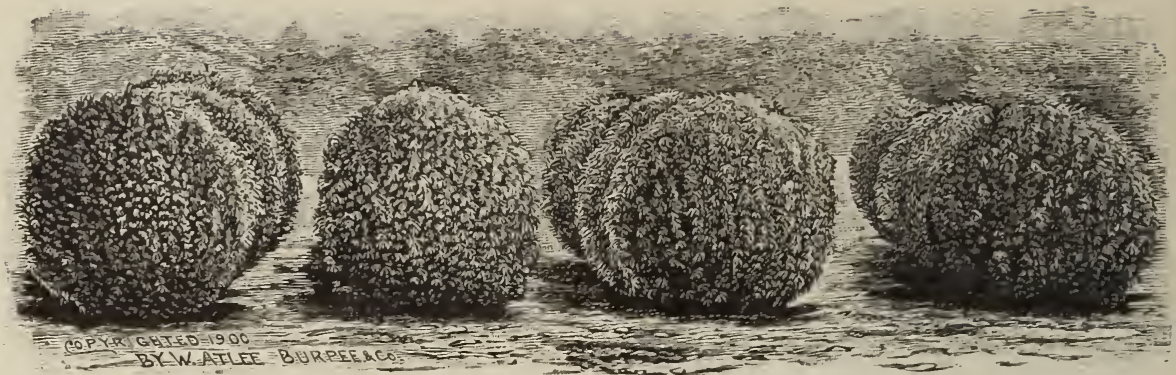

Rows of the Quick-growing Annual косніA TRICOPHYLLA,-from a Photograph taken at Fordhook Farms.

Kochia Tricophylla. This highly ornamental annual plant grows quickly from seerl sown in the open or globe-like form shown in our illustration. The plants branch freely, and the stems are clotherl with slender light green leaves. Early in the fall the ends of the shoots are thickly set with small bright scarlet flowers, - the bushy plants resemble balls of fire. The plants are most attractive either planted singly to slow the round, ball-like form on all sides or grown in continuous rows.

$\rightarrow$ Until we "resurrected" this popular plant a few years ago (first under the wrong botanical name of Kochis SCOPARIA) it had almost dropped out of cultivation. Now it is admired everywhere and has been given such popular names as Burning Bush and SUMmer CyPRess. 2118 Per pkt. 5 cts.; oz. 15 cts.

\section{Ipomcea.}

The varieties listed below are all quite distinct, both in growth and flower, from the Morning Glories, and require a longer time in which to grow and bloom, but will cover a much larger area. Bona Nox, or Evening Glory, is of very strong growth and produces large violet-purple flowers which open in the evening. The Fuchsia-flowered is of very rapid growth, with slender vines and deep green five fingered leaves, almost as delicate in effect as the Cypress vine; small rosy-pink flowers, followed by large seed pods which resemble the flower-buds of the Fuchsia.

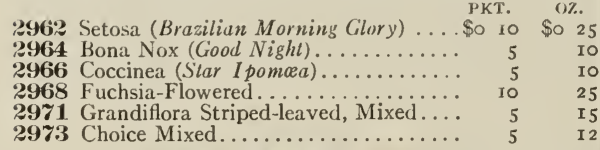

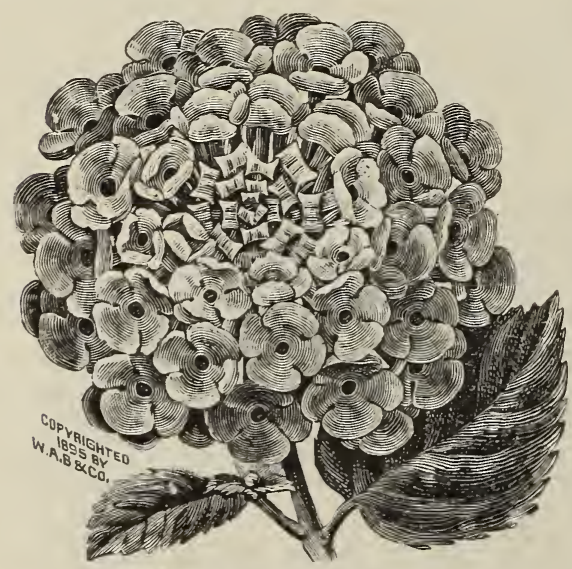

A HEAD OF LANTANA.

\section{Lantana.}

Free-flowering shrubby plants, bearing a profusion of brightly colored flowers. Our fine mixed seed will produce plants with a wide range of colors.

2120 Fine Mixed........... (1/2 oz., r 5 cts.) $\begin{aligned} & \text { PKT. } \\ & \text { 10 }\end{aligned}$

\section{Larkspur.}

These are the annuals, blooming only a single season, and must not be confused with the hardy Delphiniums, excepting the New Compact Blue, which, while blooming profusely the first season, lives over winter and blooms freely the second summer. The flowers are of good size, in open sprays, and of the deepest blue. The Double Dwarf Rocket grows eighteen inches high, stiffly erect, terminating in tall spikes of fine double blossoms; these range in shade from pure white to deep rich pink, and are frequently striped and spotted with deeper colors. The Emperor strain grows nearly three feet in height when in full bloom; the flowers show the same diversity of coloring as in the Dwarf Rocket strain, but the spikes of bloom are longer and the flowers larger. These sprays are quite useful for loose bouquets and vases.

I $\rightarrow$ The perennial Larkspurs are offered under Delphinium on page II 2 .

2122 Double Dwarf Rocket, Mixed....... \$o o5 \$o $^{\text {PKT }}$ 2122 Double Dwarf Rocket, Mixed....... \$o
$\mathbf{2 1 2 4}$ Tall Rocket Double, Mixed........ 2126 Emperor, Mixed................. 55 2128 New Compact Blue ... (1/2 oz., 25 cts.) ro 45

\section{Lathyrus Latifolius.}

\section{(Perennial Peas.)}

These are entirely hardy, coming up from the roots early in the spring. The flowers are quite similar to sweet peas, but are borne in close clusters, and are without fragrance; most desirable for cutting.

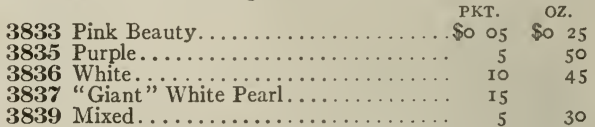

\section{Lemon Verbena.}

The Lemon Verbena (Aloysia citriodora) is much esteemed as a pot-plant. The leaves have a most refreshing fragrance.

3962 Lemon Verbena...... ( $1 / 4$ oz., $40 \mathrm{cts}$.) \$o Io \$I 50

\section{Linaria (Kenilworth Ivy).}

This grows readily from seed and is one of the finest plants for edges of vases or hanging-baskets, as well as for pot-plants in the house, and for planting out on rockwork.

2131 Cymbalaria (Kenilworth Ivy),

PKT. OZ. $(1 / 4 \mathrm{OZ}, 35$ cts. $)$ \$o 10 \$I 25

\section{Burpee's Seeds Grow!}

Our well-known motto is equally true of our Flower Seeds as of Vegetable Seeds. The vitality of each variety is proved thoroughly before the seed is put up in packets. 

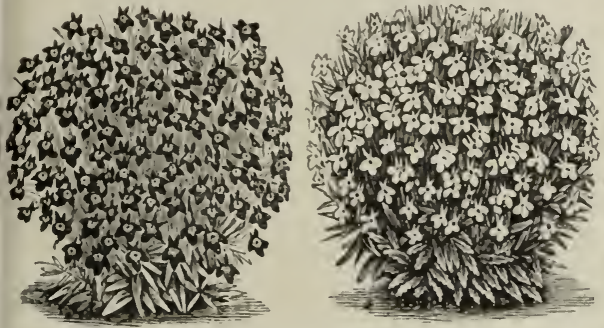

STAR OF ISCHL — LOBELIAS — WHITE GEM

\section{Lobelia.}

These dwarf compact plants make very pretty edgings for flower-beds, and florists will find them readily saleable as small pot-plants in the spring. They also make desirable plants for hanging baskets, vases, window boxes, etc. Seed sown in February and grown in small pots make fine blooming plants in May. Seed planted later produces plants that will bloom freely throughout the winter; the Lobelia is one of the best annuals for growing in the greenhouse or conservatory during the winter. Erinus compacta has flowers of a deep rich blue; E. compacta alba, pure white. The following are especially suited for pot-plants. Crystal Palace, splendid dark-blue flowers; White Gem, quite large; pure white, in greatest profusion, and Star of I schl, charming dark-blue flowers.

Tenuior or A ustralian Lobelia is distinct in every way from the foregoing varieties, the flowers being very large, color deep blue; the plant is of bush-like form, attaining a height of twelve to eighteen inclies.

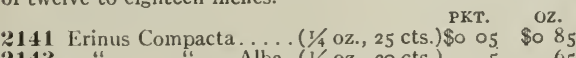
$\mathbf{2 1 4 3}$ " $"$ Alba (1/4 oz., 20 cts.) 50 $\mathbf{2 1 4 5}$ “ Crystal Palace Compacta,

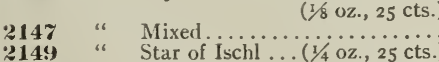
2149 “ Star of Ischl ... (1/4 oz,.,25 cts.) $\mathbf{2 1 5 5}$ Tenuior.............. (1/4/4 oz., $30 \mathrm{cts}$.)

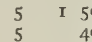

\section{Lychnis.}

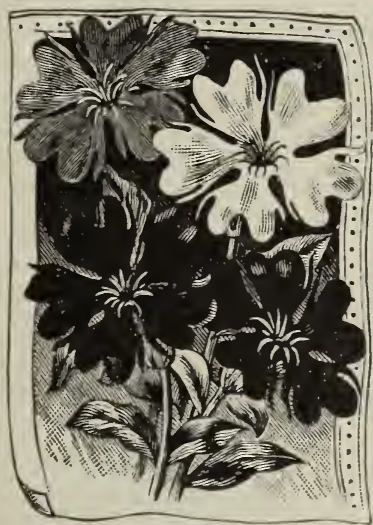

Chalcedonica is the tall hardy variety, blooming the second season from seed; it grows three feet high and has large umbels of brilliant s c a r le t flowers. Haageana hybrida blooms the first season, growing eighteen inches high, and has quite large single flowers which range in coloring from delicate rose-pink to brightest scarlet. These plants are desirable for borders of mixed perennials, and florists $\mathrm{c}$ a $\mathrm{n}$ have fine plants for sale from the open ground.

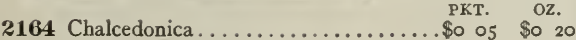
2166 Haageana Hybrida, Mixed,

(1/4 oz., 25 cts.)

\section{Burpee's Asters are grown from} stocks and for years have given most critical planters entire satisfaction. Our American strains are carefully inspected during growth and we know by the trials made at FORDHOOK that better seed cannot be obtained. It will pay you to turn back to pages 106 and 107 and note the specially fine named varieties we are offering for planting in $1_{9} 1_{4}$.

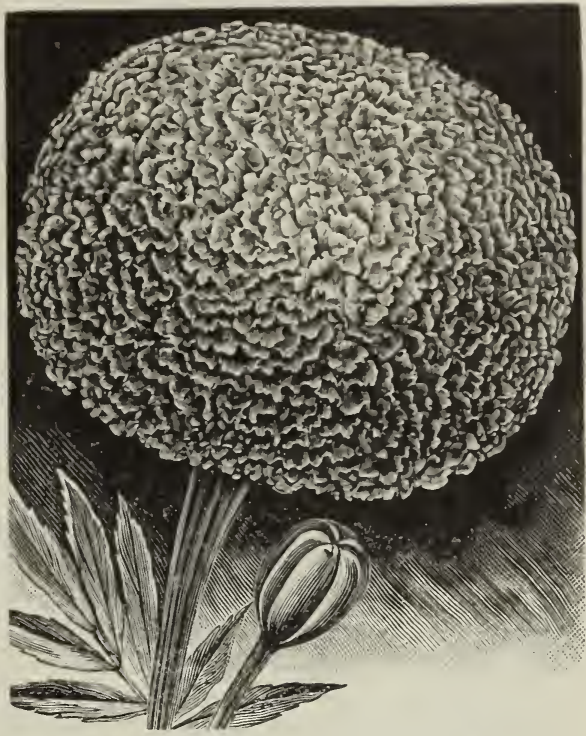

"ORANGE-BALL" MARIGOLD,-from a Photograph.

\section{Marigolds.}

Very showy free-flowering plants for summer bedding. Eldorado, a large very double flower of rich orange hue, and Lemon Queen, a pale golden yellow, grow three feet high and are extremely showy in beds of mixed flowers. The new "Lemon-Ball" and "Orange-Ball" are the most beautiful of all African Marigolds. The extra large flowers are perfectly rounded, of nearly "ball-like" form.

The Dwarf French varieties are of close compact growth, ighteen inches high, and of equal diameter, - a ball-like mass of feathery dark-green foliage; they are most profuse in bloom, and make a grand show planted in masses or as borders to other flowers. Legion of Honor is the only single-flowered variety we offer; it flowers most profusely and the bright yellow flowers of which each petal is broadly marked with rich brown, are most attractive. The Com pact Gold Striped has very double flowers, the petals being richly striped with yellow and brown; the flowers of Pulchre are a rich golden yellow, with velvety brown center; Brown Marble, reddish brown, marbled with orange; Orange-Ball, rich clear orange. The Dwarf Mixed is a fine doubleflowered strain showing a wide range of colorings.

2170 African Double, Mixed............

2172 "The Eldorado, or Dahlia-flow-

ered................ 5 . 30

" Lemon Queen............ 5 j 50

$\mathbf{2 1 7 8 ~ “ \quad ~ O r a n g e - B a l l . . . . ( 1 / 4 ~ o z . , ~} 25 \mathrm{cts}$.) ro 85

2181 French Double, Brown Marble....... 5

2183 " " Dwarf Pulchra...... 5 " 5

2185 " " " Orange-Ball.......

"2187 " "

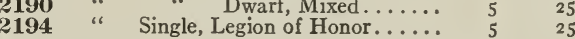

Marvel-of-Peru (Mirabilis).

Called Four-o'clocks, because the flowers remain closed until late in the afternoon, when they open rapidly and in a few minutes the plants are literally covered with bloom.

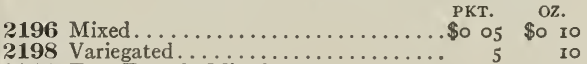

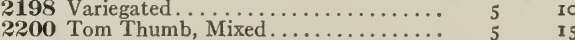

\section{Mímulus.}

The flowers of Tigrinus Grandiflorus are a bright yellow, thickly marked with rich brown dots. Moschatus is the well-known Musk Plant, the foliage of which has a strong musk fragrance.

PKT. OZ.

2242 Tigrinus Grandiflorus..(1/8 oz., $40 \mathrm{cts}$.)\$o Io $\$ 300$ 2244 Moschatus (Musk Plant),

(1/8 oz., 25 cts.) 5 I 50 


\section{Mignonette.}

This is standard florist's flower, being grown all the year round for the delightful fragrance of the spikes of bloom. We offer the finest largeflowered strains for winter forcing, as well as the best bedding varieties. $A l$ lan's Defiance is a long-spiked variety, extensively grown for the New York market. $\quad N e w$ Giant-flowered Red is one of the largest-flowered of all Mignonettes. $B$ ismarck, Nineteen Hundred and Pure Machet are large-spiked varieties and l a r g e I y grown for cut-flowers.

New Golden $\mathrm{Ma}$ chet and Improved Golden Queen are excellent $\mathrm{s}$ u $\mathrm{m}$ m e r bedding sorts, with florets of deep golden

yellow. Goliath, a new mammoth-spiked, is the largest and finest variety to plant for cutting. It produces very large spikes and crimson-red florets in the open ground, but when grown in a cool greenhouse during the winter the spikes are simply enormous in size. Giant White Spiral (Reseda alba) is not really a Mignonette, but is quite distinct in growth, reaching eighteen inches in height, with slender white flowers.

Mignonette grows most rapidly and produces the largest and finest spikes of blossoms during cool moist weather of early spring and late fall months, but wil flower freely throughout the summer from seed sown early in spring. Young plants do not transplant readily, and seed should be sown in the flower-beds or pots where plants are to bloom. Seed can be sown thinly in shallow drills early in spring when the trees are starting out in leaf. When well started the plants should be thinned out to stand six inches apart in the row.

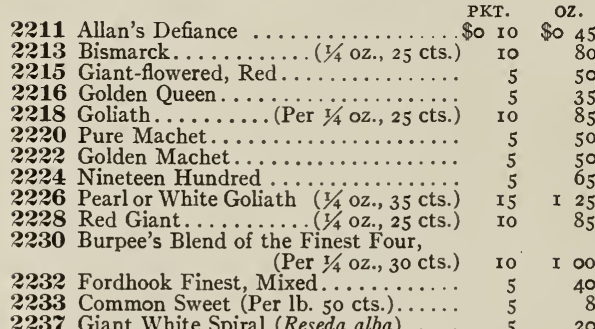

\section{Momordica.}

Summer climbers of rapid growth, with finely cut ornamental foliage, producing numbers of curious. spiny, orange-yellow fruits in the fall. When ripened, these fruits split open and disclose the large, bright, scarletcovered seeds. The ripe fruits placed in alcohol make an excellent liniment for cuts, burns, or bruises. Balsamina, or Balsam Apple, has oval fruits two or three inches long Charantia, or Balsam Pear, has fruits six to eight inches long; Charantia is the larger and better, commonly miscalled Balsam Apple.

2993 Balsamina (Balsam Apple)......... PK 05 \$o 20 2995 Charantia (Balsam Pear) .

Florists and Market Gardeners, by planting Gladioli and other summer-flowering bulbs, can easily have an additional source of income at a time when most other crops are post. Is See pages I 4110147.

\section{Moonflower.}

The While-Seeded has smooth, glossy leaves and the stems thickly set with spines; the flowers are pure white, of satiny texture and delightful jessamine fragrance. The Cross-bred is similar in growth to the White-seeded, but comes into bloom fully a month earlier, and the flowers are of immense size. Sky Blue is a large pale-blue evening bloomer with jessamine fragrance.

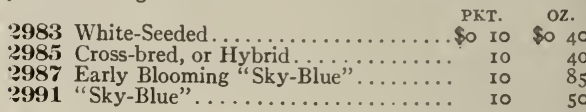

\section{Dwarf Morning Glories.}

These are of low-spreading growth, ten to twelve inches high and two feet across, bearing a profusion of delicate bell-shaped flowers one inch and a half in diameter, which resemble the tall varieties. Seed should be sown thinly in shallow drills when trees are starting out in leaf. When well started thin out or transplant to stand ten inches or more apart.

2250 Crimson-Violet............. \$o o5 \$o io

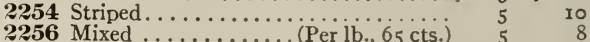

\section{Tall Morning Glories.}

The common Morning Glory is one of the brightest and most free-flowering climbers, coming into bloom quickly from seed sown early in the spring. The common type has been so long a garden favorite as to need no description, but the Japanese gardeners have bred from this old-time favorite new and greatly improved varieties which are as distinct and remarkable in their way as the fine Chrysanthemums which also come from that "Land of Flowers." Seed of the hardier sorts may be sown as early in the spring as soil can be dug in a fine loose condition, but with the finer Japanese sorts we would advise delaying planting until trees are coming into leaf or starting them in pots indoors, to be set out when weather becomes warm.

3000 Blue-Striped.

3002 Rose-Striped

3004 Violet-Striped

3006 Striped, Mixed

3009 Dark Blue.

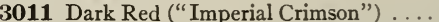

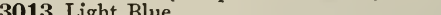

3013 Light Blue.

3015 Lilac.

3016 Deep Rose

3017 Rose

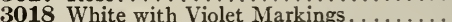

3019 White......... 5

3020 White with Rose Center or "Airy Fairy".....................

3021 Tall, Mixed (Convolvulus Major),

3024 Rochester

(Per lb., 45 cts.) $\quad 5 \quad 6$

3026 Double White Tassel

3027 Double Snow Fairy

3028 Imperial Japanese, Mixed Colors.....

\section{Musa Ensete}

\section{(Abyssinian}

Banana Tree).

Strikingly effective as single specimens as well as in clumps. The rapidity of its growth is astonishing. Seed sown early in hot-beds and repotted several times will give plants eight feet high the first summer. fully long, broad and massive, of a beautiful bright green.

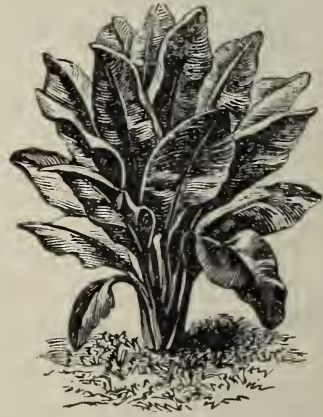

3965 Musa Ensete . .... (Ioo seeds, 75 cts.) PKT. 


\section{Burpee's New "Royal-Race" of Variegated-Leaved Tall Nasturtiums.}

3042 Burpee's Variegated Oueen. The first of this new Roval-RAcE, which is just as leaved Nasturtiums. Fvery leaf is variegated with yellow, white, and green, but in such differing degrees that the plants present a most varied aspect, particularly if each plant is given ample space either to climb or simply trail on the ground. Sone of the leaves are one-lialf to two-thirds white and yellow. The flowers are a rich scarlet-marool, deepest at base of petals. Per pkt. $10 \mathrm{cts}$.; oz. $20 \mathrm{cts}$.; per $1 / 4$ Ib. $60 \mathrm{cts}$.

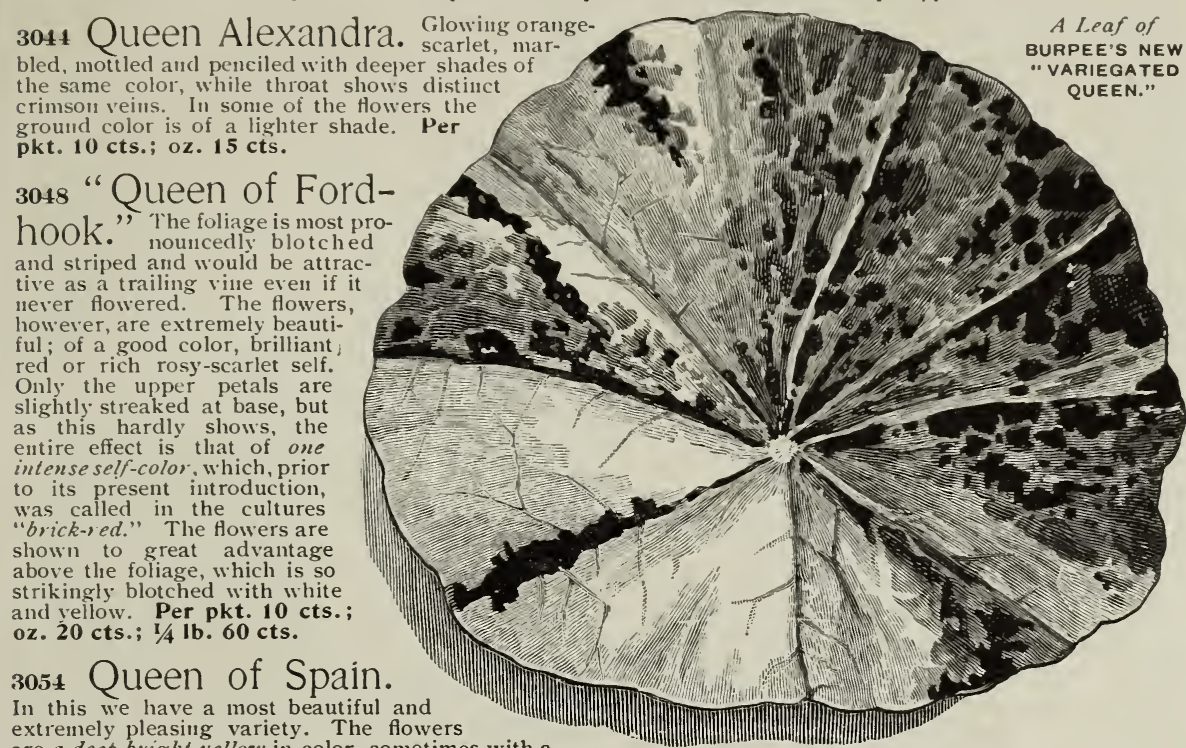
extremely pleasing variety. The flowers

are $a$ deep bright yellow in color, sometimes with a

slight suffusion of red, while the throat is penciled brown.

The flowers are large, the leaves charmingly blotched and variegated, as in others of this type; the plants flower profusely all summer long. Per pkt. $10 \mathrm{cts}$.; $0 z .20 \mathrm{cts}$.; $1 / 4 \mathrm{lb}$. $60 \mathrm{cts}$.

3016 Oueen Dowager. The leaves are beautifully variegated; some are blotched and others striped, so that practically no two leaves are alike. The flowers, borne profusely are most distinct and beautiful. Bright glowing crimson; the two upper petals are blotched with deeper crim-
son, while the caly $\mathrm{x}$ is bright yellow, -thus giving a yellow throat-like appearance. Per pkt. 10 cts.; oz. 20 cts.

3050 Queen of the Morning. A beautiful salmon-pink on a pure yellow ground. Throat is 3052 Queen of the North. A most beautiful and attractive color combination. The large

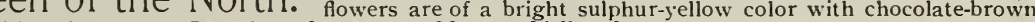
veins or pencilings in throat. Per pkt. $10 \mathrm{cts}$; 0 z. 20 cts.; $1 / 4 \mathrm{lb} .60 \mathrm{cts}$.

3056 Queen Wilhelmina. Rich rosy-scarlet fowers with crimson veins in throat. The bright oz. 20 cts.; $1 / 4 \mathrm{lb} .60 \mathrm{cts}$.

3060 Burpee's "Variegated Queens" in Mixture. This " " waw "Royal Race" of the parent variety ( $N o, 3043$ Variegated Oueen) is described above, is now offered in improved and most superb mixture for 10r4. The flowers are of many bright colors in charming contrast to the handsomely variegated foliage. The leaves are so beautifully variegated with yellow, white and greent that the plants would be worthy of culture almost for the foliage alone. Per pkt. $10 \mathrm{cts.;}$ oz. $15 \mathrm{cts} . ; 1 / 41 \mathrm{lb} .50 \mathrm{cts}$.: per $1 \mathrm{~b}$. $\$ 1.75$.

\section{New Dwarf Nasturtium,--22s5 David Burpee.}

\section{A Novelty from Holland,-The First of an Entirely New Type in Foliage.}

While in Northern Holland, August, I909, we were much impressed with this unique novelty,-lhe first of a new race. Our son David remarked that the foliage was waved and curled like the standard of a Spencer Sweet Pea, and unknown to us the originators, Messrs. Sluis \& Groot, a few months later, gave it the name SPENCERPAV, and unknown

The foliage is so unlike any other type, and at the same time so charming and unique, that it attracts admiration wherever seen. The plant makes a symmetrical bush of perfectly round formation, attaining a height of from nine to twelve inches in diameter, the beauty of which is much enhanced by the very peculiar, waved emerald-green leaves. The flowers are bright crimson-red, with richer suffusions and markings, in cont rast to a bright yellow calyx; borne on long stems, they show well above the magnificent foliage. Both as individual plants and for bordering it is invaluable,-and comes true from seed. Per pht. 10 cts.; oz. 20 cts. 


\section{Tom Thumb Nasturtiums.}

Plant seed one inch deep in rows one to two feet apart when the trees are starting out in leaf. When well started to grow, the young plants should be thinned out or transplanted to stand ten to twelve inches apart.

2300 Aurora............... Po o5 \$o o6 $\begin{gathered}\text { Po } 20 \\ \text { PKT. PER 0Z. }\end{gathered}$

230\% Beauty

2303 Beauty of Malvern

2304 Brilliant Yellow.

2306 Bronze-Colored.

2308 Cattell's Crimson.

2309 Carmine King.

2311 French Chameleon.

2313 Cloth of Gold.

2315 Cœruleum Roseum

2319 Crystal Palace Gem

2322 Deep Scarlet.

2324 Empress of India.

₹326 General Jacqueminot.

2329 Golden King. .

2331 Golden Queen

2333 King of Tom Thumbs

2335 King Theodore........

2337 Lady Bird...

2339 Pearl.

2344 Ruby King.

2346 Rudolph Virchow.

2350 Vesuvius.

2352 Mixed......(Per lib., $45 \mathrm{cts}$.)

2354 Burpee's "Gorgeous" Mixture of Tom Thumb (Per

$5 \quad 6 \quad 20$

\section{Burpee's Dwarf "Ivy-Leaved" Nasturtiums.}

PKT. PER OZ. $1 / 4 \mathrm{LB}$. 2280 Golden Butterfly........... \$o Io. \$o 20 \$o 60 2284 All Colors, Mixed (Per lb., $\$$ I.50) ro 15

\section{Dwarf Variegated-Leaved Nasturtiums.}

(QUEEN OF TOM THUMBS.)

The dwarf compact plants are of rounded form with all the leaves showily marbled or variegated in contrasting shades of white, yellow and green.

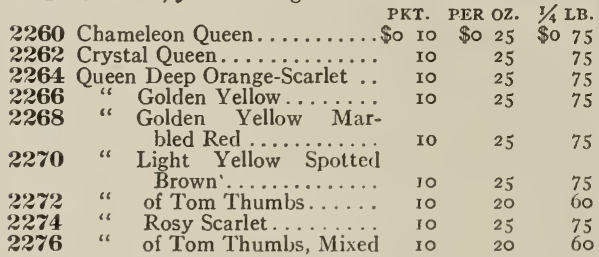

\section{The David Burpee Type of Dwarf Nasturtiums.}

PKT. PER OZ

2285 David Burpee.

So ro \$o

2287 Anna Groot.

2289 Spencer Iady Bird. .

2291 Miss Mina Groot

2293 Riemke Groot.

avid Burpee Type, Mixed ..... r.

\section{Other Nasturtiums.}

2357 Dwarf Lilliput Fairy King PKT. PER OZ. $1 / 4$ LB.

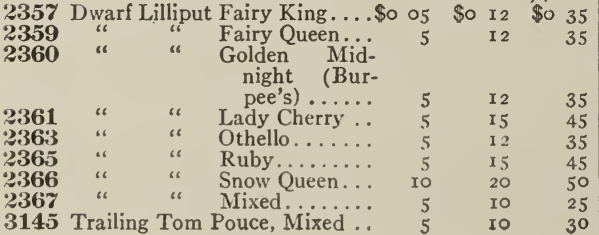

35

35 feet apart to allow them room to spread, and seed should be planted four to six inches apart in drills one inch deep. early in the spring, when the trees are starting out in leaf. Firm the soil well after the seed is planted to insure proper germination. The young plants should be thinned to stand six inches apart when well started to grow.

3061 Butterfly (Burpee's) PKT. PER OZ. $1 / 4$ LB,

3067 Dunnett's Orange.......... $5-60$

3067 Dunnett's Orange......... $55^{2} \quad 6 \quad 15$

3069 Fordhook Fashion......... 5.45

3070 Flammeum................. 5 5

307\% Golden-Leaved Scarlet...... 5 5 50

620

3078 Midnight. .......... 55125

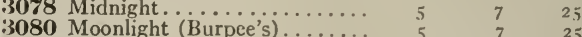

3082 Pearl.................. $54.5 \%$

3084 Prince Henry. . . . . . . . . . 5 5 620

3088 Rose................. $55^{5} \quad 7 \quad 25$

3090 Salmon Queen........... 5 5 75

3092 Scarlet. 3096 Sunlight (Burpee's)...........

3097 Twilight (Burpee's) . .......

3101 Von Moltke............. 5020

3103 Mixed.......(Per lib., $40 \mathrm{cts}$.) $\quad 5 \quad 6 \quad{ }^{2}$

3105 Hybrids of Madame Gunter,

3108 French Chameleon

3110 Fordhook Favorite Mixture of Tall Nasturtiums,

3112 Burpee's Giant - Flowered $\quad 5$ Io 25 Mixed (Per lb., \$1.50) .... Io 15 Io 40

\section{Lobb's Nasturtiums.}

3116 Aureum PKT. PER OZ. $1 / 4 \mathrm{LB}$. 3118 Brilliant............... \$o 5 \$o 10 \$o 30

3120 .

3122 Cardinal.

3126 Crystal Palace................ 5 5 5 ro

3128 Giant of Battles.......... 5 ro no

3130 Gold Garnet............. 5 n 10 30

3132 King of the Blacks........ 5 5 ro 30

3134 Lucifer............. $5{ }^{2} \quad 7 \quad 25$

3136 Queen Victoria........... 5 10 30

3138 Rudolph Virchow......... 5 5 5 10 30

3140 Spitfire ............... 5 5 75

3143 Finest Mixed. (Per lib.,6o cts.) $\begin{array}{lll}5 & 7 & 25 \\ 5 & 6 & 20\end{array}$

\section{Burpee's New Variegated-Leaved Tall Nasturtiums.}

Every leaf is variegated with yellow, white and green,-but in such differing degrees that the plants present a most varied aspect,- particularly if each plant is given ample space, either to climb or simply trail on the ground. Some of the leaves are one-half to two-thirds white and yellow, while others are mostly green but beautifully blotched and striped. See page IIO.

3042 Variegated Queen.......... PKT. PER OZ. $1 / 4 \mathrm{LB}$. 3044 Queen Alexandra........... \$o ro \$o 20 \$o 60

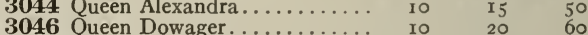
3048 Queen of Fordhook ............. $\mathbf{3 0 5 0}$ Queen of the Morning......... 10 ro 10 20 60

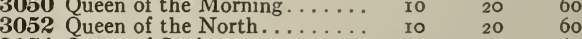
3054 Queen of Spain.......... 3056 Queen Wilhelmina.......... no 20 ro 60 3060 Burpee's Variegated Queen in Mixture..(Per lb., \$1.75) (o I $_{5} \quad 50$

\section{Burpee's Tall "Ivy-Leaved"} Nasturtiums.

The plants are of running growth, with star-like pointed leaves of rich green, veined with white, so that the young shoots, where the leaves are set closely together, have a marked resemblance to the foliage of the hardy English Ivy. The flowers are of medium size and of most distinct form. The petals are quite narrow, and standing well apart from each other present a striking star-like appearance.

PKT. PER OZ. $1 / 4$ IB. 3154 Original Ivy-leaved.........\$o Io \$o $I_{2}$ \$o 40 3156 Golden Gem............. ro ro rs 60

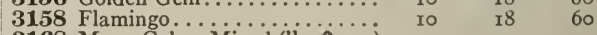
3168 Many Colors Mixed (lb., $\$ 1.50)$ s $\quad$ I5 . 40 


\section{Nicotiana.}

Very desirable for planting in shrubbery beds, but can also be used to advantage in beds by themselves. Affinis has white, Bouvardia-like fragrant flowers on long terminal tubes. Sandera Bybrids, introduced from England, grow two to three feet high, each plant forming a cluster of rich dark green leaves. New Hybrids of Affrnis are of similar habit of growth, but produce flowers having a slight fragrance. Sylvestris produces white fragrant flowers. PKT. 2371 Affinis

H........ (Per 1/2 oz., I 5 cts.)\$o o5 \$o 25 IO

ræ Hybrids (Per $1 / 2$ oz., 20 cts.)

2:375 Sylvestris

\section{Oxalis.}

Rosea grows six inches high and has bright pink flowers, Tropaloides, very dwarf, with reddish-brown leaves and yellow flowers. Valdiviana, tall green leaves, marked with brown; lemon-yellow flowers on tall stems.

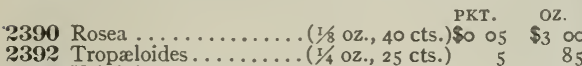
2394 Valdiviana

2396 Choice Mixed......... (1/4 oz., 75 cts.)

\section{Pansies.}

The Pansy is, without doubt, the most popular of all flowering plants and is grown over the widest extent of country. Pansies bloom most freely and produce largest and finest flowers in cool moist locations, or during early spring and late fall months. They flower, however, with great freedom, even during the hottest and driest summer from seed sown in open ground early in spring, and continue in bloom until checked by severe frosts of early winter. Choice Pansy seed has been always a leading specialty with us, and we offer not only the largest and finest collection of varieties in the world, but most care fully selected strain of each variety. Having visited repeatedly all leading growers of Europe and making hundreds of trials each season at FORDHOOK FARMS, we

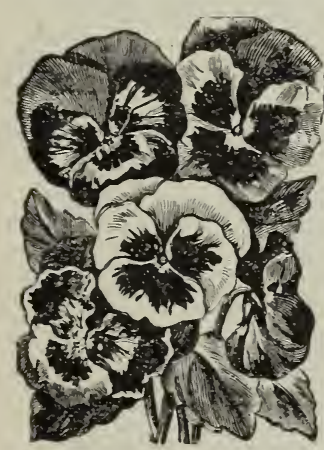
know that our seed is the best that can be obtained. From our close connection with the leading Pansy specialists in Europe, we are enabled to offer all of the choicest new strains and colorings as soon as they are ready for distribution. Seed germinates best while soil is still cool and moist. We would advise sowing in shallow drills in seed-bed early in spring when the trees are starting out in leaf, and again in Septem ber when the weathe becomes cool. As above stated, plants from the spring-sown seed

flower with great freedom throughout spring, summer and fall, while the stocky young plants grown in fall and winter produce the largest and finest flowers early the following spring. Full directions are given in our leaflet "How TO GRow PANSIES," which is sent free if requested on the order. Young plants can be transplanted readily before they commence to flower, so that they may be planted out in beds at any time when the soil is sufficiently moist.

PKT. OZ.

2397 Dark Purple.......... (1/2 oz., 45 cts.)So of So 85

2399 Emperor William ......(1/4 oz., 25 cts.) $5 \quad 85$

2401 Gold Margined......... (1/4 oz., $30 \mathrm{cts}) \quad$.$5 \quad I$

2403 King of the Blacks..... (1/4 oz., 25 cts.)

2405 Lord Beaconsfield......(1/4 0z., 25 cts.)

2407 Prince Bismarck....... (1/4 oz., $25 \mathrm{cts}$.)

2409 Pure Yellow........... (1/4 oz., $30 \mathrm{cts}$.

2411 Quadricolor............. (1/4 oz., 25 cts.)

2412 Striped and Mottled ...(1/4 oz., $30 \mathrm{cts}$.)

2413 Snow Queen.......... (1/4 oz., $30 \mathrm{cts}$.

2415 Large-Flowering, Very Fine Mixed. .

2417 Good Quality Mixed.... (1/2 oz, 30 cts.)

IVe make "Trade Packets" (containing about 2000 seeds) of any of the above separate colors, at 25 cents each.

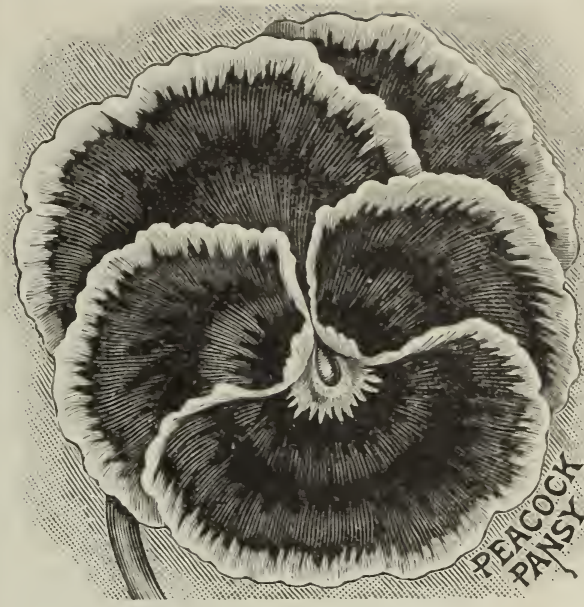

Pansy,-Imperial German.

These are unequaled as perpetual bloomers; the flowers are of large size and finest form, and may now be had in wonderful variety of color. They are of neat and compact habit of growth and established plants commence to flower very early in spring and continue to produce their lovely blooms throughout summer and into late fall. They embrace all the solid or self-colors; delicately shaded flowers five-spotted on backgrounds of every color; large spotted; edged or bordered flowers of various colors, each with a distinct rim of white; yellow, or blue, also dark and light marbled varieties; flowers with clear distinct eyes; striped flowers of striking beauty, and other vividly colored fancy varieties. Undoubtedly a splendid type for florists. Seed sown in the fall and transplanted three inches apart makes fine plants for spring sale. Our collection embraces a wide range of color.

2421 Auricula Colors ...(Per I/ $/ 8$ oz., 50 cts.)\$o Io $\$_{3} 50$ 2422 Black Prince.......(Per $1 / 8$ oz., 50 cts.) Io 350 2424 Cardinal..........(Per $1 / 8$ oz., $50 \mathrm{cts}$.) Io 350 2426 Crown Prince ..... (Per $1 / 8$ oz 50 cts.) IO 350 2428 Dark Mahogany with White Margin (Per $1 / 8$ oz. 50 cts.) 2429 Dark Mahogany with Yellow Margin

2431 Golden Queen (Per 1/8 oz., 50 cts.)

(Per $1 / 8$ 0z., $50 \mathrm{cts}$.)

24.35 Emperor IVilliam..(Per I/8 oz., 50 cts) 10 350

$\mathbf{2 4 3 7}$ Fairy Queen......(Per 1/8 oz., 50 cts.) 10 350

2438 Fancy Striped ....(Per $1 / 8 \mathrm{oz}, 50 \mathrm{cts}$.) Io 350

2439 Fire King.........(Per 1/8 oz., 50 cts.) I0 350

2441 Golden Yellow with Black Eye,

$\mathbf{2 4 4 3}$ Jet Black........(Per 1/8 oz., 50 cts.) $\begin{array}{lll}(\text { Per } 1 / 8 \text { oz., } 50 \text { cts.) } & \text { 10 } & 50 \\ 3 & 50\end{array}$

2445 Large-Spotted, Mixed,

2447 Light Blue

449 Marbled, Mixed...(Per $1 / 6$ oz, $50 \mathrm{cts}$.) 350

2451 Meteor..........(Per $1 / 8$ oz., 50 cts.) Io 350

$\mathbf{2 4 5 3}$ Odier or Five-Spotted.

457 Pelo........(Per 1/8 oz., 50 cts.) Io 350

10 350

4.59 Prince Bismarck .. (Per 1/8 oz., 50 cts.) Io 350

2461 Red Riding-Hood .(Per 1/8 oz., 50 cts.) ro 350

2463 Rosy Lilac ........(Per 1/8 oz., 50 cts.) ro 350

2465 Rosy Morn........(Per 1/ oz., $50 \mathrm{cts}$.) Io 350

2466 Royal Purple.....(Per 1/8 oz., $50 \mathrm{cts}$.) Io 350

2468 Snow Queen (Per $1 / 8$ oz, $50 \mathrm{cts}$ ) I0 3 50

$\mathbf{2 4 7 0}$ Ultramarine-Blue.. (Per I/8 oz., $50 \mathrm{cts}$.) Io 350

2472 White with Eye...(Per 1/8 oz., 50 cts.) 10.35 2474 Victoria Red......(Per 1/8 oz., 50 cts.) I0 350

2476 All Varieties, Mixed,

Florists and Market Gardeners,

by planting Gladioli and other summer-flowering bulbs, can easily have an additional source of income at a time when most other crops are past. (See pages $14 I$ to 147. ) 


\section{New Pansies, - ${ }_{2513}$ Burpee's Best Giant-Fancy.}

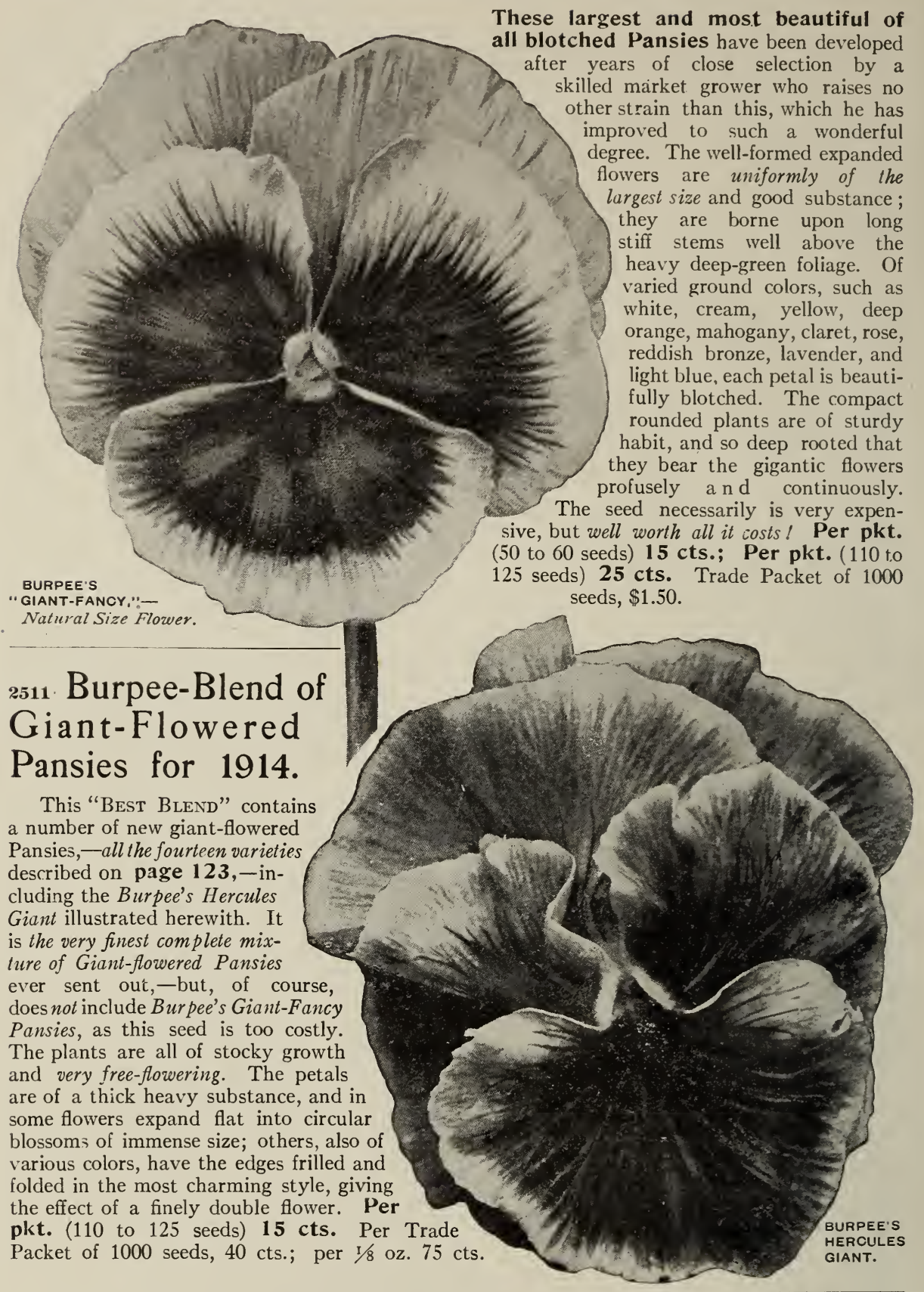

2487 The Lovely "Orchid-Flowered" Pansies. This distinct beautiful strain has be a source of constant delight to all who admire delicate art tints. While the greatly improved and will size when compared with those of the "truly giant-flowered " type, yet they are of fine shape and most exquisite colorings in very soft, pleasing pastel shades. The plants flower freely from spring until late in the fall, and the beautiful colorings-including shades of chamois, terra-cotta, pink, lilac, rose and orange-make a charming contrast to the rich velvety effects and brilliancy of the older familiar types. Per pkt. (100 to I25 seeds) 10 cts. Per Trade Packet of rooo seeds, 40 cts.; $1 / 80 z .75$ cts.; $1 / 4$ oz. $\$ 1.35 ;$ per oz. $\$ 5.00$. 


\section{The Best New "Truly Giant-Flowered" Pansies.}

249r Giant Ruffled,_-“Masterpiece.

The truly giant-sized flowers are of the most striking

character ; the petals, having a rich velvety sub-

stance and being heavily ruffled, give them the

effect of a double flower. The colors are mainl

dark rich shades, bordered, blotched or marked in ray-like veinings with contrasting colors. Per pkt. $15 \mathrm{cts}$. Per pkt. of 1000 seeds, 50 cts.; $1 / 8$ oz. 85 cts.; $1 / 4$ oz. $\$ 1.60$; per oz. $\$ 6.00$. 2499 Giant Pretiosa. Fach petal violet blotch, surrouncled by a crimsonrose ground color, eclged with white. The petals are generally curled. Per pkt. I5 cts.; per $1 / 4$ Oz. 85 cts.

2501 Giant Psyche. This is of is pure white, but each of the petals is heavily blotched with velvety violet. Pkt. I5 cts. Per rooo seeds, 5o cts.

2509 Giant Defiance. A ride colorings and markings. More than half the flowers are distinctly blotched on the three lower petals or on all five petals, while the others show "selis" of all colors. Per pkt. 15 cts. Per Trade Packet of 1000 seeds, $50 \mathrm{cts}$; $1 / 8 \mathrm{Oz} .80 \mathrm{cts}$; $1 / 4 \mathrm{Oz} . \$ 1.50$.

2505 President McKinley. Large beaurich glowing yellow, each petal blotched with deep reddish brown. Per pkt. I5 cts.; per rooo seeds, 50 cts.

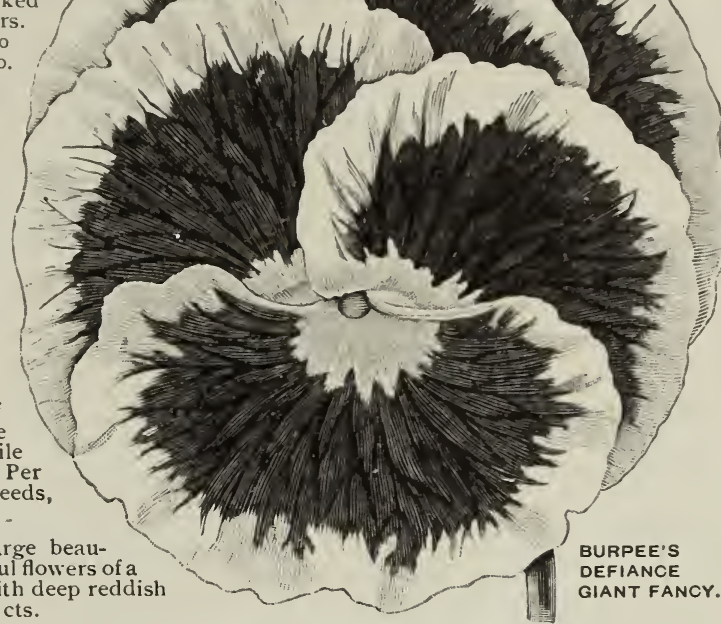

2503 President Carnot. The margin of petals is clear white, while the centers are blotched with rich

2491 Giant Bridesmaid. This might be called Giant Apple Blossom as descriptive of the lovely

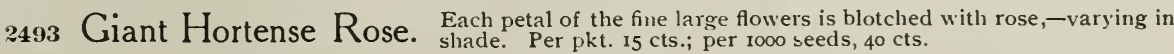

2495 Burpee's Hercules Giant. The enormous flowers are of thick heary texture. The colorself-colored in the richest tints of purple-carmine and brown, relieved by delicate shadings of a brighter or coutrasting color; others are boldly margined with white,

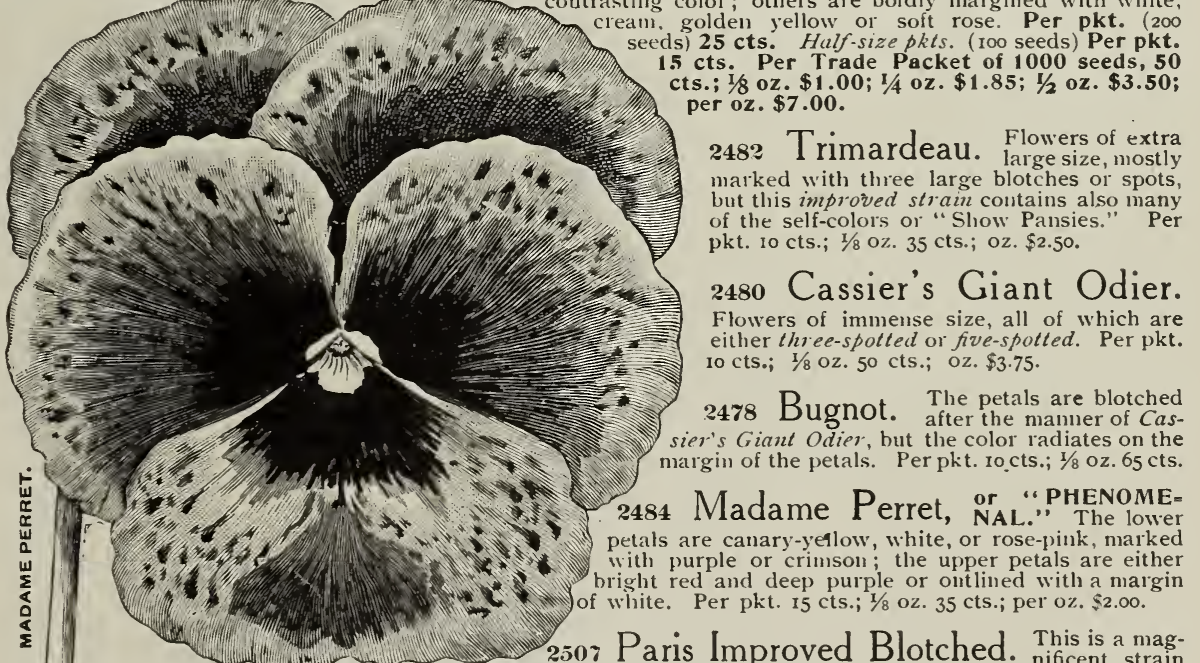
(mis Improved Blotched. nificent strain of truly giant-flowered Pansies of the richest ground colors. beautifully blotched. Per pkt. (100 to 125 seeds) $15 \mathrm{cts}$. Trade packet of 1000 seeds, $60 \mathrm{cts}$.; 1/8 oz. \$1.00.

2511 Burpee's New Blend of the Best Giant-Flowered Pansies for 1914.

This "BEST BLEND" contains a number of giant-flowered varieties of the most recent development,-including all the above. It has the very finest complete mixture of Giant-flowered Pansies ever sent out. The plants are of sturdy stocky growth and very free-flowering. The petals are of a thick heavy substance, and in most flowers expand flat into circular blossoms of immense size and all colors, while it contains also, of course, the Masterpiece type, with edges frilled and folded in the most charming style. Per pkt. 15 cts. Per

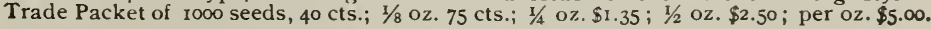




\section{The "Spencer" Type of Sweet Peas}

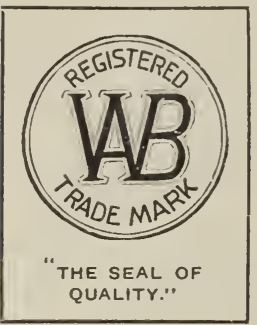

"SPENCER" Sweet PEAS are a great specialty with us! We were the first to grow the seed in America - the stock having been entrusted to us before introduction even in England, of the original Countess Spencer. We have grown "the original Beauty" and its many "sportive" children with painstaking care each season since. There are but few other growers-either in England or America-who can supply an equal assortment of True RE-SELECTED "SPENCERS" that are uniformly of such choice quality. Seedsmen and planters generally can see how superior our stocks now are by the trials at FORDHOOK FARMS next June or July, while those who may be in California are invited also to inspect the growing crops at our FLORADALE FARM in the beautiful Lompoc Valley. Every planter's garden, however, is really a trial ground, and we shall be quite content if any "Doubting Thomas" will send us only a portion of his order and note the difference in character of flowers produced!

Since the first crop of Sweet Peas in America we think the yield of seed has never been smaller than crops just harvested, considering acreage planted. If we had not located our own ranch in the fertile Lompoc Valley several years ago, we should now be obliged to decline orders for many of the Spencer varieties. Fortunately, for ourselves and customers, Mr. Lonsdale, early last winter, anticipating a "dry year," made arrangements for the sinking of a deep well at Floradale, and this well is solely responsible for our being able to offer re-selected seed of Spencer Sweet Peas at moderate prices.

I $\rightarrow$ This alphabetical list will aid planters to locate any given variety, - for color classification see pages 126 and $12 \%$.

3402 Afterglow. Rich electric shades of blue and rosy-mauve,

3406 America Spencer. Red flakes on white ground,

3408 Apple Blossom Spencer (Burpee's). A large rose and pink,

3410 Arthur Green. Rich dark claret. A large fine flower,

3412 Asta Ohn. Soft lavender with rosy-mauve suffusion,.

3414 Aurora Spencer (Burpee's). Cream-white ground,

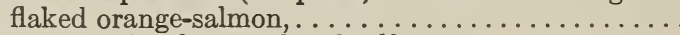

3416 Barbara. A salmon-colored self, . . . . . . . . . . .

3418 Beatrice Spencer. A fine rich pink; exquisitely waved,

3420 Bertrand Deal. A large flowered lilac mauve, .........

3422 Blanche Ferry Spencer. Standard rich rose, wings pink-

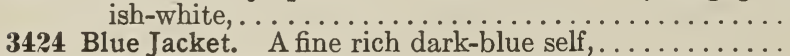

3428 Captivation Spencer (Burpee's). Rich rosy-wine red. Fine form,.

3430 Charles Foster. Pastel shades of salmon, amber and

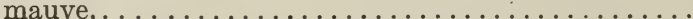

3432 Charm (Burpee's). A lovely white, with lilac-blush suffusion, $\ldots \ldots \ldots \ldots \ldots \ldots \ldots \ldots \ldots \ldots \ldots \ldots \ldots \ldots \ldots \ldots \ldots \ldots$

3434 Constance Oliver. A beautiful pink on cream ground,

3438 Countess Spencer. Rich rose-pink, the original Spencer variety, ...........................................

3440 Dainty Spencer (Burpee's). A fine white, edged rose,..

3442 Decorator (Burpee's). Deep rose, heavily suffused

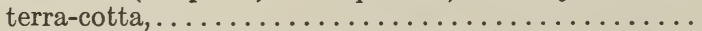

3444 Duplex Spencer. A double-flowered rich cream-pink,...

3446 Earl Spencer. A fine rich salmon self, . . . . . . . . . . .

3448 Edith Taylor. Bright salmon rose,.

3450 Elfrida Pearson. A magnificent light pink margined

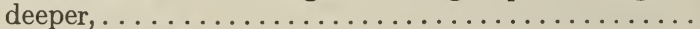

3452 Empress Eugenie. Delicate gray flaked with light lavender. Per pkt. of 15 seeds, 15 cts., . . . . . . . . . .

3454 Ethel Roosevelt (Burpee's). Primrose ground striped light pink,

3458 Flora Norton Spencer. $\ddot{A}$ fine light blue $\ldots \ldots \ldots$

3460 Florence Morse Spencer. A very popular blush-pink variety,

3462 Florence Nightingale (Burpee's).

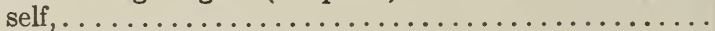

3464 Florrie. Rich pastel shades of rosy crimson-lake, .......

$\begin{array}{lll}\text { Per pkt. Per oz. } & \text { P } \\ \$ 0 & 15 & \$ 100\end{array}$

Per

10

$25 \quad \$ 0 \quad 75$

Per Ib.

10

25

10
10

$40 \quad 150$

275

10

10

10

$40 \quad 125$

30

85

300

15

$25 \quad 75$

275

10

35

100

375

15

75

10

$30 \quad 90$

350

15

$\begin{array}{lll}75 & 2 & 75\end{array}$

15

$65 \quad 2 \quad 25$

\begin{tabular}{l|l|l|}
10 & 30 & 85
\end{tabular}

300

10

\section{5}

75

275

10

25 ()

15

(1)

75

850

10

15

450

$\begin{array}{lll}40 & 1 & 25 \\ 75 & 2 & 50\end{array}$

$\begin{array}{ll}4 & 50 \\ 9 & 00\end{array}$

15

$\begin{array}{lll}75 & 2 & 50\end{array}$

900

3470 Gaiety Spencer. White ground, flaked with rose-crimson,. $\ddot{\text { Herbert. } . . . . . . . . ~ B e a u t i f u l ~ r i c h ~ b r i g h t ~ r o s y-c a r m i n e . ~}$

3472 George Herbert. Beautiful rich bright rosy-carmine,.
3476 Gladys Burt. A rich salmon-pink on cream ground,...

3478 Helen Grosvenor. A lovely bright orange-pink,........

3480 Helen Lewis. Rich orange-pink, of large size and fine form,

3482 Helen Pierce Spencer. White ground, mottled bright

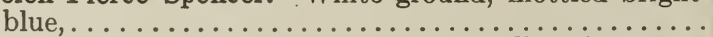

3484 Hercules. A very large rich pink of excellent form, ... 
3485 Illuminator. Rose, heavily suffused salmon-orange.

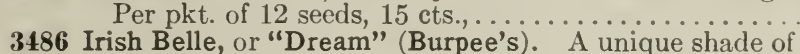
lilac, flushed pink,

3487 Isobel Malcolm. A very fine black-seeded cream self,

3488 King Edward Spencer (Burpee's). Large rich carminescarlet self, ..............................

3489 King Manoel. Rich shining maroon with violet

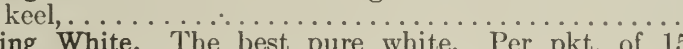

3490 King White. The best pure white. Per pkt. of 15

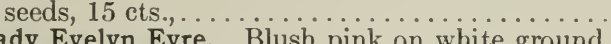

3492 Lady Evelyn Eyre. Blush pink on white ground, . . . .

3496 Loyalty. White ground, flaked with violet,

3498 Margaret Atlee. Rich pink and salmon on cream ground. Per pkt. of 20 seeds, 15 cts.,.

3500 Margaret Madison. An exquisite shade of silvery-blue,

3502 Marie Corelli (Burpee's). A splendid rosy-carmine self, .

3506 Martha Washington. White, edged and suffused light

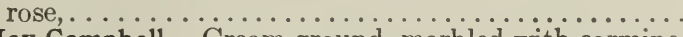

3510 May Campbell. Cream ground, marbled with carmine,

3511 Melba. A large salmon of finest form, . . . . . . . .

3514 Mercia. A beautiful rich buff-pink on cream,........

3516 Mrs. A. Ireland. Rose and pink on cream ground,

3518 Mrs. Cuthbertson. Rose pink standard, wings almost

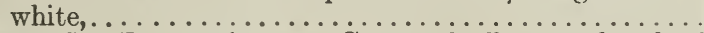

3520 Mrs. C. W. Breadmore. Creamy-buff ground, edged

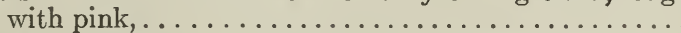

3522 Mrs. Heslington. Rich lavender, suffused rose-pink.,.

3.524 Mrs. Hugh Dickson. A lovely shade of pinkish-apricot

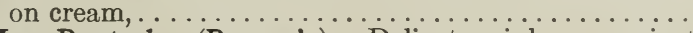

3528 Mrs. Routzahn (Burpee's). Delicate pink on apricot

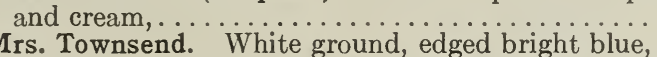

$\begin{array}{ll}3530 & \text { Mrs. Townsend. White ground, edged bright blue,.... } \\ \text { 3532 Mrs. W. J. Unwin. White ground flaked with orange- }\end{array}$

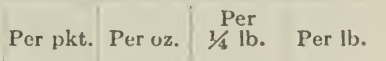
$\$ 025$

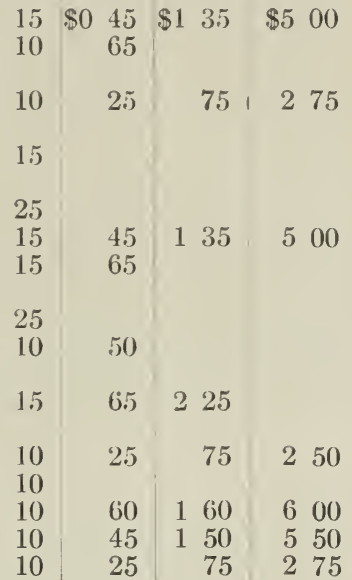

3533 Mrs. T. W. Warren. White ground penciled deep

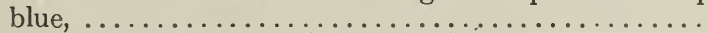

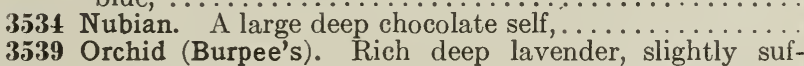
fused pink, .

3542 Othello Spencer (Burpee's). A very deep, rich maroon self, .

3543 Pearl Gray Spencer. Soft lavender or dove-gray,

3.j45 Primrose Spencer (Burpee's). Rich cream-yellow, large and fine, .................................

3547 Prince George. Rosy lilac veined rose. A pastel shade,
3551 Purple Prince Spencer (Burpee's). The standard is purplish-maroon, wings rosy-purple, . . . . . . . .

3554 Queen Victoria Spencer (Burpee's). A rich primrose

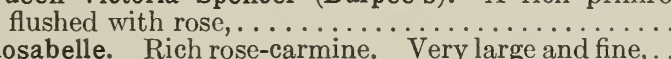

3567 Rosabelle. Rich rose-carmine. Very large and fine,...

3570 Scarlet Emperor. A rich scarlet self of finest form,...

35\%1 Scarlet Empress. A deep scarlet self, large and fine,

3572 Senator Spencer (Burpee's). Striped claret on heliotrope ground,.

3575 Stirling Stent. Rich salmon with orange suffusion;...

3579 Tennant Spencer. A lovely shade of purplish-mauve,

3581 Thomas Stevenson. An exceedingly bright orange-

358 Vermilion Brilliant (Burpee's). A large brilliant $\ldots \ldots$

3589 wedgewood. Rich azure blue. Per pkt. of 12 seeds, 15 cts., . . . . . . . . . . . . . . . . . . . ........

3590 White Spencer (Burpee's). An extra fine strain, ...
3593 W. T. Hutchins (Burpee's). Soft blush-pink on buff

3599 The New "Burpee-Blend" of Re-selected Superb "Spencer" Sweet Peas, 


\section{Superb Spencer Sweet Peas.}

\section{Arranged According to Color Classification.}

Until this season Burpee's Blue List has offered Spencer Sweet Peas in an alphabetical list, but now that the number of varieties has increased, we think it advisable to also give a color classification which should greatly aid planters who are desirous of planting only certain colors.

Lack of space prevents our giving full descriptions, and for this information please refer to pages 111 to 119 of BURPEE'S ANNUAL FOR 1914.

\section{White.}

3490 King White. The best pure white. Per pkt. of 15

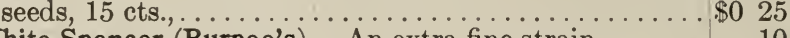

3590 White Spencer (Burpee's). An extra fine strain, . . . . . $10 \quad \begin{array}{llllll}45 & \$ 1 & 25\end{array}$

\section{Cream or Primrose.}

3487 Isobel Malcolm. A very fine black-seeded cream self,. 3545 Primrose Spencer (Burpee's). Rich cream-yellow,

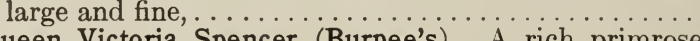

3554 Queen Victoria Spencer (Burpee's). A rich primrose flushed with rose,

\section{Cream Pink.}

3434 Constance Oliver. A beautiful pink on cream ground, . 3444 Duplex Spencer. A double flowered rich cream-pink, .

3476 Gladys Burt. A rich salmon-pink on cream ground,

3498 Margaret Atlee. Rich pink and salmon on cream ground. Per pkt. of 20 seeds, 15 cts., . . . . . . . . .

3514 Mercia. A beautiful rich buff-pink on cream,.

3524 Mrs. Hugh Dickson. A lovely shade of pinkish-apricot on cream,

3528 Mrs. Routzahn (Burpee's). Delicate pink on apricot and cream,

3593 W. T. Hutchins. Soft blush-pink on buff and cream, . . . Light Pink or Blush.

3432 Charm. A lovely white with lilac-blush suffusion,

3450 Elfrida Pearson. A magnificent light pink margined deeper, .

3460 Florence Morse Spencer. A very popular blush-pink variety, .

3492 Lady Evelyn Ey. . Blu pink o. . . . . .

\section{Deep Pink.}

3418 Beatrice Spencer. A fine rich pink, exquisitely waved, .

3438 Countess Spencer. Rich rose-pink, the original Spen-

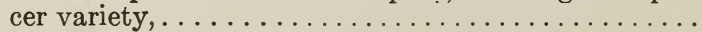

3484 Hercules. A very large rich pink of excellent form, ....

\section{Salmon Pink.}

3448 Edith Taylor. Bright salmon-rose, .

3485 Illuminator. Rose, heavily suffused salmon-orange.

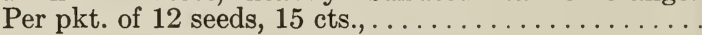

\section{Rose and Carmine.}

3442 Decorator (Burpee's). Deep rose, heavily suffused terra-cotta,...

3472 George Herbert. Beautiful rich bright rosy carmine,

3502 Marie Corelli (Burpee's). A splendid rosy-carmine self,

3567 Rosabelle. Rich rose-carmine. Very large and fine,.

\section{Crimson and Scarlet.}

3488 King Edward Spencer (Burpee's). Large rich carminescarlet self of finest form,

$35 \% 0$ Scarlet Emperor. A rich scarlet self of finest form,

35\%1 Scarlet Empress. A deep scarlet self, large and fine,

3587 Vermilion Brilliant (Burpee's). A large brilliant scarlet self,

\section{Orange.}

3478 Helen Grosvenor. A lovely bright orange pink,.

3480 Helen Lewis. Rich orange-pink, of large size and fine form,

3581 Thomas Stevenson. An exceedingly bright orange-scarlet,
10

10

10

10

10

10

25

10

10

10

10

Per lb.

$\$ 450$

65

40

110

400

350

$\begin{array}{lll}35 & 1 & 00\end{array}$

300

30

85

450

300

40
30

85

00




\section{Salmon.}

3416 Barbara. A salmon-colored self,

3446 Earl Spencer. A fine rich salmon self,

3511 Melba. A large salmon of finest form,

3575 Stirling Stent. Rich salmon with orange suffusion,...

\section{Lavender and Mauve.}

3412 Asta Ohn. Soft lavender with rosy-mauve suffusion,.

3420 Bertrand Deal. A large flowered lilac-mauve, .

3462 Florence Nightingale. A fine true lavender self,

3522 Mrs. Heslington. Rich lavender, suffused rose-pink,

3539 Orchid (Burpee's). Rich deep lavender, slightly suffused pink, .

3543 Pearl-Gray Spencer. Soft lavender or dove-gray,...

3579 Tennant Spencer. A lovely shade of purplish-mauve,

\section{Blue and Purple.}

3424 Blue Jacket. A fine rich dark blue self,

3458 Flora Norton Spencer. A fine light blue,

3500 Margaret Madison. An exquisite shade of silvery-blue,

3551 Purple Prince Spencer (Burpee's). The standard is purplish-maroon, wings rosy-purple, .

3589 Wedgwood. Rich azure blue. Per pkt. of 12 seeds, 15 cts.,

\section{Claret and Maroon.}

3410 Arthur Green. Rich dark claret. A large fine flower, 3428 Captivation Spencer (Burpee's). Rich rosy wine-red. 3489 King Manoel. Rich deep shining maroon with violet keel, 3534 Nubian. A large deep chocolate self,...

3542 Othello Spencer. A very deep, rich maroon self,

\section{Bicolors.}

3408 Apple Blossom Spencer (Burpee's). A large rose and pink, 3422 Blanche Ferry Spencer. Standard rich rose, wings pinkish-white, .

3516 Mrs. A. Ireland. Rose and pink on cream ground,

3518 Mrs. Cuthbertson. Rose-pink standard, wings almost

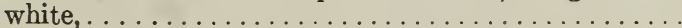

\section{Picotee Edged.}

3440 Dainty Spencer (Burpee's). A fine white, edged rose, . 3506 Martha Washington. White, edged and suffused light rose, 3520 Mrs. C. W. Breadmore. Creamy-buff, edged pink,

3530 Mrs. Townsend. White ground, edged bright blue,

\section{Pastel-Pink and Lilac.}

3402 Afterglow. Rich electric shades of blue and rosy-mauve, 3430 Charles Foster. Pastel shades of salmon, amber and mauve, 3464 Florrie. Rich pastel shades of rosy crimson-lake,

3486 Irish Belle, or "Dream" (Burpee's). A unique shade of lilac, flushed pink, .

3547 Prince George. Rosy lilac, veined rose,

\section{Striped or Flaked.}

3406 America Spencer. Red flakes on white ground,

3414 Aurora Spencer. Cream-white ground, flaked orangesalmon,

3452 Empress Eugenie. Delicate gray, flaked with light lavender. Per pkt. of 15 seeds, 15 cts.,

3454 Ethel Roosevelt. Primrose ground, striped light pink, .

3470 Gaiety Spencer. White ground, flaked with rose crimson,

3482 Helen Pierce Spencer. White ground, mottled bright blue,

3496 Loyalty. White ground, flaked with violet,

3510 May Campbell. Cream ground, marbled with carmine,

3532 Mrs. W. J. Unwin. White ground, flaked with orange-

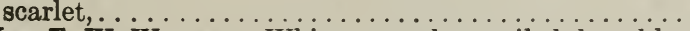

3533 Mrs. T. W. Warren. White ground, penciled deep blue,

3572 Senator Spencer (Burpee's). Striped claret on helio-

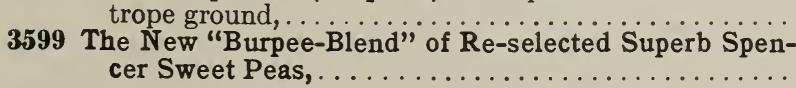

\begin{tabular}{|c|c|c|c|}
\hline $\begin{array}{l}\text { Per pkt. } \\
\text { So } 10\end{array}$ & Per oz. & $\begin{array}{c}\text { Per } \\
1 / 4 \mathrm{lb} .\end{array}$ & Per lb. \\
\hline 15 & $\$ 075$ & $\$ 250$ & $\$ 900$ \\
\hline 10 & 60 & 160 & 600 \\
\hline 10 & 45 & 125 & 450 \\
\hline 10 & 40 & $12 \pi$ & \\
\hline 15 & & & \\
\hline 10 & 30 & 85 & 300 \\
\hline 10 & 45 & 125 & 450 \\
\hline 15 & 135 & 500 & \\
\hline 10 & 50 & 175 & \\
\hline 10 & 35 & 100 & 350 \\
\hline
\end{tabular}




\section{Grandiflora SWEET PEAS.}

We are recognized throughout the world as "Headquarters for Sweet Peas." We have named and introduced more varieties than any other seedsmen excepting only Mr. Henry Eckford. Our stocks are SUPERFINE-extra selected and absolutely pure. We sell annually tons of seed to the most critical buyers in England as well as America.

If you grow Sweet Peas for cut-flowers either under glass or outdoors you should refer also to Burpee's Annual for 1914 for full descriptions, as in this price-list we are limited as to space given to descriptive matter.

Our New Leaflet telling "How to Raise the Finest Sweet Peas" gives complete information on culture of the various types-Free when requested. If you wish more information send 10 cents for copy of our book entitled "Sweet Peas Up-to-Date."

Do The New Earliest Flowering or "Christmas" Sweet Peas are marked with an asterisk $(\star)$.

All varieties of the true Gigantic Waved SPEncer Type are offered on pages 124 to $12 \%$.

\section{White.}

3169 Blanche Burpee. Grand large flowers of beautiful form,

31\%1 Burpee's Earliest White. $\star$ Pkt. 10 cts.,...............

3173 Dorothy Eckford. Grand pure white flowers, .....................

317\% Mont Blanc. $\star$ Dwarf growth; early flowering, . .

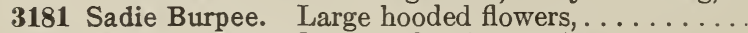

3183 Shasta. Large flowers; fine for cutting,.

\section{Primrose, or Light Yellow.}

3187 Burpee's Earliest Sunbeams. $\star$ A primrose Mont Blanc,

3189 Hon. Mrs. E. Kenyon. An enlarged Mrs. Eckford, . . . . .

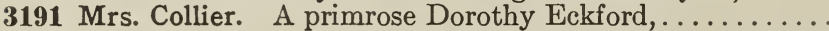

3193 Mrs. Eckford. A beautiful shade of light primrose-yellow,

\section{Primrose,-Shaded Blush.}

3197 Agnes Johnston. Bright rose-pink, shaded with cream, ...... 3199 Christmas Stella Morse. Delicate apricot. Fine for forcing, 3203 Stella Morse (Burpee's). A true apricot shade; very beautiful, 3205 Sybil Eckford. Standard delicate pink-blush on lemon ground, wings a delicate lemon.$\ldots \ldots \ldots \ldots \ldots \ldots \ldots \ldots \ldots \ldots \ldots \ldots \ldots \ldots$

\section{Light Pink.}

3209 Countess of Lathom. A soft creamy pink; flowers of large size,

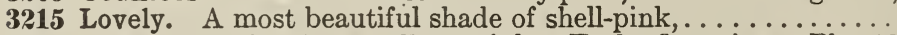
3219 Mrs. F. J. Dolansky. $\star$ Pure pink. Early flowering. Pkt. 10

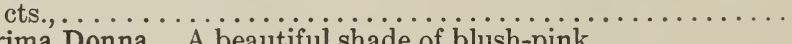

3221 Prima Donna. A beautiful shade of blush-pink, . . . . . . . .

3223 Queen of Spain. Soft buff overlaid with pink,............

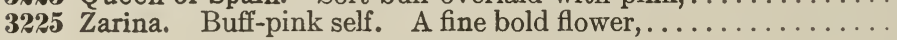

\section{Deeper Pink.} 3229 Janet Scott (Burpee's). "The Best Pink," Grandiflora, ........
3231 Mrs. Wm. Sim. $\star$ A shade of salmon-pink; excellent for forc-

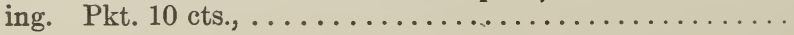

\section{Rose.}

3239 Mrs. Dugdale. Light carmine rose; very large, ........... 3241 Mrs. E. Wilde. $\star$ Bright rose. For forcing under glass, . . . . 3243 Prince of Wales. Bright self-colored deep rose tint,..........

3245 "Rose du Barri." Deep rose, overlaid with terra-cotta. Per

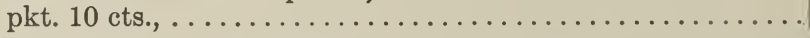

In ${ }^{\circ}$ Except where otherwise priced, all the above are 5 cents per packet. 


\section{Crimson and Scarlet.}

Per

Per oz. $1 / 4 \mathrm{lb}$.

$\$ 0 \quad 10 \$ 0 \quad 30$

$10 \quad 30$

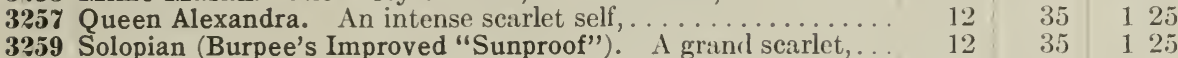

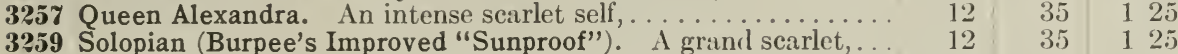

Per lb.

$\$ 100$

100

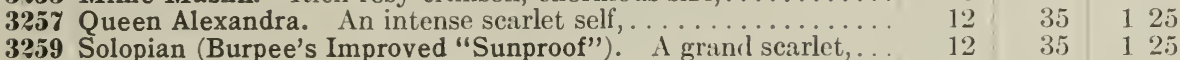

3257 Queen Alexandra. An intense scarlet self, . . . . . . . . . . . . . .
3259 Solopian (Burpee's Improved "Sunproof"). A grand scarlet, . .

\section{Orange and Salmon.}

3263 Bolton's Pink. Soft orange-salmon; stands sun wrll,

3269 Henry Eckford. Bright soft flaming orange,

3275 Miss Willmott. Of large size; deep orange-pink,

327y St. George. Rich deep orange,

\section{Lavender and Light Blue.}

3279 Countess of Radnor. Lavender, with faint purple shadings,

3281 Flora Norton. A beautiful rich lavender,

3283 Lady Grisel Hamilton. A soft shade of light liavender,

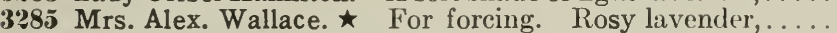

3287 Mrs. Bieberstedt. A lovely deep lavender,.

3289 Mrs. C. H. Totty. $\star$ A fine lavender; for forcing. Pkt. 10 cits.,

3291 Mrs. Geo. Higginson, Jr. A very delicate lavender,

3293 Mrs. Walter Wright. A beautiful deep mauve, .

\section{Blue and Purple.}

3295 Brilliant Blue (Burpee's) (Lord Nelson). Deep Oxford blıe; the finest dark blue, (Lord Nelson). Deep Oxford blie; 10

3301 Countess Cadogan. Color effect is that of a bright blue,........

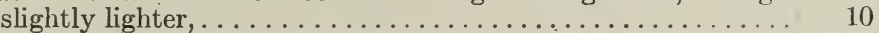

3305 Dobbie's Mid-Blue. "Deep sky-blue" .................. 10

330\% Duke of Westminster. A beautiful shade of rosy claret. . . . . . . . . 12

3313 Le Marquis. $\star$ For forcing. Color of Navy Blue,........ . .

3315 Navy Blue (Burpee's). A deep glowing violet-purple, . . . . . . .

\section{Claret and Maroon.}

3319 Black Knight. Standard wine-brown; wings brownish purple,

3321 Midnight ("Jet"). Standard maroon, wings claret,..........

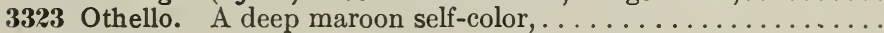

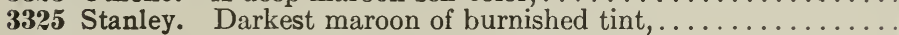

\section{Pink and White. (Bi-Color.)}

3327 Burpee's "Extreme-Early" Earliest of All. $\star$ Pkt. 10 cts.,. . 3329 Burpee's Earliest of All. $\star$ Earlier than Extra Early Blanche

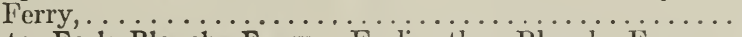

3331 Extra Early Blanche Ferry. Earlier than Blanche Ferry,.

3333 Blanche Ferry. Standard rose-pink; wings white, tinged rose,

\section{Picotee Edged.}

3335 Dainty (Burpee's). "White with pink edge," ............ 3339 Maid of Honor (Burpee's). White, edged with light blue, . . . . .

3341 Phenomenal. Silvery white, edged with purple,

\section{Striped and Mottled.}

3345. America. Silvery white, striped with bright blood-red,.......

3347 Aurora (Burpee's). Creamy white, striped orange-salmon, ... .

3349 Gladys French. White, marbled light blue, .............

3353 Helen Pierce. Bright blue mottled on white, . . . . . . . . . . .

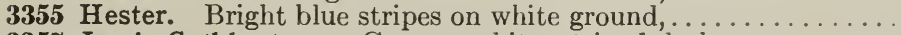

3357 Jessie Cuthbertson. Creamy white, striped dark rose, . . . . . . .

\section{Prince Olaf. Striped with blue on silvery white, $\ldots \ldots \ldots \ldots$}




\section{GRANDIFLORA SWEET PEAS,-Continued.}

\section{Burpee's Sweet Peas in Mixtures.}

In lots of $5 \mathrm{lbs}$. or more $\mathbf{5}$ cents per pound less.

3368 Fine Mixed. Contains many old and new varieties, .

Per oz. $1 / 4 \mathrm{lb}$. Per lb.

3371 Burpee's "Best Mixed." Per pkt. 10 cts.,................. $10 \quad 30 \quad 100$

3375 Fordhook Fancy Flaked. Mixture of striped and variegated.

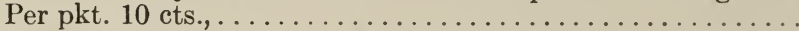

337y New Winter-Flowering Varieties Mixed, $\star \ldots \ldots \ldots \ldots \ldots \ldots \ldots \ldots$

In S $^{2}$ Except Burpee's "Best Mixed," all the above are $\mathbf{5}$ cents per packet.

\section{Waved Sweet Peas of the "Unwin" Type.}

Although of distinct origin, GLAdys UNwin is nearly of the same type as the Counless Spencer, but not so large in size. These new seedlings resemble the parent Gladys Unwin and generally come uniformly waved and fluted.

3178 Nora Unwin. Pure white,

Per pkt. Per oz. $\quad \begin{gathered}\text { Per } \\ \text { lb. Per lb. }\end{gathered}$

Gladys Unwin. Of a lovely light pink color, ......... 5 5 $12 \quad 35 \quad 125$

3282 Frank Dolby. Light lavender, ................ 5 . 5 20

\section{Dwarf CUPID Sweet Peas.}

\begin{tabular}{|c|c|c|c|c|c|}
\hline 2540 & Pink. Has pink and white flowers of the Blanche Ferry & Per pkt. & Per oz. & $\begin{array}{c}\mathrm{Per} \\
1 / 4 \mathrm{lb}\end{array}$ & Per lb. \\
\hline $\mathbf{2 5 4}$ & $\begin{array}{l}\text { type, } \\
\text { White. } \text { The original variety, } \ldots \ldots \ldots \ldots \ldots \ldots \ldots\end{array}$ & $\$ 005$ & $\$ 015$ & $\$ 0 \begin{array}{r}50 \\
50\end{array}$ & $\$ 175$ \\
\hline 254 & Cupids Mixed. Many varieties, . . . . . . . . . . & 5 & 15 & 50 & 175 \\
\hline
\end{tabular}

\section{Sweet Peas for Truckers and Market Gardeners.}

To those who have a market for cut flowers, Sweet Peas are indispensable and one of the best "money making" lines in the cut-flower trade. Although of easy cultivation, we strongly advise growers to give them a little extra attention by well manuring and working the soil as deeply as possible, as this will be well repaid by the production of superior flowers.

Sow as early in the spring as soil conditions will allow, and if the rows are made five feet apart, a crop of early salads or radishes might be planted between each row.

Fall planting is now being carried out to a considerable extent, and for this latitude we have found the end of November and early December to be the most suitable time to sow. These fall plantings commence to flower about one month earlier than the spring sown, and, owing to their superior root growth, are better able to withstand the summer heat and drought.

The following varieties will be found most suitable for cutting purposes. If only six varieties are required, we recommend Nora Unwin, white; Countess Spencer, pink; Florence Morse Spencer, blush-pink; King Edward Spencer, crimson; Florence Nightingale, lavender; and Duplex Spencer, cream-pink.

Or a more extended list might be selected from the following:

\section{Best Varieties for Cutting for Market.}

Early varieties-Burpee's Earliest White; Burpee's Reselected Earliest of All; Burpee's Earliest Sunbeams; Christmas Stella Morse; Le Marquis; Mrs. Alex. Wallace; Mrs. C. H. Totty; Mrs. E. Wilde; Mrs. F. J. Dolansky, and Mrs. Wm. Sim.

These early varieties are also suitable for growing under glass for winter blooming.

White-Dorothy Eckford and Burpee's White Spencer.

Primrose-Primrose Spencer and Queen Victoria Spencer.

Pink-Janet Scott, Constance Oliver and Mrs. Hugh Dickson.

Rose-Marie Corelli and George Herbert.

Crimson Scarlet-Vermilion Brilliant.

Lavender and Light Blue-Margaret Madison and Asta Ohn.

Blue and Purple-Purple Prince Spencer.

Orange-Helen Lewis and Thomas Stevenson.

Maroon-Othello Spencer and Nubian.

Marbled and Flaked-Helen Pierce and Ethel Roosevelt. 


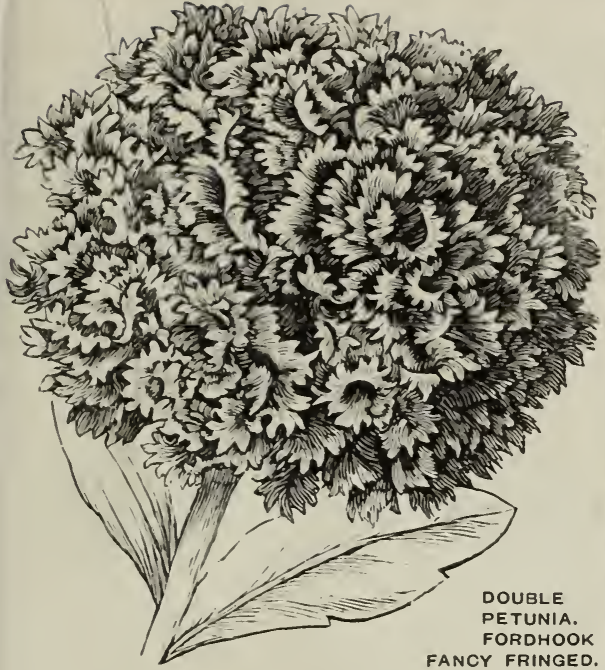

Petunia.

The grand, large-flowered strains, Burpee's Defiance, as well as the Fordhook Fancy Fringed Double and Giants of California, make fine pot-plants. Seed of the above varieties is expensive, and therefore we advise starting in the greenhouse in February or early March; grown in this way, fine plants in flower may be had for sale at planting-out time. The Dwarf Brilliant Rose is especially desirable for summer bedding, as winter blooming or house plants. Adonis has a plentiful supply of soft, rosy-carmine flowers; fine for pot culture, vases, bedding, etc. Dwarf Inimitable and Enchantress are excellent also for bedding purposes, especially as a border for taller growing plants. Rosy Morn is one of the daintiest small-flowered bedding varieties, and is most effective either planted alone or in conjunction with White Bedding or Baby Blue. Our Fringed Double produces about thirty per cent. of double-flowered plants, the flowers of which are extremely double, finely fringed, and of most beautiful colorings.

2567 Burpee's Defiance, Largest Flowering PKT. Oz. F567 Burpee's Defiance, Largest Flowering
Finest, Mixed .. (rooo seeds, 50 cts.)\$o 25 2562 White Bedding........(1/8 oz., 25 cts.) Io 2564 Hybrida Striped, Mixed..............

2551 Burpee's Baby Blue... (1/4 oz., 25 cts.) 2554 Dwarf Inimitable..... (I/4 oz., 25 cts.)

2558 Howard's Star. ...... (1 oz., 25 cts.)

2552 Dwarf Brilliant Rose .. (1/4 oz., $25 \mathrm{cts}$.)

2560 Rosy Morn.......... (1/4/4 oz., 25 cts.)

2550 Adonis.............. (1/4/4oz., 25 cts.)

2556 Enchantress

(1/4 oz., 25 cts.)

2571 Large-flowering, Mixed ( $\frac{1}{16}$ oz., $85 \mathrm{cts}$.)

2569 Giants of California, Mixed

2574 Fordhook Fancy (rooo seeds, $40 \mathrm{cts}$.)

\$o 45

\section{Pentstemon.}

Pentslemons flower freely the first season from seed if sown in the greenhouse or in an early hot-bed.

Floradale Fancy Strain contains all the best colors found in this family, from white, pink, rose, crimson, lavender and blue with every imaginable intermediate shade and many having daintily mottled and penciled markings in the throat. The flowers are almost perfectly circular and average one and a-half inches in diameter, the spikes being eighteen inches in length. Although the seed may be sown in the open, we recommend starting it in heat during February or March, transplanting the seedlings when one inch high into pots or boxes and setting out in May eighteen inches apart, when the plants will come into bloom about mid-summer and continue until frost.

3853 Mixed PKT. OZ.

........(Per $1 / 4$ oz., 50 cts.)\$o o5 \$I 50 Fancy Strain of Giant-Flowered Mixed ......(Per 1 . oz., \$1.00)

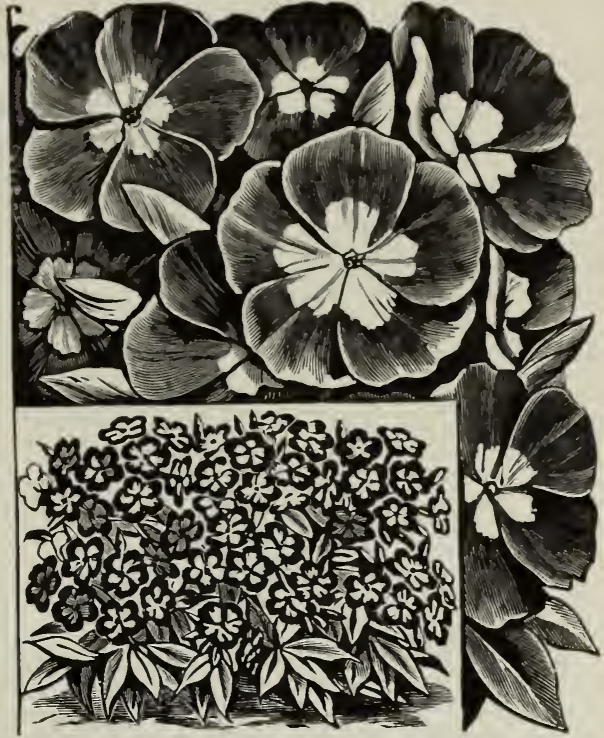

LARGE-FLOWERING DWARF PHLOX - "CECILY."

\section{Phlox Drummondii.}

These free-flowering annuals are unsurpassed in giving glorious color effects in the garden, and are also effective as cut flowers. They are easily grown and remain in flower throughout summer.

For early flowering, seed should be started indoors in March, and plants grown in pots will be in full bloom when the weather is warm enough to set them outdoors, or if sown in the open during late April or May, the plants will bloom from July until cut down by frost. Gradiflora Alba has very large trusses of snow-white flowers, which will be found extremely useful where white flowers are in demand. Grandiflora Large Blood-red is a very striking variety, the color being rich and bright, while the flowers are large. Other varieties of outstanding merit are Carnea, Chamois Rose and Violacea.

2581 Grandiflora, Fordhook Strain, Mixed. . \$o io \$o 65 2605 Fine Mixed.

2607 Starred and Fringed, Mixed........... 10 75

2583 Grandiflora Alba......(1/4 oz. 25 cts.) 5

$\mathbf{2 5 8 5}$ " Large Blood-red,

2589 “ “ Carnea... (1/4 oz., 25 cts.) 50.85

2587 " $\quad$ Brilliant...(1/4 oz., 25 cts.) 5

2591 " Chamois Rose White Eye, 5

2592 " Coccinea..(1/4 oz., 25 cts.) 50.85

2593 Eclipse............. (1/4 oz., 20 cts.) $5 \quad 75$

2595 Grandiflora Rosea Alba Oculata, cts.) ro 85

2597 " Rosea Aurea Stellata, $1 / 2$ cts.) 10

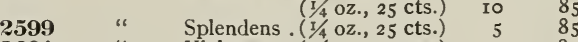

2601 " Violacea .. (1/4 oz., 25 cts.) 5

2603 " Large Yellow, (1/4 oz., 25 cts.) Io 85

2609 Nana Compacta Fireball, $1 / 4$ oz., 40 cts.) ro I 50

2611 " " Snowball (1/4 oz., 60 cts.) 10 2 o०

2613 " " Mixed ...(1/4 oz., $40 \mathrm{cts}$.) Io I 50

2615 Dwarf Large-flowering Cecily,
Mixed.............. (1/4 oz, $40 \mathrm{cts}$.) Io I 50

\section{Platycodon.}

Hardy perennials, increasing in size and freedom of flower from year to year, but flowering freely the first year from seed. On account of the shape of the flower just

3857 Grandiflorum pumilum ( $1 / 8$ oz., $25 \mathrm{cts}$.) \$o Io \$I 75 


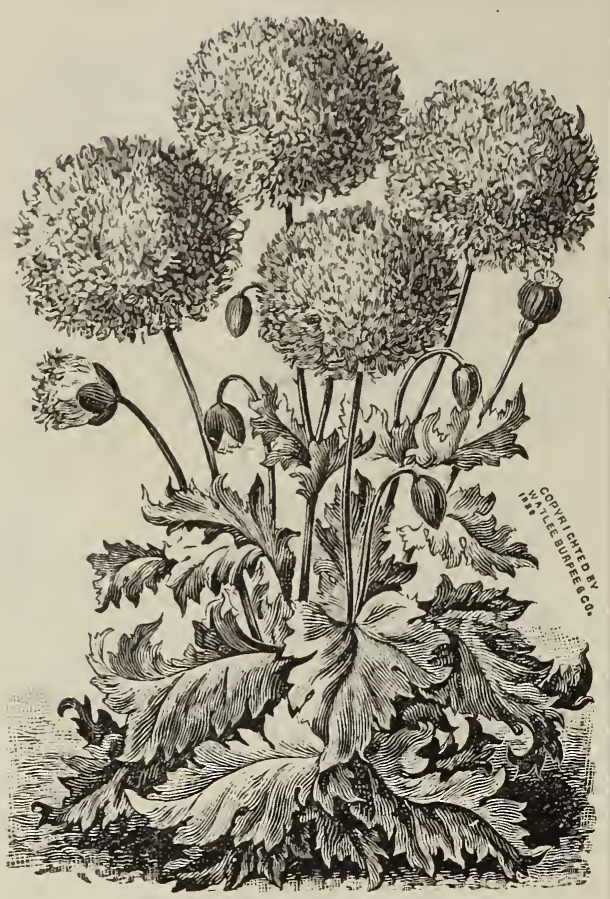

BURPEE'S FAIRY BLUSH POPPY.

\section{Poppy.}

In the named varieties of large-flowered Poppies we save seed only from carefully rogued crops, and florists planting for effective masses can depend on them to come true to name and color. Fairy Blush is finely fringed, and of a beautiful combination of soft pink and silvery white. Fordhook Fairies are a mixed strain of the fringed type, showing a varied assortment of beautiful colorings. Snowdrift is a pure white fringed variety. CarnationFlowered, Double, have the petals fringed; while the Paony-Flowered, double, have broad rounded petals of silky texture. The Tulip-Flowered is a brilliant shade of richest scarlet, the single flowers resembling those of a tulip. The Shirley is an improved strain of the Ranunculus-Flowered.

Papaver Orientale - the bright red hardy perennial Poppy is a very showy plant for border or shrubbery. Perennial Mixed contains many bright colors.

Nudicaule (Iceland Poppies) is a hardy perennial producing on long stiff stems beautiful white, yellow and orange colored flowers.

2616 Burbank Poppies

2618 The Shirley Re-Selected

2620 The Shirley, Mixed...

2625 Burbank's Silver Lining.

2629 Tulip-flowered

2634 Burpee's Fairy Blush.

2636 Fordhook Fairy, Mixed

2639 Burpee's Shrimp Pink.

2640 Snowdrift (True)

2642 Carnation, Double, Mixed

2644 Double Pæony-flowered, Mixed

3847 Perennial Mixed....... (1/4/40z., $25 \mathrm{cts}$.)

3849 Nudicaule Mixed ...... (1/4 oz., $25 \mathrm{cts}$.$) ro$

3851 Orientale............ (1/4 oz., 25 cts.) Io

\section{Polyanthus.}

Charming early spring-flowering plants, perfectly hardy and mostly effective for beds or massing. They succeed best in rich soil and in a somewhat moist and partially shaded location. The colors run from white, yellow, through the various shades of red, crimson, and rose

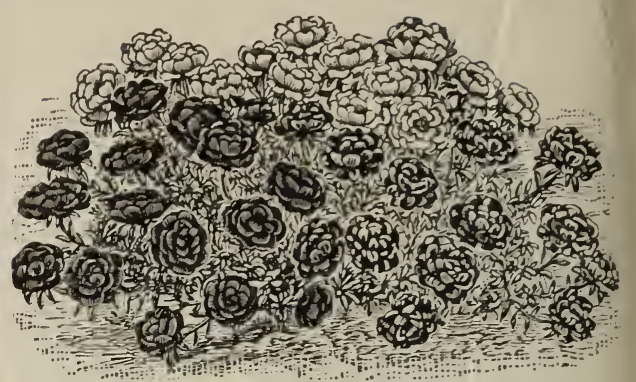

DOUBLE ROSE FLOWERED PORTULACA.

\section{Portulaca.}

The Double Rose-Flowered produces the finest double flow ers in varied colors and markings, making beautiful carpetbeds when planted in masses; it must be borne in mind, however, that even the finest double strains do not produce many double flowers until rather late in the season. The single-flowered embraces pure white and the most beautiful shades of yellow, pink, and red.

2646 Single Orange................

2648 " Red..

2650 “ White..................

2652 Finest Single, Mixed

2657 Double White.....(Per $1 / 8$ oz., 60 cts.) ro

2653 " Orange....(Per I/8 oz., 6o cts.) Io

2655 " Red .......(Per 1/8 oz., 6o cts.) Io

2659 " Mixed.........(1/8 oz., 35 cts.) Io 250

2662 Giant-flowered Parana. (1/4 oz., 25 cts.) 10

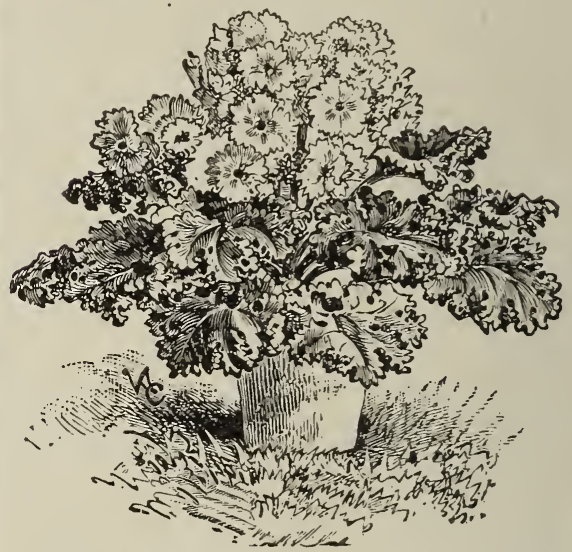

PRIMULA FIMBRIATA-SINGLE CHINESE PRIMROSE.

\section{Primula Sinensis Fimbriata.}

\section{(Fringed Chinese Primrose.)}

To have fine blooming plants for fall sales, the seed should be sown in April or May and grown in a cool situa. tion during the summer. For description of the choice named varieties, see page I68 of BURPEE'S NEW ANNUAL FOR I9I3. Our mixed strains are composed of the best named varieties, and will produce the finest and largest flowers in a great variety of colors.

Is For cultural directions see our booklet, "RARE FLOWERS FROM SEED, "-FREE with orders.

3969 Alba Magnifica

3971 Blue.

3973 C1imson Velvet.

3975 Rosy Morn.

3977 Bright Red.

3982 Fringed, Mixed

9984 Splendid Mixed, ...... (Trade pkt., $50 \mathrm{cts}$.)

(Trade pkt., 75 cts.) I5

(Trade pkt. (Trade pkt., \$r.25) 20 (Trade pkt., \$r.25) 20

(Trade pkt., \$r.25) 20 $\begin{array}{ll}\text { (Trade pkt., \$r.25) } & 20 \\ \text { (Trade pkt., \$1.00) } & 20\end{array}$ eaved Primula),

(Trade pkt., \$r.25) 20 A trade packet of Primula contains from 500 to 1000 seeds. Prices on "Trade Packets" are invariably net. 


\section{Other Primulas.}

Primula obconica grandiflora is a distinct species, flowering profusely the whole year round; the small white flowers are borne in large clusters on a tall stiff stem. Primula auricula is a fine large-flowered strain of the English "Dusty Miller"; the flowers are varied in coloring. with distinct showy markings.

Vulgaris is the common English Primrose and produces fragrant yellow flowers

$3 \$ 61$ Auricula,

PKT.

3S6.j Vulgaris trade pkt., $30 \mathrm{cts}$; 1 in, oz., 50 cts.) So 15 39s5 Obconica Grandiflora......(roo seeds, $50 \mathrm{cts}$.)

\section{Pyrethrum.}

Purlhenifolium aureum, or Golden Feather, is a dwarf compact plant, having fern-like leaves of a bright golden hue; excellent for edging foliage beds as well as for baskets and vases.

Roseum is one of the most profitable early summer flowering plants for cut flowers and is a hardy perennial. Seed should be sown in the open during early summer; transplant the seedlings to stand twelve inches apart, and a wealth of fine long-stemmed flowers will be produced the following and succeeding years. The soil should be well enriched.

3568 Parthenifolium Aureum (Golden PKT. OZ. Feather)
38 ro Roseum Mixed (Persian Insect Powder plant)..(Per 1/4 oz., 30 cts.) Io I 00

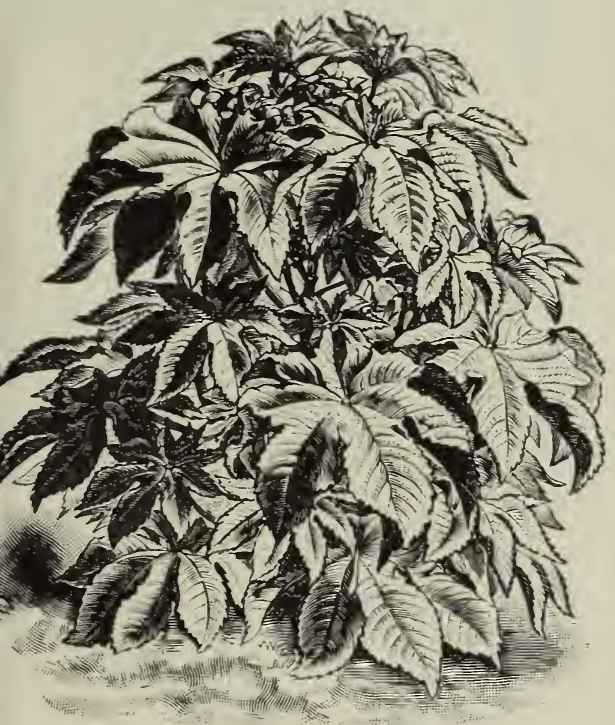

One Planl of RICINUS ZANZIBARENSIS.

\section{Ricinus (Castor-oil Bean).}

Semi-tropical plants which are grown for their large luxuriant foliage. When fully grown the plants are surmounted by large spikes of flowers which are succeeded by brilliantly colored spiny seed-pods. As they are quite susceptible to frost, seed should not be planted in open ground until the weather has become warm and trees are well in leaf. When well started transplant or thin out, leaving only a single plant in a place. The smaller varieties should stand at least two feet apart; the larger, four or five feet apart, to give ample room to develop. It is an excellent plan to start seed in the house in flower-pots during March and April, to have plants well started by the time it is warm enough to set them in the open ground.

2663 Cambodgensis............... \$o o5 \$o I2

2665 Sanginers...

$\mathbf{2 6 6 7}$ Spectabilis .

$\mathbf{2 6 6 9}$ Mixed.

............. (Per ib., 50 cts.)

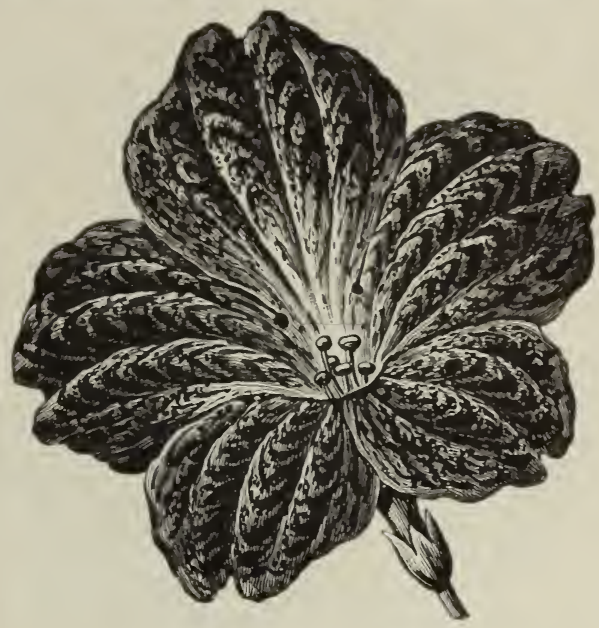

SALPIGLOSSIS GRANDIFLORA.

\section{Salpiglossis.}

A half-hardy free-flowering annual, succeeding best in cool moist soils. Seed should be sown thinly in shallow drills when trees are starting out in leaf, and when well started should be thinned out or transplanted to stand at least twelve inches apart.

2675 Mixed ............. (1/4 oz., 20 cts.)\$o o5 \$o 65 $267 \%$ Grandiflora, Finest Mixed $(1 / 4 \mathrm{oz}, 30 \mathrm{cts}$. $)$ I0 $\mathrm{I}$ o0

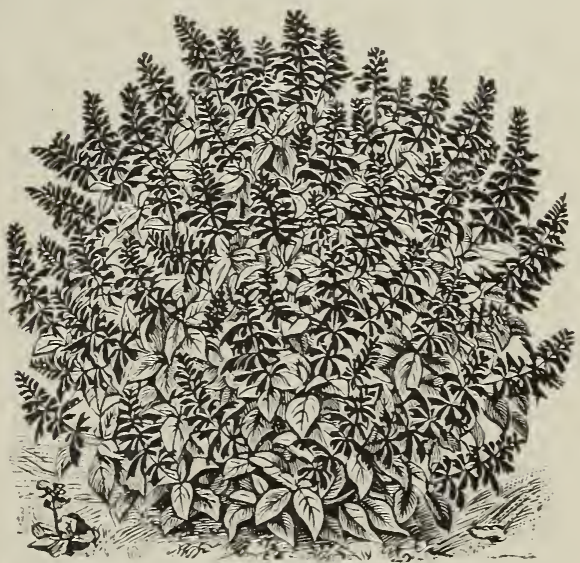

A Single Plant of SALVIA SPLENDENS.

\section{Salvia (Flowering Sage).}

There are not many plants so attractive as are these "Flowering Sages." The plants are most easily grown from seed and these seedlings bloom abundantly all summer and fall. Seed started in February will make fine bushy plants for planting out at the proper time. We are the largest growers of Salvia seed in America and the acres annually in bloom at liordhook are worth traveling many miles lo see! Farinacea has long flower spikes which resemble the English Lavender, the color being light blue, and when used as an outer row in conjunction with Splendens it creates a fine effect. The flowers of Patens are very distinct, - color a rich bright blue.

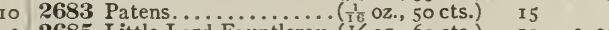
I2 2685 Little Lord Fauntleroy (1/4 oz., 6o cts.) Io 225 8 2687 Dark "Blood-Red"...(1/4 oz., 45 cts.) Io I 65 10 2689 Splendens (Scarlet Sage) $(1 / 4$ oz., 40 cts.) Io I 40 


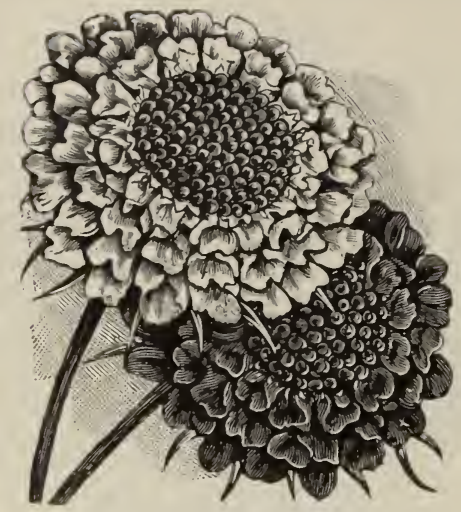

SCABIOSA, OR "MOURNING BRIDE."

\section{Scabiosa (Mourning Bride).}

These produce fine flowers in many beautiful shades, with long slender stems. The flowers are useful for cutflower work.

Caucasica is a perennial producing throughout summer beautiful pale lilac-colored flowers which are unsurpassed for cutting.

2697 Tall German Mixed.

2699 Dwarf Double, Mixed

2701 "Azure-Fairy".

2703 Double Black.

2705 Snowball.

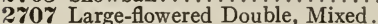

3876 Caucasica........(Per 1/4 oz., 40 cts.)

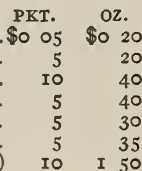

\section{Sensitive Plant.}

Curious plants, the leaves of which close up tightly when touched; small, feathery, soft pink flowers. Potted plants sell readily in the spring as a curiosity.

2709 Sensitive Plant (Mimosa Pudica)..... PKr. 05 \$z.

\section{Shamrock.}

(The National Emblem of Ireland.) This popular Trefoil is easily raised from seed and will grow in practically any soil. The seed we offer is imported by us direct from Ireland.

3878 True Irish Variety....(Per lb., \$2.50)\$o 05 \$o 25

\section{Smilax.}

This fine climber is grown extensively for use in floral decorations of all kinds. The best results are obtained by raising fresh plants from seed each spring.

3991 Myrsiphyllum Asparagoides,

PKT.

(Perlb., \$2.50)\$o o5 \$o 25

\section{Statice (Sea Lavender).}

A most useful perennial everlasting, the large sprays of small graceful blue flowers being extremely desirable for winter decoration.

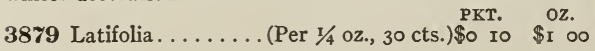

\section{Stevia.}

The Stevias are very largely grown by florists for cutflowers for early winter use, and, being quite hardy and of easy culture, no special care is required in growing them.

2713 Serrate $\quad$ (Per $1 / 4$ Oz, 25 cts. SKT. Oz.

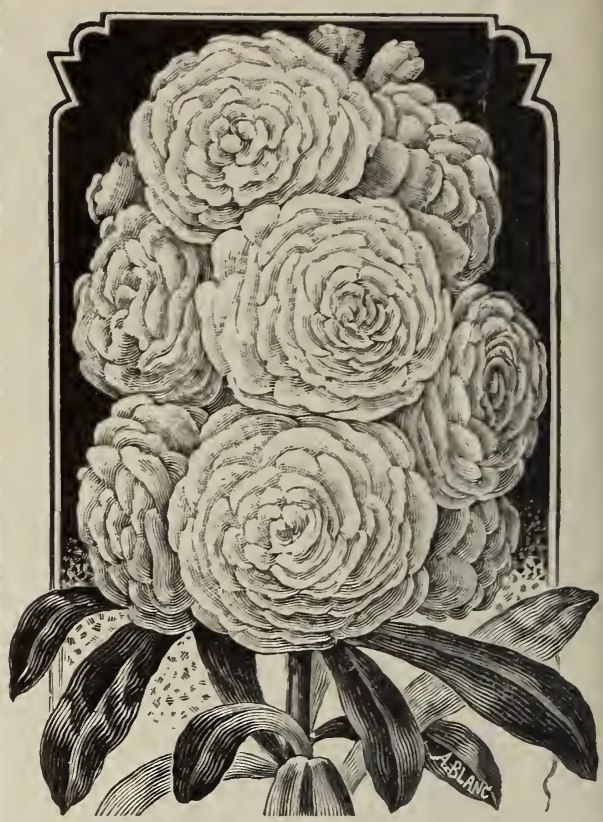

Stocks.

These make good blooming plants for bedding or for pot culture in cool locations; the large spikes of fine double flowers are also desirable for cutting. The dwarf varieties are best suited for blooming early in the spring, unless the large-flowering Globe Pyramidal can be given an early start,- six-inch pots and ample room in which to grow,when they make grand decorative plants, suitable for spring sales. The Large-flowering Dwarf is especially fine and can be had in bloom in three- and four-inch pots. White Perpetual, or "Cut-and-Come-Again," is a most useful variety for florists, furnishing a constant supply of fine white sprays throughout the season.

2742 Globe Pyramidal, Mixed,

PKT. oz.

2744 White Perpetual or (1/8 oz., $50 \mathrm{cts}$ ) \$o Io $\$ 350$ Again............. (1/8 oz., 40 cts.) I5 300 2745 "Cut-and-Come-Again," Mixed, 2746 Giant Perfection, Mixed,

(1/8 oz., 40 cts.) Io $3 \infty$ 2748 Large-flowering Dwarf, Choice, Mixed, 3880 Emperor Mixed.... (1//4 oz., $30 \mathrm{cts}$.) 5 I 00

\section{Stokesia.}

A lovely hardy plant, producing in abundance handsome lavender flowers and blooming continuously all summer; indispensable for the border and for cutting. Height two feet

3882 Cyanea (Cornflower Aster),

PKT OZ. (Per 1/4 oz., 35 cts.)\$o ro \$1 25

\section{Streptocarpus.}

The plant is of dwarf neat habit, growing about nine nches in height, is of easy culture, but must be planted indoors where it may be had in flower nearly all the year round. As pot-plants they are highly decorative.

3999 New Hybrids, Mixed (Per trade pkt., \$r.25) $\begin{aligned} & \text { PKT. } \\ & \text { \$o I5 }\end{aligned}$

Burpee's Flower Seeds are just as carefully and as thoroughly tested as our seed of any better quality than the stocks we now have in our warehouses. 


\section{Sunflowers.}

Our collection con tains the best varie ties and embraces all the types. Chrysanthemu $m$-flowered is the grandest of all double sunflowers; the flowers are always very double and brightest golden yellow in Many-flowered double branches at each leaf, and each branch produces a fine double flower, the smaller ones from the side branches resembling a fine dahlia, $-\frac{s e e}{C u}$. cume rifolius ha small single flower resembling daisies. The new Stella has fine single flowers of a larger size than the last named; while the New Seed. lings of Stella a re particularly beautiful and of much value for bouquets and house decoration.

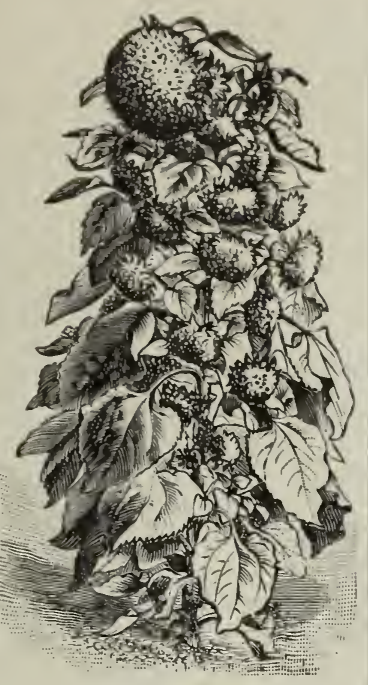

MANY FLOWERED DOUBLE SUNFLOWER.

PKT. OZ. \$o 05 \$o 20 35
15
20 20

756 Stella....................

2760 Miniature (Cucumerifolius)

276.5 Chrysanthemum-flowere

2767 Many-flowered Double.

\section{Sweet Sultan.}

\section{(Centaurea Suaveolens.)}

Stiffly erect plants, slightly resembling the thistle in growth, with very double, rich yellow flowers. The small petals are finely fringed and flowers are of a delightful fragrance. They will bloom freely in cool locations from seed sown in open ground when the trees are starting out in leaf.

2752 Centaurea Suaveolens, Yellow..... PKT. Oz. $\mathbf{2 7 5 4}$ Finest Mixed....................

\section{Sweet William.}

\section{(Dianthus Barbatus.)}

Beautiful free-flowering perennials, blooming early the next spring. The plants when in flower are eighteen inches

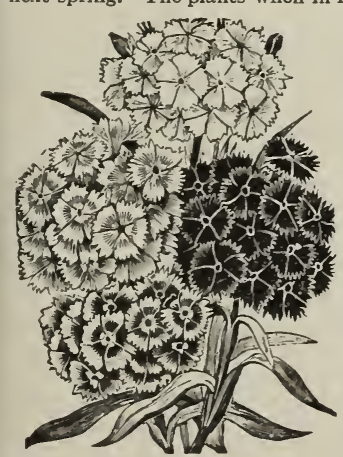

SWEET WILLIAM. in height and produce large clusters of brilliantly colored, fragrant flowers on stout stiff stems. Sow seed thinly in shallow drills early in spring. When well started, thin out or transplant to stand eight inches or more apart in the row. The young plants are of close, compact growth with rich, dark-green foliage and make excellent borders. They succeed best if planted in good, rich, well drained soil and will flower with the greatest profusion early in spring. Flowers last quite a long time and are highly desirable for cutting, being furnished with long, stiff stems.

3884 Single, Mixed.

3886 Pink Beauty ............

3890 Scarlet Beauty ......... (1/4 oz., 35 cts.) ro 3892 Double, Mixed......... (1/4 oz., 25 cts.) r 5 I 25

\section{Thunbergia (Black-eyed Susan).}

Free-flowering trailing vines of rapid growth; very pretty when used about the edges of baskets, vases or tulss of flowering plants. Seed sown in February and March make fine-blooming pot-plants for spring sales. The flowers are white, yellow, and deep orange, both selfcolored and with distinct black eye in center.

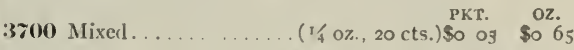

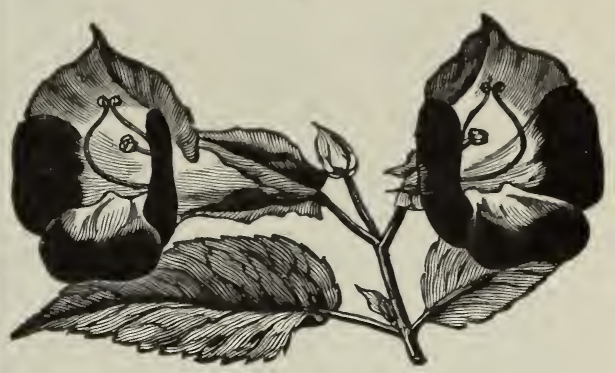

Torenia.

Beautiful free-flowering plants for summer bedding, pot culture, or planting in baskets and vases. Seed started in February makes fine blooming plants in small pots for spring sales. Fournieri, close compact growth, with deep blue flowers brightly marked with orange. White Wings, similar in growth to Fournieri, but with creamy-white flowers.

PKT.

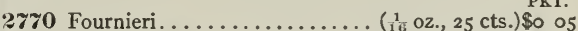

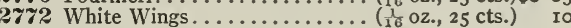

\section{Vinca (Madagascar Periwinkle).}

Free-flowering bushy plants, two feet in height, with glossy deep-green leaves. The flowers are white and deep pink, both self-colored and with a bright eye of contrasting color. Fine for bedding and pot-culture.

2796 Rosea.................. PKT. \$o \$o 60 2798 " Aiba........................ 10 \$o 60 2799 Alba Pura.

2801 Mixed Colors.................... 5

\section{Violas, or "Tufted Pansies."}

Extremely popular in Europe for bedding, Violas, or Tufted Pansies, should be used more generally in America. Sow the seed in May, and gust or September, transplant into wellenriched beds assorting as to color or arranging in any design desired. Soon after the snow is off the following spring they begin to bloom, and throughout spring and early summer will give a profusion of flowers.

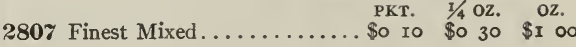

\section{Wallflower.}

Sow seed early in the spring, growing the plants in the open ground; in the fall lift and plant in pots or windowboxes for winter flowering.

3894 Fine German Double, Mixed, PKT. oz. 3897 (1/6 oz., $30 \mathrm{cts}$.)\$o 10 $\$ 2 \infty$ 


\section{Choicest Strains of VERBENA Hybrida.}

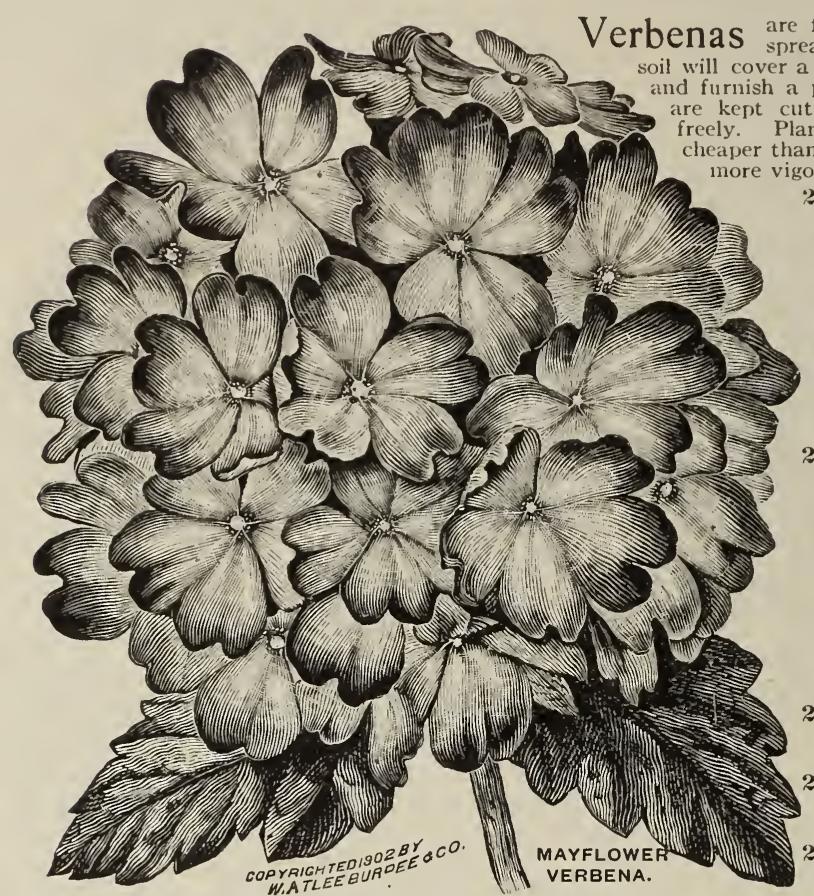

re free-flowering hardy annuals of lowspreading growth. Single plants in rich will cover a space three to four feet in diameter are kept cut, the plants will bloom much more Plants grown from seed are not only leaper than those grown from cuttings, but are '77\% BURBANK'S MAYFLOWER. See nalural size illustration of a head. Mr. Burbank has developed a strain in which the flowers are of extra large size, of many colors, but mostly lovely shades of pink, and more fragrant than in any other strain. Tlie seed we now offer has been grown on our FloRADALE FARM in California from seed procured of $\mathrm{Mr}$. Burliank. Per pkt. $10 \mathrm{cts}$; 1/8 oz. $35 \mathrm{cts}$. $1 / 4 \mathrm{oz}$. 60 cts.; $1 / 2$ OZ. \$1.0r; OZ. \$1.75.

2776 FORDHOOK FA MOUS. Large trusses in a wide range of colors. The individual blossoms are sometimes larger than a silver quarler. The colors are rich and varied, embracing all the brighter shades, but, like all strains of so-called Mammoth Verbena now in cultivation, the florets are nol uniformly so large as we hope to obtain eventually. Per pkt. Io cts.; $1 / 4$ oz. 35 cts.; per oz. \$. 25.

2784 Auricula-flowered. Bright colors, clear white eye, Per pkt. In cts.; $1 / 4$ oz. 25 cts.

2786 Light Pink. An attractive shade Per pkt. Io cts.; $1 / 4$ oz. 35 cts.; oz., $\$$ I.25.

2789 Scarlet Defiance. True; brightest scarlet, intensely rich. Per pkt. Io cts. ; $1 / 4$ oz. 30 cts.; per oz. \$I.oo.

2791 Pure White (Sea Foam). Large-flowering pure white. Per pkt. Io cts; $1 / 4$ oz. 30 cts. ; per oz. \$1.0o. 2785 Blue with White Eye. Pkt. Iocts.; $1 / 4$ oz. 35 cts. 2794 Italian Striped. Striped flowers of many bright colors. Per pkt. 5 cts.; $1 / 4$ oz. 30 cts.; oz. \$I.00.
2780 Verbena Hybrida, Extra Fine Mixed. Large in flower and corymbs. Of the richest colors, and also the finest varieties of the Auricula-eyed type. Per pkt. 5 cts. ; $1 / 4$ oz. 25 cts.; per oz. $80 \mathrm{cts}$.

2782 Hybrida, Mixed. Per pkt. 5 cts.; oz. $50 \mathrm{cts}$.

\section{Proved "Best by Test."}

"Unless you should order some variety that we do not catalog and instruct that we get it for you (when we shall send it in its original package), you may be sure that you will receive from us, "to the best of our knowledge and belief," only such stocks of strictly high-grade seeds as have been proved absolutely the "Best by Test."

A Few Words About If you buy a ton of coal or a suit of clothes, you Quality in Seeds. can judge what the quality is and decide whether you are paying a fair price. In buying seeds this is impossible. No one can tell from examination of the seeds whether they have been carefully saved from choice pedigree stocks, or whether they have been produced cheaply to sell wholesale at low prices. In fact, it is impossible to see any difference in appearance between turnip seed worth $50 \mathrm{cts}$. per lb., cabbage worth $\$ 3.00$, or cauliflower seed worth $\$ 40.00$ per lb. They all look alike,--but how different the resulting crops!

Buying seeds, therefore, must be entirely a matter of confidence.

Every truck-patch or flower-bed, large or small, is the planter's "trial ground."

We desire that our seeds and not your patience shall be tried there.

FORDHOOK FARMS (and SUNNYBROOK) render our desire attainable. 


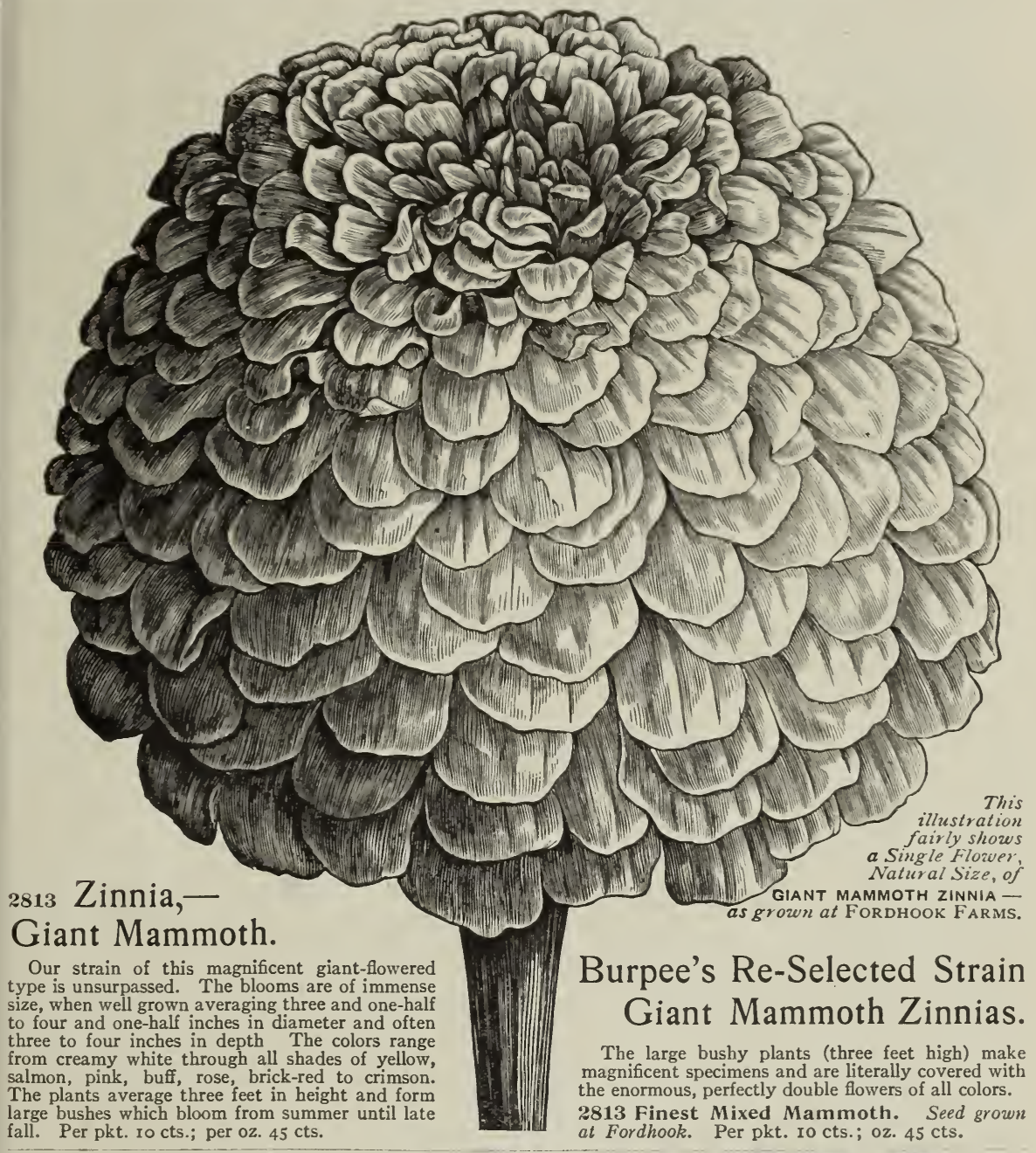

\section{Zinnias.}

Vigorous hardy annuals, readily grown from seed in open ground. They bloom in greatest profusion from early in spring until cut down by heavy frosts late in fall. Plants are of strong branching growth with abundant darkgreen foliage, each branch terminating in a bold showy flower. Seeds may be sown thinly in drills early in spring when the trees are starting out in leaf. Transplant young plants when two to three inches high to stand twelve inches apart for the dwarf kinds, and two feet apart for those of large growth. Or two or three seeds may be planted in a place where the plant is desired to grow and bloom. For early flowering, seed may be planted in cold-frames or in boxes in a sunny window and the plants set in flower-bed when danger of frost is past.

2811 Elegans, Double Lilliput._. PKT. Oz. 2813 "Giant Mammoth, Mixed....

7 Few flowers impart such rich "bits of beauty" to the garden as the different types of NASTURTIUMS.
In addition to their use in the garden and on trellises lwe would recommend planting the seed freely along fences, hedges, etc., or wherever it is desired to have bright colors in profusion. You cannot have too manyl See pages IIO and 120 .

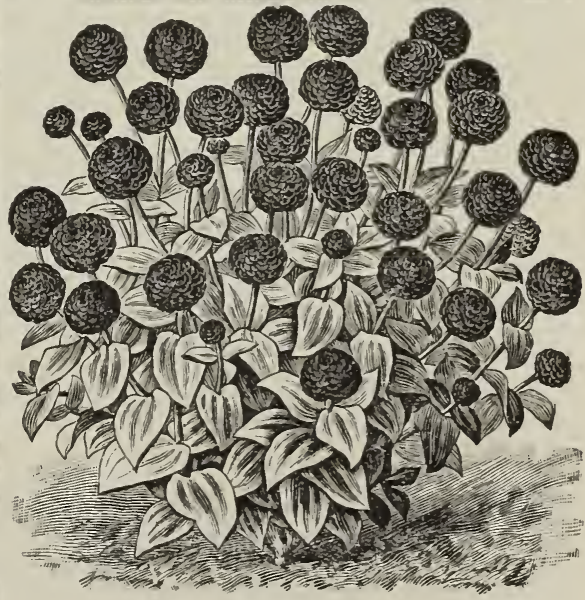

A PLANT OF DWARF DOUBLE LILLIPUT ZINNIA 


\section{EVERLASTING FLOWERS.}

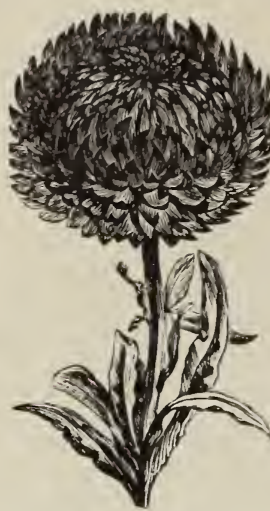

small, rounded, clover-like

The Everlasting or Straw Flowers," with their rich bright colorings, are most valuable for winter decorations. Plants grow readily from seed sown in open ground when the trees are starting out in leaf. When well started they should be thinned to stand several inches apart in the row, and should be kept cultivated to produce the finest and largest number of flowers. Flowers should be cut while freshly opened tied in small bunches and dried slowly in a cool, shady place, with the flower downward to keep the stems straight.

2833 ACROCLINIUM Mixed. Of dwarf growth with silvery foliage

pure white and rose-pink.

Per oz. I2 cts.

PKT

2835 AMMOBIUM. Erect-branching plants two feet in height, with winged stems surmounted by branching heads of small pure white flowers with bright yellow center. Per oz. Io cts.,..........

2838 GOMPHRENA (Globe Amaranth, or Bach= elor's Button), Mixed. Free-flowering plants two feet in height; small globe-shaped double flowers in bright colorings. Per oz. I 2 cts...

HELICHRYSUM. These are the finest of all Everlastings. They resemble a freshly opened Aster in form and flower in many bright colors.

2840 Fireball. Beautiful double flowers of a deep red or rich glowing crimson. Per oz. $40 \mathrm{cts.,......}$

2844 Snowball. Large, finely double flowers of pure paper whiteness. Per oz. $40 \mathrm{cts.,.}$

2842 Golden Ball. Large double flowers of a rich golden yellow. Per oz. 40 cts..............

2846 Monstrosum, Mixed. Plants grow three feet high, bearing a profusion of large double flowers of brightest colors. Per oz. 35 cts.,............

2852 XERANTHEMUM. Double flowers in varied colorings. Showy. as a summer-flowering annual as well as desirable for the dried flowers. Per oź. 35 cts...

2854 MIXED EVERLASTINGS. A single packet of this mixture sown thinly or transplanted to a proper distance when well started will give in abundance a great variety of the most attractive Everlastings, affording a bright display of blossoms during the summer months as well as furnishing bouquets of the most lasting qualities. The dried flowers retain their bright coloring and perfect form for many years. Plants grown from this mixture should be set at some little distance apart, or the stronger growing ones will crowd out those of dwarfer, weake growth. Per pkt. Io cts.; Oz. 45 cts.

2885 Mixed Annual Varieties of ORNAMENTAL GRASSES. This comprises all the annual varieties named in next column. This mixture can be sown thinly in drills, giving a large supply of the different fine plumes and sprays for drying for winter bouquets or will present a graceful effect if plants are allowed to grow and bloom without cutting. The perennial hardy varieties are not included, as their stronger growth would crowd out the small annual sorts, and the perennials would give no sprays the first season. All of these varieties will start most freely if seed is sown early in spring and only lightly covered while the soil is still cool and moist. Per pkt. Io cts.; oz. 20 cts.

\section{Burpee's Flower Seeds}

are just as carefully and as thoroughly tested as our Vegetable Seeds, and we know that there is not offered seed of any better quality than the stocks we now have in our warehouses.

\section{ORNAMENTAL GRASSES.}

Ornamental Grasses are not only of most graceful growth and flower during the summer and fall, but if sprays are cut off when freshly opened (before seed forms) and slowly dried in a cool place, they will lend a graceful, airy effect to bouquets of dried everlasting flowers. The feathery sprays of many varieties are also desirable for blending with bouquets of fresh flowers during summer, while others are used in making fancy baskets, etc. These

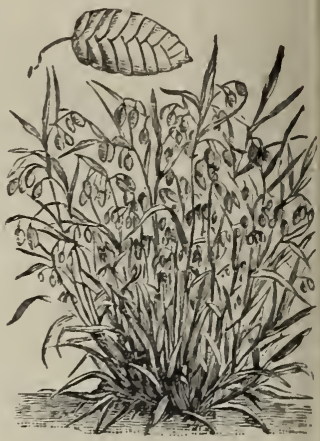
grasses are all hardy.

2858 Agrostis nebulosa. Small growth with slender leaves and finely branched feathery PER sprays; only ten inches in height. Per $1 / 4 \quad$ PKT. oz. 40 cts.; oz. 75 cts., ..........................

2860 Avena sterilis (Animated Oat). A stronggrowing grass, throwing up seed-spikes two and a
half feet in height. These bear seed closely resembling the oat, but larger in size and having the peculiarity of hopping about if the dry seed is moistened and placed on a level hard surface. Per oz. I2 cts.,.........................

2863 Briza maxima (Quaking Grass). Grows to twice the height of the preceding, with taller sprays and larger heads of seed. These are borne in a close thickened panicle resembling the rattle of a rattlesnake slightly in form. Per oz. I5 cts.,

2865 Bromus brizæformis. Large open heads or drooping panicles. Per oz. Io cts............ 2868 Coix lachryma (Job's Tears). Thick fleshy stems eighteen inches in height, with lanceshaped green leaves bearing clusters of hard seeds about the size of garden peas, from which the plant takes its name, being of peculiar pointed form. When branches are cut as soon as seeds are formed, they retain the seed a long time. Per oz. Io cts.; per lb. 50 cts.,. . . . . . . . . . . . . . . . grass of strong growth, living out without protection during our severest winters. It forms quite large clumps and in summer throws up tall spikes surmounted by long feathery plumes. These should be cut when only partially opened and dried slowly in a cool place, having a grayish or silvery tint when properly dried. Per oz. 25 cts.,....................................... An entirely hardy perennnial grass of very strong growth, six feet in height, with numerous long, slender, dark-green blades, which are boldly striped across their width with creamy yellow. Per $1 / 2$ oz. 35 cts.; oz. 60 cts... .............. 2874 Gynerium argentium (Pampas Grass). This produces the finest dried sprays, but is not hardy in our location, plants having to be taken up and wintered in a frost-proof cellar. Farther south the plants will live out if protected during winter months. It is of strong growth, with long dark-green blades, throwing up numerous plumes of largest size and most beautiful feathery ap-

pearance. Per oz. 35 cts.,..........................
(Squirrel-Tail Grass). A hardy annual grass of strong growth, having large heads with quite long beard, resembling barley to a great extent, it being a natural variety of that grain. Per oz. 20 cts.,.............................

879 Pennisetum longistylum. Graceful, long, slender blades, throwing up slender spikes twelve inches in height, bearing small feathery plumes.

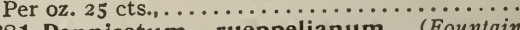

2881 Pennisetum rueppelianum (Fountain Grass). One of the most graceful in growth; the close feathery plumes are long, slender, and of a distinctly purplish coloring. Per oz. 30 cts.,....

2883 Trycholæna rosea. Beautiful feathery sprays of a soft rose tinting. Per oz. 25 cts.,.... 


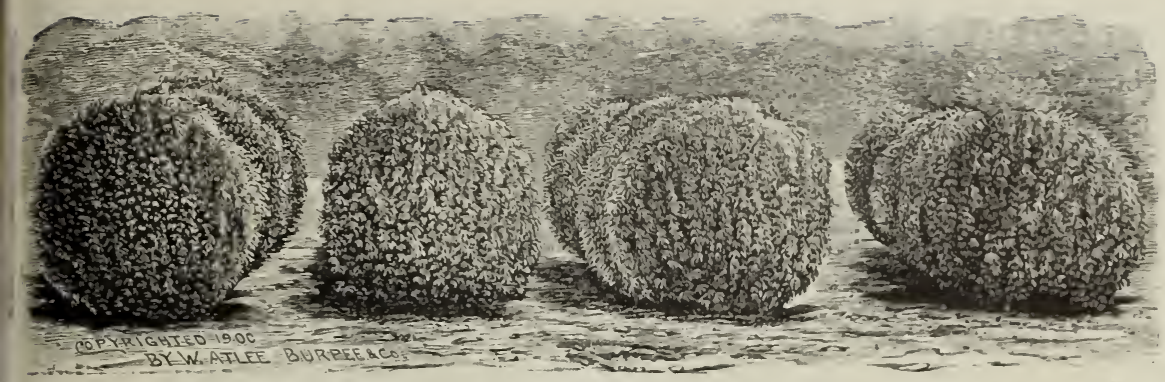

Rows of the Quick-growing Annual KOCHIA TRICOPHYLLA,-from a Pholograph laken at Fordhook Farms.

\section{Burpee's GEM COLLECTION of Annuals.}

"Encourage the Beautiful, for the Cseful encourages itself."-GokTHR.

\section{Eight Packets Beautiful Flowers for 25 Cts.}

For $25 \mathrm{CtS}$, we will mail one regular packet each of the following eight elegant Annuals,-the seed California of which has mostly been grown on our own farms in Pennsylvania, Vew Jersey and California. This assortment can be ordered as BuRPEE's GEM Col.LECTION FOR 25 CTS., or five collections for $\$ 1 . \infty,-$ mailed to separate addresses if so desired.

1524 Alyssum, Little Gem.

1643 Asters, "American=Union."

1876 Centaurea Imperialis.

1932 Cosmos, Lady Lenox.

$25 \mathrm{C}+\mathrm{s}$ invested in no other way, - unless in one of our Sweet Pea Collections, - can be productive of so 25 CtS. much pleasure. The seeds are all of THE BURPEE-QUALITY, and better strains could not be had at any price.

Wholesale. We offer any of the quick-selling popular 25=cent collections at \$2.00 per dozen cent collection we charge $\mathbf{3 5}$ cents each, and $\mathbf{8 0}$ cents each for Burpee's "Dollar Boxes," by freight or express, at purchaser's expense for transportation charges.

\section{Burpee's 1914 Collection of Nasturtiums.}

For 25 Cts. we will mail one full-size packet each of the New VARIEGated QueEn,on page 119,-BurpeE's Gorgeous Mixture OF TOM Thumb NASTURTIUms, described on page 141,-Fordhook Favorite Tall Nasturtiums, offered on page 120,- the new complete mixture of BURpeE's Tall Ivy-Leaved, offered on page 120,-DWARF Lilliput Mixed, offered on page 120, and the strikingly beautiful marbled-leaved New "QueEns" of ToM ThumB, in mixture, as described on page 120.

ID With each collection we enclose our leaflet on How to Grow Nasturtiums.

For $\$ 1.00$ we will mail one full ounce each of all the above Six SUPERB NASTURTIUMS and also a liberal For $\$ 1.00$ packet of The Distinct New DAVID BURPEE NASTURTIUM, as described on pink paper pages of Specialties for I9I4. Is The sum of one dollar could hardly be expended in any other manner that would bring so much pleasure and delight all summer long.

\section{Burpee's New THS complete book, bound in lithographed covers and con- asking,--provided you have a garden. It is an elegant book-

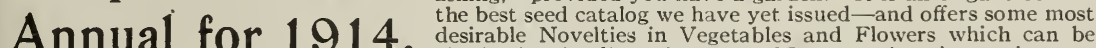 desirable Novelties in Vegetables and Flowers which can be
obtained only direct from us. Many a winter's evening can be spent profitably in planning your garden, by a careful study} of this book. Shall we send you a copy? If you appreciate Quality in Seeds you will say Yes!
W. ATLEE BURPEE \& CO.,
BURPEE BUILDINGS, The Largest Mail-Order Seed House. P H I L A D E L P H I A.

\section{Burpe, Philadelphia, is sufficient address for leteress tedegrams

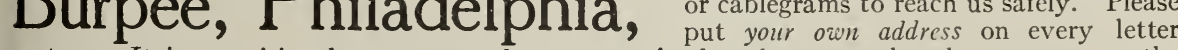 sent us. It is surprising how many orders are received each season that have to go on the "No Name File," to await a letter of complaint that gives the writer's name and address. os Should you forget our full address and want to order at any time, remember it is sufficient to write on the envelope

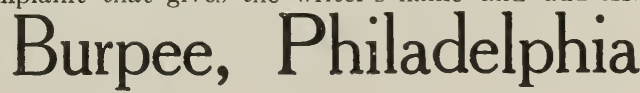




\section{Burpee's Six "Superb Spencers" for 25 Cents.}

The varieties are described on pages 124 to 127.

3418 BEATRICE SPENCER.

A rich deep pink self.

347? GEORGE HERBERT.

Bright rosy carmine; very large.

3520 MRS. C. W. BREADMORE.

Cream ground, distinctly edged rose.

\author{
| 3539 ORCHID. \\ Beautiful helio-mauve. \\ 3575 STIRLING STENT. \\ Rich glowing salmon-orange \\ 3599 BURPEE-BLEND FOR 1914. \\ Simply magnificent ( 90 to roo seeds).
}

25 Cts. buys all the above, in regular ten-cent packets containing 40 to 50

\section{Burpee's Six "Superfine Spencers" for 25 Cents.}

The varieties are described on pages 124 to 127.

3408 APPLE BLOSSOM SPENCER.

Rosy pink and white.

3444 DUPLEX SPENCER.

Rich cream-pink and apricot.

$\mathbf{3 4 5 4}$ ETHEL ROOSEVELT.

Primrose ground, flaked rose.
3542 OTHELLO SPENCER.

Rich glowing maroon self.

3579 TENNANT SPENCER.

Beautiful purplish mauve.

3581 THOMAS STEVENSON.

Glowing orange-scarlet.

25 Cts. buys all the above, in regular ten-cent

For 50 Cts. we will mail Both Collections named above and also a fifteen-

\section{Burpee's Eight "Elegant Spencers" for 50 Cents.}

The varieties marked (E) described on pink-paper pages 112 to 118 and shown on last Cover Page of Burpee's Annual for 1914.

3414 AURORA SPENCER.

Flaked orange-salmon on cream.

3440 DAINTY SPENCER.

Pure white, edged rose-pink.

3462 FLORENCE NIGHTINGALE.

Soft clear rich lavender.

3486 IRISH BELLE, or " DREAM."

Clear rich lilac, flushed pink.
3488 KING EDWARD SPENCER.

A magnificent rich crimson.

3528 MRS. ROUTZAHN.

Rich buff, suffused delicate pink.

3554 QUEEN VICTORIA SPENCER.

Beautiful primrose, flushed rose.

3587 VERMILION BRILLIANT.

Brilliant scarlet self.

50 Cts. buys all the above, in regular ten-cent packets containing 40 to 50 seeds each, except Irish Belle 50 C. and Vermilion Brilliant, our regular price for these two varieties being is cents per packet.

For $\$ 1.00$ we will mail all three collections as offered above and also a fifteen-cent packet each of KING WhITE, our greatest Novelty for 1914, and the new gigantic HERCulEs, best of all warm pinks, - making in all Twenty=two True Spencers for $\$ \mathbf{1 . 0 0}$. These are all neatly packed in a pasteboard box, together with our Leaflet on culture. In ordering it is sufficient to write for Burpee's New Dollar Box of Spencers for 1914.

Wholesale. We offer any of these superb 25=cent collections of "Spencer" Sweet Peas at $\mathbf{3}$ for $\mathbf{5 0}$ sent by freight or express. For the Fifty-cent Collection we charge 35 cents each and for Burpee's "Dollar Box" of Spencers we charge $\mathbf{8 0}$ cents each by. freight or express, at purchaser's expense for transportation charges.

The Only Gold Medal of the National Sweet Pea Society ever won by any growers outside of Great Britain was awarded to the American Firm of Burpee, at the great exhibition in London, July 23, 1909.

The Only Gold Medal of The American Sweet Pea Society was awarded again to us for "the Most Meritorious Display of Sweet Peas" at the Great Boston Show, July, 1913. W. ATLEE BURPEE \& CO., SEED GROWERS AND SWEET PEA SPECIALISTS, PHILADELPHIA, U. S.A. 


\section{Beautiful Cactus DAHLIAS.}

CAOTUS DAHLIA H. SHOESMITH. 1 pointed ends standing apart, give a distinctly starlike form to the flowers; in some the long slender
petals are charmingly curled. COCKATOO. Fine large flowers of yellow, shaded fawn and tipped white.

COUNTESS OF LONSDALE. Very large and fine; salmon-orange, suffused lavender.

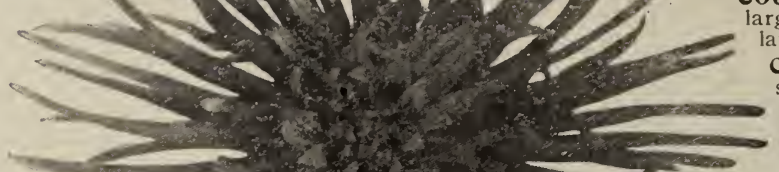

COUNTRY GIRL. The flowers are of splendid form; color golden yellow, tipped bright amber.

EVA. Exquisite form; pure white. J. H. JACKSON. Large and very attractive blooms of a rich velvety dark crimson.
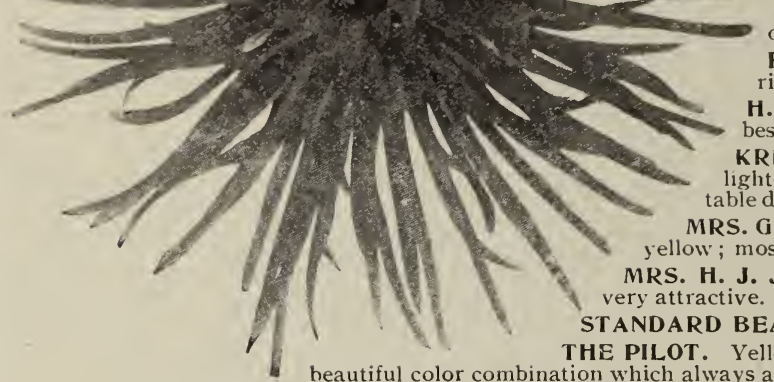

FLORADORA. Of splendid form; a rich garnet in color. 1 (1) $\begin{gathered}\text { H. SHOESMITH. See illustration. The } \\ \text { best bright red; of finest form. } \\ \text { KRIEMHILDE. Clear rose-pink, shading } \\ \text { lighter toward center. Beautiful; fine for }\end{gathered}$ table decoration.

MRS. GEO. STEVENSON. A beautiful bright yellow; most attractive for cutting.

MRS. H. J. JONES. Rich scarlet, tipped white; very attractive. A unique color combination.

STANDARD BEARER. A most brilliant scarlet.

THE PILOT. Yellow, shaded terra-cotta; very fine. A

We offer divided roots of the above Cactus Dahlias, 12 cts. each; $\$ 10.00$ per 100.

Strong field growll clumps (just as "lifted") 15 cts. each; $\$ 13.50$ per 100.

\section{Superb Show and Fancy Double DAHLIAS.}

They are especially desirable for large size, regular form, and beautiful colorings. This type of flower is most popular with florists for early autumn cutting; the flowers are all borne on long stems and bunch easily.

A. D. LIVONI. A great favorite; clear and beautiful soft pink

One of the most useful for cutting.

ARABELLA. Grand flowers; lovely primrose, shaded rose.

A free and continuous bloomer.

$B O N=T O N$. A very fine deep rich crimson.

CHAMPION ROLLO. Dark orange. The flowers are always large and of finest form.

ETHEL SCHMIDT. White, suffused pink, penciled crimson. A most profuse bloomer.

JOHN BENNETT. Yellow, tipped red; large size. Habit sturdy and free flowering.

MINNIE McCULLOUGH. Yellow, tipped red. A most beautiful color combination.

MAY LOMAS. White, suffused soft rose ; delicately beautiful. One of the best for cutting.

PENELOPE. White, tipped and flaked rosy lake. Beautiful and chaste variety.

QUEEN VICTORIA. Rich golden yellow; deservedly most popular.

RED HUSSAR. A brilliant crimson-scarlet ; intensely glowing.

WHITE SWAN. Large pure white flowers, always borne upon long stems.

Your selection of divided roots of the above, 12 cts. each; $\$ 10.00$ per 100 . Strong field grown clumps, 15 cts. each; $\$ 12.00$ per 100 .

Pæony-Flowered Dahlias. See illustration to Pize. right,-reduced in size. The fingle

curled, and somewhat resemble Pcony Chinensis. Some may throw single flowers, but all are lovely. The colors range from white and yillow through intermediate shades to darkest
crimson. This magnificent new ty pe of Dahlia has become "first favorite "with many flower lovers, due to its early and free-flowering qualities and extreme usefulness for cutting. The flowers are produced on long stout stalks quite clear above all foliage, the plants becoming a perfect mass of flowers. And no other type is so ornamental and useful for giving rich bold floral effects whether planted singly or in large masses. Strong seedling pot-grown roots at $12 \mathrm{cts}$. each; $\$ 10.00$ per 100.

Best Mixed Double DAHLIAS. These are finest field-grown well-ripened roots in DAHLIAS. mixture without names, but all extra choice double flowers of many distinct colors and shadings. The roots will produce an abundance of fine double flowers. The varieties included in this mixture are all dependable sorts for cutting purposes, therefore those who desire rather cheaper bulbs, irrespective of names, may thoroughly depend on this mixture.

Divided roots, 10 cts. each; $\$ 6.00$ per 100 . Field grown clumps, 12 cts. each; $\$ 8.00$ per 100. 


\section{Groff's Hybrid GLADIOLI.}

This mixture is made up from the original and recent introductions of this famous strain. It comprises the widest range of color possible, including shades of lilac, lavencler, and clematis, which previously were

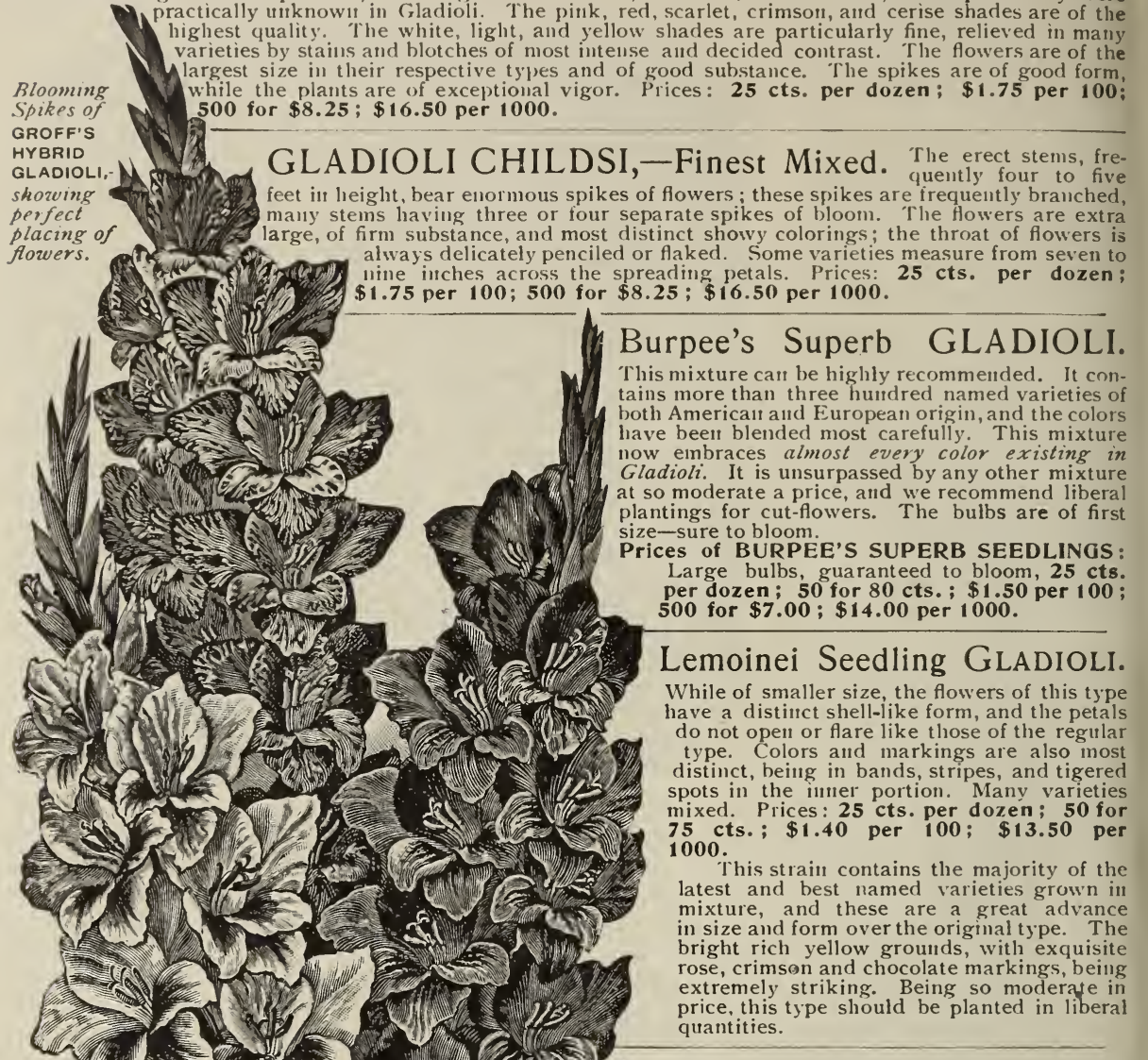

Fine Mixed GLADIOLI. This posed of a splendid assortment of standard varieties grown in a well-balanced mixture. We recommend those wislining an ample supply for cutting to plant a number of bulbs at intervals

two weeks or more apart during the spring months.

First-size Bulbs, sure to flower, in extra fine mix.

ture: 20 cts. per dozen; 50 for 75 cts.; $\$ 1.40$ per $100 ; \$ 12.50$ per 1000 .

Second-size Bulbs, which will flower the first summer if planted early and given good cultivation: $\mathbf{5 0}$ for $\mathbf{6 0}$ cts.; $\$ 1.00$ per $100 ; \$ 9.00$ per 1000 .

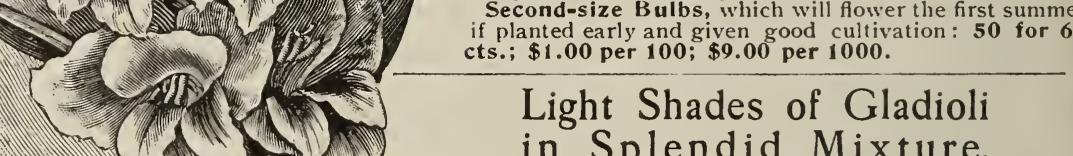

in Splendid Mixture.

Many planters prefer a mixture with the darker shades eliminated. We grow therefore a superb mixture of the best varieties, running through shades of rose, pink, orange, yellow, white, and the intermediate light shades. We call this mixture Light Shades Mixed and offer bulbs at: $40 \mathrm{cts}$. per ture Light Shades Mixed and offer hulbs at: 40 cts. per
dozen; 50 for $\$ 1.40 ; \$ 2.75$ per $100 ; \$ 25.00$ per 1000 .

The Gladiolus is justly entitled to rank among the most you have room enough for a good-sized bed purchase a huudred or more of one of the mixtures and fill the whole bed with them. They will continue in bloom for a long time and will furnish you with some of the finest material for cut-flower decorations.

We would recommend also to plant single bulbs of the named varieties in open spaces in the flower border, where their delicate coloring and increased size may have a chance to display the beauty of individual flowers. The culture of Gladioli is extremely simple and easy. Use well-rotted manure or compost to enrich the beds in the spring, dig them deeply, and make the soil as loose and fine as possible; plant the bulbs with a trowel, setting them three to four inclies below the surface and, if planted in beds, just far entough apart to permit the use of the hoe between them-say six to eight inches. 


\section{Fifteen Beautiful Named Gladioli}

America, The fowerespilikes are two to litree of loet long, bearing a great numbe fowers are of a beautiful soft lavender-pink color shading is very light and the effect is a tinted white; most charmingly attractive. $6 \mathrm{cts}$. each; $60 \mathrm{cts}$. pet dozen; it.00 per 100.

Columbia. Flowers of immense size. Color flaked chocolate, white in throat. $6 \mathrm{cts}$. each $; 65 \mathrm{cts}$. per dozen; $\$ 5.00$ per too.

Cracker Jack. Flowers average four inches ing crimson, throat mottled pale vellow. Distinct and very fire. $12 \mathrm{cts}$. each; $\$$ s. 35 per dozert; \$ \$ro.oo per 100.

Glory of Brightwood. A lovely shacle hraving a clistinct lemont throat; very bright and attractive. 6 cts. each; 65 cts. per dozent ; $\$ 5.00$ per 100 .

Hollandia. This fine variety might be described cusis. It is of vigorous growth and much esteemed for cutting. $6 \mathrm{cts}$. each; $60 \mathrm{cts}$. per dozen; $\$ 4.50$ per 100.

Jean Dieulafoy. Color deep creamy primlate blotches in the throat. Flowers rery large. I2 cts. each ; $\$ 1.35$ per dozel1 ; $\$$ io.00 per 100.

Lizzie. Of robust and upright growth, with very large spikes. Color pure white, the thre each; $\$$ I. 35 per dozen; ; $\$$ io.0o per 100 .
Meadowvale. Pure white, touched with 's im. marked with faimt pink: Flowers well arrdnged and of good size. 12 cts. each; ; \$1.35 per dozen ; \$ \$10.00 per to Mephistopheles. A rariety which invarially Color rich red, stained with black and vellow; large. cts. each; $\$$ I. 35 per dozell ; $\$ 10.00$ per 100.

Mrs. Beecher. A very large and hright the throat being attractively marbled with white cts. each ; \$1.00 per dozen ; \$9.00 per 100 .

Mrs. Francis King. A magnificent new Thons are of a delightful light scarlet aucl are we placed on the large spikes. $5 \mathrm{cts}$. each; $50 \mathrm{cts}$. pet dozell ; $\$ 4.00$ per 100

Princeps. Beautiful large flowers, well placed

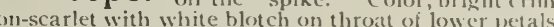
One of the handsomest varieties. $8 \mathrm{cts}$. (ach; 80 cts per dozen ; $\$ 5.50$ per 100.

Princess Altieri. Vindoubtedly one of the beautiful. Color white with reddish-crimson blotches. Flowers of immense size. Spikes long and perfectly formed. I2 cts. each; $\$$ I.35 per dozen ; \$10.00 per 100. Scribe. The spike is long and erect. Color ligh 12 cts. each; ; \$1.35 per dozen; \$10.00 per 10o.

Victory. Clear sulphur-yellow, the ends of the Victory. petals slightly 'suffused pink. Spike tall and erect. $8 \mathrm{cts}$. each; $80 \mathrm{cts}$. per dozen; $\$ 6.00$ ner 100

\section{Tuberous-Rooted BEGONIAS}

The Tuberous-rooted Begonia is a very desirable plant, either for window, conservatory, or outdoor planting, and has of recent years become a strong rival to the Geranium and Verbena for bedding.

Large Single, Mixed. These duce very large single flowers in a splendid assortment of colors. The bulbs should be started early in the spring in very light or sandy soil; give but little moisture unt il they have started into growth. Mixed, $40 \mathrm{cts}$. per dozen; $\$ 2.75$ per roo. We offer also the single-flowering bulbs in separate colors of Crimson, Pink, White, Yellow and Orange,-each color at $5 \mathrm{cts}$. each; $50 \mathrm{cts}$. per dozen ; $\$ 3.50$ per ron.

Best Double, Mixed. tered, in a magnificent range of beautiful rich colors. They produce a profusion of grand flowers. $75 \mathrm{cts}$. per dozen ; $\$ 5.00$ per I00. We can supply also the followiug separate colors: Crimson, Pink, White and Yellow, at $8 \mathrm{cts}$. each; $85 \mathrm{cts}$. per dozen; \$6.00 per 100. I.s These bulbs are all well ripened, and we guarantee them to arrive in good growing condition. Write for special prices on large quantities.

\section{Frilled and Crested Tuberous-Rooted Begonias.}

The large single blooms, measuring from four to six inches in diameter, are invariably frilled or crested in the petals. The colors are brilliant and the plants equally as vigorous as those of the older type. As pot plants for the conservatory, house or veranda, they are unrivaled, and on account of their uniquely crested aud frilled flowers, create immediate attention and unstinted admiration. In habit the plant makes a very sturdy and upright growth, the flowers being held well erect on stout stems. In cool sections we strongly recommenc their free use for bedding purposes.

Single Mixed. $75 \mathrm{cts}$. per dozen ; $\$ 5.50$ per roo

We also offer the following separate colors of these charming "Frilled and Crested" Pegonias : Scarlet, Pink, White and Yellow, at Io cts. each; $\$ 1.00$ per dozen; $\$ 7.00$ per Ioo.

$\rightarrow$ To start Begonia bulbs press them half their depth into a light sandy soil which must be well moistened, being careful to observe that the indented part of the bulb is the top. They may be set quite close together until top growth is made, when they must be potted or planted out in a partly shaded position, 


\section{Choice Summer-Flowering Hardy Lilies.}

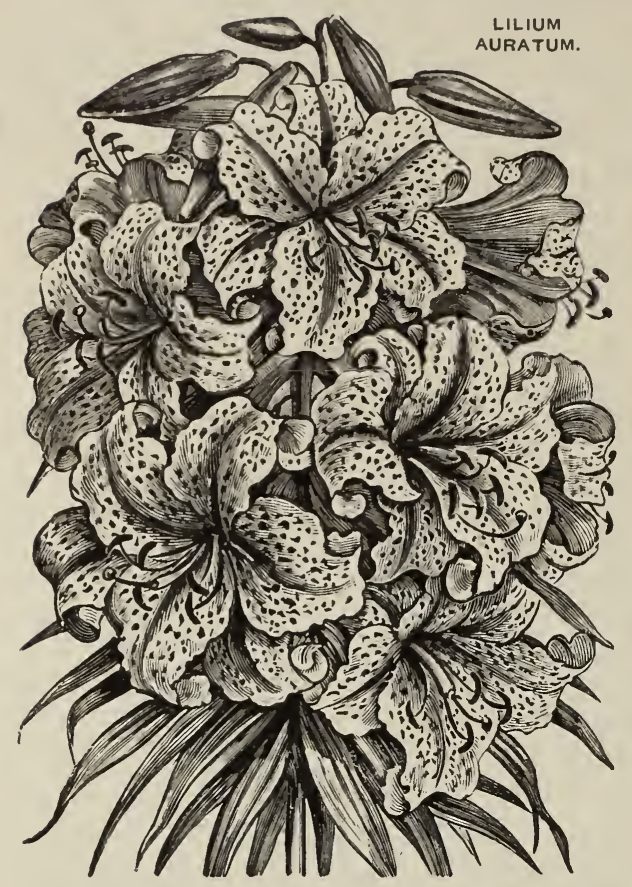

A URATUM (the Golden-Banded Lily of Japan). Petals are ivory-white, banded with rich golden yellow and heavily spotted at base w' ith deep crimsol1. $15 \mathrm{cts}$. each; $\$ 1.65$ per dozen; $\$ 12.00$ per 100 . CROCEUM. Beautiful orange-red flowers of attractive form. I5 cts. each; \$1.65 per dozen; \$12.00 per IOO.

DAVURICUM. This is the species from which was obtained the Umbellatum. It is a stronggrowing variety. Height 15 to 18 inches. The large flowers are in color a dark orange, spotted with brown, shading to yellow in throat. $15 \mathrm{cts}$. each; \$1.65 per dozen; \$12.00 per too.

LONGIFLORUM. Beautiful snow-w hite trumpetshaped flowers. $15 \mathrm{cts}$. each; $\$ 1.65$ per dozeri; $\$ 12.00$ MARTAGON: The Tunk's-Cap Lily. Very hardy flowers bright purple. I5 cts. each; \$1.65 per dozen; \$12.00 per 100 .

PARDALINUM. Flowers scarlet and yellow. spotted with a rich browil. sometimes called Leopard Lily, on account of markings. I2 cts. each; \$1.35 per dozen; \$10.00 per I00.

SPECIOSUM Rubrum or Roseum. White, shaded with deep rose. Very beautiful. I5 $\mathrm{cts}$. each; \$1.65 per dozen; \$12.00 per 100.

THUNBERGIANUM or ELEGANS, Mixed. This mixture embraces all the most beautiful varieties, ranging in color from bright orange to deep blood-red. $8 \mathrm{cts}$. each; $80 \mathrm{cts}$. per dozen. $\$ 5.50$ per 100

TIGRINUM Fortunei Giganteum. This inproved strain of Tiger Lily produces beautiful flowers of an orange-salmon shade marked with black. 8 cts. each; 80 cts. per dozen; $\$ 5.75$ per 100. UMBELLATUM, Mixed. Large flowers; colors range from black-red to crimson-rose, many being finely spotted. Bloons during June or July; highly recommended. $8 \mathrm{cts}$. each; $80 \mathrm{cts}$. per doze11; $\$ 5.50$ per 100.

Excelsior Pearl Tuberoses.

The "Excelsior" strain of DWARF PEARI. TUBEROSE has been improved in dwarf habit of growth, extreme doubleness of the large flowers, and in very early flowering. The stems being dwarf and stiffly erect, they do not need to be staked and tied as do the tall sorts.

We offer choice large-flowering bulbs at 20 cts. per dozen; 25 for 35 cts.; 100 for \$1.00; $\$ 9.00$ per 1000.' Largest size, selected bulbs, $\$ 1.50$ per 100; 200 for $\$ 2.75$, or $\$ 13.50$ per 1000 .

Variegated-Leaved Tuberose.

The long slender-pointed leaves of this variety are heavily striped or bordered with creamy white, which contrasts strikingly with the light greell ground color. The flower-stalks grow three to four feet in heiglit, producing numerous. large single flowers of delicious Jessamine-like fragrance. Planted closely they make an effective border for the flower-beds, walks, etc. The bulbs can be kept over from vear to year in a warm cellar. Price 25 cts. per doz.; $\$ 1.50$ per 100; $\$ 12.50$ per 1000 .

\section{Tuberose,-“"Albino."}

A choice selection of the early-flowering, tall, single white or "Orange Blossom Tuberose." Of quite strong growth, the spikes, three feet in height, a re closely filled with large single white flowers, which continue to open for a long time as the stalks increase in height. Price $25 \mathrm{cts}$. per dozell; \$1.50 per 100; $\$ 12.50$ per 1000.

SUMmer-Flowering Bulbs and SPEcial, Culture of DaHLias are the titles of two of our popular cultural leaflets and are sent free if asked for when placing an order. These two leaflets tell, in easily understood language, the best way to plant, cultivate and handle the bulbs offered, so if you have never grown any flowers from bulbs you need not fear about being unsuccessful.

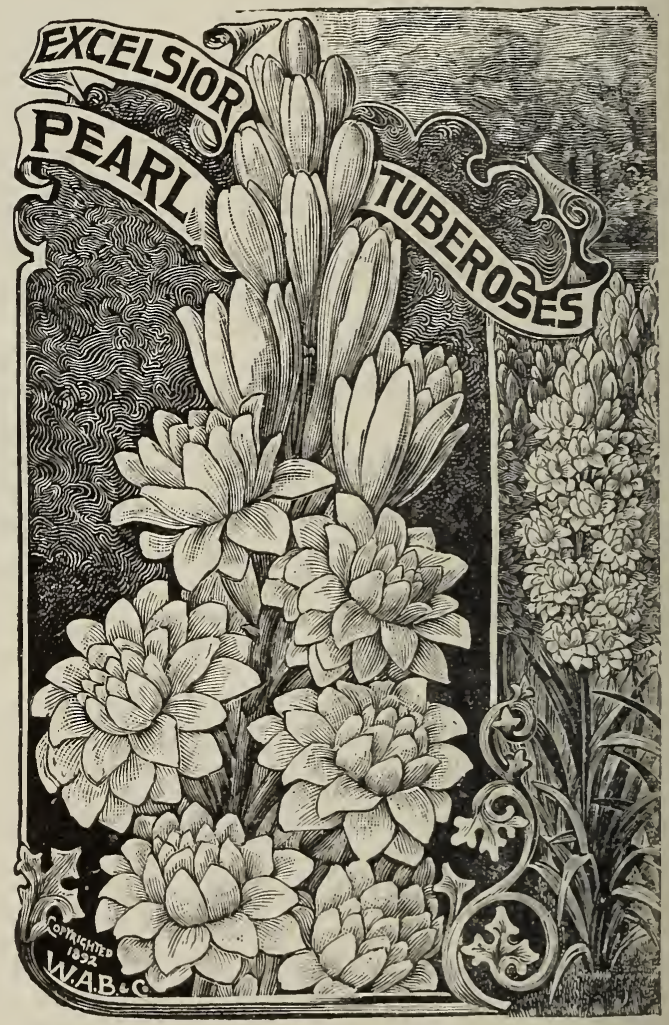




\section{Iris Germanica (Fleur de lis).}

The German Iris is frequently called "Flag Iris." These do best in a sunny location and the soil, fairly rich, should be well drained. The soft, rich colors of the handsome blooms almost equal the finest Orchids in delicate shades. For the best effect they should be planted in large groups and care taken that the roots are not covered too deeply.

Bridesmaid. White, bordered with lilac.

Dr. Thouvenet. A rich violet-blue.

Florentina. Free-flowering; pure white.

Fontarabie. Dark blue and violet.

Gervaise. Olive and light brown.

Honorable. Yellow and rich brown.

Kharput. Light blue and violet.

Kochi. Blue and dark violet.

Madame Chereau. White, edged blue.

Minerva. Light olive and brown.

Mrs. Horace Darwin. White with violet veins.

Topaz. Clear lilac.

Variegata Major. Light yellow and brown.

Any of the thirteen named varieties at I 2 cts each; \$1.25 per dozen, or \$8.00 per Ioo.

Mixed German Iris. All the above in mixture. 80 cts. per dozen; $\$ 5.50$ per 100 .

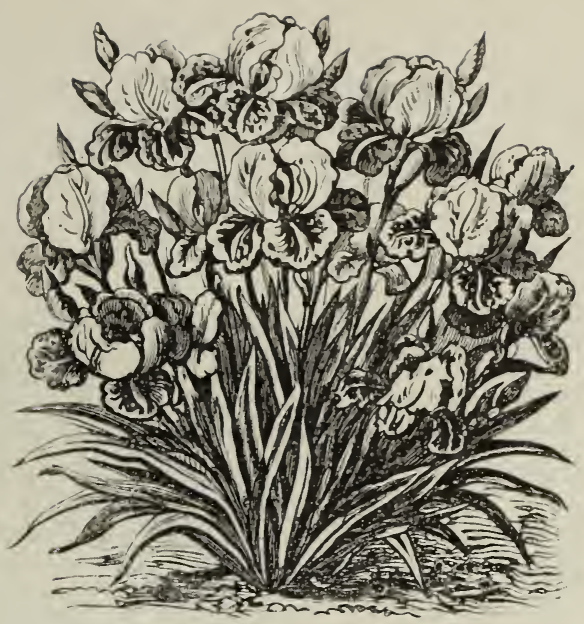

\section{Summer-Flowering Bulbs}

The bulbs offered here are of the finest quality, being grown especially for us; they are all true to name and are now properly stored in our warehouse awaiting orders. Twenty-five bulbs or more of one kind will be supplied at the rates per Ioo. Special quotations on large quantities. For Dahlias, see pages I 4 I to I 43.

St. Brigid is a lovely strain of Irish Anemones, the colorings being extremely striking. Anomatheca Cruento is sometimes called the Red Freesia, its brilliant scarlet flower spikes being bright and dainty. Apios Tuberosa is a charming climber bearing small close bunches of deep purple wisteria-like flowers. Caladium Esculentum-the popular Elephant Ear plant-is always a favorite for lawn or border decoration, and is useful as specimens when planted in large pots or tubs. The Gloxinia is among the most popular of summer pot-plants. The Cinnamon and Madeira Vines are useful climbers. Incarvillea Delavayi, the Hardy Gloxinia, is a true perennial, and although usually grown in the open border, makes a charming pot plant.

The Montbretia might be called a Miniature Gladioli, the graceful flower spikes being freely produced in fall. The various varieties of Ranunculus if planted in rich light soil will give an abundance of charming flowers throughout early summer. The Tigridia or Shell Flower, with its huge richly colored blooms is always interesting in the border. A few established clumps of Tritoma should be grown by all who have a call for cut flowers; it is specially useful in the fall, blooming freely until hard frost.

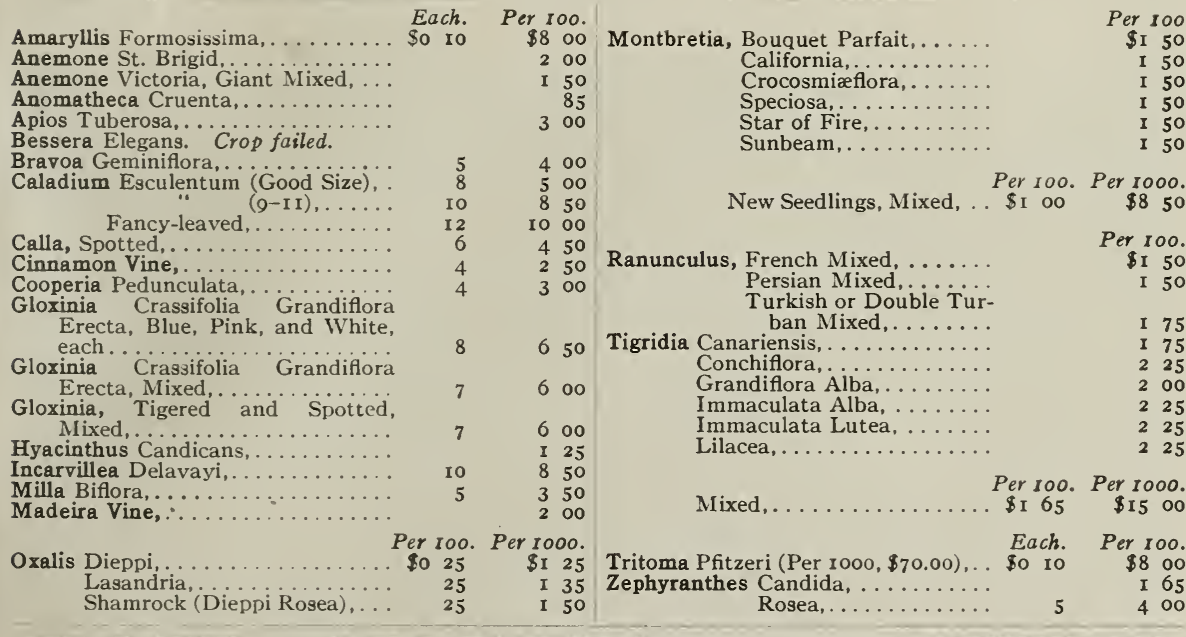

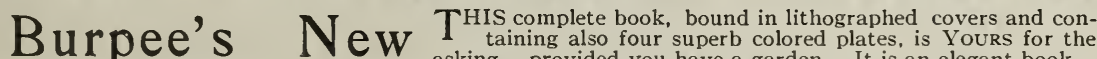 asking,- - provided you have a garden. It is an elegant book-

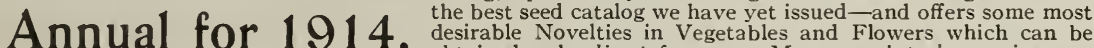 obtained only direct from us. Many a winter's evening can be spent profitably in planning your garden, by a careful study} of this book. Shall we send you a copy? If you appreciate Quality in Seeds you will say $Y e s$ !
W. ATLEE BURPEE \& CO.,
BURPEE BUILDINGS, The Largest Mail-Order Seed House. PHILADELPHIA. 
Vegetable Seeds.

Artichoke

Asparagus .

IBeans, Bush, Green-Podded, 6 to Fordhook Favorite 8 Wax-podded ....9, Io “ Limas.........II, I2

“ Pole............. I3, I 4

Giant-Podded Pole Lima I4

Beets, Garden .......... I5 to I7

Mangels, Sugar Beets .. I 8

Brussels Sprouts ............ I8

Cabbage ............. I9 to 26

Carrots................ 27

Cauliflower............ 28,29

Celery ................30,3

Chard, or Spinach Beet...... I7

Chicory................ 32

Chives................. 32

Collards

Corn, Sweet

.33 to 37

“ Pop.

Corn Salad

Cress.....

Cucumber

Dandelion .

Egg Plant

Endive..

(iourds.

Herbs.

Horse-Radislı

Kale, or Borecole.

Lettuce.............44 to 50

Martynia............... 5 I

Melons, Musk...........5I to 55

“ Spicy Cantaloupe 55 Fordhook.... 54

Water........56 to 59

Mushrooms............. 60

Mustard.............. 60

Nasturtium .........60, I I9, I 20

(Dra, or Gumbo . . . . . . . . . 60

Onion, American.......6 6I to 68

“ Foreign Varieties.65, 66, 68

Sets............ 68

Parsley ............... 69

Parsnips................ 69

Peas.............. 70 to 77

Peppers.............78 to 8 I

Potatoes.............. 82,83

Pumpkins............ 84

Radish .............84 to 88

Rhubarb............. 88

Ruta Bagas, or Swedes . . . . . . 99

Sage ................. 99

Salsify, or Vegetable Oyster . . 88

Sorrel................ 88

Spinach............... 89

Squashes.............89 to 9 I

Tobacco ................. 99

Tomatoes............92 to 98

Turnips................ 98
Farm Seeds.

Pages I00 to I03.

Buckwheat............ I00

Clovers................. I03

Corn, Field............. Ioo

Grasses.................. I02

Oats................. 103

Sorghum, or Sugar Cane...... Ioo

Lawn Grass Seed....... Ior

Flower Seeds.

A butilon................ I04

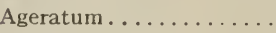

Agrostemma .........

Alyssum ....

Antirrhinum .

Aquilegia .

Arctotis Grandis . ............ I0

Asparagus............. I05

Asters............. I06, I07

Balsam ............... I08

Begonias, Free-flowering..... I 08

“ Tuberous-Rooted .. I08

Bellis................ I 08

Brachycome............. I08

C'alceolaria Hybrida ... . . . I0 108

Calendula.............. 109

Calliopsis.... . . . . . . . . . . I09

Campanula.............. 109

Candytuft.............. Iog

Carnations............. Iog

Celosia, Plumed... . . . . . . I I Io

Centaurea (Cornflower) . . . . . Iro

Chrysanthemum .......... I ro

Cineraria ............... I I I

Cobœa Scandens.......... I I I

Coleus . . . . . . . . . . . . . . . I I I

Cosmos............... III

Cyclamen............. II 2

Cypress Vine............ II

Dahlia................ II

Daisy, Shasta........... II 2

Delphinium ............. II 2

Dianthus.............. II

Digitalis............... II 3

Dimorphotheca Aurantiaca ... II 3

Dolichos................ II

Eschscholtzia ............ II 4

Euphorbia.............. I I 4

Everlasting Flowers......... I38

Feverfew . . . . . . . . . . II 4

Forget-Me-Not . . . . . . . . I I I 4

Fuchsia ............... I I4

(iaillardia .............. I I4

Geranium .............. II

Gloxinia ............... II 5

Grasses (Ornamental) . . . . . . 135

Gypsophila.............. I I 5

I eliotrope.............. II 5

Hollyhocks ............ II 5

I pomœa . . . . . . . . . . . . . I I6

Kochia Tricophylla........ II6

I.antana .............. II6

Larkspur................ I I6

Lathyrus............. I I6
PAGE

Lemon Verbena . I I6

Linaria............. . II6

Lobelia......... I I 7

Lychnis........ . II7

Marigolds . . . . . . . . . . . . I I

Marvel-of-Peru.... _. II7

Mignonette ....... . II

Mimulus.......... . II

Momordica......, , , II8

Moonflower.............. I I

Morning Glories...... ... I 18

Musa Ensete....... ... I I 8

Vasturtiums, Dwarf . . . . . I 19, I 20 Tall....... I I9, 120

Nicotiana .............. 121

Dxalis ............... I 2

Pansies ............. I I I to I 23

Giant Fancy. . . . . . . I22

Pentstemon............ I3I

Petunia.............. I3I

Phlox. .............. I 3 I

Platycodon............. I3I

Polyanthus............. I32

Poppies, Annual. . . . . . . . 132

Portulaca.............. I 32

Primula............ 132, 133

Pyrethruin............. 133

Ricinus . . . . . . . . . . . . I3,

\$alpiglossis . . . . . . . . . . . 133

Salvia......... 133

Scabiosa............... I.3.

Sensitive Plant. . . . . . . . . . 13.

Shamrock............... I.3.

Smilax............... I34

Statice... . . . . . . . . . . 134

Stevia................ I34

Stocks............... I34

Stokesia... . . . . . . . . . . I I34

Streptocarpus........... I34

Sunflowers . . . . . . . . . . . I35

Sweet Peas, Grandiflora, I 28 to 130

. " " Spencer... I I24 to I27

“ Cupid......... I30

- for Truckers and

Market Gardeners I30

“ Unwin Type..... I30

. Collections ...... I40

Sweet Sultan............ I35

Sweet William.......... I35

Thunbergia ............. I35

Torenia............... 135

Verbena ............... I36

Vinca................ 135

Viola................ 135

Wallflower . . . . . . . . . I35

Zinnia .............. I37

Summer-Flowering Bulbs. Pages 141 to 147

Miscellaneous.

Burpee's Instructive Leaflets.. 3

Helps for Market Gardeners

and Florists........... 3

Popular Collections...... I39, I 40

Quantities of Seed required in Garden and Field Culture. . 4 


\section{Growing and Saving Tomato Seed at Fordhook.}

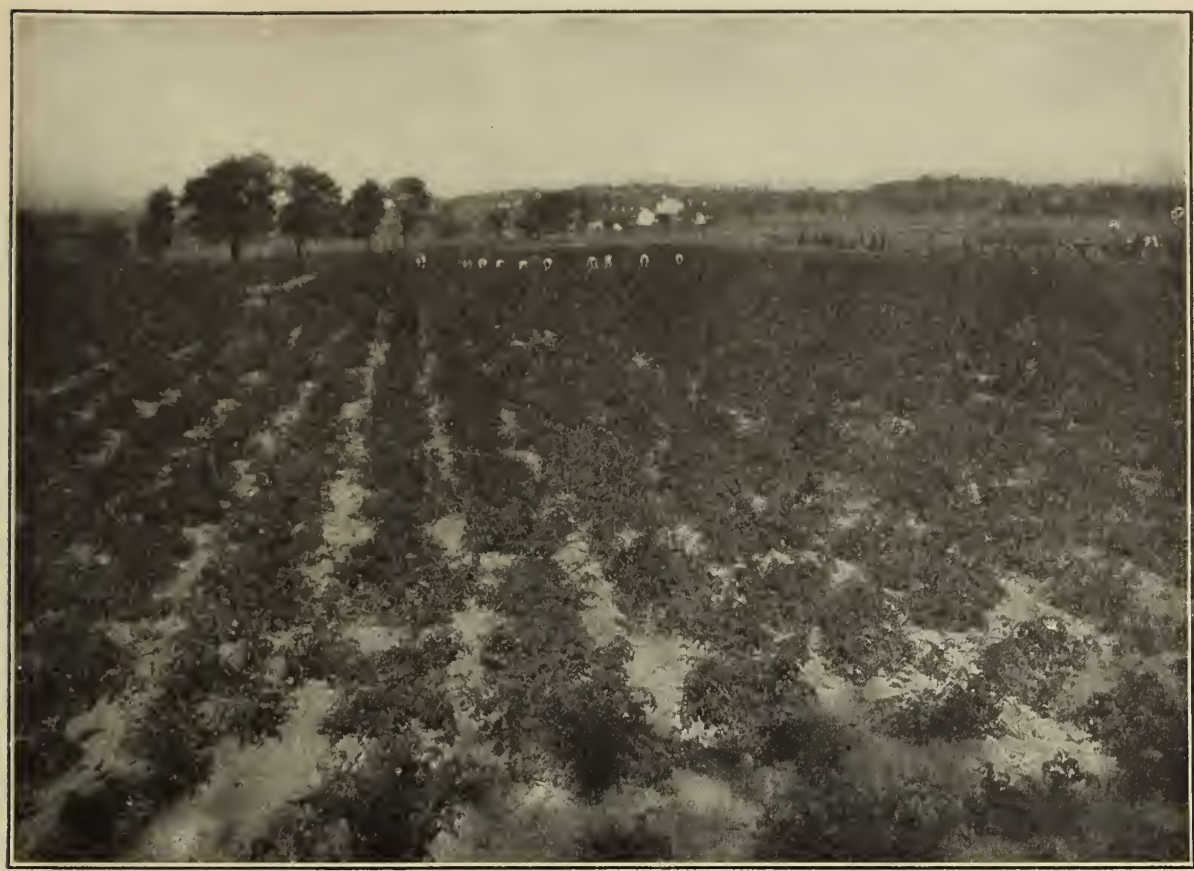

A FikLd of BURPEe's "DWARF-Giant" Tomato,-at Fordhook. Men in the distance are picking the ripe fruit while the team is loading for " the washer."

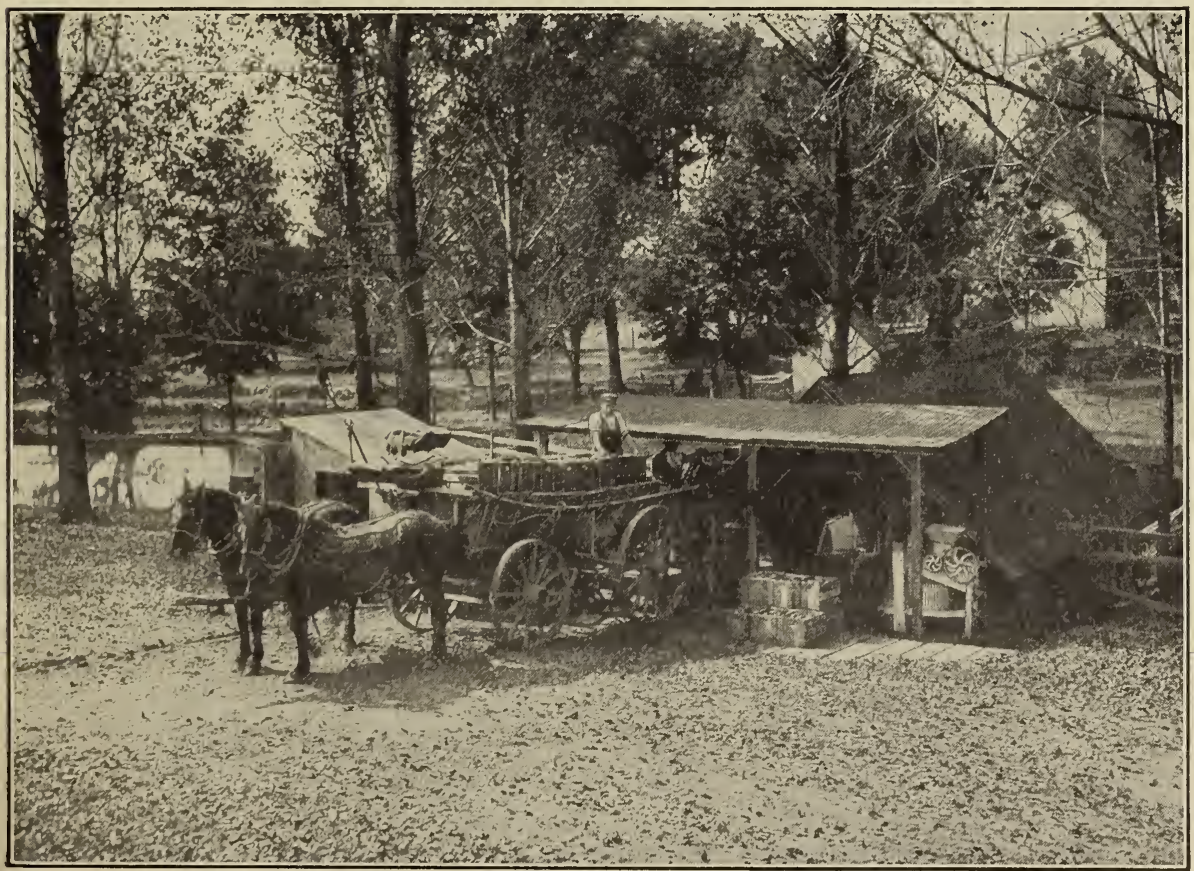

THE "TOMATO WASHER" AT FORDHOOK. Facilities are sufficient to take care of twelve hundred bushels daily. Here we save the seed only, the pulp being hauled on fields and used as a fertilizer. 


\section{Washing and Drying Tomato Seed at Fordhook.}

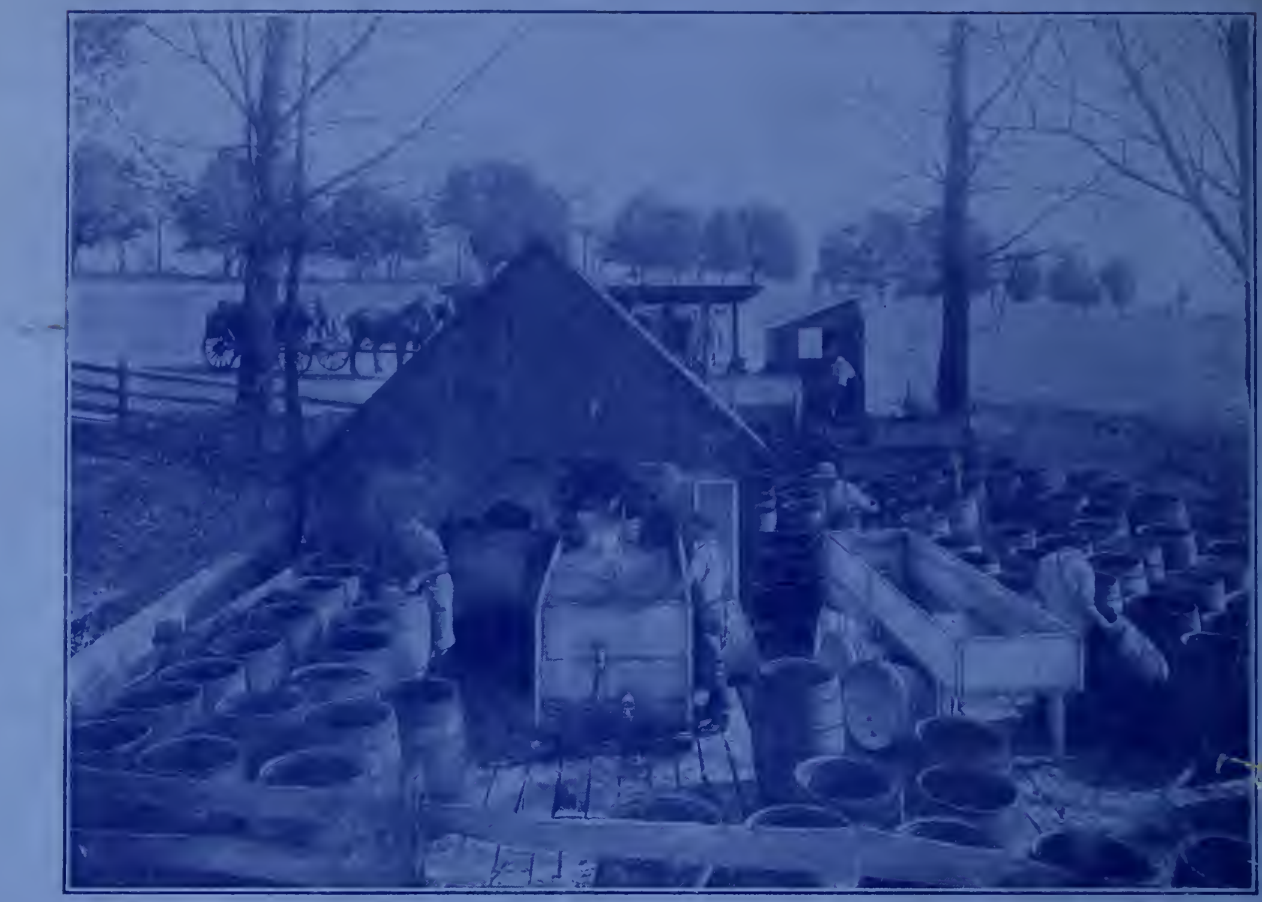

REAR VIEW OF TOMATO Washr. The barrels contain the ground mass after pulp ani skin have been removed in the separator; the large trough-like boxes are used in thoroughly washing the seeit.

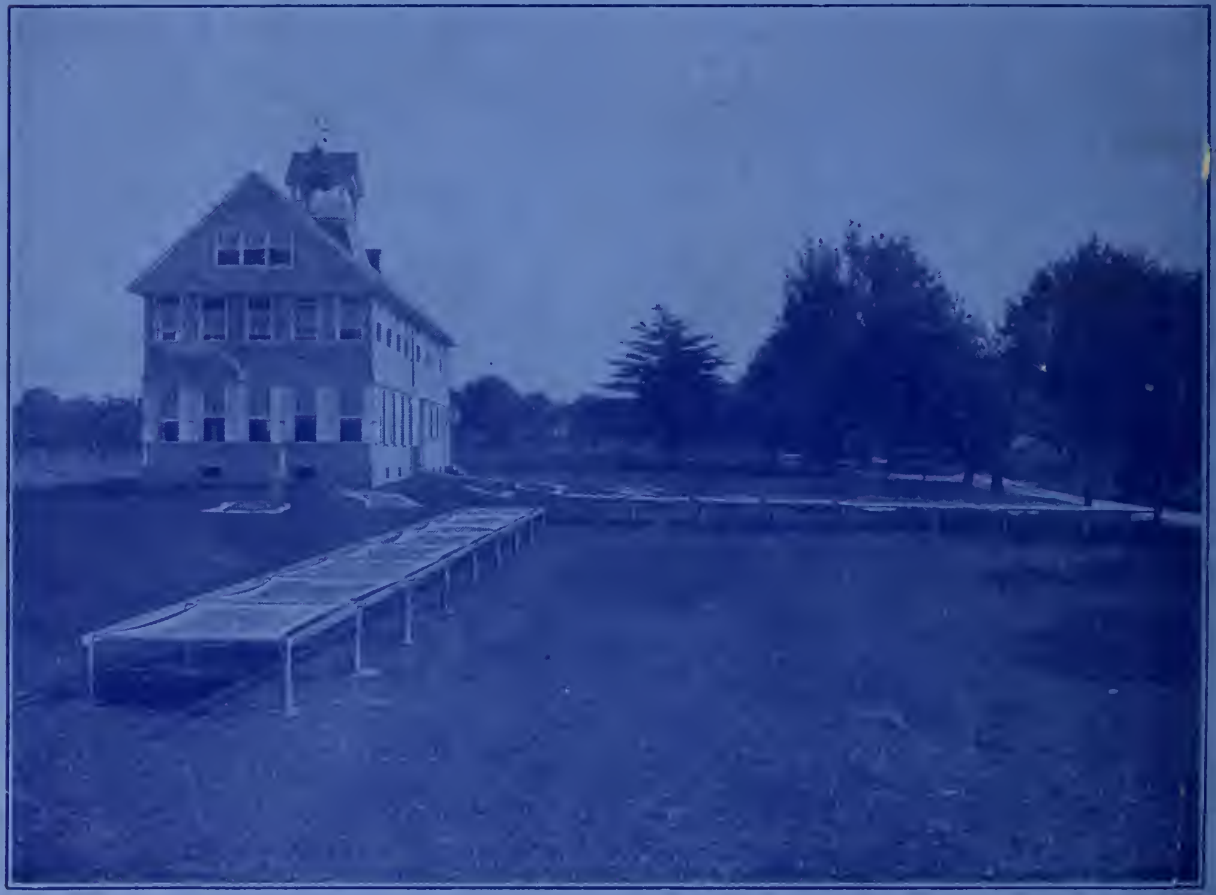

The TOMATo "DRYing Ricks' AND SFind Hot'se AT FORDHOOK. All seed is dried naturally, and when removed from the "racks" is sacked and later put through the cleaning mill. 